\title{
AVALIAÇÃO DA PRESENÇA DE CLOROFENÓIS NO RESERVATÓRIO DE SALTO GRANDE, SITUADO NA REGIÃo DE AMERICANA, ESTADO DE SÃO PAULO
}

\section{DIRLANE DE FÁTIMA DO CARMO}

Dissertação apresentada à Escola de Engenharia de São Carlos, Universidade de São Paulo, como parte dos requisitos para obtenção do título de Mestre em Ciências da Engenharia Ambiental

Orientadora: Prof ${ }^{\mathrm{a}}$. Dr $\stackrel{\mathrm{a}}{\text {. }}$ Rosana Filomena Vazoller

São Carlos, SP

Maio/2000 
ANDO DEVAGAR PORQUE JÁ TIVE PRESSA

E LEVO ESSE SORRISO PORQUE JÁ CHOREI DEMAIS

HOJE ME SINTO MAIS FORTE, MAIS FELIZ QUEM SABE,

EU SÓ LEVO A CERTEZA DE QUE MUITO POUCO EU SEI,

NADA SEI

CONHECER AS MANHAS E AS MANHÃS,

O SABOR DAS MASSAS E DAS MAÇÃS

É PRECISO AMOR PRA PODER PULSAR

É PRECISO PAZ PRA PODER SEGUIR

É PRECISO CHUVA PARA FLORIR

SINTO QUE SEGUIR A VIDA SEJA SIMPLESMENTE

CONHECER A MARCHA, IR TOCANDO EM FRENTE

COMO UM VELHO BOIADEIRO LEVANDO A BOIADA

EU VOU TOCANDO OS DIAS PELA LONGA ESTRADA, EU VOU

ESTRADA EU SOU

CONHECER AS MANHAS E AS MANHÃS

O SABOR DAS MASSAS E DAS MAÇÃS

É PRECISO AMOR PRÁ PODER PULSAR

É PRECISO PAZ PRA PODER SEGUIR

É PRECISO CHUVA PARA FLORIR

TODO MUNDO AMA UM DIA

TODO MUNDO CHORA

UM DIA A GENTE CHEGA E NO OUTRO VAI EMBORA

CADA UM DE NÓS COMPÕE A S SUA PRÓPRIA HISTÓRIA

E CADA SER EM SI CARREGA O DOM DE SER CAPAZ

DE SER FELIZ....

(Almir Sater \& Renato Teixeira) 
Dedico este trabalho

Aos meus pais,

Baltazar e Margarida,

Por serem quem são

Aos meus irmãos e cunhados:

Denilson, Denise e Dircilene,

Vânia e Jurandir;

Pela presença e apoio constante

Aos meus sobrinhos,

Douglas e Rafael,

Por tudo que representam 


\section{AGRADECIMENTOS}

A Deus, por ter me dado saúde e perseverança para a realização e conclusão deste trabalho.

A Rosana Filomena Vazoller pela orientação, apoio, estímulo, interesse, e sobretudo pelo grande exemplo que sempre foi e será, e pela inestimável amizade.

A banca examinadora, pelas sugestões e pelo interesse.

A Capes, pela bolsa concedida.

A Companhia Paulista de Força e Luz - CPFL, por ceder as instalações da Usina Hidroelétrica de Salto Grande onde os trabalhos de campo foram realizados.

A professora Elizabeth Moraes pelas correções, apoio, colaboração, cuidado e amizade.

A Maria Angela Tallarico Adorno pelo interesse, amizade e pelo auxílio constante, não só profissional como também pessoal.

A Márcia Damianovic por todas as sugestões, apoio e colaboração.

A professora Maria do Carmo Calijuri por sanar as dúvidas limnológicas.

Ao professor Eugênio Foresti, pelo apoio.

A professora Maria Olímpia e a técnica Diva, por estarem sempre dispostas a sanar dúvidas e pelas valiosas sugestões.

A toda turma do laboratório de Processos Biológicos, maior concentração de pessoas especiais por $\mathrm{m}^{2}$ : Rodrigo, Silvaninha, Regiane, Emerson, Eduardo, Nélia, Mic, Gunther, Hélio, Sidney, Juliana, André Oliveira, Aurélio, Renata, Flávio, Rogers, Chico Vela, Thiago, Werner, Giovana, Cristiano, Ariuska, Lorena, Lyda, André Campos, Eloísa, especialmente a Bernadete, Ivana, Deíza, Alessandra Ramos e Neyson.

Aos meus amigos da Universidade Federal de Viçosa, por toda a convivência e por estarem sempre torcendo por mim, de perto ou via e-mail: Adriano Alves, Lucas, Ivênio, Sidney Helder, Reginaldo, Ritinha, Mário, Adriano Jackelaitis, Ailton, Helen, Elizabeth, Dione, Graça e especialmente a Marisi, pela amizade incondicional.

Aos funcionários do CRHEA, especialmente ao Miro e Marcelo pelo grande auxílio nas coletas e a Claudete, pela disposição e atenção. 
Ao Centro de Biotecnologia Aplicada a Agropecuária, especialmente ao professor Everaldo Gonçalves Barros, pela iniciação na "vida científica".

Aos amigos do CRHEA, especialmente às maranhenses Ciclene e Andrea, aos pantaneiros e ao Clóvis, pelo auxílio na fase inicial da parte experimental do trabalho.

Aos amigos de todos os departamentos: Hidráulica e Saneamento, Geotecnia, Elétrica e Arquitetura.

A todos os amigos que aqui conheci, especialmente a Sissy, Celimar, Luci, Ricardo Gentil, Paulino, Marcelo Cad e Flávia Saia.

Ao meu amigo San pelas mensagens diárias e amizade.

As companheiras de república Luana e Mércia, pela amizade, carinho, conselhos e pela ótima convivência.

As amigas distantes Isabel Sakamoto, Sílvia Barguil e Marlete Henriques, por estarem sempre tão perto.

A toda a colaboração, paciência, dedicação e esforço da amiga Luciana Mendonça, nos gráficos, formatações, impressões e vários outros probleminhas que apareceram pelo caminho.

Ao Luiz, por tudo, principalmente nesta fase final do trabalho.

À minha família, tão especial e sempre tão perto, apesar da distância.

$\mathrm{E}$ a todos, que colaboraram de alguma forma para que esse trabalho fosse realizado. 


\section{SUMÁRIO}

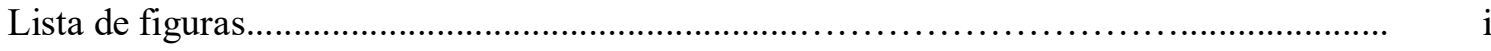

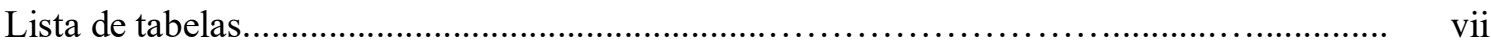

Lista de abreviaturas e siglas............................................................................... xiv

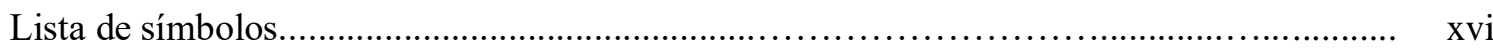

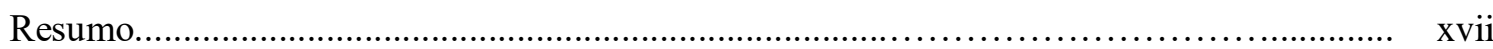

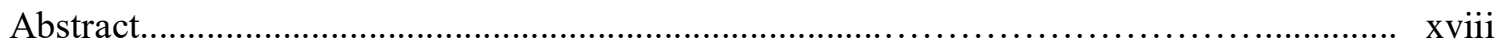

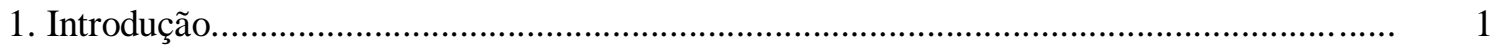

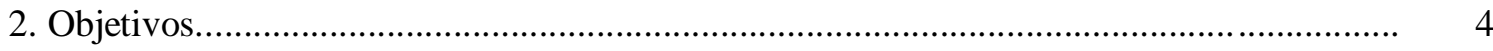

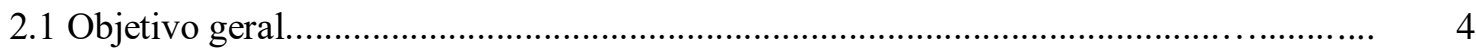

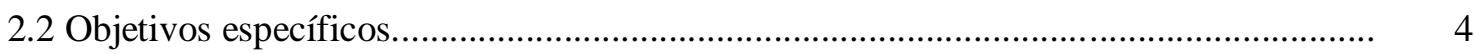

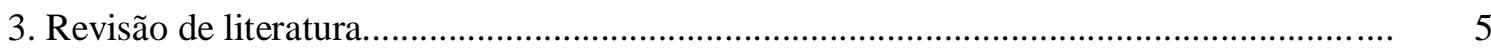

3.1 Impactos ambientais causados por compostos orgânicos halogenados e seus produtos de degradação............................................................................................................. 5

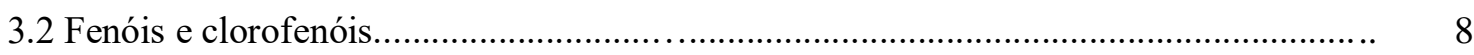

3.2.2 Clorofenóis e amostras ambientais......................................................................... 12

3.3 Compostos tóxicos em reservatórios............................................................................. 13

3.4 Coleta e preservação de amostras ambientais................................................................. 16

3.5 Análises e determinações no campo e em laboratório........................................................ 19

3.6 Procedimentos para determinação dos clorofenóis em amostras de ambientes

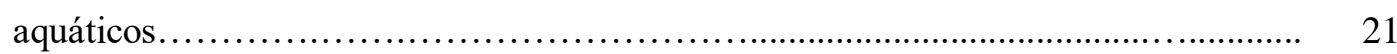

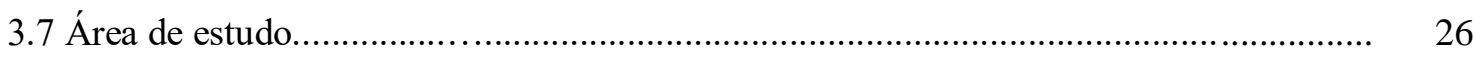

3.7.1 Usos e contaminação da água na sub-bacia do Atibaia.......................................... 26

3.7.2 Reservatório de Salto Grande............................................................................... 35

3.7.2.1. Caracterização do reservatório................................................................... 37

4. Material e Métodos.............................................................................................................. 40

4.1.Área de estudo, coleta e estocagem.......................................................................... 40

4.2 Análises e determinações no campo e em laboratório.................................................... 42

4.2.1 Variáveis físico-químicas...................................................................................... 43 
4.2.1.1 Temperatura $\left({ }^{0} \mathrm{C}\right)$, oxigênio dissolvido $(\mathrm{mg} / \mathrm{L})$, turbidez (uT), condutividade $(\mu \mathrm{S} / \mathrm{cm})$ e $\mathrm{pH}$

4.2.1.2 Material em suspensão

4.2.1.3 Carbono orgânico das amostras de água e do sedimento.............................. 44

4.2.1.4 Teor de umidade no sedimento....................................................................

4.2.2 Condições climatológicas da área do reservatório.................................................. 45

4.2.3 Variáveis hidráulicas e morfométricas do reservatório............................................. 45

4.2.4 Métodos cromatográficos..................................................................................... 45

4.2.4.1 Ragentes e tratamentos utilizados................................................................. 45

4.2.4.1.1 Reagentes utilizados................................................................ 45

4.2.4.1.2 Tratamento dos solventes.......................................................... 45

4.2.4.1.3 Tratamento das fases sólidas........................................................ $\quad 46$

4.2.4.2 Equipamentos e vidraria.......................................................................... 46

4.2.4.3 Extração, limpeza e análises cromatográficas das amostras....................... 46

4.2.4.4 Preparação de curva de calibração para determinação da concentração de clorofenóis................................................................................... 57

4.2.4.5 Controle das Análises Cromatográficas.................................................... 57

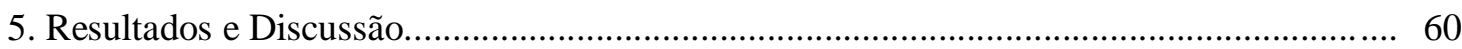

5.1 Métodos e procedimentos para o transporte e preservação das amostras de sedimentos e águas para as análises físico-químicas

5.2 Métodos e procedimentos para análises cromatográficas das amostras de sedimentos

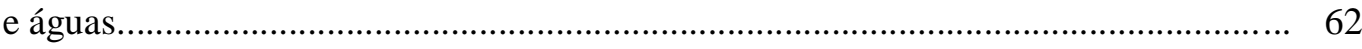

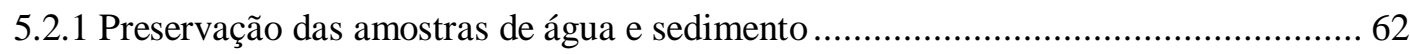

5.2.2 Etapas para escolha e/ou adequação dos procedimentos para extração e limpeza

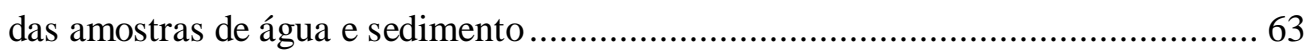

5.2.2.1 Controle das análises cromatográficas.................................................... 63

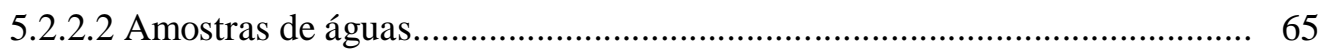

5.2.2.3 Amostras de sedimentos........................................................... 65

5.3 Resultados e discussão por campanha......................................................... 81

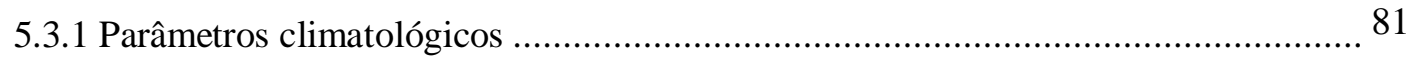

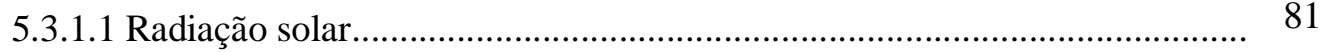

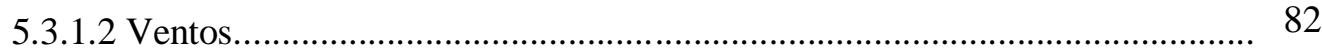

5.3.1.3 Precipitação total............................................................................... 82

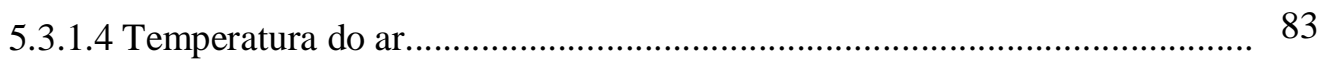

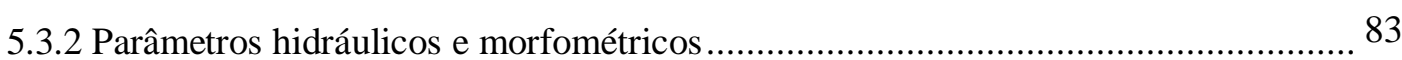


5.3.2.1 Tempo de residência. 83

5.3.3 Variáveis físicas e químicas 85

5.3.3.1 pH, condutividade ( $\mu \mathrm{S} / \mathrm{cm})$, turbidez (uT), oxigênio dissolvido e

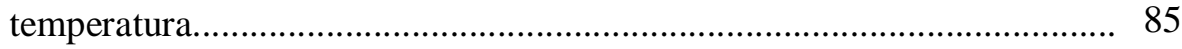

5.3.4 Análises cromatográficas 100

5.3.4.1 Valores para o cálculo da equações de calibração para análise quantitativa dos clorofenóis.................................................................................... 100

5.3.4.2 Valores de clorofenóis nas amostras de Salto Grande................................ 102

5.3.4.2.1 $1^{\mathrm{a}}$ campanha (maio).............................................................. 103

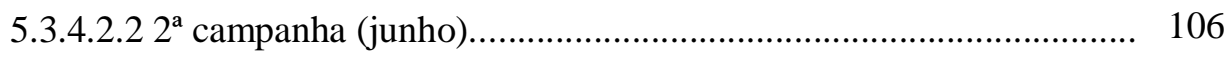

5.3.4.2.3 $3^{\mathrm{a}}$ campanha (novembro)...................................................... 109

5.3.4.2.4 $4^{\mathrm{a}}$ campanha (fevereiro)......................................................... 114

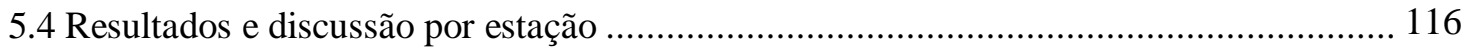

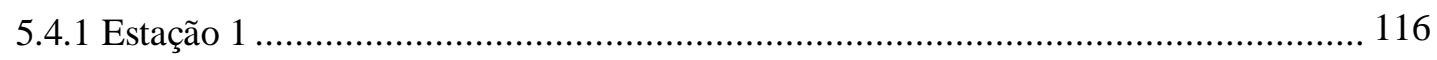

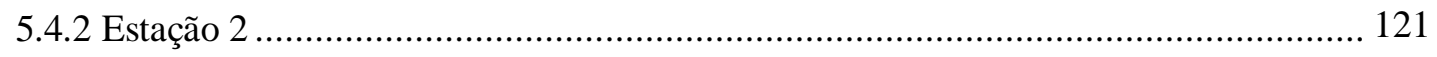

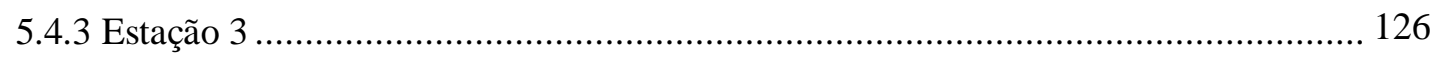

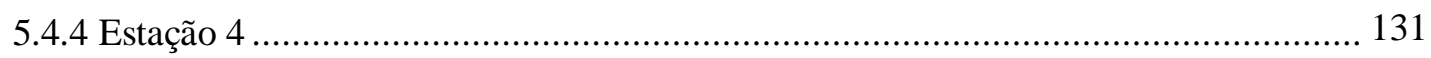

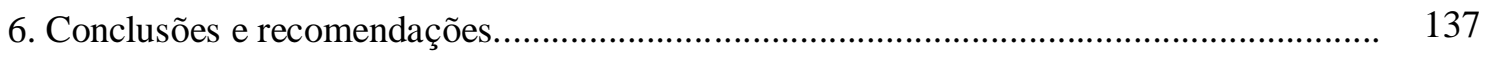

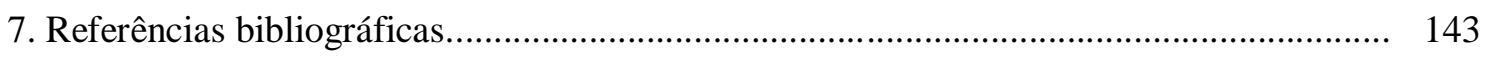

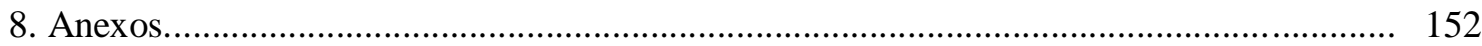




\section{LISTA DE FIGURAS}

Figura 3.1- Fluxos de aportes, acúmulos e perdas de compostos organoclorados (pesticidas e PCB's) em um reservatório (adapatado de CALHEIROS, 1993)

Figura 3.2 - Localização, carga orgânica e de fenóis remanescentes das indústrias situadas na sub-bacia do Atibaia, vazão dos efluentes e o ponto de lançamento destes nos respectivos corpos receptores (CETESB, 1999).

Figura 4.1- .Esquema do reservatório de Salto Grande, com rio Atibaia (principal formador), região de Americana (SP) e identificação das estações de coleta (p1, p2, p3 e p4). Localização no estado de São Paulo (adaptado de RIOS, 1999)

Figura.4.2 - Instrumento utilizado para coleta de sedimento (core).................................. 42

Figura 4.3 - Extração do sedimento utilizando o método ultra-som..................................... 53

Figura 4.4 - Extração do sedimento utilizando o método Soxhlet....................................... 54

Figura 4.5 - Extração do sedimento utilizando o método agitação sob barra magnética.... 55

Figura 4.6- $\quad$ Extração da água utilizando o método de extração líquido-líquido................. 56

Figura 5.1 - Tempo de residência e vazão média mensal de saída, no reservatório de Salto Grande, Americana (SP) (adaptada de TOSSINI, 1999).

Figura 5.2 - Valores das áreas de cromatogramas das amostras de água da estação 2, coletadas em maio/98, analisadas em triplicata (A, B e C).

Figura 5.3 - Valores de áreas dos cromatogramas das amostras de sedimento, das estações 2 e 4, coletadas em maio/98, analisadas em triplicata (A, B e C).....

Figura 5.4 - Valores de áreas dos cromatogramas das amostras de águas das estações 2 e 4, coletadas em junho/98, analisadas em duplicata (A e B) e triplicata (A, $\mathrm{B}$ e C)

Figura 5.5 - Valores de áreas dos cromatogramas das amostras de sedimento das estações 2 e 4, coletadas em junho/98, analisadas em triplicata (A, B e C) para o ultra-som e extraída sem repetição em Soxhlet e com agitação com barra magnética 
Figura 5.6 - Valores de áreas dos cromatogramas das amostras de águas das estações 1,2, 3 e 4, coletadas em novembro/98, analisadas em triplicata (A, B e C)....

Figura 5.7 - Valores de área des cromatogramas das amostras de sedimento das estações 1, 2, 3 e 4, coletadas em novembro/98, analisadas em triplicatas (A, B e C)

Figura 5.8 - Valores das áreas de cromatogramas das amostras de águas das estações 1, 2, 3 e 4, coletadas em fevereiro/99, analisadas em triplicata (A, B e C)

Figura 5.9 - Valores de áreas dos cromatogramas das amostras de sedimentos das estações 1, 2, 3 e 4, coletadas em fevereiro/99.

Figura 5.10 - Vista parcial do entorno da estação 1, ponto de captação de água para a cidade de sumaré, localizado a $22^{0} 45^{\prime} 43.7^{\prime \prime}$ s; $47^{0} 10^{\prime} 30.3^{\prime \prime}$ w, rio Atibaia, coleta de novembro de1998.

Figura 5.11 - Perfis de $\mathrm{pH}$ temperatura $\left({ }^{\circ} \mathrm{C}\right)$, oxigênio dissolvido $(\mathrm{mg} / \mathrm{l})$, condutividade $(\mu \mathrm{S} / \mathrm{cm})$ e turbidez (uT), na estação 1 , campanha de Novembro e Fevereiro.

Figura 5.12 - Valores das áreas obtidas pelas análises cromatográficas das amostras de água da estação 1 , coletadas em novembro/98 e fevereiro/99.

Figura 5.13 - Valores de material em suspensão total, frações inorgânicas e orgânicas e carbono total, frações inorgânicas e orgânicas das amostras de água da estação 1 de novembro/98 e fevereiro/99.

Figura 5.14 - Valores das áreas obtidas por análise cromatográfica das amostras de sedimento da estação 1 de novembro/98 e fevereiro/99.

Figura 5.15 - Valores de carbono orgânico total e umidade total a $60^{\circ} \mathrm{C}$ e $110^{\circ} \mathrm{C}$ das amostras de sedimento da estação 1 de novembro/98 e fevereiro/99.

Figura 5.16 - Vista parcial do entorno da estação 2, entrada do alagado, localizado a $22^{0} 44^{\prime} 46.7^{\prime \prime} \mathrm{S} ; 47^{0} 11^{\prime} 20.3^{\prime \prime} \mathrm{W}$, início do primeiro compartimento, coleta de novembro de 1998

Figura 5.17 - Valores das áreas obtidas pelas análises cromatográficas das amostras de água da estação 2 de maio, junho e novembro/98 e fevereiro/99.

Figura 5.18 - Valores do material em suspensão total, frações inorgânicas e orgânicas e carbono total, frações inorgânicas e orgânicas das amostras de água da estação 2 de maio, junho e novembro/98 e fevereiro/99.

Figura 5.19 - Valores das área obtidas por análises cromatográficas das amostras de sedimento da estação 2 de maio, junho e novembro/98 e fevereiro/99 
Figura 5.20 - Valores de carbono orgânico total e umidade total a $60^{\circ} \mathrm{c}$ e $110^{\circ} \mathrm{c}$ das amostras de sedimento da estação 2 de novembro/98 e fevereiro/99.

Figura 5.21 - Perfis de $\mathrm{pH}$, temperatura $\left({ }^{\circ} \mathrm{C}\right)$, oxigênio dissolvido $(\mathrm{mg} / \mathrm{l})$, condutividade $(\mu \mathrm{S} / \mathrm{cm})$ e turbidez (uT), na estação 2, campanha de Maio, Junho, Novembro de 1998 e Fevereiro de 1999.

Figura 5.22 - Vista parcial do entorno da estação 3, localizada a $22^{0} 43^{\prime} 32.8^{\prime \prime}$ S; $47^{0} 13^{\prime} 45^{\prime}$ ' W, centro do segundo compartimento, coleta de novembro de 1998.

Figura 5.23 - Vista parcial do entorno da estação 3, localizada a $22^{\circ} 43^{\prime} 32.8^{\prime \prime}$ S; $47^{0} 13^{\prime} 45^{\prime}$ ' W, centro do segundo compartimento, coleta de fevereiro de 1999.

Figura 5.24 - Vista parcial do ponto de saída dos barcos para as coletas, coleta de novembro de 1998.

Figura 5.25 - Vista parcial do ponto de saída dos barcos para as coletas, coleta de fevereiro de 1999.

Figura 5.26 - Valores das áreas obtidas pelas análises cromatográficas das amostras de água da estação 3 de novembro/98 e fevereiro/99.

Figura 5.27 - Valores do material em suspensão total, frações inorgânicas e orgânicas e carbono total, frações inorgânicas e orgânicas das amostras de água da estação 3 de novembro/98 e fevereiro/99.

Figura 5.28 - Valores das áreas obtidas pelas análises cromatográficas das amostras de sedimento da estação 3 de novembro/98 e fevereiro/99.

Figura 5.29 - Valores de carbono orgânico total e umidade total a $60^{\circ} \mathrm{C}$ e $110^{\circ} \mathrm{C}$ das amostras de sedimento da estação 3, coletadas em novembro/98 e fevereiro/99.

Figura 5.30 - Perfis de $\mathrm{pH}$, temperatura $\left({ }^{\circ} \mathrm{C}\right)$, oxigênio dissolvido $(\mathrm{mg} / \mathrm{l})$, condutividade $(\mu \mathrm{S} / \mathrm{cm})$ e turbidez (uT), na estação 3, campanhas de Novembro de 1998 e Fevereiro de1999.

Figura 5.31 - Vista parcial do entorno da estação 4, localizada a 22041'58.3' S; 47016'38.6" W, centro do segundo compartimento, coleta de novembro de 1998.

Figura 5.32 - Valores das áreas obtidas pelas análises cromatográficas das amostras de água da estação 4, coletadas em maio, junho e novembro/98 e fevereiro/99. 
Figura 5.33 - Valores do material em suspensão total, frações inorgânicas e orgânicas e carbono total, frações inorgânicas e orgânicas, das amostras de água da estação 4, coletadas em maio, junho e novembro/98 e fevereiro/99

Figura 5.34 - Valores das áreas obtidas pelas análises cromatográficas das amostras de sedimento da estação 4, coletadas em maio, junho e novembro/98.................

Figura 5.35 - Valores de carbono orgânico total e umidade total a 600c e 1100c das amostras de sedimento da estação 4, coletadas em maio, junho e novembro/98 e fevereiro/99.

Figura 5.36 - Perfis de $\mathrm{pH}$, temperatura $\left({ }^{\circ} \mathrm{C}\right)$, oxigênio dissolvido $(\mathrm{mg} / \mathrm{l})$, condutividade $(\mu \mathrm{S} / \mathrm{cm})$ e turbidez, na estação 4 , campanhas de maio, junho, e novembro de 1998 e fevereiro de 1999.

Figura 1F - Gráficos das curvas de caibração das amostras de sedimento.

Figura 2F - Gráficos das curvas de caibração das amostras de água.

Figura 1G - (a) Cromatograma da amostra de água, estação 2, coletada em maio de 1998; (b) Cromatograma da amosra de água, estação 2, coletada em junho de 1998; (c) Cromatograma da amosra de água, estação 4, coletada em junho de 1998.

Figura 2G - (a) Cromatograma da amostra de água, estação 2, coletada em novembro de 1998; (b) Cromatograma da amosra de água, estação 3 (0 m), coletada em novembro de 1998; (c) Cromatograma da amosra de água, estação 3 (2 m), coletada em novembro de 1998.

Figura 3G - (a) Cromatograma da amostra de água, estação $3(7 \mathrm{~m})$, coletada em novembro de 1998; (b) Cromatograma da amosra de água, estação 4 (0 m), coletada em novembro de 1998; (c) Cromatograma da amosra de água, estação 4 (8 m), coletada em novembro de 1998.

Figura 4G - (a) Cromatograma da amostra de água, estação 1, coletada em fevereiro de 1999; (b) Cromatograma da amosra de água, estação 2, coletada em fevereiro de 1999; (c) Cromatograma da amosra de água, estação 3, coletada em fevereiro de 1999

Figura 5G - (a) Cromatograma da amostra de água, estação $4(0 \mathrm{~m})$, coletada em fevereiro de 1999; (b) Cromatograma da amosra de água, estação 4 (2,5 m), coletada em fevereiro de 1999; (c) Cromatograma da amosra de água, estação 4 (4 m), coletada em fevereiro de 1999. 
Figura 1H - (a) Cromatograma da amostra de sedimento, estação 2, coletada em maio de 1998, extraída com ultra-som; (b) Cromatograma da amostra de sedimento, estação 4, coletada em maio de 1998, extraída com ultrasom

Figura 2H - (a) Cromatograma da amostra de sedimento, estação 2, coletada em junho de 1998, extraída com ultra-som; (b) Cromatograma da amostra de sedimento, estação 2, coletada em junho de 1998, extraída sob agitação com barra magnética; (c) Cromatograma da amostra de sedimento, estação 2, coletada em junho de 1998, extraída com Soxhlet.

Figura 3H - (a) Cromatograma da amostra de sedimento, estação 4, coletada em junho de 1998, extraída com ultra-som; (b) Cromatograma da amostra de sedimento, estação 4, coletada em junho de 1998, extraída sob agitação com barra magnética; (c) Cromatograma da amostra de sedimento, estação 4, coletada em junho de 1998, extraída com Soxhlet.

Figura 4H - (a) Cromatograma da amostra de sedimento, estação 1, coletada em novembro de 1998, extraída com ultra-som; (b) Cromatograma da amostra de sedimento, estação 1, coletada em novembro de 1998, extraída sob agitação com barra magnética; (c) Cromatograma da amostra de sedimento, estação 1, coletada em novembro de 1998, extraída com Soxhlet

Figura 5H - (a) Cromatograma da amostra de sedimento, estação 2, coletada em novembro de 1998, extraída com ultra-som; (b) Cromatograma da amostra de sedimento, estação 2, coletada em novembro de 1998, extraída extraída com Soxhlet; (c) Cromatograma da amostra de sedimento, estação 3, coletada em novembro de 1998, extraída com ultra-som.

Figura 6H - (a) Cromatograma da amostra de sedimento, estação 4, coletada em novembro de 1998, extraída com ultra-som; (b) Cromatograma da amostra de sedimento, estação 4, coletada em novembro de 1998, extraída sob agitação com barra magnética; (c) Cromatograma da amostra de sedimento, estação 4, coletada em novembro de 1998, extraída com Soxhlet.

Figura $7 \mathrm{H}$ - (a) Cromatograma da amostra de sedimento, estação 1, coletada em fevereiro de 1999, extraída com ultra-som; (b) Cromatograma da amostra de sedimento, estação 1, coletada em fevereiro de 1999, extraída sob agitação com barra magnética. 
Figura 8H - (a) Cromatograma da amostra de sedimento, estação 2, coletada em fevereiro de 1999, extraída com ultra-som; (b) Cromatograma da amostra de sedimento, estação 2, coletadaem fevereiro de 1999, extraída extraída sob agitação com barra magnética.

Figura 9H - (a) Cromatograma da amostra de sedimento, estação 3, coletada em fevereiro de 1999, extraída com ultra-som; (b) Cromatograma da amostra de sedimento, estação 3, coletada em fevereiro de 1999, extraída sob agitação com barra magnética; (c) Cromatograma da amostra de sedimento, estação 3, coletada em fevereiro de 1999, extraída com Soxhlet

Figura 10H - (a) Cromatograma da amostra de sedimento, estação 4, coletada em fevereiro de 1999, extraída com ultra-som; (b) Cromatograma da amostra de sedimento, estação 4, coletada em fevereiro de 1999, extraída sob agitação com barra magnética; (c) Cromatograma da amostra de sedimento, estação 4, coletada em fevereiro de 1999, extraída com Soxhlet.

Figura 1I - (a) Cromatograma da amostra de padrões de clorofenóis; (b) Cromatograma da amostra padrão interno, extraída segundo método proposto por DAMIANOVIC (1997) e injetada em cromatógafo a gás Hewlett Packard 5890, série II, com detector de captura de elétrons

Figura 1J - Cromatograma da amostra de n-hexano purificado, derivatizado e injetado em cromatógafo a gás Hewlett Packard 5890, série II, com detector de captura de elétrons. 


\section{LISTA DE TABELAS}

Tabela 3.1 - Possíveis origens de vários clorofenóis......................................................... 10

Tabela 3.2 - Carga remanescente de Fenóis - Kg/dia........................................................ 27

Tabela 3.3 - $\quad$ Sistemas de esgotos e cargas orgânicas de origem doméstica...................... 30

Tabela 3.4 - Carga orgânica industrial remanescente - $\operatorname{Kg} \operatorname{DBO}(5,20) /$ dia...................... 31

Tabela 3.5 - $\quad$ Indústrias e suas respectivas atividades...................................................... $\quad 32$

Tabela 4.1 - Principais etapas percorridas para adequação dos métodos de extração e limpeza das amostras de água.................................................................. 47

Tabela 4.2 - Procedimentos experimentais para adequação dos métodos de extração e limpeza das amostras de água..................................................................... 47

Tabela 4.3 - $\quad$ Principais etapas percorridas para adequação do método de extração e limpeza das amostras de sedimento.

Tabela 4.4 - Teste de comparação entre os métodos de extração de clorofenóis de sedimentos

Tabela 4.5 - Amostras e concentrações utilizadas na dopagem e volumes de solvente após a extração no teste feito para avaliar quantitativamente as amostras de Salto Grande extraídas pelo método do ultra-som

Tabela 4.6 - Preparação de curva de calibração para determinação da concentração de clorofenóis

Tabela 4.7 - $\quad$ Especificações dos padrões cromatográficos utilizados nas dopagens das amostras

Tabela 4.8 - Tempos de retenção determinados pelo cromatógrafo a gás Hewlett Packard (HP) 5980, nas condições cromatográficas dadas.

Tabela 5.1- Resultados dos testes de limpeza, valores de áreas cromatográficas e tempo de retenção para o padrão PCP........................................................ 64

Tabela 5.2 - Padrões de clorofenóis e respectivos tempos de retenção.............................. $\quad 64$

Tabela 5.3 - Considerações sobre os procedimentos estudados com o emprego do Soxhlet para extração dos clorofenóis nas amostras dos sedimentos dos reservatórios do Broa e de Salto Grande. 
Tabela 5.4 - Valores das áreas cromatográficas de clorofenóis obtidos pela extração com Soxhlet, variando-se o tempo de extração e o volume de solvente.......

Tabela 5.5 - Valores das áreas cromatográficas de clorofenóis obtidos pela extração com Soxhlet, variando-se a coluna de limpeza utilizada...............................

Tabela 5.6 - Valores das áreas cromatográficas de clorofenóis obtidos pela extração com Soxhlet, variando-se o tipo de coluna de limpeza utilizada

Tabela 5.7 - Valores das áreas cromatográficas de clorofenóis obtidos pela extração com Soxhlet, variando-se o tipo de coluna de limpeza utilizada

Tabela 5.8 - Valores das áreas cromatográficas de clorofenóis obtidos pela extração com Soxhlet, utilizando-se diferentes volumes para eluição da amostra.....

Tabela 5.9 - Considerações sobre os procedimentos estudados com o emprego da agitação com barra magnética

Tabela 5.10 - Considerações sobre os procedimentos estudados com o emprego do ultra-som.

Tabela 5.11 - Valores das áreas cromatográficas de clorofenóis no emprego da agitação com barra magnética

Tabela 5.12 - Valores das áreas cromatográficas de clorofenóis no emprego do ultrasom, utilizando-se diferentes formas de limpeza.

Tabela 5.13 - Valores das áreas cromatográficas de clorofenóis no emprego do ultrasom, testando-se a utilização da acidificação (1).

Tabela 5.14 - Valores das áreas cromatográficas de clorofenóis no emprego do ultrasom, testando-se a utilização da acidificação (2)

Tabela 5.15 - Valores das áreas cromatográficas de clorofenóis no emprego do ultrasom, testando-se a utilização da acidificação e alcalinização com diferentes tipos de solventes

Tabela 5.16 - Valores das áreas cromatográficas de clorofenóis no emprego do ultrasom, testando-se a utilização da acidificação com diferentes tipos de solventes.

Tabela 5.17 - Valores das áreas cromatográficas de clorofenóis no emprego do ultrasom, testando-se a utilização da limpeza e diferentes tipos de solventes....

Tabela 5.18 - Valores das áreas cromatográficas de clorofenóis obtidos no teste de eficiência utilizando ultra-som como método de extração

Tabela 5.19 - Resultados das injeções cromatográficas das amostras da estação 2 dopadas para padrões 
Tabela 5.20 - Resultados das injeções cromatográficas das amostras da estação 4 dopadas para padrões.

Tabela 5.21 - Resultados obtidos das injeções cromatográficas do teste de comparação entre os métodos de extração para sedimentos.

Tabela 5.22 - Resultados obtidos das injeções cromatográficas da solução de trabalho utilizada na dopagem dos sedimentos e da água com padrão interno utilizada para dopagem do branco no teste de comparação entre os métodos de extração para sedimentos....

Tabela 5.23 - Parâmetros climatológicos registrados nas campanhas................................. 81

Tabela 5.24 - Médias mensais dos valores de radiação solar para as campanhas............... 82

Tabela 5.25 - Médias mensais dos valores da velocidade do vento para as campanhas....

Tabela 5.26 - Médias mensais dos valores de precipitação para as campanhas.................. 83

Tabela 5.27 - Médias mensais dos valores de temperatura para as campanhas................ $\quad 83$

Tabela 5.28 - Tempo de Residência (dias) e vazão média mensal de saída (m3/s) de Fevereiro/98 a Fevereiro/99.

Tabela 5.29 - Ficha de bordo: variáveis físico-químicas medidas na estação 2, na campanha de Maio/98.

Tabela 5.30 - Ficha de bordo: variáveis físico-químicas medidas na estação 4, na campanha de Maio/98

Tabela 5.31 - Resultados das análises de material em suspensão total e das frações orgânica e inorgânica, e carbono total e das frações orgânica e inorgânica das amostras de água da campanha de Maio/98.

Tabela 5.32 - Ficha de bordo: variáveis físico-químicas medidas na estação 2, na campanha de Junho/98.

Tabela 5.33 - Ficha de bordo: variáveis físico-químicas medidas na estação 4, na campanha de Junho/98.

Tabela 5.34 - Resultados das análises de material em suspensão total e das frações orgânicas e inorgânicas das amostras de água da campanha de Junho/98...

Tabela 5.35 - Resultados das análises de carbono total e das frações orgânicas e inorgânicas das amostras de água da campanha de Junho/98...

Tabela 5.36 - Ficha de bordo: variáveis físico-químicas medidas na estação 1, na campanha de Novembro/98

Tabela 5.37 - Ficha de bordo: variáveis físico-químicas medidas na estação 2, na campanha de Novembro/98

Tabela 5.38 - Ficha de bordo: variáveis físico-químicas medidas na estação 3, na campanha de Novembro/98 
Tabela 5.39 - Ficha de bordo: variáveis físico-químicas medidas na estação 4, na campanha de Novembro/98.

Tabela 5.40 - Resultados das análises de material em suspensão total e das frações orgânicas e inorgânicas das amostras de água da campanha de Novembro/98.

Tabela 5.41 - Resultados das análises de carbono total e das frações orgânicas e inorgânicas das amostras de água da campanha de Novembro/98.

Tabela 5.42 - Resultados das análises de carbono total e umidade total a temperaturas de $60^{\circ} \mathrm{C}$ e $110^{\circ} \mathrm{C}$, das amostras de sedimento da campanha de Novembro/98

Tabela 5.43 - Resultados das análises de carbono total e umidade total a temperaturas de $60^{\circ} \mathrm{C}$ e $110^{\circ} \mathrm{C}$, das amostras de sedimento da campanha de Novembro/98.

Tabela 5.44 - Ficha de bordo: variáveis físico-químicas medidas na estação 1, na campanha de Fevereiro/99.

Tabela 5.45 - Ficha de bordo: variáveis físico-químicas medidas na estação 2, na campanha de Fevereiro/99.

Tabela 5.46 - Ficha de bordo: variáveis físico-químicas medidas na estação 3, na campanha de Fevereiro/99.

Tabela 5.47 - Ficha de bordo: variáveis físico-químicas medidas na estação 4, na campanha de Fevereiro/99.

Tabela 5.48 - Resultados das análises de material em suspensão total e das frações orgânicas e inorgânicas das amostras de água da campanha de Fevereiro/99.

Tabela 5.49 - Resultados das análises de carbono total e das frações orgânicas e inorgânicas das amostras de água da campanha de Fevereiro/99.

Tabela 5.50 - Resultados das análises de carbono total e umidade total (600C e 1100C) das amostras de sedimento da campanha de Fevereiro/98.

Tabela 5..51 - Resultados das análises de carbono total e umidade total (600C e 1100C) das amostras de sedimento da campanha de Fevereiro/98

Tabela 5.52 - Concentrações de clorofenóis em água e áreas de cromatogramas.

Tabela 5.53 - Equações obtidas a partir dos valores das áreas dos cromatogramas para a preparação das curvas de calibração de clorofenóis em água (Anexo C)....

Tabela 5.54 - Concentrações de clorofenóis nas amostras de sedimentos e áreas obtidas nas análises por CG/DCE. 
Tabela 5.55 - Teste para verificação de perda de clorofenóis ocorridas na coluna de

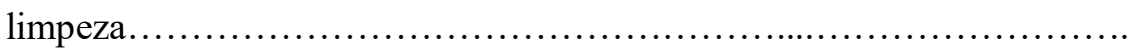

Tabela 5.56 - Equações obtidas a partir dos valores das áreas dos cromatogramas para a preparação das curvas de calibração de clorofenóis nos sedimentos.

Tabela A.1 - Procedimentos de extração com Soxhlet e resposta analítica, através da cromatografia gasosa.

Tabela A.2 - Procedimentos de extração com Soxhlet e resposta analítica, através da cromatografia gasosa. Teste 1 - Volume do solvente e tempo de extração.

Tabela A.3 - Procedimentos de extração com Soxhlet e resposta analítica, através da cromatografia gasosa. Teste 2 - Limpeza das amostras

Tabela A.4 - Procedimentos de extração com Soxhlet e resposta analítica, através da cromatografia gasosa. Teste 3 - Limpeza das amostras

Tabela A.5 - Procedimentos de extração com Soxhlet e resposta analítica, através da cromatografia gasosa. Teste 4 - Limpeza das amostras

Tabela B.1. Procedimentos de extração com agitação com barra magnética e resposta analítica, através da cromatografia gasosa. Teste 1 - Extração, tipo e volume de solvente

Tabela C.1 Procedimentos de extração com ultra-som e resposta analítica, através da cromatografia gasosa. Teste 1 - Coluna de limpeza.

Tabela C.2 - Procedimentos de extração com ultra-som e resposta analítica, através da cromatografia gasosa. Teste 2 - Utilização de amostra acidificada ou não acidificada com n-hexano/acetona 4:1

Tabela C.3 - Procedimentos de extração com ultra-som e resposta analítica, através da cromatografia gasosa. T este 3 - Utilização de amostra acidificada ou não acidificada com n-hexano/acetona $3: 1$.

Tabela C.4 - Procedimentos de extração com ultra-som e resposta analítica, através da cromatografia gasosa. Teste 4 - Utilização de amostra acidificada alcalinizada com diferentes solventes

Tabela C.5 - Procedimentos de extração com ultra-som e resposta analítica, através da cromatografia gasosa.Teste 5 - Utilização de amostra acidificada ou não acidificada com diferentes tipos de solventes

Tabela C.6 - Procedimentos de extração com ultra-som e resposta analítica, através da cromatografia gasosa. - Teste 6 - Utilização de diferentes solventes com ou sem limpeza. 
Tabela D.1 - Resultados das injeções em CG/DCE das amostras de água da campanha de novembro/98/Estação 3 (superfície)........................................................ 165

Tabela D.2 - Resultados das injeções em CG/DCE das amostras de água da campanha de maio/98/Estação 2 .

Tabela D.3 - Resultados das injeções em CG/DCE das amostras de água da campanha de junho/98/Estação 2

Tabela D.4 - Resultados das injeções em CG/DCE das amostras de água da campanha de junho/98/Estação 4

Tabela D.5 - Resultados das injeções em CG/DCE das amostras de água da campanha de novembro/98/Estação 2

Tabela D.6 - Resultados das injeções em CG/DCE das amostras de água da campanha de novembro/98/Estação 3 (superfície)

Tabela D.7 - Resultados das injeções em CG/DCE das amostras de água da campanha de novembro/98/Estação 3 (intermediário)

Tabela D.8 - Resultados das injeções em CG/DCE das amostras de água da campanha de novembro/98/Estação 3 (fundo)

Tabela D.9 - Resultados das injeções em CG/DCE das amostras de água da campanha de novembro/98/Estação 4 (superfície)

Tabela D.10 - Resultados das injeções em CG/DCE das amostras de água da campanha de novembro/98/Estação 4 (intermediário)

Tabela D.11 - Resultados das injeções em CG/DCE das amostras de água da campanha de novembro/98/Estação 4 (fundo)

Tabela D.12 - Resultados das injeções em CG/DCE das amostras de água da campanha de fevereiro/98/Estação 1

Tabela D.13 - Resultados das injeções em CG/DCE das amostras de água da campanha de fevereiro/98/Estação 2)

Tabela D.14 - Resultados das injeções em CG/DCE das amostras de água da campanha de fevereiro/98/Estação 3

Tabela D.15 - Resultados das injeções em CG/DCE das amostras de água da campanha de fevereiro/98/Estação4(superfície)

Tabela D.16 - Resultados das injeções em CG/DCE das amostras de água da campanha de fevereiro/98/Estação 4 (intermediário)

Tabela D.17 - Resultados das injeções em CG/DCE das amostras de água da campanha de fevereiro/98/Estação 4 (fundo)

Tabela E.1 - Resultados das injeções em CG/DCE das amostras de sedimento da campanha de maio/98/Estação 2 
Tabela E.2 - Resultados das injeções em CG/DCE das amostras de sedimento da campanha de maio/98/Estação 4............................................................... 168

Tabela E.3 - Resultados das injeções em CG/DCE das amostras de sedimento da campanha de junho/98/Estação 2......................................................... 168

Tabela E.4 - Resultados das injeções em CG/DCE das amostras de sedimento da de campanha de junho/98/Estação 4

Tabela E.5 - Resultados das injeções em CG/DCE das amostras de sedimento da campanha de novembro/98/Estação 1

Tabela E.6 - Resultados das injeções em CG/DCE das amostras de sedimento da campanha de novembro/98/Estação 2 .

Tabela E.7 - Resultados das injeções em CG/DCE das amostras de sedimento da campanha de novembro/98/Estação 3.....

Tabela E.8 - Resultados das injeções em CG/DCE das amostras de sedimento da campanha de novembro/98/Estação 4

Tabela E.9 - Resultados das injeções em CG/DCE das amostras de sedimento da campanha de fevereiro/98/Estação 1

Tabela E.10 - Resultados das injeções em CG/DCE das amostras de sedimento da campanha de fevereiro/98/Estação 2 .

Tabela E.11 - Resultados das injeções em CG/DCE das amostras de sedimento da campanha de fevereiro/98/Estação 3

Tabela E.12 - Resultados das injeções em CG/DCE das amostras de sedimento da campanha de fevereiro/98/Estação 4 .

Tabela 1F - Concentrações de padrões de clorofenóis e áreas de picos encontradas para amostras de sedimento.

Tabela 2F - Teste de limpeza de amostra utilizando coluna de sílica (3 $\mathrm{cm})$.

Tabela 3F - Concentrações de padrões de clorofenóis e médias dos picos de área cromatográficos

Tabela 4F - Equações das curvas de calibração e desvios

Tabela 5F - Concentrações de padrões de clorofenóis e picos de áreas cromatográficos para amostras de água

Tabela 6F - Concentrações de padrões de clorofenóis e médias dos picos de área cromatográficos

Tabela 7F - Equações das curvas de calibração e desvios 179 


\section{LISTA DE ABREVIATURAS E SIGLAS}

\section{2,4- DBP - 2,4-Dibromofenol}

ACPO - Associação de Funcionários Contaminados por Organoclorados

CETESB - Companhia de Tecnologia e Saneamento Ambiental

CG - Cromatografia Gasosa

CHL's - Compostos Clorados

CIAGRI - Centro de Informática do Campus “ Luiz de Queiroz”/USP

CONAMA - Conselho Nacional do Meio Ambiente

COT - Carbono Orgânico Total

CPFL - Companhia Paulista de Força e Luz

CPLA - Coordenadoria de Planejamento Ambiental

DAEE - Departamento de Águas e Energia Elétrica

DBO - Demanda Bioquímica De Oxigênio

DCE - Detector de Captura de Elétrons

DCP - Diclorofenol

DDT - 1,1,1 -Tricloro-2,2-bis(p-clorofenil)etano

EC - Comissão européia

ETE - Estação de Tratamento de Esgoto

FPQ - Filtro Previamente Calcinado

FS - Filtro seco

HCH's - Hexaclorociclohexanos

HP - Hewlett Packard

HPLC - "Hight Pure Liquid Chromatographic"

MAE - Extração por Microondas

MSI - Material em Suspensão Inorgânico

MSO - Material em Suspensão Orgânico

MST - Material em Suspensão Total

n.d. - Não Determinado

OD - Oxigênio Dissolvido

PCB's - Bifenilas Policloradas 
PCP - Pentaclorofenol

PO’s - Compostos Tóxicos Organoclorados

POC's - Fenóis Policlorados

POP's - Poluentes Orgânicos Persistentes

SANASA - Sociedade de Abastecimento de Água e Saneamento de Campinas

SEADE - Fundação Estadual de Análise de Dados

SM - Espectrometria De Massa

SMEWW - Standard Methods Examination Water And Wastewater

TCP - Triclorofenol

US EPA - Agência de Proteção Ambiental dos EUA 


\title{
LISTA DE SÍMBOLOS
}

\author{
$\mu \mathrm{L}-$ Microlitros \\ ${ }^{0} \mathrm{C}$ - Grau Celsius \\ $\mathrm{H}_{2} \mathrm{SO}_{4}-$ Ácido Sulfúrico \\ M - Massa \\ MW - Megawatt \\ $\mathrm{NaOH}$ - Hidróxido de Sódio \\ pKa - Constante de Dissociação \\ rpm - Rotações por Minuto \\ u.m.a - Unidade de Massa \\ uT - Unidade de Turbidez
}




\section{RESUMO}

CARMO, D. F. (2000). Avaliação da presença de clorofenóis no reservatório de Salto Grande, situado na região de Americana, Estado de São Paulo. São Carlos. 190p. Dissertação (Mestrado) - Escola de Engenharia de São Carlos, Universidade de São Paulo.

O reservatório de Salto Grande está localizado na região do Município de Americana do Estado de São Paulo. Encontra-se hipereutrofizado, em estágio avançado de contaminação e, em conseqüência, causa diversos problemas sócio-econômicos. Parte da Bacia Hidrográfica do rio Piracicaba, os aportes principais de poluentes são de origens doméstica e industrial, além dos gerados pela lixiviação de áreas agrícolas da bacia. Dentre os contaminantes, há fenóis nas cargas remanescentes das principais indústrias, destacando-se as indústrias químicas, cujos produtos manufaturados são corantes e matérias primas do segmento Nylon. O estudo sobre a distribuição qualitativa e quantitativa de clorofenóis nos sedimentos e nas águas do reservatório é importante devido a seus efeitos tóxicos e persistência. Este trabalho visou determinar os clorofenóis (pentaclorofenol, triclorofenol e diclorofenol) por cromatografia gasosa (CG/DCE), em amostras coletadas em quatro estações no reservatório, no período seco (Maio e Junho/98), e no período chuvoso (Novembro/98 e Fevereiro/99). Além disso, foram determinadas algumas variáveis físico-químicas do sistema (temperatura, oxigênio dissolvido, turbidez, condutividade, pH, material em suspensão, carbono orgânico, teor de umidade do sedimento), nas mesmas estações, como também foram consideradas as condições climatológicas da área do reservatório e suas variáveis hidráulicas e morfométricas. As etapas para as análises cromatográficas envolveram extração dos clorofenóis das amostras de água por extração líquido-líquido, e estudo do método de extração mais adequado dos clorofenóis das amostras de sedimentos (ultrasom, Soxhlet e agitação). Nas condições estudadas, os valores de clorofenóis das amostras de água e de sedimento encontraram-se na faixa de 0,010 a $0,022 \mu \mathrm{g} / \mathrm{L}$, na água e inferiores a 0,50 $\mu \mathrm{g} / \mathrm{Kg}$, no sedimento. Pelas variáveis analisadas, bem como pelos resultados obtidos, possivelmente vários fatores influíram na disponibilidade desses compostos para o meio, como pH, material em suspensão, carbono orgânico dissolvido, radiação solar e precipitação, removendo-os do meio por adsorção, fotólise, diluição e degradação microbiana. Pelos resultados encontrados nas análises cromatográficas, as concentrações dos clorofenóis na água desse reservatório estão abaixo do limite exigido por lei, $0,10 \mu \mathrm{g} / \mathrm{L}$.

Palavras-chave: clorofenóis; extração; sedimento; água, reservatório; Salto Grande. 


\section{ABSTRACT}

CARMO, D. F. (2000). Evaluation of chlorophenols in the Salto Grande reservoir, American region, State of São Paulo. São Carlos. 190p. Dissertação (Mestrado) - Escola de Engenharia de São Carlos, Universidade de São Paulo.

Salto Grande reservoir, an important municipal water system located in the region of municipal district of Americana, State of São Paulo, has a history of water quality deterioration as the result of cultural eutrophication. In consequence, noticeable social and economical problems occurred. Wastewater effluents, domestic and industrial effluents and lixiviate of agricultural areas, discharged in the Piracicaba watershed are the main contribution of reservoir pollutants. Industrial pollutants can be phenols present in the remaining loads of certain industries, standing out the chemical industries, whose manufactured products are coloring and matters as the segment Nylon. The studies on qualitative and quantitative distribution of chlorophenols in the sediments and waters of Salto Grande reservoir it is important due to its toxicant effects and persistence. This work aimed to determine the chlorophenols (pentachlorophenol, trichlorophenol and dichlorophenol) for gas chromatographic (CG/DCE) in samples collected in four stations in the reservoir, during a dry season (May and June/98) and rainy period (November/98 and February/99). Physical-chemical parameters (temperature, dissolved oxygen, turbidity, conductivity, $\mathrm{pH}$, suspension material, organic carbon, sediment humidity) were determined, and climatological conditions, hydraulic variables and morphological data were considered as well. Chromatographics analyses were done after extraction of chlorophenols using liquid-liquid extraction method for water samples and three different methods of extraction of chlorophenols from the sediments samples, ultra-sound, Soxhlet and agitation. Under studied conditions, the values of chlorophenols from water and sediment samples were respectively in the range of 0,010 to $0,022 \mu \mathrm{g} / \mathrm{L}$ and inferior of 0,50 $\mu \mathrm{g} / \mathrm{Kg}$. Several factors could be influenced the presence of chlorophenols in the samples, such as $\mathrm{pH}$, suspension material, dissolved organic carbon, solar radiation and precipitation, by stimulation of adsorption, light degradation, dilution and microbial degradation. Considered the technical analyses applied, chromatographic analyses of chlorophenols showed concentrations in the water of Salto Grande reservoir below the limit demanded by law, $0,10 \mu \mathrm{g} / \mathrm{L}$.

Keywords: chlorophenols; extraction; sediment; water, reservoir; Salto Grande 


\section{INTRODUÇÃO}

A intensificação dos processos industriais e agrícolas, bem como da disponibilidade dos rejeitos domésticos no ambiente, constituem as principais fontes de compostos tóxicos nos corpos aquáticos.

O impacto dos poluentes tóxicos pode resultar em grandes modificações e na deterioração do ecossistema aquático a curto, médio e longo prazo, além de representar um enorme problema à saúde pública. Efeitos agudos dos compostos tóxicos nos organismos vivos podem provocar, por exemplo, a rápida mortandade de peixes e, mesmo que isto não ocorra, os efeitos crônicos sobre as espécies mais sensíveis ou menos resistentes levarão com o tempo à sua diminuição e/ou desaparecimento das mesmas. Os efeitos tóxicos ocorrem segundo uma escala temporal que depende de outros fatores, como o regime de vazão das descargas poluidoras nos corpos aquáticos receptores e os ciclos de vida dos organismos afetados (SALVADOR, 1990).

Dentre os poluentes químicos, os organoclorados merecem destaque por persistirem por longo período no ambiente, pois podem apresentar estruturas pouco comuns à degradação pelos microrganismos. São resistentes a hidrólise e sofrem reações fotoquímicas formando produtos com estabilidade similar ou superior àquela apresentada pela sua estrutura original (VIDAL, 1991).

Compostos organoclorados têm sido identificados em alimentos, ar, solo e nos tecidos de organismos aquáticos e terrestres. Dentre os organoclorados, os fenóis constituem a maior classe de químicos industriais, sendo precursores e produtos de degradação de muitos pesticidas. Particularmente, os clorofenóis são largamente usados na preservação de madeiras, couros, colas e tecidos. São utilizados também na síntese de herbicidas, fungicidas e foram, por décadas, amplamente utilizados como biocidas de largo espectro (DAMIANOVIC, 1997; ALONSO et al., 1998; SANTOS et al., 1998, LEE et al., 1998). O tratamento de águas de abastecimento com cloro pode também gerar clorofenóis (WEGMAN \& HOFSTEE, 1979 apud LEE et al., 1998). A ocorrência destes compostos em amostras de água e de sedimentos pode ser associada com a lixiviação de áreas agrícolas, efluentes industriais e domésticos. 
A deposição nos cursos d'água de materiais provenientes de atividades agrícolas, assim como o despejo de um número elevado de efluentes domésticos e industriais, agravam a cada ano a situação das bacias hidrográficas, contribuindo para problemas sociais e econômicos, como por exemplo, uma maior ocorrência de enchentes e doenças. Os clorofenóis oriundos da deposição e despejo de rejeitos são potencialmente carcinogênicos e altamente persistentes (KAWAMOTO, 1989 apud LEE et al., 1998).

A preocupação com a degradação ambiental e a busca pela conservação e recuperação dos ecossistemas têm aumentado muito. Os diversos danos causados por organoclorados tanto ao meio ambiente quanto à população, por exemplo, incitaram a busca de soluções de controle e mitigação. No Brasil, foi criada uma associação de funcionários contaminados por organoclorados (ACPO). Atualmente, a ACPO faz uma campanha mundial para conscientização da opinião pública sobre os malefícios causados a saúde humana pelos poluentes orgânicos persistentes (POPs), em especial as substâncias químicas organocloradas. Uma das conquistas dessas ações visando o controle dessas substâncias tóxicas foi a interdição judicial, em junho de 1993, da unidade química da Rhodia, localizada em Cubatão, devido a vários fatores, como a morte de dezenas de pessoas por intoxicação e a contaminação de 40 mil pessoas além de 2 milhões de metros quadrados de solo e de água contaminados, devido a despejos com um montante de 300 mil toneladas de lixo químico poluente. De 1966 a 1978, a unidade de Cubatão produziu o pentaclorofenol e somente suspendeu sua fabricação no mesmo ano em que vieram a público as denúncias de mortes de trabalhadores causadas por intoxicação com o produto (ACPO, 2000).

Para que seja feito o controle da poluição ambiental, um pré-requisito é a habilidade para identificar e quantificar os compostos xenobióticos tóxicos nos ecossistemas. Logo, a busca por um método rápido, eficiente e sensível tem sido uma constante, salientando-se as dificuldades encontradas devido aos compostos estarem presentes no meio em diferentes matrizes.

Vários são os métodos para extração de organoclorados de amostras de solo e sedimentos. Pode-se exemplificar com aqueles que empregam aparelhos como Soxhlet (AIROLDI, 1997; IWATA et al., 1994; FOLCH, 1996; KHODADOUST, 1999; BRUCKMEIER et al., 1997; ALONSO et al., 1998), ultra-som (KHODADOUST, 1999; LLOMPART et al., 1997) e microondas (ALONSO et al., 1998, LLOMPART et al., 1997), ou outros procedimentos como extração em fase sólida (OUBINA et al., 1997; IWATA et al.; 1994; PERES, 1997; VICINO; 1993; BELTRAN, et al., 1993; JUNG et al., 1996) e com fluido supercrítico (PERES, 1997). Na análise da água, o método tradicional é a extração em fase líquida (GASPAR et al., 1997; ZUIN, 1997; PERES, 1997), mas a extração em fase 
sólida também tem sido bastante adotada. A identificação dos compostos nos extratos é basicamente realizada por cromatografia líquida ou gasosa, empregando-se diferentes detectores.

Este trabalho teve como objetivo principal a identificação da presença dos clorofenóis no sedimento e na água do reservatório de Salto Grande (região de Americana, no Estado de São Paulo), procurando-se analisar essa presença em relação à variação espaçotemporal; e frente aos parâmetros usuais de avaliação da qualidade e condições de um sistema aquático (matéria orgânica total, $\mathrm{pH}$, condutividade, turbidez, temperatura, regime de ventos e pluviometria). O reservatório escolhido faz parte do mais importante núcleo urbano e industrial do Estado de São Paulo, depois da Grande São Paulo, e está na unidade de bacia hidrográfica do Atibaia. Suas margens são ocupadas principalmente por canaviais, chácaras, plantações de eucaliptos e citrus. O rio Atibaia, principal fonte de alimentação do reservatório, recebe parte dos esgotos domésticos e industriais dos municípios de Campinas e Paulínia, e em conseqüência, o reservatório encontra-se atualmente em processo de hipereutrofização (ROMANINI, 1989; DEBERDT, 1997; BITAR, 1998; BOTTURA, 1998; MORAES, 1999; RIOS, 1999; MINOTI, 1999).

Os clorofenóis estudados nas amostras foram o pentaclorofenol (PCP), o triclorofenol (TCP) e o diclorofenol (DCP), escolhidos pela disponibilidade de padrões analíticos, no Laboratório de Processos Biológicos do Departamento de Hidráulica e Saneamento da Escola de Engenharia de São Carlos/Universidade de São Paulo (EESCUSP). As análises de clorofenóis foram realizadas através de cromatografia gasosa de alta resolução, com detector de captura de elétrons. O detalhamento dos procedimentos de limpeza das amostras e extração dos compostos fenólicos clorados para determinação cromatográfica constitui umas das maiores contribuições aos objetivos da presente pesquisa.

Este trabalho faz parte de um projeto maior, "Bases Limnológicas e Ecológicas para o Manejo da Qualidade da Água e Usos Múltiplos do Reservatório de Salto Grande (SP)", coordenado pela Prof ${ }^{\text {a }}$ Dra. Maria do Carmo Calijuri do Departamento de Hidráulica e Saneamento da Escola de Engenharia de São Carlos da Universidade de São Paulo, que visa subsídios necessários à recuperação e manejo eficiente do reservatório de Salto Grande, através da proposta de um modelo para o desenvolvimento sustentável desse sistema aquático, bem como a transferência do conhecimento científico para a população do local. 


\section{OBJETIVOS}

\subsection{Objetivo Geral}

$\checkmark$ Estudar a distribuição qualitativa e quantitativa dos clorofenóis (pentaclorofenol, triclorofenol e diclorofenol) nos sedimentos e nas águas do reservatório de Salto Grande, região de Americana, Estado de São Paulo.

\subsection{Objetivos Específicos}

$\checkmark$ Verificar a distribuição espaço-temporal de clorofenóis em diferentes pontos do reservatório, em épocas de coleta previamente definidas;

Adaptar procedimentos para a extração dos clorofenóis dos sedimentos e águas do reservatório e análises cromatográficas;

$\checkmark$ Determinar parâmetros físico-químicos usuais dos sedimentos e águas do reservatório, a fim de avaliá-los em conjunto com a distribuição dos clorofenóis nas amostras. 


\section{REVISÃO DE LITERATURA}

\subsection{Impactos ambientais causados por compostos orgânicos halogenados e seus produtos de degradação}

De acordo com a resolução do CONAMA (Conselho Nacional do Meio Ambiente artigo 48, decreto n.88351/83, resolução n.001/1986): "Impacto Ambiental significa qualquer alteração das propriedades físicas, químicas e biológicas do meio ambiente, causada por qualquer forma de matéria ou energia resultante das atividades humanas, que direta ou indiretamente, afetem: a saúde, a segurança e o bem estar da população; as atividades sociais e econômicas; a biota; as condições estéticas e sanitárias do meio ambiente e as qualidades dos recursos ambientais".

A poluição química é responsável por diversos impactos, sendo desta forma, uma questão de grande preocupação com o aumento da consciência púbica para problemas ambientais (IWATA et al.,1994).

Alguns poluentes químicos são chamados xenobióticos por serem compostos artificialmente elaborados, e portanto exógenos e estranhos ao ambiente biológico, principalmente se são biocidas (HASKELL, 1985).

O uso destes compostos xenobióticos muito contribuiu para aumentar o rendimento na agricultura, proteger os rebanhos e eliminar vetores transmissores de doenças (THAO et al.,1993). Porém, foi responsável por diversos impactos ambientais. Em muitas áreas, o impacto foi causado pelo uso intensivo desses compostos, em função do crescimento populacional e da crescente demanda pelo suprimento de alimentos (MAIA, 1992). Os herbicidas e nematicidas merecem destaque por serem contaminantes ambientais potenciais, devido à sua aplicação direta no solo e possível transporte ao lençol freático, através das partículas do solo e da água de chuva (MAIA, 1992). 
É lícito supor que a intensificação da produção agrícola, o cultivo de monoculturas para a nutrição humana e o crescimento industrial, requerem a regularização do uso decompostos potencialmente tóxicos, visto que, águas naturais, solos, sedimentos, dentre outros, podem ser contaminados por esses ou por produtos de suas transformações. A simples proibição do uso destes compostos, se feita sem critérios, também pode ser responsável por diversos impactos ambientais.

Um exemplo que pode incorrer em ação proibitiva irregular é a tendência que há em julgar um grupo de compostos químicos, a partir de um representante da mesma classe, desconsiderando a especificidade e composição de cada composto, o que pode resultar na retirada do produto do mercado. Procedimentos como esses, podem não afetar as nações mais ricas, que rapidamente substituem os produtos proibidos por alternativos de maior custo. Por sua vez, nações pobres possuem graves problemas de saúde pública e provavelmente estão mais interessadas em solucionar seus problemas imediatos, sem considerar os efeitos ambientais em longo prazo, persistindo na utilização de tais substâncias (MAIA, 1992).

Dentre os poluentes químicos, os compostos organoclorados merecem destaque devido à contaminação e ao risco ecológico causado por seu uso indiscriminado e a sua produção em larga escala, desde a década de 50. Esses contaminantes ambientais têm sido considerados como onipresentes e persistentes em vários ambientes e biota (THAO et al., 1993).

Apesar de muitos países desenvolvidos terem proibido o uso de certos compostos altamente poluentes na década de 70, os organoclorados ainda são usados em países em desenvolvimento, principalmente na zona tropical (THAO et al., 1993).

Uma das consequiências mais sérias do uso indiscriminado de compostos organoclorados é o desenvolvimento de resistência nas pragas, bastante comum nos sistemas biológicos que procuram, de alguma forma, uma resposta a condições adversas do meio. Alguns desses compostos podem ter persistência de 10 a 12 anos no solo (VICINO, 1993).

Os insetos raramente perdem a resistência que adquirem e esta não se restringe apenas a um único composto químico, mas sim a um grupo de inseticidas. A resistência adquirida só desenvolve-se após uma exposição prolongada. Então, se há permanência dos compostos na água e no solo, é inevitável esta exposição por longo tempo. O desenvolvimento da resistência adquirida pelos insetos, exige o emprego de compostos mais ativos, para obtenção do mesmo resultado, levando a uma maior contaminação ambiental (MAIA, 1992). 
Em trabalho realizado nos estuários e ambientes costeiros marinhos das ilhas Fiji (região do Pacífico Sul), MORRISON et al. (1996) mostraram que nesses ambientes as populações estão particularmente suscetíveis às conseqüências do manuseio e disposição incorreta de compostos organoclorados. Os problemas são grandes devido à falta de registros formais relacionados aos tipos e quantidades usadas desses compostos. Assim, os autores (opt. cit.) indicaram que a primeira etapa para atingir a meta de proteção ambiental desse tipo de poluição na região, seria conseguir-se mudanças no uso dos compostos organoclorados, como a racionalização do emprego dos compostos nos países da região do Pacífico Sul e o monitoramento de produtos residuais e persistentes no meio.

A importância desta etapa é também observada quando se considera a rápida dissipação de produtos tóxicos no ambiente. As regiões tropicais e subtropicais podem facilitar essa rápida dissipação devido às condições climáticas de alta temperatura e chuvas intensas. Desta forma, esses compostos podem espalhar-se por todo o globo, atingindo até mesmo, áreas remotas, como o norte e o sul polares, através de transporte atmosférico de longo alcance. A transferência de poluentes através de longas distâncias é feita por meio de movimentos atmosféricos e esses poluentes podem penetrar na atmosfera por vaporização ou por co-destilação com água. Acredita-se que até $50 \%$ dos resíduos de poluentes encontrados na atmosfera são transferidos desta forma (THAO et al., 1993).

De acordo com o trabalho feito por IWATA et al. (1994), a fim de elucidar a distribuição de alguns organoclorados persistentes em ambientes tropicais, analisou-se a distribuição de alguns organoclorados em amostras de ar, águas de rios e sedimentos da Ásia oriental e meridional (Índia, Tailândia, Vietnã, Malásia e Indonésia), bem como da Oceania (Nova Guiné e Ilhas Solomons), para elucidar sua distribuição geográfica em ambientes tropicais. Concentrações dos organoclorados em amostras abióticas coletadas em Taiwan, Japão e Austrália foram monitoradas com fins de comparação. As concentrações atmosféricas e hidrosféricas de HCHs (hexaclorociclohexanos) e DDTs [1,1,1-Tricloro-2,2bis(p-clorofenil) etano] e seus metabólitos, em países tropicais em desenvolvimento, estavam aparentemente mais altas que as observadas em nações industrializadas, sugerindo o uso intensivo desses produtos em baixas latitudes. Os CHLs (compostos clorados) e PCBs (bifenilos policlorados) foram ocasionalmente observados em altos níveis nos trópicos, significando que seu uso nessas áreas tem-se expandindo para o sul. A distribuição de padrões de organoclorados em sedimentos mostrou pequenas variações espaciais em termos globais, indicando que esses produtos liberados nos ambientes tropicais são dispersos rapidamente através do ar e da água, e são menos retidos em sedimentos (IWATA et al., 1994). 
Considerando o potencial poluidor dos recursos naturais por contaminantes tóxicos, os resíduos industriais e os provenientes das atividades agrícolas apresentam maior potencial que os efluentes sanitários, pois estes são relativamente homogêneos e mais facilmente tratados pela autodepuração dos sistemas aquáticos receptores ou pela instalação de processos simples de tratamento (MONTICELI et al., 1993).

Dentre os organoclorados presentes em efluentes industriais e oriundos da lixiviação de áreas agrícolas, o impacto causado pelo HCB (hexaclorobenzeno), PCB e por fenóis, particularmente os clorofenóis, torna-os de grande interesse ambiental.

Os clorofenóis destacam-se como potencialmente poluidores, tóxicos e persistentes, sendo comumente formados em diferentes processos industriais, biogeoquímicos e de transformação de compostos tóxicos (OUBINA et al., 1997).

Segundo PAASIVIRTA apud ALONSO et al. (1998), recentes estudos têm demonstrado que compostos fenólicos, em particular clorofenóis, são os mais tóxicos contaminantes de nematóides do solo, como a minhoca, que é um animal considerado como um bom indicador da taxa de impacto de compostos químicos orgânicos no solo.

Exemplos desta contaminação potencial dos clorofenóis são observados em países como o Brasil, em que o Pentaclorofenol (PCP) e seus sais, foram amplamente utilizados como pesticidas. Atualmente, pela resolução $\mathrm{n}^{\circ}$ 005, de 20 de novembro de 1985, do Conselho Nacional do Meio Ambiente (CONAMA), o PCP e o Pentaclorofenato de sódio, estão entre as atividades consideradas potencialmente poluidoras e seu transporte, estocagem e uso, dependem de prévio licenciamento por órgão estadual competente, integrante do Sistema Nacional do Meio Ambiente ou da Secretaria Especial do Meio Ambiente.

A presença do PCP também pôde ser determinada no ar, água e solo de várias partes da Europa como resultado do uso por várias décadas (MUIR \& EDULJEE, 1999). Na década de 80, a preocupação com a toxicidade do PCP e potenciais efeitos adversos sobre o homem e o ambiente levaram a ações de regularização para limitar seu uso (MUIR \& EDULJEE, 1999).

\subsection{Fenóis e Clorofenóis}

Os fenóis ocorrem naturalmente, sendo unidades constituintes de plantas e formados como produtos em processos metabólicos (GUOLAN et al., 1996; TESAROVÁ \& PACÁKOVÁ, 1983). São também importantes matérias-primas de indústrias químicas, como por exemplo, de indústrias de resinas (fenóis-formaldeídos), de vernizes e de papéis, bem como de produtos farmacêuticos, inseticidas e herbicidas. Muitos compostos fenólicos são largamente usados como intermediários em sínteses químicas de vários biocidas de largo 
espectro, usados na preservação de alimentos, couros, colas, alguns tecidos e outros materiais. São especialmente usados como antioxidantes em materiais que contenham óleos ou gorduras (GUOLAN et al., 1996; TESAROVÁ \& PACÁKOVÁ, 1983).

A toxicidade das moléculas fenólicas apresenta-se, em grande maioria, em concentrações superiores aos limites organolépticos de aceitabilidade das águas. Os critérios de qualidade de água para consumo humano são baseados nos limiares de percepção de gosto e odor, que muitas vezes, são extremamente baixos, como no caso dos clorofenóis (LIMA \& ROMANELLI, 1995; WORLD HEALTH ORGANIZATION, 1987). O 2-clorofenol, por exemplo, apresenta uma concentração limite para percepção pelo organismo humano de 0,01 $\mu \mathrm{g} / \mathrm{L}$ (LIMA \& ROMANELLI, 1995).

Os clorofenóis são substâncias químicas orgânicas formadas a partir de uma molécula de fenol (1-hidroxibenzeno) com a substituição de um ou mais átomos de hidrogênio por um ou mais átomos de cloro, e representam a maior classe de contaminantes liberada no ambiente através de diferentes processos industriais. São contaminantes onipresentes na água e no solo. Quantidades significativas desses compostos podem ser formadas e atingem com certa facilidade o ambiente, como os subprodutos do processo de branqueamento de papel através do cloro, os resíduos municipais incinerados, as águas residuárias cloradas e os compostos de transformação de hexaclorobenzeno e lindano (WORLD HEALTH ORGANIZATION, 1987; DAMIANOVIC, 1997).

LORES et al. (1981), em seu trabalho sobre método para confirmação de clorofenóis na urina humana, apresenta uma tabela com alguns clorofenóis e suas possíveis origens (Tabela 3.1). Todos os clorofenóis apresentados são originados da degradação ou metabolização de pesticidas.

Esses compostos, em geral, são prontamente absorvidos pela pele, mas rapidamente eliminados pela urina, inalterados ou como conjugados simples. São ácidos fracos, com capacidade de permear a pele humana in vitro (ROBERTS et al. apud FAWEEL \& HUNT, 1988). Acredita-se que os clorofenóis são absorvidos prontamente pelo trato gastrointestinal, porém não há informações conclusivas. Supõe-se que os clorofenóis sejam distribuídos principalmente nos órgãos como o fígado e o rim (SOMANI \& KHALIQUE, apud FAWEEL \& HUNT, 1988).

A toxicidade aguda dos clorofenóis ao homem é caracterizada pelo aumento da taxa respiratória, suor, náusea e vômito (FAWEEL \& HUNT, 1988). Em solução aquosa com concentração superior a $1 \%$, os clorofenóis causam severa irritação à pele, mas não apresentam efeito tóxico crônico por sua rápida excreção ou metabolização (MATOLCSY, 1988 apud DAMIANOVIC, 1997). 
Tabela 3.1 - Possíveis origens de vários clorofenóis

\begin{tabular}{|c|c|c|}
\hline Compostos & Origens & Tipos de Pesticidas \\
\hline 2-Clorofenol & $2,4-\mathrm{D}$ & Herbicida \\
\hline 3-Clorofenol & PCP (pentaclorofenol) & Fungicida \\
\hline 4- Clorofenol & Cloroxuron & Herbicida \\
\hline 2,6- Diclorofenol & Lindano & Inseticida \\
\hline \multirow{3}{*}{ 2,4- Diclorofenol } & VC-13 & Inseticida \\
\hline & m-Diclorobenzeno & Fumigante \\
\hline & $2,4-\mathrm{D}$ & Herbicida \\
\hline \multirow{2}{*}{ 2,3- Diclorofenol } & Lindano & Inseticida \\
\hline & $\sigma$-Diclorobenzeno & Fumigante \\
\hline \multirow{3}{*}{ 2,5-Diclorofenol } & Lindano & Inseticida \\
\hline & $\rho$-Diclorobenzeno & \\
\hline & $2,4,5-\mathrm{T}$ & Herbicida \\
\hline \multirow{3}{*}{ 3,4- Diclorofenol } & PCP & Fungicida \\
\hline & $\sigma$-Diclorobenzeno & Fumigante \\
\hline & Diuron & Herbicida \\
\hline \multirow{2}{*}{ 3,5- Diclorofenol } & Lindano & Inseticida \\
\hline & PCP & Fungicida \\
\hline 2,3,4- Triclorofenol & Lindano & Inseticida \\
\hline \multirow{2}{*}{ 2,3,5- Triclorofenol } & Lindano & Inseticida \\
\hline & PCP & Fungicida \\
\hline 2,3,6- Triclorofenol & Lindano & Inseticida \\
\hline \multirow{5}{*}{ 2,4,5- Triclorofenol } & Ronnel & Inseticida \\
\hline & Tetraclorovinila & Inseticida \\
\hline & Erbon & Herbicida \\
\hline & $2,4,5-\mathrm{T}$ & Herbicida \\
\hline & HCB (Hexaclorobenzeno) & Fungicida \\
\hline 2,4,6- Triclorofenol & Lindano & Inseticida \\
\hline 3,4,5- Triclorofenol & Lindano & Inseticida \\
\hline \multirow{2}{*}{ 2,3,5,6- Tetraclorofenol } & $\mathrm{HCB}$ & Fungicida \\
\hline & PCP & Tipo de Pesticida \\
\hline \multirow{2}{*}{ 2,3,4,6- Tetraclorofenol } & PCP (impuro) & Fungicida \\
\hline & Lindano & Inseticida \\
\hline \multirow{3}{*}{ 2,3,4,5- Tetraclorofenol } & PCP & Fungicida \\
\hline & Lindano & Inseticida \\
\hline & $\mathrm{HCB}$ & Fungicida \\
\hline \multirow{4}{*}{ Pentaclorofenol } & PCP & Fungicida \\
\hline & Lindano & Inseticida \\
\hline & HCB & Fungicida \\
\hline & PCNB (pentacloronitrobenzeno) & Fungicida \\
\hline
\end{tabular}

Fonte: LORES et al., 1981

Embora as informações toxicológicas para alguns isômeros dos diclorofenóis sejam escassas, os diclorofenóis e os triclorofenóis parecem ter toxicidade aguda e crônica 
relativamente baixas. Deve-se considerar porém, o poder carcinogênico do 2,4,6triclorofenol. Um aumento no número de tumores foi encontrado em ratos e camundongos tratados com altas concentrações desse composto. As altas doses usadas que resultaram em toxicidade podem ter sido muito importantes no desenvolvimento do tumor. Esses estudos podem não ser representativos do potencial carcinogênico desses compostos em baixas doses, cujos testes não resultaram em danos ao tecido (FAWELL \& HUNT,1988).

Devido à elevada toxidez aos animais terrestres e à vida aquática, muitos clorofenóis têm sido incluídos na legislação ambiental em todo o mundo. Em relação a isto, a Comissão Européia (EC) incluiu os seguintes fenóis em seu diretivo 76/464/CEE como substâncias perigosas lançadas em ambientes aquáticos: 2-amino-4-clorofenol, 4-cloro-3-metilfenol, 2clorofenol, 3-clorofenol, 4-clorofenol, pentaclorofenol e triclorofenóis. A Agência de Proteção Ambiental dos EUA (USEPA) também fornece uma lista de poluentes principais, incluindo 11 compostos fenólicos. Alguns deles são comuns à lista da EC, porém existem outros como o 2-nitrofenol, 4-nitrofenol, 2,4-dinitrofenol, 2-4-dimetilfenol e 2,4,6triclorofenol (KEITH \& TELLIARD, apud OUBINA et al., 1997).

Dentre os clorofenóis, o pentaclorofenol (PCP) é um dos poluentes prioritários e foi classificado pela USEPA como sendo, provavelmente, cancerígeno humano, baseado em evidências suficientes de estudos sobre toxicidade animal e dados clínicos humanos (USEPA,1990 apud OUBINA et al., 1997; DAMIANOVIC , 1997). Dessa forma, a USEPA fixou o limite de quantificação prática do PCP e o nível máximo de contaminação em águas de abastecimento em $1 \mu \mathrm{g} / \mathrm{L}$ (OUBINA et al., 1997).

A produção de PCP é feita através da cloração do fenol e pela hidrólise do hexaclorobenzeno (AIROLDI, 1997). A produção mundial deste composto é estimada na ordem de 30.000 toneladas por ano. Devido a seu largo espectro de eficiência como pesticida de baixo custo, o PCP e seus sais têm sido usados como fungicidas, algicidas, bactericidas, herbicidas, inseticidas e molusquicidas, com uma variedade de aplicações no campo industrial, agrário e doméstico (WORLD HEALTH ORGANIZATION, 1987). O PCP pode ser usado na indústria madeireira para controlar o crescimento de cupim e fungos; na indústria de construção para controlar mofo e bolor em superfícies como telhas e blocos de concreto; na indústria de tintas para proteção das mesmas e do látex; na indústria de couro para fornecer proteção contra bolor em sapatos.

Nos últimos anos, a maioria dos países desenvolvidos tem restringido o uso do PCP, especialmente para a agricultura e aplicação doméstica (WORLD HEALTH ORGANIZATION, 1987). 


\subsubsection{Clorofenóis e amostras ambientais}

Várias pesquisas em todo o mundo têm identificado os clorofenóis em amostras de água (AHLBORG \& THUNBERG apud FAWELL \& HUNT, 1988). A ocorrência é em princípio associada com efluentes industriais e efluentes sanitários, podendo também estar associada a produtos de degradação pelo uso de herbicidas contendo ácidos fenólicos. Os clorofenóis produzidos durante a cloração da água ocorrem particularmente, quando há níveis altos de fenóis e níveis baixos de amônia (FAWELL \& HUNT,1988).

Em trabalho realizado por GASPAR et al. (1997), amostras de água foram coletadas de cinco cidades do estado de São Paulo e selecionadas de acordo com sua proximidade de indústrias de couro, químicas ou de papel. Todas as amostras analisadas continham resíduos de PCP, em níveis menores que o limite de detecção do método de cromatografia gasosa com detector de captura eletrônica. As amostras seguiram protocolo de extração líquidolíquido e derivatização in situ. O limite de detecção do método foi de $1 \mu \mathrm{g} / \mathrm{L}$ e a eficiência foi demonstrada por valores médios de recuperação (78 a 108\%) estudados em 3 níveis de dopagem (2, 10 e $20 \mu \mathrm{g} / \mathrm{L})$. Uma das conclusões deste estudo foi observar que o PCP não era um contaminante ambiental expressivo destas cidades, mas que estudos de monitoramento seriam necessários para avaliar a poluição causada pelo PCP no ambiente brasileiro.

Em outro trabalho, realizado por OUBINA et al. (1997), também foram encontrados clorofenóis durante o monitoramento de PCP feito em efluentes de uma indústria de papel e amostra de solo do Brasil (São Paulo), utilizando como padrão material de referência registrado. Neste trabalho, o teste de ELISA foi comparado com extração em fase sólida seguida por cromatografia líquida (LC). Os valores encontrados de PCP nas águas residuárias pelo teste ELISA, variaram de 2,66 a 9,30 $\mu \mathrm{g} / \mathrm{L}$. Pela extração em fase sólida, os valores de PCP encontrados variaram de 1,10 a 8,60 e os de 2,4,6-triclorofenol de 1,70 a $10,10 \mu \mathrm{g} / \mathrm{L}$.

Nas amostras de solo de São Paulo analisadas pelo método de ELISA foi verificada uma perda de aproximadamente 50\% durante a limpeza das amostras, sendo encontrados 9,76 $\mu \mathrm{g} / \mathrm{L}$ de PCP em amostra que não passou por este processo. Os efluentes de indústria de polpa e celulose sofrem tratamento primário, que consiste na eliminação de material em suspensão, e tratamento secundário com oxidação microbiana de constituintes orgânicos dissolvidos fermentáveis. Porém, os clorofenóis não são completamente eliminados nesses 
processos. Em análise feita utilizando o teste Elisa, foram detectados antes dos tratamentos $1,79 \mu \mathrm{g} / \mathrm{L}$ de PCP e depois, $1,27 \mu \mathrm{g} / \mathrm{L}$. Na extração em fase sólida foram encontrados o 2clorofenol e o 2,4-diclorofenol, apresentando 27,30 e 17,50 $\mu \mathrm{g} / \mathrm{L}$, respectivamente antes dos tratamentos e 18,30 e 13,00 $\mu \mathrm{g} / \mathrm{L}$, respectivamente depois dos tratamentos.

Conclui-se que a persistência ambiental e o potencial de danos à saúde, tornam necessário o monitoramento dos clorofenóis, mais especificamente o PCP, em solos, sedimentos, e águas, principalmente se estas últimas são utilizadas para abastecimento público.

\subsection{Compostos tóxicos em reservatórios}

A construção de represas representa, por um lado o progresso, através da produção de energia elétrica, do abastecimento de água potável, da irrigação, da regularização da vazão dos rios possibilitando o controle de enchentes, mas por outro, provoca uma série de alterações de caráter hidrológico, com repercussões climáticas e ecológicas, que de modo geral, afetam profundamente a flora e a fauna, tanto aquáticas quanto terrestres. Além disto, o próprio crescimento populacional e industrial, favorecido pelo melhor suprimento de energia e água na região, leva ao aumento na geração de efluentes e resíduos poluidores, portadores em geral, de altas cargas de nutrientes orgânicos e minerais, eventualmente substâncias tóxicas, que devem consequentemente ser afastadas das comunidades. Entretanto, o veículo natural de escoamento dessas impurezas é a própria água dos rios e das represas, a qual terá forçosamente suas características físicas, químicas e ecológicas substancialmente modificadas (BRANCO \& ROCHA, 1977).

As barragens podem perturbar profundamente não só o comportamento natural dos rios represados, como também atingir as regiões circunvizinhas, produzindo modificações hidrológicas, geológicas e paisagísticas, além de alterar as próprias características físicas e químicas da água represada (BRANCO \& ROCHA, 1977).

É muito importante a coleta de dados específicos do reservatório, incluindo quantidade e qualidade de compostos que entram nestes ambientes, condições climáticas, usos gerais ou específicos da terra, tipos de indústrias, efluentes urbanos, densidade e tipos de sedimentos, zonas de deposição e erosão, transporte de sedimentos, quantidade e tamanho da partícula; bioacumulação de contaminantes; geoquímica e mineralogia dos sedimentos; perfis horizontais e verticais dos constituintes físicos (por exemplo, porosidade, propriedades geotécnicas, conteúdo de água, densidade, tamanho da partícula) e químicos (por exemplo, conteúdo de matéria orgânica, concentrações de nutrientes, metais e contaminantes orgânicos) característicos dos sedimentos de fundo (MUDROCH \& MACKNIGHT, 1991). 
Os compostos tóxicos e seus produtos de degradação quando alcançam sistemas aquáticos, podem sofrer alterações como a diluição pelo fluxo de água, vaporização e degradação lenta pela biota, podendo apresentar-se parcialmente dissolvidos na água e parcialmente adsorvidos nos sedimentos, plantas aquáticas, planctons, invertebrados aquáticos, detritos em suspensão e peixes (HASKELL, 1985, PERES, 1997). A maioria dos poluentes, independente do modo pelo qual eles alcancem os sistemas aquáticos é dividida rapidamente entre a água, o material em suspensão e o sedimento (HASKELL, 1985).

Em ambientes eutróficos, por exemplo, há a possibilidade de aumento da solubilidade dos compostos tóxicos organoclorados (POs) e dos bifenilos policlorados (PCBs) devido à grande quantidade de substâncias orgânicas dissolvidas na água e de materiais em suspensão, que por sua vez, promovem processos de adsorção, favorecendo a presença no compartimento água. Desta forma, os dados obtidos sobre POs e PCBs também devem ser correlacionados com os mecanismos intrínsecos de funcionamento do ecossistema, como a estratificação térmica da coluna d'água, a distribuição vertical do oxigênio dissolvido, a concentração de material em suspensão, a biomassa de fitoplâncton, as variações climatológicas (ventos e precipitação) e as variações no regime hidráulico da represa, determinantes da dinâmica de disponibilidade destes compostos num ambiente aquático eutrofizado (CALHEIROS, 1993).

A estratificação térmica, por exemplo, é uma situação que ocorre em muitos ambientes aquáticos durante os meses do verão, com ausência de ventos, e pode causar o desenvolvimento de camadas de água, cujas propriedades físico-químicas variam drasticamente. Diferenças entre o epilímio e o hipolímio podem ocorrer também com respeito a concentrações de compostos tóxicos (GUENZI et al., 1974).

Os materiais fluviais, os quais assentam-se durante período de baixo fluxo ou sob condições de morbidez, contêm, muitas vezes, quantidades de compostos tóxicos que podem ser quantificadas nas águas superficiais. Obviamente, é importante analisar materiais do fundo concomitantemente as águas superficiais, para que se tenham dados significantes. (GUENZI et al., 1974).

Segundo CALHEIROS (1993), os POs e PCBs apresentam alta adsorção em matéria em suspensão, tanto biótica quanto abiótica, que tem seu destino final no sedimento. Assim, o compartimento sedimento é um bom indicador do grau de contaminação do ambiente, uma vez que funciona como um receptor, via sedimentação, destes poluentes de alta persistência, além de outros compostos, refletindo as atividades realizadas em toda a bacia hidrográfica ao longo do espaço e do tempo. Quando se trabalha com a identificação de clorofenóis, por exemplo, é importante que sejam analisados os sedimentos devido à estabilidade desses 
compostos e seus produtos de degradação nesses ambientes, fornecendo uma fonte contínua de contaminação do ambiente aquático (RAO, 1978).

Estes compostos tóxicos alteram os ciclos naturais de matéria e energia, podendo provocar condições de não equilíbrio dos ecossistemas aquáticos e terrestres, reduzindo a resiliência dos ambientes. Além disso, seu uso generalizado e inadequado traz problemas ambientais diretos (como poluição do solo e da água) e indiretos (como inespecificidade de ação e biomagnificação) (CALHEIROS, 1993). A inespecificidade da ação leva a um desequilíbrio ecológico devido a diversos efeitos como por exemplo, a proliferação de algas, a contaminação de organismos, dentre outros. Esta contaminação de diferentes organismos e a recalcitrância desses compostos conduz a biomagnificação. Esta denota o processo pelo qual a concentração de um composto aumenta em diferentes organismos, ocupando níveis tróficos sucessivos (CALHEIROS, 1993). A acumulação ocorre pela dificuldade de excreção ou não utilização da substância na respiração, logo, quanto maior o número de organismos contaminados ingeridos, maior a quantidade de substância acumulada no organismo que os ingere (CARVALHO, 1980).

O estudo de sedimentos deve ser feito através de "cores”, para que sejam conhecidas suas propriedades físico-químicas, bem como mudanças ao longo do tempo (AIROLDI, 1997). Os sedimentos podem ser diferentes do solo de origem ou pode haver grande semelhança entre eles. Se a taxa de sedimentação renovável pela erosão for lenta em relação à taxa de processos limnológicos, os quais determinam as características do sedimento, então estes podem ser substancialmente diferentes do solo de origem. Desta forma, os sedimentos podem diferir consideravelmente dos solos, na quantidade e tipo de matéria orgânica e pela composição de grupos funcionais, tipos e números de microrganismos, conteúdo de minerais amorfos incluindo compostos de ferro e manganês, sais como os carbonatos e sulfatos de cálcio, e resíduos celulares oriundos da morte de algas, bactérias e vegetação aquática (GUENZI et al., 1974).

O sedimento pode também ser alterado consideravelmente pelas atividades humanas. Materiais lipofílicos como resíduos de petróleo têm sido incorporados em camadas de sedimentos, fornecendo assim uma distribuição dos poluentes lipossolúveis. Estes materiais lipofílicos criam problemas adicionais na extração e isolamento de compostos contidos em sedimentos (GUENZI et al., 1974).

Em alguns trabalhos citados por STRACHAN et al. (1982) sobre adsorção de poluentes em sedimentos, os fatores mais importantes que afetaram este processo foram as concentrações dos compostos dos materiais em suspensão, argila e matéria orgânica, a 
granulometria, o pH, a temperatura e o estado de oxigenação dos sistemas aquáticos analisados.

GUENZI et al. (1974) ressaltaram que a concentração de compostos tóxicos na água de lagos e reservatórios é provavelmente mais elevada no início da primavera e no final do verão, porque há a introdução destes no sistema hidrológico durante estes períodos de elevado uso. A concentração máxima de compostos tóxicos nos sedimentos não necessariamente ocorrerá após a lixiviação, porque a deposição de material erodido depende da freqüência e da intensidade das chuvas.

Em relação à distribuição do material de assoreamento, os condicionantes principais são a distância das áreas fonte de sedimentos e a topografia de fundo do reservatório (COELHO, 1993).

A construção de uma barragem num canal fluvial faz com que a velocidade do fluxo que adentra o reservatório por ela formado seja drasticamente reduzida, devido ao aumento da seção transversal da corrente, provocando queda acentuada ou mesmo eliminação da turbulência do fluxo, responsável pela manutenção do material sólido em suspensão. A conseqüência é a deposição de grande parte ou mesmo toda a carga sedimentar transportada pela corrente, fazendo dos reservatórios locais ideais para a acumulação de sedimentos (COELHO,1993).

$\mathrm{Na}$ Figura 3.1, foram representadas todas as possíveis fontes de compostos organoclorados para reservatórios em geral e também as alterações que estes poluentes podem sofrer quando alcançam esses ambientes aquáticos.

\subsection{Coleta e preservação de amostras ambientais}

No passado pouca atenção foi dada a seleção de técnicas analíticas e de amostragem, se comparada com aquela destinada aos outros aspectos do desenvolvimento experimental. Freqüentemente, os métodos empregados eram avaliados de forma inadequada ou aplicados diretamente sem primeiro determinar sua aplicabilidade às condições locais (GUENZI et al., 1974).

Porém, a coleta, preservação e prévio preparo de amostras para análise de resíduos são importantes passos para que resultados significativos sejam alcançados (GUENZI et al., 1974). Atualmente, observa-se o aumento da preocupação com estes passos, mas ainda é insuficiente. 


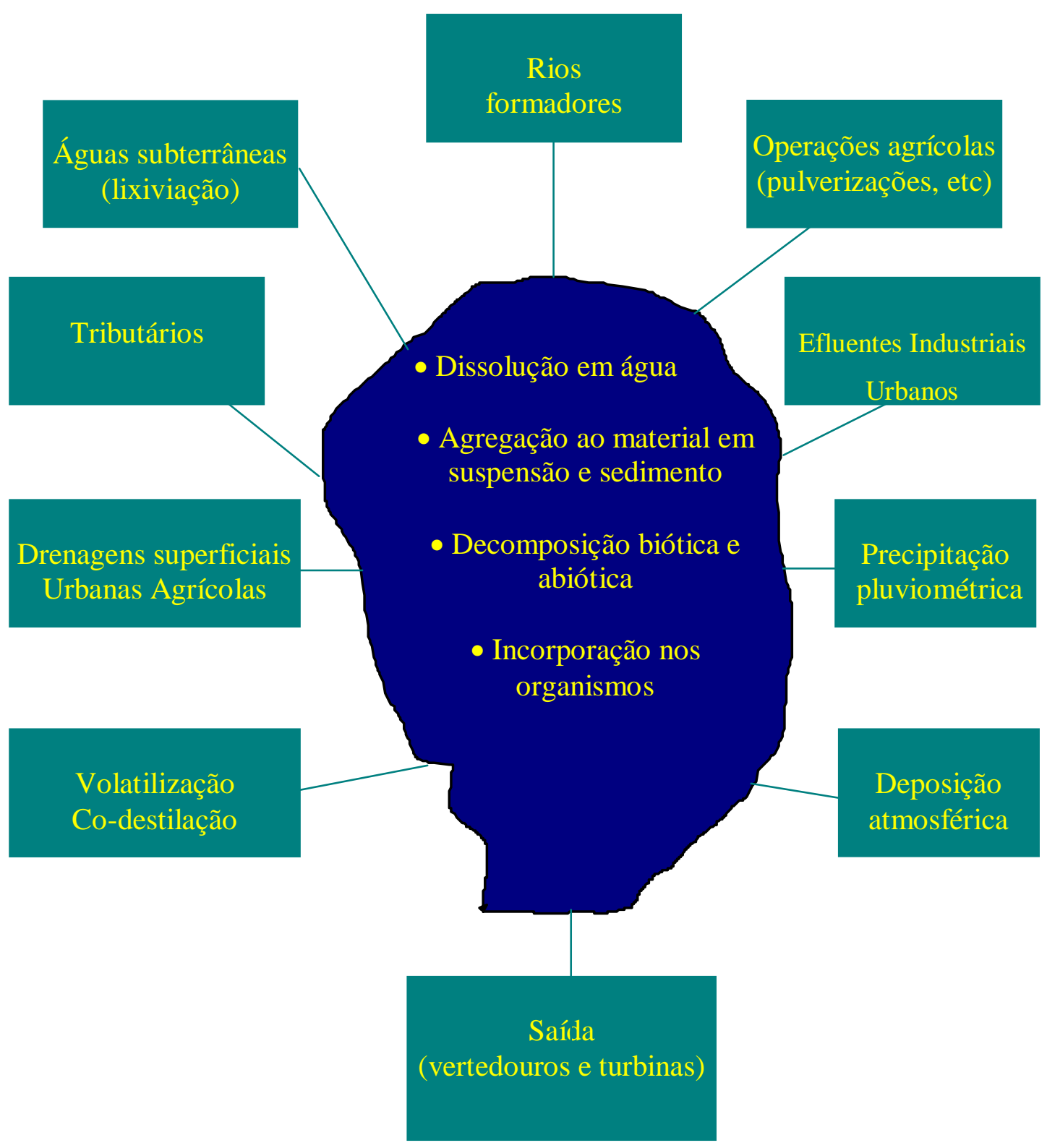

FigurA 3.1 - FLUXOS DE APORTES, ACÚMULOS E PERDAS DE COMPOSTOS ORGANOCLORADOS (PESTICIDAS E PCBS) EM UM RESERVATÓRIO (CALHEIROS, 1993).

No caso das análises com a finalidade de estimar os níveis de poluentes em ambientes aquáticos, o procedimento correto para coleta de amostras envolve considerações cuidadosas de muitos fatores, incluindo época do ano em que a amostragem é feita, direção prevalecente do vento, estratificação térmica e salinidade, atividades agrícolas e industriais e descargas de resíduos municipais dentro do corpo aquático (GUENZI et al., 1974).

O melhor e mais conceituado método analítico pode conduzir a resultados incorretos se a amostra não for bem manuseada e preparada. $\mathrm{O}$ objetivo do correto manuseio e preparação 
do material é minimizar estes efeitos indesejáveis através da menor contaminação ou menor alteração das amostras (MUDROCH \& MACKNIGHT, 1991).

Alguns cuidados devem ser tomados na coleta, armazenamento e transporte das amostras, de acordo com a análise a ser realizada. Para tal, as seguintes recomendações do Standard methods for the examination of water and wastewater (SMEWW, 1995) são destacadas:

para análises de carbono orgânico total na água e no sedimento é importante que o material seja coletado e armazenado em frascos de vidro, devendo ser mantidos sob baixas temperaturas quando estocados;

$\checkmark$ no caso da análise de material em suspensão na água, esta deve ser feita, de preferência, logo após a coleta;

$\checkmark$ para a análise granulométrica do sedimento, o material deve ser mantido sob baixas temperaturas para sua preservação ideal.

O intervalo entre a coleta e a análise deve ser o menor possível a fim de diminuir mudanças nas amostras, principalmente devido à atividade microbiana. Para minimizar prováveis alterações, técnicas de preservação são usadas visando à integridade da amostra depois da coleta. Estas medidas incluem não somente a preservação no campo, mas também a documentação formal, acondicionamento, transporte e estocagem das amostras. As mudanças mais comuns que podem ocorrer, são mudanças físicas, como a volatilização, adsorção, difusão e precipitação e as mudanças químicas, como a oxidação, mudanças fotoquímicas e degradação microbiana. As alterações podem ser minimizadas com uma variedade de técnicas, incluindo o uso de recipientes adequados para as amostras, adição de produtos químicos e controle de temperatura. Métodos de preservação estão limitados ao controle do pH, adição química e manutenção em baixas temperaturas (SMEWW, 1995). Por exemplo, para evitar a ação microbiana, as amostras podem ser mantidas a baixas temperaturas a fim de diminuir a degradação dos poluentes presentes. Condições de $\mathrm{pH}$ extremas (valores muito baixos ou muito elevados) e baixas condições de temperatura são eficientes para minimizar a degradação (KEITH, 1988).

É necessário preservar as amostras de acordo com a taxa de degradação do analito, que pode ser extremamente rápida. Obviamente, alguns métodos de tratamento no campo podem ser requeridos, para retardar a degradação dos compostos tóxicos, sem alterar a amostra (GUENZI et al., 1974). A estocagem de amostras de solos ou sedimentos a $4^{\circ} \mathrm{C}$ pode, na maioria dos casos, reduzir a degradação química ou microbiana dos compostos tóxicos. (GUENZI et al., 1974). Porém, o rápido congelamento de amostras no campo e a sua manutenção sob baixas temperaturas estão entre os mais efetivos métodos para 
minimizar a degradação química e microbiana de compostos tóxicos e a priori, parece ser o método mais satisfatório de preservação, sendo bastante empregado.

Os recipientes para armazenamento do material também devem ser cuidadosamente escolhidos, de acordo com o tipo de análise que será feita, para que não sejam fontes de contaminação ou não interfiram nos resultados. Os recipientes plásticos devem ser evitados sempre que possível. As amostras de sedimentos para análises orgânicas podem ser estocadas em recipientes de vidro ou de metal (MUDROCH \& MACKNIGHT, 1991).

A coleta de sedimentos envolve o uso de draga ou core. O core é preferido quando suspeita-se da presença de poluentes que podem mudar com a profundidade de material coletado. A coleta de amostras através do core é feita empurrando manualmente ou contando com a gravidade para forçar o dispositivo a entrar no sedimento. O coletor do tipo gravidade pode ter, ou não, um pistão para reduzir fricção entre o sedimento e a parede do dispositivo coletor. A operação e construção deste dispositivo coletor é simples e barata (GUENZI et al., 1974).

A água geralmente é coletada utilizando-se a garrafa de Van Dorn.

\subsection{Análises e determinações no campo e em laboratório}

De acordo com a substância analisada e a influência exercida sobre a disponibilidade dos poluentes tóxicos nas amostras, algumas variáveis ambientais devem ser consideradas, como:

a) Umidade $(\%)$

Nas análises de solo e sedimento, o teor de umidade das amostras de solo e de sedimento é crítico para estabelecer recuperações quantitativas de muitos compostos tóxicos (GUENZI et al., 1974).

b) Matéria Orgânica

A matéria orgânica do solo é complexa e sua verdadeira identidade muito incerta para permitir uma descrição realista em modelos cinéticos de sorção e biodegradação de compostos tóxicos (SSSA, 1991).

Em matrizes sólidas, por exemplo, o isolamento, em geral, de compostos fenólicos, não é direto, devido à forte ligação de alguns fenóis com a matéria orgânica (ALONSO et al., 1998).

GAO et al. (1998), estudando a concentração e distribuição de 7 pesticidas em amostras de sedimento verificou que havia uma variação espacial, mas não uma variação 
temporal e que o conteúdo de matéria orgânica do sedimento contribuía principalmente na distribuição desta concentração, sendo que, em geral, o carbono orgânico dissolvido adsorvia pesticidas, resultando em uma maior concentração total na solução dos poros do sedimento quando na ausência deste. GAO et al. (1998) concluíram que este "efeito" de solubilização pode aumentar a remobilização do pesticida e a disponibilidade no ambiente aquático.

b) Material em Suspensão (mg/L)

Compostos tóxicos, como visto no item 3.3 , podem ficar adsorvidos no material em suspensão. Desta forma, a quantificação desse material, pode ser de grande importância para verificar a interferência causada pelos mesmos na amostra.

c) Temperatura da água $\left({ }^{\circ} \mathrm{C}\right)$

A temperatura desempenha um papel importante de controle no meio aquático, condicionando as influências de uma série de variáveis físico-químicas.

A estratificação térmica, por exemplo, é um fenômeno em muitos ambientes aquáticos durante os meses do verão e pode causar o desenvolvimento de duas camadas de água as quais variam drasticamente as propriedades físico-químicas. Diferenças entre o hipolímio e o epilímio podem influenciar as concentrações de pesticidas (GUENZI et al., 1974).

d) Oxigênio dissolvido ( $\mathrm{mg} / \mathrm{L})$

O oxigênio dissolvido é essencial ao metabolismo respiratório da maior parte dos organismos aquáticos. A dinâmica da distribuição do oxigênio nos lagos é governada por um equilíbrio entre as entradas da atmosfera e a fotossíntese, bem como pelas perdas devidas às oxidações químicas e bióticas. A distribuição do oxigênio é importante para as necessidades diretas de muitos organismos e afeta a solubilidade e a disponibilidade de muitos nutrientes, e portanto a produtividade dos ecossistemas aquáticos (WETZEL, 1983).

e) Turbidez (uT)

A turbidez da água é a medida de sua capacidade em dispersar a radiação. Quantitativamente, este fenômeno pode ser expresso em termos de coeficiente de dispersão ou alguma unidade empírica. Os principais responsáveis pela turbidez da água são principalmente as partículas suspensas (bactérias, fitoplâncton, detritos orgânicos e inorgânicos) e em menor proporção os compostos dissolvidos (ESTEVES, 1988). Partículas 
suspensas alteram a toxicidade de poluentes, por influenciar em sua biodisponibilidade, já que a maioria dos compostos organoclorados pode sofrer adsorção.

f) Condutividade $\left(\mu \mathrm{S} . \mathrm{cm}^{-1}\right)$

A condutividade elétrica da água está relacionada com sua capacidade em conduzir a corrente elétrica. É uma das variáveis mais importantes em Limnologia, visto que pode fornecer dados significantes tanto sobre o metabolismo do ecossistema aquático, como sobre fenômenos importantes que ocorram na sua bacia de drenagem. A condutividade pode ajudar por exemplo, a detectar fontes poluidoras nos ecossistemas aquáticos (ESTEVES, 1988).

g) $\mathrm{pH}$

$\mathrm{O}$ pH é definido como o logaritmo negativo da concentração molar de íons hidrogênio, sendo que a alcalinidade ou acidez de uma solução é freqüentemente expressa em termos da concentração deste íon (ESTEVES, 1988).

A solubilidade e a taxa de partição são propriedades dos compostos orgânicos ionizáveis que variam significativamente em função do $\mathrm{pH}$. Estas substâncias ionizáveis na fase aquosa podem existir tanto como espécies protonadas quanto desprotonadas, sendo o equilíbrio dependente do $\mathrm{pH}$ em relação à constante de dissociação (pKa). Muitos poluentes importantes como clorofenóis, nitrofenóis e dinitrofenóis são ionizáveis (DAMIANOVIC, 1997).

$\mathrm{O} \mathrm{pH}$ pode ser considerado como uma das variáveis ambientais mais importantes e, ao mesmo tempo, uma das mais difíceis de interpretar.

\subsection{Procedimentos para determinação dos clorofenóis em amostras de ambientes aquáticos}

A meta de qualquer procedimento de monitoramento é a determinação confiável e precisa da identidade e da quantidade de poluentes presentes na amostra (GUENZI et al., 1974). Logo, além dos cuidados na coleta e preservação, o método utilizado para extração e análise das amostras deve ser determinado cuidadosamente.

Geralmente, os procedimentos de monitoramento de poluentes podem ser arbitrariamente divididos, em extração, limpeza, análise e identificação, e cada um tem que abranger características a fim de alcançar a meta de precisão e confiabilidade na determinação de compostos tóxicos (GUENZI et al., 1974). Estes passos serão discutidos mais detalhadamente a seguir: 
a) Extração

Uma grande variedade de técnicas, instrumentos e até mesmo diferentes condições de extração têm sido usadas para separar pesticidas da água, solo e sedimentos. A escolha formal do extrator depende primeiramente das características dos pesticidas e tipos de sistemas a serem analisados (GUENZI et al., 1974).

Os métodos convencionais de extração de tais compostos em água são: extração líquido-líquido (ZUIN, 1997; GEISSLER \& SCHOLER,1994; KURÁN \& SOJÁK, 1996; GASPAR et al., 1997; GEISSLER \& SCHOLER, 1994), em fase sólida (VIDAL, 1991; ZHI et al.,1996; KURÁN \& SOJÁK, 1996; JUNG et al., 1996; BELTRAN et al., 1993; SOJO \& DJAUHARI, 1998) e com fluido supercrítico (DE MARTINIS, 1993).

ZUIN (1997) utilizou procedimentos em que as amostras sofriam extração líquido-líquido, para análise de PCP em águas naturais provenientes da Baixada Santista, uma região altamente contaminada por resíduos industriais. No procedimento desenvolvido, $1 \mathrm{~L}$ de água natural pré-acidificada era tratada com $1 \mathrm{~mL}$ de ácido sulfúrico concentrado e extraída em 3 porções de hexano (100, 50 e $50 \mathrm{~mL}$, respectivamente), empregando funil de separação de 2L. A fase orgânica combinada era seca com sulfato de sódio, concentrada a $1 \mathrm{~mL}$, derivatizada e injetada em CG/DCE.

GEISSLER \& SCHOLER (1994) também utilizaram a extração líquido-líquido contínua para análise de fenol, 8 tipos de clorofenóis e 7 de nitrofenóis secundários em águas poluídas secundárias, em concentrações de 0,1 e $0,25 \mathrm{~g} / \mathrm{L}$. A concentração era feita em rotaevaporador e as amostras eram derivatizadas com diazometano ou com hidróxido trimetilsulfônico, sendo analisadas em CG/EM. Estes autores também utilizaram a extração em fase sólida com cartuchos comerciais (RP-C18), com e sem adição de $30 \mathrm{~g} / \mathrm{L}$ de cloreto de sódio, como comparação. Neste último procedimento, em geral, as recuperações foram baixas, especialmente para fenol, metilfenol e alguns nitrofenóis.

Para extração de poluentes em amostras sólidas, os métodos clássicos mais usados são: extração em destilador Soxhlet, tratamento ácido e/ou alcalino das amostras e volatilização seletiva, além de outros. (AIROLDI, 1997).

A extração em Soxhlet é o método mais amplamente usado quando compostos orgânicos têm de ser extraídos de materiais sólidos, como os solos, sedimentos, pós, areia e resíduos orgânicos sólidos (BRUNER, 1993).

Os sistemas de extração e solventes tradicionalmente usados para sedimentos são combinações de hexano-acetona usando um agitador ou extrator Soxhlet (GUENZI et al., 1974), os quais geralmente encontram a maior taxa de recuperação. 
AIROLDI (1997) desenvolveu uma metodologia para análise de PCP e HCB (hexaclorobenzeno) em solos contaminados de um bairro da cidade de São Vicente (SP), utilizando Soxhlet. No procedimento eram utilizados $10 \mathrm{~g}$ de solo in natura, extraídos por 3 horas com $150 \mathrm{~mL}$ de hexano tratado. O extrato era concentrado a $1 \mathrm{~mL}$, derivatizado e limpo em coluna de Florisil $(1 \mathrm{~g})$, utilizando $10 \mathrm{~mL}$ de hexano como eluente. A amostra então concentrada a $1 \mathrm{~mL}$ era analisada em CG/DCE.

Atualmente, novos métodos de extração para materiais sólidos vêm sendo utilizados, como a extração com microondas e extração utilizando ultra-som. Segundo LLOMPART et al. (1997), desde 1995, o número de aplicações ambientais utilizando microondas cresceu rapidamente, tendo sido usado na extração de pesticidas de sedimentos, água e de solos. Muitos trabalhos também têm sido realizados comparando esses e outros novos procedimentos com o tradicional Soxhlet.

ALONSO et al. (1998), estabeleceram uma metodologia analítica para a determinação de compostos fenólicos livres e ligados em amostras sólidas usando Soxhlet e extração por microondas (MAE). As condições ótimas foram determinadas pela mistura de porções de sedimentos não contaminados com uma mistura de 11 fenóis representativos, incluídos particularmente na lista da união européia e na lista de poluentes prioritários da EPA. A eficiência da extração com microondas, também foi investigada e comparada com a extração com o Soxhlet. Em geral, os valores obtidos usando MAE foram similares àqueles encontrados com a extração com Soxhlet. Entretanto, o MAE apresentou algumas vantagens quando comparado ao Soxhlet, como menor volume de solvente para extração e tempo sensivelmente menor de extração (30 a 40 min para 12 horas). Além disso, a mesma composição de solventes usadas para o Soxhlet foi válida para o MAE, não sendo necessários testes para adaptação(ALONSO et al., 1998).

SANTOS et al. (1998) determinaram clorofenóis em amostras de solo contaminadas utilizando extração com fluido supercrítico e detecção em cromatografia líquida com detector eletroquímico. Segundo os autores, foram encontradas: boa repetibilidade (4.9 to $11.8 \%$ ), boa reprodutibilidade (4.9 to $12.5 \%$ ), e baixos limites de detecção (3 to $150 \mathrm{ng} / \mathrm{L}$ ). Os resultados mostraram que a extração com fluido supercrítico e detecção por cromatografia líquida com DCE foi um procedimento rápido e limpo, e que pode ser usado para análise de clorofenóis em solos contaminados, com a vantagem de reduzir o consumo de solventes e eliminar os passos de limpeza.

Comparando a extração em fluido supercrítico com a extração com Soxhlet, o tempo total requerido para o método analítico integral foi reduzido de 2 dias para 1,5 horas. 
O banho ultra-sônico também é utilizado para amostras de solo e sedimento, apresentando vantagens em relação ao Soxhlet como o menor volume de solvente utilizado, menor tempo de extração, sendo que também oferece uma boa recuperação (LLOMPART et al., 1997). No trabalho de LLOMPART et al. (1997) a recuperação de fenóis e isômeros deste em amostras de solo foi cerca de $50 \%$ da real quantidade adicionada ao solo.

Em trabalhos realizados por KHODADOUST et al. (1999) e WALL \& STRATTON (1991) apud KHODADOUST et al. (1999) foram encontrados resultados semelhantes em amostras de solo extraídas com banho ultra-sônico e em Soxhlet. WALL \& STRATTON (1991) obtiveram recuperações comparáveis de PCP em solos arenosos, com 2,1\% de matéria orgânica, extraídos em Soxhlet tendo como solvente hexano-acetona (1:1) e extraídos com ultra-som, tendo como solvente etanol-tolueno. No trabalho de KHODADOUST et al. (1999), a recuperação de PCP em amostras de solo com partículas menores que $0,075 \mathrm{~mm}$ foi ligeiramente maior utilizando aparelho Soxhlet.

b) Limpeza

Em materiais complexos, como os solos e os sedimentos, os passos de extração têm que, na medida do possível, promover uma extração quantitativa dos poluentes, sem uma excessiva co-extração de materiais que possam interferir nas análises (GUENZI et al., 1974). Porém, quando estas substâncias estão presentes é necessário utilizar métodos de limpeza a fim de melhorar a confiabilidade qualitativa do método. Logo, a função da limpeza é um passo opcional na metodologia analítica de poluentes e seu uso depende do grau de pureza do extrato e da sensibilidade analítica desejada, bem como da variedade de impurezas existentes. Alguns tipos de água, muitos solos e a maioria dos extratos dos sedimentos, requerem algum tipo de limpeza, independente do método analítico escolhido. Os procedimentos de limpeza podem permitir uma distribuição quantitativa dos pesticidas para os passos analíticos e são também bastante importantes, para a determinação de baixas concentrações de pesticidas, aumentando muito a confiabilidade (GUENZI et al., 1974).

\section{c) Análise e identificação}

Para análise das substâncias extraídas, os métodos de separação (especialmente cromatografia líquida e gasosa) representam um importante papel, principalmente na determinação de resíduos de poluentes, seus metabólitos e os produtos de degradação no ambiente aquático (HATRÍK \& TEKEL, 1996).

A cromatografia líquida e a gasosa são atualmente as melhores técnicas para determinação de traços de resíduos de poluentes. A cromatografia gasosa é um instrumento 
muito importante e largamente usado para análises rotineiras de resíduos de compostos tóxicos (CHAU \& AFGHAN, 1982).

A precisão da cromatografia gasosa é determinada pelo grau de recuperação dos analitos em cada fase da análise, a pureza dos padrões usados e o grau de separação dos interferentes (CHAU \& AFGHAN, 1982).

A cromatografia gasosa somente é útil na análise de gases e de substâncias voláteis e termicamente estáveis. Quando isto não ocorre, particularmente no caso de substâncias de alta massa molecular e/ou contendo grupos funcionais fortemente polares, há necessidade de derivatização (COLLINS, 1997). A derivatização é a transformação de um composto químico em outro, com o intuito de facilitar a separação dos compostos de interesse dos interferentes, aumentar a sensibilidade para detectores específicos ou oferecer dados de confirmação para identificação dos compostos (GROB, 1983), e pode ser feita por pentafluorobenzilação, acetilação ou metilação. Na determinação de compostos clorofenólicos em amostras ambientais por CG/DCE, a acetilação ou a metilação são os métodos mais usados.

Após o preparo da amostra para análise cromatográfica, a mesma é introduzida por um sistema de injeção em uma coluna contendo a fase estacionária. O uso de um detector adequado na saída da coluna torna possível a detecção e quantificação destas substâncias (COLLINS et al., 1997). O limite de detecção é determinado pelo detector, o tipo e quantidade de compostos interferentes e o grau de concentração obtido na preparação da amostra. Em geral, o detector mais sensível e específico disponível para o composto de interesse deve ser usado para otimizar o sinal em relação a ruídos e, consequentemente, melhorar a precisão e reduzir o limite de detecção (GROB, 1983).

Em um sistema de cromatografia em fase gasosa o detector é, o principal responsável pela quantidade mínima de substância a ser detectada, enquanto que em princípio cabe à coluna estabelecer a quantidade máxima (LANÇAS, 1993). O detector por captura de elétrons tem alta sensibilidade para detecção de compostos halogenados e é preferido para a determinação de clorofenóis (GROB, 1983).

O detector de massas também pode ser utilizado nestas análises e trata-se de uma versão simplificada e econômica do espectrômetro de massas acoplado a cromatografia gasosa, tornando-se um poderoso aliado na identificação de compostos tóxicos. Esta associação permite obter informações a respeito da estrutura e da massa molecular do analito. Desde que a fragmentação dos compostos seja feita de uma maneira reprodutível, o espectro obtido pode ser considerado como a impressão digital do composto (VICINO, 1993). 
O resultado da análise obtido após a adição de um composto tóxico em uma amostra, seguido pela extração, dá uma medida de recuperação baseada na quantidade conhecida do composto que foi adicionado (GUENZI et al., 1974).

\section{7 Área de estudo}

Este trabalho foi desenvolvido no reservatório de Salto Grande (Americana/SP).

A bacia hidrográfica em que se encontra localizado o reservatório de Salto Grande, é de grande importância para a região, principalmente em sua função de abastecimento público. Entretanto, está inserida em uma região de intenso crescimento tanto populacional quanto industrial.

Logo, é crescente a preocupação com os inúmeros danos causados pelos diversos efluentes lançados, tanto pelas indústrias, quanto domésticos, além dos poluentes carreados pela lixiviação devido a desproteção das margens do rio Atibaia.

Considerando especificamente os clorofenóis, razão do presente trabalho, e analisando as indústrias presentes na região cujos efluentes podem apresentar fenóis lançados nos corpos hídricos, como observado na Tabela 3.2, justifica-se a importância da análise dessas substâncias no reservatório de Salto Grande.

\subsubsection{Usos e Contaminação da Água na Sub-Bacia do Atibaia}

Há uma íntima relação entre as bacias dos rios Piracicaba e Capivari e a bacia do Alto Tietê, onde situa-se a região metropolitana de São Paulo, havendo reversão de água para fins de abastecimento público para as cidades de Jundiaí $\left(1,2 \mathrm{~m}^{3} / \mathrm{s}\right)$ e da Grande São Paulo $\left(33 \mathrm{~m}^{3} / \mathrm{s}\right)$. A água revertida consome cerca de $50 \%$ da vazão destes rios, não voltando a ser restituída nem sob a forma de esgoto (MONTICELI \& MARTINS, 1993).

As bacias dos rios Piracicaba e Capivari extendem-se por $14.400 \mathrm{Km}^{2}$, onde atualmente existem 56 sedes de municípios e parte de 10 outros, cujas sedes encontram-se em bacias adjacentes (MONTICELI \& MARTINS, 1993). 
Tabela 3.2 - Carga Remanescente de Fenóis - Kg/dia

\begin{tabular}{|c|c|c|c|c|c|}
\hline Indústria & Município & $\begin{array}{l}\text { Corpo } \\
\text { Receptor }\end{array}$ & $\begin{array}{c}\text { Carga de } \\
\text { Fenóis } \\
\text { (Kg/dia) }\end{array}$ & $\begin{array}{c}\text { Carga } \\
\text { Percentual }\end{array}$ & $\begin{array}{c}\% \\
\text { Acumulada }\end{array}$ \\
\hline Bann Química Ltda. & Paulínia & Rio Atibaia & 36,90 & 87,1928 & 87,20 \\
\hline Rhodia Brasil Ltda. & Paulínia & Rio Atibaia & 1,59 & 3,7571 & 90,9 \\
\hline $\begin{array}{l}\text { Elisabeth S. A. Ind. Têxtil - } \\
\text { Fabr. II }\end{array}$ & Itatiba & $\begin{array}{c}\text { Rib. } \\
\text { Jacarezinho }\end{array}$ & 1,04 & 2,4575 & 93,4 \\
\hline $\begin{array}{l}\text { Rhodiaco Indústrias } \\
\text { Químicas Ltda. }\end{array}$ & Paulínia & Rio Atibaia & 0,62 & 1,4650 & 94,9 \\
\hline $\begin{array}{llll}\text { Petróleo } & \text { Brasileiro } & \text { S. } & \text { A. } \\
\text { REPLAN } & & & \\
\end{array}$ & Paulínia & Rio Atibaia & 0,61 & 1,4414 & 96,3 \\
\hline $\begin{array}{l}\text { Rigesa Celulose Papel Embal. } \\
\text { Ltda. }\end{array}$ & Valinhos & $\begin{array}{c}\text { Rib. } \\
\text { Pinheiros }\end{array}$ & 0,30 & 0,7089 & 97,0 \\
\hline $\begin{array}{l}\text { J. Bresler S. A. Papel Papelão } \\
\text { Bem. }\end{array}$ & Paulínia & Rio Atibaia & 0,27 & 0,6380 & 97,7 \\
\hline $\begin{array}{l}\text { Tinturaria Estamparia Cofina } \\
\text { Ltda. }\end{array}$ & $\begin{array}{c}\text { B. J. } \\
\text { Perdões }\end{array}$ & C. L. Azeda & 0,25 & 0,5907 & 98,3 \\
\hline $\begin{array}{l}\text { Timavo do Brasil S. A. Ind. } \\
\text { Têxtil }\end{array}$ & Itatiba & Rib. Jacaré & 0,21 & 0,4962 & 98,7 \\
\hline $\begin{array}{l}\text { Elizabeth S. A. Ind. Têxtil } \\
\text { Fábrica III }\end{array}$ & Itatiba & Rib. Jacaré & 0,14 & 0,3308 & 99,1 \\
\hline Têxtil Duomo S. A. & Itatiba & Rede Pública & 0,11 & 0,2599 & 99,3 \\
\hline Ind. Gessy Lever Ltda. & Valinhos & C. Invernada & 0,07 & 0,1654 & 99,5 \\
\hline $\begin{array}{l}\text { Elisabeth S. A. Ind. Têxtil } \\
\text { Fábrica I }\end{array}$ & Itatiba & Rede Pública & 0,05 & 0,1181 & 99,6 \\
\hline Granjas Mara S. A. & Itatiba & C. Juremas & 0,05 & 0,1181 & 99,7 \\
\hline $\begin{array}{ll}\text { Covolan } & \text { Beneficiamento } \\
\text { Têxtil Ltda. } & \\
\end{array}$ & Itatiba & Rib. Jacaré & 0,03 & 0,0709 & 99,8 \\
\hline $\begin{array}{l}\text { Linhasita Ind. Linha para } \\
\text { Coser Ltda. }\end{array}$ & Itatiba & Rede Pública & 0,02 & 0,0473 & 99,9 \\
\hline Fibralin Têxtil S. A. & Itatiba & Rede Pública & 0,01 & 0,0236 & 99,9 \\
\hline Avícola Vinhendense Ltda. & Vinhedo & $\begin{array}{c}\text { Af. R. } \\
\text { Pinheiros }\end{array}$ & 0,01 & 0,0236 & 99,9 \\
\hline CHR Hansen Ind. Com. Ltda. & Valinhos & Rede Pública & 0,01 & 0,0236 & 99,9 \\
\hline Cartonifício Valinhos S. A. & Valinhos & $\begin{array}{c}\text { Rib. } \\
\text { Pinheiros }\end{array}$ & 0,01 & 0,0236 & 100,0 \\
\hline Shell Brasil S. A. & Paulínia & Rio Atibaia & 0,01 & 0,0236 & 100,0 \\
\hline $\begin{array}{ll}\text { Prodome } & \text { Química } \\
\text { Farmacêutica } & \\
\end{array}$ & Campinas & Rio Atibaia & 0,01 & 0,0236 & 100,0 \\
\hline $\begin{array}{l}\text { Laticínios Suíço Holandês } \\
\text { Ltda. }\end{array}$ & Itatiba & Rio Atibaia & 0,00 & 0,00 & 100,0 \\
\hline Witco do Brasil Ltda. & Itatiba & Rib. Jacaré & 0,00 & 0,00 & 100,0 \\
\hline Frigorífico Martini Ltda. & Valinhos & Rede Pública & 0,00 & 0,00 & 100,0 \\
\hline Espetinhos Mimi Ltda. & Vinhedo & $\begin{array}{c}\text { Rib. } \\
\text { Pinheiros }\end{array}$ & 0,00 & 0,00 & 100,0 \\
\hline TOTAL & & & 42,32 & & \\
\hline
\end{tabular}

Fonte: CETESB (1999) 
Na Bacia do rio Piracicaba, em 1991, estavam instaladas cerca de 230 indústrias com utilização significativa de água, ou seja, com uma captação da bacia de cerca de $16 \mathrm{~m}^{3} / \mathrm{s}$, e com aproximadamente $14 \mathrm{~m}^{3} / \mathrm{s}$ de retorno da água na forma de efluentes. Cerca de $5 \%$ das cargas orgânicas urbanas eram removidas por estações de tratamento e a parte restante (76 ton de DBO/dia) ainda era lançada diretamente nos rios (GOBBO, 1991). Na sub-bacia do Atibaia, segundo o Departamento de Água e Energia Elétrica (1995) apud CETESB (1999), as quantidades demandadas por setores de atividades em 1995, eram de 2,84 $\mathrm{m}^{3} / \mathrm{s}$ para uso industrial, 1,45 m³ para irrigação e $4,55 \mathrm{~m}^{3} / \mathrm{s}$ para uso urbano. Em relação às cargas orgânicas dos dez municípios que lançam esgotos na bacia, somente dois possuem sistema de tratamento, removendo apenas $1,3 \%$ da carga poluidora potencial dessa bacia.

Dentre as indústrias situadas nas bacias dos Rios Piracicaba e Capivari, cerca de 20 são responsáveis por aproximadamente $90 \%$ da água utilizada industrialmente. Os grandes utilizadores de água, com exceção da Fábrica de Papel Santa Therezinha, localizada em Bragança Paulista, estão situados na porção territorial de maior densidade urbana, ou seja, regiões banhadas pelos rios Piracicaba, Capivari e baixos rios Corumbataí, Atibaia e Jaguari. O maior consumidor é a Rhodia Indústria Química, empresa do grupo francês Rhône Poulenc, que consome cerca de 3 mil litros por segundo de água, valor equivalente a uma cidade com 900 mil habitantes. Somente a Rhodia utiliza cerca de $23 \%$ do total de água da vazão industrial captada nas duas bacias. As usinas de açúcar e de álcool representam 33\% do total, o que é equivalente a 4300 litros por segundo (MONTICELI \& MARTINS, 1993).

Como no caso da captação de água dos rios, um pequeno número de unidades industriais é responsável pela maior parcela das cargas poluidoras lançadas nos corpos d'água. Considerando-se a sub-bacia do Atibaia, oito indústrias geram cerca de $80 \%$ da carga poluidora (MONTICELI \& MARTINS, 1993).

A sub-bacia do Rio Atibaia drena, parcial ou totalmente, os municípios paulistas de Americana, Campinas, Jaguariúna, Nova Odessa, Paulínia, Valinhos, Vinhedo, Itatiba, Jarinu, Morungaba, Atibaia, Bom Jesus dos Perdões, Bragança Paulista, Joanópolis, Nazaré Paulista e Piracaia. Nessa sub-bacia, a densidade industrial aumenta de montante para jusante. Nas cabeceiras, encontra-se maior atividade agrícola enquanto os grandes centros consumidores concentram-se do ponto médio à foz, chegando ao ápice no município de Paulínia, onde localiza-se um pólo petroquímico (CETESB, 1999).

As atividades produtivas, especialmente dos setores industrial e terciário, ocorrem de forma concentrada em alguns municípios da sub-bacia, notadamente na área conurbada. Como decorrência dessa concentração, é nesses trechos da sub-bacia que os recursos naturais 
encontram-se mais degradados e onde a disponibilidade e a qualidade dos recursos hídricos são motivos de preocupação (CETESB, 1999).

A ocupação do solo, associada ao desenvolvimento da região e ao baixo aproveitamento atual das águas subterrâneas é responsável pelos usos expressivos, múltiplos e crescentes dos recursos hídricos superficiais da sub-bacia, dentre os quais destacam-se: abastecimento urbano e industrial, irrigação, entrada de efluentes sanitários e industriais, geração de energia elétrica e recreação (CETESB, 1999).

Segundo dados fornecidos pelo DAEE - Departamento de Águas e Energia Elétrica, as quantidades demandadas por setores de atividades em 1995 eram de 2,84 $\mathrm{m}^{3} / \mathrm{s}$ para uso industrial, $1,45 \mathrm{~m}^{3} / \mathrm{s}$ para irrigação e $4,55 \mathrm{~m}^{3} / \mathrm{s}$ para uso urbano (CETESB, 1999).

Os usos industriais da água estão predominantemente localizados junto ao Polo Petroquímico de Paulínia e caraterizam-se como não consuntivos, ou seja, considera-se o retorno ao rio das águas captadas. Embora as águas captadas retornem ao rio, não interferindo, em tese, na contabilização hídrica, alguns trechos específicos do rio são afetados substancialmente pelas retiradas. Exemplo da influência dessas captações são os cerca de $1,5 \mathrm{~m}^{3} / \mathrm{s}$ captados pela Rhodia próximo ao Córrego Peva que, retornando ao rio 3 $\mathrm{Km}$ a jusante, causam nos períodos de estiagens, além de acentuada perturbação no regime hidráulico do rio, condições sanitárias críticas no trecho intermediário entre a captação e o lançamento (CETESB, 1999).

Quanto às captações para finalidades agrícolas, são estimadas em cerca de $1,15 \mathrm{~m}^{3} / \mathrm{s}$ em toda a sub-bacia (SEADE, 1992 apud CETESB, 1999) e caraterizam-se pela não concentração em determinado trecho do rio, além da agravante de ser uma utilização totalmente consuntiva (CETESB, 1999).

As cargas poluidoras potenciais de origem doméstica foram calculadas com base nas populações urbanas atendidas por rede de esgotos, adotando-se a contribuição de $54 \mathrm{~g}$ de

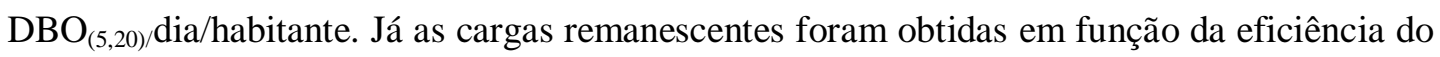
sistema de tratamento, quando existente. A Tabela 3.3 mostra a relação dos municípios cujos esgotos são lançados no Rio Atibaia ou seus afluentes, suas populações com as porcentagens de atendimento por coleta de esgotos, e as cargas poluidoras potenciais e remanescentes. Com uma população urbana estimada em 692.469 habitantes, praticamente todo o esgoto doméstico desses municípios é lançado sem tratamento nos corpos receptores. São lançados diariamente $30.341,11 \mathrm{Kg}$ de $\mathrm{DBO}_{(5,20)}$. Dos dez municípios que lançam esgotos na subbacia, somente dois possuem sistema de tratamento, removendo apenas $1,3 \%$ da carga poluidora potencial dessa sub-bacia (CETESB, 1999). 
Tabela 3.3 -Sistemas de Esgotos e Cargas Orgânicas de Origem Doméstica

\begin{tabular}{|c|c|c|c|c|c|c|c|}
\hline \multirow{2}{*}{\multicolumn{2}{|c|}{ Municípios }} & \multicolumn{2}{|c|}{ População } & \multicolumn{2}{|c|}{$\begin{array}{c}\text { Cargas Orgânicas } \\
\left.\text { (Kg DBO }_{5,20} / \text { dia }\right)\end{array}$} & \multirow{2}{*}{ ETE } & \multirow{2}{*}{$\begin{array}{c}\text { Corpos } \\
\text { Receptores }\end{array}$} \\
\hline & & $\begin{array}{l}\text { Urbana } \\
\text { (hab.) }{ }^{(1)}\end{array}$ & $\left|\begin{array}{lr}\% & \text { Atendida } \\
\text { por } & \text { Coleta } \\
(2)\end{array}\right|$ & Potencial $^{(3)}$ & Remanescente & & \\
\hline \multirow{2}{*}{\multicolumn{2}{|c|}{$\begin{array}{l}\text { Atibaia } \\
\text { Bom Jesus dos } \\
\text { Perdões }\end{array}$}} & 84.609 & 40 & $1.828,55$ & $1.827,55$ & Não & Rio Atibaia \\
\hline & & 9.966 & 90 & 484,35 & 484,35 & Não & Rio Atibainha \\
\hline \multirow{6}{*}{ 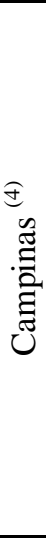 } & $\begin{array}{l}\text { ETE } \\
\text { Samambaia }\end{array}$ & 52.791 & 86 & $2.451,61$ & $2.451,61$ & Em obras & $\begin{array}{l}\text { Ribeirão } \\
\text { Samambaia }\end{array}$ \\
\hline & $\begin{array}{l}\text { ETE } \\
\text { Joaquim } \\
\text { Egídio } \\
\end{array}$ & 1.337 & 86 & 62,09 & 62,09 & Não & $\begin{array}{l}\text { Ribeirão das } \\
\text { Cabras }\end{array}$ \\
\hline & $\begin{array}{l}\text { ETE } \\
\text { Souzas }\end{array}$ & 11.593 & 86 & 538,38 & 538,38 & Não & Rio Atibaia \\
\hline & $\begin{array}{l}\text { ETE Barão } \\
\text { Geraldo }\end{array}$ & 27.163 & 86 & $1.261,45$ & $1.261,45$ & Não & $\begin{array}{l}\text { Ribeirão } \\
\text { Anhumas }\end{array}$ \\
\hline & $\begin{array}{l}\text { ETE Santa } \\
\text { Candida }\end{array}$ & 4.721 & 86 & 219,24 & 219,14 & Não & $\begin{array}{l}\text { Ribeirão } \\
\text { Anhumas }\end{array}$ \\
\hline & $\begin{array}{l}\text { ETE } \\
\text { Anhumas }\end{array}$ & 256.015 & 100 & $13.824,81$ & $13.824,81$ & Não & $\begin{array}{l}\text { Ribeirão } \\
\text { Anhumas }\end{array}$ \\
\hline \multicolumn{2}{|c|}{ Itatiba } & 63.443 & 88 & $3.014,81$ & $3.014,81$ & Não & $\begin{array}{l}\text { Ribeirão } \\
\text { Jacarezinho }\end{array}$ \\
\hline \multicolumn{2}{|c|}{ Jarinu } & 7.566 & 50 & 204,28 & $30,64^{(6)}$ & $\begin{array}{c}\text { Lagoa } \\
\text { Facultativa } \\
\end{array}$ & \begin{tabular}{|l|} 
Ribeirão \\
Campo Largo \\
\end{tabular} \\
\hline \multicolumn{2}{|c|}{$\begin{array}{l}\text { Nazaré } \\
\text { Paulista }\end{array}$} & 5.028 & 95 & 257,93 & $38,69^{(6)}$ & $\begin{array}{c}\text { Lagoa } \\
\text { Facultativa } \\
\end{array}$ & Rio Atibainha \\
\hline \multicolumn{2}{|c|}{ Paulínia } & 39.842 & 80 & $1.721,17$ & $1.721,17$ & Não & Rio Atibaia \\
\hline \multicolumn{2}{|c|}{ Piracaia } & 20.224 & 75 & 819,07 & 819,07 & Em obras & Rio Cachoeira \\
\hline \multicolumn{2}{|c|}{ Valinhos } & 69.637 & 70 & $2.632,28$ & $2.632,28$ & Não & $\begin{array}{l}\text { Ribeirão } \\
\text { Pinheiros } \\
\end{array}$ \\
\hline \multicolumn{2}{|c|}{ Vinhedo } & 38.534 & 68 & $1.414,97$ & $1.414,97$ & Em obras & \begin{tabular}{|l|} 
Ribeirão \\
Pinheiros \\
\end{tabular} \\
\hline \multicolumn{2}{|c|}{ TOTAL } & 692.469 & ------ & $30.733,99$ & $30.341,11$ & \multicolumn{2}{|c|}{ Remoção: $1,3 \%$} \\
\hline
\end{tabular}

Fonte : CETESB (1999)

(1) Dados fornecidos pela Fundação SEADE - 1996

(2) Dados fornecidos pelas Prefeituras Municipais (1996/1997)

(3) Dados estimados utilizando-se contribuição per capita de $0,054 \mathrm{Kg} \mathrm{DBO}(5,20) /$ dia/habitante

(4) Dados de população do Município de Campinas fornecidos pela SANASA em função dos contribuintes de cada futura ETE

(5) Estimada eficiência de remoção de DBO de 85\%

(6) Considerada eficiência de remoção de DBO de $85 \%$ conforme dados obtidos em amostragem realizada pela CETESB

Para a verificação da contribuição da carga poluidora de origem industrial, a CETESB realizou amostragens compostas em um período de 24 horas, nos meses de maio e junho de 1998, nos efluentes tratados das principais indústrias da sub-bacia. Os valores de 
carga orgânica remanescente obtidos foram listados em ordem decrescente na Tabela 3.4. Foi verificado que 14 indústrias eram responsáveis por cerca de $99 \%$ do total da carga orgânica de origem industrial inventariada e lançada na sub-bacia. A carga orgânica remanescente total foi de 4.373,48 Kg DBO/dia (CETESB, 1999).

Tabela 3.4 - Carga Orgânica Industrial Remanescente - $\mathrm{Kg} \mathrm{DBO} \mathrm{O}_{(5,20)} /$ dia

\begin{tabular}{|c|c|c|c|c|}
\hline Indústria & Município & $\begin{array}{c}\text { Corpo } \\
\text { Receptor }\end{array}$ & $\begin{array}{c}\text { Carga } \\
\text { Orgânica } \\
\end{array}$ & $\begin{array}{c}\% \\
\text { Acumulada }\end{array}$ \\
\hline Rhodiaco Indústrias Químicas Ltda. & Paulínia & Rio Atibaia & $1.080,60$ & 24,70 \\
\hline Rhodia Brasil Ltda. & Paulínia & Rio Atibaia & 793,00 & 42,84 \\
\hline J. Bresler S.A. Papel Papelão Bem. & Paulínia & Rio Atibaia & 600,40 & 56,57 \\
\hline $\begin{array}{l}\text { Elisabeth S.A. Ind. Têxtil - Fábrica } \\
\text { II }\end{array}$ & Itatiba & Rib. Jacaré & 371,60 & 61,06 \\
\hline Granjas Mara S.A. & Itatiba & C. Juremas & 290,40 & 71,70 \\
\hline Petróleo Brasileiro S.A. REPLAN & Paulínia & Rio Atibaia & 269,20 & 77,80 \\
\hline Têxtil Duomo S.A. & Itatiba & R.P. & 202,88 & 82,50 \\
\hline Rigesa Celulose Papel Emb. Ltda. & Valinhos & $\begin{array}{c}\text { Rib. } \\
\text { Pinheiros }\end{array}$ & 186,42 & 86,76 \\
\hline Bann Química Ltda. & Paulínia & Rio Atibaia & 162,00 & 90,47 \\
\hline $\begin{array}{l}\text { Covolan Beneficiamento Têxtil } \\
\text { Ltda. }\end{array}$ & Itatiba & Rib. Jacaré & 141,22 & 93,69 \\
\hline Elizabeth S.A. Ind. Têxtil Fábrica1 & Itatiba & C. Cióffi & 55,97 & 94,97 \\
\hline Fibralin Têxtil S.A. & Itatiba & R.P. & 51,99 & 96,16 \\
\hline Timavo do Brasil S.A. Ind. Têxtil & Itatiba & Rib. Jacaré & 45,44 & 97,20 \\
\hline $\begin{array}{llll}\begin{array}{l}\text { Elizabeth } \\
\text { FábricaIII }\end{array} & \text { S.A. } & \text { Ind. } & \text { Têxtil } \\
\end{array}$ & Itatiba & Rib. Jacaré & 38,16 & 98,70 \\
\hline $\begin{array}{l}\text { Ind. Gessy Lever Ltda. Shell Brasil } \\
\text { S.A. }\end{array}$ & Valinhos & C. Invernada & 35,61 & 98,89 \\
\hline Shell Brasil S.A. & Paulínia & Rio Atibaia & 17,80 & 99,29 \\
\hline Avícola Vinhendense Ltda. & Vinhedo & $\begin{array}{c}\text { Rib. } \\
\text { Pinheiros } \\
\end{array}$ & 10,53 & 99,54 \\
\hline $\begin{array}{l}\text { Linhasita Ind. Linha para Coser } \\
\text { Ltda. }\end{array}$ & Itatiba & R.P. & 6,16 & 99,68 \\
\hline Tinturaria Estamparia Cofina Ltda. & B.J.Perdões & C.L. Azeda & 5,11 & 99,77 \\
\hline CHR Hansen Ind. Com. Ltda. & Valinhos & R.P. & 2,76 & 99,85 \\
\hline Prodome Química Farmacêutica & Campinas & Rio Atibaia & 1,80 & 99,89 \\
\hline Laticínio Suíço Holandês Ltda. & Itatiba & Rio Atibaia & 1,22 & 99,93 \\
\hline Cartonifício Valinhos S.A. & Valinhos & $\begin{array}{c}\text { Rib. } \\
\text { Pinheiros } \\
\end{array}$ & 1,17 & 99,95 \\
\hline Frigorífico Martini Ltda. & Valinhos & Rib. Jardim & 1,14 & 99,98 \\
\hline Espetinhos Mimi Ltda. & Vinhedo & $\begin{array}{c}\text { Rib. } \\
\text { Pinheiros } \\
\end{array}$ & 0,50 & 99,99 \\
\hline Witco do Brasil Ltda. & Itatiba & Rib. Jacaré & 0,40 & 100,00 \\
\hline Total & & & $4.373,48$ & 100,00 \\
\hline
\end{tabular}


Também foram efetuadas análises de fenóis nas amostras de efluentes tratados das principais indústrias avaliadas. A Tabela 3.2 apresentou os dados obtidos, listados em ordem decrescente da carga remanescente de fenóis. Verificou-se que apenas uma indústria é responsável por 87,2\% dessa carga (CETESB, 1999).

A Figura 3.2 apresenta a localização das indústrias amostradas, a carga orgânica e de fenóis remanescentes, assim como a vazão dos efluentes e o ponto de lançamento destes nos respectivos corpos receptores, sendo a atividade de cada uma dessas indústrias indicada na Tabela 3.5.

Tabela 3.5 - Indústrias e suas respectivas atividades

\begin{tabular}{|c|c|}
\hline Indústria & Atividade \\
\hline J. Bresler S/A Papel Papelão e Embalagem & Fábrica de Papel e Papelão \\
\hline Shell Brasil S. A. & Indústria Química \\
\hline Petróleo Brasileiro S. A. - Petrobrás Replan & Refinaria de Petróleo \\
\hline $\begin{array}{l}\text { Rhodia S. A. } \\
\end{array}$ & Indústria Química \\
\hline Bann Química Ltda. & Indústria Química \\
\hline Prodome Química e Farmacêutica Ltda. & Fábrica de Produtos Farmacêuticos \\
\hline Laticínios Suíço Holandês Ltda. & Fábrica de Laticínios \\
\hline Tinturaria e Estamparia Cofina Ltda. & Tinturaria e Estamparia \\
\hline Indústrias Gessy Lever Ltda. & Fábrica de Sabões e Sabonetes \\
\hline Cartonifício Valinhos S.A. & Fábrica de Papel e Papelão \\
\hline Rigesa Celulose Papel e Embalagens Ltda. & Fábrica de Papelão e Embalagens \\
\hline Chr Hansen Indústria e Comércio Ltda. & Fábrica de Coalhos e Coagulantes \\
\hline Frigorífico Martini Ltda. & Fábrica de Produtos Alimentares \\
\hline Avícola Vinhendense Ltda. & Abate de Aves \\
\hline Granjas Mara S/A & Abate de Aves \\
\hline Elisabeth S. A. Ind. Têxtil III & Indústria Têxtil \\
\hline Elisabeth S. A. Ind. Têxtil - Fábrica II & Estamparia E Tingimento de Tecidos \\
\hline Elisabeth S. A. Ind. Têxtil I & Indústria Têxtil \\
\hline Covolan Beneficiamentos Têxteis Ltda. & Estamparia E Tingimento de Tecidos \\
\hline Têxtil Duomo S.A. & Indústria Têxtil \\
\hline Witco & Fábrica de Silicone \\
\hline Timavo do Brasil S.A. Ind. Têxtil & Tingimento de Tecidos \\
\hline Linhasita Ind. de Linhas P/ Coser Ltda. & Fabricação de Linhas \\
\hline Fibralin S. A. & $\begin{array}{c}\text { Estamparia Tingimento e Acabamento de } \\
\text { Tecidos }\end{array}$ \\
\hline Rhodíaco & Indústria Química \\
\hline
\end{tabular}


Figura 3.2 - Localização, carga orgânica e de fenóis remanescentes das indústrias situadas na sub-bacia do Atibaia vazão dos efluentes e o ponto de lançamento destes nos respectivos corpos receptores (CETESB, 1999) 
A carga orgânica remanescente de origem doméstica da sub-bacia é de $30.341,11 \mathrm{Kg}$ $\mathrm{DBO}_{(5,20)} /$ dia e de origem industrial é de $4.373,48 \mathrm{Kg} \mathrm{DBO}_{(5,20)} /$ dia, perfazendo o total de $34.714,59 \mathrm{Kg} \mathrm{DBO}(5,20) /$ dia. Pode-se concluir que a carga orgânica doméstica representa o principal problema do Rio Atibaia, em termos de cargas localizadas, que correspondem a 87,4\% do total (CETESB, 1999). A qualidade das águas do Atibaia é boa até a foz do Ribeirão Anhumas, onde são lançados os esgotos de Campinas, com concentração de oxigênio dissolvido sempre acima de $4 \mathrm{mg} / \mathrm{L}$ (CETESB, 1979), mesmo quando o Rio apresenta menores vazões durante os meses de inverno. A jusante do ribeirão, observa-se que a concentração de oxigênio dissolvido cai para zero, certamente em virtude das cargas poluidoras recebidas das indústrias e do esgoto sanitário de Campinas (COELHO,1993).

Poucos quilômetros a jusante do Ribeirão Anhumas, o Rio recebe ainda os dejetos do polo petroquímico de Paulínia e também os esgotos da cidade de Paulínia, que tem apresentado crescimento acelerado nos últimos anos (COELHO,1993).

Logo, o Rio Atibaia, vem recebendo efluente sanitário e industrial, passando por Campinas, Sumaré, Paulínia e chega bastante poluído em Americana, onde suas margens são represadas na região do Salto Grande, apresentando-se em crescente processo de deterioração. $\mathrm{O}$ material em suspensão presente nos efluentes lançados, bem como no erodido das margens, é sedimentado no reservatório, provocando o seu assoreamento (GOBBO, 1991), e sendo também uma possível fonte de contaminação por poluentes adsorvidos e/ou lixiviados.

O reservatório é responsável pela autodepuração das águas do Rio Atibaia, sofrendo por isto todos os impactos decorrentes deste fenômeno. Em função do aporte de nutrientes e condições hidráulicas ocorrem também importantes florações de algas do gênero Anabaena, ocorrendo entretanto com mais freqüência a espécie Microcystis aeruginosa, responsáveis por efeitos adversos à qualidade organoléptica, visto que os sistemas de tratamento de Americana e Piracicaba não conseguem eliminar as toxinas produzidas por estas algas, das águas do Rio Piracicaba, usadas para abastecimento público destas cidades (MONTICELI \& MARTINS, 1993; CETESB, 1999).

Portanto é de grande importância a análise dos compostos tóxicos presentes no reservatório de Salto Grande, ou seja, avaliar sua qualidade e quantidade, a fim de dimensionar os níveis de contaminação ambiental. A obtenção de valores seguros poderá nortear decisões para o controle, recuperação e manejo do sistema em questão. 


\subsubsection{Reservatório de Salto Grande}

O Reservatório de Salto Grande está localizado no município de Americana, São Paulo.

O município de Americana (SP) está localizado a $22^{0} 44^{\prime}$ de latitude sul e $47^{0} 20^{\prime}$ de longitude oeste, no estado de São Paulo, na Depressão Periférica paulista e possui os maiores índices de poluição por sulfeto da região (MONTICELI \& MARTINS, 1993).

O clima de Americana é típico da região. Sua área está localizada na zona de interseção das 3 maiores correntes da circulação regional: massa de ar equatorial e tropical continentais, massa tropical Atlântica e massa Polar. Como resultado da influência dessas massas de ar, o clima da região é marcado por dois períodos distintos: um período seco e frio, correspondendo aos meses de abril a setembro e outro período mais úmido e quente, correspondendo aos meses de outubro a março.

A temperatura média anual varia de $18^{\circ}$ Celsius no trecho superior da Bacia, a $20^{\circ} \mathrm{C}$ no trecho inferior.

Em Americana, atualmente, a ocupação industrial é de $88,65 \%$ constituída por tecelagens, o que transforma esta cidade no maior pólo têxtil do país. As terras agrícolas da região, tradicionalmente pertencentes a pequenos agricultores, pouco a pouco, vêm sendo cedidas por sistema de arrendamento à agroindústria da cana-de-açúcar (RIBEIRO \& FERREIRA, apud, BOTTURA, 1998).

A confluência dos rios Atibaia e Jaguari ocorre em Americana, dando origem ao Rio Piracicaba, que drena por terrenos sedimentares, com seu curso naturalmente retificado, sendo navegável até sua foz no curso médio do Rio Tietê (GOBBO,1991).

Em 1911, no rio Atibaia, foi construída a Usina de Salto Grande para fornecer energia elétrica à indústria de tecidos, que foi adquirida pela CPFL (Companhia Paulista de Força e Luz) em 1930 (BOTTURA, 1998). Posteriormente, em 1949, aproveitando a mesma queda d'água, a CPFL construiu a Usina Hidrelétrica de Americana. O reservatório foi criado para atender a crescente demanda de energia necessária ao processo de industrialização (instalação de tecelagens) e urbanização (BOTTURA, 1998).

A partir de 1949, com a construção do reservatório de Salto Grande, houve um processo acelerado de modificação nas áreas do entorno do reservatório (BOTTURA, 1998). A região de Americana até então, tinha sua economia baseada na agricultura, com culturas comerciais e de subsistência, criações para consumo próprio e criação de gado de leite. Era 
uma sociedade ligada ao meio rural em sua origem. A lavoura era a base da subsistência dos indivíduos e todas as outras atividades eram complementares a ela (BOTTURA, 1998).

O reservatório transformou a região em um grande pólo turístico, trazendo outras opções de trabalho à população local e aos imigrantes, visto que estes podiam trabalhar em hotéis, restaurantes, aluguel de barcos ou como caseiros nas casas de veraneio. As terras que antes eram cultivadas, foram então vendidas e loteadas e iniciou-se um processo de valorização destas terras por meio da especulação imobiliária. O loteamento do entorno do reservatório ocorreu a partir de 1955. Uma ampla estrutura com hotéis e bares foi então montada para atender ao grande fluxo de turistas. As terras de grande parte do entorno do reservatório foram ocupadas por luxuosas casas de veraneio, com piscinas e "piers" particulares (BOTTURA, 1998).

Na década de 50, as indústrias de tecido se proliferaram na região e acabaram por iniciar um processo radical de alteração das características econômicas de Americana, transformando-a em um grande pólo têxtil. Devido a esta mudança, houve uma necessidade crescente de mão-de-obra, atraindo imigrantes de várias localidades e aumentando a urbanização da região, fazendo com que parte da zona agrícola fosse loteada para este fim. Assim, pôde-se observar um rápido processo de urbanização na bacia hidrográfica (BOTTURA, 1998).

No período de 1960/70, a concentração populacional começa a atingir proporções significativas na bacia do rio Piracicaba, com taxas de 5,1\% ao ano, enquanto na Grande São Paulo e outras regiões o crescimento era de 3,5\% ao ano. Muitas indústrias instalaram-se na região, pois o governo incentivou nesta época o desenvolvimento do interior do Estado de São Paulo, através de sua Política Estadual de Desenvolvimento Urbano e Regional. Este crescimento urbano, associado ao processo de desenvolvimento social e agrícola, permitiu aglomeração contínua de várias cidades da bacia, incluindo Americana, visto que, o processo de urbanização do interior obedece a lógica das redes viárias e das barreiras naturais (MONTICELI \& MARTINS, 1993; SECRETARIA DO MEIO AMBIENTE, 1997). Este programa também provocou a desconcentração e a descentralização da atividade industrial, que até então eram polarizadas nas áreas metropolitanas (PROCHNOW, 1990 apud BOTTURA, 1998).

Na década de 80, devido a este processo de urbanização, industrialização e com isto, o alto índice de poluição na área da bacia hidrográfica do reservatório, o turismo na região entra em declínio. Com o aumento da poluição e deterioração da qualidade da água do reservatório, especialmente por processos como a eutrofização cultural e a proliferação de macrófitas aquáticas, pôde-se observar a ocorrência de usos conflitantes deste meio, havendo 
mudanças nos usos múltiplos da água. Houve o comprometimento da utilização tradicional deste recurso (pesca, lazer, entre outras) em detrimento a utilização deste reservatório como dispersor de poluentes (BOTTURA, 1998).

Segundo BOTTURA (1998), a pesca artesanal e profissional que outrora era abundante, encontra-se modificada pelo estado de deterioração do reservatório. Muitos dos antigos pescadores diminuíram ou cessaram suas atividades.

As terras próximas do reservatório, que antes eram as de maior valor, tornaram-se menos valorizadas. A região tornou-se um bairro dormitório porque a maioria das pessoas trabalha em outras localidades (BOTTURA, 1998).

A atividade agrícola também sofreu mudanças. Atualmente, a grande maioria das lavouras feitas na região, é para comercialização, sendo caracterizadas pelas grandes propriedades arrendadas sobretudo com culturas de laranja e cana-de-açúcar. A maioria das poucas terras agrícolas desta região foi arrendada para a agroindústria da cana-de-açúcar (BOTTURA, 1998).

\subsubsection{Caracterização do Reservatório}

A área mínima inundada do reservatório corresponde a $10,55 \mathrm{Km}^{2}$ e a máxima a, $13,25 \mathrm{Km}^{2}$, sendo a profundidade média de $8,00 \mathrm{~m}$ e a máxima de $19,80 \mathrm{~m}$. O volume máximo é de $106 \times 10^{6} \mathrm{~m}^{3}$, sendo o volume de água para geração de $35 \times 10^{6} \mathrm{~m}^{3}$.

O reservatório está localizado na área de Depressão Periférica paulista que tem a forma de um corredor, de topografia colinosa e encontra-se entre as cuestas basálticas (a oeste do Estado de SP) e as elevações cristalinas do Planalto Atlântico (a leste).

Na Depressão Periférica paulista afloram terrenos sedimentares com grandes variedades de rochas, onde destacam-se arenitos, argilitos, silitos, calcários e folhelos. Destacam-se também as rochas magmáticas extrusivas e intrusivas.

$\mathrm{O}$ relevo apresenta-se em colinas, com encostas suaves e topos aplainados com declividade de encosta de até $15 \%$. Às margens do reservatório, as colinas têm seus topos nivelados em torno de $600 \mathrm{~m}$. Há um desnível aproximado de 70 metros entre o topo das colinas e a lâmina d'água do reservatório.

O relevo apresenta-se em colinas amplas com topos extensos e aplainados, interflúvios (divisores de água) com áreas de até $4 \mathrm{Km}^{2}$, vertentes com perfis retilíneos, predominantemente convexos, resultando em elevações de encostas suaves e vales abertos. 
O reservatório de Salto Grande tem, à sua margem direita, áreas de plantações de cana-de-açúcar; a margem esquerda é limitada por algumas plantações de Citrus e a nordeste há áreas de plantio de eucaliptos.

Ao longo do curso do rio Atibaia, antes do represamento, havia matas galeria com faixas de vegetação entre 50 e 100 metros de largura (BOTTURA, 1998). Atualmente, às margens dos rios Jaguari e Piracicaba conservam-se manchas isoladas da mata natural, secundária.

O volume total de material sedimentar depositado no reservatório em 40 anos foi calculado em $9.397 .703 \mathrm{~m}^{3}$ (8.86\% do volume total) representando uma perda anual média da ordem de $0.22 \%$ do volume total, sendo que $80 \%$ desse volume concentra-se em seu terço a montante, fato que comprova a grande preponderância dos sedimentos carreados para o interior do reservatório pelo Rio Atibaia, única drenagem significativa a alimentar o reservatório, sobre os sedimentos produzidos nos entornos do mesmo. O volume de assoreamento calculado por este método deve ser considerado como ordem de grandeza, o que significa que se pode afirmar com segurança que, em 40 anos, depositaram-se no reservatório cerca de 10 bilhões de $\mathrm{m}^{3}$ de sedimentos correspondendo a pouco menos de $10 \%$ de seu volume total (COELHO, 1993).

O processo de assoreamento não ocorre de maneira linear em toda extensão longitudinal do reservatório. Pelo contrário, as próprias características do vale submerso, que apresenta um gradiente muito pequeno, desfavorecendo a progressão de correntes de densidade, acarreta uma distribuição bastante diferenciada de espessura das colunas sedimentares, com a sedimentação tendendo a progredir em uma frente bastante abrupta a partir da cabeceira do reservatório na forma de um delta. Em 40 anos foram perdidos pouco mais de 5\% do volume útil do reservatório, representando uma perda anual média de apenas 0,15\% do volume de água gerador de energia (COELHO,1993).

A distribuição dos sedimentos de fundo faz-se em função da distância da principal área fonte de sedimentos que é o Rio Atibaia e da topografia de fundo do reservatório, que por sua vez é condicionada pela existência de dois saltos submersos que devem sua existência a corpos de diabásio que cortam o vale transversalmente. Estes saltos dividem o reservatório em três compartimentos distintos em termos de profundidade máxima e distribuição de sedimentos (COELHO,1993).

O primeiro destes compartimentos, localiza-se a montante do Salto, sendo denominado por Saltinho, na cabeceira do reservatório. Com profundidade máxima original de $7 \mathrm{~m}$, encontra-se hoje quase totalmente assoreado, com depósitos de material de assoreamento acima da linha d'água e já estabilizados por vegetação cobrindo grande parte 
de sua extensão. As colunas sedimentares das amostras tiradas neste setor, em locais ainda abaixo da linha d'água apresentaram espessuras de assoreamento variáveis entre 2 e 3 metros (COELHO,1993). O segundo compartimento, entre o Saltinho e o Salto do Foguete, apresenta profundidade máxima próxima de 14 metros e caracteriza-se pela grande variação das espessuras de assoreamento (COELHO,1993). O terceiro compartimento, entre o Salto do Foguete e a barragem, tem profundidade máxima de 20 metros e é o que apresenta as menores espessuras de assoreamento. A pequena espessura de sedimentos encontrada neste setor deve ser creditada principalmente à distância da principal fonte de sedimentos que é o Atibaia, já que o mesmo deposita grande parte de sua carga sedimentar logo na entrada do reservatório (COELHO,1993).

Atualmente, o reservatório de Salto Grande tem capacidade de geração de $30 \mathrm{MW}$ de energia, 10MW por unidade geradora, sendo também utilizado para fins de abastecimento e recreação. 


\section{MATERIAL E MÉTODOS}

\section{1 Área de Estudo, Coleta e Estocagem}

Este trabalho foi realizado com amostras coletadas no Reservatório de Salto Grande na região de Americana/SP. Foram coletadas amostras de água e sedimento em 3 estações no reservatório e uma estação no Rio Atibaia.

A primeira estação (P1) está localizada no Rio Atibaia, no ponto de captação de água para a cidade de Sumaré, localizado a $22^{\circ} 45^{\prime} 43.7^{\prime \prime} \mathrm{S} ; 47^{0} 10^{\prime} 30.3^{\prime \prime}$ W. A segunda estação (P2) está localizada na entrada área alagada $\left(22^{\circ} 44^{\prime} 46.7^{\prime \prime} \mathrm{S} ; 47^{0} 11^{\prime} 20.3^{\prime \prime} \mathrm{W}\right)$, início do primeiro compartimento; a terceira estação (P3) está no segundo compartimento $\left(22^{0} 43^{\prime} 32.8^{\prime \prime} \mathrm{S}\right.$; $47^{0} 13.45^{\prime \prime} \mathrm{W}$ ) e a quarta estação (P4) no terceiro compartimento, $22^{0} 41^{\prime} 58.3^{\prime \prime} \mathrm{S} ; 47^{0} 16.38 .6^{\prime \prime}$ W (Figura 4.1).

Foram feitas duas coletas na estação seca (Maio e Junho) e duas coletas na estação chuvosa (Novembro e Fevereiro). As primeiras coletas foram realizadas com a finalidade de caracterizar o reservatório, ou seja, observar as condições de entrada e saída do reservatório.

Na primeira coleta, feita no mês de maio de 1998, foram coletadas amostras de água e sedimento na estação 2 e amostra de sedimento na estação 4. Na segunda coleta, feita no mês de Junho de 1998, foram coletadas amostras de água e sedimento nas estações 2 e 4 . As duas coletas seguintes, foram feitas em Novembro de 1998 e Fevereiro de 1999, sendo coletadas amostras de água e sedimento nas estações 1, 2, 3 e 4 .

A coleta de sedimento foi feita utilizando core (Figura 4.2). O sedimento coletado (aproximadamente 50 centímetros) foi estratificado no campo, de $10 \mathrm{em} 10 \mathrm{~cm} \mathrm{e} \mathrm{cada}$ camada foi acondicionada em recipientes de vidro com tampa e colocada imediatamente sob baixa temperatura, usando-se um recipiente de isopor com gelo. A estocagem do material antes das análises foi feita em freezer $\left(-18^{\circ} \mathrm{C}\right)$. Exceção foi feita para a primeira coleta, em que as amostras foram mantidas apenas sob refrigeração, a $4^{0} \mathrm{C}$, pois foram utilizadas para alguns testes de extração e limpeza. 


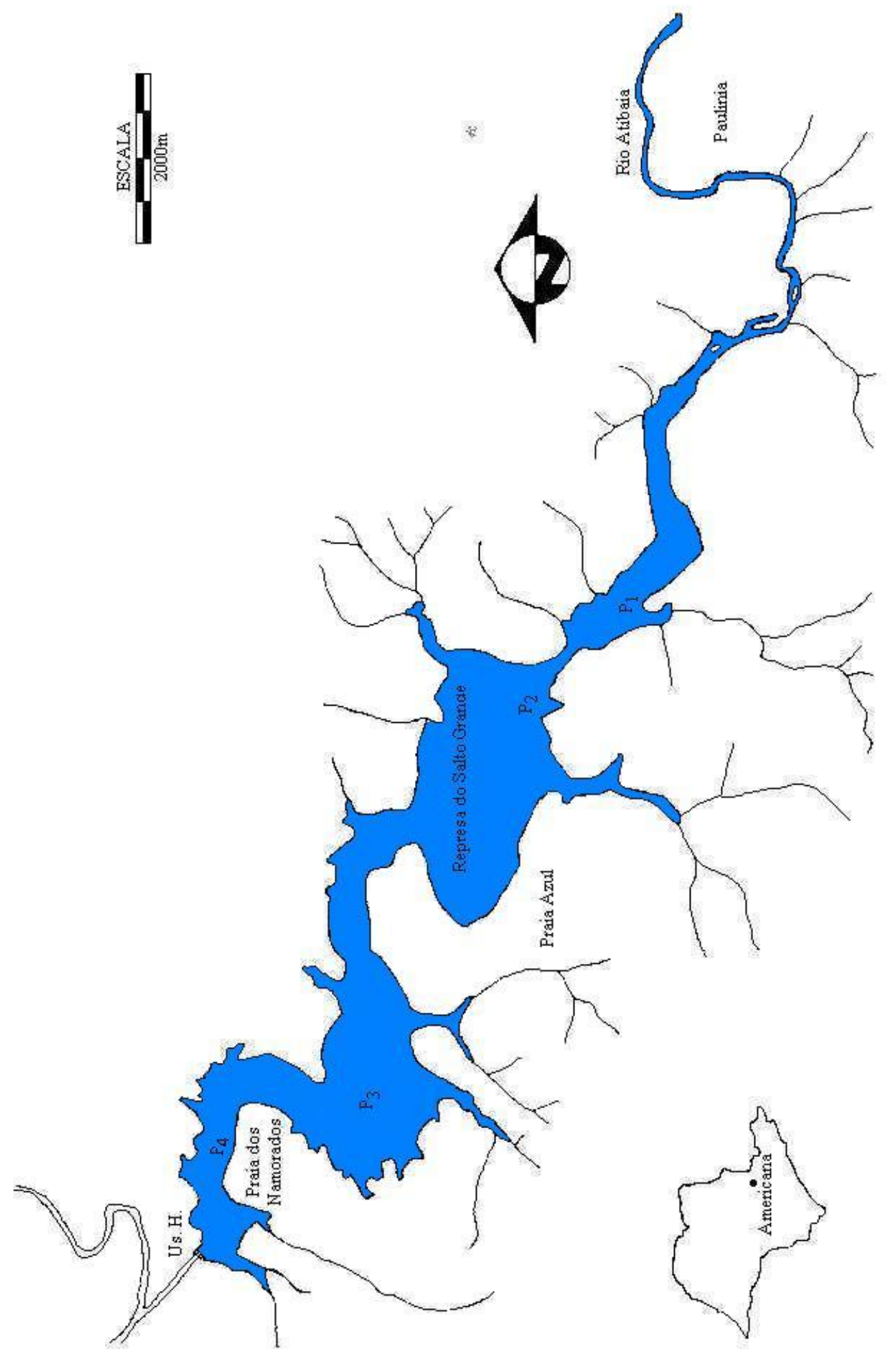

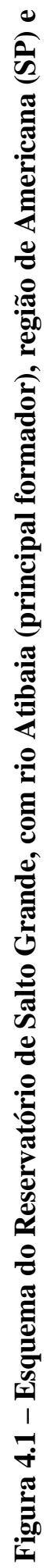


Apesar da coleta dos sedimentos ter possibilitado a estratificação das amostras em uma altura de 50,0 cm, optou-se, devido a demanda experimental, em realizar as análises com a mistura dos sedimentos, assim cada camada do perfil foi misturada com agitador mecânico. Seguiu-se a retirada de porções de 20 gramas de cada camada homogeneizada, e misturou-se as mesmas novamente com o agitador. Obteve-se então, uma amostra composta de 100 gramas, da coluna de sedimento (50,0 $\mathrm{cm}$ ) de cada estação. Desta amostra composta, trabalhou-se com análises em triplicata, utilizando-se amostras de 20 gramas.

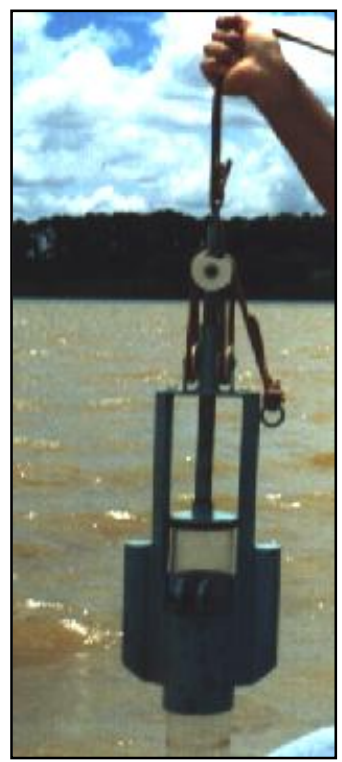

FIGURA.4.2 - INSTRUMENTO UTILIZADO PARA COLETA DE SEDIMENTO (CORE).

A água foi coletada com amostrador de Van Dorn, exceto na primeira coleta, em que foi coletada a coluna d'água. $\mathrm{O}$ acondicionamento foi feito em recipiente de vidro âmbar com tampa. Para cada estação, era coletado um volume de aproximadamente 3,5 litros, sendo acidificado no campo para atingir um $\mathrm{pH}<2$. O recipiente também foi colocado sob baixa temperatura no campo, e mantido sob refrigeração $\left(4^{0} \mathrm{C}\right)$, até o momento da análise.

\subsection{Análises e determinações no campo e em laboratório}

As amostras coletadas foram analisadas quanto a certos parâmetros físico-químicos (temperatura, oxigênio dissolvido, turbidez, condutividade, $\mathrm{pH}$, material em suspensão, carbono orgânico total, etc.), e a presença de clorofenóis foi determinada por cromatografia gasosa. Variáveis hidráulicas e morfométricas do reservatório também foram obtidas, além das condições climatológicas da região durante as campanhas realizadas. 


\subsubsection{Variáveis físico-químicas}

\subsubsection{Temperatura $\left({ }^{\circ} \mathrm{C}\right)$, Oxigênio Dissolvido $(\mathrm{mg} / \mathrm{L})$, Turbidez, Condutividade $(\mu \mathrm{S} / \mathrm{cm})$ e $\mathrm{pH}$}

No campo foram determinados, para as amostras de água, temperatura, teor de oxigênio dissolvido, turbidez, condutividade e pH. As medidas foram feitas de $50 \mathrm{em} 50 \mathrm{~cm}$, utilizando-se o instrumento Horiba (U-10), que era calibrado na primeira estação da coleta.

\subsubsection{Material em suspensão}

Para determinação do material em suspensão (total, orgânico e inorgânico) foi utilizada a técnica gravimétrica descrita por TEIXEIRA et al. (1965) e TUNDISI (1969), com modificações baseadas em WETZEL \& LIKENS (1991).

Foram utilizados filtros de fibra de vidro GF/C (Whatman), $0,45 \mu \mathrm{m}$, calcinados em mufla a $480^{\circ} \mathrm{C}$ por 1 hora, sendo posteriormente pesados em balança analítica. Após a filtragem de um volume conhecido da amostra de água, os filtros foram colocados na estufa a $60^{\circ} \mathrm{C}$ por 24 horas, para eliminar a umidade e realizar a segunda pesagem. As diferenças de massa entre os filtros após e antes da passagem de volumes conhecidos de amostras de água forneceram as quantidades de material em suspensão total, em mg/L.

Para determinação da quantidade de material em suspensão orgânico e inorgânico, os filtros utilizados para determinação do material em suspensão total foram calcinados em mufla a $480^{\circ} \mathrm{C}$ por 1 hora, resfriados e pesados. A diferença de massa entre os filtros secos a $60^{\circ} \mathrm{C}$ e calcinados forneceu a quantidade de material em suspensão orgânico (mg/L) e a diferença entre a massa inicial e após calcinação, a quantidade de material em suspensão inorgânico.

Para a determinação do material em suspensão, a filtragem foi feita no campo logo após a coleta das amostras de água e sedimento. No mês de Junho, as amostras foram acidificadas antes da filtração.

\subsubsection{Carbono orgânico das amostras de água e do sedimento}

Amostras de água de $100 \mathrm{~mL}$ de cada estação foram filtradas em campo em filtro GF/C (Whatman), e armazenadas em frasco de vidro, sendo colocadas sob baixas temperaturas $\left(4^{0} \mathrm{C}\right)$ imediatamente. Em laboratório foram estocadas nesta mesma temperatura até o momento das análises, sendo analisadas no aparelho do Laboratório do Centro de Recursos Hídricos e Ecologia Aplicada (CRHEA). Estas análises seguiram protocolo adotado por esse laboratório. 
Para análise de carbono orgânico (COT) das amostras de sedimento, 5,0g de cada amostra composta dos meses de Novembro e Fevereiro foram secas sob temperatura entre 40 e $60^{\circ} \mathrm{C}$ e trituradas em almofariz com pistilo. $\mathrm{O}$ material foi peneirado integralmente em peneira de malha de $60 \mu$ e armazenado em um frasco de vidro, sendo posteriormente enviado para análise de COT no laboratório de Biogeoquímica Ambiental, da Universidade Federal de São Carlos. Essas análises seguiram protocolo de orientação do Prof. Dr. Antônio Aparecido Mozeto.

\subsubsection{Teor de Umidade no Sedimento}

Foi utilizado o método gravimétrico (KIEHL apud AIROLDI, 1997). Tomaram-se 5,0 gramas das amostras compostas de sedimento, de Novembro de 1998 e Fevereiro de 1999 , procedeu-se à secagem em estufa à temperatura de $60-65^{\circ} \mathrm{C}$ por 20 horas (período mínimo de 16 horas e máximo de 24 horas, segundo KIEHL apud AIROLDI, 1997) e, então, pesaram-se as amostras secas. A porcentagem de umidade foi determinada pela seguinte fórmula:

$\left.\% \mathrm{U}_{(60-65}{ }^{0} \mathrm{C}\right)=100 x\left(\mathrm{M}-\mathrm{M}_{1}\right) / \mathrm{M}$

em que:

$\mathrm{M}=$ massa da amostra antes da secagem;

$\mathrm{M}_{1}=$ massa da amostra seca a $60-65^{\circ} \mathrm{C}$.

As amostras secas a $60-65^{\circ} \mathrm{C}$ foram levadas à estufa a $100-110^{\circ} \mathrm{C}$, por 20 horas. A porcentagem de umidade foi calculada pela seguinte fórmula, em função do peso da amostra seca a $60-65^{\circ} \mathrm{C}$ :

$\mathrm{U}=\mathrm{M}_{2} / \mathrm{M}$

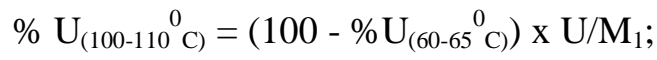

$\mathrm{M}_{2}=$ massa da amostra seca a $100-110^{\circ} \mathrm{C}$.

A umidade perdida por aquecimento representa a umidade do sedimento na amostragem.

\subsubsection{Condições climatológicas da área do reservatório}

Os parâmetros climatológicos considerados neste trabalho foram radiação global $\left(\mathrm{cal} / \mathrm{cm}^{2} . \mathrm{d}\right)$, insolação (horas/dia), precipitação $(\mathrm{mm})$, UR $(\%)$, vento máximo $(\mathrm{m} / \mathrm{s})$, vento médio $(\mathrm{Km} / \mathrm{h})$, temperatura máxima $\left({ }^{0} \mathrm{C}\right)$, temperatura mínima $\left({ }^{0} \mathrm{C}\right)$, temperatura média $\left({ }^{0} \mathrm{C}\right)$ e evaporação (mm). Os valores dos parâmetros foram obtidos pela Estação Climatológica da 
Escola Superior de Agricultura Luiz de Queiroz, da Universidade de São Paulo, campus de Piracicaba (SP) (CIAGRI, 1999).

\subsubsection{Variáveis hidráulicas e morfométricas do reservatório}

Os dados de vazão defluente, afluente, turbinada e vertida, o nível de água e o volume médio mensal para o Reservatório de Salto Grande, foram fornecidos pela Companhia Paulista de Força e Luz, baseados nos dados de operação da usina (CPFL, 1999 apud TOSSINI, 1999). O tempo médio mensal de residência da água foi obtido pela divisão do volume médio mensal do reservatório pela vazão média mensal de saída.

\subsubsection{Métodos cromatográficos}

\subsubsection{Reagentes e tratamentos utilizados}

\subsection{Reagentes utilizados}

Hexano (Merck); ácido sulfúrico concentrado (Merck); Hidróxido de sódio (PAACS, Synth), sulfato de sódio anidro (Carlo Erba); Silicagel 60 (70-230 mesh ASTM).

\subsection{Tratamento dos solventes}

O n-hexano foi obtido da Merck, grau PA, e passou por uma etapa de purificação, segundo PERRIN et al. (1980), que consistia nos seguintes procedimentos: 2 litros de nhexano ficavam sob agitação com $200 \mathrm{~mL}$ de $\mathrm{H}_{2} \mathrm{SO}_{4}$ concentrado, por 4 horas. Em seguida, era feita a separação do n-hexano e do ácido em funil de separação. Passava-se então para a "lavagem" do n-hexano com $500 \mathrm{~mL}$ de água destilada. Fazia-se novamente a separação em funil, e procedia-se a neutralização do n-hexano com $300 \mathrm{~mL}$ de $\mathrm{NaOH} 2 \mathrm{~N}$, e então, novamente separava-se o solvente em funil e lavava-se com água destilada. Finalmente, o nhexano residual era separado em funil e uma pequena quantidade de sulfato de sódio era adicionada para secagem. Posteriormente, o n-hexano era transferido para balão de 
destilação de 2 litros e destilado em coluna Vigreux, sob aquecimento de $150^{\circ} \mathrm{C}$, por aproximadamente 6 horas.

\subsection{Tratamento das fases sólidas}

A sílica e o florisil utilizados nas limpezas das amostras, este último apenas empregado nos testes de limpeza, eram mantidos em estufa a $100^{\circ} \mathrm{C}$ (PERRIN et al., 1980). Eram deixados em dessecador 30 minutos antes de serem utilizados.

\subsubsection{Equipamentos e vidraria}

Os equipamentos foram: ultra-som modelo $\mathrm{T} 7$, série $\mathrm{C} / \mathrm{T}$, no. $0594021,50 \mathrm{~W}$ de potência, centrífuga FANEM, modelo 204NR e tubos de vidro para centrífuga (volume de $40 \mathrm{~mL}$ ), Funil de separação SQUIBB, PYREX, $500 \mathrm{~mL}$, destilador em coluna Vigreux, evaporador rotativo TE 120 Tecnal, série $8730152,220 \mathrm{~V}, 2200 \mathrm{~W}$, agitador Superohm, Soxhlet Pyrex, no. 3740 e cartuchos Schleicher \& Schuell $(33$ x 80 $\mathrm{mm}$, ref. 350240), balões de vidro Pyrex, $500 \mathrm{~mL}$, no. 4100 , bomba à vácuo Primar, modelo 121, $32 \mathrm{~V}, 1 / 4 \mathrm{CV}$ (no. 572, 56 desloc. $\mathrm{L} / \mathrm{min}, 220 \mathrm{~W}$ ); mantas aquecedoras FISATOM, $30 \mathrm{~W}$ de potência, modelo 752 , série 54727 e QUIMIS, $1500 \mathrm{~W}$, modelo 313A21, série 707996; cromatógrafo a gás Hewlett Packard 5890, série II com detector de captura de elétrons (CG/DCE) e cromatógrafo a gás HP 5890, série II, acoplado a espectrômetro de massas HP 5972 A, MSD.

\subsubsection{Extração, limpeza e análises cromatográficas das amostras}

Para adequação dos métodos de análises cromatográficas das amostras de água e sedimento foram testados diferentes procedimentos para emprego de solventes e limpeza das amostras. As Tabelas 4.1 e 4.2 resumem algumas das etapas percorridas para a adequação dos métodos de extração e limpeza das amostras de água. As quantidades de amostras de sedimento, os volumes e tipos de solventes utilizados na extração e limpeza dessas amostras estão detalhadamente descritos na Tabela 4.3. 
Tabela 4.1 - Principais etapas percorridas para adequação dos métodos de extração e limpeza das amostras de água

\begin{tabular}{c|c|c|c}
\hline Procedimentos & Parâmetros testados & Variações & Opção \\
\hline \multirow{4}{*}{ Extração } & Volume de amostra & $500 \mathrm{~mL} ; 1000 \mathrm{~mL}$ & $1000 \mathrm{~mL}$ \\
\cline { 2 - 4 } & Acidificação & $1 \mathrm{~mL} ; 2 \mathrm{~mL}$ & $\begin{array}{c}2 \mathrm{~mL}, \mathrm{com} \\
\text { verificação do pH }\end{array}$ \\
\cline { 2 - 4 } & $\begin{array}{c}\text { Lavagens sucessivas com } \\
\text { n-hexano }\end{array}$ & $\begin{array}{c}\text { 2 lavagens; sem } \\
\text { lavagens sucessivas }\end{array}$ & $\begin{array}{c}\text { Sem lavagens } \\
\text { sucessivas }\end{array}$ \\
\cline { 2 - 4 } & $\begin{array}{c}\text { Filtragem das amostras } \\
\text { Limpeza }\end{array}$ & $\begin{array}{c}\text { Sem e com filtragem } \\
\text { das amostras }\end{array}$ & Com filtragem \\
& $\begin{array}{c}\text { Tipos e tamanhos de } \\
\text { colunas ou ausência de } \\
\text { limpeza }\end{array}$ & $\begin{array}{c}\text { Sílica }(1 \mathrm{e} 3 \mathrm{~cm}) ; \\
\text { Florisil }(1 \mathrm{e} 3 \mathrm{~cm})\end{array}$ & Sem limpeza \\
\hline
\end{tabular}


Tabela 4.2 - Procedimentos experimentais para adequação dos métodos de extração e limpeza das amostras de água

\begin{tabular}{|c|c|c|}
\hline Estação/Campanha & Amostras & Procedimentos selecionados \\
\hline \multirow{3}{*}{ Maio/1 ${ }^{\text {a Campanha }}$} & $\begin{array}{l}\mathrm{A} \\
(*)\end{array}$ & $\begin{array}{l}\rightarrow 1 \mathrm{~L} \text { de amostra }+200 \mathrm{~mL} \text { de } \mathrm{n} \text {-hexano }+1 \\
\mathrm{~mL} \text { de ácido sulfúrico em sucessivas lavagens } \\
\text { com n-hexano }(50 \mathrm{~mL}, 2 \text { vezes }), \text { não fazendo- } \\
\text { se limpeza. }\end{array}$ \\
\hline & $\begin{array}{l}\mathrm{B} \\
(*)\end{array}$ & $\begin{array}{l}\rightarrow 0,5 \mathrm{~L} \text { de amostra }+200 \mathrm{~mL} \text { de } \mathrm{n} \text {-hexano }+ \\
1 \text { mL de ácido sulfúrico em sucessivas } \\
\text { lavagens com n-hexano ( } 25 \mathrm{~mL} \text {, 2vezes), } \\
\text { fazendo-se limpeza em coluna de sílica } 1 \mathrm{~cm} ; \\
\rightarrow \text { não foi utilizado padrão interno. }\end{array}$ \\
\hline & $\begin{array}{l}\mathrm{C} \\
(*)\end{array}$ & $\begin{array}{l}\rightarrow 1 \mathrm{~L} \text { de amostra }+200 \mathrm{~mL} \text { de } \mathrm{n} \text {-hexano }+1 \\
\mathrm{~mL} \text { de ácido sulfúrico em sucessivas lavagens } \\
\text { com n-hexano }(25 \mathrm{~mL}, 2 \text { vezes }) \text {, fazendo-se } \\
\text { limpeza em coluna de florisil } 1 \mathrm{~cm} ; \\
\rightarrow \text { não foi utilizado padrão interno. }\end{array}$ \\
\hline Junho/2 ${ }^{\text {a }}$ Campanha & Triplicatas & $\begin{array}{l}\rightarrow 1 \mathrm{~L} \text { de amostra }+200 \mathrm{~mL} \text { de } \mathrm{n} \text {-hexano }+1 \\
\mathrm{~mL} \text { de ácido sulfúrico em sucessivas lavagens } \\
\text { com n-hexano ( } 25 \mathrm{~mL}, 2 \text { vezes }) ; \\
\rightarrow \text { não foi utilizado padrão interno. }\end{array}$ \\
\hline $3^{\mathrm{a}}$ Campanha & $\begin{array}{l}\text { Estações 1, 2, } 3 \\
\text { e 4(superfície) }\end{array}$ & $\begin{array}{l}\rightarrow \text { mesmo procedimento da } 2^{\mathrm{a}} \text { Campanha, } \\
\text { alterando-se apenas o volume de ácido para } \\
2 \mathrm{~mL} \text {, sendo o pH final confirmado com fita de } \\
\mathrm{pH} ; \\
\rightarrow \text { foi utilizado padrão interno. }\end{array}$ \\
\hline $\begin{array}{l}\text { Novembro/ } 3^{\mathrm{a}} \text { Campanha } \\
\text { Fevereiro } / 4^{\mathrm{a}} \text { Campanha }\end{array}$ & $\begin{array}{l}\text { Estação } \quad 4 \\
\text { (fundo) e todas } \\
\text { as estações da } \\
4^{\mathrm{a}} \text { Campanha }\end{array}$ & $\begin{array}{l}\rightarrow \text { filtração das amostras a vácuo, em filtros } \\
\text { de fibra de vidro GF/C (Whatman); } \\
\rightarrow 1 \text { L de amostra }+200 \mathrm{~mL} \text { de } \mathrm{n}-\mathrm{hexano}+2 \\
\mathrm{~mL} \text { de ácido sulfúrico, sem sucessivas } \\
\text { lavagens com n-hexano. }\end{array}$ \\
\hline
\end{tabular}

Obs.: (*) as amostras A, B e C são amostras da mesma estação, 2. 

Tabela 4.3 - Principais etapas percorridas para adequação do método de extração e limpeza das amostras de sedimento

\begin{tabular}{|c|c|c|c|c|}
\hline Procedimentos & $\begin{array}{l}\text { Parâmetros } \\
\text { testados }\end{array}$ & Variações & Método em que a variação foi testada & Opção \\
\hline \multirow{11}{*}{ Extração } & Métodos & $\begin{array}{c}\text { Soxhlet, ultra-som e agitação sob } \\
\text { barra magnética }\end{array}$ & -------------------- & ultra-som \\
\hline & \multirow{3}{*}{$\begin{array}{l}\text { Quantidade de } \\
\text { amostra }\end{array}$} & $5 \mathrm{~g}$ & Soxhlet & \multirow{3}{*}{$20 \mathrm{~g}$} \\
\hline & & $10 \mathrm{~g}$ & Soxhlet e ultra-som & \\
\hline & & $20 \mathrm{~g}$ & Soxhlet, ultra-som e agitação sob barra magnética & \\
\hline & \multirow{2}{*}{$\begin{array}{l}\text { Acidificação e } \\
\text { alcalinização }\end{array}$} & Acidificação (ausente e presente) & Soxhlet, ultra-som e agitação sob barra magnética & \multirow{2}{*}{ acidificação } \\
\hline & & Alcalinização (ausente e presente) & ultra-som & \\
\hline & \multirow{5}{*}{ Solvente } & Hexano & Soxhlet, ultra-som e agitação sob barra magnética & \multirow{5}{*}{ Hexano/acetona 4:1 } \\
\hline & & Hexano/acetona $2: 1$ & ultra-som & \\
\hline & & Hexano/acetona 3:1 & ultra-som & \\
\hline & & Hexano/acetona 4:1 & ultra-som & \\
\hline & & Acetona & Soxhlet e agitação sob barra magnética & \\
\hline Limpeza & $\begin{array}{l}\text { Tipos e tamanhos } \\
\text { de Colunas ou } \\
\text { ausência de } \\
\text { limpeza }\end{array}$ & Sílica (1 e $3 \mathrm{~cm}$ ); Florisil ( 1 e $3 \mathrm{~cm}$ ) & Soxhlet e ultra-som & $\begin{array}{l}\text { Em princípio sílica } 1 \mathrm{~cm}, \\
\text { posteriormente sílica } \\
3 \mathrm{~cm}\end{array}$ \\
\hline
\end{tabular}


O método utilizado para extração de clorofenóis das amostras de água foi baseado em ZUIN (1997). Para extração do sedimento o método do ultra-som foi baseado em LLOMPART et al.(1997), o método Soxhlet foi baseado no trabalho de AIROLDI (1997) e o método de agitação com barra magnética foi baseado em orientações dos pesquisadores do Laboratório de Cromatografia do Instituto de Química de São Carlos e no trabalho de THAO et al. (1993)

O ultra-som foi o procedimento escolhido a partir dos testes citados na Tabela $4.2 \mathrm{e}$ de um teste conclusivo feito para verificar a eficiência do método e reprodutibilidade. Este teste foi feito da seguinte forma:

1) Quatro porções de 20 gramas de sedimento da represa do Lobo foram centrifugados e o excesso de água retirado;

2) Uma porção foi usada como branco e a ela somente foram adicionados $300 \mu \mathrm{L}$ de solução de 2,4-dibromofenol 13,16mg/L e $10 \mathrm{~mL}$ de água destilada. Para as demais foram adicionados além do 2,4-dibromofenol, $10 \mathrm{~mL}$ de solução de PCP $4 \mu \mathrm{g} / \mathrm{L}$.

3) As amostras foram então colocadas no ultra-som por 30 minutos para facilitar a dopagem. Em seguida, foram levadas para a geladeira e permaneceram em repouso por 38 horas;

4) As amostras foram centrifugadas, acidificadas com $1 \mathrm{~mL}$ de $\mathrm{H}_{2} \mathrm{SO}_{4}$ e deixadas por 30 minutos no ultra-som. Em seguida foram centrifugadas por 5 minutos a $3000 \mathrm{rpm}$. A água foi retirada;

5) Foram adicionados $25 \mathrm{~mL}$ de solução de hexano/acetona $4: 1$ a cada amostra e estas foram extraídas, por 1 hora, no ultra-som, em frequiência de 50/60 Hz. A cada intervalo de 12 minutos, adicionava-se gelo no ultra-som e no penúltimo intervalo, a água foi trocada.

6) As amostras foram deixadas no freezer por 30 minutos e em seguida, levadas para centrifugar por 5 minutos a $3000 \mathrm{rpm}$.

7) Da fração orgânica foram retirados $5 \mathrm{~mL}$ de cada amostra e o restante foi colocado no freezer.

8) Estas alíquotas de $5 \mathrm{~mL}$ foram concentradas para $1 \mathrm{~mL}$ sob fluxo de nitrogênio, derivatizadas e injetadas no cromatógrafo em seguida.

Todas as amostras de sedimento do reservatório de Salto Grande foram então extraídas por este método, em triplicata, fazendo-se a limpeza, como mostra a Figura 4.3.

Nessa etapa, buscou-se quantificar os clorofenóis nas amostras de sedimento do reservatório. Para isso, foram dopadas amostras de sedimento do reservatório de Salto 
Grande. As amostras usadas foram das estações $2(0-50 \mathrm{~cm}) \mathrm{e} 4(20-50 \mathrm{~cm})$, coletadas em Fevereiro e guardadas em sacos de polietileno, sob refrigeração. De cada camada foi retirada uma alíquota de 20 gramas e feita a mistura. Obtiveram-se então, duas amostras compostas de cada estação.

A calibração foi feita da seguinte forma: - para cada dopagem utilizou-se 20 gramas de cada amostra e $10 \mathrm{~mL}$ da solução de trabalho como descrito adiante, em triplicata. Para o branco, utilizaram-se 20 gramas do sedimento e $10 \mathrm{~mL}$ de água destilada, e a dopagem foi com o 2,4-dibromofenol. A solução de trabalho continha: 2,5-diclorofenol; 2,3,4triclorofenol; 2,3,6-triclorofenol; 2,4,6-triclorofenol; pentaclorofenol e 2,4-dibromofenol, usado como padrão interno.

As amostras dopadas foram colocadas no ultra-som por 12 minutos, e em seguida, levadas para o freezer, onde permaneceram por 18 horas.

Posteriormente, foram adicionados a cada amostra, $2 \mathrm{~mL}$ de $\mathrm{H}_{2} \mathrm{SO}_{4}$ e $15 \mathrm{~mL}$ de hexano/acetona 4:1, sendo extraídas em ultra-som por 1 hora, com banho de gelo.

$\mathrm{O}$ volume recuperado de cada amostra (Tabela 4.4) foi concentrado a $1 \mathrm{~mL}$ e todas as amostras, em princípio, passariam por coluna de sílica $(3 \mathrm{~cm})$, com $5 \mathrm{~mL}$ de hexano/acetona 3:1 como eluente, sendo o eluato concentrado a $1 \mathrm{~mL}$ novamente, derivatizado e injetado em cromatógrafo a gás com DCE, mesmo procedimento adotado para todas as amostras de Salto Grande, de todas as estações, em todas as campanhas. Entretanto, nesta calibração, somente as amostras da estação 2 e as amostras dopadas com solução de clorofenóis em concentração de $0,25 \mathrm{mg} / \mathrm{L}$ e duas das amostras da triplicata dopadas com solução de clorofenóis com concentração de $0,50 \mathrm{mg} / \mathrm{L}$ passaram pela coluna de limpeza. As demais não passaram por este procedimento porque pelos valores de áreas dos cromatogramas encontrados nas amostras limpas suspeitou-se que havia perdas na coluna de limpeza

Logo, os resultados obtidos para a primeira tentativa de quantificar as áreas de picos dos clorofenóis no cromatograma não foram satisfatórios, como pode ser visto no item 5.2.2.3 do capítulo de Resultados e Discussão. Assim, realizou-se um novo teste sobre os métodos de extração. Concomitante ao ultra-som, empregou-se dois outros métodos para a extração de clorofenóis de amostras de sedimentos dopadas, utilizando-se novamente o Soxhlet e a agitação com barra magnética, em amostras de sedimentos dopadas.

Utilizou-se uma amostra de sedimento de Salto Grande, da estação 2, coletada em Novembro, retirando porções de cada perfil, da seguinte forma: 0-10 $\mathrm{cm} \rightarrow 50$ gramas; 10$20 \mathrm{~cm} \rightarrow 30$ gramas; $20-30 \mathrm{~cm} \rightarrow 30$ gramas; $30-40 \mathrm{~cm} \rightarrow 30$ gramas. Estas alíquotas foram misturadas, dando origem a uma amostra composta, de 140 gramas. Desta amostra composta foram retiradas sub-amostras de 20 gramas, e doparam-se as mesmas com uma solução de 
trabalho contendo padrões de clorofenóis (2,5-diclorofenol; 2,3,4-triclorofenol; 2,3,6triclorofenol; 2,4,6-triclorofenol; pentaclorofenol) e dibromofenol, cada um adicionado em uma concentração final de 1,00 mg/L. Em cada dopagem foram utilizados 20 gramas do sedimento e $10 \mathrm{~mL}$ da solução de trabalho de $1,00 \mathrm{mg} / \mathrm{L}$, com uma réplica.

Tabela 4.4-Amostras e concentrações utilizadas na dopagem e volumes de solvente após a extração no teste feito para avaliar quantitativamente as amostras de Salto Grande, extraídas pelo método do ultra-som.

\begin{tabular}{|c|c|c|c|}
\hline Estação & Amostras & $\begin{array}{c}\text { Concentração } \\
(\mathrm{mg} / \mathrm{L})\end{array}$ & $\begin{array}{c}\text { Volume de solvente retirado após a } \\
\text { extração }(\mathrm{mL})\end{array}$ \\
\hline \multirow{10}{*}{2} & $0,25 \mathrm{a}$ & \multirow{3}{*}{0,25} & 10,6 \\
\hline & $0,25 \mathrm{~b}$ & & 10,0 \\
\hline & $0,25 \mathrm{c}$ & & 8,1 \\
\hline & $0,50 \mathrm{a}$ & \multirow{3}{*}{0,50} & 7,5 \\
\hline & $0,50 \mathrm{~b}$ & & 10,5 \\
\hline & $0,50 \mathrm{c}$ & & 7,7 \\
\hline & $1,00 \mathrm{a}$ & \multirow{3}{*}{1,00} & 9,8 \\
\hline & $1,00 \mathrm{~b}$ & & 9,4 \\
\hline & $1,00 \mathrm{c}$ & & 7,00 \\
\hline & Branco & Sem dopagem & 9,10 \\
\hline \multirow{10}{*}{4} & 0,25 aа & \multirow{3}{*}{0,25} & 7,4 \\
\hline & $0,25 \mathrm{bb}$ & & 9,2 \\
\hline & $0,25 \mathrm{cc}$ & & 8,5 \\
\hline & 0,50 aa & \multirow{3}{*}{0,50} & 7,5 \\
\hline & $0,50 \mathrm{bb}$ & & 9,1 \\
\hline & $0,50 \mathrm{cc}$ & & 9,4 \\
\hline & 1,00 aa & \multirow{3}{*}{1,00} & 8,7 \\
\hline & $1,00 \mathrm{bb}$ & & 9,6 \\
\hline & $1,00 \mathrm{cc}$ & & 8,0 \\
\hline & Branco & Sem dopagem & 6,0 \\
\hline
\end{tabular}

As amostras dopadas foram colocadas em recipientes tampados e no ultra-som por 12 minutos. Em seguida, foram deixadas em temperatura ambiente por 18 horas. Antes da extração, cada amostra foi acidificada com $2 \mathrm{~mL}$ de $\mathrm{H}_{2} \mathrm{SO}_{4}$ concentrado. A solução de trabalho foi retirada e analisada posteriormente pelo método proposto por DAMIANOVIC (1997), a $6 \mathrm{~mL}$ da solução de trabalho retirada foram adicionados $90 \mathrm{mg}$ de $\mathrm{NaCl}, 20 \mu \mathrm{L}$ de solução concentrada de $\mathrm{H}_{2} \mathrm{SO}_{4}$ e $2 \mathrm{~mL}$ de hexano grau HPLC. As misturas foram agitadas durante $1 \mathrm{~min}$, centrifugadas a $16000 \mathrm{rpm} / 5 \mathrm{~min}$, e $1 \mathrm{~mL}$ da fração orgânica foi transferido para tudo de ensaio de $1 \mathrm{~mL}$, a fim de a amostra ser derivatizada e injetada em CG/DCE. Os métodos, tempo de extração dos clorofenóis dos sedimentos, bem como os tipos de solventes empregados estão discriminados na Tabela 4.5. 
Tabela 4.5 - Teste de comparação entre os métodos de extração de clorofenóis de sedimentos

\begin{tabular}{c|c|c}
\hline Tipo de Extração & Tempo de Extração & Solvente \\
\hline ultra-som & 1 hora & $20 \mathrm{~mL}$ (hexano/acetona 4:1) \\
\hline Soxhlet & 6 horas & $250 \mathrm{~mL}$ de hexano \\
\hline Agitação & 1 hora & $20 \mathrm{~mL}$ (hexano/acetona 4:1) \\
\hline
\end{tabular}

Como procedimento auxiliar, e com a finalidade de comparação, visto que provavelmente ocorreram perdas nos valores de áreas dos cromatogramas obtidos com o ultra-som nas amostras de Salto Grande, foram feitas outras extrações com Soxhlet e agitação, e para isso uma amostra de cada ponto foi testada, exceto para as amostras de maio (estação 2 e 4) e Fevereiro (estação 3). Deve-se considerar entretanto, que as amostras que foram extraídas com Soxhlet e com agitação, não passaram por coluna de limpeza. As etapas dos procedimentos de extração estão definidas nas Figuras 4.3 a 4.5.

Para a extração da água foi utilizada sempre, para todas as amostras, a extração líquido-líquido, porém alguns passos foram modificados ao longo das análises, de acordo com os resultados obtidos. Portanto, essas etapas estão discutidas no capítulo de Resultados e Discussão, item 5.3.4.2. A Figura 4.6 mostra o esquema das etapas selecionadas como o melhor procedimento para a extração dos clorofenóis da água, e que foi aplicado às amostras coletadas em Novembro (estação 4/14 m) e Fevereiro (todas as estações). 


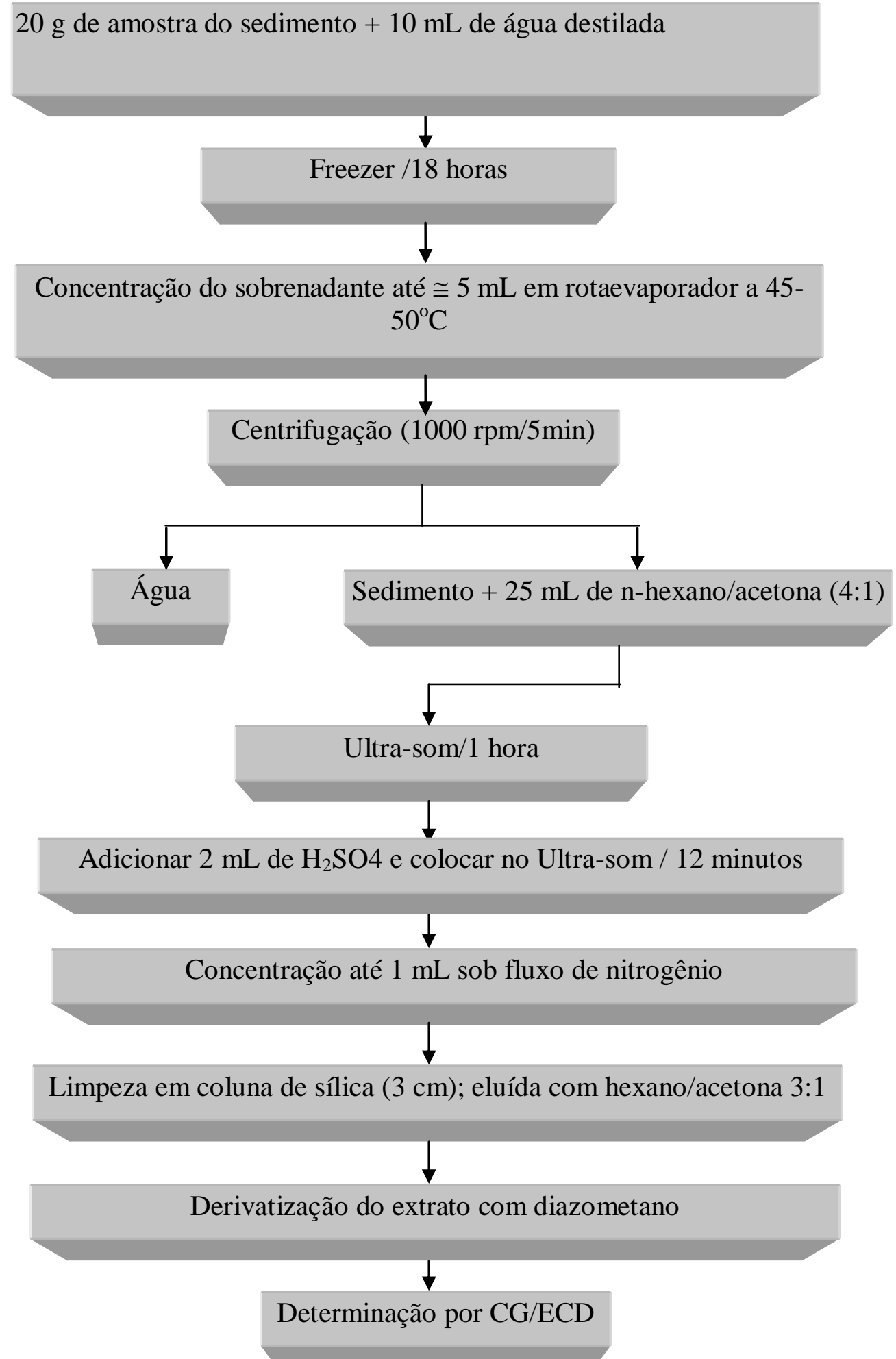

FIGURA 4.3 - EXTRAÇÃO DO SEDIMENTO UTILIZANDO O MÉTODO ULTRA-SOM. 
$20 \mathrm{~g}$ de amostra do sedimento $+10 \mathrm{~mL}$ de água destilada $+300 \mu \mathrm{L}$ de 2,4-dibromofenol

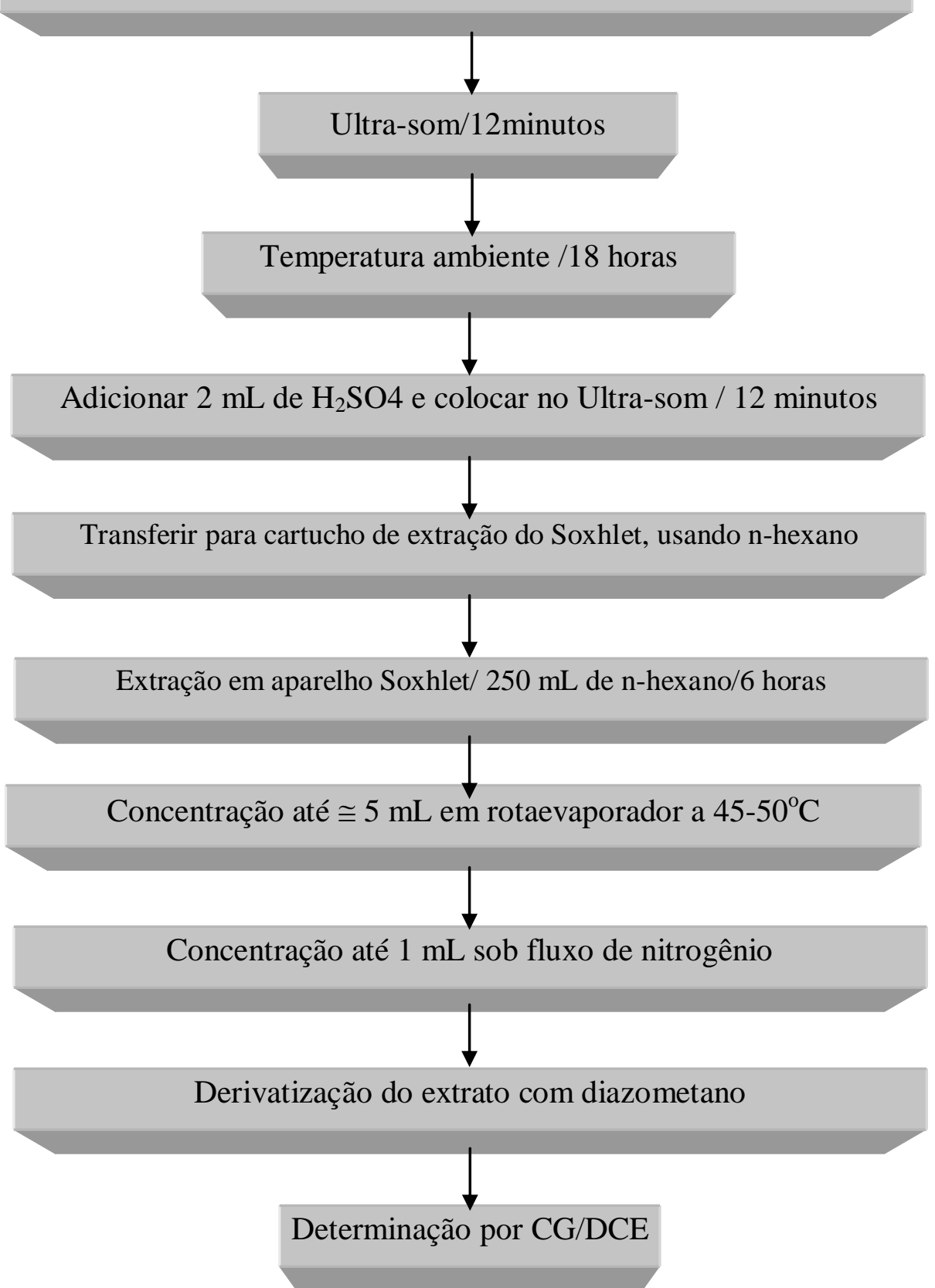

FIGURA 4.4 - EXTRAÇÃO DO SEDIMENTO UTILIZANDO O MÉTODO SOXHLET. 
$20 \mathrm{~g}$ de amostra do sedimento $+10 \mathrm{~mL}$ de água destilada $+300 \mu \mathrm{L}$ de 2,4-dibromofenol

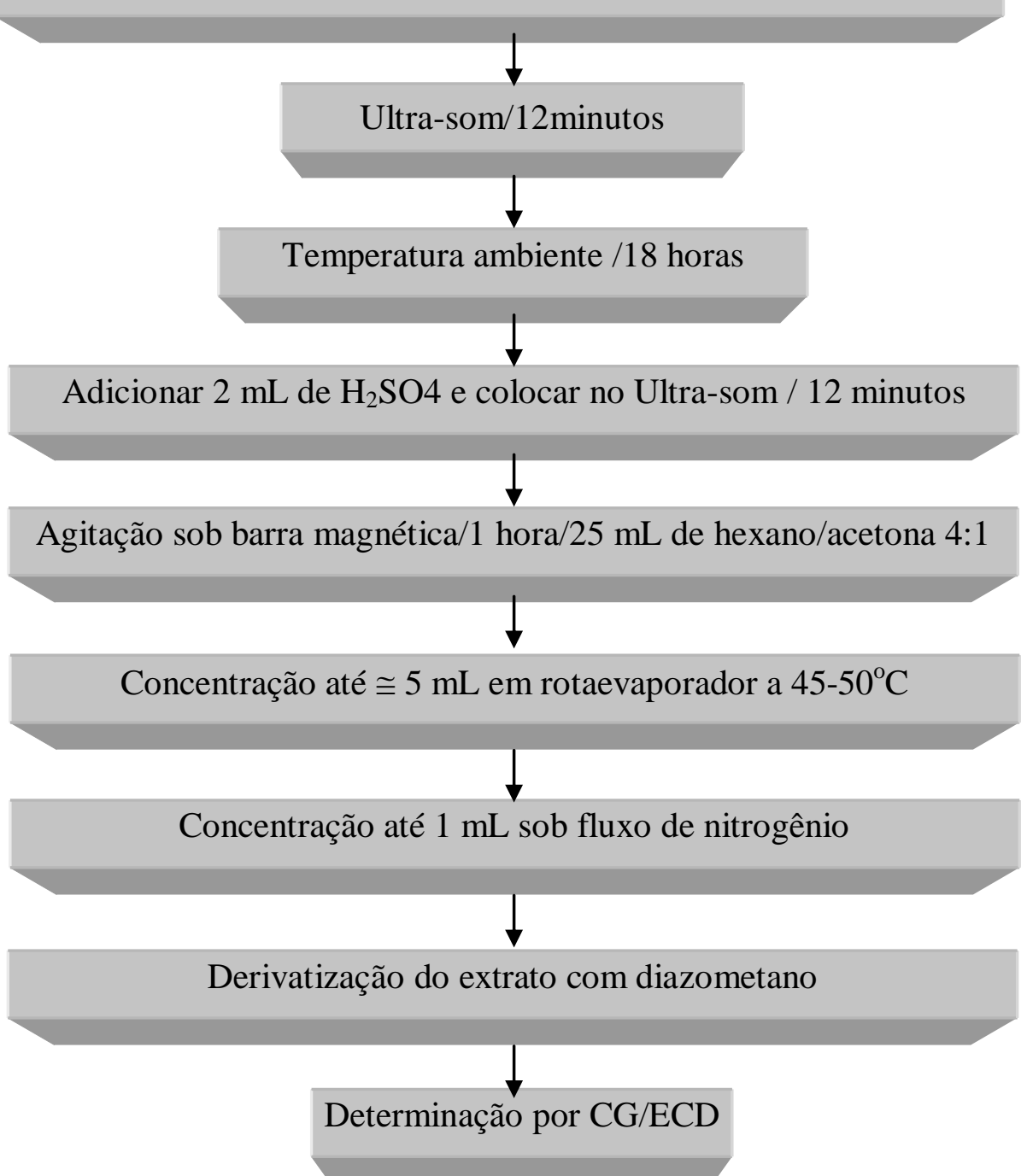

FIGURA 4.5 - EXTRAÇÃO DO SEDIMENTO UTILIZANDO O MÉTODO AGITAÇÃO SOB BARRA MAGNÉTICA 


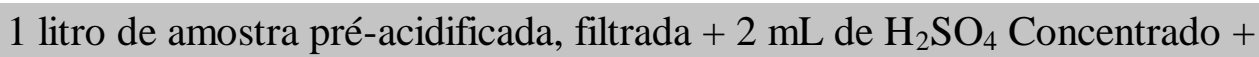
$200 \mathrm{~mL}$ de hexano purificado

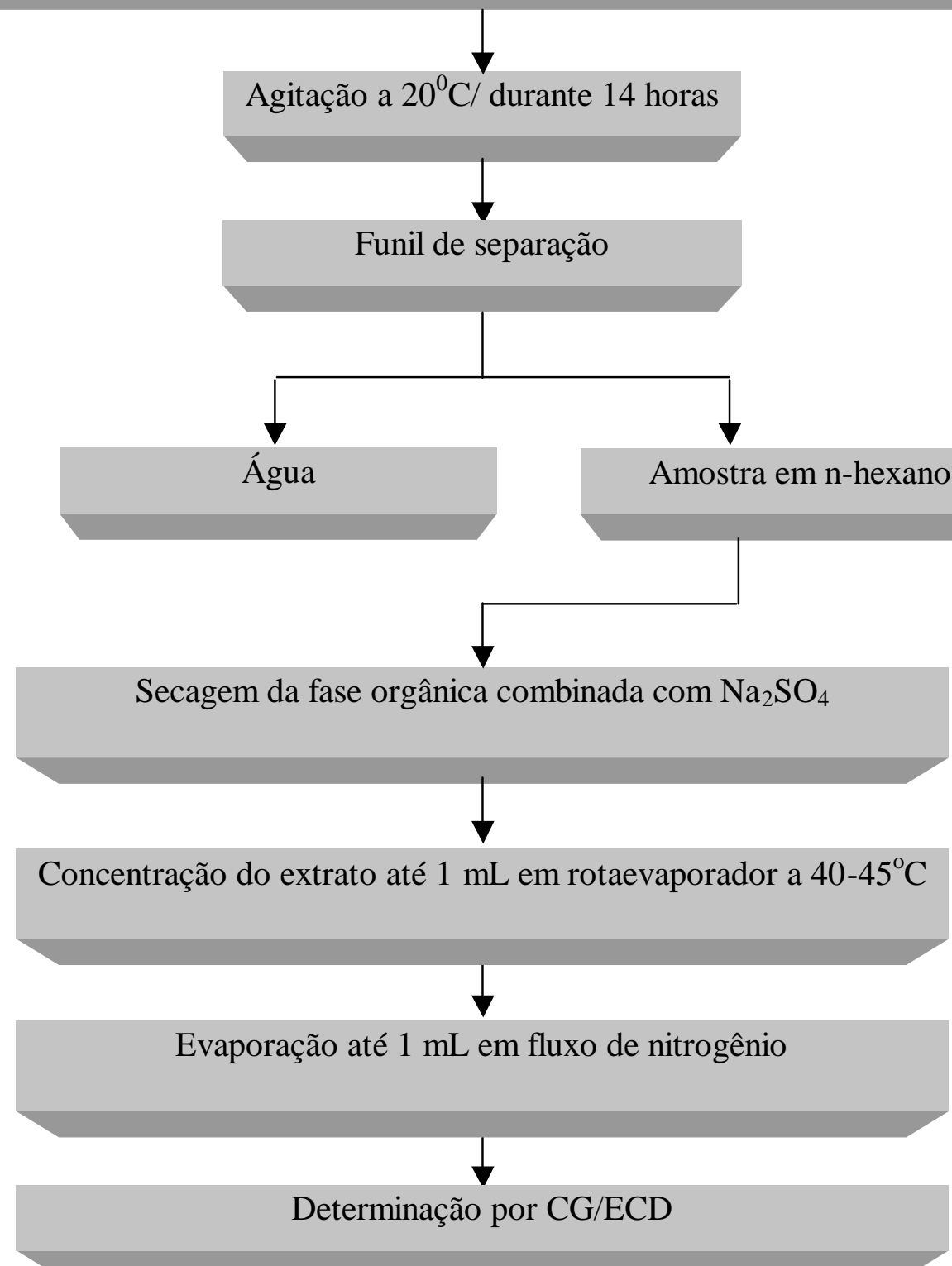

FIGURA 4.6- EXTRAÇÃO DA ÁGUA UTILIZANDO O MÉTODO DE EXTRAÇÃO LÍQUIDO-LÍQUIDO. 


\subsubsection{Preparação de curva de calibração para determinação da concentração de clorofenóis}

Para quantificação dos clorofenóis nas amostras de água e sedimento foi utilizado o procedimento de padronização externa, ou seja, foram preparadas soluções padrões de clorofenóis que foram adicionadas a amostras de água e de sedimento. A partir da correlação entre a concentração dos padrões e a área dos picos encontrada na injeção em CG/DCE, foram calculadas equações, pelas quais seriam feitas as quantificações. Este protocolo foi baseado em ZUIN (1997) e LANÇAS (1993). Para dopagem das amostras foram utilizadas as concentrações indicadas na Tabela 4.6:

Tabela 4.6 - Concentrações de padrões de clorofenóis utilizados na dopagem de amostras de água e sedimento

\begin{tabular}{c|c}
\hline Água $(\mu \mathrm{g} / \mathrm{L})$ & Sedimento $(\mu \mathrm{g} / \mathrm{Kg})$ \\
\hline 0,01 & 0,50 \\
\hline 0,05 & 2,50 \\
\hline 0,10 & 5,00 \\
\hline 0,25 & 12,50 \\
\hline
\end{tabular}

As extrações para água e sedimento foram feitas em triplicata.

Para quantificação da água, foram dopadas amostras de 1 L de água destilada, seguindo o procedimento como na Figura 4.6, em triplicatas.

No caso do sedimento foi usada uma amostra de Salto Grande, estação 4, coletada em Maio e estocada sob refrigeração por 9 meses. A amostra foi misturada com bastão de vidro e a dopagem feita com o material in natura. Em seguida, as amostras ficaram sob agitação com barra magnética por 1 hora. Posteriormente foram acidificadas; o solvente foi adicionado e o procedimento seguido como na Figura 4.3. As análises foram feitas em triplicata, com a utilização de um branco. Para o cálculo da equação de quantificação foram escolhidas para cada concentração, as duas áreas mais próximas entre as triplicatas, obtendo-se a média das mesmas.

\subsubsection{Controle das Análises Cromatográficas}


Para garantir a confiança dos valores a serem obtidos através de determinações cromatográficas dos clorofenóis nas amostras do reservatório de Salto Grande, foram considerados como critérios importantes a escolha de um cromatógrafo adequado às análises e a utilização de padrões cromatográficos grau analítico.

Em todos os testes de extração do presente trabalho, seja com amostras de água destilada (extração líquido-líquido) ou com amostras de sedimento do Reservatório do Lobo e/ou de Salto Grande (extração com Soxhlet, agitação sob barra magnética e ultra-som), foram utilizados padrões de clorofenóis e também padrão interno (2,4-Dibromofenol), em dopagem com concentrações conhecidas. Os padrões cromatográficos utilizados foram da marca Supelco International, não diluídos, nas especificações dadas na Tabela 4.7:

Tabela 4.7 - Especificações dos padrões cromatográficos utilizados nas dopagens de amostras

\begin{tabular}{|c|c|c|}
\hline Padrões & $\begin{array}{c}\text { Quantida } \\
\text { de } \\
\text { adquirid } \\
\text { a (mg) }\end{array}$ & $\begin{array}{c}\text { Indicaçã } \\
\text { o em } \\
\text { catálogo } \\
\text { da } \\
\text { Supelco } \\
\text { Internat } \\
\text { ional }\end{array}$ \\
\hline $\begin{array}{c}2,5- \\
\text { Diclorof } \\
\text { enol }\end{array}$ & 1000 & $44-2320$ \\
\hline $\begin{array}{c}2,3,4- \\
\text { triclorofe } \\
\text { nol }\end{array}$ & 50 & $44-2283$ \\
\hline $\begin{array}{c}2,3,6- \\
\text { Triclorof } \\
\text { enol }\end{array}$ & 100 & $44-2287$ \\
\hline $\begin{array}{c}2,4,6- \\
\text { Triclorof } \\
\text { enol }\end{array}$ & 5000 & $4-8518$ \\
\hline
\end{tabular}




\begin{tabular}{r|r|r}
\hline $\begin{array}{r}\text { Pentaclo } \\
\text { rofenol }\end{array}$ & 5000 & $4-8555$ \\
\hline $2,4-$ & 1000 & $44-2312$ \\
Dibromo & & \\
fenol & & \\
\hline
\end{tabular}

O cromatógrafo a gás utilizado nas análises foi o Hewlett Packard 5890, série II, que é amplamente utilizado na análise de organoclorados em amostras ambientais, como pode ser visto nos trabalhos de MORRISON et al., (1996); FOLCH et al. (1996); THAO et al. (1993); TANABE et al. (1994) e, na análise específica de alguns clorofenóis, como no trabalho de KHODADOUST et al. (1999); ZUIN (1997) e AIROLDI (1997), entre outros.

Este aparelho foi usado com a Coluna SPBTM-5 (poli-5\%-difenil-95\%dimetilssiloxano; $30 \mathrm{~m}$ x 0,25 $\mathrm{mm}$ x 0,25 $\mu \mathrm{m}$ ). Os gases utilizados foram o hidrogênio, como gás de arraste, em uma vazão de $1 \mathrm{~mL} / \mathrm{min}$ e o nitrogênio, como gás auxiliar, em uma vazão de $30 \mathrm{~mL} / \mathrm{min}$ para amostras de sedimento e $62,5 \mathrm{~mL} / \mathrm{min}$ para amostras de água. As amostras foram sempre injetadas nas seguintes condições: temperatura do injetor $280^{\circ} \mathrm{C}$, temperatura do detector de $300^{\circ} \mathrm{C}$, temperatura do forno $50^{\circ} \mathrm{C}$, permanecendo nesta por 2 min, posteriormente a temperatura subia à $70^{\circ} \mathrm{C}$, a uma taxa de incremento de $5^{\circ} \mathrm{C} / \mathrm{min}$, e a uma taxa de incremento de $8^{0} \mathrm{C} / \mathrm{min}$ passava a $200^{\circ} \mathrm{C}$, temperatura em que permanecia constante por 5 min. O volume de amostra injetado foi de $1 \mu \mathrm{L}$ em injetor splitless.

Os tempos de retenção encontrados na injeção dos padrões foram utilizados para identificar os clorofenóis nas amostras do reservatório de Salto Grande (Tabela 4.8).

Alguns testes em que amostras de água destilada $(500 \mathrm{~mL})$ foram dopadas com $5 \mu \mathrm{L}$ de solução de PCP em concentração de $10 \mu \mathrm{L} / \mathrm{L}$, extraídas como demonstrado na Figura 4.6 e em que foram testadas diferentes colunas de limpeza, com diferentes eluentes, sendo injetadas no cromatógrafo, podem confirmar a acuracidade do tempo de retenção deste padrão. Outro teste que confirma os tempos de retenção de cada clorofenol utilizado, foi feito pela utilização de uma solução de clorofenóis $(0,25 \mathrm{mg} / \mathrm{L})$ e uma solução de 2,4Dibromofenol (3,1416 mg/L) extraídas pelo método proposto por DAMIANOVIC (1997). Os resultados obtidos estão no item 5.2.2.1 de Resultados e Discussão.

Para as amostras de sedimento, os tempos de retenção puderam ser confirmados nos testes de dopagem, tanto com amostras do reservatório do Lobo, quanto com amostras de 
Salto Grande e os resultados foram apresentados no decorrer do capítulo de Resultados e Discussão.

Tabela 4.8 - Tempos de retenção determinados pelo cromatógrafo a gás Hewlett Packard (HP) 5980, nas condições cromatográficas dadas

\begin{tabular}{r|c}
\hline Padrões & $\begin{array}{c}\text { Tempo de } \\
\text { Retenção }\end{array}$ \\
\hline 2,5 -Diclorofenol & $15^{\prime} 009+/-0,05$ \\
\hline $2,4,6$-Triclorofenol & $15^{\prime} 960+/-0,05$ \\
\hline $2,3,6$-Triclorofenol & $16^{\prime} 764+/-0,05$ \\
\hline $2,4-$ Dibromofenol & $18^{\prime} 509+/-0,05$ \\
\hline $2,3,4$-triclorofenol & $19^{\prime} 125+/-0,05$ \\
\hline Pentaclorofenol & $22^{\prime} 543+/-0,05$ \\
\hline
\end{tabular}

Para confirmação dos resultados, uma amostra de água e uma amostra com padrões de clorofenóis foram enviadas para o Instituto de Química Analítica da Universidade Estadual de Campinas, para serem injetadas em Cromatógrafo a gás HP 5890, série II, acoplado a espectrômetro de massas HP 5972 A, MSD, nas seguintes condições cromatográficas: Coluna capilar HP-Ultra $2(25 \mathrm{~m}$ x $0,25 \mathrm{~mm}$ x $0,25 \mu \mathrm{m})$, Temperatura do injetor $280^{\circ} \mathrm{C}$, temperatura do detector de $285^{\circ} \mathrm{C}$, temperatura da coluna $100^{\circ} \mathrm{C}(5 \mathrm{~min})$, $15^{\circ} \mathrm{C} / \mathrm{min}, 280^{\circ} \mathrm{C}$ (20min), volume de injeção $2 \mu \mathrm{L}$, split 1:25, gás de arraste $\mathrm{He}, 1 \mathrm{~mL} / \mathrm{min}$, aquisição do massa 40 a 600 u.m.a. Entretanto, não foram obtidos resultados, como comentado no item 5.3.4.2 do capítulo Resultados e Discussão. 


\section{RESULTADOS E DISCUSSÃO}

O reservatório de Salto Grande encontra-se em processo de hipereutrofização e estágio avançado de contaminação devida, principalmente, ao lançamento de resíduos industriais e esgotos doméstica, além da lixiviação de áreas agrícolas. Essa situação do reservatório apresenta diversas conseqüências, como a diminuição da diversidade de peixes em biomassa, odor de matéria orgânica em decomposição e também problemas sociais, como a desvalorização da região do entorno pela sua transformação em zona de prostituição, como pode ser visto no histórico da região apresentado no trabalho de BOTTURA (1998).

$\mathrm{Na}$ bacia hidrográfica onde encontra-se localizado o reservatório de Salto Grande, considerando o histórico apresentado no relatório técnico preliminar de Julho de 1999 da CETESB, a presença de fenóis nas cargas remanescentes das principais indústrias pode atingir cerca de $40 \mathrm{~kg} /$ dia (Tabela 3.2 da revisão de literatura). Nesse relatório, quanto ao lançamento de fenóis, destacam-se as indústrias químicas, cujos produtos manufaturados são corantes (como por exemplo, o índigo blue) e matérias primas do segmento Nylon.

Quando trabalha-se com a presença de poluentes em reservatórios, algumas variáveis físico-químicas são de grande importância, como visto no item 3.5 da revisão de literatura. Neste trabalho, optou-se pelas análises de $\mathrm{pH}$, temperatura, condutividade, oxigênio dissolvido, carbono total, umidade do sedimento e material em suspensão, pois esses parâmetros relacionam-se, em diferentes níveis, com presença de poluentes tóxicos, em relação à solubilidade, degradação, adsorção e toxicidade, bem como com a desorção desses compostos da matriz escolhida (solo, sedimento, água, material em suspensão, etc.). Além disso, alguns desses parâmetros podem nortear a detecção de fontes de poluição.

Este capítulo foi organizado de forma a deixar claro todos os cuidados, opções e medidas tomadas desde a coleta do material e preservação de amostras em campo, bem como sua estocagem e análises em laboratório, considerando todos os procedimentos para determinação dos parâmetros físico-químicos e cromatográficos. Em relação às análises cromatográficas foram apresentadas todas as etapas e condições vencidas para escolher e/ou adaptar os procedimentos mais adequados para extração e limpeza das amostras, antes de suas injeções CG/DCE. 
Os resultados obtidos para todas as análises efetuadas foram apresentados e discutidos por campanha realizada. Como foram feitas 4 coletas (Maio, Junho e Novembro de 1998 e Fevereiro de 1999), cada mês de coleta representa uma campanha, sendo primeiramente analisados os parâmetros climatológicos, seguidos dos hidráulicos, morfométricos e os físico-químicos e, finalmente, as análises cromatográficas. Essas últimas compreendem as curvas de calibração para a determinação quantitativa de clorofenóis na água e sedimento, os resultados de procedimentos de extração e limpeza das amostras, as respostas quanto ao tempo de retenção de cada composto clorado, bem como as áreas obtidas nos cromatogramas após injeção das amostras de água e sedimento, respectivamente. $\mathrm{Na}$ discussão dos resultados cromatográficos, alguns parâmetros físico-químicos de interesse são discutidos em conjunto.

Como há estações comuns entre as campanhas, para finalizar este capítulo, a discussão foi feita por estação, correlacionando-se todos os parâmetros estudados.

\subsection{Métodos e procedimentos para o transporte e preservação das amostras de sedimentos e águas para as análises físico-químicas}

Amostras coletadas em campo estão sujeitas a inúmeras influências (forma de coleta, temperatura local e de manutenção para transporte, métodos químicos de preservação, entre outras). Assim, os procedimentos de transporte, preservação em campo e em laboratório das amostras coletadas no presente trabalho experimental procuraram seguir as orientações dos Laboratórios do Centro de Recursos Hídricos e Ecologia Aplicada e de Processos Biológicos do Departamento de Hidráulica e Saneamento da EESC-USP.

As determinações de $\mathrm{pH}$, condutividade, turbidez, temperatura e oxigênio dissolvido foram feitas em campo, não havendo necessidade de acondicionar e/ou transportar as amostras.

Para a análise de material em suspensão, as amostras foram filtradas em campo (filtro $0,45 \mu \mathrm{m}$ ) e os filtros transportados para laboratório em temperatura ambiente, como indicado pelo SMEEW (1995). As análises foram feitas no dia seguinte às amostragens. Portanto, a determinação do material em suspensão foi feita após um período máximo de 20 horas, o que foi adequado para não haver alterações qualitativas e quantitativa das amostras.

As análises de carbono orgânico da água foram realizadas com as amostras filtradas, o que influiu nos valores obtidos, como será discutido posteriormente. No caso das amostras de sedimento, estas foram mantidas congeladas por cerca de 3 meses, quando foram 
misturados os sedimentos coletados em perfis, secados, peneirados e imediatamente enviados para o laboratório onde foram feitas as análises de carbono orgânico total ${ }^{1}$. Como recomendado pelo SMEWW (1995), as amostras de água e sedimento para análise de carbono foram acondicionadas em frascos de vidro. Assim, os procedimentos seguidos para transporte e preservação das amostras foram considerados adequados.

\subsection{Métodos e procedimentos para análises cromatográficas das amostras de sedimentos e águas}

\subsubsection{Preservação das amostras de água e sedimento}

Em geral, o tempo transcorrido entre a coleta e a análise da amostra é responsável por resultados mais confiáveis. As recomendações do SMEWW (1995) pontuam que a análise de clorofenóis em amostras de água seja realizada em um período máximo de 28 dias, devendo as amostras ser mantidas ácidas, através da diminuição do $\mathrm{pH}$ a um valor menor que 2,0, e armazenadas sob refrigeração, em frascos de vidro.

As amostras de água coletadas em Maio e Junho ( $1^{\mathrm{a}}$ e $2^{\mathrm{a}}$ campanhas) tiveram o tempo entre as coletas e as análises cromatográficas superior ao recomendado pelo SMEWW (1995). Devido às dificuldades encontradas para adaptação dos procedimentos de extração e limpeza das amostras, as mesmas somente foram analisadas em Agosto, ou seja, o tempo de estocagem foi de 2 a 3 meses, sempre sob refrigeração $\left(4^{0} \mathrm{C}\right)$, sendo as amostras mantidas acidificadas. As amostras de água de Novembro e Fevereiro foram analisadas no mesmo mês em que foram coletadas.

A acidificação em campo, para preservação das amostras de água, foi feita segundo o SMEWW (1995), utilizando-se alíquotas de $\mathrm{H}_{2} \mathrm{SO}_{4}$ até que o $\mathrm{pH}$ ficasse menor que 2,0, confirmado com fita de papel Carlo Erba.

As amostras de sedimento foram acondicionadas em recipientes de vidro, mantidas sob baixas temperaturas no campo, em recipiente de isopor com gelo, e posteriormente congeladas em laboratório, como recomendado por MUDROCH \& MACKNIGH (1994).

As amostras de sedimentos, coletadas em Maio, foram mantidas sob refrigeração $\left(4^{\circ} \mathrm{C}\right)$, visto que, parte das mesmas foi utilizada em alguns testes de extração e limpeza, para adaptação de procedimentos analíticos. As demais amostras de sedimento foram mantidas congeladas até a extração com ultra-som, que foi feita nos meses de Junho, Julho e Agosto de 1999, ficando portanto, armazenadas de 5 a 12 meses. As extrações adicionais com

\footnotetext{
${ }^{1}$ Laboratório de Biogeoquímica Ambiental da Universidade Federal de São Carlos.
} 
Soxhlet e agitação com barra magnética foram feitas em Novembro, ou seja, 5 meses após as primeiras análises com o ultra-som.

A refrigeração das amostras de sedimentos no campo, com posterior congelamento em laboratório, caracterizou-se como um procedimento efetivo para manutenção dos sedimentos antes da extração, limpeza e análise cromatográfica, o que consiste em prática importante para minimizar a degradação química e microbiana dos clorofenóis.

Todos os procedimentos foram feitos para amostras de sedimentos dos reservatórios do Lobo e de Salto Grande. As amostras do Lobo, entretanto, foram mantidas sob refrigeração.

5.2.2 Etapas para escolha elou adequação dos procedimentos para extração e limpeza das amostras de água e sedimento

\subsubsection{Controle das Análises Cromatográficas}

Pelos testes de extração com amostras de água destilada $(500 \mathrm{~mL})$, dopadas com 5 $\mu \mathrm{L}$ de solução de PCP em concentração de $10 \mu \mathrm{L} / \mathrm{L}$ e extraídas como demonstrado na Figura 4.6 de Materiais e Métodos, o uso de diferentes eluentes e colunas de limpeza, não interferiu nos tempos de retenção encontrados nos cromatogramas, sempre coerentes e precisos, como pode ser visto na Tabela 5.1.

No teste com a solução de padrões de clorofenóis e padrão interno 2,4-Dibromofenol (3,1416 mg/L), extraídas como proposto por Damianovic (1997), derivatizadas e injetadas em CG/DCE, também foi feita a confirmação de todos os tempos de retenção, sendo apresentados na Tabela 5.2. 
Tabela 5.1 - Resultados dos testes de limpeza, valores de áreas cromatográficas e tempo de retenção para o padrão $\mathrm{PCP}$

\begin{tabular}{|c|c|c|c|c|}
\hline \multirow[t]{2}{*}{ Amostras } & \multirow[t]{2}{*}{ Tratamento } & \multirow[t]{2}{*}{$\begin{array}{l}\text { Volume e tipo de eluente } \\
\text { utilizado na Limpeza }\end{array}$} & \multicolumn{2}{|c|}{$\begin{array}{l}\text { Áreas do padrão PCP em } \\
\text { cromatograma e tempo de } \\
\text { retenção (min) }\end{array}$} \\
\hline & & & Amostra & Descarte \\
\hline 1 & Sílica $(1 \mathrm{~cm})$ & $10 \mathrm{~mL}$ de Hexano/Acetona 1:1/ & $\begin{array}{l}1426510 \\
(22 ’ 526)\end{array}$ & n.d. \\
\hline 2 & Florisil $(1 \mathrm{~cm})$ & $10 \mathrm{~mL}$ de Hexano/Acetona $1: 1$ & $\begin{array}{l}101794 \\
\left(22^{\prime} 523\right)\end{array}$ & n.d. \\
\hline 3 & Florisil $(1 \mathrm{~cm})$ & $\begin{array}{c}10 \mathrm{~mL} \text { de Hexano/Acetona 1:1 } \\
\text { (Passagem da amostra pela mesma } \\
\text { coluna) }\end{array}$ & n.d. & $\begin{array}{c}33829 \\
\left(22^{\prime} 532\right)\end{array}$ \\
\hline 4 & Florisil $(1 \mathrm{~cm})$ & $\begin{array}{c}10 \mathrm{~mL} \text { de Hexano/Acetona 1:1 } \\
\text { (Passagem da amostra por outra } \\
\text { coluna) }\end{array}$ & $\begin{array}{c}92410 \\
\left(222^{\prime} 530\right)\end{array}$ & $\begin{array}{l}127498 \\
\left(22^{\prime} 546\right)\end{array}$ \\
\hline 5 & Florisil $(3 \mathrm{~cm})$ & $10 \mathrm{~mL}$ de Hexano/Acetona 3:1 & $\begin{array}{l}120647 \\
\left(222^{\prime} 530\right)\end{array}$ & $\begin{array}{c}28416 \\
\left(222^{\prime} 530\right)\end{array}$ \\
\hline 6 & Sílica $(3 \mathrm{~cm})$ & $10 \mathrm{~mL}$ de Hexano/Acetona 3:1 & n.d. & $\begin{array}{c}20280 \\
\left(222^{\prime} 532\right)\end{array}$ \\
\hline 7 & LC-SAX & $2 \mathrm{~mL}$ de $\mathrm{n}$-hexano & $\begin{array}{l}208303 \\
\left(22^{\prime} 531\right)\end{array}$ & $\begin{array}{c}22558 \\
\left(22^{\prime} 548\right)\end{array}$ \\
\hline \multirow{2}{*}{8} & \multirow{2}{*}{ Florisil $(3 \mathrm{~cm})$} & $10 \mathrm{~mL}$ de Hexano/Acetona 3:1 & n.d. & \multirow{2}{*}{ n.d. } \\
\hline & & $10 \mathrm{~mL}$ de Hexano/Acetona 2:1 & n.d. & \\
\hline \multirow{2}{*}{9} & \multirow{2}{*}{ Sílica $(1 \mathrm{~cm})$} & $10 \mathrm{~mL}$ de Hexano/Acetona 3:1 & $\begin{array}{l}12463393 \\
\left(22^{\prime} 563\right)\end{array}$ & \multirow{2}{*}{ n.d. } \\
\hline & & $10 \mathrm{~mL}$ de Hexano/Acetona 2:1 & $\begin{array}{l}4031662 \\
(22 ’ 545)\end{array}$ & \\
\hline
\end{tabular}

Tabela 5.2 - Padrões de clorofenóis e respectivos tempos de retenção

\begin{tabular}{c|c}
\hline Padrões & Tempo de retenção \\
\hline $2,5-\mathrm{DCP}$ & $15^{\prime} 026$ \\
\hline $2,4,6-\mathrm{TCP}$ & $15^{\prime} 975$ \\
\hline $2,3,6-\mathrm{TCP}$ & $16^{\prime} 780$ \\
\hline $2,3,4-\mathrm{TCP}$ & $19^{\prime} 141$ \\
\hline PCP & $22^{\prime} 557$ \\
\hline $2,4-\mathrm{DBP}$ & $18^{\prime} 516$ \\
\hline
\end{tabular}




\subsubsection{Amostras de águas}

Para a análise da água, o procedimento escolhido foi o da extração líquido-líquido, baseado no trabalho de ZUIN (1997). Entretanto, foram necessárias algumas modificações no procedimento adotado, como observado no capítulo Material e métodos, com o objetivo de adaptar-se algumas etapas às amostras do reservatório de Salto Grande. Estas alterações visaram aprimorar a capacidade de extração dos clorofenóis pelo método proposto por ZUIN (1997), uma vez que a autora trabalhou com amostras oriundas de uma região altamente contaminada por esses compostos, o que era improvável nas amostras estudadas no presente trabalho. Outro fator responsável pelas alterações no procedimento foi a necessidade de eliminar-se possíveis fontes de interferência para a obtenção de áreas cromatográficas mais confiáveis, de forma a alcançar melhores respostas com o método analítico escolhido.

Logo, não foram realizados testes com amostras previamente dopadas, sendo os procedimentos de extração estudados apenas com amostras de águas do reservatório de Salto Grande. As alterações foram feitas ao longo das análises, de acordo com os resultados obtidos. Assim sendo, as etapas para adaptação do procedimento de extração para as amostras de águas do reservatório de Salto Grande e a discussão dos valores de clorofenóis para as condições do reservatório serão abordadas no item 5.3.4.2 do presente capítulo. Os resultados obtidos nos estudos sobre procedimentos de extração desses compostos, nas amostras de água, foram considerados no âmbito da avaliação da presença de clorofenóis no reservatório, nas diferentes campanhas, mesmo com possíveis perdas devidas à adaptação ou à inadequação do método escolhido.

\subsubsection{Amostras de sedimentos}

Inicialmente, o método proposto para a extração dos clorofenóis dos sedimentos foi através do aparelho Soxhlet, procedimento tradicionalmente usado para extrair pesticidas de solos e sedimentos, como observado por BRUNER (1993) e GUENZI (1974).

Dessa forma, a extração com o Soxhlet foi testada em amostras de sedimentos oriundas dos reservatórios do Lobo ( $22^{0} 10^{\prime} \mathrm{S}$ e $47^{0} 57^{\prime} \mathrm{W}$, São Paulo) e de Salto Grande ( $22^{0} 44^{\prime}$ 'S e $47^{0} 15^{\prime} \mathrm{W}$, São Paulo). As amostras do reservatório do Lobo eram dopadas, como explicado no item 4.2.4.3 em Material e Métodos, a fim de servirem como referência ao estudo de métodos extrativos de clorofenóis. O reservatório do Lobo, localizado no município de Itirapina, difere consideravelmente do reservatório de Salto Grande, pois não se caracteriza como receptor de poluentes tóxicos industriais. Assim, foi feita a escolha do 
sedimento do reservatório do Lobo para possibilitar uma avaliação adequada da presença dos clorofenóis após dopagem dos sedimentos.

No entanto, nos primeiros testes para estudos sobre as quantidades de amostras a serem utilizadas, tipo e volume de solvente e diferentes formas de limpeza, não foram obtidos bons resultados com a utilização de Soxhlet. A Tabela 5.3 mostra as principais considerações resultantes desses testes, assim como a avaliação dos resultados obtidos com o emprego do Soxhlet para extração dos clorofenóis nas amostras dos sedimentos dos reservatórios do Lobo e de Salto Grande, o primeiro teste após dopagem com uma solução de clorofenóis. As considerações foram consequiência da avaliação dos valores de áreas de pico obtidos com as determinações cromatográficas, após o uso do método extrativo e de limpeza das amostras, sugerindo a necessidade do estudo de outras técnicas extrativas dos clorofenóis. As Tabelas do Anexo A mostram detalhes dos procedimentos de extração e limpeza das amostras, com as variações das condições testadas e conclusões obtidas, e os valores de áreas de picos obtidas nas determinações cromatográficas. 
Tabela 5.3 - Considerações sobre os procedimentos estudados com o emprego do Soxhlet para extração dos clorofenóis nas amostras dos sedimentos dos reservatórios do Lobo e de Salto Grande.

\begin{tabular}{|c|c|}
\hline Testes & \\
\hline $\begin{array}{l}\text { Tempo de } \\
\text { extração e } \\
\text { volume do } \\
\text { solvente }\end{array}$ & $\begin{array}{l}\rightarrow \text { Não ocorreu refluxo no aparelho com volumes de } 200 \mathrm{~mL} \text { de solvente. O } \\
\text { menor volume para que houvesse refluxo foi de } 250 \mathrm{~mL} \text {; } \\
\rightarrow \text { o tempo de extração de } 6 \text { h não otimizou a obtenção de resultados para os } \\
\text { sedimentos do Lobo, entretanto, dos sedimentos de Salto Grande, extraiu } \\
\text { diferentes tipos de clorofenóis, com áreas consideráveis, mesmo em } \\
\text { sedimentos não dopados, por isso, foi o tempo de extração adotado; } \\
\rightarrow \text { nas condições estudadas, para os sedimentos do Lobo, verificou-se apenas } \\
\text { a presença de } 2,3,5 \text {-TCP; entretanto, para Salto Grande, foram verificados } \\
\text { diferentes tipos de clorofenóis. }\end{array}$ \\
\hline $\begin{array}{l}\text { Colunas de } \\
\text { Limpeza } \\
\left(1^{\underline{0}} \text { teste }\right)\end{array}$ & $\begin{array}{l}\rightarrow \text { As colunas de Florisil }(3,0 \mathrm{~cm}) \text { e Sílica }(3,0 \mathrm{~cm}) \text {, apresentaram bons } \\
\text { resultados utilizando } 250 \mathrm{~mL} \text { de solvente, em Soxhlet, durante } 6 \text { horas. } \\
\rightarrow \text { A utilização das colunas de Sílica }(1,0 \mathrm{~cm}) \text { e Florisil }(1,0 \mathrm{~cm}) \text {, com } 250 \mathrm{~mL} \\
\text { do solvente, em Soxhlet durante } 6 \text { horas, revelou melhores resultados com a } \\
\text { Sílica. } \\
\rightarrow \text { Nesse teste foram utilizados os sedimentos de Salto Grande. }\end{array}$ \\
\hline $\begin{array}{l}\text { Colunas de } \\
\text { Limpeza } \\
\left(2^{0} \text { teste }\right)\end{array}$ & $\begin{array}{l}\rightarrow \text { As colunas de Sílica }(1,0 \text { e } 3,0 \mathrm{~cm}) \text { e Florisil }(1,0 \text { e } 3,0 \mathrm{~cm}) \text { utilizando o } \\
\text { método de extração com } 250 \mathrm{~mL} \text { do solvente, em Soxhlet durante } 3 \text { horas. não } \\
\text { apresentaram desempenho satisfatório, havendo muita perda pelo descarte; } \\
\rightarrow \text { Neste teste foram utilizados os sedimentos de Salto Grande. }\end{array}$ \\
\hline $\begin{array}{l}\text { Colunas de } \\
\text { Limpeza } \\
\left(3^{\underline{0}} \text { teste }\right)\end{array}$ & $\begin{array}{l}\rightarrow \text { Foram utilizadas novamente colunas de Sílica }(1,0 \mathrm{~cm}) \text { e Florisil }(3,0 \mathrm{~cm}) \\
\text { com } 250 \mathrm{~mL} \text { do solvente, em Soxhlet a } 6 \text { horas, testando na eluição a } \\
\text { recuperação dos eluentes em frascos separados, ao invés de recuperá-los em } \\
\text { um mesmo frasco, como fora feito anteriormente. Eram passados pelas } \\
\text { colunas } 10 \mathrm{~mL} \text { de solução hexano/acetona } 3: 1 \text {, seguidos pelos mesmos } \\
\text { solventes, porém } 2: 1 \text {. A maior parte dos compostos entretanto foi eluída na } \\
\text { primeira condição; } \\
\rightarrow \text { Nesse teste foram utilizados os sedimentos de Salto Grande. }\end{array}$ \\
\hline $\begin{array}{l}\text { Colunas de } \\
\text { Limpeza } \\
\left(4^{\underline{0}} \text { teste }\right)\end{array}$ & $\begin{array}{l}\rightarrow \text { Utilizando-se } 3 \text { eluições sucessivas, com } 5,0 \mathrm{~mL} \text { de n-hexano em coluna de } \\
\text { Sílica }(1,0 \mathrm{~cm}) \text {, em Soxhlet, durante } 6 \text { horas, com } 300 \mathrm{~mL} \text { do solvente, os } \\
\text { clorofenóis foram eluídos na primeira aplicação; } \\
\rightarrow \text { Nesse teste foram utilizados os sedimentos de Salto Grande. }\end{array}$ \\
\hline & $\begin{array}{l}\rightarrow \text { Optou-se pela utilização da coluna de Sílica } 1 \mathrm{~cm} \text {, com solução de } \\
\text { hexano/acetona 3:1 como eluente, volume de } 5 \mathrm{~mL} \text {, em única eluição; } \\
\rightarrow \text { Nesse teste foram utilizados os sedimentos de Salto Grande. }\end{array}$ \\
\hline
\end{tabular}


Em todos os testes, não se obteve reprodutibilidade em nenhuma das amostras, ou seja, em amostras do mesmo ponto, extraídas da mesma forma, não eram recuperados os mesmos clorofenóis, e quando recuperados, a diferença entre as áreas era bastante discrepante, como pode ser visto nas Tabelas 5.4 a 5.8.

Apesar do teste com o sedimento do Lobo, dopado com a solução de clorofenóis ter relevado a necessidade do uso de volumes maiores de solventes para extração, o resultado obtido ficou aquém do esperado. Apenas o composto 2,3,5-TCP foi recuperado, o que fica bastante distante do conjunto de clorofenóis adicionados aos sedimentos. Deve-se considerar também que as áreas de picos obtidas nas duplicatas não se reproduziram. Considerando que esse sistema aquático não se caracteriza por receber poluentes industriais tóxicos, podendo permitir uma avaliação adequada da presença dos clorofenóis, após dopagem de seus sedimentos, é provável que o tempo de extração e o uso do Soxhlet tenham sido subdimensionados à natureza do sedimento testado.

Nos testes realizados com o Soxhlet observou-se que a utilização de acetona, como solvente para extração da amostra dopada do sedimento do reservatório do Lobo, resultou em uma amostra muito densa após concentração em rotaevaporador, não permitindo a obtenção de uma amostra adequada para análise cromatográfica. Em todos os testes, nas condições estudadas, não foram verificadas respostas que garantissem a certeza de sua aplicação (Tabelas 5.16 a 5.19). A extração em Soxhlet é tradicionalmente adotada para solos e sedimentos contaminados (AIROLDI, 1997; LLOMPART et al., 1997; ALONSO et al., 1998), mas as opções por outros métodos extrativos têm sido estudadas e avaliadas em busca da diminuição do tempo necessário a extração, bem como do volume de solvente utilizado. ALONSO et al. (1998) obtiveram boas respostas utilizando microondas (MAE) para extração de clorofenóis de sedimentos, com menor volume de extração e redução de tempo em relação ao Soxhlet. Ainda, o uso do Soxhlet pode ser substituído por extração com fluido supercrítico (SANTOS et al., 1998) e o emprego do ultra-som (LLOMPART et al., 1997).

A limpeza das amostras também é necessária, principalmente quando se trata de amostras complexas como os sedimentos. Neste trabalho foram testadas colunas de Sílica e Florisil, em diferentes tamanhos, com diferentes eluentes, entretanto, as perdas na coluna foram consideráveis. Essas perdas em coluna de limpeza também foram ressaltadas por OUBINA et al. (1996), em amostras de solo. 
Tabela 5.4 - Valores das áreas cromatográficas de clorofenóis obtidos pela extração com Soxhlet, variando-se o tempo de extração e o volume de solvente

Teste 1

Amostra: Sedimento do Reservatório do Lobo

Dopagem: $100 \mu \mathrm{L}$ de solução de Clorofenóis $(1 \mathrm{mg} / \mathrm{L})$

\begin{tabular}{c|c|c|c}
\hline Amostra & Tempo de Extração & Volume de Solvente & $2,3,5-\mathrm{TCP}$ \\
\hline 1A & 3 horas $(*)$ & $200 \mathrm{~mL}$ de Hexano & 71990 \\
\cline { 4 - 4 } 1B & & & 100446 \\
\hline 2A & 6 horas & $300 \mathrm{~mL}$ de Hexano & 84053 \\
\cline { 1 - 1 } & & & ------- \\
\hline
\end{tabular}

Obs.: (*) não houve refluxo

Tabela 5.5 - Valores das áreas cromatográficas de clorofenóis obtidos pela extração com Soxhlet, variando-se a coluna de limpeza utilizada

\section{Teste 2}

Amostra: Sedimento de Salto Grande/Estação 2 (perfil 1)/Maio

Dopagem: Não houve dopagem com solução de clorofenóis e também não houve dopagem com padrão interno $(2,4-\mathrm{DBP})$

\begin{tabular}{c|c|c|c|c|c|c|c|c|c}
\hline Am. & $3,5-$ & $2,5-$ & $3,4-$ & $2,4,6-$ & $2,3,6-$ & $2,4,5-$ & $2,4-$ & $2,3,4-$ & PCP \\
& DCP & DCP & DCP & TCP & TCP & TCP & DBP & TCP & \\
\hline 1 & 146519 & -------- & ------- & 31422 & -------- & -------- & 61439 & --------- & 58894 \\
$(*)$ & ---- & 72907 & 23357 & ------- & ----- & ----- & 24717 & ------- & 16872 \\
\hline 2A & ------ & ------- & ------- & ------ & ------- & ------- & 20381 & -------- & 19892 \\
$(* *)$ & 24612 & 43580 & ------ & 24703 & 24414 & ------- & ------- & -------- & ------- \\
\hline 2B & 103267 & 212635 & 153324 & 164763 & 179400 & 139107 & 514537 & 165530 & 108914 \\
$(* *)$ & ------ & ------ & ------- & ------- & ----- & ----- & 20381 & -------- & ------ \\
\hline
\end{tabular}

Obs.: (*) amostras limpas em coluna de Florisil $(3 \mathrm{~cm})$

(**) amostras limpas em coluna de Sílica $(3 \mathrm{~cm})$

Tabela 5.6 - Valores das áreas cromatográficas de clorofenóis obtidos pela extração com Soxhlet, variando-se o tipo de coluna de limpeza utilizada

Teste 3

\begin{tabular}{|c|c|c|c|c|}
\hline \multicolumn{5}{|c|}{$\begin{array}{l}\text { Amostra: Sedimento de Salto Grande/Estação } 2 \text { (perfil 1)/Maio } \\
\text { Dopagem: } 5 \mu \mathrm{L} \text { de solução de Clorofenóis }(1 \mathrm{mg} / \mathrm{L}) \text {. Não houve dopagem com padrão } \\
\text { interno }\end{array}$} \\
\hline Amostra & & 3,5-DCP & 2,4,6-ТCP & \\
\hline 1 & Sílica $(1,0 \mathrm{~cm})$ & $\begin{array}{l}93979 \text { (amostra) } \\
38525 \text { (descarte) }\end{array}$ & $\begin{array}{c}------------ \\
29291 \text { (descarte) }\end{array}$ & $\begin{array}{l}20053(\mathrm{amo} \\
48276 \text { (desc }\end{array}$ \\
\hline 2 & Sílica $(3,0 \mathrm{~cm})$ & $\begin{array}{l}---------------- \\
------------ \\
\end{array}$ & $\begin{array}{l}26116 \text { (amostra) } \\
38098 \text { (descarte) }\end{array}$ & $\begin{array}{c}------------- \\
21009 \text { (descarte) }\end{array}$ \\
\hline 1 & $\begin{array}{c}\text { Florisil } \\
(1,0 \mathrm{~cm}) \\
\end{array}$ & $\begin{array}{c}314607 \text { (amostra) } \\
40309 \text { (descarte) }\end{array}$ & $\begin{array}{c}22998 \text { (amostra) } \\
----\end{array}$ & $\begin{array}{c}------------ \\
151734 \text { (descarte) }\end{array}$ \\
\hline
\end{tabular}




\begin{tabular}{|c|c|c|c|c|}
\hline 2 & $\begin{array}{l}\text { Florisil } \\
(3.0 \mathrm{~cm})\end{array}$ & $\begin{array}{l}40073 \text { (amostra) } \\
66612 \text { (descarte) }\end{array}$ & ---------------- & 90236 (amostra) \\
\hline
\end{tabular}

Tabela 5.7 - Valores das áreas cromatográficas de clorofenóis obtidos pela extração com Soxhlet, variando-se o tipo de coluna de limpeza utilizada

\section{Teste 4}

Amostra: Sedimento de Salto Grande/Estação 2 (perfil 1)/Maio

Dopagem: $10 \mu \mathrm{L}$ de solução de Clorofenóis (1 mg/L). Não houve dopagem com padrão interno

\begin{tabular}{c|c|c|c|c|c|c}
\hline Am. & Coluna & $3,5-\mathrm{DCP}$ & $2,4,6-\mathrm{TCP}$ & $2,4-\mathrm{DBP}$ & $2,3,4-\mathrm{TCP}$ & PCP \\
\hline 1 & Sílica & ------- & 44716 & --------- & ---------- & -------- \\
& $(1,0 \mathrm{~cm})$ & 32858 & $20797(3: 1)$ & $36179(3: 1)$ & -------- & $2463393(3: 1)$ \\
& & ------- & $44815(2: 1)$ & ---------- & $50217(3: 1)$ & $1629024(2: 1)$ \\
\hline 1 & Florisil & ------ & ------ & $59666(3: 1)$ & $22935(3: 1)$ \\
& $(3,0 \mathrm{~cm})$ & $29394(3: 1)$ & $44832(3: 1)$ & $51976(3: 1)$ & $44022(2: 1)$ & $34894(2: 1)$ \\
& & $25636(2: 1)$ & $26176(2: 1)$ & ---------- & -------- & ------- \\
\hline
\end{tabular}

Tabela 5.8 - Valores das áreas cromatográficas de clorofenóis obtidos pela extração com Soxhlet, utilizando-se diferentes volumes para eluição da amostra

\section{Teste 5}

Amostra: Sedimento de Salto Grande/Estação 4 (perfil 1)/Maio

Dopagem: Não houve dopagem com solução de clorofenóis e também não houve dopagem com padrão interno $(2,4-\mathrm{DBP})$

\begin{tabular}{c|c|c|c|c|c|c|c|c|c}
\hline Am. & Eluição & $\begin{array}{c}3,5- \\
\text { DCP }\end{array}$ & $\begin{array}{c}2,5- \\
\text { DCP }\end{array}$ & $\begin{array}{c}3,4- \\
\text { DCP }\end{array}$ & $\begin{array}{c}2,4,6- \\
\text { TCP }\end{array}$ & $\begin{array}{c}2,3,6- \\
\text { TCP }\end{array}$ & $\begin{array}{c}2,4,5- \\
\text { TCP }\end{array}$ & $\begin{array}{c}2,4- \\
\text { DBP }\end{array}$ & $\begin{array}{c}2,3,4- \\
\text { TCP }\end{array}$ \\
\hline \multirow{3}{*}{1} & $\begin{array}{c}5,0 \mathrm{~mL} \\
\text { de } \\
\text { hexano } \\
\text { (3vezes) }\end{array}$ & 36137 & 45067 & 55757 & 55590 & 52658 & 45387 & 62858 & 29865 \\
\cline { 3 - 10 } & 26770 & -------- & -------- & 32835 & ------- & -------- & -------- & $---\cdot----$ \\
\hline
\end{tabular}

Em função dos resultados obtidos durante o emprego do aparelho Soxhlet, foram realizados testes de extração com ultra-som e sob agitação com barra magnética, com base na literatura (LLOMPART et al., 1997; THAO et al., 1993). Nesses testes também foram usados os sedimentos dos reservatórios do Lobo e de Salto Grande, dopados ou não com diferentes concentrações de clorofenóis. Nas Tabelas 5.9 e 5.10 estão indicadas as considerações sobre os procedimentos estudados com o emprego da agitação com barra magnética e ultra-som, respectivamente. Os resultados em áreas cromatográficas encontrados para extração com agitação são mostrados na Tabela 5.11 e os obtidos com ultra-som nas Tabelas 5.12 a 5.17.

Os detalhes dos procedimentos e resultados de análises cromatográficas podem ser verificados nos Anexos B e C, respectivamente. O item 4.2.4.3 de Material e Métodos 
também mostra considerações sobre o método extrativo de clorofenóis com ultra-som, utilizado nesse trabalho.

Tabela 5.9 - Considerações sobre os procedimentos estudados com o emprego da agitação com barra magnética.

\begin{tabular}{|c|c|}
\hline Testes & Observações \\
\hline agitação magnética & $\begin{array}{l}\rightarrow \text { Esse teste foi feito com sedimentos do reservatório do Lobo e as } \\
\text { amostras ficaram sob agitação por } 1 \text { hora. Deve-se considerar que } \\
\text { uma amostra foi acidificada com } 2 \mathrm{~mL} \text { de ácido sulfúrico } \\
\text { concentrado e a outra não. } \\
\rightarrow \text { Houve boa extração dos clorofenóis, sendo que amostra } \\
\text { acidificada apresentou melhores resultados. } \\
\rightarrow \text { As áreas encontradas para o PCP foram bastante consideráveis e } \\
\text { muito superiores àquelas encontradas em todos os testes com o } \\
\text { Soxhlet; } \\
\rightarrow \text { O método foi considerado pouco prático, devido às sucessivas } \\
\text { lavagens com o solvente n-hexano e necessidade de separação em } \\
\text { funil. }\end{array}$ \\
\hline
\end{tabular}

Tabela 5.10-Considerações sobre os procedimentos estudados com o emprego do ultrasom

\begin{tabular}{|c|c|}
\hline Testes & Observações \\
\hline $\begin{array}{l}\text { ultra-som } \\
\left(1^{0} \text { teste }\right)\end{array}$ & $\begin{array}{l}\rightarrow \text { A área encontrada para o PCP, após a extração por esse método } \\
\text { em amostra do Lobo, extraída com } 50 \mathrm{~mL} \text { de n-hexano, foi maior do } \\
\text { que as encontradas após utilização do Soxhlet, porém, ainda não } \\
\text { havia reprodutibilidade entre as duplicatas. }\end{array}$ \\
\hline $\begin{array}{l}\text { ultra-som } \\
\left(2^{\underline{0}} \text { teste }\right)\end{array}$ & $\begin{array}{l}\rightarrow \text { Não houve diferença significativa entre as amostras acidificadas e } \\
\text { não acidificadas, exceto para o PCP, em que a área da amostra não } \\
\text { acidificada foi muito superior. }\end{array}$ \\
\hline $\begin{array}{l}\text { ultra-som } \\
\left(3^{0} \text { teste }\right)\end{array}$ & $\begin{array}{l}\rightarrow \text { Nessa redução do volume do solvente pela metade, os resultados } \\
\text { foram melhores, sendo que, as áreas obtidas para as amostras } \\
\text { acidificadas foram um pouco superiores às amostras não- } \\
\text { acidificadas. }\end{array}$ \\
\hline $\begin{array}{c}\text { Alcalinização das } \\
\text { amostras e uso de } \\
\text { água destilada como } \\
\text { solvente versus } \\
\text { alcalinização e uso } \\
\text { de n-hexano como } \\
\text { solvente }\end{array}$ & $\begin{array}{l}\rightarrow \text { houve pouca extração dos clorofenóis quando comparado ao teste } \\
\text { anterior em que foi utilizado o n-hexano e o n-hexano/acetona } 3: 1 \\
\text { como solvente, estando a amostra acidificada ou não; } \\
\rightarrow \text { a alcalinilização com utilização do n-hexano como solvente } \\
\text { apresentou boa extração apenas para o PCP, sem reprodução nas } \\
\text { duplicatas. }\end{array}$ \\
\hline Alcalinização versus & $\rightarrow$ A amostra acidificada apresentou maior \\
\hline
\end{tabular}




\begin{tabular}{c|l}
\hline Acidificação & $\begin{array}{l}\text { clorofenóis, principalmente para o PCP, mostrando-se bastante } \\
\text { superior a amostra alcalinizada }\end{array}$ \\
\hline Hexano versus & $\begin{array}{l}\rightarrow \text { utilizando hexano/acetona 4:1 como solvente, os resultados foram } \\
\text { superiores, entretanto, deve-se considerar que as amostras extraídas } \\
\text { com n-hexano foram limpas e pode ter havido perdas na limpeza. }\end{array}$ \\
\hline
\end{tabular}

Tabela 5.11 - Valores das áreas cromatográficas de clorofenóis no emprego da agitação com barra magnética

\section{Teste 1}

Amostra: Sedimento do Lobo

Dopagem: $100 \mu \mathrm{L}$ de solução de PCP $(1 \mathrm{mg} / \mathrm{mL})$

Solvente: $200 \mathrm{~mL}$ de solução de acetona

Limpeza: Coluna de Sílica $(1 \mathrm{~cm})$ e $10 \mathrm{~mL}$ de solução de Hexano/acetona 3:1 como eluente.

\begin{tabular}{c|c|c|c|c|c|c}
\hline \multirow{2}{*}{ Amostras } & \multicolumn{6}{|c}{ Compostos (Área/Tempo de Retenção) } \\
\cline { 2 - 7 } & $3,5-\mathrm{DCP}$ & $3,4-\mathrm{DCP}$ & $2,4,6-\mathrm{TCP}$ & $2,3,6-\mathrm{TCP}$ & $2,4-\mathrm{DBP}$ & PCP \\
\hline $1(* *)$ & 64945 & 70930 & 79841 & 65942 & 8200 & $2.0581 \times 10^{7}$ \\
\hline $1(*)$ & ---------- & ---------- & --------- & --------- & --------- & $1.26162 \times 10^{7}$ \\
\hline
\end{tabular}

Tabela 5.12 - Valores das áreas cromatográficas de clorofenóis no emprego do ultrasom, utilizando-se diferentes formas de limpeza

\section{Teste 1}

Amostra: Sedimento da Represa do Lobo

Dopagem: $50 \mu \mathrm{L}$ de solução de Clorofenóis $(1 \mathrm{mg} / \mathrm{L})$

Solvente: $50 \mathrm{~mL}$ de Hexano

\begin{tabular}{c|c|c|c|c}
\hline Amostras & Limpeza & $3,5-\mathrm{DCP}$ & $2,4,6-\mathrm{TCP}$ & PCP \\
\hline 1A & \multirow{2}{*}{ Sílica 3,0 cm } & 44998 & 36698 & 9812373 \\
\cline { 3 - 5 } & & ------------- & ------------ & 4136005 \\
\hline 1B & C18 & ------------- & ------------ & 322474 \\
\hline 1C & &
\end{tabular}

Tabela 5.13 - Valores das áreas cromatográficas de clorofenóis no emprego do ultrasom, testando-se a utilização da acidificação (1)

\section{Teste 2}

Amostra: Sedimento da Represa do Lobo

Dopagem: $50 \mu \mathrm{L}$ de solução de Clorofenóis $(1 \mathrm{mg} / \mathrm{L})$

Solvente: $50 \mathrm{~mL}$ de Hexano/acetona 4:1

Limpeza: Coluna de Sílica $(3,0 \mathrm{~cm})$ e $5 \mathrm{~mL}$ de solução de Hexano/acetona 3:1 como eluente

\begin{tabular}{c|c|c|c|c|c}
\hline Amostras & Acidificação & $3,5-\mathrm{DCP}$ & $2,4,6-\mathrm{TCP}$ & $2,4-\mathrm{DBP}$ & PCP \\
\hline 1 & Presente & --------- & 57862 & 65757 & --------- \\
\hline 2 & Ausente & 37239 & 30135 & 68772 & $17 \times 10^{7}$ \\
\hline
\end{tabular}


Tabela 5.14 - Valores das áreas cromatográficas de clorofenóis no emprego do ultrasom, testando-se a utilização da acidificação (2)

\begin{tabular}{|c|c|c|c|c|c|c|}
\hline \multicolumn{7}{|c|}{$\begin{array}{c}\text { Teste } 3 \\
\end{array}$} \\
\hline \multicolumn{7}{|c|}{ Amostra: Sedimento da Represa de Salto Grande/ Estação 4/ Maio } \\
\hline \multicolumn{7}{|c|}{ Dopagem: $100 \mu \mathrm{L}$ de solução de Clorofenóis ( 1 mg/L) } \\
\hline \multicolumn{7}{|c|}{ Solvente: $25 \mathrm{~mL}$ de Hexano/acetona 3:1 } \\
\hline \multicolumn{7}{|c|}{$\begin{array}{l}\text { Limpeza: Coluna de Sílica }(3,0 \mathrm{~cm}) \text { e } 5,0 \mathrm{~mL} \text { de solução de Hexano/acetona } 3: 1 \text { como } \\
\text { eluente }\end{array}$} \\
\hline Amostras & Acidificação & $3,5-\mathrm{DCP}$ & 3,4-DCP & 2,4-DBP & $2,3,4-\mathrm{TCP}$ & $\mathrm{PCP}$ \\
\hline $1 \mathrm{~A}$ & & 167747 & 1010770 & 143287 & 108909 & 136128 \\
\hline 1B & Ausente & 105030 & 130447 & 170006 & 120580 & --------- \\
\hline
\end{tabular}

Tabela 5.15 - Valores das áreas cromatográficas de clorofenóis no emprego do ultrasom, testando-se a utilização da acidificação e alcalinização com diferentes tipos de solventes

\section{Teste 4}

Amostra: Sedimento da Represa do Lobo

Dopagem: $100 \mu \mathrm{L}$ de solução de Clorofenóis $(1 \mathrm{mg} / \mathrm{L})$

Limpeza: Coluna de Sílica $(3,0 \mathrm{~cm})$ e 5,0 mL de solução de Hexano/acetona 3:1 como eluente

\begin{tabular}{c|c|c|c|c|c|c|c}
\hline Amostras & $\begin{array}{c}\text { Acidificação/ } \\
\text { Alcalinização }\end{array}$ & Solvente & $\begin{array}{c}3,5- \\
\text { DCP }\end{array}$ & $\begin{array}{c}2,5- \\
\text { DCP }\end{array}$ & $\begin{array}{c}2,4,6- \\
\text { TCP }\end{array}$ & $\begin{array}{c}2,3,4- \\
\text { TCP }\end{array}$ & PCP \\
\hline 1 & $\begin{array}{c}\text { Alcalinização } \\
(\bullet)\end{array}$ & Água & 52172 & 21733 & 27785 & ------- & 143263 \\
\hline 2A & $\begin{array}{c}\text { Alcalinização } \\
(\bullet \bullet)\end{array}$ & $\begin{array}{c}25 \mathrm{~mL} \text { de } \\
\text { hexano }\end{array}$ & 28092 & ------- & ------- & -------- & 1029772 \\
\hline 2B & $\begin{array}{c}\text { Alcalinização } \\
(\bullet \bullet)\end{array}$ & $\begin{array}{c}25 \mathrm{~mL} \text { de } \\
\text { Hexano }\end{array}$ & 37061 & 21481 & 37368 & ------- & 24124 \\
\hline 4 & Acidificação & $\begin{array}{c}25 \mathrm{~mL} \text { de } \\
\text { Hexano }\end{array}$ & 30603 & 21308 & 47626 & 63960 & $1,56 \times 10^{7}$ \\
\hline
\end{tabular}


Tabela 5.16 - Valores das áreas cromatográficas de clorofenóis no emprego do ultrasom, testando-se a utilização da acidificação com diferentes tipos de solventes

\section{Teste 5}

Amostra: Sedimento da Represa do Lobo

Dopagem: $1 \mathrm{~mL}$ de solução intermediária de Clorofenóis $(4 \mu \mathrm{g} / \mathrm{L})$

Limpeza: neste teste não foi feita limpeza

\begin{tabular}{|c|c|c|c|c|c|c|c|}
\hline Amostras & Acidificação & Solvente & $\begin{array}{l}3,5- \\
\text { DCP }\end{array}$ & $\begin{array}{c}2,3,6- \\
\text { TCP }\end{array}$ & 2,4-DBP & $\begin{array}{c}2,3,4- \\
\text { TCP }\end{array}$ & $\mathrm{PCP}$ \\
\hline $1 \mathrm{~A}$ & \multirow{2}{*}{ Ausente } & \multirow{3}{*}{$\begin{array}{c}25 \mathrm{~mL} \\
\text { de } \\
\text { Hexano }\end{array}$} & 84183 & 210831 & 9055725 & 35792 & 1082705 \\
\hline $1 \mathrm{~B}$ & & & 25501 & |------ & 25052 & 109228 & $1.21 \times 10^{7}$ \\
\hline 2 & Presente & & ------ & ------ & ------ & ------ & $1.53 \times 10^{7}$ \\
\hline 1 & Ausente & \multirow{2}{*}{$\begin{array}{c}25 \mathrm{~mL} \\
\text { de } \\
\text { Hexano/ } \\
\text { acetona } \\
4: 1\end{array}$} & ----- & ----- & ---------- & ----- & $1.32 \times 10^{7}$ \\
\hline 2 & Presente & & ------ & ------ & ------ & ------ & $1.74 \times 10^{7}$ \\
\hline $1 \mathrm{~A}$ & \multirow{3}{*}{ Presente } & \multirow{3}{*}{$\begin{array}{c}25 \mathrm{~mL} \\
\text { de } \\
\text { Hexano/ } \\
\text { acetona } \\
4: 1\end{array}$} & ------ & ------ & ------ & $\begin{array}{l}----- \\
\end{array}$ & $1.62 \times 10^{7}$ \\
\hline $1 \mathrm{~B}$ & & & ------ & 75049 & 3178882 & 152009 & 731216 \\
\hline $1 \mathrm{C}$ & & & ------ & ------ & 1468739 & 88477 & 250248 \\
\hline
\end{tabular}

Tabela 5.17 - Valores das áreas cromatográficas de clorofenóis no emprego do ultrasom, testando-se a utilização da limpeza e diferentes tipos de solventes

\section{Teste 6}

Amostra: Sedimento da Represa de Salto Grande/ Estação 4/ Maio

Dopagem: não houve dopagem com solução de clorofenóis, apenas com o padrão interno (800 $\mu \mathrm{L}$ de solução $2,5 \mu \mathrm{g} / \mathrm{L}$ )

\begin{tabular}{|c|c|c|c|c|c|c|c|}
\hline Amostras & Solvente & Limpeza & $\begin{array}{l}3,4- \\
\text { DCP }\end{array}$ & $\begin{array}{c}2,3,6- \\
\text { TCP }\end{array}$ & $\begin{array}{l}2,4- \\
\text { DBP }\end{array}$ & $\begin{array}{c}2,3,4- \\
\text { TCP }\end{array}$ & PCP \\
\hline $1 \mathrm{~A}$ & \multirow{2}{*}{$\begin{array}{c}25 \mathrm{~mL} \mathrm{de} \\
\text { Hexano/ } \\
\text { acetona } \\
4: 1\end{array}$} & \multirow[b]{2}{*}{ Não houve } & 40309 & ---------- & 78081 & ---------- & 150815 \\
\hline 1B & & & ----------- & 133392 & 6226888 & 350168 & ---------- \\
\hline $1 \mathrm{~A}$ & \multirow[b]{2}{*}{$\begin{array}{c}50 \mathrm{~mL} \text { de } \\
\text { Hexano }\end{array}$} & \multirow{2}{*}{$\begin{array}{c}\text { Sílica } \\
(5,0 \mathrm{~cm}) \\
\text { com } 5,0 \mathrm{~mL} \\
\text { de Hexano/ } \\
\text { acetona } 2: 1\end{array}$} & 132581 & 75453 & 265755 & 79290 & 54447 \\
\hline $1 \mathrm{~B}$ & & & 58848 & 76671 & 99243 & 21537 & 52970 \\
\hline
\end{tabular}


Os ensaios realizados com ultra-som resultaram em boa capacidade de extração e valores de áreas confiáveis, além de procedimentos mais simples e rápidos. Ao analisar os valores mostrados nas Tabelas 5.12 a 5.17, as áreas de picos de PCP extraídas por ultra-som foram, em ordem de grandeza, maiores que as encontradas quando empregou-se a extração com Soxhlet.

O teste de eficiência, conclusivo para a escolha do ultra-som como método de extração, mostrou boa capacidade extrativa e reprodutibilidade. As etapas do método foram descritas no item 4.2.4.3, Material e Métodos. As áreas de pico obtidas a partir da avaliação de três amostras de sedimentos do Lobo, dopados com solução de PCP $(4,0 \mu \mathrm{g} / \mathrm{L})$ e com o padrão interno, 2,4-Dibromofenol $(300,0 \mu \mathrm{g} / \mathrm{L})$ são mostradas na Tabela 5.18. Foi utilizada como controle, uma amostra desse mesmo reservatório dopada apenas com o 2,4-DBP. Esta tabela também mostra o fator de resposta, coeficiente entre área encontrada para o PCP e a área encontrada para o 2,4-DBP. Através dos valores desse fator, nota-se a boa reprodutibilidade entre as amostras.

Tabela 5.18 - Valores das áreas cromatográficas de clorofenóis obtidos no teste de eficiência utilizando ultra-som como método de extração.

\begin{tabular}{l|c|c|c}
\hline \multicolumn{4}{c}{ Sedimento do Lobo dopado } \\
\cline { 2 - 4 } \multicolumn{1}{c}{ Amostra } & 2,4 -dibromofenol & Pentaclorofenol & Fator de Resposta \\
\hline Branco (controle) & 368.088 & -------------- & -------------- \\
\hline Sedimento dopado (1) & 224.890 & 461.369 & 2.051 \\
\hline Sedimento dopado (2) & 219.009 & 373.911 & 1.707 \\
\hline Sedimento dopado (3) & 292.331 & 559.254 & 1.913 \\
\hline
\end{tabular}

Os resultados da Tabela 5.18 revelaram que o ultra-som respondeu adequadamente, considerando os valores de áreas de picos dos cromatogramas obtidos para os sedimentos dopados 1, 2 e 3. Assim, as amostras de sedimento de Salto Grande foram então extraídas com o método do ultra-som. Posteriormente às análises feitas com esse método, em triplicata, para todas as amostras de Salto Grande, e para avaliar quantitativamente as mesmas, amostras de sedimentos da estação 2 desse reservatório foram dopadas com solução contendo padrões de clorofenóis em três concentrações e 2,4-Dibromofenol.

Porém, através desse teste observou-se somente extração de Pentaclorofenol nas amostras limpas e nas concentrações de $0,25 \mathrm{mg} / \mathrm{L}$ (área de 60.040 ) e 0,50 mg/L (área de 151.557), como pode ser visto na Tabela 5.19. Os primeiros resultados das análises cromatográficas mostraram que poderiam estar ocorrendo perdas de clorofenóis durante a 
limpeza das amostras. Todas as amostras estavam sendo limpas como indicado na Figura 4.3 de Material e Métodos. Dessa forma, as amostras da estação 4 foram testadas sem limpeza na coluna de sílica, e os resultados estão organizados na Tabela 5.20. 
Tabela 5.19 - Resultados das injeções cromatográficas das amostras da estação 2 dopadas para padrões .

\begin{tabular}{|c|c|c|c|c|c|c|c|c|c|}
\hline \multicolumn{10}{|c|}{ Ultra =som/Estacão 4} \\
\hline Amostra & Concentração & & & & & & & & \\
\hline (Data) & $(\mathrm{mg} / \mathrm{L})$ & 2,5-DCP & 3,5-DCP & 2,4,6-TCP & $2,3,6-\mathrm{TCP}$ & $2,4,5-\mathrm{TCP}$ & 2,4-DBP & 2,3,4-ТCP & $\mathrm{PCP}$ \\
\hline Branco & ----------- & ----------- & ----------- & ----------- & ----------- & ----------- & ----------- & ----------- & ----------- \\
\hline $0,25 \mathrm{a}$ & 0,25 & ----------- & ----------- & ----------- & ----------- & ----------- & ----------- & ----------- & ----------- \\
\hline $0,25 \mathrm{~b}$ & 0,25 & ----------- & ----------- & ----------- & ----------- & ----------- & ----------- & ----------- & ----------- \\
\hline $0,25 \mathrm{c}$ & 0,25 & ----------- & ----------- & ----------- & ----------- & ----------- & ----- & ----------- & $\begin{array}{c}60.040 \\
(22.554) \\
\end{array}$ \\
\hline $0,50 \mathrm{a}$ & 0,50 & ---------- & ---------- & ----------- & ----------- & ---------- & ----------- & ----------- & ----------- \\
\hline $0,50 \mathrm{~b}$ & 0,50 & ----------- & ---- & -- & & ------ & & & $\begin{array}{r}151.557 \\
(22.554) \\
\end{array}$ \\
\hline $0,50 \mathrm{c}$ & 0,50 & ----------- & ----------- & ----------- & ----------- & ---------- & ---------- & $----\cdot$ & ----------- \\
\hline $1,00 \mathrm{a}$ & 1,00 & ----------- & ----------- & ----------- & ----------- & ----------- & ----------- & ----------- & ---- \\
\hline $1,00 \mathrm{~b}$ & 1,00 & ---------- & ----------- & ----------- & ----------- & ----------- & ------------ & ----------- & --- \\
\hline $1,00 \mathrm{c}$ & 1,00 & ----------- & ----------- & ----------- & ----------- & ----------- & ----------- & ----------- & ----- \\
\hline
\end{tabular}

Obs.: Todas as amostras foram limpas em coluna de sílica $(3 \mathrm{~cm})$, utilizando hexano/acetona 3:1 como eluente 
Tabela 5.20 - Resultados das injeções cromatográficas das amostras da estação 4 dopadas para padrões.

\begin{tabular}{|c|c|c|c|c|c|c|c|c|c|}
\hline \multicolumn{10}{|c|}{ Ultra-som/Estacão 4} \\
\hline \multirow{2}{*}{$\begin{array}{l}\text { Amostra } \\
\text { (Data) }\end{array}$} & \multirow{2}{*}{$\begin{array}{l}\text { Concentração } \\
(\mathrm{mg} / \mathrm{L})\end{array}$} & \multicolumn{8}{|c|}{ Compostos (Área/ tempo de Retenção) } \\
\hline & & 2,5-DCP & 3,5-DCP & 2,4,6-TCP & $2,3,6-\mathrm{TCP}$ & 2,4,5-ТCP & 2,4-DBP & 2,3,4-ТCP & PCP \\
\hline Branco & ----------- & ----------- & ----------- & ----------- & ----------- & ---------- & ----------- & ---------- & ----------- \\
\hline $0,25 \mathrm{aa}^{*}$ & 0,25 & ----------- & ----------- & ----------- & ----------- & ----------- & ----------- & ----------- & ----------- \\
\hline $0,25 \mathrm{bb}^{*}$ & 0,25 & ----------- & ----------- & ----------- & ----------- & ----------- & ----------- & ----------- & ---------- \\
\hline $0,25 \mathrm{cc}^{*}$ & 0,25 & ----------- & ----------- & ----------- & ----------- & ----------- & ----------- & ----------- & ----------- \\
\hline $0,50 \mathrm{aa}^{*}$ & 0,50 & ----- & & ------ & ----------- & ----------- & $\begin{array}{c}22.778 \\
(18.770) \\
\end{array}$ & $\begin{array}{l}174.516 \\
(19.835) \\
\end{array}$ & \\
\hline $0,50 \mathrm{bb}^{*}$ & 0,50 & ----------- & ----------- & ----------- & ----------- & ----------- & ---------- & ----------- & ----------- \\
\hline $0,50 \mathrm{cc}$ & 0,50 & ----------- & ----------- & $\begin{array}{c}46.547 \\
(15.984) \\
\end{array}$ & -----. & $\begin{array}{c}27.548 \\
(18.465) \\
\end{array}$ & $\begin{array}{c}48.336 \\
(18.766) \\
\end{array}$ & & $\begin{array}{l}100.630 \\
(22.565) \\
\end{array}$ \\
\hline 1,00 aa & 1,00 & ------------ & ---------- & $\begin{array}{l}177.350 \\
(15.978) \\
\end{array}$ & $\begin{array}{l}198.358 \\
(16.783) \\
\end{array}$ & ----------- & & $\begin{array}{l}101.645 \\
(19.146) \\
\end{array}$ & $\begin{array}{r}183.398 \\
(22.559) \\
\end{array}$ \\
\hline $1,00 \mathrm{bb}$ & 1,00 & ----------- & ----------- & $\begin{array}{c}88.644 \\
(15.973) \\
\end{array}$ & $\begin{array}{l}112.546 \\
(16.778) \\
\end{array}$ & --- & & $\begin{array}{c}79.935 \\
(19.141) \\
\end{array}$ & $\begin{array}{l}230.345 \\
(22.555)\end{array}$ \\
\hline $1,00 \mathrm{cc}$ & 1,00 & ----------- & ----------- & $\begin{array}{c}39.913 \\
(15.976) \\
\end{array}$ & $\begin{array}{c}48.025 \\
(16.781) \\
\end{array}$ & --- & & $\begin{array}{c}71.336 \\
(19.143) \\
\end{array}$ & $\begin{array}{l}317.452 \\
(22.555) \\
\end{array}$ \\
\hline
\end{tabular}

Obs.: Todas as amostras marcadas (*) foram limpas em coluna de sílica $(3 \mathrm{~cm})$, utilizando hexano/acetona 3:1 como eluente 
Os resultados das Tabelas 5.19 e 5.20 mostram que a recuperação dos clorofenóis nas amostras da estação 2 e 4 não foram consistentes, o que levou a uma nova avaliação do método extrativo escolhido. Porém, esse método já havia sido utilizado com amostras do reservatório de Salto Grande, que estão apresentados nas Tabelas 1E a 12E, dos Anexos.

Para evidenciar possíveis perdas pelo método escolhido, novamente foram realizados testes de extração com os procedimentos empregando Soxhlet e a agitação com barra magnética. A amostra utilizada foi da estação 2 de Salto Grande, coletada em Novembro. Os procedimentos de extração utilizados estão descritos no item 4.2.4.3 de Materiais e Métodos, e os resultados nas Tabelas 5.21 e 5.22. A Tabela 5.22 apresenta os resultados obtidos da análise da solução de trabalho, retirada após 18 horas de contato com o sedimento e após acidificação e extraída pelo método proposto por DAMIANOVIC (1997).

De acordo com esses resultados, foi questionada a escolha inicialmente feita pelo método do ultra-som e a limpeza das amostras. Assim, as amostras restantes de Salto Grande foram analisadas novamente, utilizando-se a agitação e o Soxhlet, sem procedimentos de limpeza. As amostras analisadas por esses métodos foram as da $2^{\mathrm{a}}$ campanha, as estações 1 , 2 e 4 da $3^{\text {a }}$ campanha e as estações 1,3 e 4 da $4^{\text {a }}$ campanha. As amostras da estação 2 da $4^{\text {a }}$ campanha foram analisadas somente com ultra-som e agitação sob barra magnética. Objetivava-se com isto, comparar os resultados, para certificar-se da tomada de decisão, tanto pelo método de extração quanto pelo de limpeza, podendo-se tirar conclusões mais acertadas.

A curva de calibração para quantificação das amostras foi feita apenas com extração pelo método do ultra-som, portanto, as amostras extraídas pelos outros procedimentos foram utilizadas apenas para comparação por área dos cromatogramas, sem quantificação.

Todas as análises feitas, tanto cromatográficas, quanto as demais, serão discutidas por campanha, no item 5.3. 
Tabela 5.21 - Resultados obtidos das injeções cromatográficas do teste de comparação entre os métodos de extração para sedimentos

Sedimento/ Estação 2/ Novembro

\begin{tabular}{|c|c|c|c|c|c|c|c|c|c|}
\hline \multirow{2}{*}{$\begin{array}{l}\text { Tipo de } \\
\text { Extração }\end{array}$} & \multirow{2}{*}{ Amostras } & \multicolumn{8}{|c|}{ Compostos (Área/ tempo de Retenção) } \\
\hline & & 2,5-DCP & 3,5-DCP & 2,4,6-TCP & $2,3,6-\mathrm{TCP}$ & $2,4,5-\mathrm{TCP}$ & 2,4-DBP & 2,3,4-ТCP & PCP \\
\hline \multirow{3}{*}{ Ultra-som } & Branco & ----------- & ----------- & ----------- & ----------- & ----------- & $\begin{array}{c}38.446 \\
(18.529)\end{array}$ & ----------- & $\begin{array}{c}30.823 \\
(22.559)\end{array}$ \\
\hline & 1 & ----------- & ----------- & $\begin{array}{c}65.178 \\
(15.977) \\
\end{array}$ & $\begin{array}{c}49.151 \\
(16.782)\end{array}$ & ----------- & $\begin{array}{c}33.191 \\
(18.758)\end{array}$ & $\begin{array}{c}32.698 \\
(19.144) \\
\end{array}$ & $\begin{array}{c}64.882 \\
(22.557) \\
\end{array}$ \\
\hline & 2 & ----------- & ----------- & $\begin{array}{l}189.766 \\
(15.972)\end{array}$ & $\begin{array}{c}184.423 \\
(16.778)\end{array}$ & ----------- & $\begin{array}{c}32.056 \\
(18.753) \\
\end{array}$ & $\begin{array}{c}33.251 \\
(19.471)\end{array}$ & $\begin{array}{l}357.714 \\
(22.553)\end{array}$ \\
\hline \multirow{2}{*}{ Agitação } & 1 & ----------- & ----------- & $\begin{array}{c}1.168 .427 \\
(15.970)\end{array}$ & $\begin{array}{c}1.153 .014 \\
(16.775)\end{array}$ & ----------- & ----------- & $\begin{array}{l}653.186 \\
(19.136) \\
\end{array}$ & $\begin{array}{c}2.397 .653 \\
(22.552)\end{array}$ \\
\hline & 2 & ----------- & ---------- & $\begin{array}{c}1.563 .807 \\
(15.968)\end{array}$ & $\begin{array}{c}1.498 .105 \\
(16.773)\end{array}$ & & & $\begin{array}{l}822.458 \\
(19.135)\end{array}$ & $\begin{array}{c}3.260 .665 \\
(22.551)\end{array}$ \\
\hline \multirow{2}{*}{ Soxhlet } & 1 & $\begin{array}{c}61.779 \\
(15.034)\end{array}$ & & $\begin{array}{c}1.746 .429 \\
(15.982)\end{array}$ & $\begin{array}{c}1.805 .279 \\
(16.786)\end{array}$ & $\begin{array}{c}56.249 \\
(18.193) \\
\end{array}$ & $\begin{array}{l}376.808 \\
(18.460)\end{array}$ & $\begin{array}{l}875.745 \\
(19.145) \\
\end{array}$ & $\begin{array}{c}2.239 .615 \\
(22.563)\end{array}$ \\
\hline & 2 & $\begin{array}{c}56.227 \\
(15.023)\end{array}$ & $\begin{array}{c}77.167 \\
(15.268)\end{array}$ & $\begin{array}{c}1.536 .104 \\
(15.971)\end{array}$ & $\begin{array}{c}1.566 .407 \\
(16.776)\end{array}$ & $\begin{array}{c}52.493 \\
(18.184)\end{array}$ & $\begin{array}{l}333.681 \\
(18.451)\end{array}$ & $\begin{array}{c}797.868 \\
(19.136)\end{array}$ & $\begin{array}{c}1.870 .664 \\
(22.553)\end{array}$ \\
\hline
\end{tabular}


Tabela 5.22- Resultados obtidos das injeções cromatográficas da solução de trabalho utilizada na dopagem dos sedimentos e da água com padrão interno utilizada para dopagem do branco no teste de comparação entre os métodos de extração para sedimentos

\begin{tabular}{|c|c|c|c|c|c|c|c|c|c|}
\hline \multicolumn{10}{|c|}{ Água da dopagem do Sedimento/ Estação 2/ Novembro (Área/ tempo de Retenção) } \\
\hline \multirow{2}{*}{$\begin{array}{c}\text { Tipo de } \\
\text { Extração }\end{array}$} & \multirow[b]{2}{*}{ Amostras } & \multicolumn{8}{|c|}{ Compostos (Área/ tempo de Retenção) } \\
\hline & & 2,5-DCP & 3,5-DCP & 2,4,6-TCP & $2,3,6-\mathrm{TCP}$ & $2,4,5-\mathrm{TCP}$ & 2,4-DBP & $2,3,4-\mathrm{TCP}$ & $\mathrm{PCP}$ \\
\hline \multirow{3}{*}{ Ultra-som } & Branco & & ---- & ------------ & ------------ & & & ----------- & $\begin{array}{l}550.094 \\
(22.684)\end{array}$ \\
\hline & 1 & ----------- & ----------- & $\begin{array}{l}179.313 \\
(15.977)\end{array}$ & $\begin{array}{l}226.381 \\
(16.786)\end{array}$ & ----------- & ----------- & $\begin{array}{c}39.166 \\
(19.149)\end{array}$ & $\begin{array}{l}198.661 \\
(22.559)\end{array}$ \\
\hline & 2 & ----- & ----------- & $\begin{array}{l}253.302 \\
(15.972)\end{array}$ & $\begin{array}{l}320.967 \\
(16.778)\end{array}$ & --- & & $\begin{array}{c}65.583 \\
(19.144)\end{array}$ & $\begin{array}{l}108.245 \\
(22.555)\end{array}$ \\
\hline \multirow{2}{*}{ Agitação } & 1 & ---- & ----- & $\begin{array}{l}265.701 \\
(15.972)\end{array}$ & $\begin{array}{l}324.301 \\
(16.777)\end{array}$ & ----- & ----------- & $\begin{array}{c}82.621 \\
(19.142)\end{array}$ & $\begin{array}{l}139.063 \\
(22.552) \\
\end{array}$ \\
\hline & 2 & --- & ----------- & $\begin{array}{l}236.279 \\
(15.968)\end{array}$ & $\begin{array}{l}290.688 \\
(16.773)\end{array}$ & ----------- & & $\begin{array}{c}72.668 \\
(19.138)\end{array}$ & $\begin{array}{l}117.168 \\
(22.549)\end{array}$ \\
\hline \multirow{2}{*}{ Soxhlet } & 1 & ---------- & ----------- & $\begin{array}{l}167.583 \\
(15.973) \\
\end{array}$ & $\begin{array}{l}208.847 \\
(16.778) \\
\end{array}$ & ----------- & ----------- & $\begin{array}{c}45.223 \\
(19.144) \\
\end{array}$ & $\begin{array}{c}86.653 \\
(22.553) \\
\end{array}$ \\
\hline & 2 & ----------- & ----------- & $\begin{array}{l}354.663 \\
(15.969)\end{array}$ & $\begin{array}{l}427.053 \\
(16.774)\end{array}$ & ----------- & ----------- & $\begin{array}{c}97.192 \\
(19.139)\end{array}$ & $\begin{array}{l}209.031 \\
(22.550)\end{array}$ \\
\hline
\end{tabular}





\subsection{Resultados e Discussão por Campanha}

\subsubsection{Parâmetros Climatológicos}

$\mathrm{Na}$ Tabela 5.23 estão apresentados todos os parâmetros climatológicos registrados para os dias de coletas. Os valores serão discutidos, posteriormente, em relação a cada condição do reservatório de Salto Grande, em campanha realizada.

Tabela 5.23- Parâmetros climatológicos registrados nas campanhas

\begin{tabular}{l|c|c|c|c}
\hline \multirow{2}{*}{ Parâmetros Climatológicos } & \multicolumn{4}{|c}{ Campanhas } \\
\cline { 2 - 5 } & $27 / 05 / 98$ & $18 / 06 / 98$ & $06 / 11 / 98$ & $25 / 02 / 99$ \\
\hline Radiação Global $\left(\mathrm{cal} / \mathrm{cm}^{2} . d\right)$ & 116 & 252 & 642 & 410 \\
\hline Insolação (horas/dia) & 2,8 & 6,9 & 10,4 & 5,4 \\
\hline Precipitação (mm) & 9,9 & 17,8 & 0,0 & 7,1 \\
\hline UR (\%) & 96 & 82,0 & 65 & 90 \\
\hline Vento médio (Km/h) & 7,2 & 10,8 & 5,3 & 5,6 \\
\hline Temperatura máxima $\left({ }^{0} \mathrm{C}\right)$ & 24,6 & 28,3 & 32,9 & 30,7 \\
\hline Temperatura. Mínima $\left({ }^{0} \mathrm{C}\right)$ & 16,0 & 13,0 & 17,0 & 20,1 \\
\hline Temperatura. Média $\left({ }^{0} \mathrm{C}\right)$ & 20,3 & 20,7 & 25,0 & 25,4 \\
Evaporação $(\mathrm{mm})$ & 1,40 & 4,61 & 5,86 & 5,29 \\
\hline
\end{tabular}

Fonte: CIAGRI (1999)

\subsubsection{Radiação solar}

Na Tabela 5.24 estão apresentados os valores da radiação solar nos meses da coleta.

Para os meses de Maio e Junho foram obtidos os menores valores do ano. Entretanto, considerando o dia da coleta, o menor valor encontrado foi para a campanha de Maio. Em Novembro ocorreu um dos maiores valores de radiação do ano e o maior, considerando os dias das coletas. 
Tabela 5.24 - Médias mensais dos valores de radiação solar para as campanhas.

\begin{tabular}{c|c|c}
\hline Campanhas & Radiação (cal/cm $\mathbf{2}$.dia) & Insolação (horas/dia) \\
\hline Maio/98 & 293,00 & 6,17 \\
\hline Junho/98 & 278,60 & 6,69 \\
\hline Novembro/98 & 474,27 & 7,79 \\
\hline Fevereiro/99 & 410,04 & 5,37 \\
\hline
\end{tabular}

Fonte: CIAGRI (1999)

\subsubsection{Ventos}

$\mathrm{Na}$ Tabela 5.25 estão apresentados os valores da velocidade do vento para os meses da coleta. As velocidades máxima e a média atingiram os maiores picos anuais no mês de Novembro. Entre os dias específicos das coletas, as maiores velocidades foram atingidas na campanha de Junho. A direção do vento predominante foi a mesma, exceto para o mês de Fevereiro.

Tabela 5.25 - Médias mensais dos valores da velocidade do vento para as campanhas

\begin{tabular}{c|c|c}
\hline Campanhas & $\begin{array}{c}\text { Velocidade máxima }(\mathbf{m} / \mathbf{s}) / \\
\text { direção }\end{array}$ & Velocidade média $(\mathbf{K m} / \mathbf{h})$ \\
\hline Maio/98 & $5,82 /$ sul & 6,09 \\
\hline Junho/98 & $6,25 /$ sul & 6,48 \\
\hline Novembro/98 & $9,66 /$ sul & 9,27 \\
\hline Fevereiro/99 & $8,73 /$ leste & 5,64 \\
\hline
\end{tabular}

Fonte: CIAGRI (1999)

\subsubsection{Precipitação total}

Nas campanhas de Junho e Novembro, obteve-se a mesma precipitação média mensal, porém, houve melhor distribuição no mês de Novembro. Em Junho, a maior precipitação ocorreu no dia da coleta. A maior precipitação média mensal das campanhas foi na de Fevereiro. (Tabela 5.26). 
Tabela 5.26 - Médias mensais dos valores de precipitação para as campanhas

\begin{tabular}{c|c|c}
\hline Campanhas & Precipitação média $(\mathbf{m m})$ & Dias de chuva \\
\hline Maio/98 & 97,60 & 10 \\
\hline Junho/98 & 26,60 & 2 \\
\hline Novembro/98 & 26,60 & 19 \\
\hline Fevereiro/99 & 198,30 & 5 \\
\hline
\end{tabular}

Fonte: CIAGRI (1999)

\subsubsection{Temperatura do ar}

Na Tabela 5.27 estão apresentados os valores das temperaturas máxima, média e mínima mensais, considerando os meses em que foram feitas as coletas. A maior temperatura mensal entre as campanhas foi encontrada no mês de Fevereiro. Considerando o dia da coleta, a maior temperatura foi registrada na campanha de Novembro. As menores temperaturas entre as campanhas foram registradas no mês de Junho.

Tabela 5.27 - Médias mensais dos valores de temperatura para as campanhas

\begin{tabular}{c|c|c|c}
\hline \multirow{2}{*}{ Campanhas } & \multicolumn{3}{|c}{ Temperaturas $\left(^{\mathbf{0}} \mathbf{C}\right)$} \\
\cline { 2 - 4 } & Máxima & Média & Mínima \\
\hline Maio/98 & 24,95 & 12,80 & 18,87 \\
\hline Junho/98 & 24,12 & 9,86 & 17,00 \\
\hline Novembro/98 & 24,12 & 16,45 & 23,24 \\
\hline Fevereiro/99 & 30,73 & 20,05 & 25,41 \\
\hline
\end{tabular}

Fonte: CIAGRI (1999)

\subsubsection{Parâmetros Hidráulicos e Morfométricos}

\subsubsection{Tempo de Residência}

O tempo médio de residência da água no reservatório foi calculado mensalmente, dividindo-se o volume médio mensal do reservatório pela vazão média mensal de saída, em $\mathrm{m}^{3} /$ dia. Na Tabela 5.28 são apresentados os tempos de residência calculados, bem como as vazões médias mensais de saída de Fevereiro/98 a Fevereiro/99. Na Figura 5.1, podem ser bem visualizados os tempos de residência máximo e mínimo desse período. Considerando as campanhas, o menor tempo de residência foi obtido em Fevereiro e o maior em Novembro. 
Tabela 5.28 - Tempo de Residência (dias) e vazão média mensal de saída $\left(\mathrm{m}^{3} / \mathrm{s}\right)$ de Fevereiro/98 a Fevereiro/99

\begin{tabular}{c|c|c}
\hline Meses & Tempo de Residência (dias) & Vazão média mensal de saída $\left(\mathbf{m}^{\mathbf{3}} / \mathbf{s}\right)$ \\
\hline Fev/98 & 19,04 & 64,43 \\
\hline Mar/98 & 26,08 & 47,04 \\
\hline Abr/98 & 63,06 & 19,46 \\
\hline Maio/98 & 49,05 & 25,01 \\
\hline Jun/98 & 74,08 & 16,56 \\
\hline Jul/98 & 96,46 & 12,72 \\
\hline Ago/98 & 110,03 & 11,15 \\
\hline Set/98 & 107,57 & 11,41 \\
\hline Out/98 & 39,12 & 31,36 \\
\hline Nov/98 & 102,93 & 11,92 \\
\hline Dez/99 & 27,56 & 44,52 \\
\hline Jan/99 & 12,74 & 96,28 \\
\hline Fev/99 & 14,23 & 86,24 \\
\hline
\end{tabular}

Fonte: CPFL (1999)

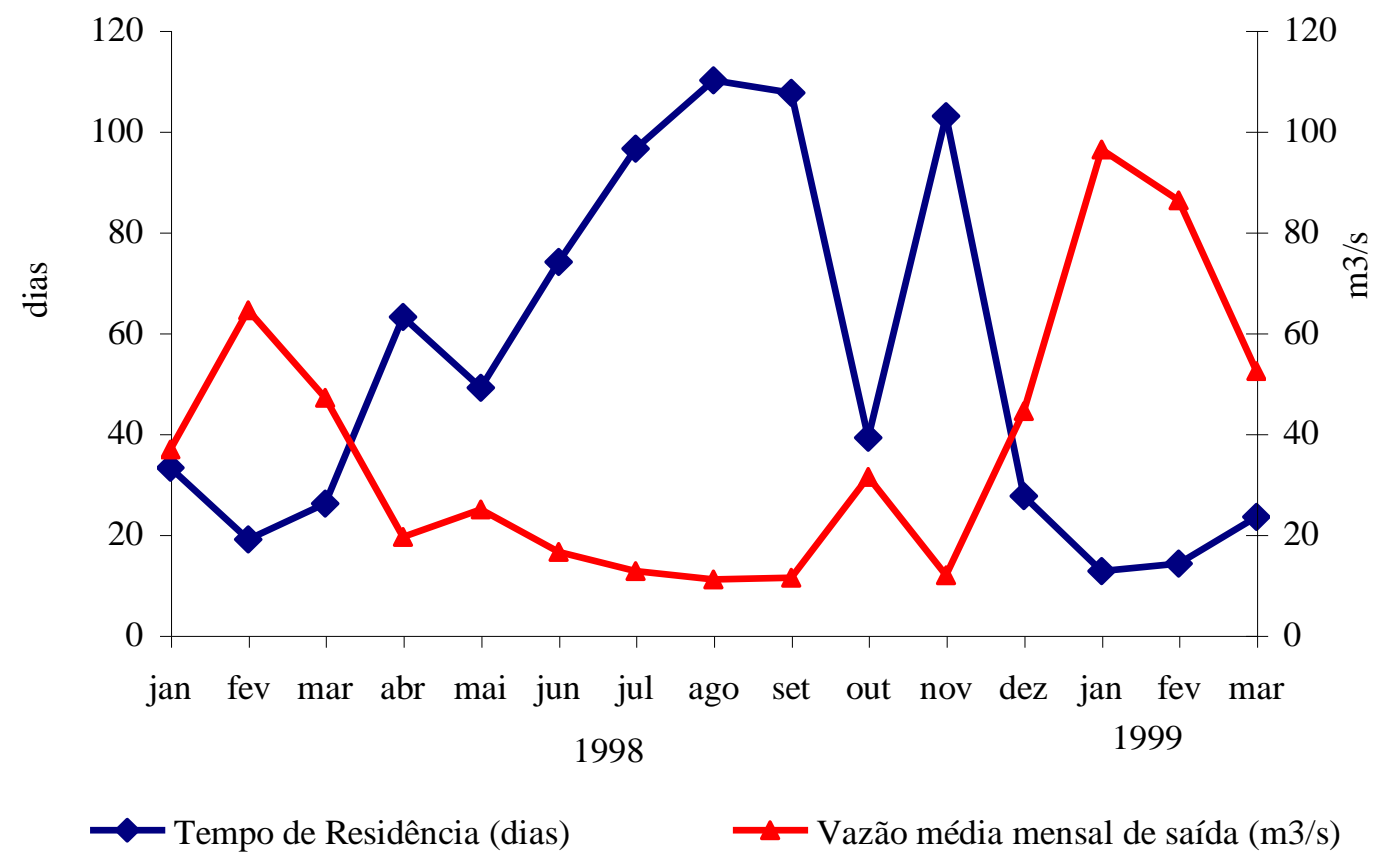

FIGURA 5.1 - TEMPO DE RESIDÊNCIA E VAZÃO MÉDIA MENSAL DE SAÍDA, NO RESERVATÓRIO DE SALTO GRANDE, AMERICANA (SP) (ADAPTADA DE TOSSINI, 1999). 


\subsubsection{Variáveis Físicas e Químicas}

\subsubsection{1. $\mathrm{pH}$, condutividade ( $\mu \mathrm{S} / \mathrm{cm}$ ), Turbidez (uT), oxigênio dissolvido $(\mathrm{mg} / \mathrm{L})$ e temperatura $\left({ }^{\circ} \mathrm{C}\right)$}

a) Maio:

Na primeira campanha, realizada em maio de 1998, foram feitas coletas em duas estações, 2 e 4, que representam o início do primeiro e o terceiro compartimento, respectivamente. As amostras de água foram coletadas apenas na estação 2. As estações escolhidas estão localizadas em pontos extremos e apresentaram características bem distintas para as variáveis condutividade e oxigênio dissolvido. Tal fato já havia sido observado por KIMMEL et al. (1990) apud RICHTER et al. (1991). Segundo os autores (op. cit.), em um reservatório, o tempo de retenção intermediário entre rios e lagos e os aportes predominantemente de uma fonte principal, no caso o rio Atibaia, resultam em um gradiente longitudinal das características limnológicas, ao longo do maior eixo, que nesse caso, liga a estação 2 a 4, acompanhando a calha do rio. As Tabelas 5.29 e 5.30 apresentam as fichas de bordo das estações, ou seja, os valores dos parâmetros físico-químicos medidos durante a coleta.

Os valores de pH para a estação 2, em coluna d'água de $2 \mathrm{~m}$, variaram de 6,73 a 6,49, enquanto para a estação 4, em uma coluna d'água de $11 \mathrm{~m}$, esta variação foi de 7,44 a 6,14 .

Na estação 2, o valor de turbidez encontrado foi em torno de 30, e a condutividade foi de aproximadamente $293 \mu \mathrm{S} / \mathrm{cm}$, enquanto que na estação 4, não foi possível verificar o valor da turbidez e enquanto que os valores de condutividade foram muito superiores aos da estação 2, chegando atingir $86 \mu \mathrm{S} / \mathrm{cm}$. Sendo a condutividade elétrica dependente da quantidade de sais dissolvidos na água e aproximadamente proporcional à sua quantidade (RICHTER et al., 1991), supõe-se que essa discrepância seja devida à estratificação térmica ocorrida na estação 4, em que a variação de temperatura da superfície para o fundo chegou a $3,4^{0} \mathrm{C}$. Segundo AGOSTINHO et al. (1997), a estratificação térmica propicia a liberação de compostos químicos a partir do sedimento e também o acúmulo de elementos oriundos da decomposição no hipolímnio.

$\mathrm{O}$ oxigênio dissolvido (OD) permaneceu praticamente constante na estação 2, porém, sofreu um gradiente de variação bastante acentuado na estação 4, onde apresentou concentração de 14,62 mg/L na superfície da coluna d'água, e concentração de $0,41 \mathrm{mg} / \mathrm{L}$ no fundo. Essa estratificação química pode ter sido intensificada pela estratificação térmica, 
visto que aportes de oxigênio para as camadas mais profundas d'água ocorrem durante períodos de circulação completa. Nesse caso, há influência também da estação seca, quando o tempo de residência da água é maior. Outro fator que pode explicar essa estratificação química é a matéria orgânica em maior quantidade nessa estação, e seu acúmulo nas camadas mais profundas. Essa afirmação pode ser confirmada pelos valores encontrados na análise de carbono orgânico total da água (Tabela 5.31). Estando o oxigênio envolvido diretamente com o processo de fotossíntese e respiração e/ou decomposição, a hora em que foi feita a coleta na estação 4, também pode ter contribuído para esses valores. Esse horário está no intervalo de maior intensidade solar do dia, logo, nas camadas superiores, onde há maior penetração da luz, é estimulada a fotossíntese, com conseqüente produção de oxigênio e intenso consumo de gás carbônico do meio. Nas camadas mais profundas, zona afótica, ocorre fenômeno inverso, havendo decomposição da matéria orgânica pela atividade dos microrganismos, com consumo de oxigênio e produção de gás carbônico.

A análise de material em suspensão, revelou predomínio de material inorgânico, enquanto na análise de carbono total, predomínio de carbono orgânico (Tabela 5.31). Essas análises foram feitas somente para a estação 2 , porque não foram coletadas amostras de água na estação 4, apenas foram avaliadas as variáveis físico-químicas na coluna d'água quando da coleta do sedimento.

Os diferentes tipos de carbono orgânico de um ecossistema aquático continental podem ser agrupados em duas categorias: carbono orgânico detrital e carbono orgânico particulado da biota, que somados, formam o carbono orgânico total. O carbono orgânico detrital é composto por duas frações, carbono particulado detrital e carbono orgânico dissolvido (ESTEVES, 1988). Como pela técnica utilizada, filtra-se a água, essas medidas de carbono orgânico são relativas ao carbono orgânico dissolvido e portanto não há relação entre a análise de material em suspensão e a análise de carbono total.

A predominância de material inorgânico é devida aos aportes do rio Atibaia, muito influente na estação 2. Para a estação 4, possivelmente a concentração de carbono orgânico seria maior, devido às condições locais dessa estação, sob influência das macrófitas, que juntamente com o fitoplâncton, constituem importante fonte de carbono orgânico dissolvido para a coluna d'água. Em função desses resultados, é também esperado que o teor de matéria orgânica no sedimento da estação 4 seja mais elevado que na estação 2 , devido à deposição de material em suspensão, principalmente da decomposição de macrófitas.

As análises de carbono orgânico total e umidade não foram realizadas nos sedimentos porque não houve quantidade disponível, visto que as amostras dessa campanha 
foram utilizadas prioritariamente para determinar e ajustar procedimentos de extração para análises cromatográficas.

Tabela 5.29 - Ficha de bordo: parâmetros físico-químicos medidos na estação 2, na campanha de Maio/98

\begin{tabular}{c|c|c|c|c|c}
\hline \multicolumn{7}{c}{ Estação: 2 } \\
\multicolumn{7}{c}{ Horário da coleta: 11:30 } \\
\hline $\begin{array}{c}\text { Profundidades } \\
(\mathrm{m})\end{array}$ & $\begin{array}{c}\text { Valores } \\
\text { de } \mathrm{pH}\end{array}$ & $\begin{array}{c}\text { Condutividade } \\
(\mu \mathrm{S} / \mathrm{cm})\end{array}$ & $\begin{array}{c}\text { Valores de } \\
\text { turbidez }(\mathrm{uT})\end{array}$ & $\begin{array}{c}\text { Valores de Oxigênio } \\
\text { dissolvido }(\mathrm{mg} / \mathrm{L})\end{array}$ & $\begin{array}{c}\text { Temperatura } \\
\left({ }^{0} \mathrm{C}\right)\end{array}$ \\
\hline 0,00 & 6,59 & 293 & 30,00 & 2,29 & 21,60 \\
\hline 0,50 & 6,52 & 293 & 21,00 & 2,16 & 21,60 \\
\hline 1,00 & 6,49 & 293 & 27,00 & 2,34 & 21,60 \\
\hline 1,50 & 6,73 & 294 & 20,00 & 2,54 & 21,60 \\
\hline 2,00 & 6,64 & 293 & 22,00 & 2,18 & 21,60 \\
\hline
\end{tabular}

Tabela 5.30 - Ficha de bordo: parâmetros físico-químicos medidos na estação 4, na campanha de Maio/98

\begin{tabular}{c|c|c|c|c}
\hline \multicolumn{5}{c}{ Horário da coleta: 13:00 h } \\
\hline $\begin{array}{c}\text { Profundidades } \\
(\mathrm{m})\end{array}$ & Valores de pH & $\begin{array}{c}\text { Condutividade } \\
(\mu \mathrm{S} / \mathrm{cm})\end{array}$ & $\begin{array}{c}\text { Valores de Oxigênio } \\
\text { dissolvido }(\mathrm{m} / \mathrm{L})\end{array}$ & $\begin{array}{c}\text { Temperatura } \\
\left({ }^{0} \mathrm{C}\right)\end{array}$ \\
\hline 0,00 & 7,35 & 85,00 & 14,62 & 24,20 \\
\hline 0,50 & 7,35 & 86,00 & 14,16 & 23,80 \\
\hline 1,00 & 7,44 & 86,00 & 15,37 & 23,20 \\
\hline 1,50 & 7,44 & 86,00 & 15,50 & 22,80 \\
\hline 2,00 & 7,44 & 86,00 & 13,27 & 22,10 \\
\hline 2,50 & 7,09 & 86,00 & 13,27 & 22,10 \\
\hline 3,00 & 6,78 & 86,00 & 11,67 & 21,90 \\
\hline 3,50 & 6,45 & 86,00 & 9,73 & 21,50 \\
\hline 4,00 & 6,43 & 86,00 & 4,92 & 21,50 \\
\hline 4,50 & 6,34 & 96,00 & 3,43 & 21,20 \\
\hline 5,00 & 6,34 & 96,00 & 2,30 & 21,10 \\
\hline 5,50 & 6,24 & 86,00 & 2,30 & 21,10 \\
\hline 6,00 & 6,22 & 86,00 & 1,30 & 21,00 \\
\hline 6,50 & 6,22 & 86,00 & 1,01 & 21,00 \\
\hline 7,00 & 6,22 & 86,00 & 1,01 & 20,90 \\
\hline 7,50 & 6,22 & 86,00 & 0,73 & 20,90 \\
\hline 8,00 & 6,16 & 86,00 & 0,59 & 20,90 \\
\hline 8,50 & 6,15 & 86,00 & 0,59 & 20,90 \\
\hline 9,00 & 6,15 & 86,00 & 0,47 & 20,90 \\
\hline 9,50 & 6,15 & 86,00 & 0,44 & 20,80 \\
\hline 10,00 & 6,14 & 86,00 & 0,38 & 20,80 \\
\hline 10,50 & 6,14 & 87,00 & 0,41 & 20,80 \\
\hline 11,00 & 6,14 & 87,00 & 0,41 & 20,80 \\
\hline & & & & \\
\hline
\end{tabular}


Tabela 5.31 - Resultados das análises de Material em Suspensão Total e das frações orgânica e inorgânica, e Carbono total e das frações orgânica $e$ inorgânica das amostras de água da campanha de Maio/98

\begin{tabular}{|c|c|c|c|}
\hline Estação & MST (mg/L) & MSO (mg/L) & MSI (mg/L) \\
\hline \multirow{4}{*}{2} & 28,21 & 6,41 & 21,79 \\
\hline & & & \\
\hline & CT (mg/L) & COT (mg/L) & CI (mg/L) \\
\hline & 5,80 & 3,13 & 2,67 \\
\hline
\end{tabular}

b) Junho

Na campanha de Junho foram feitas coletas de água e de sedimento nas mesmas estações da campanha anterior, estações 2 e 4. Apesar de serem pontos extremos considerando o reservatório, entrada e saída, não foram observadas diferenças relevantes entre as 2 estações como na primeira campanha (Tabelas 5.32 e 5.33). Na primeira campanha, os resultados mostraram diferenças marcantes entre os mesmos pontos de coleta. As velocidades elevadas dos ventos no dia da coleta, também a maior dentre as campanhas, podem explicar os valores das variáveis medidas, pois facilitam a mistura na coluna d'água..

Os valores de pH variaram de 6,83 a 6,76 para a estação 2 , em uma coluna de água de 2,20 m, e de 6,65 a5,90 para a estação 4, em uma coluna de água de 14,80 m. Comparadas à primeira campanha, houve diferenças menores entre os valores de $\mathrm{pH}$ nas duas estações dessa campanha, ou seja, houve maior uniformidade na campanha de Junho.

A condutividade registrada nas 2 estações estava em torno de $100 \mu \mathrm{S} / \mathrm{cm}$, exceto no ponto mais profundo de coleta da estação 4, onde os valores de condutividade atingiram 201 $\mu \mathrm{S} / \mathrm{cm}$. O mesmo ocorreu na estação 4 da Campanha de Maio. Esse fato, pode ser explicado pelo elevado número de macrófitas e matéria orgânica nessa estação. Pelas considerações de AGOSTINHO \& GOMES (1997), nessa situação, as camadas mais profundas são anóxicas, com altos valores de condutividade, sendo um indicativo de altas taxas de decomposição da matéria orgânica.

Os valores de oxigênio dissolvido foram baixos nas duas estações, atingindo valores próximos a zero nas camadas mais profundas da estação 4, a 14,50 m, possivelmente pelo fato da coleta ter sido feita pela manhã, em estação seca, de baixas temperaturas, apresentando menor luminosidade e consequentemente, menor taxa fotossintética. Esses valores de luminosidade precipitação e temperatura foram os mais baixos entre as campanhas, como visto nas Tabelas 5.24, 5.26 e 5.27, respectivamente. 
Os valores de material em suspensão total $(\mathrm{mg} / \mathrm{L})$ na estação 2 revelam que a fração inorgânica foi superior à orgânica, Tabela 5.34. Os valores de carbono total $(\mathrm{mg} / \mathrm{L})$ mostram o predomínio de carbono inorgânico, Tabela 5.35. Nessa estação, as diferenças foram maiores entre as concentrações de carbono orgânico e inorgânico.

$\mathrm{Na}$ estação 4, entretanto, predominou o material em suspensão orgânico, como pode ser visto na Tabela 5.34, porém, no caso do carbono total, houve predomínio do carbono inorgânico, Tabela 5.35. A alta concentração de material em suspensão orgânico nesse ponto, era esperada, visto que é uma região com alta densidade de macrófitas e a coleta foi feita em estação cujo tempo de residência também é elevado.

A comparação entre os valores de material em suspensão e carbono total ficou prejudicada pela filtração das amostras para análise em aparelho COT. No caso dessas duas estações, o valor de carbono orgânico pode estar subestimado devido ao procedimento analítico, visto que foram analisados somente os teores de carbono orgânico dissolvido.

Tabela 5.32 - Ficha de bordo: parâmetros físico-químicos medidos na estação 2, na campanha de Junho/98

Estação 2

Horário da coleta: 8:35 h

\begin{tabular}{c|c|c|c|c|c}
\hline $\begin{array}{c}\text { Profundidades } \\
(\mathrm{m})\end{array}$ & $\begin{array}{c}\text { Valores } \\
\mathrm{de} \mathrm{pH}\end{array}$ & $\begin{array}{c}\text { Condutividade } \\
(\mu \mathrm{S} / \mathrm{cm})\end{array}$ & $\begin{array}{c}\text { Valores de } \\
\text { turbidez }(\mathrm{uT})\end{array}$ & $\begin{array}{c}\text { Valores de Oxigênio } \\
\text { dissolvido }(\mathrm{mg} / \mathrm{L})\end{array}$ & $\begin{array}{c}\text { Temperaturas } \\
\left({ }^{0} \mathrm{C}\right)\end{array}$ \\
\hline 0,00 & 6,83 & 106,00 & 3,08 & 3,08 & 17,8 \\
\hline 0,50 & 6,83 & 106,00 & 4,00 & 2,89 & 17,7 \\
\hline 1,00 & 6,82 & 104,00 & 3,00 & 2,99 & 17,7 \\
\hline 1,50 & 6,81 & 104,00 & 3,00 & 3,09 & 17,7 \\
\hline 2,00 & 6,79 & 104,00 & 3,00 & 3,33 & 17,7 \\
\hline 2,20 & 6,76 & 106,00 & 6,00 & 3,18 & 17,7 \\
\hline
\end{tabular}


Tabela 5.33 - Ficha de bordo: parâmetros físico-químicos medidos na estação 4, na campanha de Junho/98

\begin{tabular}{|c|c|c|c|c|c|}
\hline \multicolumn{6}{|c|}{$\begin{array}{c}\text { Estação } 4 \\
\text { Horário da coleta: 9:15 h }\end{array}$} \\
\hline $\begin{array}{l}\text { Profundidades } \\
\text { (m) }\end{array}$ & $\begin{array}{l}\text { Valores } \\
\text { de } \mathrm{pH}\end{array}$ & $\begin{array}{l}\text { Condutividade } \\
(\mu \mathrm{S} / \mathrm{cm})\end{array}$ & $\begin{array}{l}\text { Valores de } \\
\text { turbidez (uT) }\end{array}$ & $\begin{array}{l}\text { Valores de Oxigênio } \\
\text { dissolvido (mg/L) }\end{array}$ & $\begin{array}{c}\text { Temperatura } \\
\mathrm{S}\left({ }^{\circ} \mathrm{C}\right)\end{array}$ \\
\hline 0,00 & 6,65 & 100,00 & 0,00 & 2,70 & 19,00 \\
\hline 0,50 & 6,61 & 101,00 & 1,00 & 2,79 & 19,00 \\
\hline 1,00 & 6,57 & 100,00 & 0,00 & 2,75 & 19,00 \\
\hline 1,50 & 6,53 & 100,00 & 0,00 & 2,70 & 19,00 \\
\hline 2,00 & 6,50 & 99,00 & 0,00 & 2,69 & 19,00 \\
\hline 2,50 & 6,48 & 98,00 & 0,00 & 2,63 & 19,00 \\
\hline 3,00 & 6,46 & 99,00 & 0,00 & 2,60 & 19,00 \\
\hline 3,50 & 6,45 & 99,00 & 0,00 & 2,61 & 19,00 \\
\hline 4,00 & 6,42 & 100,00 & 1,00 & 2,60 & 19,00 \\
\hline 4,50 & 6,42 & 101,00 & 0,00 & 2,56 & 19,00 \\
\hline 5,00 & 6,39 & 101,00 & 0,00 & 2,51 & 19,00 \\
\hline 5,50 & 6,38 & 100,00 & 0,00 & 2,56 & 19,00 \\
\hline 6,00 & 6,37 & 99,00 & 0,00 & 2,52 & 19,00 \\
\hline 6,50 & 6,36 & 99,00 & 0,00 & 2,51 & 19,00 \\
\hline 7,00 & 6,33 & 102,00 & 0,00 & 2,48 & 19,00 \\
\hline 7,50 & 6,30 & 101,00 & 0,00 & 2,50 & 19,00 \\
\hline 8,00 & 6,29 & 100,00 & 1,00 & 2,55 & 19,00 \\
\hline 8,50 & 6,27 & 106,00 & 0,00 & 2,50 & 19,00 \\
\hline 9,00 & 6,25 & 101,00 & 0,00 & 2,51 & 19,00 \\
\hline 9,50 & 6,22 & 104,00 & 0,00 & 2,53 & 19,00 \\
\hline 10,00 & 6,21 & 103,00 & 0,00 & 2,59 & 19,00 \\
\hline 10,50 & 6,19 & 105,00 & 0,00 & 2,66 & 19,00 \\
\hline 11,00 & 6,16 & 107,00 & 0,00 & 2,63 & 19,00 \\
\hline 11,50 & 6,09 & 106,00 & 1,00 & 2,18 & 19,00 \\
\hline 12,00 & 6,06 & 108,00 & 0,00 & 2,04 & 19,00 \\
\hline 12,50 & 6,01 & 118,00 & 1,00 & 1,72 & 19,00 \\
\hline 13,00 & 5,95 & 105,00 & 1,00 & 1,57 & 18,90 \\
\hline 13,50 & 5,94 & 175,00 & 0,00 & 1,23 & 18,90 \\
\hline 14,00 & 5,91 & 194,00 & 1,00 & 0,70 & 18,80 \\
\hline 14,50 & 5,90 & 198,00 & 0,00 & 0,38 & 18,80 \\
\hline 14,80 & 5,90 & 201,00 & 1,00 & 0,16 & 18,80 \\
\hline
\end{tabular}

Tabela 5.34 - Resultados das análises de Material em Suspensão Total e das frações orgânicas e inorgânicas das amostras de água da campanha de Junho/98

\begin{tabular}{c|c|c|c}
\hline Estações & MST (mg/L) & MSO (mg/L) & MSI (mg/L) \\
\hline 2 & 6,36 & 0,91 & 5,45 \\
\hline 4 & 9,00 & 7,00 & 2,00 \\
\hline
\end{tabular}


Tabela 5.35 - Resultados das análises de Carbono total e das frações orgânicas e inorgânicas das amostras de água da campanha de Junho/98

\begin{tabular}{c|c|c|c}
\hline Estação & CT (mg/L) & COT (mg/L) & CI (mg/L) \\
\hline 2 & 7,77 & 2,18 & 5,60 \\
\hline 4 & 4,88 & 2,17 & 2,71 \\
\hline
\end{tabular}

c) Novembro

Na campanha de Novembro foram feitas 4 coletas, sendo coletadas amostras de água e sedimento em todas as estações. Os valores das medições das variáveis físico-químicas nas amostras de águas, feitas em campo, estão apresentados nas Tabelas 5.36 a 5.39.

Os valores de pH variaram de 6,00 a 6,75 nas 4 estações, porém, no início da coluna d'água da estação 3 , até a profundidade de 1,50 m, esses valores encontravam-se elevados, apresentando valores próximos a 8,00, os maiores valores de $\mathrm{pH}$ encontrados nas amostras d'água de todas as campanhas. Esses altos valores de $\mathrm{pH}$ e as altas concentrações de oxigênio dissolvido na superfície da água, podem ser explicados, pela alta taxa de radiação encontrada nessa campanha e conseqüentemente, imensa atividade fotossintética das algas presentes em toda a extensão do reservatório, principalmente no terceiro compartimento. Isto porque, a comunidade fitoplanctônica afeta diretamente os teores de oxigênio dissolvido e pH da superfície, elevando os valores em direção à região lacustre.

As taxas de oxigênio dissolvido foram baixas nas 4 estações. Na estação 1 houve pequena variação, apresentando um valor mínimo de $2,89 \mathrm{mg} / \mathrm{L}(0,50 \mathrm{~m})$ e um valor máximo de 3,33 mg/L (2,00 m), em uma coluna d'água de 2,0 m. Na estação 2 também houve pequena variação, de 0,39 (superfície) a 0,03 (final da coluna d'água; 2,40 m). Na estação 3, houve grande variação das concentrações de oxigênio dissolvido na coluna d'água, sendo que nos primeiros metros da coluna os valores estavam em torno de $10,0 \mathrm{mg} / \mathrm{L}$, atingindo 0,0 $\mathrm{mg} / \mathrm{L}$ a partir de uma profundidade de 5,50 m. Pode-se supor que a atividade fotossintética na superfície seja responsável por essa condição, e a decomposição da matéria orgânica no fundo, e em se tratando de região lacustre pela condição mais reduzida. Para a estação 4, os valores de oxigênio dissolvido foram reduzidos, variando de $0,43(8 \mathrm{~m})$ a $3,96(0,50 \mathrm{~m})$, sendo que na parte intermediária da coluna, de 6 a $10 \mathrm{~m}$, foram apresentados os menores valores. A coluna de água desta estação era de 17,50 m.

Outra possível explicação para esses baixos valores de oxigênio dissolvido nas duas primeiras estações, observados nessa campanha é o volume reduzido de água observado nesse período no rio Atibaia e na entrada do reservatório, justificado pela baixa precipitação e elevadas temperaturas e radiação, como pode ser observado nas Tabelas 5.26, 5.27 e 5.24, 
respectivamente. Essa visível diminuição do volume da água aliada a altas temperaturas e concentração de matéria orgânica, segundo ESTEVES (1988) contribui bastante para o grau de desoxigenação das águas.

A condutividade foi praticamente a mesma na estação 1 e 2, variando de 314 a 316 $\mu \mathrm{S} / \mathrm{cm}$. Nas demais estações o valor encontrado variou em uma faixa de 211 a 263 para a estação 3 e de 199 a $218 \mu \mathrm{S} / \mathrm{cm}$ para a estação 4 . Esses valores encontrados são considerados altos e podem ser atribuídos a diversos fatores, dentre eles, merecem destaque o elevado número de algas, o baixo volume de água observado nesta campanha e a ausência de chuvas.

A temperatura entre as estações variou de 22,2 a $27,6^{\circ} \mathrm{C}$, com estratificação na terceira e quarta estações, com variação de 5,4 e $3,4{ }^{0} \mathrm{C}$, respectivamente. Essa estratificação é atribuída a vários fatores, dentre eles, o menor fluxo d'água e as temperaturas mais elevadas na superfície.

Tabela 5.36 - Ficha de bordo: parâmetros físico-químicos medidos na estação 1, na campanha de Novembro/98

\begin{tabular}{c|c|c|c|c|c}
\hline \multicolumn{7}{c}{ Horário da coleta: 10:40 h. } \\
\hline $\begin{array}{c}\text { Profundidades } \\
(\mathrm{m})\end{array}$ & $\begin{array}{c}\text { Valores } \\
\text { de } \mathrm{pH}\end{array}$ & $\begin{array}{c}\text { Valores de } \\
\text { Condutividade } \\
(\mu \mathrm{S} / \mathrm{cm})\end{array}$ & $\begin{array}{c}\text { Valores de } \\
\text { turbidez }(\mathrm{uT})\end{array}$ & $\begin{array}{c}\text { Valores de } \\
\text { Oxigênio dissolvido } \\
(\mathrm{mg} / \mathrm{L})\end{array}$ & $\begin{array}{c}\text { Temperaturas } \\
\left({ }^{0} \mathrm{C}\right)\end{array}$ \\
\hline 0,00 & 6,23 & 316,00 & 3,08 & 3,08 & 24,80 \\
\hline 0,50 & 6,33 & 316,00 & 4,00 & 2,89 & 24,70 \\
\hline 1,00 & 6,22 & 314,00 & 3,50 & 2,99 & 24,70 \\
\hline 1,50 & 6,21 & 314,00 & 3,50 & 3,09 & 24,70 \\
\hline 2,00 & 6,19 & 314,00 & 3,50 & 3,33 & 24,70 \\
\hline
\end{tabular}

Tabela 5.37 - Ficha de bordo: parâmetros físico-químicos medidos na estação 2, na campanha de Novembro/98

\begin{tabular}{c|c|c|c|c|c}
\hline \multicolumn{7}{c}{ Horário da coleta: 11:00 h. } \\
\hline $\begin{array}{c}\text { Profundidades } \\
(\mathrm{m})\end{array}$ & $\begin{array}{c}\text { Valores } \\
\text { de pH }\end{array}$ & $\begin{array}{c}\text { Condutividade } \\
(\mu \mathrm{S} / \mathrm{cm})\end{array}$ & $\begin{array}{c}\text { Valores de } \\
\text { turbidez }(\mathrm{uT})\end{array}$ & $\begin{array}{c}\text { Valores de } \\
\text { Oxigênio dissolvido } \\
(\mathrm{mg} / \mathrm{L})\end{array}$ & $\begin{array}{c}\text { Temperatura } \\
\left({ }^{0} \mathrm{C}\right)\end{array}$ \\
\hline 0,00 & 6,28 & 314,00 & 4,00 & 0,39 & 24,30 \\
\hline 0,50 & 6,23 & 314,00 & 4,00 & 0,35 & 24,00 \\
\hline 1,00 & 6,22 & 315,00 & 4,00 & 0,32 & 24,00 \\
\hline 1,50 & 6,24 & 315,00 & 4,00 & 0,03 & 23,90 \\
\hline 2,00 & 6,21 & 315,00 & 4,00 & 0,08 & 23,80 \\
\hline 2,40 & 6,23 & 314,00 & 185,00 & 0,03 & 23,80 \\
\hline
\end{tabular}

Observação: o alto valor encontrado para a turbidez a $2,40 \mathrm{~m}$ deve-se, provavelmente a ressuspensão de material. 
Tabela 5.38 - Ficha de bordo: parâmetros físico-químicos medidos na estação 3, na campanha de Novembro/98

Estação 3

Horário da coleta: 11:35 h.

\begin{tabular}{c|c|c|c|c|c}
\hline $\begin{array}{c}\text { Profundidades } \\
(\mathrm{m})\end{array}$ & $\begin{array}{c}\text { Valores } \\
\text { de } \mathrm{pH}\end{array}$ & $\begin{array}{c}\text { Valores de } \\
\text { condutividade } \\
(\mu \mathrm{S} / \mathrm{cm})\end{array}$ & $\begin{array}{c}\text { Valores de } \\
\text { turbidez }(\mathrm{uT})\end{array}$ & $\begin{array}{c}\text { Valores de } \\
\text { Oxigênio dissolvido } \\
(\mathrm{mg} / \mathrm{L})\end{array}$ & $\begin{array}{c}\text { Temperaturas } \\
\left({ }^{0} \mathrm{C}\right)\end{array}$ \\
\hline 0,00 & 8,12 & 234,00 & -- & 12,07 & 27,60 \\
\hline 0,50 & 8,12 & 234,00 & -- & 11,79 & 26,00 \\
\hline 1,00 & 7,92 & 229,00 & -- & 10,77 & 25,70 \\
\hline 1,50 & 7,78 & 230,00 & -- & 10,63 & 25,10 \\
\hline 2,00 & 6,44 & 260,00 & -- & 4,68 & 24,00 \\
\hline 2,50 & 6,42 & 263,00 & -- & 1,42 & 23,70 \\
\hline 3,00 & 6,28 & 242,00 & -- & 1,46 & 23,70 \\
\hline 3,50 & 6,19 & 245,00 & -- & 1,48 & 23,00 \\
\hline 4,00 & 6,15 & 213,00 & -- & 0,45 & 22,80 \\
\hline 4,50 & 6,11 & 211,00 & -- & 0,75 & 22,60 \\
\hline 5,00 & 6,11 & 211,00 & -- & 0,70 & 22,60 \\
\hline 5,50 & 6,03 & 212,00 & -- & 0,00 & 22,40 \\
\hline 6,00 & 6,02 & 213,00 & -- & 0,00 & 22,40 \\
\hline 6,50 & 6,02 & 214,00 & -- & 0,00 & 22,30 \\
\hline 7,00 & 6,01 & 227,00 & -- & 0,00 & 22,30 \\
\hline 7,50 & 6,01 & 215,00 & -- & 0,00 & 22,30 \\
\hline 8,00 & 6,01 & 214,00 & -- & 0,00 & 22,30 \\
\hline 8,10 & 6,00 & 255,00 & -- & 0,00 & 22,20 \\
\hline
\end{tabular}

Analisando-se os valores da matéria em suspensão total e suas frações, Tabela 5.40, observa-se o predomínio de material inorgânico nas estações 1 e 2 . Nas estações 1 e 2, podese inferir, como anteriormente comentado, que seus elevados valores de material inorgânico sejam conseqüência da influência de aportes do rio Atibaia.

$\mathrm{Na}$ estação 3 predominou o material orgânico, resultado já esperado, devido à presença de macrófitas e algas nesse compartimento.

$\mathrm{Na}$ estação 4, o material orgânico foi predominante apenas na parte superior, entretanto, as diferenças encontradas na parte intermediária e no fundo, não são consideradas significativas.

As concentrações de carbono orgânico dissolvido foram maiores na grande maioria das estações, devidas à alta atividade do fitoplâncton e das macrófitas aquáticas, excretandoo, através do metabolismo celular. Além disso, essa alta concentração de carbono orgânico dissolvido já era esperada, pela concentração significativa de algas e também e pela presença de macrófitas em grande quantidade (Tabela 5.41). 
Tabela 5.39 - Ficha de bordo: parâmetros físico-químicos medidos na estação 4, na campanha de Novembro/98.

\begin{tabular}{c|c|c|c|c|c}
\hline \multicolumn{7}{c}{ Horário da coleta: 12:45 h. } \\
\hline $\begin{array}{c}\text { Profundidades } \\
(\mathrm{m})\end{array}$ & $\begin{array}{c}\text { Valores } \\
\text { de pH }\end{array}$ & $\begin{array}{c}\text { Valores de } \\
\text { Condutividade } \\
(\mu \mathrm{S} / \mathrm{cm})\end{array}$ & $\begin{array}{c}\text { Valores de } \\
\text { turbidez (uT) }\end{array}$ & $\begin{array}{c}\text { Valores de } \\
\text { Oxigênio dissolvido } \\
(\mathrm{mg} / \mathrm{L})\end{array}$ & $\begin{array}{c}\text { Temperatura } \\
\left({ }^{\circ} \mathrm{C}\right)\end{array}$ \\
\hline 0,00 & 6,75 & 201,00 & 2,00 & 3,64 & 25,30 \\
\hline 0,50 & 6,75 & 200,00 & 2,00 & 3,96 & 25,60 \\
\hline 1,00 & 6,76 & 200,00 & 2,00 & 3,92 & 24,70 \\
\hline 1,50 & 6,70 & 200,00 & 3,00 & 3,25 & 24,20 \\
\hline 2,00 & 6,70 & 200,00 & 1,00 & 2,10 & 23,90 \\
\hline 2,50 & 6,65 & 200,00 & 2,00 & 1,47 & 23,70 \\
\hline 3,00 & 6,68 & 200,00 & 2,00 & 1,68 & 23,50 \\
\hline 3,50 & 6,64 & 200,00 & 2,00 & 1,90 & 23,00 \\
\hline 4,00 & 6,61 & 199,00 & 3,00 & 1,54 & 22,90 \\
\hline 4,50 & 6,58 & 199,00 & 3,00 & 1,54 & 22,80 \\
\hline 5,00 & 6,55 & 200,00 & 3,00 & 1,32 & 22,80 \\
\hline 5,50 & 6,54 & 200,00 & 3,00 & 1,30 & 22,70 \\
\hline 6,00 & 6,54 & 200,00 & 3,00 & 0,84 & 22,70 \\
\hline 6,50 & 6,67 & 200,00 & 3,00 & 0,80 & 22,70 \\
\hline 7,00 & 6,41 & 199,00 & 3,00 & 0,98 & 22,60 \\
\hline 7,50 & 6,41 & 201,00 & 3,00 & 0,99 & 22,60 \\
\hline 8,00 & 6,41 & 201,00 & 3,00 & 0,43 & 22,60 \\
\hline 8,50 & 6,33 & 201,00 & 3,00 & 0,13 & 22,60 \\
\hline 9,00 & 6,32 & 201,00 & 3,00 & 0,14 & 22,60 \\
\hline 9,50 & 6,30 & 201,00 & 3,00 & 0,04 & 22,50 \\
\hline 10,00 & 6,22 & 201,00 & 3,00 & 0,81 & 22,50 \\
\hline 10,50 & 6,21 & 201,00 & 2,00 & 1,33 & 22,50 \\
\hline 11,00 & 6,17 & 202,00 & 2,00 & 1,60 & 22,50 \\
\hline 11,50 & 6,14 & 202,00 & 2,00 & 1,65 & 22,50 \\
\hline 12,00 & 6,13 & 203,00 & 2,00 & 1,71 & 22,50 \\
\hline 12,50 & 6,15 & 202,00 & 2,00 & 1,85 & 22,50 \\
\hline 13,00 & 6,14 & 202,00 & 2,00 & 1,85 & 22,50 \\
\hline 13,50 & 6,14 & 206,00 & 2,00 & 2,10 & 22,50 \\
\hline 14,00 & 6,16 & 207,00 & 2,00 & 2,11 & 22,50 \\
\hline 14,50 & 6,16 & 207,00 & 2,00 & 2,12 & 22,40 \\
\hline 15,00 & 6,17 & 207,00 & 2,00 & 2,13 & 22,40 \\
\hline 15,50 & 6,17 & 209,00 & 2,00 & 2,14 & 22,30 \\
\hline 16,00 & 6,19 & 209,00 & 2,00 & 2,14 & 22,40 \\
\hline 16,50 & 6,19 & 211,00 & 2,00 & 2,14 & 22,40 \\
\hline 17,00 & 6,17 & 215,00 & 2,00 & 2,14 & 22,30 \\
\hline 17,50 & 6,17 & 218,00 & 2,00 & 2,15 & 22,20 \\
\hline & & & & & \\
\hline
\end{tabular}


Tabela 5.40 - Resultados das análises de material em suspensão total e das frações orgânicas e inorgânicas das amostras de água da campanha de Novembro/98

\begin{tabular}{l|c|c|c}
\hline \multicolumn{1}{c|}{ Estações } & MST (mg/L) & MSO (mg/L) & MSI (mg/L) \\
\hline 1 & 12,40 & 4,90 & 7,50 \\
\hline 2 & 16,30 & 5,50 & 10,80 \\
\hline 3 (superior) & 12,80 & 11,20 & 2,67 \\
\hline 3 (intermediário) & 13,20 & 10,10 & 3,10 \\
\hline 3 (fundo) & 6,30 & 4,30 & 2,00 \\
\hline 4 (superior) & 5,70 & 4,90 & 0,80 \\
\hline 4 (intermediário) & 7,30 & 3,50 & 3,80 \\
\hline 4 (fundo) & 5,30 & 2,50 & 2,80 \\
\hline
\end{tabular}

Tabela 5.41 - Resultados das análises de carbono total e das frações orgânicas $e$ inorgânicas das amostras de água da campanha de Novembro/98

\begin{tabular}{l|c|c|c}
\hline \multicolumn{1}{c|}{ Estação } & CT (mg/L) & COT $\mathbf{m g} / \mathbf{L})$ & CI $\mathbf{( m g / L )}$ \\
\hline 1 & 8,99 & 5,29 & 3,70 \\
\hline 2 & 8,28 & 4,19 & 4,09 \\
\hline 3 (superior) & 13,60 & 7,92 & 5,67 \\
\hline 3 (intermediário) & 11,03 & 6,04 & 4,99 \\
\hline 3 (fundo) & 9,87 & 4,97 & 4,90 \\
\hline $4 \mathrm{~s}$ & 10,17 & 5,08 & 5,09 \\
\hline $4 \mathrm{i}$ & 10,39 & 5,29 & 5,10 \\
\hline $4 \mathrm{f}$ & 9,56 & 4,65 & 4,99 \\
\hline
\end{tabular}

Nas amostras de sedimento foram analisados o teor de carbono orgânico total (Tabela 5.42), assim como os teores de umidade a 60 e $110^{\circ} \mathrm{C}$ (Tabela 5.43). Os valores da concentração de carbono total foram considerados baixos quando comparados aos encontrados por PATELLA (1998) no sedimento do reservatório de Guarapiranga, também eutrofizado, correspondendo aproximadamente ao dobro dos valores determinados para Salto Grande.

ESTEVES \& CAMARGO (1982), em trabalho de caracterização de sedimentos de 17 reservatórios no estado de São Paulo, inclusive Salto Grande, classificaram os mesmos como sendo do tipo mineral. Nesses reservatórios o maior valor encontrado de carbono total foi $6,83 \mathrm{mg} / \mathrm{L}$ e o menor 1,28 $\mathrm{mg} / \mathrm{L}$.

A umidade total dos sedimentos é equiparável aos valores encontrados por AIROLDI (1997) em solos de trincheira de São Vicente (SP), sendo dessa forma, considerados relativamente baixos 
Tabela 5.42 e 5.43 - Resultados das análises de Carbono total e Umidade Total a temperaturas de $60^{\circ} \mathrm{C} e 110^{\circ} \mathrm{C}$, das amostras de sedimento da campanha de Novembro/98

\begin{tabular}{c|c}
\hline Estação & COT (mg/L) \\
\hline 1 & 2,30 \\
\hline 2 & 1,39 \\
\hline 3 & 0,72 \\
\hline 4 & 4,74 \\
\hline
\end{tabular}

\begin{tabular}{c|c|c|c}
\hline Estação & $\mathbf{U}_{\mathbf{6 0}}(\boldsymbol{\%})$ & $\mathbf{U}_{\mathbf{1 1 0}}(\boldsymbol{\%})$ & $\mathbf{U T}(\boldsymbol{\%})$ \\
\hline 1 & 41,78 & 11,37 & 53,15 \\
\hline 2 & 35,89 & 12,45 & 48,34 \\
\hline 3 & 47,23 & 9,69 & 56,92 \\
\hline 4 & 38,49 & 12,23 & 50,72 \\
\hline
\end{tabular}

d) Fevereiro

Na campanha de Fevereiro foram feitas coletas de água e sedimento em todas as estações (1, 2, 3 e 4). Nessa campanha, não houve diferenças consideráveis entre as estações, exceto para as concentrações de oxigênio dissolvido (Tabelas 5.44, 5.45, 5.46 a 5.47).

Tabela 5.44 - Ficha de bordo: parâmetros físico-químicos medidos na estação 1, na campanha de Fevereiro/99

\section{Estação 1}

Horário da coleta: 11:25

\begin{tabular}{c|c|c|c|c|c}
\hline $\begin{array}{c}\text { Profundidades } \\
(\mathrm{m})\end{array}$ & $\begin{array}{c}\text { Valores } \\
\text { de } \mathrm{pH}\end{array}$ & $\begin{array}{c}\text { Valores de } \\
\text { Condutividade } \\
(\mu \mathrm{S} / \mathrm{cm})\end{array}$ & $\begin{array}{c}\text { Valores de } \\
\text { turbidez (uT) }\end{array}$ & $\begin{array}{c}\text { Valores de } \\
\text { Oxigênio dissolvido } \\
(\mathrm{mg} / \mathrm{L})\end{array}$ & $\begin{array}{c}\text { Temperaturas } \\
\left({ }^{0} \mathrm{C}\right)\end{array}$ \\
\hline 0,00 & 6,44 & 94,00 & 38 & 6,27 & 24,7 \\
\hline 0,50 & 6,43 & 94,00 & 38 & 6,65 & 24,7 \\
\hline 1,00 & 6,41 & 97,00 & 38 & 6,15 & 24,6 \\
\hline 1,50 & 6,43 & 98,00 & 38 & 6,47 & 24,6 \\
\hline 2,00 & 6,41 & 98,00 & 39 & 6,50 & 24,6 \\
\hline
\end{tabular}

Tabela 5.45 - Ficha de bordo: parâmetros físico-químicos medidos na estação 2, na campanha de Fevereiro/99

\begin{tabular}{c|c|c|c|c|c}
\hline \multicolumn{7}{c}{ Horário da coleta: 12:00 } \\
\hline $\begin{array}{c}\text { Profundidades } \\
(\mathrm{m})\end{array}$ & $\begin{array}{c}\text { Valores } \\
\text { de pH }\end{array}$ & $\begin{array}{c}\text { Valores de } \\
\text { condutividade } \\
(\mu \mathrm{S} / \mathrm{cm})\end{array}$ & $\begin{array}{c}\text { Valores de } \\
\text { turbidez }(\mathrm{uT})\end{array}$ & $\begin{array}{c}\text { Valores de } \\
\text { Oxigênio dissolvido } \\
(\mathrm{mg} / \mathrm{L})\end{array}$ & $\begin{array}{c}\text { Temperaturas } \\
\left({ }^{0} \mathrm{C}\right)\end{array}$ \\
\hline 0,00 & 6,65 & 94,00 & 53 & 5,94 & 25,0 \\
\hline 0,50 & 6,51 & 94,00 & 58 & 5,64 & 25,0 \\
\hline 1,00 & 6,33 & 94,00 & 56 & 5,80 & 24,9 \\
\hline
\end{tabular}


Tabela 5.46 - Ficha de bordo: parâmetros físico-químicos medidos na estação 3, na campanha de Fevereiro/99

\begin{tabular}{c|c|c|c|c|c}
\hline \multicolumn{7}{c}{ Horário da coleta: 12:45 } \\
\hline $\begin{array}{c}\text { Profundidades } \\
(\mathrm{m})\end{array}$ & $\begin{array}{c}\text { Valores } \\
\text { de pH }\end{array}$ & $\begin{array}{c}\text { Valores de } \\
\text { condutividade } \\
(\mu \mathrm{S} / \mathrm{cm})\end{array}$ & $\begin{array}{c}\text { Valores de } \\
\text { turbidez }(\mathrm{uT})\end{array}$ & $\begin{array}{c}\text { Valores de } \\
\text { Oxigênio dissolvido } \\
(\mathrm{mg} / \mathrm{L})\end{array}$ & $\begin{array}{c}\text { Temperaturas } \\
\left({ }^{0} \mathrm{C}\right)\end{array}$ \\
\hline 0,00 & 6,44 & 72,00 & -- & 3,07 & 26,6 \\
\hline 0,50 & 6,31 & 104,00 & -- & 2,90 & 26,6 \\
\hline 1,00 & 6,41 & 104,00 & -- & 2,75 & 26,4 \\
\hline 1,50 & 6,16 & 104,00 & -- & 3,39 & 26,1 \\
\hline 2,00 & 6,16 & 104,00 & -- & 2,17 & 25,8 \\
\hline 2,50 & 6,12 & 73,00 & -- & 2,36 & 25,6 \\
\hline 3,00 & 6,15 & 103,00 & -- & 2,48 & 25,5 \\
\hline 3,50 & 6,09 & 102,00 & -- & 2,61 & 25,4 \\
\hline 4,00 & 6,09 & 101,00 & -- & 3,00 & 25,4 \\
\hline 4,50 & 6,09 & 101,00 & -- & 3,21 & 25,4 \\
\hline 5,00 & 6,09 & 100,00 & -- & 3,46 & 25,4 \\
\hline 5,50 & 6,09 & 99,00 & -- & 3,49 & 25,3 \\
\hline 6,00 & 6,08 & 100,00 & -- & 3,58 & 25,3 \\
\hline 6,50 & 5,99 & 81,00 & -- & 3,23 & 25,3 \\
\hline 7,00 & 6,05 & 99,00 & -- & 3,17 & 25,2 \\
\hline 7,50 & 6,02 & 101,00 & -- & 2,15 & 25,2 \\
\hline 8,00 & 5,99 & 105,00 & -- & 1,30 & 25,2 \\
\hline 8,50 & 5,98 & 106,00 & -- & 0,92 & 25,1 \\
\hline 9,00 & 5,98 & 103,00 & -- & 1,78 & 25,1 \\
\hline 9,50 & 6,01 & 101,00 & -- & 2,25 & 25,0 \\
\hline 10,00 & 6,02 & 99,00 & -- & 2,06 & 24,9 \\
\hline & & & & &
\end{tabular}

Tabela 5.47 - Ficha de bordo: parâmetros físico-químicos medidos na estação 4, na campanha de Fevereiro/99

\begin{tabular}{c|c|c|c|c|c}
\hline \multicolumn{7}{c}{ Horário da coleta: 13:35 } \\
\hline $\begin{array}{c}\text { Profundidades } \\
(\mathrm{m})\end{array}$ & $\begin{array}{c}\text { Valores } \\
\text { de pH }\end{array}$ & $\begin{array}{c}\text { Valores de } \\
\text { Condutividade } \\
(\mu \mathrm{S} / \mathrm{cm})\end{array}$ & $\begin{array}{c}\text { Valores de } \\
\text { turbidez }(\mathrm{uT})\end{array}$ & $\begin{array}{c}\text { Valores de } \\
\text { Oxigênio dissolvido } \\
(\mathrm{mg} / \mathrm{L})\end{array}$ & $\begin{array}{c}\text { Temperaturas } \\
\left({ }^{0} \mathrm{C}\right)\end{array}$ \\
\hline 0,00 & 6,52 & 93,00 & -- & 4,80 & 27,7 \\
\hline 0,50 & -- & -- & -- & -- & -- \\
\hline 1,00 & -- & -- & -- & -- & -- \\
\hline 1,50 & 6,12 & 96,00 & -- & 3,13 & 26,6 \\
\hline 2,00 & -- & -- & -- & -- & -- \\
\hline 2,50 & 6,21 & 99,00 & -- & 2,19 & 26,2 \\
\hline 3,00 & 5,93 & 98,00 & -- & 1,81 & 26,3 \\
\hline 3,50 & -- & -- & -- & -- & -- \\
\hline 4,00 & -- & -- & -- & -- & -- \\
\hline 4,50 & 5,92 & 98,00 & -- & 1,69 & 26,3 \\
\hline 5,00 & 5,98 & 100,00 & -- & 1,15 & 26,1 \\
\hline
\end{tabular}


$\mathrm{O}$ pH entre as estações variou de 5,92 a 6,65; a condutividade de 94 a $104 \mu \mathrm{S} / \mathrm{cm}$ e a temperatura de 24,6 a $27,7^{\circ} \mathrm{C}$.

A única diferença significativa entre as estações foi a variação do oxigênio dissolvido. Nas duas primeiras estações, os valores variaram de 5,64 a 6,65 mg/L, enquanto que, nas duas últimas, os valores chegaram a variar de 3,07 a 0,92 mg/L na estação 3 e de 4,80 a 1,15 na estação 4. Essa redução da concentração de oxigênio pode ser explicada pela elevada precipitação nessa campanha, visto que, a elevada concentração de material em suspensão inorgânico causa um sombreamento para as algas, ou seja, falta radiação para a realização da fotossíntese, causando menor produção de oxigênio. Outros fatores que podem explicar o consumo de oxigênio dissolvido no verão são o aumento na concentração de sólidos em suspensão e, conseqüentemente, a presença de bactérias adsorvidas, e também o aumento da temperatura, aumentando a atividade bacteriana e, conseqüentemente, aumentando a taxa de decomposição, levando a um maior consumo de oxigênio.

A taxa de material em suspensão foi bastante elevada na primeira e na segunda estação, sendo que em todas as estações houve predomínio de material inorgânico (Tabela 5.48). Esse grande aporte de inorgânicos no reservatório foi devido à elevada precipitação nessa campanha, que apresentou uma média de 198,3 mm, como visto na Tabela 5.26. Os rios que abastecem o reservatório não têm proteção de matas ciliares, permitindo que com as chuvas, bastante material seja carreado para suas águas. O mesmo problema acontece no reservatório, onde podem ser vistas plantações de cana-de-açúcar adentrando suas margens.

Como esperado, pela baixa taxa de residência das águas, houve predomínio também do carbono inorgânico (Tabela 5.49).

Tabela 5.48 - Resultados das análises de material em suspensão total e das frações orgânicas e inorgânicas das amostras de água da campanha de Fevereiro/99

\begin{tabular}{c|c|c|c}
\hline Estações & MST & MSO & MSI \\
\hline 1 & 114,00 & 10,00 & 104,00 \\
\hline 2 & 213,00 & 43,00 & 170,00 \\
\hline 3 & 47,25 & 13,75 & 33,50 \\
\hline $4(0 \mathrm{~m})$ & 17,80 & 5,10 & 12,70 \\
\hline $4(2,5 \mathrm{~m})$ & 14,50 & 3,90 & 10,60 \\
\hline $4(5 \mathrm{~m})$ & 13,70 & 3,90 & 9,80 \\
\hline
\end{tabular}


Tabela 5.49 - Resultados das análises de Carbono total e das frações orgânicas e inorgânicas das amostras de água da campanha de Fevereiro/99

\begin{tabular}{c|c|c|c}
\hline Estação & CT $(\mathbf{m g} / \mathbf{L})$ & $\mathbf{C O}(\mathbf{m g} / \mathbf{L})$ & $\mathbf{C I} \mathbf{~ m g / L )}$ \\
\hline 1 & 8,22 & 2,48 & 5,74 \\
\hline 2 & 9,51 & 3,10 & 6,41 \\
\hline 3 & 8,76 & 2,72 & 6,04 \\
\hline $4(0 \mathrm{~m})$ & 8,69 & 2,77 & 5,92 \\
\hline $4(2,5 \mathrm{~m})$ & 8,20 & 2,36 & 5,83 \\
\hline $4(5 \mathrm{~m})$ & 8,26 & 2,41 & 5,85 \\
\hline
\end{tabular}

Nas amostras de sedimento foram analisados os teores de carbono total (Tabela 5.50) e também o teor de umidade a 60 e $105^{\circ} \mathrm{C}$ (Tabela 5.51). Os valores encontrados para CT em Fevereiro, quando comparados aos valores encontrados na campanha de Novembro, foram considerados equivalentes para as estações 1 e 3 e sofreram decréscimo em torno de $1 \mathrm{mg} / \mathrm{L}$ para as estações 2 e 4.

Em relação aos valores de umidade para as estações 2, 3 e 4, esses sofreram acréscimo na campanha de Fevereiro.

Tabela 5.50 e 5.51 - Resultados das análises de Carbono total e Umidade Total $\left(60^{\circ} \mathrm{C}\right.$ e $110^{\circ} \mathrm{C}$ ) das amostras de sedimento da campanha de Fevereiro/98

\begin{tabular}{|c|c|c|c|}
\hline \multicolumn{2}{|c|}{ Estação } & \multicolumn{2}{|c|}{ CT (mg/L) } \\
\hline \multicolumn{2}{|c|}{1} & \multicolumn{2}{|c|}{2,07} \\
\hline \multicolumn{2}{|c|}{2} & \multicolumn{2}{|c|}{0,57} \\
\hline \multicolumn{2}{|c|}{3} & \multicolumn{2}{|c|}{0,62} \\
\hline \multicolumn{2}{|c|}{4} & \multicolumn{2}{|c|}{3,64} \\
\hline Estação & $\mathrm{U}_{60}(\%)$ & $\mathrm{U}_{110}(\%)$ & UT $(\%)$ \\
\hline 1 & 40,48 & 9,52 & 50,00 \\
\hline 2 & 47,50 & 9,11 & 56,61 \\
\hline 3 & 61,24 & 7,45 & 68,69 \\
\hline 4 & 64,39 & 5,14 & 69,53 \\
\hline
\end{tabular}




\subsubsection{Análises Cromatográficas}

\subsubsection{Valores para o cálculo das equações de calibração para análise quantitativa dos clorofenóis}

Os valores das concentrações injetadas de cada clorofenol (2,5-DCP; 2,4,6-TCP; 2,3,6-TCP; 2,3,4-TCP e PCP) e as médias das duas áreas de pico mais aproximadas entre as três originadas nos cromatogramas estão apresentadas nas Tabelas 5.52 e 5.54, respectivamente para análise quantitativa dos teores dos clorofenóis em amostras de água e de sedimento. O composto 2,4-DBP foi utilizado como padrão interno. A partir desses valores, foram calculadas as equações apresentadas nas Tabelas 5.53 e 5.56. Todas as áreas encontradas na injeção de cada concentração, as médias e os gráficos com o cálculo das equações estão apresentados no Anexo F.

a) Equações de calibração para análise quantitativa de clorofenóis nas amostras de água

As amostras de água foram preparadas como descrito no item 4.2.4.4 do capítulo de Material e Métodos. Na Tabela 5.52 são apresentadas as concentrações de dopagem com os padrões em $\mu \mathrm{g} / \mathrm{L}$, e os respectivos valores de áreas de picos obtidos.

Tabela 5.52 - Concentrações de clorofenóis em água e áreas de cromatogramas

\begin{tabular}{c|c|c|c|c|c|c}
\hline $\begin{array}{c}\text { Concentração } \\
(\boldsymbol{\mu g} / \mathbf{L})\end{array}$ & $\mathbf{2 , 5}$ DCP & $\mathbf{2 , 4 , 6 - T C P}$ & $\mathbf{2 , 3 , 6 - T C P}$ & $\mathbf{2 , 3 , 4 - T C P}$ & PCP & $\mathbf{2 , 4 - D B P}$ \\
\hline $1,00 \times 10^{-2}$ & $4,33 \times 10^{4}$ & $1,72 \times 10^{6}$ & $2,01 \times 10^{6}$ & $1,01 \times 10^{6}$ & $2,94 \times 10^{6}$ & $9,22 \times 10^{4}$ \\
\hline $5,00 \times 10^{-2}$ & $3,29 \times 10^{5}$ & $1,25 \times 10^{7}$ & $1,30 \times 10^{7}$ & $9,61 \times 10^{6}$ & $1,56 \times 10^{7}$ & $1,13 \times 10^{5}$ \\
\hline $1,00 \times 10^{-1}$ & $7,10 \times 10^{5}$ & $1,81 \times 10^{7}$ & $1,77 \times 10^{7}$ & $1,62 \times 10^{7}$ & $2,19 \times 10^{7}$ & $1,38 \times 10^{5}$ \\
\hline $2,50 \times 10^{-1}$ & $2,53 \times 10^{6}$ & $2,51 \times 10^{7}$ & $2,36 \times 10^{7}$ & $2,20 \times 10^{7}$ & $2,61 \times 10^{7}$ & $5,24 \times 10^{4}$ \\
\hline
\end{tabular}

Comparando-se as áreas dos cromatogramas encontradas na injeção dos padrões, com as obtidas na injeção das amostras de águas do reservatório de Salto Grande, foi observado que essas últimas estavam próximas das áreas encontradas para a menor concentração injetada, logo, as equações para a água foram calculadas considerando apenas as três menores concentrações (Tabela 5.53):

Tabela 5.53 - Equações obtidas a partir dos valores das áreas dos cromatogramas para a preparação das curvas de calibração de clorofenóis em água (Anexo C)

\section{Clorofenóis}

Equações

$\mathbf{R}^{2}$ 


\begin{tabular}{c|c|c}
2,5 DCP & $\mathrm{y}=7 \times 10^{6} \mathrm{X}-34764$ & 0,9997 \\
\hline $2,4,6-\mathrm{TCP}$ & $\mathrm{y}=2 \times 10^{8} \mathrm{X}+1 \times 10^{6}$ & 0,9408 \\
\hline $2,3,6-\mathrm{TCP}$ & $\mathrm{y}=2 \times 10^{8} \mathrm{X}+2 \times 10^{6}$ & 0,9195 \\
\hline $2,3,4-\mathrm{TCP}$ & $\mathrm{y}=2 \times 10^{8} \mathrm{X}+19465$ & 0,9802 \\
\hline PCP & $\mathrm{y}=2 \times 10^{8} \mathrm{X}+2 \times 10^{6}$ & 0,9371 \\
\hline
\end{tabular}

b) Equações de calibração para análise quantitativa das amostras de sedimento

As amostras de sedimento foram preparadas como descrito no item 4.2.4.4 de Material e Métodos. As concentrações de dopagem e os resultados obtidos estão apresentados na Tabela 5.54.

Tabela 5.54 - Concentrações de clorofenóis nas amostras de sedimentos e áreas obtidas nas análises por $C G / D C E$

\begin{tabular}{c|c|c|c|c|c|c}
\hline $\begin{array}{c}\text { Concentração } \\
(\boldsymbol{\mu g} / \mathbf{K g})\end{array}$ & $\mathbf{2 , 5}$ DCP & $\mathbf{2 , 4 , 6 - T C P}$ & $\mathbf{2 , 3 , 6 - T C P}$ & $\mathbf{2 , 4 - D B P}$ & $\mathbf{2 , 3 , 4 - T C P}$ & PCP \\
\hline 0,50 & ------- & ------- & ------- & ------- & $1,07 \times 10^{5}$ & $5,60 \times 10^{5}$ \\
\hline 2,50 & $1,15 \times 10^{5}$ & $3,31 \times 10^{6}$ & $2,48 \times 10^{6}$ & $4,79 \times 10^{4}$ & $1,84 \times 10^{6}$ & $3,14 \times 10^{6}$ \\
\hline 5,00 & $2,14 \times 10^{5}$ & $6,40 \times 10^{6}$ & $5,76 \times 10^{6}$ & $4,02 \times 10^{4}$ & $2,80 \times 10^{6}$ & $4,50 \times 10^{6}$ \\
\hline 12,50 & $6,35 \times 10^{4}$ & $1,10 \times 10^{7}$ & $1,08 \times 10^{7}$ & $7,96 \times 10^{4}$ & $8,71 \times 10^{6}$ & $1,58 \times 10^{7}$ \\
\hline
\end{tabular}

Nas amostras tratadas com soluções de clorofenóis na concentração de $0,50 \mu \mathrm{g} / \mathrm{Kg}$, foram feitas limpezas utilizando-se coluna de sílica 3,0 cm e 5,0 $\mathrm{mL}$ de hexano/acetona 3:1 como eluente. No entanto, quando as amostras foram injetadas, apenas foram detectadas áreas de 2,3,4-TCP e do PCP. A partir da concentração de $2,50 \mu \mathrm{g} / \mathrm{Kg}$, as amostras não passaram por processo de limpeza, uma vez que, considerando os resultados desse teste, antes e após o procedimento de limpeza, bem como resultados obtidos em testes anteriores, como descrito no item 5.2.2.3 deste capítulo, tornou-se evidente que havia perdas na coluna de limpeza.

Para ter-se noção dessa perda, foram comparadas três amostras dopadas com 2,5 $\mu \mathrm{g} / \mathrm{Kg}$ de solução de clorofenóis, sendo que em duas não foram realizados os procedimentos de limpeza. Na amostra em que a limpeza foi feita, procedeu-se como estabelecido em Material e Métodos, porém, posteriormente ao eluente indicado, fez-se passar $5 \mathrm{~mL}$ de acetona pela coluna, sendo essa solução recolhida em outro frasco, concentrada, derivatizada e injetada.

Na Tabela 5.55 são mostrados os resultados encontrados para os procedimentos anteriormente descritos, onde se observam perdas na coluna de limpeza.

Tabela 5.55 - Teste para verificação de perda de clorofenóis ocorridas na coluna de limpeza 


\begin{tabular}{c|c|c|c|c|c|c}
\hline Amostra & 2,5 DCP & 2,4,6-TCP & 2,3,6-TCP & 2,4-DBP & 2,3,4-TCP & PCP \\
\hline $\mathrm{a}^{(1)}$ & ------- & $4,97 \times 10^{-4}$ & ------- & ------- & -------- & ------- \\
\hline $\mathrm{aa}^{(2)}$ & $5,3 \times 10^{-4}$ & $2,02 \times 10^{-6}$ & $1,61 \times 10^{-6}$ & $3,26 \times 10^{-4}$ & $8,22 \times 10^{-5}$ & ------- \\
\hline $\mathrm{b}^{(3)}$ & $1,21 \times 10^{-5}$ & $3,48 \times 10^{-6}$ & $2,62 \times 10^{-6}$ & $5,11 \times 10^{-4}$ & $1,86 \times 10^{-6}$ & $3,70 \times 10^{-6}$ \\
\hline $\mathrm{c}^{(3)}$ & $1,09 \times 10^{-5}$ & $3,14 \times 10^{-6}$ & $2,34 \times 10^{-6}$ & $4,46 \times 10^{-4}$ & $1,82 \times 10^{-6}$ & $2,58 \times 10^{-6}$ \\
\hline
\end{tabular}

Obs.: (1) Amostra em que foi feita a limpeza; (2) Amostra a, após passagem da acetona; (3)

Amostras b e c dopadas com $2,50 \mu \mathrm{g} / \mathrm{Kg}$, sem limpeza.

Como pode ser visto nesses resultados, é possível afirmar que nas amostras de Salto Grande, submetidas à limpeza, ocorreu perda de substâncias e as áreas dos picos foram subestimadas.

As equações determinadas a partir dos resultados da Tabela 5.54 são mostradas na Tabela 5.56, sendo que as áreas das amostras submetidas à limpeza não foram consideradas.

Tabela 5.56 - Equações obtidas a partir dos valores das áreas dos cromatogramas para a preparação das curvas de calibração de clorofenóis nos sedimentos

\begin{tabular}{c|c|c}
\hline Clorofenóis & Equações & $\mathbf{R}^{\mathbf{2}}$ \\
\hline $2,4,6-\mathrm{TCP}$ & $\mathrm{y}=4 \times 10^{7} \mathrm{X}+2 \times 10^{6}$ & 0,9719 \\
\hline $2,3,6-\mathrm{TCP}$ & $\mathrm{y}=4 \times 10^{7} \mathrm{X}+1 \times 10^{6}$ & 0,9754 \\
\hline $2,3,4-\mathrm{TCP}$ & $\mathrm{y}=4 \times 10^{7} \mathrm{X}-291261$ & 0,9872 \\
\hline PCP & $\mathrm{y}=7 \times 10^{7} \mathrm{X}-992977$ & 0,9794 \\
\hline
\end{tabular}

\subsubsection{Valores de clorofenóis nas amostras de Salto Grande}

A identificação dos clorofenóis nas amostras de Salto Grande foi baseada no tempo de retenção dos compostos presentes nas amostras, em relação ao tempo de retenção dos padrões. A utilização do tempo de retenção pode incorrer em erros, visto que diferentes compostos podem apresentar o mesmo tempo de retenção e serem eluídos simultaneamente. Entretanto, os compostos encontrados tanto na água quanto no sedimento têm grande probabilidade de serem clorofenóis, já que houve bastante coerência entre os tempos de retenção e os compostos detectados tanto nas amostras de água quanto nas de sedimento. A confirmação só seria possível com o auxílio de um instrumento analítico auxiliar, via de regra, um espectrômetro de massas ou um cromatógrafo acoplado a um detector de massas.

Foram enviadas para a Central Analítica do Instituto de Química da Universidade Estadual de Campinas, para análise em cromatógrafo a 
gás acoplado a um detector de massas, duas amostras, sendo uma de padrões de clorofenóis $(1,0 \mathrm{mg} / \mathrm{L})$ e a outra, uma amostra de sedimento que apresentou a maior das áreas de picos no CG/DCE. Nas condições empregadas, nenhum sinal considerável foi detectado em nenhuma das amostras. Deve-se ressaltar, que a sensibilidade do detector de massas é bem inferior à do detector por captura de elétrons. Logo, os derivados de clorofenóis presentes no padrão e os possivelmente presentes na amostra, estavam em concentrações inferiores ao limite de detecção do detector de massas da Central Analítica do Instituto de Química da Universidade Estadual de Campinas. Para aumentar-se a concentração dos compostos, de forma a tornar possível a detecção pelo massa, teríase que aumentar a quantidade de sedimento e água usados nas extrações. No entanto, neste trabalho, isso não foi possível, pela quantidade de material que se dispunha.

Os resultados da presença de clorofenóis serão discutidos preferencialmente em relação às áreas de picos dos cromatogramas, evitando-se a discussão dos valores de concentrações, em geral, em limites inferiores a 0,01 $\mu \mathrm{g} / \mathrm{L}$ para água e $0,50 \mu \mathrm{g} / \mathrm{Kg}$ para sedimento. A posteriori, no item 5.5, serão considerados os resultados das análises cromatográficas para a mesma estação nas 4 campanhas, correlacionando-os com os valores obtidos nos demais parâmetros físico-químicos analisados, bem como em relação às condições climatológicas da região à época das coletas. As características hidráulicas e morfométricas do reservatório também serão correlacionadas aos demais resultados.

\subsubsection{1 $\quad 1^{a}$ Campanha (Maio)}

As primeiras modificações feitas no método de ZUIN (1997) adotado neste trabalho, ocorreram nessa campanha, visto que havia a necessidade de adaptar-se um procedimento de extração proposto, para as amostras de Salto Grande. Como nas amostras desse reservatório esperava-se uma menor concentração de clorofenóis que nas amostras de ZUIN (1997), visto que esta trabalhou com amostras de uma área potencialmente contaminada, as primeiras alterações foram no tempo de extração e forma de agitação, visando um maior e melhor contato das amostras com o solvente. No presente trabalho, optou-se por uma agitação em incubador rotativo, durante 14 horas (overnight). ZUIN (1997) utilizou para extração dos 
clorofenóis um funil de separação de 2 L, com agitação manual, não especificando o tempo de agitação.

Foram também testados o volume de amostra na extração e diferentes colunas de limpeza. Nessa campanha não se utilizou nenhum padrão interno nas análises cromatográficas (Tabela 1A/anexos).

As amostras de água da estação 2 foram coletadas em coluna d'água com profundidade de dois metros. As amostras A, B e C, indicadas na Figura 5.2, são amostras de água da mesma estação 2, porém alterando-se as condições de extração. Nas amostras A e C utilizou-se um volume de $1 \mathrm{~L}$, e na amostra B, um volume de 0,5 L. Foram testadas como colunas de limpeza a de Sílica (coluna de 1,0 cm) na amostra B, e a de Florisil (coluna de 1,0 $\mathrm{cm})$ na amostra C. Na amostra A não foi feita limpeza.

Os resultados dos picos de áreas dos cromatogramas das análises das amostras de Maio (estação 2) são apresentados nas Tabelas 1D e 2D dos Anexos. Os resultados das análises são apresentados em áreas de cromatogramas, bem como o respectivo tempo de retenção, em minutos.

O melhor resultado encontrado, em pico de área de cromatograma, foi obtido na amostra A. Comparando-a com a amostra B, pode-se concluir que houve perdas consideráveis de substâncias na amostra B, ou pelo menor volume utilizado na extração ou pela adsorção à coluna, ou ainda, por ambos. Outra possível fonte de perdas pode estar relacionada à presença de emulsão ocorrida nas amostras de água dessa estação. Com a formação dessa camada entre a água e o hexano, possivelmente devido a presença de material em suspensão, maior quantidade de sulfato de sódio foi utilizada na secagem e provavelmente causou perda de uma parte de clorofenóis.

Os valores apresentados para os clorofenóis (PoC's), na Figura 5.2, são as áreas de picos dos cromatogramas obtidos nas injeções em CG/DCE, das amostras de água da estação 2. Os valores obtidos utilizando as equações da Tabela 5.53 mostram que a amostra A apresentou 2,5-DCP em torno de 0,02 $\mu \mathrm{g} / \mathrm{L}$, e para os demais clorofenóis as concentrações foram menores que $0,01 \mu \mathrm{g} / \mathrm{L}$. Esses valores estão abaixo do limite máximo exigido pela Portaria 36 (1990) do Diário Oficial da União/Ministério da Saúde, de 0,10 $\mu \mathrm{g} / \mathrm{L}$.

As amostras de sedimentos foram analisadas após extração com ultra-som e os resultados, apresentados na Figura 5.3. As Tabelas 1E e 2E em Anexos mostram os valores dos picos de áreas dos cromatogramas de clorofenóis após análises em CG/DCE. As amostras A, B e C indicadas nessas Tabelas e na Figura 5.3, referem-se a triplicatas de cada estação. As extrações de sedimento dessa campanha foram feitas apenas em ultra-som, por 
não haver mais amostras disponíveis para extração em Soxhlet e sob agitação com barra magnética.

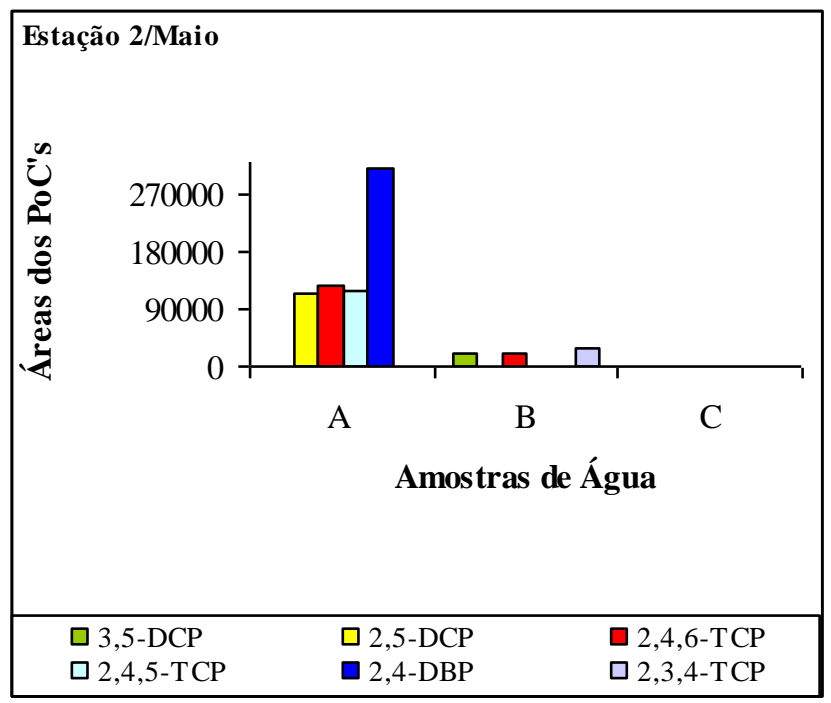

FIGURA 5.2 - VALORES DAS ÁREAS DE CROMATOGRAMAS DAS AMOSTRAS DE ÁGUA DA ESTAÇÃO 2, COLETADAS EM MAIO/98, ANALISADAS EM TRIPLICATA (A, B E C)

$\mathrm{Na}$ estação 2, somente foi detectado o padrão interno, com respostas bastante similares em duas amostras da triplicata (áreas nos cromatogramas de 147.546 e 141.294). Apesar de terem sido detectados clorofenóis nas amostras de água dessa estação, as concentrações encontradas foram baixas. A possibilidade de adsorção em material em suspensão poderia justificar as concentrações relativamente baixas de clorofenóis nas amostras de água, já que foi determinada uma concentração de material em suspensão de $28,21 \mathrm{mg} / \mathrm{L}$ e com um tempo de residência das águas no reservatório de 49 dias, pudesse ocorrer a deposição de material em suspensão. Entretanto, nos sedimentos não foram verificados clorofenóis. Esta estação está próxima a entrada do reservatório, em que o Rio Atibaia flui para alimentá-lo, assim considerando a velocidade do sistema, poder-se-ia inferir observações realizadas por outros autores em estudos realizados com água corrente de canal, simulando um curso de um rio. Nesses estudos, citados por DAMIANOVIC (1997), o PCP adicionado foi removido por uma combinação de mecanismos físico-químicos, como adsorção, volatilização e fotólise. A fotólise foi mais evidente na superfície e muito atenuada no fundo. A fotólise foi responsável por 5 a $28 \%$ da remoção, em função da luminosidade; a volatilização contribuiu com menos de $0,006 \%$, a adsorção com menos de $5 \%$. O mecanismo de remoção mais importante foi devido a degradação microbiana entre 26 a $46 \%$, que não 
pode ser descartada em um sistema como o reservatório de Salto Grande, que recebe um conjunto de águas residuárias capazes de promover o crescimento e a ação microbiana.

$\mathrm{Na}$ estação 4 foram detectadas 3 substâncias semelhantes às encontradas na análise da água da estação 2, em áreas também bastante similares: 2,5-DCP; 2,4,6-TCP e 2,4,5-TCP. Nessa estação não foi feita análise da água, não sendo possível fazer inferências sobre água e sedimento. Na campanha de maio as áreas dos cromatogramas obtidas nas análises de clorofenóis no sedimento da estação 4, em geral, foram bastante semelhantes, sempre em torno de 60.000 , correspondendo a uma concentração menor que $2,50 \mu \mathrm{g} / \mathrm{Kg}$ para todas as substâncias detectadas e de possível quantificação pelas equações da Tabela 5.56. Os valores das áreas de picos podem estar subestimados devido a prováveis perdas na coluna de limpeza.
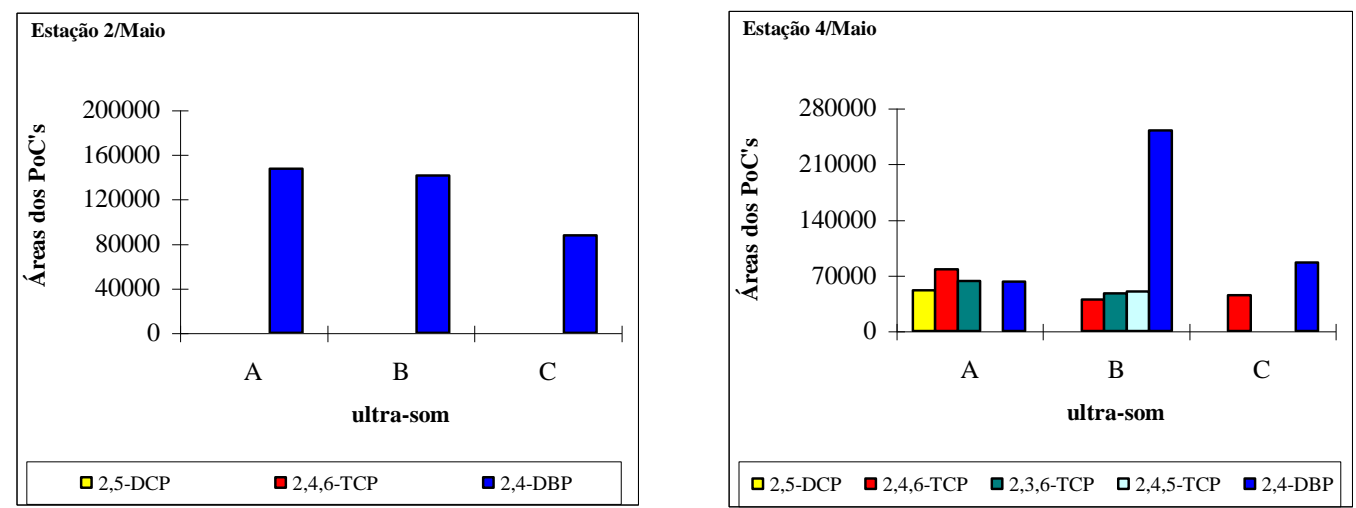

FIGURA 5.3 - VALORES DE ÁREAS DOS CROMATOGRAMAS DAS AMOSTRAS DE SEDIMENTO, DAS ESTAÇÕES 2 E 4, COLETADAS EM MAIO/98, ANALISADAS EM TRIPLICATA (A, B E C)

\subsubsection{2 $2^{\mathrm{a}}$ Campanha (Junho)}

Nessa campanha também foram feitas alterações nos procedimentos analíticos para as amostras de água, buscando a obtenção de áreas de picos mais similares, entre as réplicas das amostras.

Não foram feitas limpezas nas amostras de água dessa campanha, porém ainda utilizou-se a "lavagem" com $50 \mathrm{~mL}$ de n-hexano, por 2 vezes, após a extração de 16 horas, como na primeira campanha. Essa "lavagem" consistia em acrescentar n-hexano purificado, no hexano da extração das amostras, fazendo-se uma agitação manual, por aproximadamente 
5 minutos e retirando-se água residual, se houvesse. Empregaram-se alíquotas de $120 \mu \mathrm{L}$ de 2,4-dibromofenol como padrão interno nas amostras analisadas.

Foram feitas análises cromatográficas em duplicata das amostras de água da estação 2, e somente foi encontrado PCP, cujas áreas de picos nos cromatogramas foram da ordem de 4123786 para a amostra A, correspondendo a uma concentração de $0,011 \mu \mathrm{g} / \mathrm{L} \mathrm{e,} \mathrm{318559,}$ para amostra B; correspondendo a uma concentração menor que $0,010 \mu \mathrm{g} / \mathrm{L}$ (Figura 5.4). O composto PCP também foi observado nas amostras de sedimentos da estação 2 e 4 (Figuras 5.5), com valores de picos de áreas variáveis entre as triplicatas. Para a estação 2, considerando-se os métodos de extração com o ultra-som e o Soxhlet, detectou-se o PCP, com áreas de 57221 e 103710, respectivamente. Deve-se considerar que não foram realizadas limpezas nas amostras extraídas com o Soxhlet, mas foram feitas nas amostras extraídas pelo método do ultra-som, e perdas podem ter ocorrido nas colunas de limpeza. $\mathrm{Na}$ estação 4, entre as triplicatas das amostras extraídas com ultra-som foram observadas áreas de pico de 232206 e 71790, sendo que em uma das amostras, o composto PCP não foi detectado. Na análise com o Soxhlet foi observada uma área de 100940. Essas áreas encontradas para os clorofenóis (PoC's) no sedimento corresponderam a concentrações menores que $2,50 \mu \mathrm{g} / \mathrm{Kg}$.

As amostras de água da estação 4 foram feitas em triplicatas, porém, os valores não foram próximos entre elas, exceto para o PCP, como pode ser visto na Figura 5.3. Para o 2,5DCP, por exemplo, as triplicatas apresentaram concentrações de $0,012 \mu \mathrm{g} / \mathrm{L}, 0,016 \mu \mathrm{g} / \mathrm{L}$, e $0,010 \mu \mathrm{g} / \mathrm{L}$. O valor do pico de área 2,3,6-TCP foi de 1410515, um dos maiores valores determinados em todas as campanhas o grupo de clorofenóis analisados. Entretanto, não houveram picos de áreas similares entre as réplicas.

As amostras de sedimento foram submetidas à extração com ultra-som, em triplicata, e duas amostras foram extraídas com Soxhlet e agitação com barra magnética, respectivamente Os valores das áreas de picos em cromatogramas são apresentados na Tabela 3E e 4E dos Anexos. Em geral, as amostras de sedimento dessa campanha, apresentaram valores de áreas dos cromatogramas inferiores aos das campanhas de Novembro e Fevereiro, e superiores aos determinados nas amostras de Maio, correspondendo a concentrações menores que $0,50 \mu \mathrm{g} / \mathrm{Kg}$ para o pentaclorofenol e menores que $2,50 \mu \mathrm{g} / \mathrm{Kg}$ para os demais clorofenóis. (Figura 5.5).

A coluna d'água, entre essas duas estações, tem profundidades bem diferentes: a maior profundidade determinada para a coluna d'água da estação 2 foi $2,20 \mathrm{~m}$, e para a estação quatro, igual a 14,80 m. As amostras de água foram coletadas sempre na superfície da coluna d'água. O composto PCP esteve presente nas duas estações, na água e sedimento, 
sendo que na estação 2 foi o único a ser observado nas amostras de águas e sedimentos. A concentração de PCP na água sofreu decréscimo da estação 2 para a 4 . Na estação 4 foram encontrados diferentes tipos de clorofenóis, tanto no sedimento quanto na água, entretanto não houve similaridade entre os valores de áreas dos cromatogramas nas réplicas das amostras de água.

Considerando-se que o tempo de residência nessa campanha foi o segundo maior entre as campanhas, 74 dias, e que houve semelhança entre os valores dos parâmetros físicoquímicos entre as duas estações, exceto para os valores de $\mathrm{pH}$ e condutividade, pode-se atribuir as diferenças dos clorofenóis entre as estações à velocidade do fluxo da água, maior na estação 2 podendo ter provocado a diluição dos compostos, assim como o pH menor na estação 4, permitindo sua solubilização no compartimento água. No sedimento, pela alta adsorção em material em suspensão apresentada pelos organoclorados e em se tratando de um período com baixo fluxo (maior tempo de residência), a taxa de sedimentação desse material formando os sedimentos é alta, apresentando então os mesmos clorofenóis encontrados no compartimento água, além de outros que podem ter se acumulado.

Cabe comentar que na água, o PCP, em geral, está presente na forma ionizada, podendo absorver radiação e sofrer degradação catalítica. Uma pequena parcela do composto pode ainda sofrer volatilização ou ser degradada por microrganismos. Entretanto, a maior parte do PCP presente adsorve à matéria suspensa na água e acaba sendo incorporada ao sedimento, o que pode alterar a disponibilidade do composto a outros processos de degradação. Ao todo, acredita-se que o composto permaneça na água por um período de duas horas a 120 dias (NAKAYAMA, 1999).

Nas Figuras 5.4 e 5.5 estão representados os valores das réplicas das amostras pelas letras A, B e C.
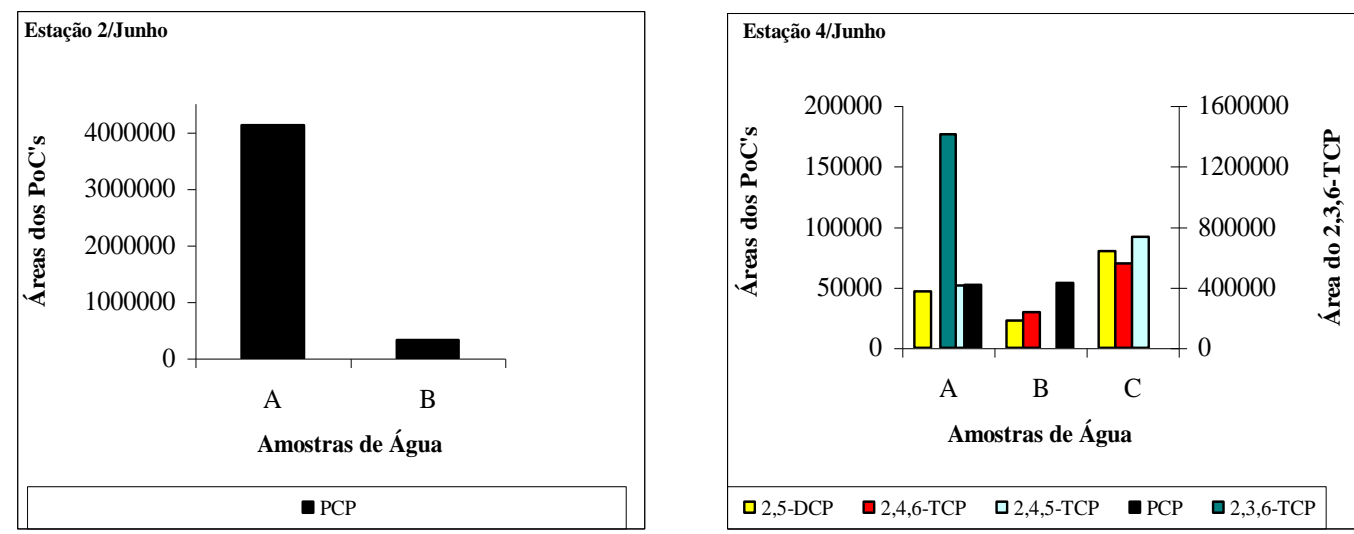
FIGURA 5.4 - VALORES DE ÁREAS DOS CROMATOGRAMAS DAS AMOSTRAS DE ÁGUAS DAS ESTAÇÕES 2 E 4, COLETADAS EM JUNHO/98, ANALISADAS EM DUPLICATA (A E B) E TRIPLICATA (A, B E C).
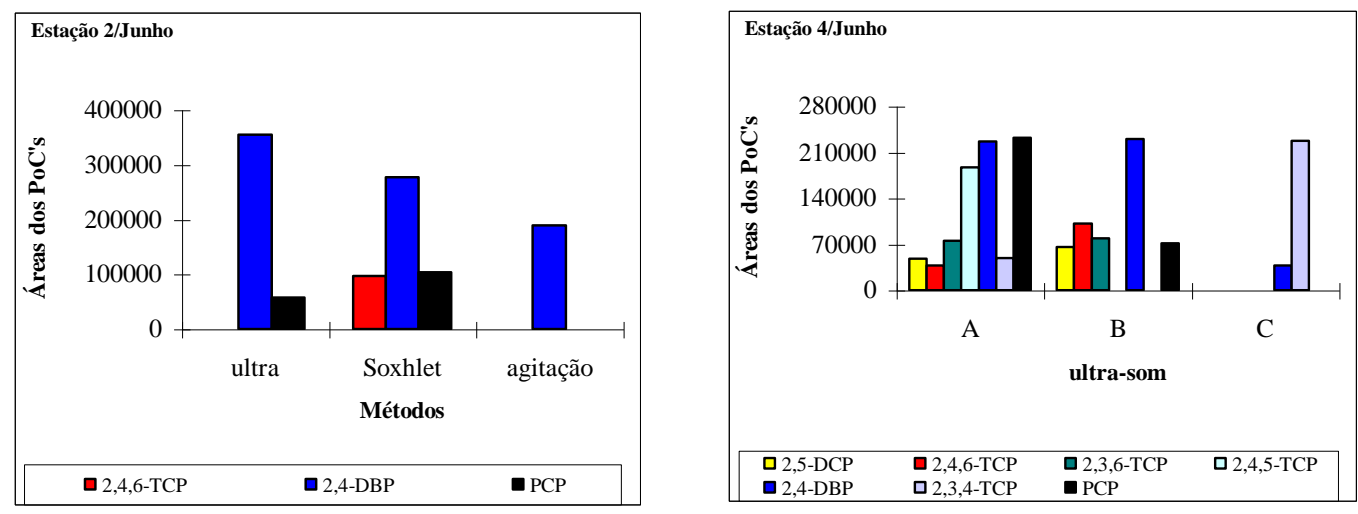

FIGURA 5.5 - VALORES DE ÁREAS DOS CROMATOGRAMAS DAS AMOSTRAS DE SEDIMENTO DAS ESTAÇÕES 2 E 4, COLETADAS EM JUNHO/98, ANALISADAS EM TRIPLICATA (A, B E C) PARA O ULTRA-SOM E EXTRAÍDA SEM REPETIÇÃO EM SOXHLET E COM AGITAÇÃO COM BARRA MAGNÉTICA.

\subsubsection{2 $\quad 3^{a}$ Campanha (Novembro)}

Nessa campanha outras alterações foram feitas nos procedimentos de análises, visto que os valores das áreas dos cromatogramas da $1^{\mathrm{a}}$ e $2^{\mathrm{a}}$ campanhas continuavam com valores de áreas pouco similares entre réplicas de uma mesma amostra. O volume utilizado na acidificação das amostras anterior aos procedimentos de extração, indicado por ZUIN (1997), foi uma das alterações. A adição de 1,0 mL de ácido sulfúrico nas amostras não foi eficiente para aprimorar o método extrativo e, assim, substituiu-se a alíquota de 1,0 mL do ácido para 1,0 L de amostra (condição empregada nas amostras da $1^{\mathrm{a}}$ e $2^{\mathrm{a}}$ campanhas), por 2,0 $\mathrm{mL}$ para 1,0 $\mathrm{L}$ de amostra. As amostras da $3^{\mathrm{a}}$ e $4^{\mathrm{a}}$ campanhas também foram acidificadas dessa forma, como visto na Tabela 4.2 de Material e Métodos. $\mathrm{O} \mathrm{pH}$ foi lido com fita de $\mathrm{pH}$, estando sempre abaixo do valor 2. A acidificação é necessária para que o equilíbrio de ionização dos clorofenóis presentes nas amostras privilegie a forma molecular, solúvel no solvente usado em todas as extrações, o hexano. No entanto, ao empregar uma maior quantidade de ácido, não observou-se alteração nas respostas das análises cromatográficas, podendo-se inferir que a acidificação não era necessária (ver Tabelas $4 \mathrm{D}, 5 \mathrm{D}, 6 \mathrm{D}, 7 \mathrm{D} 8 \mathrm{D}$ e 9D dos Anexos).

Com esses resultados obtidos das amostras oriundas das estações 1, 2, 3 e 4 (amostras coletadas na superfície), buscou-se otimizar novamente os procedimentos para 
extração e análise cromatográfica. As amostras de água da estação 4 coletadas nas profundidades de 8 e $14 \mathrm{~m}$ foram filtradas em filtro de fibra de vidro GF/C (Whatman), 0,45 $\mu \mathrm{m}$ e no procedimento foram eliminadas as lavagens sucessivas com n-hexano. Os valores das áreas de pico dos cromatogramas com essas alterações foram bastante similares, como pode ser visto nas Tabelas 10D e 11D dos Anexos, sendo as amostras da $4^{\mathrm{a}}$ campanha também tratadas pelo mesmo procedimento. Acreditou-se que a falta de reprodutibilidade poderia ser tanto devido às perdas decorrentes das lavagens, quanto da presença de material em suspensão, que provavelmente são pontos de adsorção dos clorofenóis, como comentado por STRACHAN et al. (1982).

Segundo DAMIANOVIC (1997), muitos poluentes aromáticos como hidrocarbonetos aromáticos policlorados são altamente apolares, apresentando baixa solubilidade em água e tendência à adsorção em matéria orgânica de solos e sedimentos. Quando atingem corpos d'água profundos, o composto PCP por exemplo, pode complexar-se com co-solventes, como ácidos fúlvico e húmico, diminuindo sua capacidade de adsorção e facilitando o mecanismo de transporte como partícula coloidal. A adsorção de PCP é limitada pela solubilidade da forma protonada a baixo $\mathrm{pH}$ e pela forma desprotonada a elevado pH. A forma neutra do PCP é fortemente hidrofóbica, com solubilidade de 11 a 14 $\mathrm{mg} / \mathrm{L}$ e coeficiente de partição de 5:1. Dessa forma, essa substância pode ser fortemente adsorvida em soluções aquosas, tanto em sistema de águas superficiais, profundas ou em sistemas ricos em matéria orgânica.

Todas as amostras dessa campanha foram dopadas com $120 \mu \mathrm{L}$ do padrão interno, 2,4-dibromofenol. 2,3,6-TCP foi constatado em todas as amostras de água de todas as estações analisadas nessa campanha, apresentando áreas de pico relevantes nos cromatogramas das estações 2 e 3 nas amostras de água das profundidades de 2 e 7m, e na amostra de superfície da estação 4. Nessas estações o material em suspensão orgânico foi o mais representativo, exceto na estação 2.

2,3,4-TCP também esteve presente na maioria das estações, exceto na amostra da estação 3 da profundidade de $2 \mathrm{~m}$ e na amostra de superfície da estação 4 . Porém, as áreas dos picos nos cromatogramas foram inferiores `as encontradas para o 2,3,6-TCP na maioria das estações, exceto na estação 4, amostras de águas coletadas nas profundidades de 8 e 14m. Nas estações 1, 2 e 4, predominou o material em suspensão inorgânico nas amostras de água das profundidades de 8 e $14 \mathrm{~m}$. O PCP também esteve presente em todas as estações, exceto na profundidade de $14 \mathrm{~m}$ da estação 4, mas com menores valores das áreas obtidas nas determinações cromatográficas se comparadas àquelas observadas para 2,3,6-TCP. 
Todas as áreas dos cromatogramas obtidas nas análises das amostras de água corresponderam a concentrações inferiores a $0,01 \mu \mathrm{g} / \mathrm{L}$.

Essa campanha foi a que apresentou amostras com a maior variedade de clorofenóis em todas as estações (Figura 5.6), frente aos padrões estudados nesse trabalho. A primeira e a segunda estações apresentaram bastante similaridade entre alguns parâmetros como pH, condutividade, turbidez, temperatura, material em suspensão inorgânico como predominante e carbono orgânico como predominante, somente variando a concentração de oxigênio dissolvido. Entretanto, as análises cromatográficas da estação 2 apresentaram maior variedade de clorofenóis, porém com valores de áreas menores e não semelhantes entre as réplicas. Comparando-se os valores das áreas de picos dos cromatogramas comuns às duas estações, apenas os correspondentes ao composto 2,4,6-TCP apresentaram maiores áreas na estação 2; os demais, referentes aos compostos 2,3,6-TCP, 2,3,4-TCP e PCP, foram maiores na estação 1 .

$\mathrm{Na}$ estação 3, comparando-se as 3 profundidades $(0,2$ e $7 \mathrm{~m})$ em que a coleta foi feita, os valores das áreas de picos dos cromatogramas encontrados para as amostras à uma profundidade de $2 \mathrm{~m}$ foram os maiores, e com boas réplicas. Os valores de áreas dos cromatogramas encontrados para as amostras à uma profundidade de $7 \mathrm{~m}$ foram menores, entretanto, uma maior variedade de clorofenóis foi encontrada nessa camada.

$\mathrm{Na}$ estação 4, comparando-se as camadas onde a coleta foi feita, as áreas correspondentes ao PCP foram diminuindo nas amostras da superfície até a profundidade de $14 \mathrm{~m}$. Os valores das áreas de picos dos cromatogramas do composto 2,3,6-TCP foram elevados na superfície, entretanto houve um decréscimo a valores semelhantes nas amostras coletadas às profundidades de 8 e 14 m. 2,3,4-TCP foi detectado nas profundidades de 8 e 14 $\mathrm{m}$, não sendo detectado na superfície.

Nas amostras de sedimento, a distribuição dos clorofenóis entre as estações foi mais irregular. Considerando-se as substâncias extraídas em todos os métodos utilizados, somente 2,3,4-TCP esteve presente em todas as estações dessa campanha (Figura 5.7). Esse fato possivelmente foi devido à alta taxa de deposição de material em suspensão nessa campanha, provocada pelo elevado tempo de residência, cerca de 102 dias. 

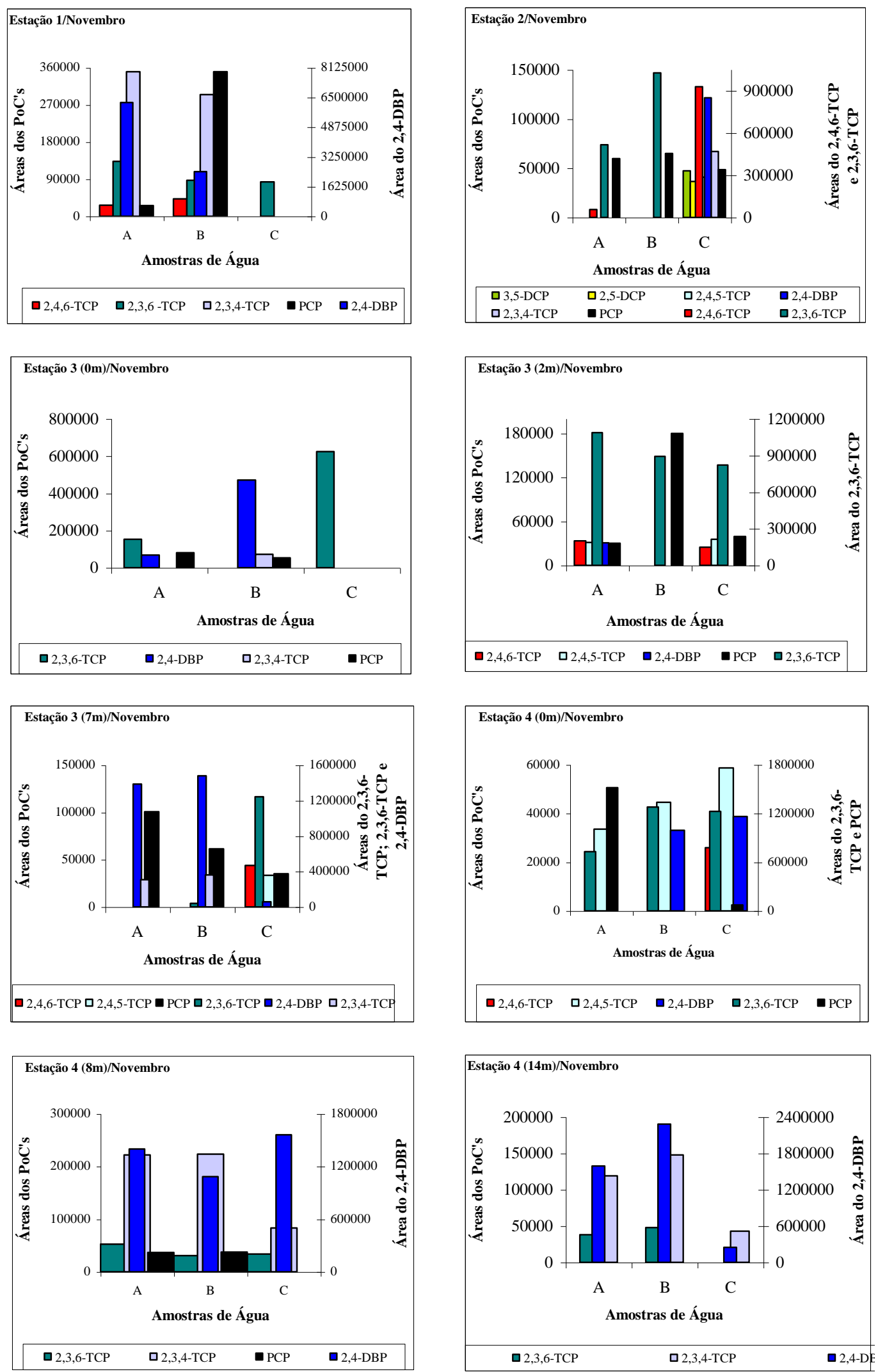
FIGURA 5.6 - VALORES DE ÁREAS DOS CROMATOGRAMAS DAS AMOSTRAS DE ÁGUAS DAS ESTAÇÕES 1,2, 3 E 4, COLETADAS EM NOVEMBRO/98, ANALISADAS EM TRIPLICATA ( $A, B E C)$.

Nas amostras de sedimento, a distribuição dos clorofenóis entre as estações foi mais irregular. Considerando-se as substâncias extraídas em todos os métodos utilizados, somente o composto 2,3,4-TCP esteve presente em todas as estações dessa campanha (Figura 5.7). Esse fato possivelmente foi devido à alta taxa de deposição de material em suspensão nessa campanha, provocada pelo alto tempo de residência, permitindo uma constante renovação do sedimento.

Nas estações 1 e 4, houve uma maior variedade de substâncias presentes, basicamente as mesmas, considerando a extração utilizando agitação e Soxhlet, sendo as áreas encontradas menores que $2,50 \mu \mathrm{g} / \mathrm{Kg}$ para os clorofenóis encontrados.

Nas estações 2 e 3, a variedade de clorofenóis encontrada foi bem menor. As substâncias presentes foram PCP, 2,3,4-TCP e 2,4,5-TCP, estando as concentrações calculadas de PCP em valores inferiores a $0,50 \mu \mathrm{g} / \mathrm{Kg}$ e para 2,3,4-TCP, menores que $2,5 \mu \mathrm{g} / \mathrm{Kg}$. Deve-se ressaltar, que na estação 3, apenas o método do ultra-som foi utilizado.

Os teores de carbono total nas estações 1 e 4, em que uma maior variedade de clorofenóis foi observada, foram superiores aos obtidos nas amostras das estações 2 e 3. 

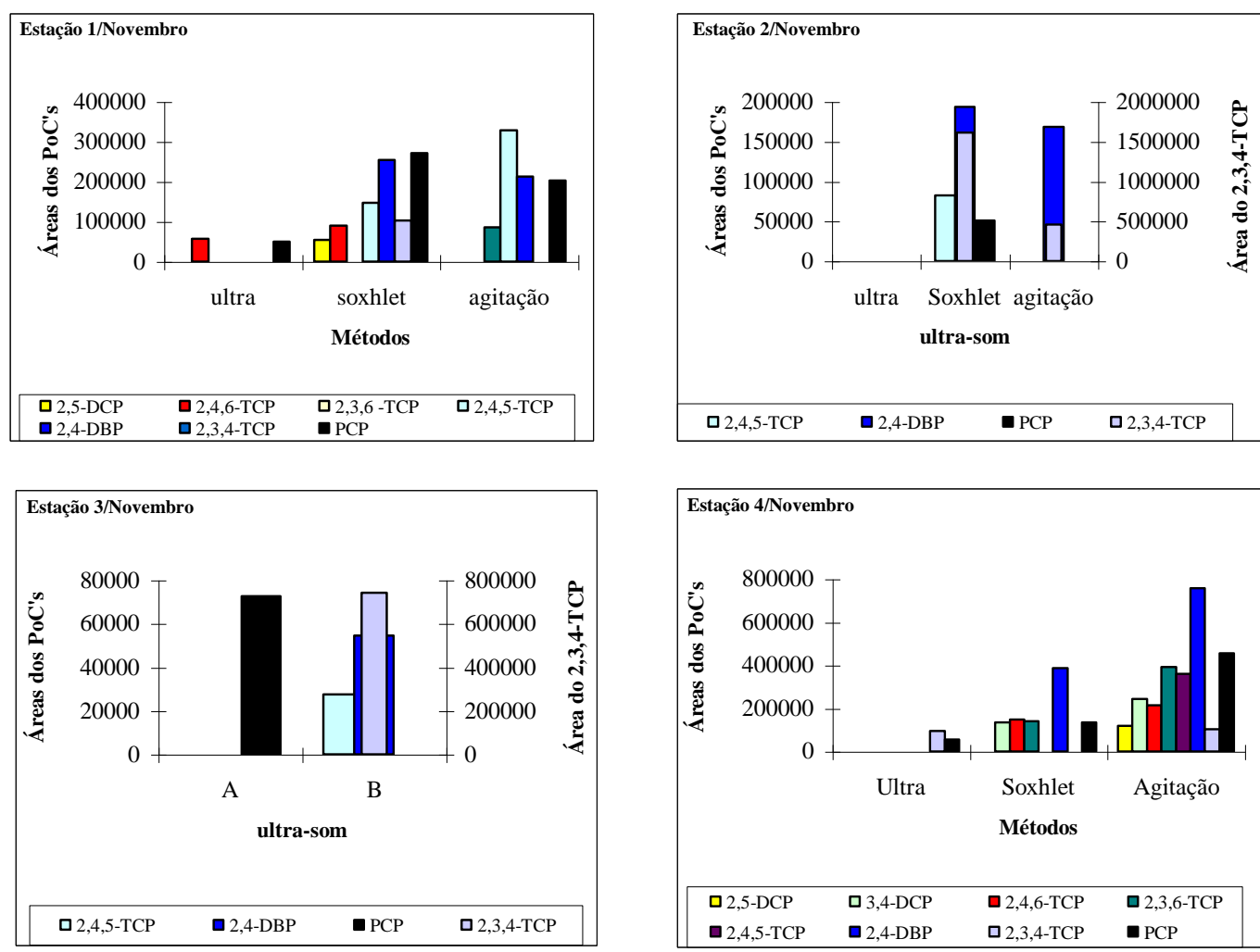

FIGURA 5.7 - VALORES DE ÁREA DES CROMATOGRAMAS DAS AMOSTRAS DE SEDIMENTO DAS ESTAÇÕES 1,2, 3 E 4, COLETADAS EM NOVEMBRO/98, ANALISADAS EM TRIPLICATAS (A, $B E C)$.

\subsection{4 ${ }^{\mathrm{a}}$ Campanha (Fevereiro)}

Nas análises das amostras de água da campanha de Novembro e Fevereiro, o composto 2,3,4-TCP esteve presente em todas as estações (Figura 5.8). PCP também foi encontrado na maioria das estações, não sendo verificado nas amostras de superfície da estação 4. As respostas das estações 1 e 2 foram bastante similares, verificando-se as presenças dos compostos PCP e 2,3,4-TCP nas triplicatas, porém, as áreas encontradas na estação 2 foram bem menores para 2,3,4-TCP. As concentrações dos clorofenóis foram menores que $0,010 \mu \mathrm{g} / \mathrm{Kg}$. As respostas das amostras das estações 3 e 4 foram semelhantes, apresentando sempre os compostos 2,3,4-TCP e 2,3,6-TCP. PCP também esteve presente nas amostras das estações 3 e 4, nessa última nas profundidades de 2,5 e $4 \mathrm{~m}$. 
Nas análises das amostras de sedimentos da estação 1 observaram-se resultados similares nas réplicas, empregando-se como métodos extrativos o ultra-som e o Soxhlet (Figura 5.9). Pela análise das amostras extraídas com o ultra-som, 2,3,6-TCP esteve presente nas estações 1,2 e 3, assim como foi detectado pelo método de extração com agitação na estação 4.

Comparando-se as respostas encontradas nas análises dos sedimentos e das águas, diferentes tipos de clorofenóis foram determinados nas estações 2 e 4, sendo bastante similares em ambas as amostras. Considere-se que os tipos de clorofenóis encontrados são aqueles cujos padrões cromatográficos permitem comparação. As concentrações determinadas de PCP foram menores que $0,50 \mu \mathrm{g} / \mathrm{kg}$, e para os demais clorofenóis inferiores a $2,50 \mu \mathrm{g} / \mathrm{Kg}$.

Como na campanha de Novembro, as estações 1 e 4 em Fevereiro de 1999 apresentaram uma maior variedade de clorofenóis, assim como as maiores áreas de picos de cromatogramas. Os valores de carbono orgânico total também foram maiores para estas duas estações. 

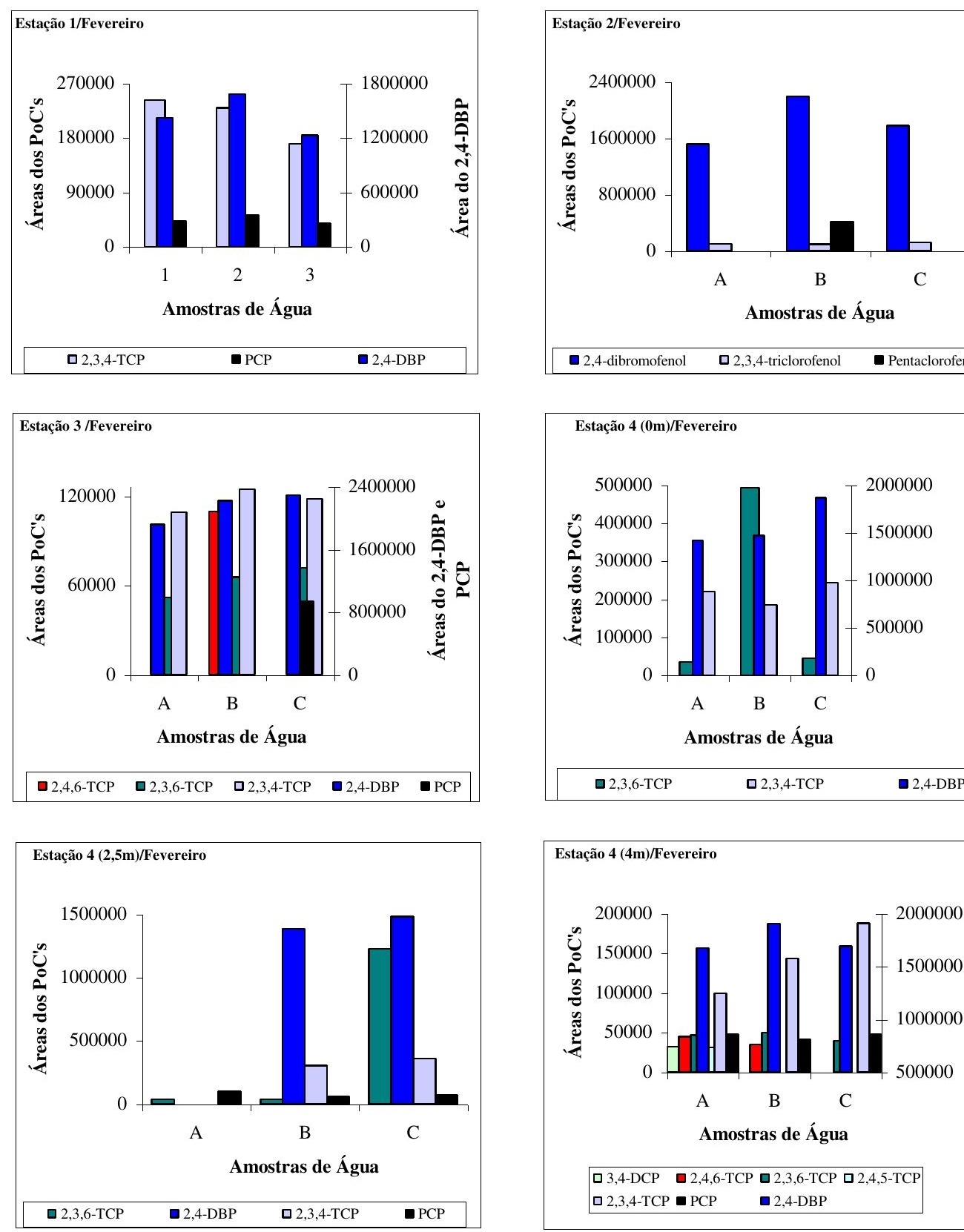

FigURA 5.8 - VALORES DAS ÁREAS DE CROMATOGRAMAS DAS AMOSTRAS DE ÁGUAS DAS ESTAÇÕES 1, 2, 3 E 4, COLETADAS EM FEVEREIRO/99, ANALISADAS EM TRIPLICATA $(A, B E C)$ 

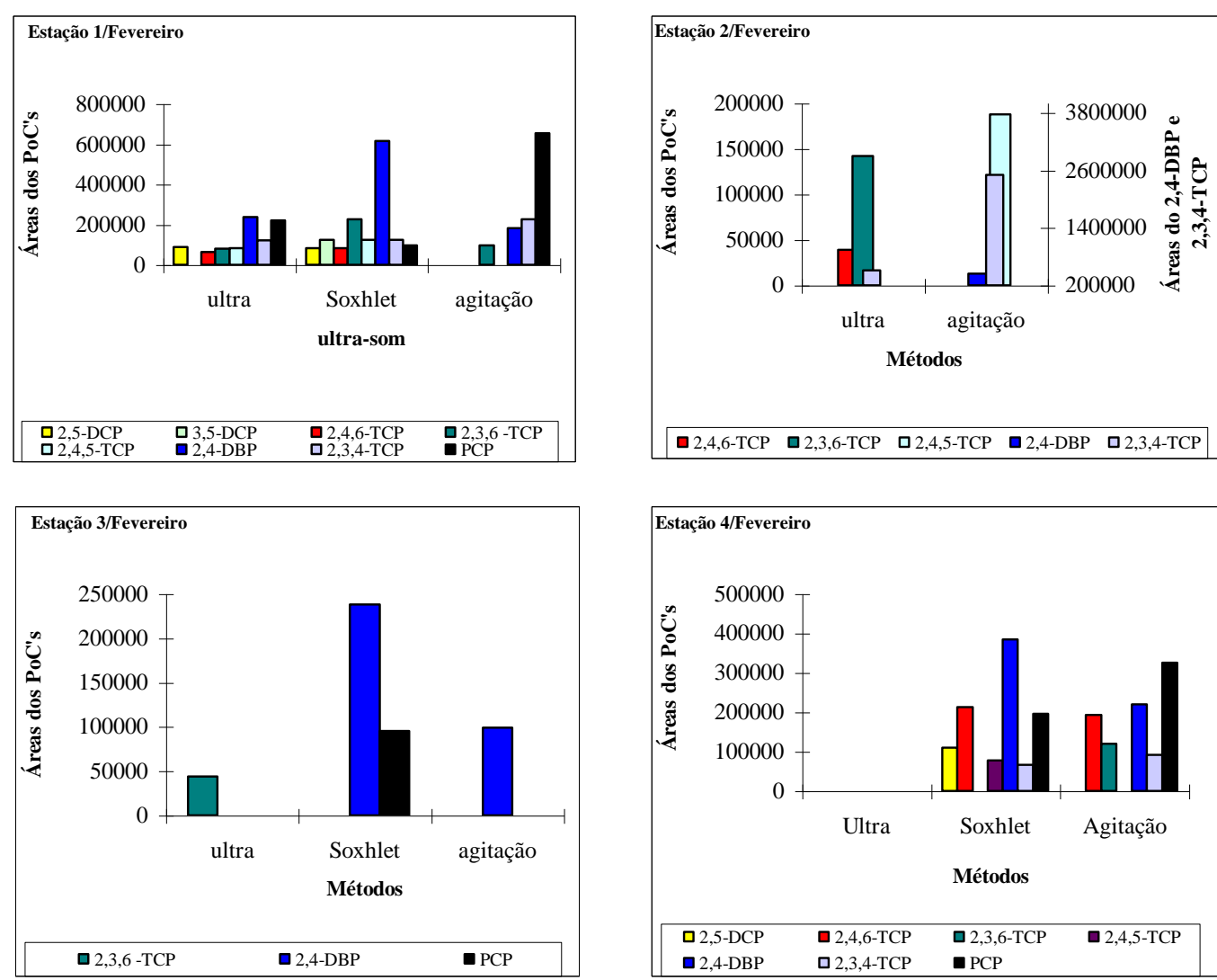

FIGURA 5.9 - VALORES DE ÁREAS DOS CROMATOGRAMAS DAS AMOSTRAS DE SEDIMENTOS DAS ESTAÇÕES 1, 2, 3 E 4, COLETADAS EM FEVEREIRO/99

\subsection{Resultados e Discussão por Estação}

\subsubsection{Estação 1}

Nessa estação foram feitas coletas apenas em Novembro de 1998 e Fevereiro de 1999. Na Figura 5.10 está apresentada uma vista parcial dessa estação, onde pode ser visto o ponto de captação de água para a cidade de Sumaré, em coleta feita em Novembro de 1998. 


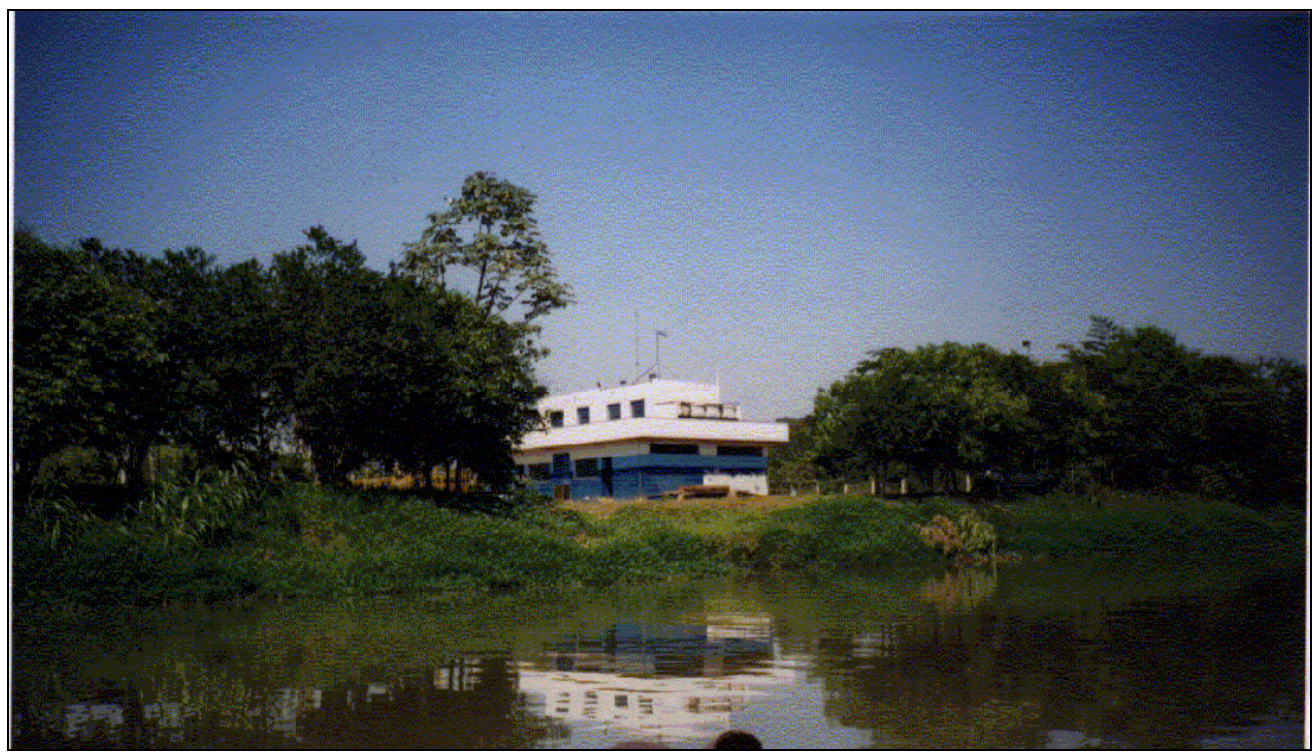

FIGURA 5.10 - VISTA PARCIAL DO ENTORNO DA ESTAÇÃO 1, PONTO DE CAPTAÇÃO DE ÁGUA PARA

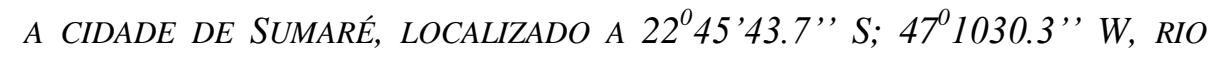
ATIBAIA, COLETA DE NOVEMBRO DE 1998.

Os parâmetros físico-químicos medidos nas colunas d'água da estação 1, nas campanhas de Novembro e Fevereiro, estão apresentados na Figura 5.11.
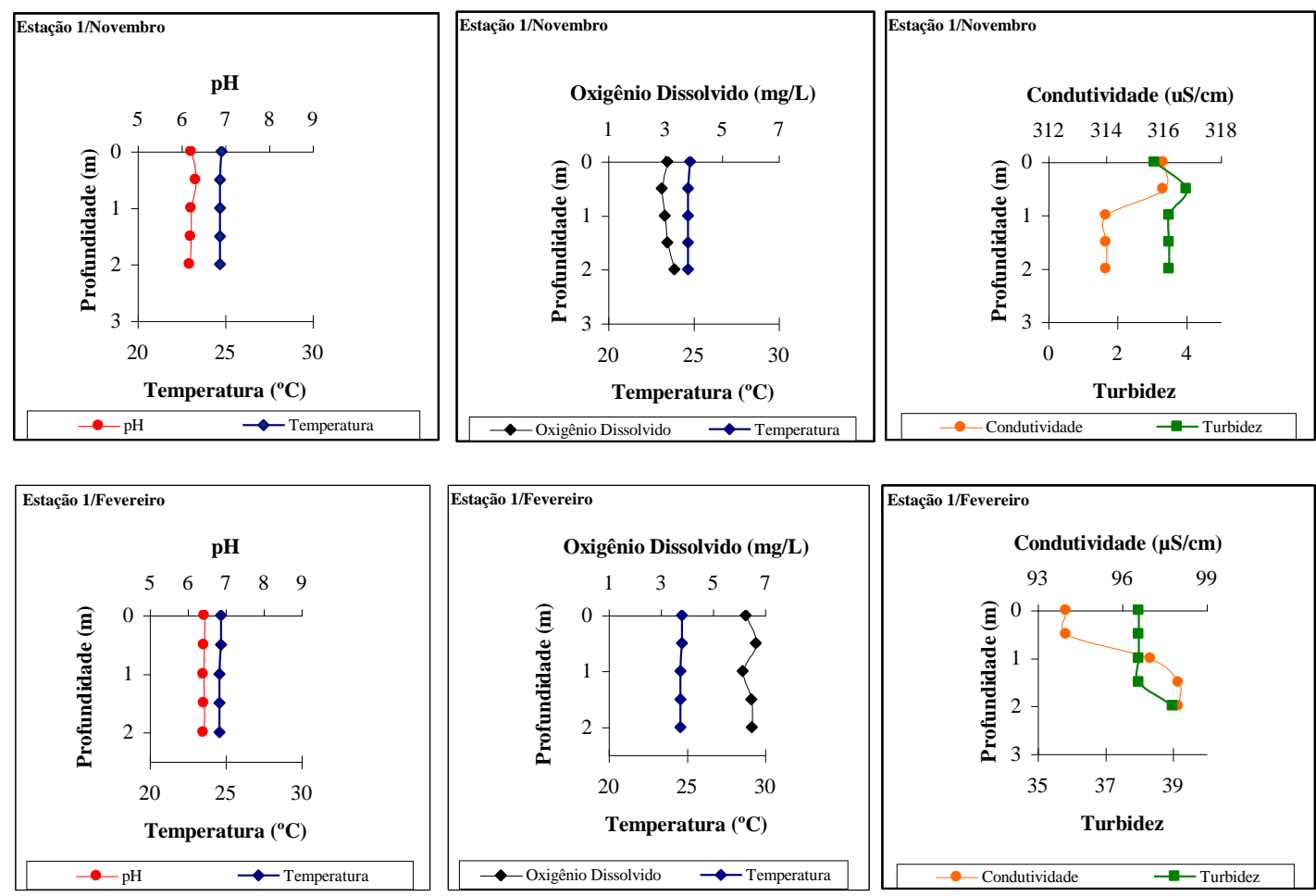

Figura 5.11 - Perfis de pH, temperatura $\left({ }^{\circ} \mathrm{C}\right)$, oxigênio dissolvido $(\mathrm{mg} / \mathrm{L})$, condutividade ( $\mu \mathrm{S} / \mathrm{cm})$ e turbidez, na Estação 1, campanhas de Novembro e Fevereiro 
$\mathrm{Na}$ análise da água, 2,3,4-TCP e PCP foram encontrados em ambas as campanhas, sendo que as áreas de pico de 2,3,4-TCP nos cromatogramas corresponderam a concentrações em torno de $0,010 \mu \mathrm{g} / \mathrm{L}$.

Em Novembro, a amostra que apresentou melhor resposta para o padrão interno foi considerada como valor de resposta. Ocorreu decréscimo nas áreas de pico de PCP dos cromatogramas nessa estação, nas coletas de Novembro para Fevereiro, de 350.651 para 40.284, respectivamente. Pode ter havido diluição de compostos no sistema devida às chuvas. Na Figura 5.12, são apresentados os valores das áreas dos cromatogramas das amostras de água da estação 1 nas campanhas de Novembro e Fevereiro.

NAS DUAS CAMPANHAS PREDOMINOU O MATERIAL INORGÂNICO EM SUSPENSÃO, SENDO QUE, EM FEVEREIRO, A DIFERENÇA ENTRE O CONTEÚdO DE MATERIAIS ORGÂNICOS E INORGÂNICOS FOI MUITO MAIOR, DEVIDA, PRINCIPALMENTE, `A INTENSA PRECIPITAÇÃO QUE FACILITA A INTRODUÇÃO DE MATERIAL INORGÂNICO NAS ÁGUAS DO RIO ATIBAIA. NA FigURA 5.13, SÃO APRESENTADOS ESSES VALORES PARA AS AMOSTRAS DE ÁGUA DA ESTAÇÃO 1 DAS $3^{\mathrm{A}}$ E $4^{\mathrm{A}}$ CAMPANHAS.

Ao considerar-se as características do solo no entorno do reservatório e sua influência na época de chuvas, pode-se comentar alguma interferência físico-química na disponibilidade de clorofenóis na água do reservatório. Se em regime de chuvas mais intensas ocorre grande movimentação de material lixiviado para dentro de um sistema aquático, esses com certeza podem servir como suporte para adsorção de compostos organoclorados. O predomínio de material inorgânico pode ter possibilitado a adsorção dos clorofenóis nesse período mais chuvoso. Por exemplo, solos mineralizados permitem maior mobilidade do PCP, ao contrário de solos arenosos, argilosos ácidos e ricos em matéria orgânica (NAKAYAMA, 1999). A região do reservatório de Americana possui solos caracteristicamente argilosos.

A análise dos clorofenóis dos sedimentos coletados nessa estação foi feita em triplicata, utilizando-se a extração pelos três métodos estudados: ultra-som (amostras estudadas em triplicata), Soxhlet e agitação . Os clorofenóis extraídos com ultra-som foram 2,4,6-TCP em ambas as campanhas, com valores de áreas de pico próximas a 60.000, e PCP, também detectado em ambas as campanhas, valores de picos de área em torno de $60.000 \mathrm{em}$ Novembro. Pelos cálculos, os valores das áreas corresponderam a concentrações inferiores a $0,50 \mu \mathrm{g} / \mathrm{Kg}$ para 2,4,6-TCP, e menores que $0,50 \mu \mathrm{g} / \mathrm{Kg}$ para PCP.

Pela extração com o Soxhlet, além de 2,4,6-TCP e PCP, também foi comum nas duas campanhas, o 2,5-DCP. Assim como foi observado para os valores de áreas de pico das 
amostras de água, PCP sofreu decréscimo entre as campanhas de Novembro e Fevereiro, considerando as áreas de pico dos cromatogramas de 271.296 para 97.394, respectivamente.

Pelo método de extração com agitação, observaram-se os clorofenóis 2,3,6-TCP com áreas em torno de 90.000 em ambas as campanhas, e PCP, com valores de 202.841 para 652. 973, respectivamente, para Novembro e para Fevereiro. Na Figura 5.14 são apresentados os valores das áreas de pico dos cromatogramas para os três métodos de extração empregados para sedimentos da estação 1. Cada método foi representado por uma letra, sendo o ultrasom (u), o Soxhlet (S) e a agitação sob barra magnética (a). No método do ultra-som, foram plotadas no gráfico as áreas mais representativas e as mais semelhantes entre as triplicatas. Todos os demais gráficos serão apresentados dessa forma.

Os teores de carbono orgânico e a umidade nessa estação praticamente não sofreram alteração entre as campanhas de Novembro e Fevereiro (Figura 5.15).

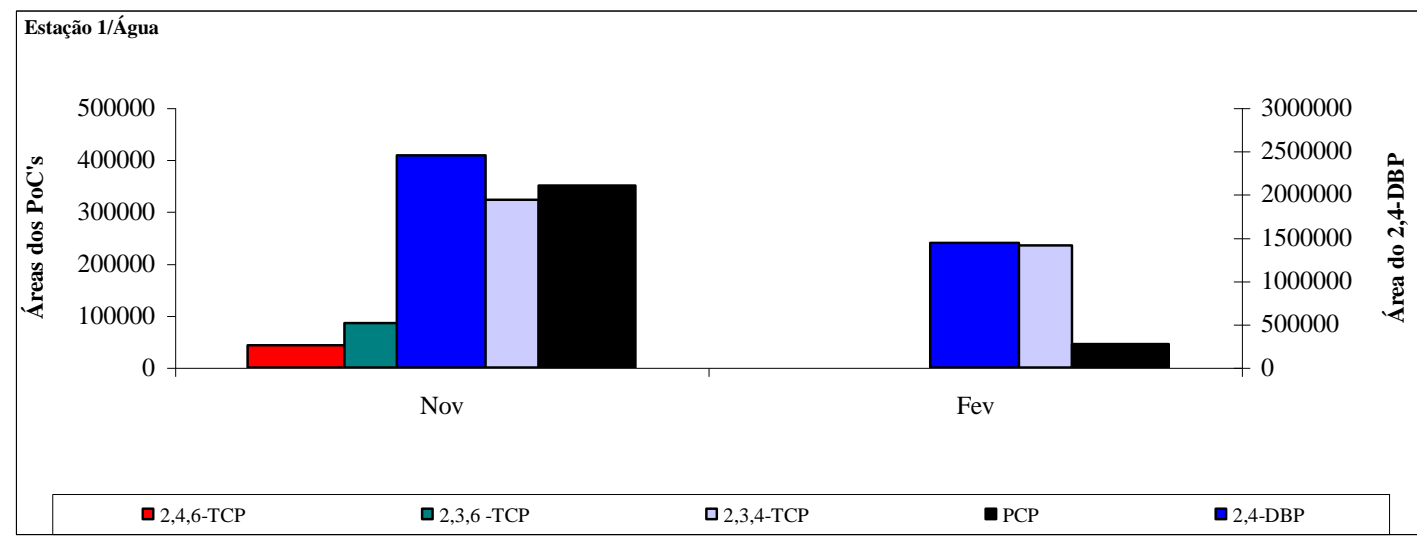

FIGURA 5.12 - VALORES DAS ÁREAS OBTIDAS PELAS ANÁLISES CROMATOGRÁFICAS DAS AMOSTRAS DE ÁGUA DA ESTAÇÃO 1, COLETADAS EM NOVEMBRO/98 E FEVEREIRO/99
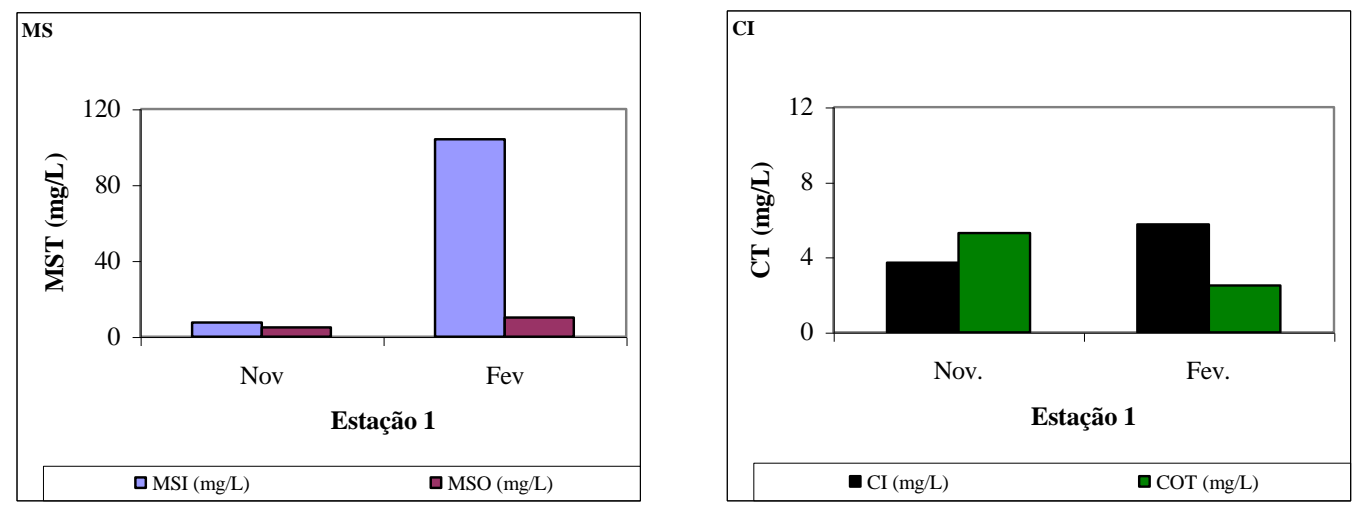


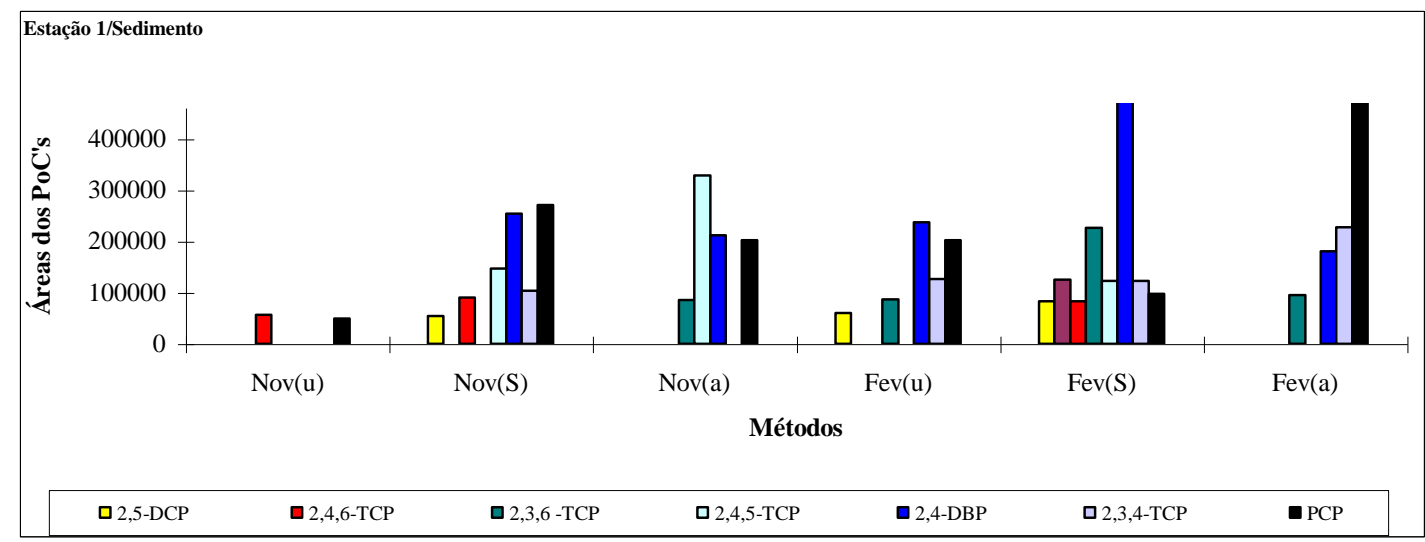

FIGURA 5.14 - VALORES DAS ÁREAS OBTIDAS POR ANÁLISE CROMATOGRÁFICA DAS AMOSTRAS DE SEDIMENTO DA ESTAÇÃO 1 DE NOVEMBRO/98 E FEVEREIRO/99.
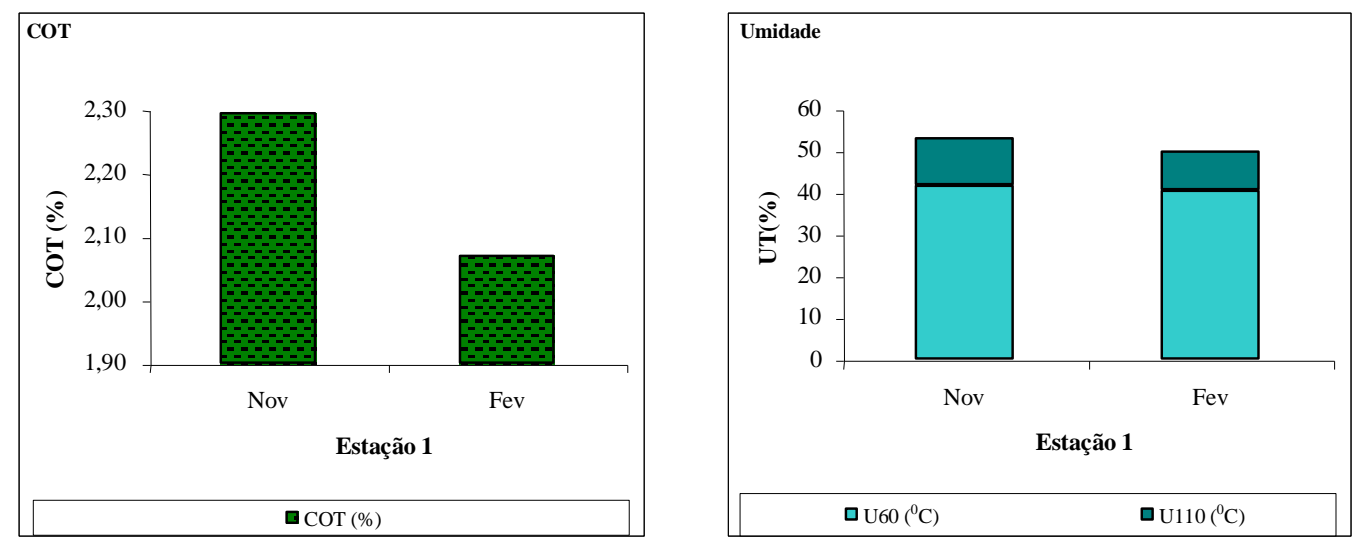

Figura 5.15 - Valores de carbono orgânico total e umidade total a $60^{\circ} \mathrm{C}$ e $110^{\circ} \mathrm{C}$ das amostras de sedimento da estação 1 de Novembro/98 e Fevereiro/99.

Na estação 1, verificou-se que o conteúdo de material em suspensão inorgânico foi predominante nas duas campanhas, possivelmente pelo carreamento de material pelo rio, já que esta estação está localizada no mesmo e tem uma velocidade de fluxo maior que todas as estações. Outro fator que contribuiu bastante para este elevado conteúdo inorgânico na $4^{\mathrm{a}}$ campanha é a influência de chuvas, provavelmente devido a lixiviação de materiais do solo do entorno para o reservatório. Isso pode influenciar os valores de condutividade, turbidez e oxigênio dissolvido, mostrados nas Tabelas 5.36 e 5.44. na $2^{\text {a }}$ campanha, uma possível explicação é o carreamento de material inorgânico. Na estação 1 , o pH da coluna d'água até $2 \mathrm{~m}$ sempre esteve próximo a faixa de 6,1 a 6,4 em ambas as campanhas, no entanto, os 
valores de condutividade diminuíram muito de Novembro/98 para Fevereiro/99, cerca de 316 para $94 \mu \mathrm{S} / \mathrm{cm}$, respectivamente. Isso pode ser devido ao aumento do fluxo de correntes em virtude da precipitação nesses meses, de 26 para 198mm, segundo o CIAGRI (1999), que também justifica o aumento do teor de oxigênio dissolvido de 3 para $6,5 \mathrm{mg} / \mathrm{L}$ e de turbidez de 3,5 uT para 38 uT. Os principais clorofenóis encontrados foram PCP, 2,3,4-TCP, 2,4,6TCP e 2,5-DCP.

\subsubsection{Estação 2}

Nesta estação, foram feitas coletas de água e sedimento nos meses de Maio, Junho e Novembro de 1998 e Fevereiro de 1999. Na Figura 5.16, tem-se uma visão da paisagem da estação obtida na coleta de Novembro/98.

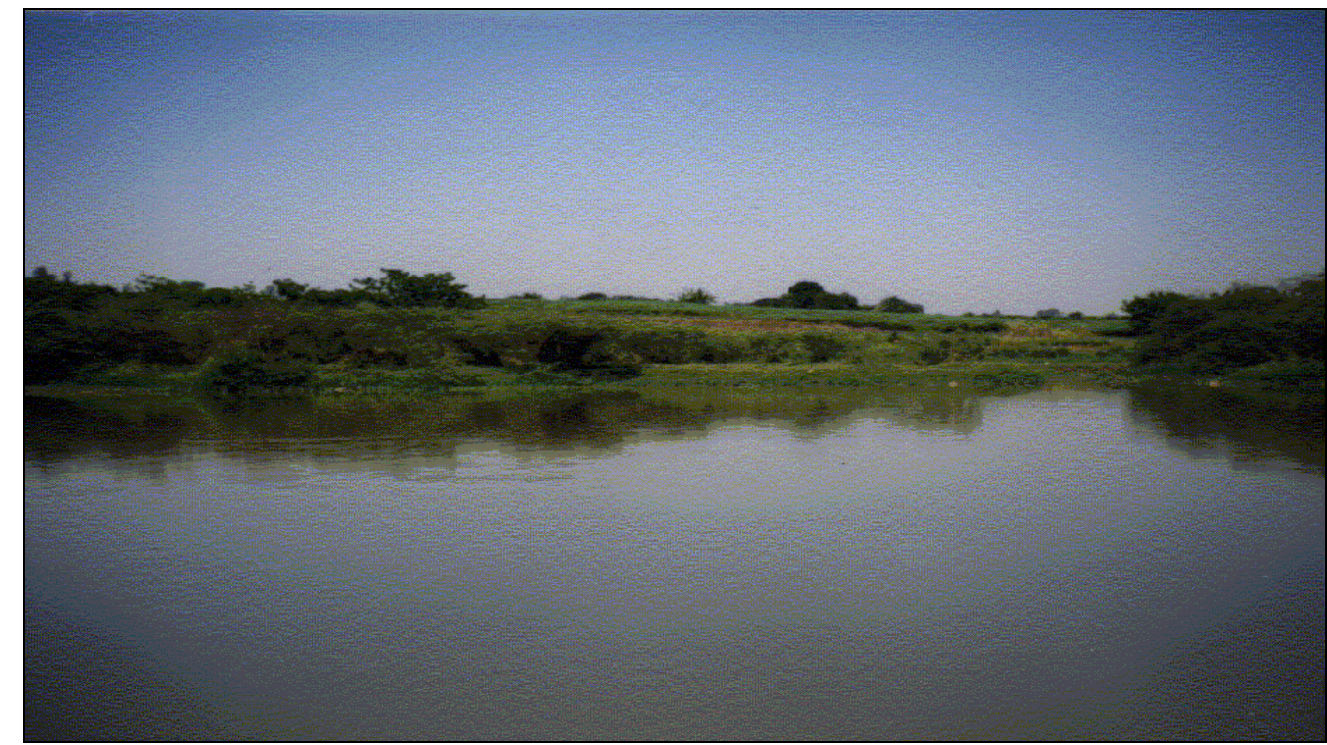

FIGURA 5.16 - VISTA PARCIAL DO ENTORNO DA ESTAÇÃO 2, ENTRADA DO ALAGADO,

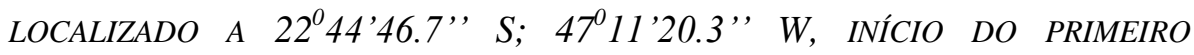
COMPARTIMENTO, COLETA DE NOVEMBRO DE 1998.

O composto PCP foi comum em todas as campanhas, apresentando maiores valores de áreas em Junho de 1998 e Fevereiro de 1999, respectivamente, de 4.123.786 e 413.033. O valor da área de pico de PCP, no cromatograma, em Junho, foi obtido apenas em uma amostra das três réplicas, correspondendo a uma concentração de $0,011 \mu \mathrm{g} / \mathrm{L}$. Porém, devese considerar que nessa campanha ainda não se obtinha áreas similares entre as triplicatas, devido, provavelmente, a uma acidificação inadequada e a distribuição irregular de material em suspensão, que é um possível ponto de adsorção de clorofenóis. 
O composto 2,3,4-TCP não foi detectado apenas na campanha de Junho e apresentou maior área de pico em Fevereiro de 1999, igual a 94.253. Todas as áreas de pico encontradas para os clorofenóis nessa estação corresponderam a concentrações inferiores a $0,01 \mu \mathrm{g} / \mathrm{L}$, exceto para PCP, como já foi visto e para 2,5-DCP, que apresentou concentrações de $0,021 \mu \mathrm{g} / \mathrm{L}$ na campanha de Maio e de $0,010 \mu \mathrm{g} / \mathrm{L}$ na campanha de Novembro. Essas áreas de pico em cromatogramas são apresentadas na Figura 5.17.

Em Maio, houve predominância do teor de carbono orgânico, e em Junho e Fevereiro predominaram teores de carbono inorgânico. Em Novembro, o carbono orgânico foi aproximadamente igual ao carbono inorgânico (Figura 5.18).

As análises do sedimento mostraram que nenhum clorofenol foi comum a todas as campanhas, como pode ser observado na Figura 5.19. Na campanha de Novembro, não foi detectado nenhum clorofenol pelo método extrativo com ultra-som, sendo que em Maio, Junho e Fevereiro, apenas 2,4,6-TCP esteve presente, com concentrações inferiores a $2,50 \mu \mathrm{g} / \mathrm{Kg}$.

A análise de carbono e umidade total foram feitas apenas para as amostras de Novembro e Fevereiro, sendo os valores obtidos apresentados na Figura 5.20.

O conteúdo de carbono orgânico total para a campanha de Novembro foi quase 3 vezes maior que o da campanha de Fevereiro, enquanto que, a umidade total de Novembro foi aproximadamente $8 \%$ menor que a umidade total de Fevereiro. Estes valores podem ser explicados pela elevada precipitação e pelo tempo de residência. Em Novembro, o tempo de residência foi maior devido a menor precipitação, e a taxa de deposição foi maior que a de Fevereiro, permitindo uma maior predominância de material orgânico no sedimento.

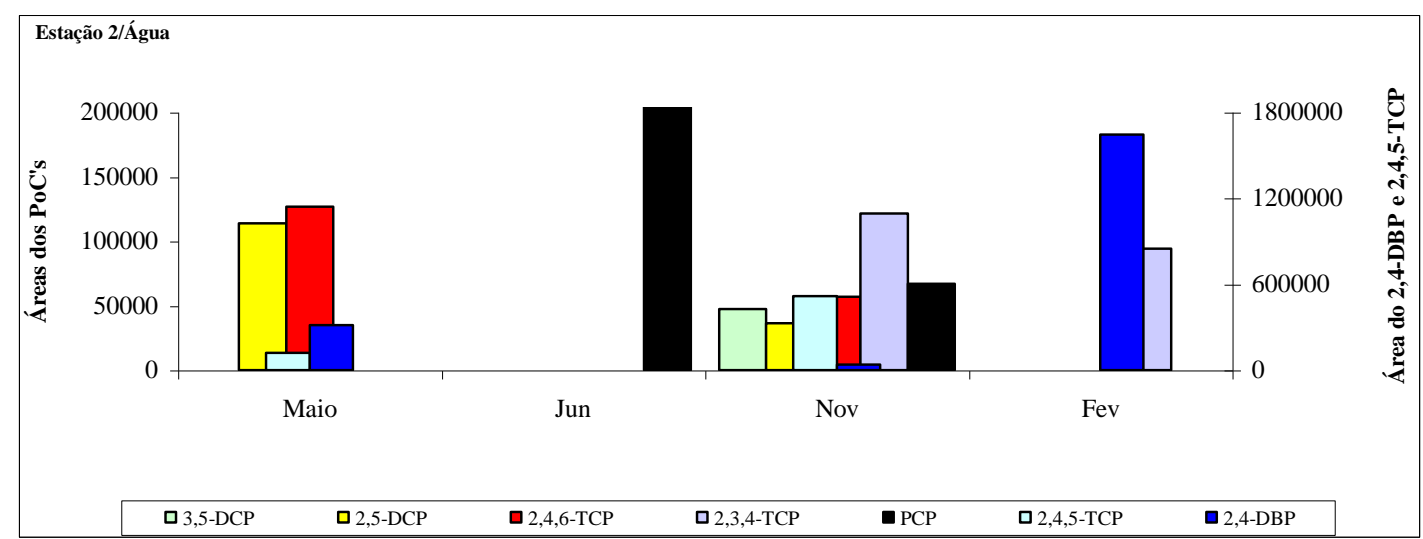

Figura 5.17 - Valores das áreas obtidas pelas análises cromatográficas das amostras de água da estação 2 de Maio, Junho e Novembro/98 e Fevereiro/99. 

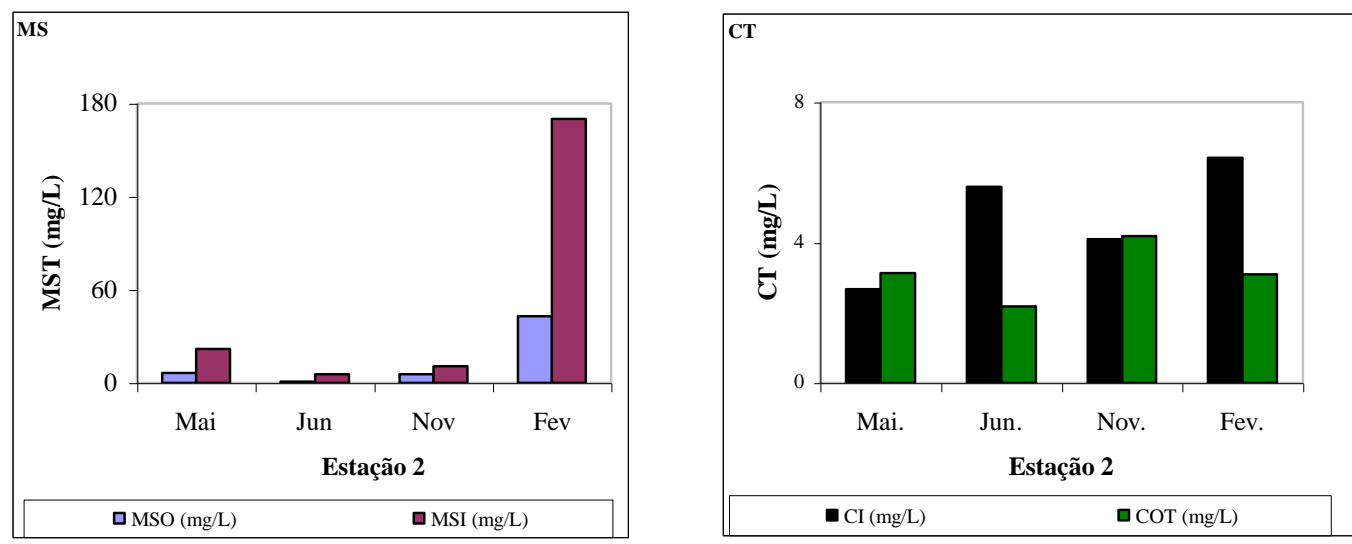

FIGURA 5.18 - VALORES DO MATERIAL EM SUSPENSÃO TOTAL, FRAÇÕES INORGÂNICAS E ORGÂNICAS E CARBONO TOTAL, FRAÇÕES INORGÂNICAS E ORGÂNICAS DAS AMOSTRAS DE ÁGUA DA ESTAÇÃO 2 DE MAIO, JUNHO E NOVEMBRO/98 E FEVEREIRO/99.

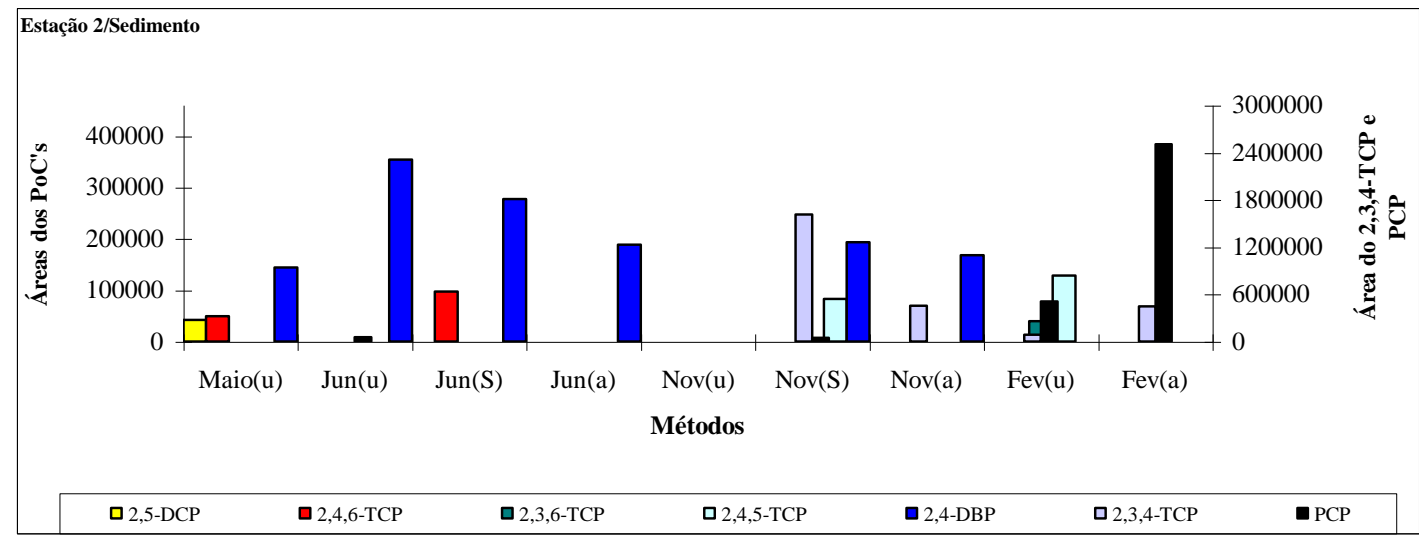

FIGURA 5.19 - VALORES DAS ÁREA OBTIDAS POR ANÁLISES CROMATOGRÁFICAS DAS AMOSTRAS DE SEDIMENTO DA ESTAÇÃO 2 DE MAIO, JUNHO E NOVEMBRO/98 E FEVEREIRO/99.
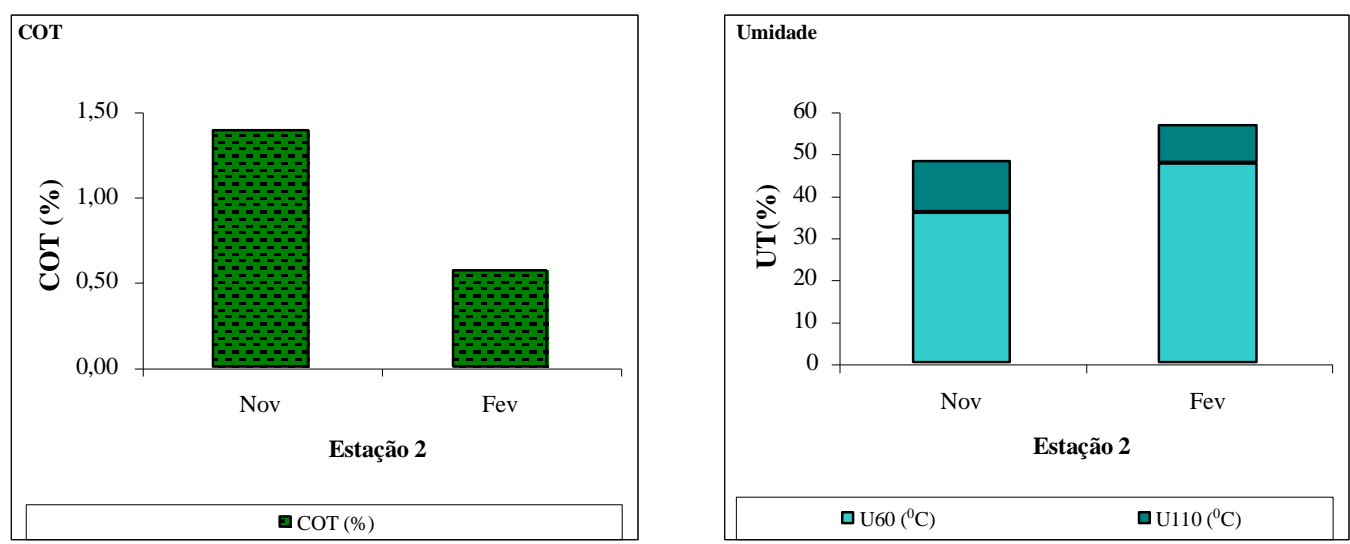


\section{FIGURA 5.20 - VALORES DE CARBONO ORGÂNICO TOTAL E UMIDADE TOTAL A $60^{\circ} \mathrm{C}$ E $110^{\circ} \mathrm{C}$ DAS AMOSTRAS DE SEDIMENTO DA ESTAÇÃO 2 DE NOVEMBRO/98 E FEVEREIRO/99}

$\mathrm{Na}$ estação 2, verificou-se que nas amostras de água predominou o conteúdo de material em suspensão inorgânico provavelmente devido a grande influência que esta estação sofre do rio Atibaia, recebendo aportes de material, visto que se localiza no início do reservatório. Os valores de condutividade, turbidez e oxigênio dissolvido, mostrados nas Tabelas 5.27, 5.30, 5.35 e 5.43 sofreram pequenas variações nas estações, porém superiores entre as campanhas, exceto para os valores de $\mathrm{pH}$ da coluna d'água até $2,40 \mathrm{~m}$, que oscilaram entre as campanhas na faixa de 6,21 a 6,81 . Os valores de condutividade da primeira a quarta campanha, estiveram próximos a, respectivamente, 2,93, 104, 314 e $94 \mu \mathrm{S} / \mathrm{cm}$. É provável que o acréscimo na campanha de Novembro tenha sido devido à intensa atividade fotossintética observada nessa época, ao mesmo tempo em que ocorria a degradação da matéria orgânica nas camadas mais profundas. Os valores de turbidez decresceram de 30 uT para 6 uT da primeira para segunda campanha, mantendo-se em 4 uT na terceira, e 53 uT na segunda. Esses valores talvez possam ser explicados pela precipitação medida no período amostrado, como observado na Tabela 5.26, a precipitação diminuiu de 97,60 $\mathrm{mm}$ para 26,60 $\mathrm{mm}$, de Maio para Junho, apresentando valores semelhantes ao de Junho, em Novembro, e igual a 198,30 mm em Fevereiro. Os valores de oxigênio dissolvido nessa estação nas quatro campanhas foram de 2,16 e 2,89 mg/L, respectivamente para a primeira e segunda, decrescendo a $0,03 \mathrm{mg} / \mathrm{L}$ na terceira e igual a $5,94 \mathrm{mg} / \mathrm{L}$ na quarta campanha. Os valores determinados em todas as campanhas para a maioria das estações são considerados baixos devido ao estado de hipereutrofização em que se encontra o reservatório, com predominância de decomposição em determinados compartimentos. Os principais clorofenóis encontrados na água foram PCP e 2,3,4-TCP, e no sedimento 2,4,6TCP.

As variáveis físico-químicas medidas nas colunas d'água da estação 2, em todas as campanhas, estão apresentadas na Figura 5.21. 

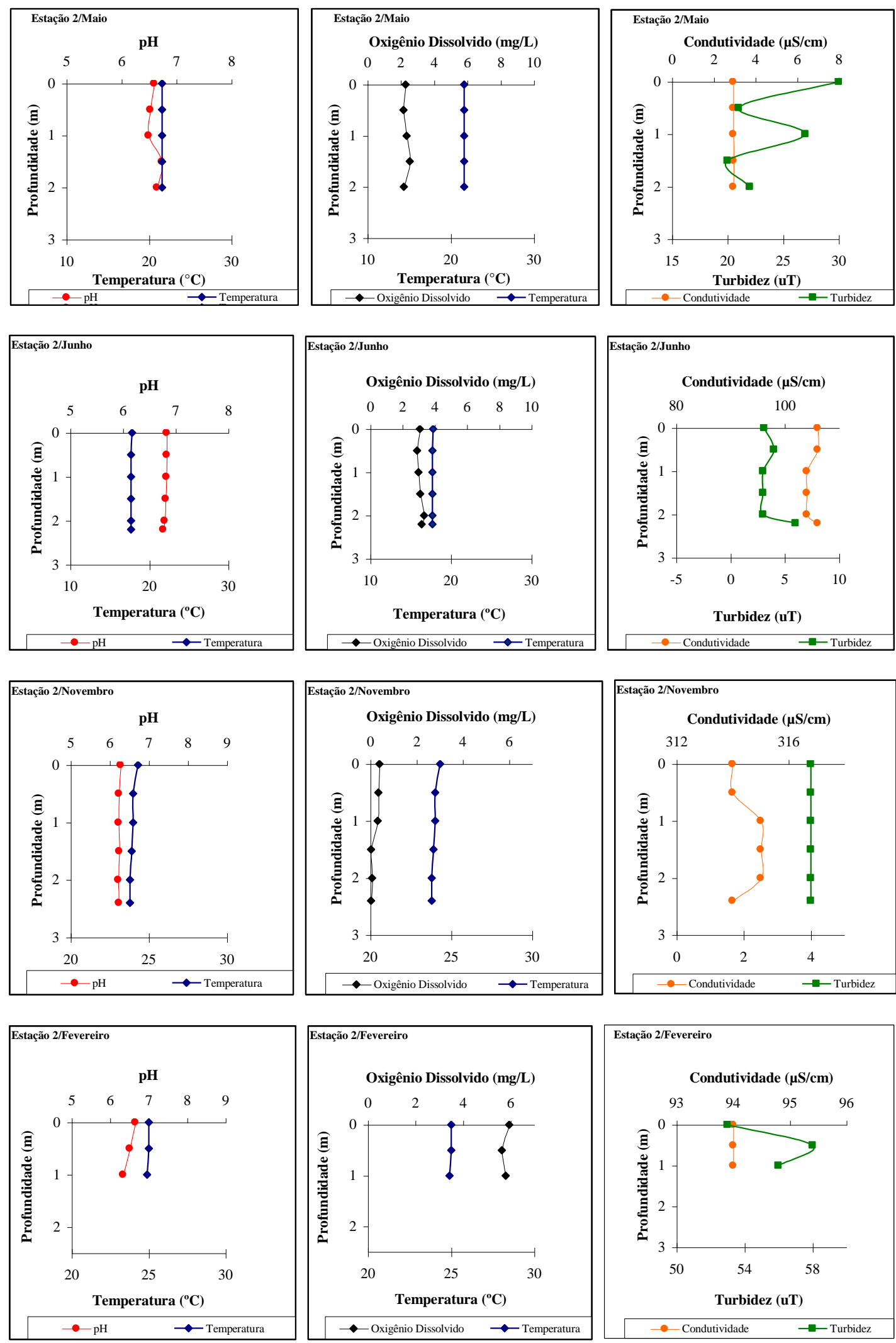

Figura 5.21 - Perfis de pH, temperatura $\left({ }^{\circ} \mathrm{C}\right)$, oxigênio dissolvido $(\mathrm{mg} / \mathrm{L})$, condutividade ( $\mu$ S/cm) e turbidez, na Estação 2, campanhas de Maio, Junho e Novembro de 1998 e Fevereiro de 1999. 


\subsubsection{Estação 3}

Nessa estação foram feitas coletas apenas nas campanhas de Novembro e Fevereiro. Nas Figuras 5.22 e 5.23, podem ser notadas as diferenças entre as campanhas de Novembro e Fevereiro, atribuídas principalmente à elevada precipitação ocorrida na campanha de Fevereiro e conseqüente carreamento de material para o reservatório.

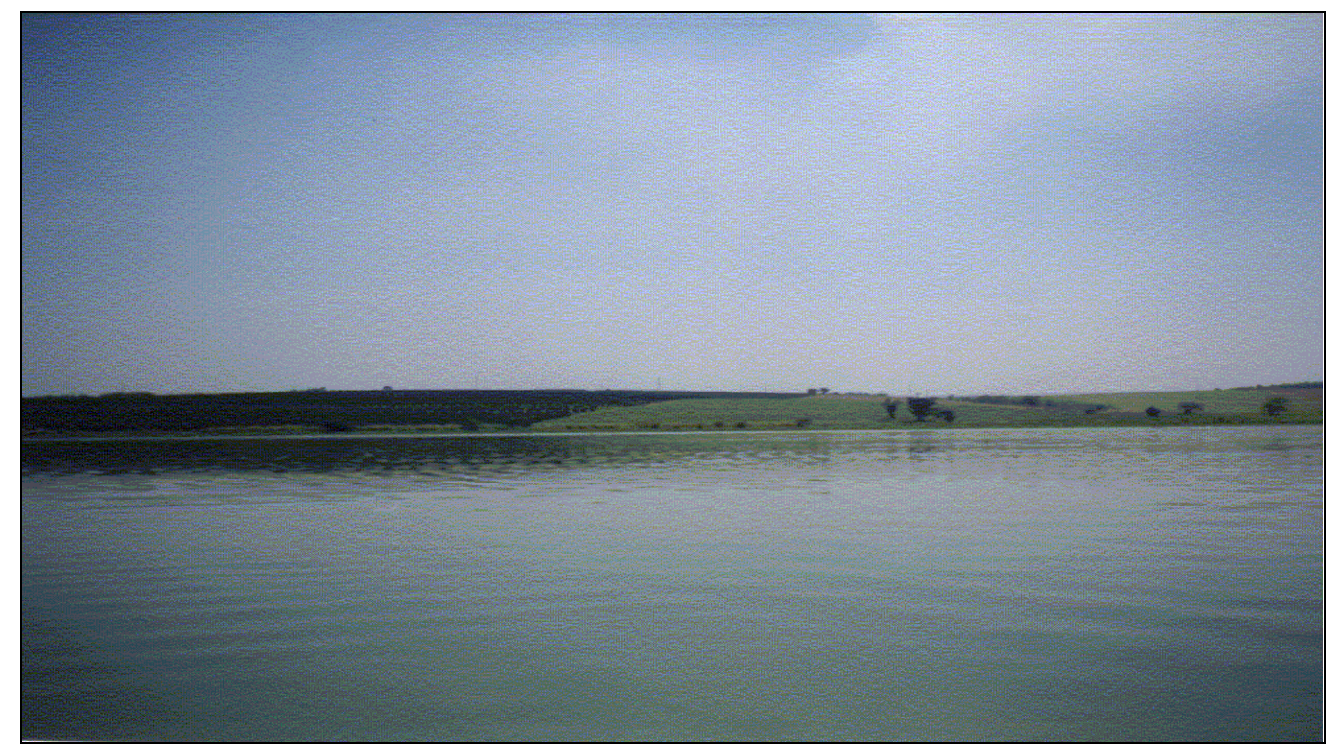

FIGURA 5.22 - VISTA PARCIAL DO ENTORNO DA ESTAÇ̃̃O 3, LOCALIZADA A 22 43'32.8'" S; $47^{\circ} 13^{\prime} 45^{\prime}$ ' $W$, CENTRO DO SEGUNDO COMPARTIMENTO, COLETA DE NOVEMBRO DE 1998 .

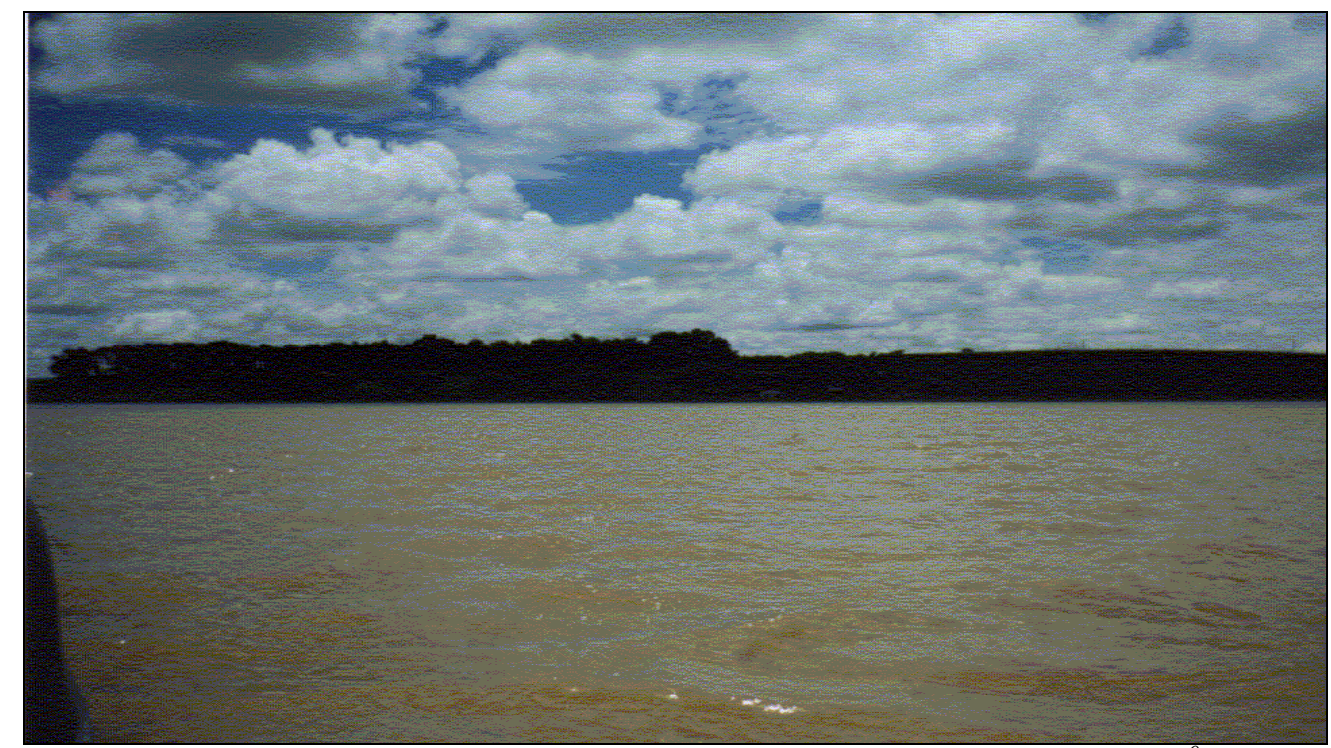

FIGURA 5.23 - VISTA PARCIAL DO ENTORNO DA ESTAÇ̃̃O 3, LOCALIZADA A 220 43'32.8'" S; $47^{\circ} 13$ ' $45^{\prime}$ ' W, CENTRO DO SEGUNDO COMPARTIMENTO, COLETA DE FEVEREIRO DE 1999. 
Na campanha de Novembro houve estratificação química da água e a coleta foi feita em 3 profundidades.

O composto 2,3,6-TCP esteve presente em ambas as campanhas, entretanto apresentou-se com maiores áreas de picos nos cromatogramas da campanha de Novembro, nas três profundidades coletadas, respectivamente para 0,2 e $7 \mathrm{~m}$ a $624.503 ; 857.951$ e 1245.420, todas estas áreas correspondem a concentrações inferiores a $0,01 \mu \mathrm{g} / \mathrm{L}$.

A substância 2,5-DCP somente foi detectada em uma das amostras da triplicata realizada na camada mais profunda da campanha de Novembro $(7 \mathrm{~m})$, não sendo detectada na campanha de Fevereiro, entretanto, a área de pico de cromatograma encontrada nessa amostra correspondeu a uma concentração de $0,013 \mu \mathrm{g} / \mathrm{L}$, enquanto as concentrações para os demais clorofenóis detectados corresponderam a valores inferiores a $0,01 \mu \mathrm{g} / \mathrm{L}$.

Os cromatogramas das análises de Novembro e Fevereiro mostraram que houve um decréscimo de 2,3,4-TCP de uma campanha para outra. Em Novembro, esse composto foi detectado em duas profundidades diferentes, na superfície e em $7 \mathrm{~m}$, com maiores valores nessa última. O valor médio das áreas dos picos foi de 333.89. Em Fevereiro, a área média dos picos dos cromatogramas da triplicata foi 121.351 para o composto 2,3,4-TCP. Esse decréscimo ocorrido nas áreas de pico do clorofenol pode ser devido `a diluição favorecida pela maior precipitação na campanha de Fevereiro e pode ser observado na Figura 5.26.

O composto PCP também esteve presente nas amostras das campanhas de Novembro, nas três profundidades, e em Fevereiro, sendo que a maior área de PCP encontrada nos cromatogramas foi nessa última campanha, igual a 937975. Não se pode considerar esse valor como conclusivo, visto que foi encontrado em apenas uma das amostras das triplicatas realizadas.

O material em suspensão orgânico predominou em todas as camadas da campanha de Novembro, como pode ser visto na Figura 5.27. Esse valor era esperado, visto que, dentre as campanhas, o tempo de residência de Novembro foi o maior, permitindo uma maior deposição de material. Em Fevereiro, houve predominância do material em suspensão inorgânico e do carbono inorgânico devido, principalmente, ao aporte de material carreado pelas chuvas. Estas últimas considerações sobre material em suspensão são observadas na análise das Figuras 5.24 e 5.25. Na campanha de Novembro, o elevado número de macrófitas e também o florescimento de algas, foram verificados também em toda extensão do reservatório, o que não ocorreu na campanha de Fevereiro. 


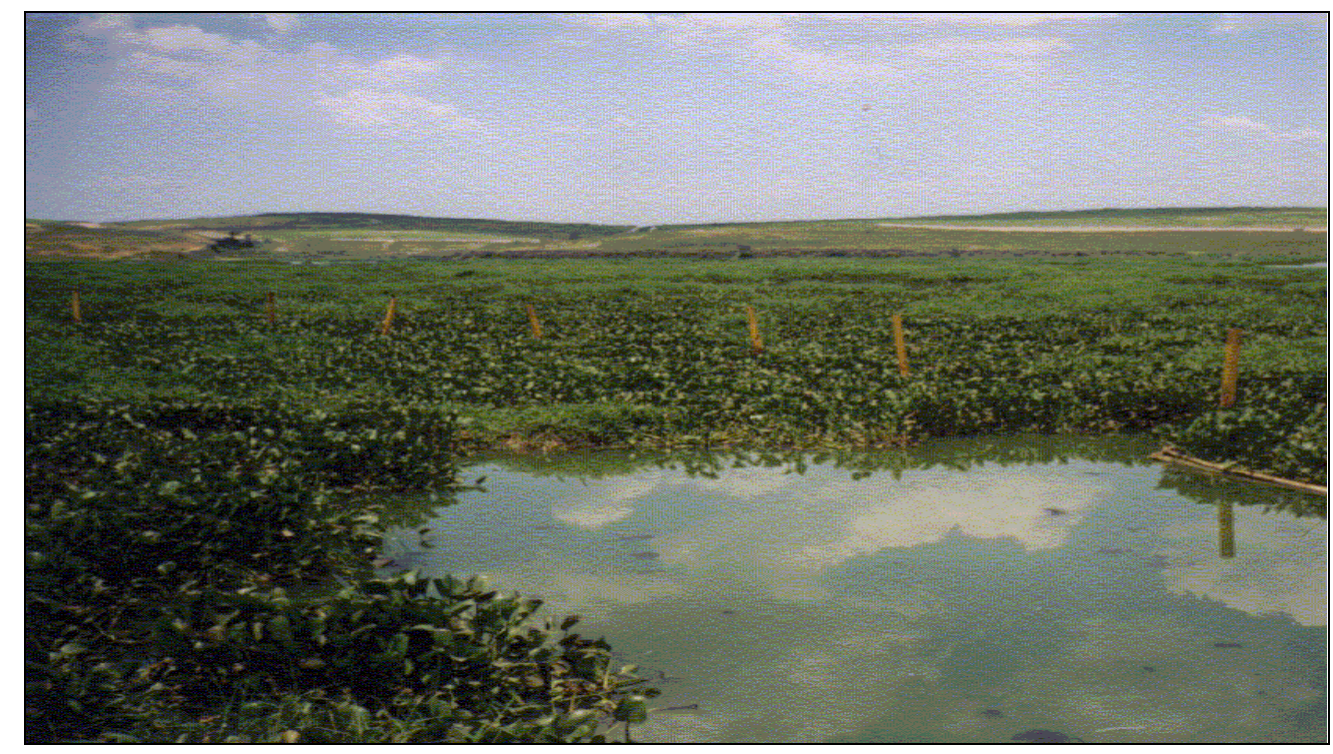

FIGURA 5.24 - VISTA PARCIAL DO PONTO DE SAÍDA DOS BARCOS PARA AS COLETAS, COLETA DE NOVEMBRO DE 1998.

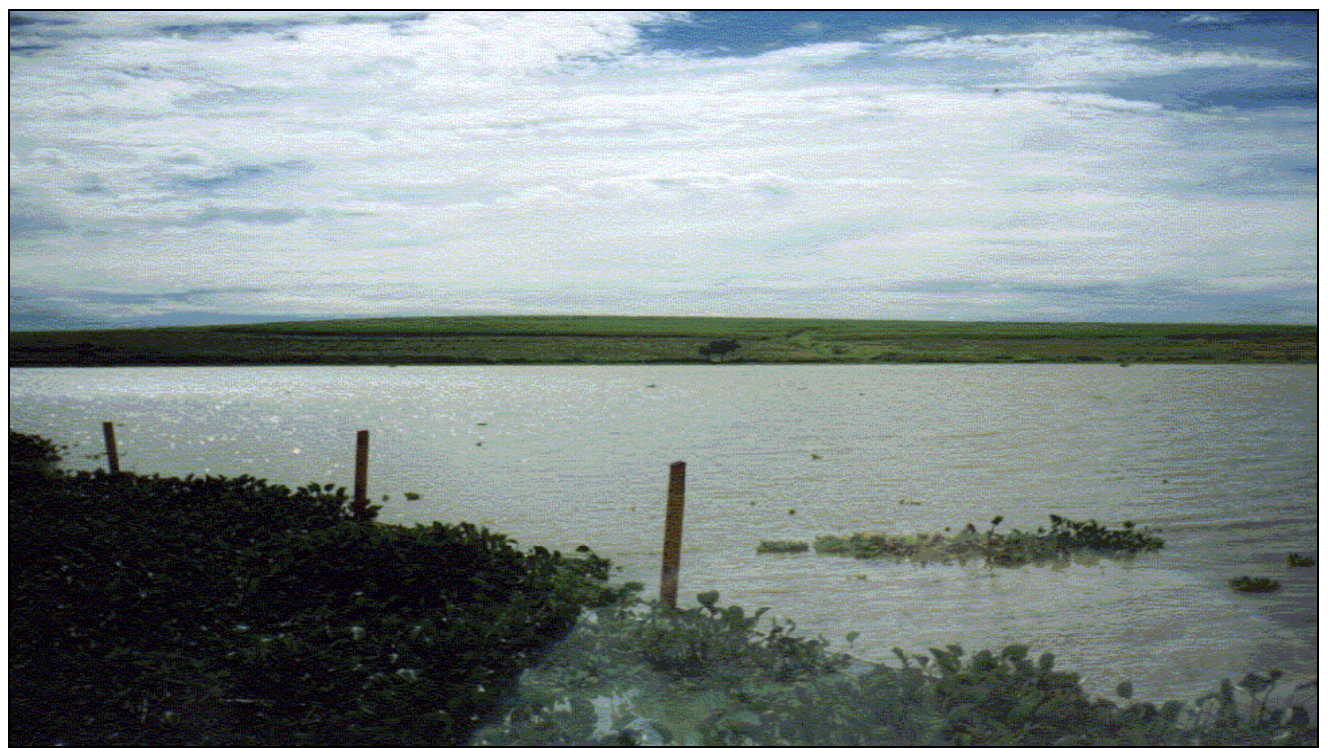

FIGURA 5.25 - VISTA PARCIAL DO PONTO DE SAÍDA DOS BARCOS PARA AS COLETAS, COLETA DE FEVEREIRO DE 1999.

$\mathrm{Na}$ análise dos sedimentos da campanha de Novembro foi utilizado apenas o método extrativo do ultra-som. Comparando-se os valores de áreas de picos cromatográficos encontrados nessa estação em Novembro e Fevereiro, utilizando-se o ultra-som como método extrativo, não foram encontrados clorofenóis comuns às 2 campanhas. Na campanha de Novembro foram detectados 2,3,4-TCP, em concentração de 0,025 $\mu \mathrm{g} / \mathrm{Kg}$, e PCP, em concentrações inferiores $2,5 \mu \mathrm{g} / \mathrm{Kg}$, e na campanha de Fevereiro, apenas 2,3,6-TCP, também em concentrações inferiores a 2,5 $\mu \mathrm{g} / \mathrm{Kg}$. Estes valores podem ser observados na Figura 
5.27. Os resultados com extração em Soxhlet mostraram que a detecção foi apenas do composto PCP na campanha de Fevereiro.

O carbono total da campanha de Novembro foi $10 \%$ maior que o da campanha de Fevereiro, enquanto que a umidade total foi $12 \%$ menor (Figura 5.29).

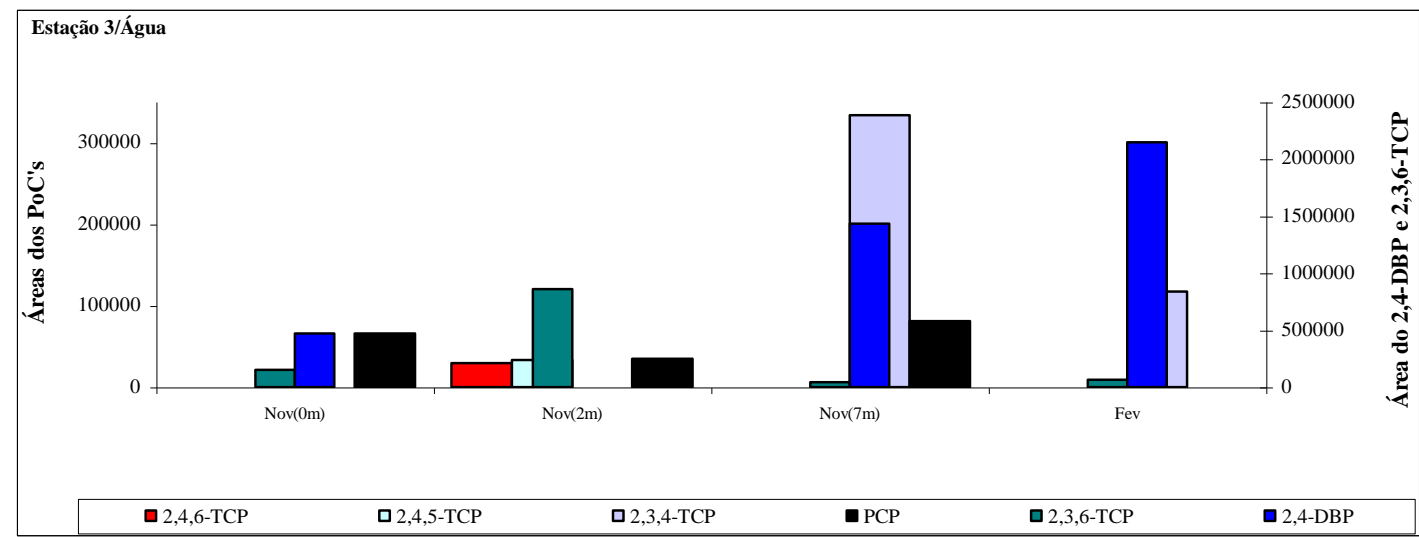

FIGURA 5.26 - VALORES DAS ÁREAS OBTIDAS PELAS ANÁLISES CROMATOGRÁFICAS DAS AMOSTRAS DE ÁGUA DA ESTAÇÃO 3 DE NOVEMBRO/98 E FEVEREIRO/99.
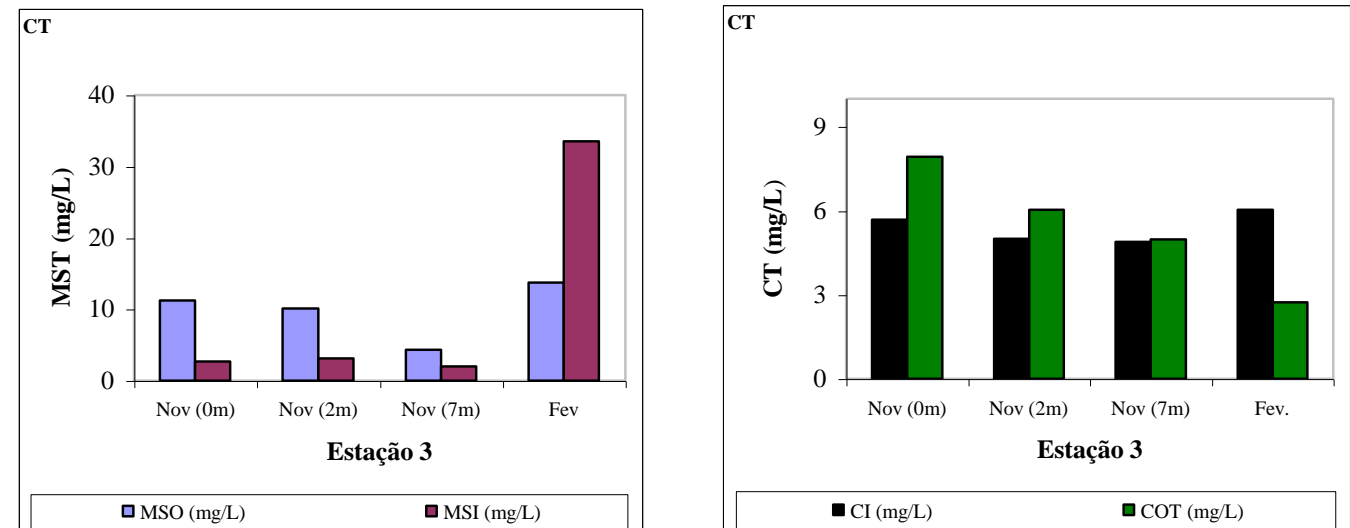

FIGURA 5.27 - VALORES DO MATERIAL EM SUSPENSÃO TOTAL, FRAÇÕES INORGÂNICAS E ORGÂNICAS E CARBONO TOTAL, FRAÇÕES INORGÂNICAS E ORGÂNICAS DAS AMOSTRAS DE ÁGUA DA ESTAÇÃO 3 DE NOVEMBRO/98 E FEVEREIRO/99. 


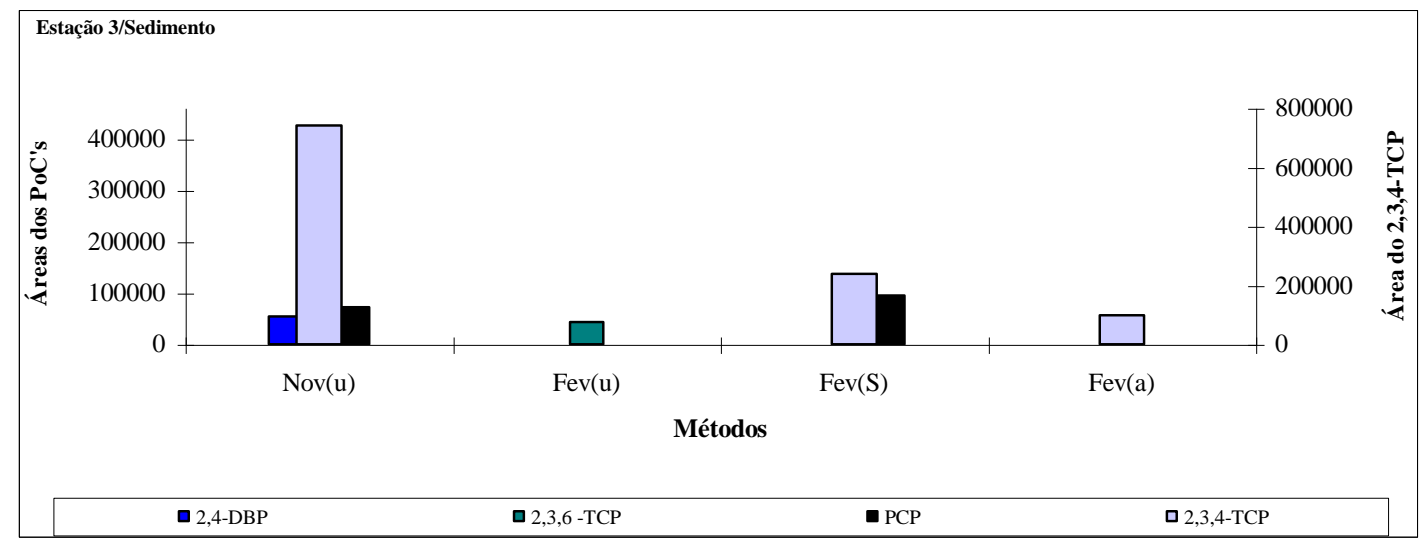

FIGURA 5.28 - VALORES DAS ÁREAS OBTIDAS PELAS ANÁLISES CROMATOGRÁFICAS DAS AMOSTRAS DE SEDIMENTO DA ESTAÇÃO 3 DE NOVEMBRO/98 E FEVEREIRO/99.
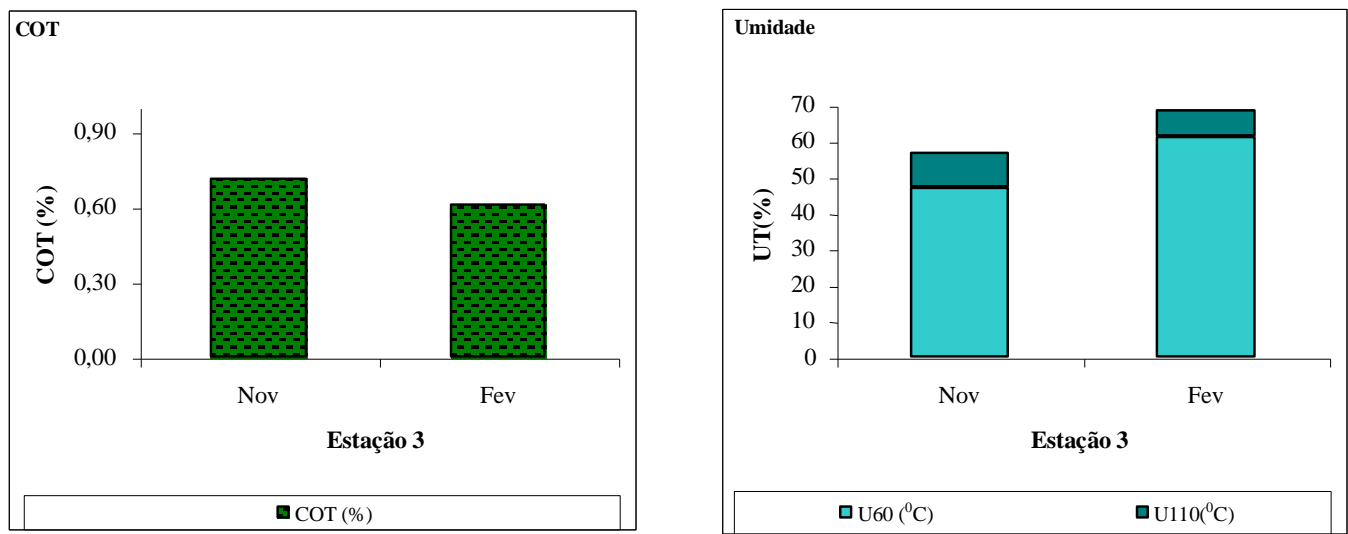

FIGURA 5.29 - VALORES DE CARBONO ORGÂNICO TOTAL E UMIDADE TOTAL A $60^{\circ} \mathrm{C}$ E $110^{\circ} \mathrm{C}$ DAS AMOSTRAS DE SEDIMENTO DA ESTAÇÃO 3, COLETADAS EM NOVEMBRO/98 E FEVEREIRO/99.

Na estação 3, verificou-se que o conteúdo de material em suspensão orgânico predominou em Novembro e o inorgânico em Fevereiro, justificados pelo maior comprimento do dia e conseqüentemente maior biomassa de macrófitas e algas em Novembro e a carga inorgânica elevada em Fevereiro é devido ao aporte de material em conseqüência da intensa precipitação. Na coluna d'água até $10 \mathrm{~m}$, houve estratificação térmica e química apenas na campanha de Novembro, cujas causas podem ser devidas a diversos fatores, como alta radiação (Tabela 5.24), horário em que a coleta foi feita (pico máximo de insolação), baixa precipitação (Tabela 5.26) e provavelmente pela baixa incidência de ventos no dia da coleta (Tabela 5.23), condições essas que possibilitam intensa atividade fotossintética na superfície, degradação da matéria orgânica no fundo e baixa circulação da água. 
Quanto aos clorofenóis encontrados na água, 2,36-TCP, 2,3,4-TCP e PCP foram comuns em ambas as campanhas, sendo que para 2,3,4-TCP houve um decréscimo na concentração de Novembro para Fevereiro possivelmente devido a diluição. Na análise dos sedimentos não houve clorofenóis comuns às duas campanhas.

Os parâmetros físico-químicos medidos nas colunas d'água da estação 3, nas campanhas de Novembro e Fevereiro, estão apresentados na Figura 5.30.
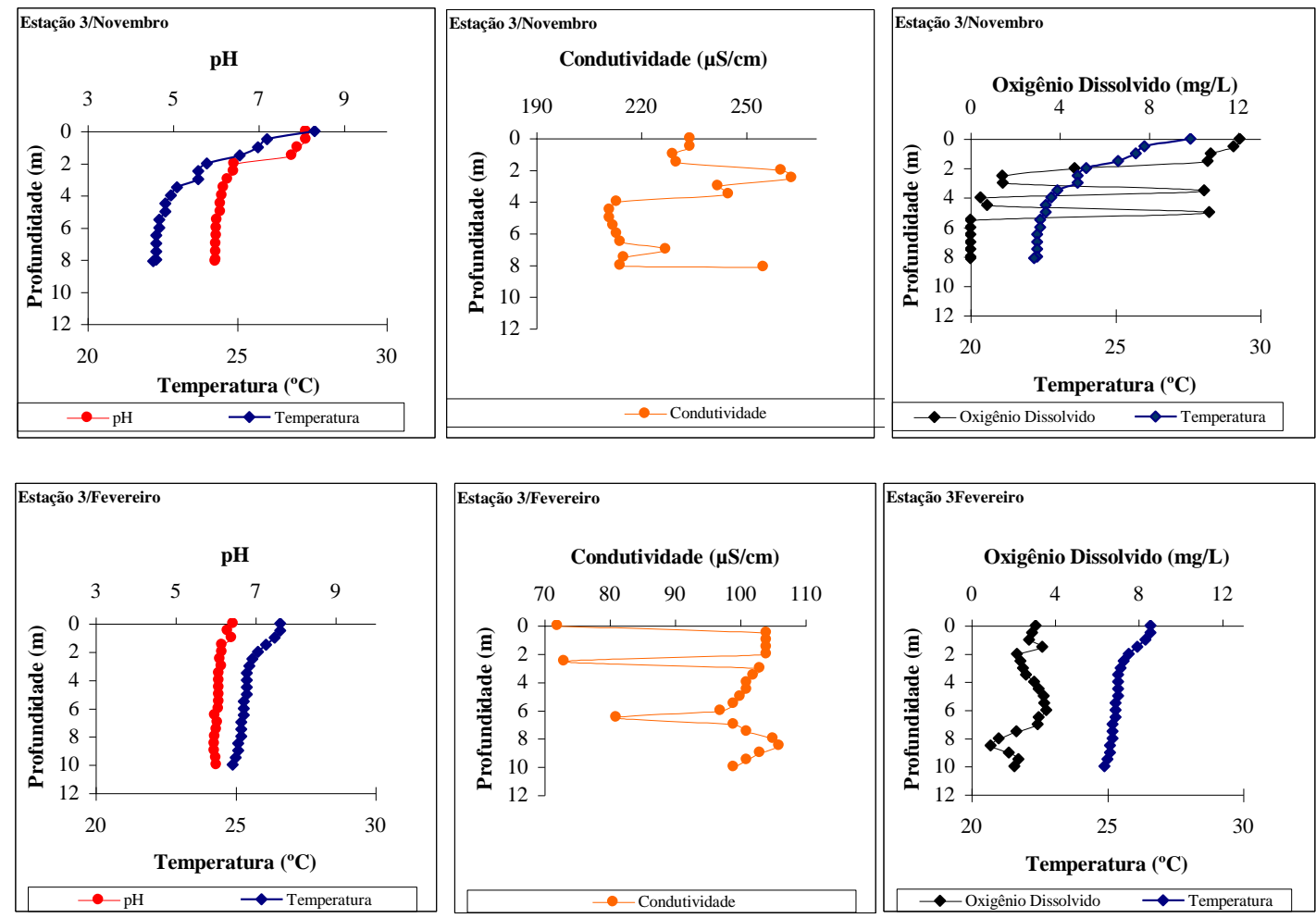

Figura 5.30 - Perfis de pH, temperatura $\left({ }^{\circ} \mathrm{C}\right)$, oxigênio dissolvido $(\mathrm{mg} / \mathrm{L})$, condutividade ( $\mu \mathrm{S} / \mathrm{cm})$ e turbidez, na Estação 3, campanhas de Novembro e Fevereiro

\subsubsection{Estação 4}

Foram feitas coletadas de água nas campanhas de Junho e Novembro de 1998 e Fevereiro de 1999. Para o sedimento foram feitas nessa estação coletas em todas as campanhas. Uma visão da estação está apresentada na Figura 5.31. 


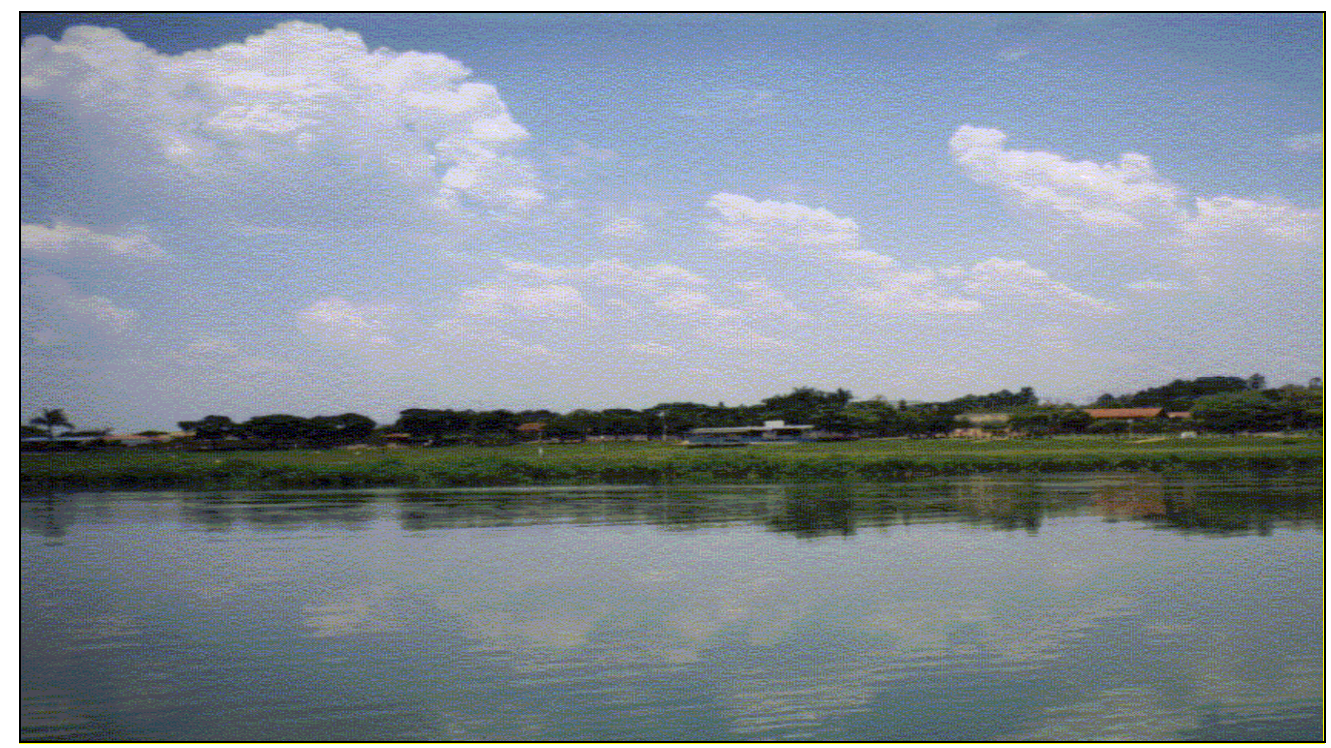

FIGURA 5.31 - VISTA PARCIAL DO ENTORNO DA ESTAÇÃO 4, LOCALIZADA A 22041'58.3'” S; 47'16'38.6" W, CENTRO DO SEGUNDO COMPARTIMENTO, COLETA DE NOVEMBRO DE 1998.

Houve estratificação no reservatório nas campanhas de Novembro e Fevereiro, tendo sido realizadas coletas em 3 profundidades, na superfície, a 8 e $14 \mathrm{~m}$ em Novembro, e na superfície e a 2, 5 e 4 em Fevereiro.

O composto 2,3,6-TCP foi comum a todas as campanhas, estando presente inclusive nas 3 profundidades coletadas em Novembro e em Fevereiro, sempre em concentrações inferiores a $0,010 \mu \mathrm{g} / \mathrm{L}$. Foram registradas maiores áreas de picos nos cromatogramas dos meses de Junho e Novembro na superfície, respectivamente, 1.410 .515 e 1.253.805. Ao contrário do que ocorreu na estação 3, para a campanha de Novembro, quando as maiores áreas dos cromatogramas foram detectadas no fundo, nessa estação a maior área foi registrada na superfície. Em Fevereiro, as áreas dos cromatogramas apresentaram-se como na estação 3, como pode ser observado na Figura 5.32.

A substância PCP também foi encontrada nos cromatogramas em todas as campanhas, em concentrações inferiores a $0,010 \mu \mathrm{g} / \mathrm{L}$, porém não foi detectado na camada inferior do reservatório, tanto na campanha de Novembro, como na superfície do reservatório, na campanha de Fevereiro.

O composto 2,5-DCP somente foi detectado na campanha de Junho, sendo determinadas concentrações de $0,012,0,016$ e inferior a $0,01 \mu \mathrm{g} / \mathrm{L}$ nas amostras da triplicata.

O material em suspensão inorgânico foi maior na superfície do reservatório em Novembro e nas 3 camadas de Fevereiro (superfície, 8 e 14m). Na camada inferior do reservatório, na campanha de Novembro, a 4m, o material em suspensão orgânico foi 
aproximadamente igual ao material inorgânico (Figura 5.33). Em Novembro, o carbono inorgânico foi aproximadamente igual ao inorgânico em todas as camadas (superfície, 8 e 14m) e em Fevereiro, foi maior em todas as camadas (superfície, 2,5 e 4m).

Observando-se os resultados das análises do sedimento, independente do método de extração de clorofenóis empregado, 2,5-DCP, 2,3,6-TCP e 2,4,5-TCP foram registrados em todas as campanhas (Figura 5.34). 2,3,4-TCP só não foi registrado na campanha de Maio. Na campanha de Fevereiro, através da extração por ultra-som não detectou-se nenhum pico de clorofenol, e na campanha de Novembro, apenas detectaram-se os compostos 2,3,4-TCP e o PCP, em concentrações inferiores a $2,50 \mu \mathrm{g} / \mathrm{Kg}$. Nas campanhas de Maio e Junho registraram-se diferentes áreas de clorofenóis, apresentando os seguintes compostos em comum: 2,5-DCP, 2,4,6-TCP, 2,3,6-TCP e 2,3,4-TCP, em concentrações inferiores a 2,50 $\mu \mathrm{g} / \mathrm{Kg}$. Nas extrações com o Soxhlet feitas em Junho, Novembro e Fevereiro, os compostos 2,4,6-TCP e PCP foram detectados. Através do método de extração com agitação, empregado nas mesmas campanhas, além de 2,4,6-TCP e de PCP, foi detectado também 2,3,6-TCP.

O teor de carbono total da campanha de Novembro foi $1 \%$ maior que o teor de Fevereiro. Enquanto a umidade total de Fevereiro foi aproximadamente 19\% maior que a de Novembro, provavelmente devido à elevada precipitação na última campanha (Figura 5.35).

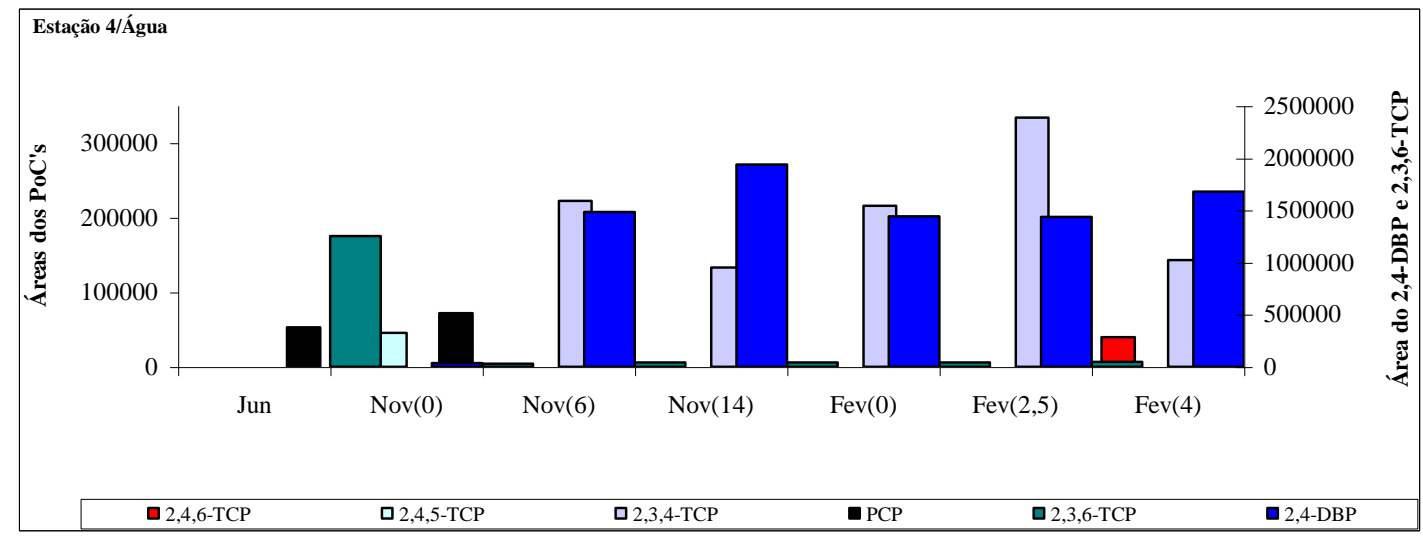

FIGURA 5.32 - VALORES DAS ÁREAS OBTIDAS PELAS ANÁLISES CROMATOGRÁFICAS DAS AMOSTRAS DE ÁGUA DA ESTAÇÃO 4, COLETADAS EM MAIO, JUNHO E NOVEMBRO/98 E FEVEREIRO/99. 

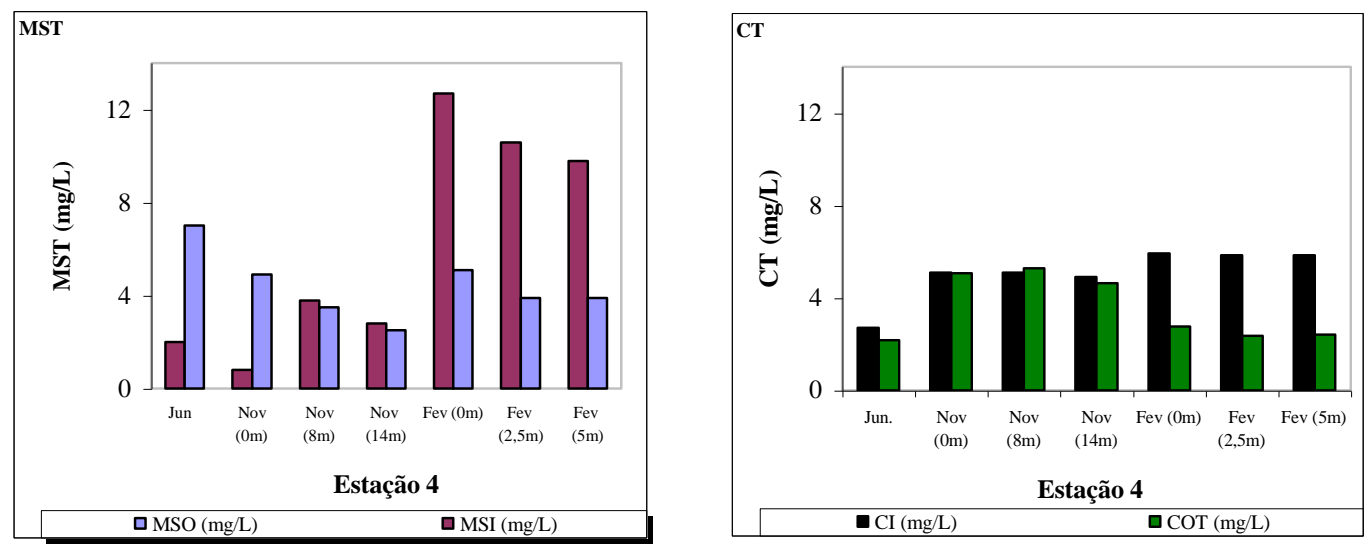

Figura 5.33 - Valores do material em suspensão total, frações inorgânicas e orgânicas e carbono total, frações inorgânicas e orgânicas, das amostras de água da estação 4, coletadas em Maio, Junho e Novembro/98 e Fevereiro/99.

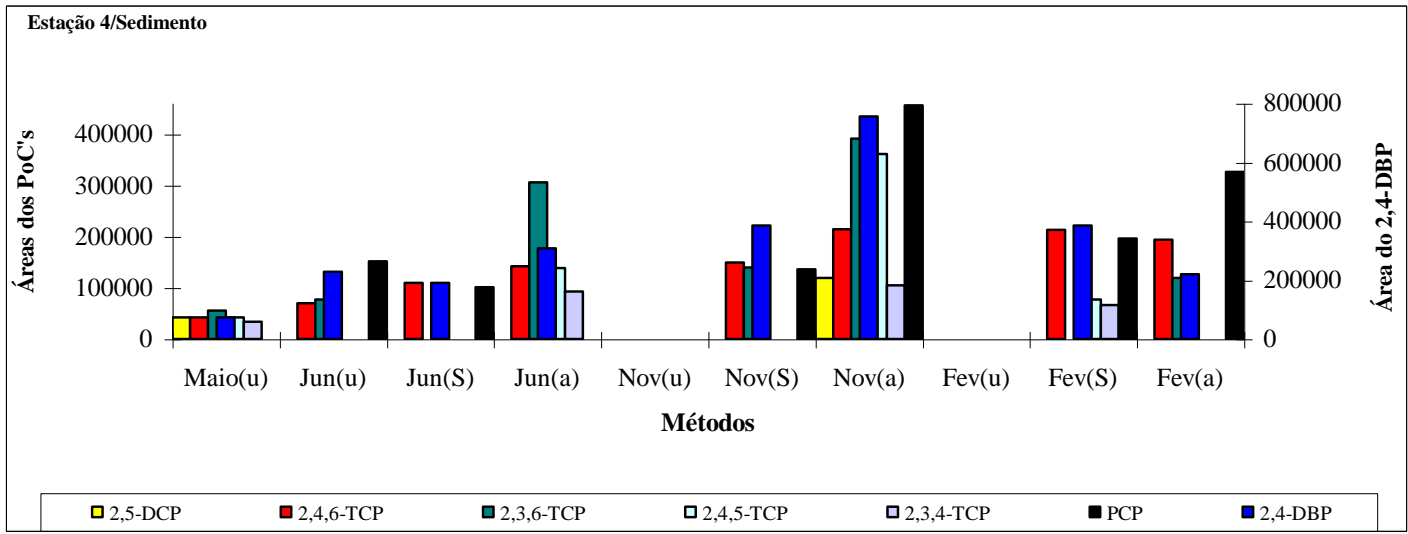

FIGURA 5.34 - VALORES DAS ÁREAS OBTIDAS PELAS ANÁLISES CROMATOGRÁFICAS DAS AMOSTRAS DE SEDIMENTO DA ESTAÇÃO 4, COLETADAS EM MAIO, JUNHO E NOVEMBRO/98.
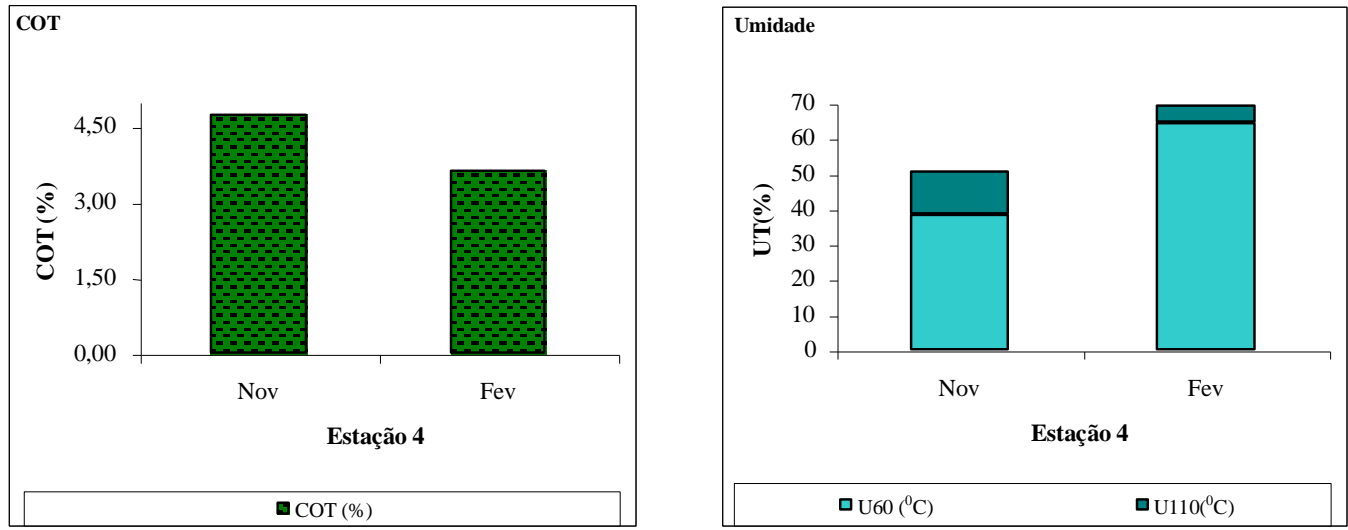
FIGURA 5.35 - VALORES DE CARBONO ORGÂNICO TOTAL E UMIDADE TOTAL A $60^{\circ} \mathrm{C}$ E $110^{\circ} \mathrm{C}$ DAS AMOSTRAS DE SEDIMENTO DA ESTAÇÃO 4, COLETADAS EM MAIO, JUNHO E NOVEMBRO/98 E FEVEREIRO/99.

$\mathrm{Na}$ segunda campanha as análises visaram basicamente a caracterização do reservatório. Nessa estação foram coletadas amostras de água em diferentes profundidades na $3^{\mathrm{a}}$ e $4^{\mathrm{a}}$ campanhas. Em Fevereiro, houve predominância de material inorgânico nas três profundidades coletadas, enquanto em Novembro este conteúdo foi variável, com predomínio do material orgânico na superfície, porém a diferença entre o conteúdo inorgânico e orgânico nas outras camadas não foi considerada significativa. Os valores de condutividade foram reduzidos praticamente à metade, de Novembro a Fevereiro. Uma possível explicação para este fato é a atividade fotossintética e a degradação de matéria orgânica determinada na campanha de Novembro, pelo alto florescimento de algas a grande decomposição de matéria orgânica com consumo de oxigênio.

$\mathrm{Na}$ análise de clorofenóis em amostras de água dessa estação, os compostos 2,3,6TCP e PCP foram comuns a todas as campanhas, em concentrações inferiores a 0,010 $\mu \mathrm{g} / \mathrm{L}$. Para o sedimento, utilizando o método de extração ultra-som, foram comuns as campanhas de Maio, Junho e Fevereiro os compostos 2,3,6-TCP e 2,4,6-TCP, em concentrações inferiores a 2,50 $\mu \mathrm{g} / \mathrm{Kg}$. O composto 2,3,4-TCP foi comum a todas as campanhas apresentando sempre concentrações inferiores a $2,50 \mu \mathrm{g} / \mathrm{Kg}$.

Os parâmetros físico-químicos medidos nas colunas d'água da estação 4, em todas as campanhas, estão apresentados na Figura 5.36. 

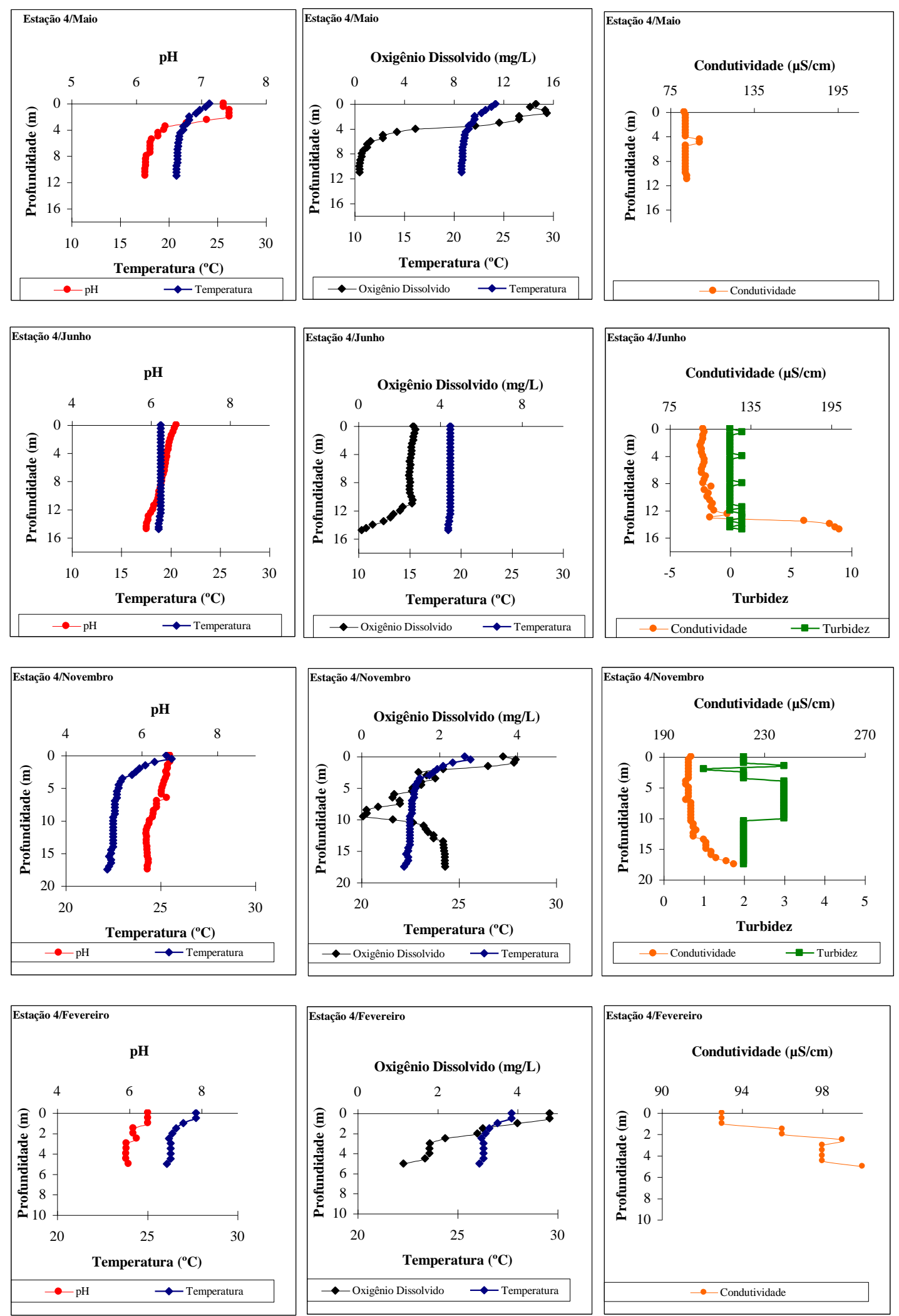

FIGURA 5.36 - PERFIS DE PH, TEMPERATURA $\left({ }^{\circ} \mathrm{C}\right)$, OXIGÊNIO DISSOLVIDO (MG/L), CONDUTIVIDADE ( $\mu$ S/CM) E TURBIDEZ, NA ESTAÇÃO 4, CAMPANHAS DE MAIO, JUNHO, E NOVEMBRO DE 1998 E FEVEREIRO DE 1999. 


\section{RESULTADOS E DISCUSSÃO}

O reservatório de Salto Grande encontra-se em processo de hipereutrofização e estágio avançado de contaminação devida, principalmente, ao lançamento de resíduos industriais e esgotos doméstica, além da lixiviação de áreas agrícolas. Essa situação do reservatório apresenta diversas conseqüências, como a diminuição da diversidade de peixes em biomassa, odor de matéria orgânica em decomposição e também problemas sociais, como a desvalorização da região do entorno pela sua transformação em zona de prostituição, como pode ser visto no histórico da região apresentado no trabalho de BOTTURA (1998).

$\mathrm{Na}$ bacia hidrográfica onde encontra-se localizado o reservatório de Salto Grande, considerando o histórico apresentado no relatório técnico preliminar de Julho de 1999 da CETESB, a presença de fenóis nas cargas remanescentes das principais indústrias pode atingir cerca de $40 \mathrm{~kg} /$ dia (Tabela 3.2 da revisão de literatura). Nesse relatório, quanto ao lançamento de fenóis, destacam-se as indústrias químicas, cujos produtos manufaturados são corantes (como por exemplo, o índigo blue) e matérias primas do segmento Nylon.

Quando trabalha-se com a presença de poluentes em reservatórios, algumas variáveis físico-químicas são de grande importância, como visto no item 3.5 da revisão de literatura. Neste trabalho, optou-se pelas análises de $\mathrm{pH}$, temperatura, condutividade, oxigênio dissolvido, carbono total, umidade do sedimento e material em suspensão, pois esses parâmetros relacionam-se, em diferentes níveis, com presença de poluentes tóxicos, em relação à solubilidade, degradação, adsorção e toxicidade, bem como com a desorção desses compostos da matriz escolhida (solo, sedimento, água, material em suspensão, etc.). Além disso, alguns desses parâmetros podem nortear a detecção de fontes de poluição.

Este capítulo foi organizado de forma a deixar claro todos os cuidados, opções e medidas tomadas desde a coleta do material e preservação de amostras em campo, bem como sua estocagem e análises em laboratório, considerando todos os procedimentos para determinação dos parâmetros físico-químicos e cromatográficos. Em relação às análises cromatográficas foram apresentadas todas as etapas e condições vencidas para escolher e/ou adaptar os procedimentos mais adequados para extração e limpeza das amostras, antes de suas injeções CG/DCE. 
Os resultados obtidos para todas as análises efetuadas foram apresentados e discutidos por campanha realizada. Como foram feitas 4 coletas (Maio, Junho e Novembro de 1998 e Fevereiro de 1999), cada mês de coleta representa uma campanha, sendo primeiramente analisados os parâmetros climatológicos, seguidos dos hidráulicos, morfométricos e os físico-químicos e, finalmente, as análises cromatográficas. Essas últimas compreendem as curvas de calibração para a determinação quantitativa de clorofenóis na água e sedimento, os resultados de procedimentos de extração e limpeza das amostras, as respostas quanto ao tempo de retenção de cada composto clorado, bem como as áreas obtidas nos cromatogramas após injeção das amostras de água e sedimento, respectivamente. $\mathrm{Na}$ discussão dos resultados cromatográficos, alguns parâmetros físico-químicos de interesse são discutidos em conjunto.

Como há estações comuns entre as campanhas, para finalizar este capítulo, a discussão foi feita por estação, correlacionando-se todos os parâmetros estudados.

\subsection{Métodos e procedimentos para o transporte e preservação das amostras de sedimentos e águas para as análises físico-químicas}

Amostras coletadas em campo estão sujeitas a inúmeras influências (forma de coleta, temperatura local e de manutenção para transporte, métodos químicos de preservação, entre outras). Assim, os procedimentos de transporte, preservação em campo e em laboratório das amostras coletadas no presente trabalho experimental procuraram seguir as orientações dos Laboratórios do Centro de Recursos Hídricos e Ecologia Aplicada e de Processos Biológicos do Departamento de Hidráulica e Saneamento da EESC-USP.

As determinações de $\mathrm{pH}$, condutividade, turbidez, temperatura e oxigênio dissolvido foram feitas em campo, não havendo necessidade de acondicionar e/ou transportar as amostras.

Para a análise de material em suspensão, as amostras foram filtradas em campo (filtro $0,45 \mu \mathrm{m}$ ) e os filtros transportados para laboratório em temperatura ambiente, como indicado pelo SMEEW (1995). As análises foram feitas no dia seguinte às amostragens. Portanto, a determinação do material em suspensão foi feita após um período máximo de 20 horas, o que foi adequado para não haver alterações qualitativas e quantitativa das amostras.

As análises de carbono orgânico da água foram realizadas com as amostras filtradas, o que influiu nos valores obtidos, como será discutido posteriormente. No caso das amostras de sedimento, estas foram mantidas congeladas por cerca de 3 meses, quando foram 
misturados os sedimentos coletados em perfis, secados, peneirados e imediatamente enviados para o laboratório onde foram feitas as análises de carbono orgânico total ${ }^{2}$. Como recomendado pelo SMEWW (1995), as amostras de água e sedimento para análise de carbono foram acondicionadas em frascos de vidro. Assim, os procedimentos seguidos para transporte e preservação das amostras foram considerados adequados.

\subsection{Métodos e procedimentos para análises cromatográficas das amostras de sedimentos e águas}

\subsubsection{Preservação das amostras de água e sedimento}

Em geral, o tempo transcorrido entre a coleta e a análise da amostra é responsável por resultados mais confiáveis. As recomendações do SMEWW (1995) pontuam que a análise de clorofenóis em amostras de água seja realizada em um período máximo de 28 dias, devendo as amostras ser mantidas ácidas, através da diminuição do $\mathrm{pH}$ a um valor menor que 2,0, e armazenadas sob refrigeração, em frascos de vidro.

As amostras de água coletadas em Maio e Junho ( $1^{\mathrm{a}}$ e $2^{\mathrm{a}}$ campanhas) tiveram o tempo entre as coletas e as análises cromatográficas superior ao recomendado pelo SMEWW (1995). Devido às dificuldades encontradas para adaptação dos procedimentos de extração e limpeza das amostras, as mesmas somente foram analisadas em Agosto, ou seja, o tempo de estocagem foi de 2 a 3 meses, sempre sob refrigeração $\left(4^{0} \mathrm{C}\right)$, sendo as amostras mantidas acidificadas. As amostras de água de Novembro e Fevereiro foram analisadas no mesmo mês em que foram coletadas.

A acidificação em campo, para preservação das amostras de água, foi feita segundo o SMEWW (1995), utilizando-se alíquotas de $\mathrm{H}_{2} \mathrm{SO}_{4}$ até que o $\mathrm{pH}$ ficasse menor que 2,0, confirmado com fita de papel Carlo Erba.

As amostras de sedimento foram acondicionadas em recipientes de vidro, mantidas sob baixas temperaturas no campo, em recipiente de isopor com gelo, e posteriormente congeladas em laboratório, como recomendado por MUDROCH \& MACKNIGH (1994).

As amostras de sedimentos, coletadas em Maio, foram mantidas sob refrigeração $\left(4^{\circ} \mathrm{C}\right)$, visto que, parte das mesmas foi utilizada em alguns testes de extração e limpeza, para adaptação de procedimentos analíticos. As demais amostras de sedimento foram mantidas congeladas até a extração com ultra-som, que foi feita nos meses de Junho, Julho e Agosto de 1999, ficando portanto, armazenadas de 5 a 12 meses. As extrações adicionais com

\footnotetext{
${ }^{2}$ Laboratório de Biogeoquímica Ambiental da Universidade Federal de São Carlos.
} 
Soxhlet e agitação com barra magnética foram feitas em Novembro, ou seja, 5 meses após as primeiras análises com o ultra-som.

A refrigeração das amostras de sedimentos no campo, com posterior congelamento em laboratório, caracterizou-se como um procedimento efetivo para manutenção dos sedimentos antes da extração, limpeza e análise cromatográfica, o que consiste em prática importante para minimizar a degradação química e microbiana dos clorofenóis.

Todos os procedimentos foram feitos para amostras de sedimentos dos reservatórios do Lobo e de Salto Grande. As amostras do Lobo, entretanto, foram mantidas sob refrigeração.

5.2.2 Etapas para escolha elou adequação dos procedimentos para extração e limpeza das amostras de água e sedimento

\subsubsection{Controle das Análises Cromatográficas}

Pelos testes de extração com amostras de água destilada $(500 \mathrm{~mL})$, dopadas com 5 $\mu \mathrm{L}$ de solução de PCP em concentração de $10 \mu \mathrm{L} / \mathrm{L}$ e extraídas como demonstrado na Figura 4.6 de Materiais e Métodos, o uso de diferentes eluentes e colunas de limpeza, não interferiu nos tempos de retenção encontrados nos cromatogramas, sempre coerentes e precisos, como pode ser visto na Tabela 5.1.

No teste com a solução de padrões de clorofenóis e padrão interno 2,4-Dibromofenol (3,1416 mg/L), extraídas como proposto por Damianovic (1997), derivatizadas e injetadas em CG/DCE, também foi feita a confirmação de todos os tempos de retenção, sendo apresentados na Tabela 5.2. 
Tabela 5.1 - Resultados dos testes de limpeza, valores de áreas cromatográficas e tempo de retenção para o padrão $\mathrm{PCP}$

\begin{tabular}{|c|c|c|c|c|}
\hline \multirow[t]{2}{*}{ Amostras } & \multirow[t]{2}{*}{ Tratamento } & \multirow[t]{2}{*}{$\begin{array}{l}\text { Volume e tipo de eluente } \\
\text { utilizado na Limpeza }\end{array}$} & \multicolumn{2}{|c|}{$\begin{array}{l}\text { Áreas do padrão PCP em } \\
\text { cromatograma e tempo de } \\
\text { retenção (min) }\end{array}$} \\
\hline & & & Amostra & Descarte \\
\hline 1 & Sílica $(1 \mathrm{~cm})$ & $10 \mathrm{~mL}$ de Hexano/Acetona 1:1/ & $\begin{array}{l}1426510 \\
(22 ’ 526)\end{array}$ & n.d. \\
\hline 2 & Florisil $(1 \mathrm{~cm})$ & $10 \mathrm{~mL}$ de Hexano/Acetona $1: 1$ & $\begin{array}{l}101794 \\
\left(22^{\prime} 523\right)\end{array}$ & n.d. \\
\hline 3 & Florisil $(1 \mathrm{~cm})$ & $\begin{array}{c}10 \mathrm{~mL} \text { de Hexano/Acetona 1:1 } \\
\text { (Passagem da amostra pela mesma } \\
\text { coluna) }\end{array}$ & n.d. & $\begin{array}{c}33829 \\
\left(22^{\prime} 532\right)\end{array}$ \\
\hline 4 & Florisil $(1 \mathrm{~cm})$ & $\begin{array}{c}10 \mathrm{~mL} \text { de Hexano/Acetona 1:1 } \\
\text { (Passagem da amostra por outra } \\
\text { coluna) }\end{array}$ & $\begin{array}{c}92410 \\
\left(222^{\prime} 530\right)\end{array}$ & $\begin{array}{l}127498 \\
\left(22^{\prime} 546\right)\end{array}$ \\
\hline 5 & Florisil $(3 \mathrm{~cm})$ & $10 \mathrm{~mL}$ de Hexano/Acetona 3:1 & $\begin{array}{c}120647 \\
\left(222^{\prime} 530\right)\end{array}$ & $\begin{array}{c}28416 \\
\left(222^{\prime} 530\right)\end{array}$ \\
\hline 6 & Sílica $(3 \mathrm{~cm})$ & $10 \mathrm{~mL}$ de Hexano/Acetona 3:1 & n.d. & $\begin{array}{c}20280 \\
\left(222^{\prime} 532\right)\end{array}$ \\
\hline 7 & LC-SAX & $2 \mathrm{~mL}$ de $\mathrm{n}$-hexano & $\begin{array}{l}208303 \\
\left(22^{\prime} 531\right)\end{array}$ & $\begin{array}{c}22558 \\
\left(22^{\prime} 548\right)\end{array}$ \\
\hline \multirow{2}{*}{8} & \multirow{2}{*}{ Florisil $(3 \mathrm{~cm})$} & $10 \mathrm{~mL}$ de Hexano/Acetona 3:1 & n.d. & \multirow{2}{*}{ n.d. } \\
\hline & & $10 \mathrm{~mL}$ de Hexano/Acetona 2:1 & n.d. & \\
\hline \multirow{2}{*}{9} & \multirow{2}{*}{ Sílica $(1 \mathrm{~cm})$} & $10 \mathrm{~mL}$ de Hexano/Acetona 3:1 & $\begin{array}{l}12463393 \\
\left(22^{\prime} 563\right)\end{array}$ & \multirow{2}{*}{ n.d. } \\
\hline & & $10 \mathrm{~mL}$ de Hexano/Acetona 2:1 & $\begin{array}{l}4031662 \\
(22 ’ 545)\end{array}$ & \\
\hline
\end{tabular}

Tabela 5.2 - Padrões de clorofenóis e respectivos tempos de retenção

\begin{tabular}{c|c}
\hline Padrões & Tempo de retenção \\
\hline $2,5-\mathrm{DCP}$ & $15^{\prime} 026$ \\
\hline $2,4,6-\mathrm{TCP}$ & $15^{\prime} 975$ \\
\hline $2,3,6-\mathrm{TCP}$ & $16^{\prime} 780$ \\
\hline $2,3,4-\mathrm{TCP}$ & $19^{\prime} 141$ \\
\hline PCP & $22^{\prime} 557$ \\
\hline $2,4-\mathrm{DBP}$ & $18^{\prime} 516$ \\
\hline
\end{tabular}




\subsubsection{Amostras de águas}

Para a análise da água, o procedimento escolhido foi o da extração líquido-líquido, baseado no trabalho de ZUIN (1997). Entretanto, foram necessárias algumas modificações no procedimento adotado, como observado no capítulo Material e métodos, com o objetivo de adaptar-se algumas etapas às amostras do reservatório de Salto Grande. Estas alterações visaram aprimorar a capacidade de extração dos clorofenóis pelo método proposto por ZUIN (1997), uma vez que a autora trabalhou com amostras oriundas de uma região altamente contaminada por esses compostos, o que era improvável nas amostras estudadas no presente trabalho. Outro fator responsável pelas alterações no procedimento foi a necessidade de eliminar-se possíveis fontes de interferência para a obtenção de áreas cromatográficas mais confiáveis, de forma a alcançar melhores respostas com o método analítico escolhido.

Logo, não foram realizados testes com amostras previamente dopadas, sendo os procedimentos de extração estudados apenas com amostras de águas do reservatório de Salto Grande. As alterações foram feitas ao longo das análises, de acordo com os resultados obtidos. Assim sendo, as etapas para adaptação do procedimento de extração para as amostras de águas do reservatório de Salto Grande e a discussão dos valores de clorofenóis para as condições do reservatório serão abordadas no item 5.3.4.2 do presente capítulo. Os resultados obtidos nos estudos sobre procedimentos de extração desses compostos, nas amostras de água, foram considerados no âmbito da avaliação da presença de clorofenóis no reservatório, nas diferentes campanhas, mesmo com possíveis perdas devidas à adaptação ou à inadequação do método escolhido.

\subsubsection{Amostras de sedimentos}

Inicialmente, o método proposto para a extração dos clorofenóis dos sedimentos foi através do aparelho Soxhlet, procedimento tradicionalmente usado para extrair pesticidas de solos e sedimentos, como observado por BRUNER (1993) e GUENZI (1974).

Dessa forma, a extração com o Soxhlet foi testada em amostras de sedimentos oriundas dos reservatórios do Lobo ( $22^{0} 10^{\prime} \mathrm{S}$ e $47^{0} 57^{\prime} \mathrm{W}$, São Paulo) e de Salto Grande ( $22^{0} 44^{\prime}$ 'S e $47^{0} 15^{\prime} \mathrm{W}$, São Paulo). As amostras do reservatório do Lobo eram dopadas, como explicado no item 4.2.4.3 em Material e Métodos, a fim de servirem como referência ao estudo de métodos extrativos de clorofenóis. O reservatório do Lobo, localizado no município de Itirapina, difere consideravelmente do reservatório de Salto Grande, pois não se caracteriza como receptor de poluentes tóxicos industriais. Assim, foi feita a escolha do 
sedimento do reservatório do Lobo para possibilitar uma avaliação adequada da presença dos clorofenóis após dopagem dos sedimentos.

No entanto, nos primeiros testes para estudos sobre as quantidades de amostras a serem utilizadas, tipo e volume de solvente e diferentes formas de limpeza, não foram obtidos bons resultados com a utilização de Soxhlet. A Tabela 5.3 mostra as principais considerações resultantes desses testes, assim como a avaliação dos resultados obtidos com o emprego do Soxhlet para extração dos clorofenóis nas amostras dos sedimentos dos reservatórios do Lobo e de Salto Grande, o primeiro teste após dopagem com uma solução de clorofenóis. As considerações foram consequiência da avaliação dos valores de áreas de pico obtidos com as determinações cromatográficas, após o uso do método extrativo e de limpeza das amostras, sugerindo a necessidade do estudo de outras técnicas extrativas dos clorofenóis. As Tabelas do Anexo A mostram detalhes dos procedimentos de extração e limpeza das amostras, com as variações das condições testadas e conclusões obtidas, e os valores de áreas de picos obtidas nas determinações cromatográficas. 
Tabela 5.3 - Considerações sobre os procedimentos estudados com o emprego do Soxhlet para extração dos clorofenóis nas amostras dos sedimentos dos reservatórios do Lobo e de Salto Grande.

\begin{tabular}{|c|c|}
\hline Testes & \\
\hline $\begin{array}{l}\text { Tempo de } \\
\text { extração e } \\
\text { volume do } \\
\text { solvente }\end{array}$ & $\begin{array}{l}\rightarrow \text { Não ocorreu refluxo no aparelho com volumes de } 200 \mathrm{~mL} \text { de solvente. O } \\
\text { menor volume para que houvesse refluxo foi de } 250 \mathrm{~mL} \text {; } \\
\rightarrow \text { o tempo de extração de } 6 \text { h não otimizou a obtenção de resultados para os } \\
\text { sedimentos do Lobo, entretanto, dos sedimentos de Salto Grande, extraiu } \\
\text { diferentes tipos de clorofenóis, com áreas consideráveis, mesmo em } \\
\text { sedimentos não dopados, por isso, foi o tempo de extração adotado; } \\
\rightarrow \text { nas condições estudadas, para os sedimentos do Lobo, verificou-se apenas } \\
\text { a presença de } 2,3,5 \text {-TCP; entretanto, para Salto Grande, foram verificados } \\
\text { diferentes tipos de clorofenóis. }\end{array}$ \\
\hline $\begin{array}{l}\text { Colunas de } \\
\text { Limpeza } \\
\left(1^{\underline{0}} \text { teste }\right)\end{array}$ & $\begin{array}{l}\rightarrow \text { As colunas de Florisil }(3,0 \mathrm{~cm}) \text { e Sílica }(3,0 \mathrm{~cm}) \text {, apresentaram bons } \\
\text { resultados utilizando } 250 \mathrm{~mL} \text { de solvente, em Soxhlet, durante } 6 \text { horas. } \\
\rightarrow \text { A utilização das colunas de Sílica }(1,0 \mathrm{~cm}) \text { e Florisil }(1,0 \mathrm{~cm}) \text {, com } 250 \mathrm{~mL} \\
\text { do solvente, em Soxhlet durante } 6 \text { horas, revelou melhores resultados com a } \\
\text { Sílica. } \\
\rightarrow \text { Nesse teste foram utilizados os sedimentos de Salto Grande. }\end{array}$ \\
\hline $\begin{array}{l}\text { Colunas de } \\
\text { Limpeza } \\
\left(2^{\underline{0}} \text { teste }\right)\end{array}$ & $\begin{array}{l}\rightarrow \text { As colunas de Sílica }(1,0 \text { e } 3,0 \mathrm{~cm}) \text { e Florisil }(1,0 \text { e } 3,0 \mathrm{~cm}) \text { utilizando o } \\
\text { método de extração com } 250 \mathrm{~mL} \text { do solvente, em Soxhlet durante } 3 \text { horas. não } \\
\text { apresentaram desempenho satisfatório, havendo muita perda pelo descarte; } \\
\rightarrow \text { Neste teste foram utilizados os sedimentos de Salto Grande. }\end{array}$ \\
\hline $\begin{array}{l}\text { Colunas de } \\
\text { Limpeza } \\
\left(3^{\underline{0}} \text { teste }\right)\end{array}$ & $\begin{array}{l}\rightarrow \text { Foram utilizadas novamente colunas de Sílica }(1,0 \mathrm{~cm}) \text { e Florisil }(3,0 \mathrm{~cm}) \\
\text { com } 250 \mathrm{~mL} \text { do solvente, em Soxhlet a } 6 \text { horas, testando na eluição a } \\
\text { recuperação dos eluentes em frascos separados, ao invés de recuperá-los em } \\
\text { um mesmo frasco, como fora feito anteriormente. Eram passados pelas } \\
\text { colunas } 10 \mathrm{~mL} \text { de solução hexano/acetona } 3: 1 \text {, seguidos pelos mesmos } \\
\text { solventes, porém } 2: 1 \text {. A maior parte dos compostos entretanto foi eluída na } \\
\text { primeira condição; } \\
\rightarrow \text { Nesse teste foram utilizados os sedimentos de Salto Grande. }\end{array}$ \\
\hline $\begin{array}{l}\text { Colunas de } \\
\text { Limpeza } \\
\left(4^{\underline{0}} \text { teste }\right)\end{array}$ & $\begin{array}{l}\rightarrow \text { Utilizando-se } 3 \text { eluições sucessivas, com } 5,0 \mathrm{~mL} \text { de n-hexano em coluna de } \\
\text { Sílica }(1,0 \mathrm{~cm}) \text {, em Soxhlet, durante } 6 \text { horas, com } 300 \mathrm{~mL} \text { do solvente, os } \\
\text { clorofenóis foram eluídos na primeira aplicação; } \\
\rightarrow \text { Nesse teste foram utilizados os sedimentos de Salto Grande. }\end{array}$ \\
\hline & $\begin{array}{l}\rightarrow \text { Optou-se pela utilização da coluna de Sílica } 1 \mathrm{~cm} \text {, com solução de } \\
\text { hexano/acetona 3:1 como eluente, volume de } 5 \mathrm{~mL} \text {, em única eluição; } \\
\rightarrow \text { Nesse teste foram utilizados os sedimentos de Salto Grande. }\end{array}$ \\
\hline
\end{tabular}


Em todos os testes, não se obteve reprodutibilidade em nenhuma das amostras, ou seja, em amostras do mesmo ponto, extraídas da mesma forma, não eram recuperados os mesmos clorofenóis, e quando recuperados, a diferença entre as áreas era bastante discrepante, como pode ser visto nas Tabelas 5.4 a 5.8.

Apesar do teste com o sedimento do Lobo, dopado com a solução de clorofenóis ter relevado a necessidade do uso de volumes maiores de solventes para extração, o resultado obtido ficou aquém do esperado. Apenas o composto 2,3,5-TCP foi recuperado, o que fica bastante distante do conjunto de clorofenóis adicionados aos sedimentos. Deve-se considerar também que as áreas de picos obtidas nas duplicatas não se reproduziram. Considerando que esse sistema aquático não se caracteriza por receber poluentes industriais tóxicos, podendo permitir uma avaliação adequada da presença dos clorofenóis, após dopagem de seus sedimentos, é provável que o tempo de extração e o uso do Soxhlet tenham sido subdimensionados à natureza do sedimento testado.

Nos testes realizados com o Soxhlet observou-se que a utilização de acetona, como solvente para extração da amostra dopada do sedimento do reservatório do Lobo, resultou em uma amostra muito densa após concentração em rotaevaporador, não permitindo a obtenção de uma amostra adequada para análise cromatográfica. Em todos os testes, nas condições estudadas, não foram verificadas respostas que garantissem a certeza de sua aplicação (Tabelas 5.16 a 5.19). A extração em Soxhlet é tradicionalmente adotada para solos e sedimentos contaminados (AIROLDI, 1997; LLOMPART et al., 1997; ALONSO et al., 1998), mas as opções por outros métodos extrativos têm sido estudadas e avaliadas em busca da diminuição do tempo necessário a extração, bem como do volume de solvente utilizado. ALONSO et al. (1998) obtiveram boas respostas utilizando microondas (MAE) para extração de clorofenóis de sedimentos, com menor volume de extração e redução de tempo em relação ao Soxhlet. Ainda, o uso do Soxhlet pode ser substituído por extração com fluido supercrítico (SANTOS et al., 1998) e o emprego do ultra-som (LLOMPART et al., 1997).

A limpeza das amostras também é necessária, principalmente quando se trata de amostras complexas como os sedimentos. Neste trabalho foram testadas colunas de Sílica e Florisil, em diferentes tamanhos, com diferentes eluentes, entretanto, as perdas na coluna foram consideráveis. Essas perdas em coluna de limpeza também foram ressaltadas por OUBINA et al. (1996), em amostras de solo. 
Tabela 5.4 - Valores das áreas cromatográficas de clorofenóis obtidos pela extração com Soxhlet, variando-se o tempo de extração e o volume de solvente

Teste 1

Amostra: Sedimento do Reservatório do Lobo

Dopagem: $100 \mu \mathrm{L}$ de solução de Clorofenóis $(1 \mathrm{mg} / \mathrm{L})$

\begin{tabular}{c|c|c|c}
\hline Amostra & Tempo de Extração & Volume de Solvente & $2,3,5-\mathrm{TCP}$ \\
\hline 1A & 3 horas $(*)$ & $200 \mathrm{~mL}$ de Hexano & 71990 \\
\cline { 4 - 4 } 1B & & & 100446 \\
\hline 2A & 6 horas & $300 \mathrm{~mL}$ de Hexano & 84053 \\
\cline { 1 - 1 } & & & ------- \\
\hline
\end{tabular}

Obs.: (*) não houve refluxo

Tabela 5.5 - Valores das áreas cromatográficas de clorofenóis obtidos pela extração com Soxhlet, variando-se a coluna de limpeza utilizada

\section{Teste 2}

Amostra: Sedimento de Salto Grande/Estação 2 (perfil 1)/Maio

Dopagem: Não houve dopagem com solução de clorofenóis e também não houve dopagem com padrão interno $(2,4-\mathrm{DBP})$

\begin{tabular}{c|c|c|c|c|c|c|c|c|c}
\hline Am. & $3,5-$ & $2,5-$ & $3,4-$ & $2,4,6-$ & $2,3,6-$ & $2,4,5-$ & $2,4-$ & $2,3,4-$ & PCP \\
& DCP & DCP & DCP & TCP & TCP & TCP & DBP & TCP & \\
\hline 1 & 146519 & -------- & ------- & 31422 & -------- & -------- & 61439 & --------- & 58894 \\
$(*)$ & ---- & 72907 & 23357 & ------- & ----- & ----- & 24717 & ------- & 16872 \\
\hline 2A & ------ & ------- & ------- & ------ & ------- & ------- & 20381 & -------- & 19892 \\
$(* *)$ & 24612 & 43580 & ------ & 24703 & 24414 & ------- & ------- & -------- & ------- \\
\hline 2B & 103267 & 212635 & 153324 & 164763 & 179400 & 139107 & 514537 & 165530 & 108914 \\
$(* *)$ & ------ & ------ & ------- & ------- & ----- & ----- & 20381 & -------- & ------ \\
\hline
\end{tabular}

Obs.: (*) amostras limpas em coluna de Florisil $(3 \mathrm{~cm})$

(**) amostras limpas em coluna de Sílica $(3 \mathrm{~cm})$

Tabela 5.6 - Valores das áreas cromatográficas de clorofenóis obtidos pela extração com Soxhlet, variando-se o tipo de coluna de limpeza utilizada

Teste 3

\begin{tabular}{|c|c|c|c|c|}
\hline \multicolumn{5}{|c|}{$\begin{array}{l}\text { Amostra: Sedimento de Salto Grande/Estação } 2 \text { (perfil 1)/Maio } \\
\text { Dopagem: } 5 \mu \mathrm{L} \text { de solução de Clorofenóis }(1 \mathrm{mg} / \mathrm{L}) \text {. Não houve dopagem com padrão } \\
\text { interno }\end{array}$} \\
\hline Amostra & & 3,5-DCP & 2,4,6-ТCP & \\
\hline 1 & Sílica $(1,0 \mathrm{~cm})$ & $\begin{array}{l}93979 \text { (amostra) } \\
38525 \text { (descarte) }\end{array}$ & $\begin{array}{c}------------ \\
29291 \text { (descarte) }\end{array}$ & $\begin{array}{l}20053(\mathrm{amo} \\
48276 \text { (desc }\end{array}$ \\
\hline 2 & Sílica $(3,0 \mathrm{~cm})$ & $\begin{array}{l}---------------- \\
------------ \\
\end{array}$ & $\begin{array}{l}26116 \text { (amostra) } \\
38098 \text { (descarte) }\end{array}$ & $\begin{array}{c}------------- \\
21009 \text { (descarte) }\end{array}$ \\
\hline 1 & $\begin{array}{c}\text { Florisil } \\
(1,0 \mathrm{~cm}) \\
\end{array}$ & $\begin{array}{c}314607 \text { (amostra) } \\
40309 \text { (descarte) }\end{array}$ & $\begin{array}{c}22998 \text { (amostra) } \\
----\end{array}$ & $\begin{array}{c}------------ \\
151734 \text { (descarte) }\end{array}$ \\
\hline
\end{tabular}




\begin{tabular}{|c|c|c|c|c|}
\hline 2 & $\begin{array}{l}\text { Florisil } \\
(3,0 \mathrm{~cm})\end{array}$ & $\begin{array}{l}40073 \text { (amostra) } \\
66612 \text { (descarte) }\end{array}$ & ---------------- & 90236 (amostra) \\
\hline
\end{tabular}

Tabela 5.7 - Valores das áreas cromatográficas de clorofenóis obtidos pela extração com Soxhlet, variando-se o tipo de coluna de limpeza utilizada

\section{Teste 4}

Amostra: Sedimento de Salto Grande/Estação 2 (perfil 1)/Maio

Dopagem: $10 \mu \mathrm{L}$ de solução de Clorofenóis $(1 \mathrm{mg} / \mathrm{L})$. Não houve dopagem com padrão interno

\begin{tabular}{c|c|c|c|c|c|c}
\hline Am. & Coluna & $3,5-\mathrm{DCP}$ & $2,4,6-\mathrm{TCP}$ & $2,4-\mathrm{DBP}$ & $2,3,4-\mathrm{TCP}$ & PCP \\
\hline 1 & Sílica & ------- & 44716 & --------- & ---------- & --------- \\
& $(1,0 \mathrm{~cm})$ & 32858 & $20797(3: 1)$ & $36179(3: 1)$ & ------- & $2463393(3: 1)$ \\
& & ------- & $44815(2: 1)$ & ----------- & $50217(3: 1)$ & $1629024(2: 1)$ \\
\hline 1 & Florisil & ------ & ------ & $59666(3: 1)$ & $22935(3: 1)$ \\
& $(3,0 \mathrm{~cm})$ & $29394(3: 1)$ & $44832(3: 1)$ & $51976(3: 1)$ & $44022(2: 1)$ & $34894(2: 1)$ \\
& & $25636(2: 1)$ & $26176(2: 1)$ & ---------- & -------- & ------- \\
\hline
\end{tabular}

Tabela 5.8 - Valores das áreas cromatográficas de clorofenóis obtidos pela extração com Soxhlet, utilizando-se diferentes volumes para eluição da amostra

\begin{tabular}{|c|c|c|c|c|c|c|c|c|c|}
\hline \multicolumn{10}{|c|}{ Teste 5} \\
\hline \multicolumn{10}{|c|}{ Amostra: Sedimento de Salto Grande/Estação 4 (perfil 1)/Maio } \\
\hline \multicolumn{10}{|c|}{$\begin{array}{l}\text { Dopagem: Não houve dopagem com solução de clorofenóis e também não houve dopagem } \\
\text { com padrão interno }(2,4-\mathrm{DBP})\end{array}$} \\
\hline Am. & Eluição & $\begin{array}{c}3,5- \\
\text { DCP }\end{array}$ & $\begin{array}{c}2,5- \\
\text { DCP }\end{array}$ & $\begin{array}{c}\text { 3,4- } \\
\text { DCP }\end{array}$ & $\begin{array}{c}2,4,6- \\
\text { TCP }\end{array}$ & $\begin{array}{c}2,3,6- \\
\text { TCP }\end{array}$ & $\begin{array}{c}2,4,5- \\
\text { TCP }\end{array}$ & $\begin{array}{c}2,4- \\
\text { DBP }\end{array}$ & $\begin{array}{c}2,3,4- \\
\text { TCP }\end{array}$ \\
\hline \multirow{3}{*}{1} & \multirow{3}{*}{$\begin{array}{c}5,0 \mathrm{~mL} \\
\text { de } \\
\text { hexano } \\
\text { (3vezes) }\end{array}$} & 36137 & 45067 & 55757 & 55590 & 52658 & 45387 & 62858 & 29865 \\
\hline & & 26770 & -------- & -------- & 32835 & -------- & -------- & -------- & ------- \\
\hline & & 25894 & ------- & -------- & --------- & --------- & --------- & --------- & -------- \\
\hline
\end{tabular}

Em função dos resultados obtidos durante o emprego do aparelho Soxhlet, foram realizados testes de extração com ultra-som e sob agitação com barra magnética, com base na literatura (LLOMPART et al., 1997; THAO et al., 1993). Nesses testes também foram usados os sedimentos dos reservatórios do Lobo e de Salto Grande, dopados ou não com diferentes concentrações de clorofenóis. Nas Tabelas 5.9 e 5.10 estão indicadas as considerações sobre os procedimentos estudados com o emprego da agitação com barra magnética e ultra-som, respectivamente. Os resultados em áreas cromatográficas encontrados para extração com agitação são mostrados na Tabela 5.11 e os obtidos com ultra-som nas Tabelas 5.12 a 5.17.

Os detalhes dos procedimentos e resultados de análises cromatográficas podem ser verificados nos Anexos B e C, respectivamente. O item 4.2.4.3 de Material e Métodos 
também mostra considerações sobre o método extrativo de clorofenóis com ultra-som, utilizado nesse trabalho.

Tabela 5.9 - Considerações sobre os procedimentos estudados com o emprego da agitação com barra magnética.

\begin{tabular}{c|l}
\hline \multicolumn{1}{c|}{ Testes } & \multicolumn{1}{c}{ Observações } \\
\hline & $\rightarrow$ Esse teste foi feito com sedimentos do reservatório do Lobo e as \\
amostras ficaram sob agitação por 1 hora. Deve-se considerar que \\
uma amostra foi acidificada com $2 \mathrm{~mL}$ de ácido sulfúrico \\
anitação magnética \\
$\begin{array}{l}\rightarrow \text { Houve boa extração dos clorofenóis, sendo que amostra } \\
\text { acidificada apresentou melhores resultados. } \\
\rightarrow \text { As áreas encontradas para o PCP foram bastante consideráveis e } \\
\text { muito superiores àquelas encontradas em todos os testes com o } \\
\text { Soxhlet; } \\
\rightarrow \text { O método foi considerado pouco prático, devido às sucessivas } \\
\text { lavagens com o solvente n-hexano e necessidade de separação em } \\
\text { funil. }\end{array}$ \\
\hline
\end{tabular}

Tabela 5.10-Considerações sobre os procedimentos estudados com o emprego do ultrasom

\begin{tabular}{c|l}
\hline Testes & \multicolumn{1}{c}{ Observaçães } \\
\hline $\begin{array}{c}\text { ultra-som } \\
\left(1^{0} \text { teste }\right)\end{array}$ & $\begin{array}{l}\rightarrow \text { A área encontrada para o PCP, após a extração por esse método } \\
\text { em amostra do Lobo, extraída com } 50 \mathrm{~mL} \text { de n-hexano, foi maior do } \\
\text { que as encontradas após utilização do Soxhlet, porém, ainda não } \\
\text { havia reprodutibilidade entre as duplicatas. }\end{array}$ \\
\hline $\begin{array}{c}\left(2^{\underline{0}} \text { teste }\right) \\
\text { ultra-som }\end{array}$ & $\begin{array}{l}\rightarrow \text { Não houve diferença significativa entre as amostras acidificadas e } \\
\text { não acidificadas, exceto para o PCP, em que a área da amostra não } \\
\text { acidificada foi muito superior. }\end{array}$ \\
\hline $\begin{array}{c}\text { Alcalinização das } \\
\text { amostras e uso de }\end{array}$ & $\begin{array}{l}\rightarrow \text { Nessa redução do volume do solvente pela metade, os resultados } \\
\text { foram melhores, sendo que, as áreas obtidas para as amostras } \\
\text { acidificadas foram um pouco superiores às amostras não- } \\
\text { acidificadas. }\end{array}$ \\
$\begin{array}{c}\text { água destilada como pouca extração dos clorofenóis quando comparado ao teste } \\
\text { anterior em que foi utilizado o n-hexano e o n-hexano/acetona 3:1 } \\
\text { solvente versus }\end{array}$ & $\begin{array}{l}\rightarrow \text { a alcalinilização com utilização do n-hexano como solvente } \\
\text { alcalinização e uso } \\
\text { de n-hexano comou boa extração apenas para o PCP, sem reprodução nas } \\
\text { duplicatas. }\end{array}$ \\
\hline solvente
\end{tabular}




\begin{tabular}{c|l}
\hline Acidificação & $\begin{array}{l}\text { clorofenóis, principalmente para o PCP, mostrando-se bastante } \\
\text { superior a amostra alcalinizada }\end{array}$ \\
\hline Hexano versus & $\begin{array}{l}\rightarrow \text { utilizando hexano/acetona 4:1 como solvente, os resultados foram } \\
\text { superiores, entretanto, deve-se considerar que as amostras extraídas } \\
\text { com n-hexano foram limpas e pode ter havido perdas na limpeza. }\end{array}$ \\
\hline
\end{tabular}

Tabela 5.11 - Valores das áreas cromatográficas de clorofenóis no emprego da agitação com barra magnética

\section{Teste 1}

Amostra: Sedimento do Lobo

Dopagem: $100 \mu \mathrm{L}$ de solução de PCP $(1 \mathrm{mg} / \mathrm{mL})$

Solvente: $200 \mathrm{~mL}$ de solução de acetona

Limpeza: Coluna de Sílica $(1 \mathrm{~cm})$ e $10 \mathrm{~mL}$ de solução de Hexano/acetona 3:1 como eluente.

\begin{tabular}{c|c|c|c|c|c|c}
\hline \multirow{2}{*}{ Amostras } & \multicolumn{6}{|c}{ Compostos (Área/Tempo de Retenção) } \\
\cline { 2 - 7 } & $3,5-\mathrm{DCP}$ & $3,4-\mathrm{DCP}$ & $2,4,6-\mathrm{TCP}$ & $2,3,6-\mathrm{TCP}$ & $2,4-\mathrm{DBP}$ & PCP \\
\hline $1(* *)$ & 64945 & 70930 & 79841 & 65942 & 8200 & $2.0581 \times 10^{7}$ \\
\hline $1(*)$ & ---------- & ---------- & --------- & --------- & --------- & $1.26162 \times 10^{7}$ \\
\hline
\end{tabular}

Tabela 5.12 - Valores das áreas cromatográficas de clorofenóis no emprego do ultrasom, utilizando-se diferentes formas de limpeza

\section{Teste 1}

Amostra: Sedimento da Represa do Lobo

Dopagem: $50 \mu \mathrm{L}$ de solução de Clorofenóis $(1 \mathrm{mg} / \mathrm{L})$

Solvente: $50 \mathrm{~mL}$ de Hexano

\begin{tabular}{c|c|c|c|c}
\hline Amostras & Limpeza & $3,5-\mathrm{DCP}$ & $2,4,6-\mathrm{TCP}$ & PCP \\
\hline 1A & \multirow{2}{*}{ Sílica 3,0 cm } & 44998 & 36698 & 9812373 \\
\cline { 3 - 5 } & & ------------- & ------------ & 4136005 \\
\hline 1B & C18 & ------------- & ------------ & 322474 \\
\hline 1C & &
\end{tabular}

Tabela 5.13 - Valores das áreas cromatográficas de clorofenóis no emprego do ultrasom, testando-se a utilização da acidificação (1)

\section{Teste 2}

Amostra: Sedimento da Represa do Lobo

Dopagem: $50 \mu \mathrm{L}$ de solução de Clorofenóis $(1 \mathrm{mg} / \mathrm{L})$

Solvente: $50 \mathrm{~mL}$ de Hexano/acetona 4:1

Limpeza: Coluna de Sílica $(3,0 \mathrm{~cm})$ e $5 \mathrm{~mL}$ de solução de Hexano/acetona 3:1 como eluente

\begin{tabular}{c|c|c|c|c|c}
\hline Amostras & Acidificação & $3,5-\mathrm{DCP}$ & $2,4,6-\mathrm{TCP}$ & $2,4-\mathrm{DBP}$ & PCP \\
\hline 1 & Presente & --------- & 57862 & 65757 & --------- \\
\hline 2 & Ausente & 37239 & 30135 & 68772 & $17 \times 10^{7}$ \\
\hline
\end{tabular}


Tabela 5.14 - Valores das áreas cromatográficas de clorofenóis no emprego do ultrasom, testando-se a utilização da acidificação (2)

\begin{tabular}{|c|c|c|c|c|c|c|}
\hline \multicolumn{7}{|c|}{$\begin{array}{c}\text { Teste } 3 \\
\end{array}$} \\
\hline \multicolumn{7}{|c|}{ Amostra: Sedimento da Represa de Salto Grande/ Estação 4/ Maio } \\
\hline \multicolumn{7}{|c|}{ Dopagem: $100 \mu \mathrm{L}$ de solução de Clorofenóis ( 1 mg/L) } \\
\hline \multicolumn{7}{|c|}{ Solvente: $25 \mathrm{~mL}$ de Hexano/acetona 3:1 } \\
\hline \multicolumn{7}{|c|}{$\begin{array}{l}\text { Limpeza: Coluna de Sílica }(3,0 \mathrm{~cm}) \text { e } 5,0 \mathrm{~mL} \text { de solução de Hexano/acetona } 3: 1 \text { como } \\
\text { eluente }\end{array}$} \\
\hline Amostras & Acidificação & $3,5-\mathrm{DCP}$ & 3,4-DCP & 2,4-DBP & $2,3,4-\mathrm{TCP}$ & $\mathrm{PCP}$ \\
\hline $1 \mathrm{~A}$ & & 167747 & 1010770 & 143287 & 108909 & 136128 \\
\hline 1B & Ausente & 105030 & 130447 & 170006 & 120580 & --------- \\
\hline
\end{tabular}

Tabela 5.15 - Valores das áreas cromatográficas de clorofenóis no emprego do ultrasom, testando-se a utilização da acidificação e alcalinização com diferentes tipos de solventes

\section{Teste 4}

Amostra: Sedimento da Represa do Lobo

Dopagem: $100 \mu \mathrm{L}$ de solução de Clorofenóis $(1 \mathrm{mg} / \mathrm{L})$

Limpeza: Coluna de Sílica $(3,0 \mathrm{~cm})$ e 5,0 mL de solução de Hexano/acetona 3:1 como eluente

\begin{tabular}{c|c|c|c|c|c|c|c}
\hline Amostras & $\begin{array}{c}\text { Acidificação/ } \\
\text { Alcalinização }\end{array}$ & Solvente & $\begin{array}{c}3,5- \\
\text { DCP }\end{array}$ & $\begin{array}{c}2,5- \\
\text { DCP }\end{array}$ & $\begin{array}{c}2,4,6- \\
\text { TCP }\end{array}$ & $\begin{array}{c}2,3,4- \\
\text { TCP }\end{array}$ & PCP \\
\hline 1 & $\begin{array}{c}\text { Alcalinização } \\
(\bullet)\end{array}$ & Água & 52172 & 21733 & 27785 & ------- & 143263 \\
\hline 2A & $\begin{array}{c}\text { Alcalinização } \\
(\bullet \bullet)\end{array}$ & $\begin{array}{c}25 \mathrm{~mL} \text { de } \\
\text { hexano }\end{array}$ & 28092 & ------- & ------- & -------- & 1029772 \\
\hline 2B & $\begin{array}{c}\text { Alcalinização } \\
(\bullet \bullet)\end{array}$ & $\begin{array}{c}25 \mathrm{~mL} \text { de } \\
\text { Hexano }\end{array}$ & 37061 & 21481 & 37368 & ------- & 24124 \\
\hline 4 & Acidificação & $\begin{array}{c}25 \mathrm{~mL} \text { de } \\
\text { Hexano }\end{array}$ & 30603 & 21308 & 47626 & 63960 & $1,56 \times 10^{7}$ \\
\hline
\end{tabular}


Tabela 5.16 - Valores das áreas cromatográficas de clorofenóis no emprego do ultrasom, testando-se a utilização da acidificação com diferentes tipos de solventes

\section{Teste 5}

Amostra: Sedimento da Represa do Lobo

Dopagem: $1 \mathrm{~mL}$ de solução intermediária de Clorofenóis $(4 \mu \mathrm{g} / \mathrm{L})$

Limpeza: neste teste não foi feita limpeza

\begin{tabular}{|c|c|c|c|c|c|c|c|}
\hline Amostras & Acidificação & Solvente & $\begin{array}{l}3,5- \\
\text { DCP }\end{array}$ & $\begin{array}{c}2,3,6- \\
\text { TCP }\end{array}$ & $2,4-\mathrm{DBP}$ & $\begin{array}{c}2,3,4- \\
\text { TCP }\end{array}$ & PCP \\
\hline $1 \mathrm{~A}$ & \multirow{2}{*}{ Ausente } & \multirow{3}{*}{$\begin{array}{c}25 \mathrm{~mL} \\
\text { de } \\
\text { Hexano }\end{array}$} & 84183 & 210831 & 9055725 & 35792 & 1082705 \\
\hline 1B & & & 25501 & |------ & 25052 & 109228 & $1.21 \times 10^{7}$ \\
\hline 2 & Presente & & ------ & ------ & ------ & ------ & $1.53 \times 10^{7}$ \\
\hline 1 & Ausente & \multirow{2}{*}{$\begin{array}{c}25 \mathrm{~mL} \\
\text { de } \\
\text { Hexano/ } \\
\text { acetona } \\
4: 1\end{array}$} & ------ & ------ & ---------- & ----- & $1.32 \times 10^{7}$ \\
\hline 2 & Presente & & ----- & ------ & ------ & ------ & $1.74 \times 10^{7}$ \\
\hline $1 \mathrm{~A}$ & \multirow{3}{*}{ Presente } & \multirow{3}{*}{$\begin{array}{c}25 \mathrm{~mL} \\
\mathrm{de} \\
\text { Hexano/ } \\
\text { acetona } \\
4: 1\end{array}$} & ------ & ------ & ------ & ------ & $1.62 \times 10^{7}$ \\
\hline 1B & & & ------ & 75049 & 3178882 & 152009 & 731216 \\
\hline $1 \mathrm{C}$ & & & ------ & ------ & 1468739 & 88477 & 250248 \\
\hline
\end{tabular}

Tabela 5.17 - Valores das áreas cromatográficas de clorofenóis no emprego do ultrasom, testando-se a utilização da limpeza e diferentes tipos de solventes

\section{Teste 6}

Amostra: Sedimento da Represa de Salto Grande/ Estação 4/ Maio

Dopagem: não houve dopagem com solução de clorofenóis, apenas com o padrão interno (800 $\mu \mathrm{L}$ de solução $2,5 \mu \mathrm{g} / \mathrm{L}$ )

\begin{tabular}{|c|c|c|c|c|c|c|c|}
\hline Amostras & Solvente & Limpeza & $\begin{array}{l}3,4- \\
\text { DCP }\end{array}$ & $\begin{array}{c}2,3,6- \\
\text { TCP }\end{array}$ & $\begin{array}{l}2,4- \\
\text { DBP }\end{array}$ & $\begin{array}{c}2,3,4- \\
\text { TCP }\end{array}$ & PCP \\
\hline $1 \mathrm{~A}$ & \multirow{2}{*}{$\begin{array}{c}25 \mathrm{~mL} \mathrm{de} \\
\text { Hexano/ } \\
\text { acetona } \\
4: 1\end{array}$} & \multirow[b]{2}{*}{ Não houve } & 40309 & ---------- & 78081 & ---------- & 150815 \\
\hline 1B & & & ----------- & 133392 & 6226888 & 350168 & ---------- \\
\hline $1 \mathrm{~A}$ & \multirow[b]{2}{*}{$\begin{array}{c}50 \mathrm{~mL} \text { de } \\
\text { Hexano }\end{array}$} & \multirow{2}{*}{$\begin{array}{c}\text { Sílica } \\
(5,0 \mathrm{~cm}) \\
\text { com } 5,0 \mathrm{~mL} \\
\text { de Hexano/ } \\
\text { acetona } 2: 1\end{array}$} & 132581 & 75453 & 265755 & 79290 & 54447 \\
\hline $1 \mathrm{~B}$ & & & 58848 & 76671 & 99243 & 21537 & 52970 \\
\hline
\end{tabular}


Os ensaios realizados com ultra-som resultaram em boa capacidade de extração e valores de áreas confiáveis, além de procedimentos mais simples e rápidos. Ao analisar os valores mostrados nas Tabelas 5.12 a 5.17, as áreas de picos de PCP extraídas por ultra-som foram, em ordem de grandeza, maiores que as encontradas quando empregou-se a extração com Soxhlet.

O teste de eficiência, conclusivo para a escolha do ultra-som como método de extração, mostrou boa capacidade extrativa e reprodutibilidade. As etapas do método foram descritas no item 4.2.4.3, Material e Métodos. As áreas de pico obtidas a partir da avaliação de três amostras de sedimentos do Lobo, dopados com solução de PCP $(4,0 \mu \mathrm{g} / \mathrm{L})$ e com o padrão interno, 2,4-Dibromofenol $(300,0 \mu \mathrm{g} / \mathrm{L})$ são mostradas na Tabela 5.18. Foi utilizada como controle, uma amostra desse mesmo reservatório dopada apenas com o 2,4-DBP. Esta tabela também mostra o fator de resposta, coeficiente entre área encontrada para o PCP e a área encontrada para o 2,4-DBP. Através dos valores desse fator, nota-se a boa reprodutibilidade entre as amostras.

Tabela 5.18 - Valores das áreas cromatográficas de clorofenóis obtidos no teste de eficiência utilizando ultra-som como método de extração.

\begin{tabular}{l|c|c|c}
\hline \multicolumn{4}{c}{ Sedimento do Lobo dopado } \\
\cline { 2 - 4 } \multicolumn{1}{c}{ Amostra } & 2,4 -dibromofenol & Pentaclorofenol & Fator de Resposta \\
\hline Branco (controle) & 368.088 & -------------- & -------------- \\
\hline Sedimento dopado (1) & 224.890 & 461.369 & 2.051 \\
\hline Sedimento dopado (2) & 219.009 & 373.911 & 1.707 \\
\hline Sedimento dopado (3) & 292.331 & 559.254 & 1.913 \\
\hline
\end{tabular}

Os resultados da Tabela 5.18 revelaram que o ultra-som respondeu adequadamente, considerando os valores de áreas de picos dos cromatogramas obtidos para os sedimentos dopados 1, 2 e 3. Assim, as amostras de sedimento de Salto Grande foram então extraídas com o método do ultra-som. Posteriormente às análises feitas com esse método, em triplicata, para todas as amostras de Salto Grande, e para avaliar quantitativamente as mesmas, amostras de sedimentos da estação 2 desse reservatório foram dopadas com solução contendo padrões de clorofenóis em três concentrações e 2,4-Dibromofenol.

Porém, através desse teste observou-se somente extração de Pentaclorofenol nas amostras limpas e nas concentrações de $0,25 \mathrm{mg} / \mathrm{L}$ (área de 60.040 ) e $0,50 \mathrm{mg} / \mathrm{L}$ (área de 151.557), como pode ser visto na Tabela 5.19. Os primeiros resultados das análises cromatográficas mostraram que poderiam estar ocorrendo perdas de clorofenóis durante a 
limpeza das amostras. Todas as amostras estavam sendo limpas como indicado na Figura 4.3 de Material e Métodos. Dessa forma, as amostras da estação 4 foram testadas sem limpeza na coluna de sílica, e os resultados estão organizados na Tabela 5.20. 
Tabela 5.19 - Resultados das injeções cromatográficas das amostras da estação 2 dopadas para padrões .

\begin{tabular}{|c|c|c|c|c|c|c|c|c|c|}
\hline \multicolumn{10}{|c|}{ Ultra =som/Estacão 4} \\
\hline Amostra & Concentração & & & & & & & & \\
\hline (Data) & $(\mathrm{mg} / \mathrm{L})$ & 2,5-DCP & $3,5-\mathrm{DCP}$ & 2,4,6-TCP & 2,3,6-TCP & 2,4,5-TCP & 2,4-DBP & 2,3,4-TCP & PCP \\
\hline Branco & ----------- & ----------- & ----------- & ----------- & ----------- & ----------- & ----------- & ----------- & ----------- \\
\hline $0,25 \mathrm{a}$ & 0,25 & ----------- & ----------- & ----------- & ----------- & ----------- & ----------- & ----------- & ----------- \\
\hline $0,25 \mathrm{~b}$ & 0,25 & ----------- & ----------- & ----------- & ----------- & ----------- & ----------- & ----------- & ----------- \\
\hline $0,25 \mathrm{c}$ & 0,25 & ----------- & & & & ----------- & & & $\begin{array}{c}60.040 \\
(22.554)\end{array}$ \\
\hline $0,50 \mathrm{a}$ & 0,50 & ---------- & ----------- & ----------- & -------- & ----------- & -------- & ---------- & ----------- \\
\hline $0,50 \mathrm{~b}$ & 0,50 & ---------- & & & --- & ---- & & & $\begin{array}{r}151.557 \\
(22.554) \\
\end{array}$ \\
\hline $0,50 \mathrm{c}$ & 0,50 & ----------- & ----------- & ----------- & ----------- & ----------- & ---------- & ---------- & ----- \\
\hline $1,00 \mathrm{a}$ & 1,00 & ---------- & ---------- & ----------- & ----------- & ---------- & ----------- & ----------- & ---- \\
\hline $1,00 \mathrm{~b}$ & 1,00 & ----------- & ----------- & ---------- & ----------- & ---------- & ----------- & ---- & \\
\hline $1,00 \mathrm{c}$ & 1,00 & ----------- & ----------- & ----------- & ----------- & ----------- & -- & ----------- & \\
\hline
\end{tabular}

Obs.: Todas as amostras foram limpas em coluna de sílica $(3 \mathrm{~cm})$, utilizando hexano/acetona 3:1 como eluente 
Tabela 5.20 - Resultados das injeções cromatográficas das amostras da estação 4 dopadas para padrões.

\begin{tabular}{|c|c|c|c|c|c|c|c|c|c|}
\hline \multicolumn{10}{|c|}{ Ultra-som/Estacão 4} \\
\hline \multirow{2}{*}{$\begin{array}{l}\text { Amostra } \\
\text { (Data) }\end{array}$} & \multirow{2}{*}{$\begin{array}{l}\text { Concentração } \\
(\mathrm{mg} / \mathrm{L})\end{array}$} & \multicolumn{8}{|c|}{ Compostos (Área/ tempo de Retenção) } \\
\hline & & $2,5-\mathrm{DCP}$ & $3,5-\mathrm{DCP}$ & 2,4,6-TCP & $2,3,6-\mathrm{TCP}$ & 2,4,5-TCP & 2,4-DBP & 2,3,4-TCP & PCP \\
\hline Branco & ----------- & ----------- & ----------- & ----------- & ----------- & ----------- & ----------- & ----------- & ----------- \\
\hline $0,25 \mathrm{aa}^{*}$ & 0,25 & ----------- & ----------- & ----------- & ----------- & ----------- & ----------- & ----------- & ----------- \\
\hline $0,25 \mathrm{bb}^{*}$ & 0,25 & ----------- & ----------- & ----------- & ----------- & ----------- & ----------- & ----------- & ----------- \\
\hline $0,25 \mathrm{cc}^{*}$ & 0,25 & ----------- & ------------ & ----------- & ----------- & ----------- & ----------- & ----------- & ----- \\
\hline $0,50 \mathrm{aa}^{*}$ & 0,50 & ----------- & & & & ---- & $\begin{array}{c}22.778 \\
(18.770) \\
\end{array}$ & $\begin{array}{l}174.516 \\
(19.835) \\
\end{array}$ & \\
\hline $0,50 \mathrm{bb}^{*}$ & 0,50 & ----------- & ---------- & ----------- & ----------- & ----------- & ---------- & ----------- & ---------- \\
\hline $0,50 \mathrm{cc}$ & 0,50 & ----- & & $\begin{array}{c}46.547 \\
(15.984)\end{array}$ & & $\begin{array}{c}27.548 \\
(18.465)\end{array}$ & $\begin{array}{c}48.336 \\
(18.766)\end{array}$ & & $\begin{array}{l}100.630 \\
(22.565)\end{array}$ \\
\hline 1,00 aa & 1,00 & ----------- & & $\begin{array}{l}177.350 \\
(15.978)\end{array}$ & $\begin{array}{l}198.358 \\
(16.783)\end{array}$ & $---\cdot$ & & $\begin{array}{l}101.645 \\
(19.146)\end{array}$ & $\begin{array}{l}183.398 \\
(22.559)\end{array}$ \\
\hline $1,00 \mathrm{bb}$ & 1,00 & ------ & & $\begin{array}{c}88.644 \\
(15.973)\end{array}$ & $\begin{array}{l}112.546 \\
(16.778)\end{array}$ & & & $\begin{array}{c}79.935 \\
(19.141)\end{array}$ & $\begin{array}{l}230.345 \\
(22.555)\end{array}$ \\
\hline $1,00 \mathrm{cc}$ & 1,00 & ----------- & ----------- & $\begin{array}{c}39.913 \\
(15.976)\end{array}$ & $\begin{array}{c}48.025 \\
(16.781)\end{array}$ & & & $\begin{array}{c}71.336 \\
(19.143)\end{array}$ & $\begin{array}{l}317.452 \\
(22.555)\end{array}$ \\
\hline
\end{tabular}

Obs.: Todas as amostras marcadas $(*)$ foram limpas em coluna de sílica $(3 \mathrm{~cm})$, utilizando hexano/acetona 3:1 como eluente 
Os resultados das Tabelas 5.19 e 5.20 mostram que a recuperação dos clorofenóis nas amostras da estação 2 e 4 não foram consistentes, o que levou a uma nova avaliação do método extrativo escolhido. Porém, esse método já havia sido utilizado com amostras do reservatório de Salto Grande, que estão apresentados nas Tabelas 1E a 12E, dos Anexos.

Para evidenciar possíveis perdas pelo método escolhido, novamente foram realizados testes de extração com os procedimentos empregando Soxhlet e a agitação com barra magnética. A amostra utilizada foi da estação 2 de Salto Grande, coletada em Novembro. Os procedimentos de extração utilizados estão descritos no item 4.2.4.3 de Materiais e Métodos, e os resultados nas Tabelas 5.21 e 5.22. A Tabela 5.22 apresenta os resultados obtidos da análise da solução de trabalho, retirada após 18 horas de contato com o sedimento e após acidificação e extraída pelo método proposto por DAMIANOVIC (1997).

De acordo com esses resultados, foi questionada a escolha inicialmente feita pelo método do ultra-som e a limpeza das amostras. Assim, as amostras restantes de Salto Grande foram analisadas novamente, utilizando-se a agitação e o Soxhlet, sem procedimentos de limpeza. As amostras analisadas por esses métodos foram as da $2^{\mathrm{a}}$ campanha, as estações 1 , 2 e 4 da $3^{\text {a }}$ campanha e as estações 1,3 e 4 da $4^{\text {a }}$ campanha. As amostras da estação 2 da $4^{\text {a }}$ campanha foram analisadas somente com ultra-som e agitação sob barra magnética. Objetivava-se com isto, comparar os resultados, para certificar-se da tomada de decisão, tanto pelo método de extração quanto pelo de limpeza, podendo-se tirar conclusões mais acertadas.

A curva de calibração para quantificação das amostras foi feita apenas com extração pelo método do ultra-som, portanto, as amostras extraídas pelos outros procedimentos foram utilizadas apenas para comparação por área dos cromatogramas, sem quantificação.

Todas as análises feitas, tanto cromatográficas, quanto as demais, serão discutidas por campanha, no item 5.3 . 
Tabela 5.21 - Resultados obtidos das injeções cromatográficas do teste de comparação entre os métodos de extração para sedimentos

Sedimento/ Estação 2/ Novembro

\begin{tabular}{|c|c|c|c|c|c|c|c|c|c|}
\hline \multirow{2}{*}{$\begin{array}{l}\text { Tipo de } \\
\text { Extração }\end{array}$} & \multirow{2}{*}{ Amostras } & \multicolumn{8}{|c|}{ Compostos (Área/ tempo de Retenção) } \\
\hline & & 2,5-DCP & 3,5-DCP & 2,4,6-TCP & $2,3,6-\mathrm{TCP}$ & $2,4,5-\mathrm{TCP}$ & 2,4-DBP & 2,3,4-TCP & PCP \\
\hline \multirow{3}{*}{ Ultra-som } & Branco & ----------- & ----------- & ----------- & ----------- & ----------- & $\begin{array}{c}38.446 \\
(18.529)\end{array}$ & ----------- & $\begin{array}{c}30.823 \\
(22.559)\end{array}$ \\
\hline & 1 & ----------- & ----------- & $\begin{array}{c}65.178 \\
(15.977) \\
\end{array}$ & $\begin{array}{c}49.151 \\
(16.782)\end{array}$ & ----------- & $\begin{array}{c}33.191 \\
(18.758)\end{array}$ & $\begin{array}{c}32.698 \\
(19.144) \\
\end{array}$ & $\begin{array}{c}64.882 \\
(22.557) \\
\end{array}$ \\
\hline & 2 & ----------- & ----------- & $\begin{array}{l}189.766 \\
(15.972)\end{array}$ & $\begin{array}{c}184.423 \\
(16.778)\end{array}$ & ----------- & $\begin{array}{c}32.056 \\
(18.753) \\
\end{array}$ & $\begin{array}{c}33.251 \\
(19.471)\end{array}$ & $\begin{array}{l}357.714 \\
(22.553)\end{array}$ \\
\hline \multirow{2}{*}{ Agitação } & 1 & ----------- & ----------- & $\begin{array}{c}1.168 .427 \\
(15.970)\end{array}$ & $\begin{array}{c}1.153 .014 \\
(16.775)\end{array}$ & ----------- & ----------- & $\begin{array}{l}653.186 \\
(19.136) \\
\end{array}$ & $\begin{array}{c}2.397 .653 \\
(22.552)\end{array}$ \\
\hline & 2 & ----------- & ----------- & $\begin{array}{c}1.563 .807 \\
(15.968)\end{array}$ & $\begin{array}{c}1.498 .105 \\
(16.773)\end{array}$ & & & $\begin{array}{l}822.458 \\
(19.135)\end{array}$ & $\begin{array}{c}3.260 .665 \\
(22.551)\end{array}$ \\
\hline \multirow{2}{*}{ Soxhlet } & 1 & $\begin{array}{c}61.779 \\
(15.034)\end{array}$ & & $\begin{array}{c}1.746 .429 \\
(15.982)\end{array}$ & $\begin{array}{c}1.805 .279 \\
(16.786)\end{array}$ & $\begin{array}{c}56.249 \\
(18.193) \\
\end{array}$ & $\begin{array}{l}376.808 \\
(18.460)\end{array}$ & $\begin{array}{l}875.745 \\
(19.145) \\
\end{array}$ & $\begin{array}{c}2.239 .615 \\
(22.563)\end{array}$ \\
\hline & 2 & $\begin{array}{c}56.227 \\
(15.023)\end{array}$ & $\begin{array}{c}77.167 \\
(15.268)\end{array}$ & $\begin{array}{c}1.536 .104 \\
(15.971)\end{array}$ & $\begin{array}{c}1.566 .407 \\
(16.776)\end{array}$ & $\begin{array}{c}52.493 \\
(18.184)\end{array}$ & $\begin{array}{l}333.681 \\
(18.451)\end{array}$ & $\begin{array}{c}797.868 \\
(19.136)\end{array}$ & $\begin{array}{c}1.870 .664 \\
(22.553)\end{array}$ \\
\hline
\end{tabular}


Tabela 5.22- Resultados obtidos das injeções cromatográficas da solução de trabalho utilizada na dopagem dos sedimentos e da água com padrão interno utilizada para dopagem do branco no teste de comparação entre os métodos de extração para sedimentos

\begin{tabular}{|c|c|c|c|c|c|c|c|c|c|}
\hline \multicolumn{10}{|c|}{ Água da dopagem do Sedimento/ Estação 2/ Novembro (Área/ tempo de Retenção) } \\
\hline \multirow{2}{*}{$\begin{array}{c}\text { Tipo de } \\
\text { Extração }\end{array}$} & \multirow[b]{2}{*}{ Amostras } & \multicolumn{8}{|c|}{ Compostos (Área/ tempo de Retenção) } \\
\hline & & 2,5-DCP & 3,5-DCP & 2,4,6-TCP & $2,3,6-\mathrm{TCP}$ & $2,4,5-\mathrm{TCP}$ & 2,4-DBP & $2,3,4-\mathrm{TCP}$ & $\mathrm{PCP}$ \\
\hline \multirow{3}{*}{ Ultra-som } & Branco & & ---- & ------------ & ------------ & & & ----------- & $\begin{array}{l}550.094 \\
(22.684)\end{array}$ \\
\hline & 1 & ----------- & ----------- & $\begin{array}{l}179.313 \\
(15.977)\end{array}$ & $\begin{array}{l}226.381 \\
(16.786)\end{array}$ & ----------- & ----------- & $\begin{array}{c}39.166 \\
(19.149)\end{array}$ & $\begin{array}{l}198.661 \\
(22.559)\end{array}$ \\
\hline & 2 & ----- & ----------- & $\begin{array}{l}253.302 \\
(15.972)\end{array}$ & $\begin{array}{l}320.967 \\
(16.778)\end{array}$ & --- & & $\begin{array}{c}65.583 \\
(19.144)\end{array}$ & $\begin{array}{l}108.245 \\
(22.555)\end{array}$ \\
\hline \multirow{2}{*}{ Agitação } & 1 & ---- & ----- & $\begin{array}{l}265.701 \\
(15.972)\end{array}$ & $\begin{array}{l}324.301 \\
(16.777)\end{array}$ & ----- & ----------- & $\begin{array}{c}82.621 \\
(19.142)\end{array}$ & $\begin{array}{l}139.063 \\
(22.552) \\
\end{array}$ \\
\hline & 2 & --- & ----------- & $\begin{array}{l}236.279 \\
(15.968)\end{array}$ & $\begin{array}{l}290.688 \\
(16.773)\end{array}$ & ----------- & & $\begin{array}{c}72.668 \\
(19.138)\end{array}$ & $\begin{array}{l}117.168 \\
(22.549)\end{array}$ \\
\hline \multirow{2}{*}{ Soxhlet } & 1 & ---------- & ----------- & $\begin{array}{l}167.583 \\
(15.973) \\
\end{array}$ & $\begin{array}{l}208.847 \\
(16.778) \\
\end{array}$ & ----------- & ----------- & $\begin{array}{c}45.223 \\
(19.144) \\
\end{array}$ & $\begin{array}{c}86.653 \\
(22.553) \\
\end{array}$ \\
\hline & 2 & ----------- & ----------- & $\begin{array}{l}354.663 \\
(15.969)\end{array}$ & $\begin{array}{l}427.053 \\
(16.774)\end{array}$ & ----------- & ----------- & $\begin{array}{c}97.192 \\
(19.139)\end{array}$ & $\begin{array}{l}209.031 \\
(22.550)\end{array}$ \\
\hline
\end{tabular}





\subsection{Resultados e Discussão por Campanha}

\subsubsection{Parâmetros Climatológicos}

$\mathrm{Na}$ Tabela 5.23 estão apresentados todos os parâmetros climatológicos registrados para os dias de coletas. Os valores serão discutidos, posteriormente, em relação a cada condição do reservatório de Salto Grande, em campanha realizada.

Tabela 5.23- Parâmetros climatológicos registrados nas campanhas

\begin{tabular}{l|c|c|c|c}
\hline \multirow{2}{*}{ Parâmetros Climatológicos } & \multicolumn{4}{|c}{ Campanhas } \\
\cline { 2 - 5 } & $27 / 05 / 98$ & $18 / 06 / 98$ & $06 / 11 / 98$ & $25 / 02 / 99$ \\
\hline Radiação Global $\left(\mathrm{cal} / \mathrm{cm}^{2} . \mathrm{d}\right)$ & 116 & 252 & 642 & 410 \\
\hline Insolação (horas/dia) & 2,8 & 6,9 & 10,4 & 5,4 \\
\hline Precipitação (mm) & 9,9 & 17,8 & 0,0 & 7,1 \\
\hline UR (\%) & 96 & 82,0 & 65 & 90 \\
\hline Vento médio (Km/h) & 7,2 & 10,8 & 5,3 & 5,6 \\
\hline Temperatura máxima $\left({ }^{0} \mathrm{C}\right)$ & 24,6 & 28,3 & 32,9 & 30,7 \\
\hline Temperatura. Mínima $\left({ }^{0} \mathrm{C}\right)$ & 16,0 & 13,0 & 17,0 & 20,1 \\
\hline Temperatura. Média $\left({ }^{0} \mathrm{C}\right)$ & 20,3 & 20,7 & 25,0 & 25,4 \\
Evaporação $(\mathrm{mm})$ & 1,40 & 4,61 & 5,86 & 5,29 \\
\hline
\end{tabular}

Fonte: CIAGRI (1999)

\subsubsection{Radiação solar}

Na Tabela 5.24 estão apresentados os valores da radiação solar nos meses da coleta.

Para os meses de Maio e Junho foram obtidos os menores valores do ano. Entretanto, considerando o dia da coleta, o menor valor encontrado foi para a campanha de Maio. Em Novembro ocorreu um dos maiores valores de radiação do ano e o maior, considerando os dias das coletas. 
Tabela 5.24 - Médias mensais dos valores de radiação solar para as campanhas.

\begin{tabular}{c|c|c}
\hline Campanhas & Radiação (cal/cm $\mathbf{2}$.dia) & Insolação (horas/dia) \\
\hline Maio/98 & 293,00 & 6,17 \\
\hline Junho/98 & 278,60 & 6,69 \\
\hline Novembro/98 & 474,27 & 7,79 \\
\hline Fevereiro/99 & 410,04 & 5,37 \\
\hline
\end{tabular}

Fonte: CIAGRI (1999)

\subsubsection{Ventos}

$\mathrm{Na}$ Tabela 5.25 estão apresentados os valores da velocidade do vento para os meses da coleta. As velocidades máxima e a média atingiram os maiores picos anuais no mês de Novembro. Entre os dias específicos das coletas, as maiores velocidades foram atingidas na campanha de Junho. A direção do vento predominante foi a mesma, exceto para o mês de Fevereiro.

Tabela 5.25 - Médias mensais dos valores da velocidade do vento para as campanhas

\begin{tabular}{c|c|c}
\hline Campanhas & $\begin{array}{c}\text { Velocidade máxima }(\mathbf{m} / \mathbf{s}) / \\
\text { direção }\end{array}$ & Velocidade média $(\mathbf{K m} / \mathbf{h})$ \\
\hline Maio/98 & $5,82 /$ sul & 6,09 \\
\hline Junho/98 & $6,25 /$ sul & 6,48 \\
\hline Novembro/98 & $9,66 /$ sul & 9,27 \\
\hline Fevereiro/99 & $8,73 /$ leste & 5,64 \\
\hline
\end{tabular}

Fonte: CIAGRI (1999)

\subsubsection{Precipitação total}

Nas campanhas de Junho e Novembro, obteve-se a mesma precipitação média mensal, porém, houve melhor distribuição no mês de Novembro. Em Junho, a maior precipitação ocorreu no dia da coleta. A maior precipitação média mensal das campanhas foi na de Fevereiro. (Tabela 5.26). 
Tabela 5.26 - Médias mensais dos valores de precipitação para as campanhas

\begin{tabular}{c|c|c}
\hline Campanhas & Precipitação média $(\mathbf{m m})$ & Dias de chuva \\
\hline Maio/98 & 97,60 & 10 \\
\hline Junho/98 & 26,60 & 2 \\
\hline Novembro/98 & 26,60 & 19 \\
\hline Fevereiro/99 & 198,30 & 5 \\
\hline
\end{tabular}

Fonte: CIAGRI (1999)

\subsubsection{Temperatura do ar}

Na Tabela 5.27 estão apresentados os valores das temperaturas máxima, média e mínima mensais, considerando os meses em que foram feitas as coletas. A maior temperatura mensal entre as campanhas foi encontrada no mês de Fevereiro. Considerando o dia da coleta, a maior temperatura foi registrada na campanha de Novembro. As menores temperaturas entre as campanhas foram registradas no mês de Junho.

Tabela 5.27 - Médias mensais dos valores de temperatura para as campanhas

\begin{tabular}{c|c|c|c}
\hline \multirow{2}{*}{ Campanhas } & \multicolumn{3}{|c}{${\text { Temperaturas }\left({ }^{0} \mathbf{C}\right)}$} \\
\cline { 2 - 4 } & Máxima & Média & Mínima \\
\hline Maio/98 & 24,95 & 12,80 & 18,87 \\
\hline Junho/98 & 24,12 & 9,86 & 17,00 \\
\hline Novembro/98 & 24,12 & 16,45 & 23,24 \\
\hline Fevereiro/99 & 30,73 & 20,05 & 25,41 \\
\hline
\end{tabular}

Fonte: CIAGRI (1999)

\subsubsection{Parâmetros Hidráulicos e Morfométricos}

\subsubsection{Tempo de Residência}

O tempo médio de residência da água no reservatório foi calculado mensalmente, dividindo-se o volume médio mensal do reservatório pela vazão média mensal de saída, em $\mathrm{m}^{3} /$ dia. Na Tabela 5.28 são apresentados os tempos de residência calculados, bem como as vazões médias mensais de saída de Fevereiro/98 a Fevereiro/99. Na Figura 5.1, podem ser bem visualizados os tempos de residência máximo e mínimo desse período. Considerando as campanhas, o menor tempo de residência foi obtido em Fevereiro e o maior em Novembro. 
Tabela 5.28 - Tempo de Residência (dias) e vazão média mensal de saída $\left(\mathrm{m}^{3} / \mathrm{s}\right)$ de Fevereiro/98 a Fevereiro/99

\begin{tabular}{c|c|c}
\hline Meses & Tempo de Residência (dias) & Vazão média mensal de saída $\left(\mathbf{m}^{\mathbf{3}} / \mathbf{s}\right)$ \\
\hline Fev/98 & 19,04 & 64,43 \\
\hline Mar/98 & 26,08 & 47,04 \\
\hline Abr/98 & 63,06 & 19,46 \\
\hline Maio/98 & 49,05 & 25,01 \\
\hline Jun/98 & 74,08 & 16,56 \\
\hline Jul/98 & 96,46 & 12,72 \\
\hline Ago/98 & 110,03 & 11,15 \\
\hline Set/98 & 107,57 & 11,41 \\
\hline Out/98 & 39,12 & 31,36 \\
\hline Nov/98 & 102,93 & 11,92 \\
\hline Dez/99 & 27,56 & 44,52 \\
\hline Jan/99 & 12,74 & 96,28 \\
\hline Fev/99 & 14,23 & 86,24 \\
\hline
\end{tabular}

Fonte: CPFL (1999)

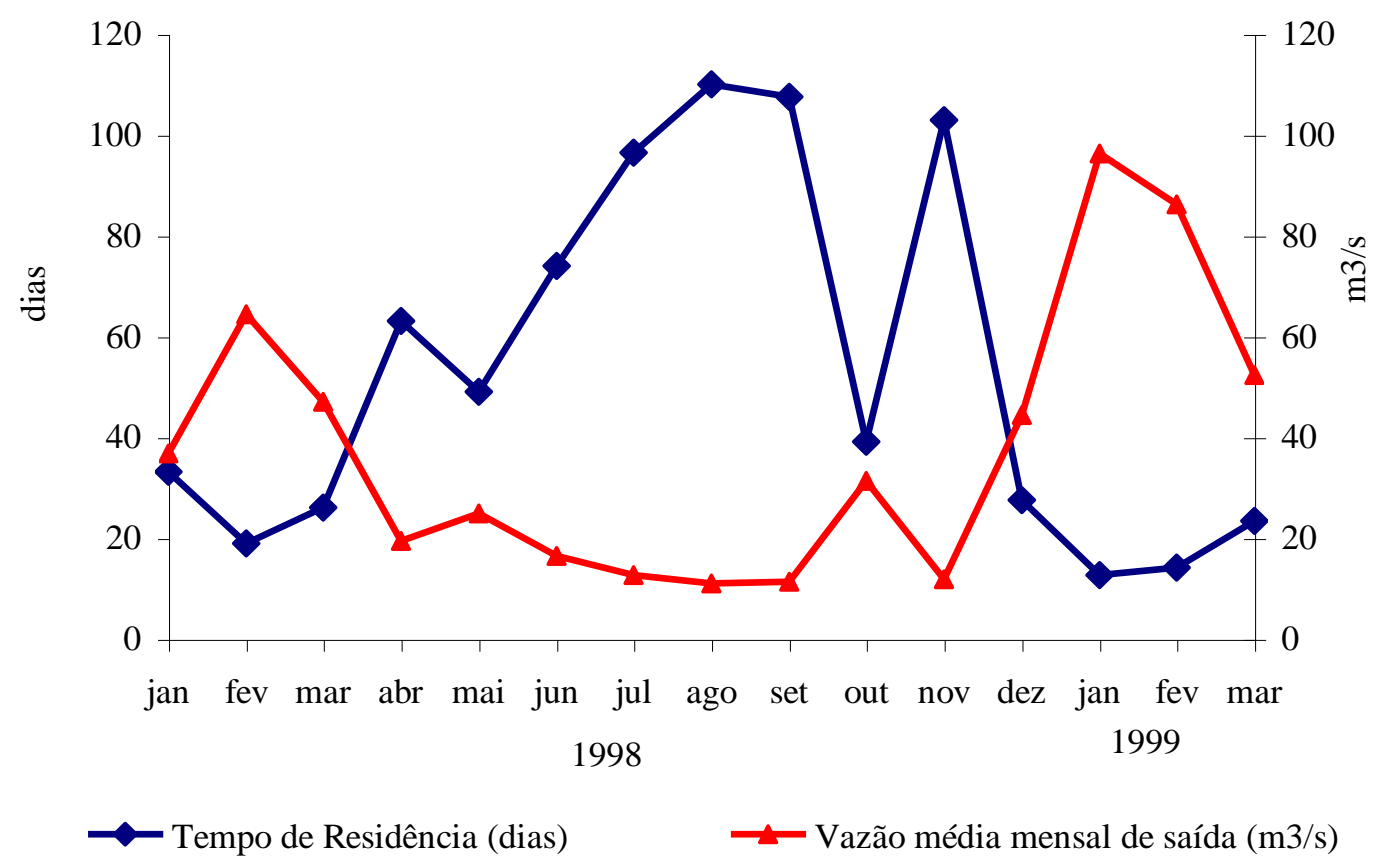

FIGURA 5.1 - TEMPO DE RESIDÊNCIA E VAZÃO MÉDIA MENSAL DE SAÍDA, NO RESERVATÓRIO DE SALTO GRANDE, AMERICANA (SP) (ADAPTADA DE TOSSINI, 1999). 


\subsubsection{Variáveis Físicas e Químicas}

\subsubsection{1. $\mathrm{pH}$, condutividade ( $\mu \mathrm{S} / \mathrm{cm}$ ), Turbidez (uT), oxigênio dissolvido $(\mathrm{mg} / \mathrm{L})$ e temperatura $\left({ }^{0} \mathrm{C}\right)$}

c) Maio:

Na primeira campanha, realizada em maio de 1998, foram feitas coletas em duas estações, 2 e 4, que representam o início do primeiro e o terceiro compartimento, respectivamente. As amostras de água foram coletadas apenas na estação 2. As estações escolhidas estão localizadas em pontos extremos e apresentaram características bem distintas para as variáveis condutividade e oxigênio dissolvido. Tal fato já havia sido observado por KIMMEL et al. (1990) apud RICHTER et al. (1991). Segundo os autores (op. cit.), em um reservatório, o tempo de retenção intermediário entre rios e lagos e os aportes predominantemente de uma fonte principal, no caso o rio Atibaia, resultam em um gradiente longitudinal das características limnológicas, ao longo do maior eixo, que nesse caso, liga a estação 2 a 4, acompanhando a calha do rio. As Tabelas 5.29 e 5.30 apresentam as fichas de bordo das estações, ou seja, os valores dos parâmetros físico-químicos medidos durante a coleta.

Os valores de pH para a estação 2, em coluna d'água de $2 \mathrm{~m}$, variaram de 6,73 a 6,49, enquanto para a estação 4, em uma coluna d'água de $11 \mathrm{~m}$, esta variação foi de 7,44 a 6,14 .

Na estação 2, o valor de turbidez encontrado foi em torno de 30, e a condutividade foi de aproximadamente $293 \mu \mathrm{S} / \mathrm{cm}$, enquanto que na estação 4, não foi possível verificar o valor da turbidez e enquanto que os valores de condutividade foram muito superiores aos da estação 2, chegando atingir $86 \mu \mathrm{S} / \mathrm{cm}$. Sendo a condutividade elétrica dependente da quantidade de sais dissolvidos na água e aproximadamente proporcional à sua quantidade (RICHTER et al., 1991), supõe-se que essa discrepância seja devida à estratificação térmica ocorrida na estação 4, em que a variação de temperatura da superfície para o fundo chegou a $3,4^{0} \mathrm{C}$. Segundo AGOSTINHO et al. (1997), a estratificação térmica propicia a liberação de compostos químicos a partir do sedimento e também o acúmulo de elementos oriundos da decomposição no hipolímnio.

O oxigênio dissolvido (OD) permaneceu praticamente constante na estação 2, porém, sofreu um gradiente de variação bastante acentuado na estação 4, onde apresentou concentração de 14,62 mg/L na superfície da coluna d'água, e concentração de $0,41 \mathrm{mg} / \mathrm{L}$ no fundo. Essa estratificação química pode ter sido intensificada pela estratificação térmica, 
visto que aportes de oxigênio para as camadas mais profundas d'água ocorrem durante períodos de circulação completa. Nesse caso, há influência também da estação seca, quando o tempo de residência da água é maior. Outro fator que pode explicar essa estratificação química é a matéria orgânica em maior quantidade nessa estação, e seu acúmulo nas camadas mais profundas. Essa afirmação pode ser confirmada pelos valores encontrados na análise de carbono orgânico total da água (Tabela 5.31). Estando o oxigênio envolvido diretamente com o processo de fotossíntese e respiração e/ou decomposição, a hora em que foi feita a coleta na estação 4, também pode ter contribuído para esses valores. Esse horário está no intervalo de maior intensidade solar do dia, logo, nas camadas superiores, onde há maior penetração da luz, é estimulada a fotossíntese, com conseqüente produção de oxigênio e intenso consumo de gás carbônico do meio. Nas camadas mais profundas, zona afótica, ocorre fenômeno inverso, havendo decomposição da matéria orgânica pela atividade dos microrganismos, com consumo de oxigênio e produção de gás carbônico.

A análise de material em suspensão, revelou predomínio de material inorgânico, enquanto na análise de carbono total, predomínio de carbono orgânico (Tabela 5.31). Essas análises foram feitas somente para a estação 2 , porque não foram coletadas amostras de água na estação 4, apenas foram avaliadas as variáveis físico-químicas na coluna d'água quando da coleta do sedimento.

Os diferentes tipos de carbono orgânico de um ecossistema aquático continental podem ser agrupados em duas categorias: carbono orgânico detrital e carbono orgânico particulado da biota, que somados, formam o carbono orgânico total. O carbono orgânico detrital é composto por duas frações, carbono particulado detrital e carbono orgânico dissolvido (ESTEVES, 1988). Como pela técnica utilizada, filtra-se a água, essas medidas de carbono orgânico são relativas ao carbono orgânico dissolvido e portanto não há relação entre a análise de material em suspensão e a análise de carbono total.

A predominância de material inorgânico é devida aos aportes do rio Atibaia, muito influente na estação 2. Para a estação 4, possivelmente a concentração de carbono orgânico seria maior, devido às condições locais dessa estação, sob influência das macrófitas, que juntamente com o fitoplâncton, constituem importante fonte de carbono orgânico dissolvido para a coluna d'água. Em função desses resultados, é também esperado que o teor de matéria orgânica no sedimento da estação 4 seja mais elevado que na estação 2 , devido à deposição de material em suspensão, principalmente da decomposição de macrófitas.

As análises de carbono orgânico total e umidade não foram realizadas nos sedimentos porque não houve quantidade disponível, visto que as amostras dessa campanha 
foram utilizadas prioritariamente para determinar e ajustar procedimentos de extração para análises cromatográficas.

Tabela 5.29 - Ficha de bordo: parâmetros físico-químicos medidos na estação 2, na campanha de Maio/98

\begin{tabular}{c|c|c|c|c|c}
\hline \multicolumn{7}{c}{ Estação: 2 } \\
\multicolumn{7}{c}{ Horário da coleta: 11:30 } \\
\hline $\begin{array}{c}\text { Profundidades } \\
(\mathrm{m})\end{array}$ & $\begin{array}{c}\text { Valores } \\
\text { de } \mathrm{pH}\end{array}$ & $\begin{array}{c}\text { Condutividade } \\
(\mu \mathrm{S} / \mathrm{cm})\end{array}$ & $\begin{array}{c}\text { Valores de } \\
\text { turbidez }(\mathrm{uT})\end{array}$ & $\begin{array}{c}\text { Valores de Oxigênio } \\
\text { dissolvido }(\mathrm{mg} / \mathrm{L})\end{array}$ & $\begin{array}{c}\text { Temperatura } \\
\left({ }^{0} \mathrm{C}\right)\end{array}$ \\
\hline 0,00 & 6,59 & 293 & 30,00 & 2,29 & 21,60 \\
\hline 0,50 & 6,52 & 293 & 21,00 & 2,16 & 21,60 \\
\hline 1,00 & 6,49 & 293 & 27,00 & 2,34 & 21,60 \\
\hline 1,50 & 6,73 & 294 & 20,00 & 2,54 & 21,60 \\
\hline 2,00 & 6,64 & 293 & 22,00 & 2,18 & 21,60 \\
\hline
\end{tabular}

Tabela 5.30 - Ficha de bordo: parâmetros físico-químicos medidos na estação 4, na campanha de Maio/98

\begin{tabular}{c|c|c|c|c}
\hline \multicolumn{5}{c}{ Horário da coleta: 13:00 h } \\
\hline $\begin{array}{c}\text { Profundidades } \\
(\mathrm{m})\end{array}$ & Valores de pH & $\begin{array}{c}\text { Condutividade } \\
(\mu \mathrm{S} / \mathrm{cm})\end{array}$ & $\begin{array}{c}\text { Valores de Oxigênio } \\
\text { dissolvido }(\mathrm{m} / \mathrm{L})\end{array}$ & $\begin{array}{c}\text { Temperatura } \\
\left({ }^{0} \mathrm{C}\right)\end{array}$ \\
\hline 0,00 & 7,35 & 85,00 & 14,62 & 24,20 \\
\hline 0,50 & 7,35 & 86,00 & 14,16 & 23,80 \\
\hline 1,00 & 7,44 & 86,00 & 15,37 & 23,20 \\
\hline 1,50 & 7,44 & 86,00 & 15,50 & 22,80 \\
\hline 2,00 & 7,44 & 86,00 & 13,27 & 22,10 \\
\hline 2,50 & 7,09 & 86,00 & 13,27 & 22,10 \\
\hline 3,00 & 6,78 & 86,00 & 11,67 & 21,90 \\
\hline 3,50 & 6,45 & 86,00 & 9,73 & 21,50 \\
\hline 4,00 & 6,43 & 86,00 & 4,92 & 21,50 \\
\hline 4,50 & 6,34 & 96,00 & 3,43 & 21,20 \\
\hline 5,00 & 6,34 & 96,00 & 2,30 & 21,10 \\
\hline 5,50 & 6,24 & 86,00 & 2,30 & 21,10 \\
\hline 6,00 & 6,22 & 86,00 & 1,30 & 21,00 \\
\hline 6,50 & 6,22 & 86,00 & 1,01 & 21,00 \\
\hline 7,00 & 6,22 & 86,00 & 1,01 & 20,90 \\
\hline 7,50 & 6,22 & 86,00 & 0,73 & 20,90 \\
\hline 8,00 & 6,16 & 86,00 & 0,59 & 20,90 \\
\hline 8,50 & 6,15 & 86,00 & 0,59 & 20,90 \\
\hline 9,00 & 6,15 & 86,00 & 0,47 & 20,90 \\
\hline 9,50 & 6,15 & 86,00 & 0,44 & 20,80 \\
\hline 10,00 & 6,14 & 86,00 & 0,38 & 20,80 \\
\hline 10,50 & 6,14 & 87,00 & 0,41 & 20,80 \\
\hline 11,00 & 6,14 & 87,00 & 0,41 & 20,80 \\
\hline & & & & \\
\hline
\end{tabular}


Tabela 5.31 - Resultados das análises de Material em Suspensão Total e das frações orgânica e inorgânica, e Carbono total e das frações orgânica $e$ inorgânica das amostras de água da campanha de Maio/98

\begin{tabular}{|c|c|c|c|}
\hline Estação & MST (mg/L) & MSO (mg/L) & MSI (mg/L) \\
\hline \multirow{4}{*}{2} & 28,21 & 6,41 & 21,79 \\
\hline & & & \\
\hline & CT (mg/L) & COT (mg/L) & CI (mg/L) \\
\hline & 5,80 & 3,13 & 2,67 \\
\hline
\end{tabular}

d) Junho

Na campanha de Junho foram feitas coletas de água e de sedimento nas mesmas estações da campanha anterior, estações 2 e 4. Apesar de serem pontos extremos considerando o reservatório, entrada e saída, não foram observadas diferenças relevantes entre as 2 estações como na primeira campanha (Tabelas 5.32 e 5.33). Na primeira campanha, os resultados mostraram diferenças marcantes entre os mesmos pontos de coleta. As velocidades elevadas dos ventos no dia da coleta, também a maior dentre as campanhas, podem explicar os valores das variáveis medidas, pois facilitam a mistura na coluna d'água..

Os valores de pH variaram de 6,83 a 6,76 para a estação 2 , em uma coluna de água de 2,20 m, e de 6,65 a5,90 para a estação 4, em uma coluna de água de 14,80 m. Comparadas à primeira campanha, houve diferenças menores entre os valores de $\mathrm{pH}$ nas duas estações dessa campanha, ou seja, houve maior uniformidade na campanha de Junho.

A condutividade registrada nas 2 estações estava em torno de $100 \mu \mathrm{S} / \mathrm{cm}$, exceto no ponto mais profundo de coleta da estação 4, onde os valores de condutividade atingiram 201 $\mu \mathrm{S} / \mathrm{cm}$. O mesmo ocorreu na estação 4 da Campanha de Maio. Esse fato, pode ser explicado pelo elevado número de macrófitas e matéria orgânica nessa estação. Pelas considerações de AGOSTINHO \& GOMES (1997), nessa situação, as camadas mais profundas são anóxicas, com altos valores de condutividade, sendo um indicativo de altas taxas de decomposição da matéria orgânica.

Os valores de oxigênio dissolvido foram baixos nas duas estações, atingindo valores próximos a zero nas camadas mais profundas da estação 4, a 14,50 m, possivelmente pelo fato da coleta ter sido feita pela manhã, em estação seca, de baixas temperaturas, apresentando menor luminosidade e consequentemente, menor taxa fotossintética. Esses valores de luminosidade precipitação e temperatura foram os mais baixos entre as campanhas, como visto nas Tabelas 5.24, 5.26 e 5.27, respectivamente. 
Os valores de material em suspensão total $(\mathrm{mg} / \mathrm{L})$ na estação 2 revelam que a fração inorgânica foi superior à orgânica, Tabela 5.34. Os valores de carbono total $(\mathrm{mg} / \mathrm{L})$ mostram o predomínio de carbono inorgânico, Tabela 5.35. Nessa estação, as diferenças foram maiores entre as concentrações de carbono orgânico e inorgânico.

$\mathrm{Na}$ estação 4, entretanto, predominou o material em suspensão orgânico, como pode ser visto na Tabela 5.34, porém, no caso do carbono total, houve predomínio do carbono inorgânico, Tabela 5.35. A alta concentração de material em suspensão orgânico nesse ponto, era esperada, visto que é uma região com alta densidade de macrófitas e a coleta foi feita em estação cujo tempo de residência também é elevado.

A comparação entre os valores de material em suspensão e carbono total ficou prejudicada pela filtração das amostras para análise em aparelho COT. No caso dessas duas estações, o valor de carbono orgânico pode estar subestimado devido ao procedimento analítico, visto que foram analisados somente os teores de carbono orgânico dissolvido.

Tabela 5.32 - Ficha de bordo: parâmetros físico-químicos medidos na estação 2, na campanha de Junho/98

Estação 2

Horário da coleta: 8:35 h

\begin{tabular}{c|c|c|c|c|c}
\hline $\begin{array}{c}\text { Profundidades } \\
(\mathrm{m})\end{array}$ & $\begin{array}{c}\text { Valores } \\
\mathrm{de} \mathrm{pH}\end{array}$ & $\begin{array}{c}\text { Condutividade } \\
(\mu \mathrm{S} / \mathrm{cm})\end{array}$ & $\begin{array}{c}\text { Valores de } \\
\text { turbidez }(\mathrm{uT})\end{array}$ & $\begin{array}{c}\text { Valores de Oxigênio } \\
\text { dissolvido }(\mathrm{mg} / \mathrm{L})\end{array}$ & $\begin{array}{c}\text { Temperaturas } \\
\left({ }^{0} \mathrm{C}\right)\end{array}$ \\
\hline 0,00 & 6,83 & 106,00 & 3,08 & 3,08 & 17,8 \\
\hline 0,50 & 6,83 & 106,00 & 4,00 & 2,89 & 17,7 \\
\hline 1,00 & 6,82 & 104,00 & 3,00 & 2,99 & 17,7 \\
\hline 1,50 & 6,81 & 104,00 & 3,00 & 3,09 & 17,7 \\
\hline 2,00 & 6,79 & 104,00 & 3,00 & 3,33 & 17,7 \\
\hline 2,20 & 6,76 & 106,00 & 6,00 & 3,18 & 17,7 \\
\hline
\end{tabular}


Tabela 5.33 - Ficha de bordo: parâmetros físico-químicos medidos na estação 4, na campanha de Junho/98

\begin{tabular}{|c|c|c|c|c|c|}
\hline \multicolumn{6}{|c|}{$\begin{array}{c}\text { Estação } 4 \\
\text { Horário da coleta: 9:15 h }\end{array}$} \\
\hline $\begin{array}{l}\text { Profundidades } \\
\text { (m) }\end{array}$ & $\begin{array}{l}\text { Valores } \\
\text { de } \mathrm{pH}\end{array}$ & $\begin{array}{l}\text { Condutividade } \\
(\mu \mathrm{S} / \mathrm{cm})\end{array}$ & $\begin{array}{l}\text { Valores de } \\
\text { turbidez (uT) }\end{array}$ & $\begin{array}{l}\text { Valores de Oxigênio } \\
\text { dissolvido (mg/L) }\end{array}$ & $\begin{array}{c}\text { Temperatura } \\
\mathrm{S}\left({ }^{\circ} \mathrm{C}\right)\end{array}$ \\
\hline 0,00 & 6,65 & 100,00 & 0,00 & 2,70 & 19,00 \\
\hline 0,50 & 6,61 & 101,00 & 1,00 & 2,79 & 19,00 \\
\hline 1,00 & 6,57 & 100,00 & 0,00 & 2,75 & 19,00 \\
\hline 1,50 & 6,53 & 100,00 & 0,00 & 2,70 & 19,00 \\
\hline 2,00 & 6,50 & 99,00 & 0,00 & 2,69 & 19,00 \\
\hline 2,50 & 6,48 & 98,00 & 0,00 & 2,63 & 19,00 \\
\hline 3,00 & 6,46 & 99,00 & 0,00 & 2,60 & 19,00 \\
\hline 3,50 & 6,45 & 99,00 & 0,00 & 2,61 & 19,00 \\
\hline 4,00 & 6,42 & 100,00 & 1,00 & 2,60 & 19,00 \\
\hline 4,50 & 6,42 & 101,00 & 0,00 & 2,56 & 19,00 \\
\hline 5,00 & 6,39 & 101,00 & 0,00 & 2,51 & 19,00 \\
\hline 5,50 & 6,38 & 100,00 & 0,00 & 2,56 & 19,00 \\
\hline 6,00 & 6,37 & 99,00 & 0,00 & 2,52 & 19,00 \\
\hline 6,50 & 6,36 & 99,00 & 0,00 & 2,51 & 19,00 \\
\hline 7,00 & 6,33 & 102,00 & 0,00 & 2,48 & 19,00 \\
\hline 7,50 & 6,30 & 101,00 & 0,00 & 2,50 & 19,00 \\
\hline 8,00 & 6,29 & 100,00 & 1,00 & 2,55 & 19,00 \\
\hline 8,50 & 6,27 & 106,00 & 0,00 & 2,50 & 19,00 \\
\hline 9,00 & 6,25 & 101,00 & 0,00 & 2,51 & 19,00 \\
\hline 9,50 & 6,22 & 104,00 & 0,00 & 2,53 & 19,00 \\
\hline 10,00 & 6,21 & 103,00 & 0,00 & 2,59 & 19,00 \\
\hline 10,50 & 6,19 & 105,00 & 0,00 & 2,66 & 19,00 \\
\hline 11,00 & 6,16 & 107,00 & 0,00 & 2,63 & 19,00 \\
\hline 11,50 & 6,09 & 106,00 & 1,00 & 2,18 & 19,00 \\
\hline 12,00 & 6,06 & 108,00 & 0,00 & 2,04 & 19,00 \\
\hline 12,50 & 6,01 & 118,00 & 1,00 & 1,72 & 19,00 \\
\hline 13,00 & 5,95 & 105,00 & 1,00 & 1,57 & 18,90 \\
\hline 13,50 & 5,94 & 175,00 & 0,00 & 1,23 & 18,90 \\
\hline 14,00 & 5,91 & 194,00 & 1,00 & 0,70 & 18,80 \\
\hline 14,50 & 5,90 & 198,00 & 0,00 & 0,38 & 18,80 \\
\hline 14,80 & 5,90 & 201,00 & 1,00 & 0,16 & 18,80 \\
\hline
\end{tabular}

Tabela 5.34 - Resultados das análises de Material em Suspensão Total e das frações orgânicas e inorgânicas das amostras de água da campanha de Junho/98

\begin{tabular}{c|c|c|c}
\hline Estações & MST (mg/L) & MSO (mg/L) & MSI (mg/L) \\
\hline 2 & 6,36 & 0,91 & 5,45 \\
\hline 4 & 9,00 & 7,00 & 2,00 \\
\hline
\end{tabular}


Tabela 5.35 - Resultados das análises de Carbono total e das frações orgânicas e inorgânicas das amostras de água da campanha de Junho/98

\begin{tabular}{c|c|c|c}
\hline Estação & CT (mg/L) & COT (mg/L) & CI (mg/L) \\
\hline 2 & 7,77 & 2,18 & 5,60 \\
\hline 4 & 4,88 & 2,17 & 2,71 \\
\hline
\end{tabular}

c) Novembro

Na campanha de Novembro foram feitas 4 coletas, sendo coletadas amostras de água e sedimento em todas as estações. Os valores das medições das variáveis físico-químicas nas amostras de águas, feitas em campo, estão apresentados nas Tabelas 5.36 a 5.39.

Os valores de pH variaram de 6,00 a 6,75 nas 4 estações, porém, no início da coluna d'água da estação 3 , até a profundidade de 1,50 m, esses valores encontravam-se elevados, apresentando valores próximos a 8,00, os maiores valores de $\mathrm{pH}$ encontrados nas amostras d'água de todas as campanhas. Esses altos valores de $\mathrm{pH}$ e as altas concentrações de oxigênio dissolvido na superfície da água, podem ser explicados, pela alta taxa de radiação encontrada nessa campanha e conseqüentemente, imensa atividade fotossintética das algas presentes em toda a extensão do reservatório, principalmente no terceiro compartimento. Isto porque, a comunidade fitoplanctônica afeta diretamente os teores de oxigênio dissolvido e pH da superfície, elevando os valores em direção à região lacustre.

As taxas de oxigênio dissolvido foram baixas nas 4 estações. Na estação 1 houve pequena variação, apresentando um valor mínimo de $2,89 \mathrm{mg} / \mathrm{L}(0,50 \mathrm{~m})$ e um valor máximo de 3,33 mg/L (2,00 m), em uma coluna d'água de 2,0 m. Na estação 2 também houve pequena variação, de 0,39 (superfície) a 0,03 (final da coluna d'água; 2,40 m). Na estação 3, houve grande variação das concentrações de oxigênio dissolvido na coluna d'água, sendo que nos primeiros metros da coluna os valores estavam em torno de $10,0 \mathrm{mg} / \mathrm{L}$, atingindo 0,0 $\mathrm{mg} / \mathrm{L}$ a partir de uma profundidade de 5,50 m. Pode-se supor que a atividade fotossintética na superfície seja responsável por essa condição, e a decomposição da matéria orgânica no fundo, e em se tratando de região lacustre pela condição mais reduzida. Para a estação 4, os valores de oxigênio dissolvido foram reduzidos, variando de $0,43(8 \mathrm{~m})$ a 3,96 $(0,50 \mathrm{~m})$, sendo que na parte intermediária da coluna, de 6 a $10 \mathrm{~m}$, foram apresentados os menores valores. A coluna de água desta estação era de 17,50 m.

Outra possível explicação para esses baixos valores de oxigênio dissolvido nas duas primeiras estações, observados nessa campanha é o volume reduzido de água observado nesse período no rio Atibaia e na entrada do reservatório, justificado pela baixa precipitação e elevadas temperaturas e radiação, como pode ser observado nas Tabelas 5.26, 5.27 e 5.24, 
respectivamente. Essa visível diminuição do volume da água aliada a altas temperaturas e concentração de matéria orgânica, segundo ESTEVES (1988) contribui bastante para o grau de desoxigenação das águas.

A condutividade foi praticamente a mesma na estação 1 e 2, variando de 314 a 316 $\mu \mathrm{S} / \mathrm{cm}$. Nas demais estações o valor encontrado variou em uma faixa de 211 a 263 para a estação 3 e de 199 a 218 S/cm para a estação 4. Esses valores encontrados são considerados altos e podem ser atribuídos a diversos fatores, dentre eles, merecem destaque o elevado número de algas, o baixo volume de água observado nesta campanha e a ausência de chuvas.

A temperatura entre as estações variou de 22,2 a $27,6^{\circ} \mathrm{C}$, com estratificação na terceira e quarta estações, com variação de 5,4 e $3,4{ }^{0} \mathrm{C}$, respectivamente. Essa estratificação é atribuída a vários fatores, dentre eles, o menor fluxo d'água e as temperaturas mais elevadas na superfície.

Tabela 5.36 - Ficha de bordo: parâmetros físico-químicos medidos na estação 1, na campanha de Novembro/98

\begin{tabular}{c|c|c|c|c|c}
\hline \multicolumn{7}{c}{ Horário da coleta: 10:40 h. } \\
\hline $\begin{array}{c}\text { Profundidades } \\
(\mathrm{m})\end{array}$ & $\begin{array}{c}\text { Valores } \\
\text { de } \mathrm{pH}\end{array}$ & $\begin{array}{c}\text { Valores de } \\
\text { Condutividade } \\
(\mu \mathrm{S} / \mathrm{cm})\end{array}$ & $\begin{array}{c}\text { Valores de } \\
\text { turbidez }(\mathrm{uT})\end{array}$ & $\begin{array}{c}\text { Valores de } \\
\text { Oxigênio dissolvido } \\
(\mathrm{mg} / \mathrm{L})\end{array}$ & $\begin{array}{c}\text { Temperaturas } \\
\left({ }^{0} \mathrm{C}\right)\end{array}$ \\
\hline 0,00 & 6,23 & 316,00 & 3,08 & 3,08 & 24,80 \\
\hline 0,50 & 6,33 & 316,00 & 4,00 & 2,89 & 24,70 \\
\hline 1,00 & 6,22 & 314,00 & 3,50 & 2,99 & 24,70 \\
\hline 1,50 & 6,21 & 314,00 & 3,50 & 3,09 & 24,70 \\
\hline 2,00 & 6,19 & 314,00 & 3,50 & 3,33 & 24,70 \\
\hline
\end{tabular}

Tabela 5.37 - Ficha de bordo: parâmetros físico-químicos medidos na estação 2, na campanha de Novembro/98

\begin{tabular}{c|c|c|c|c|c}
\hline \multicolumn{7}{c}{ Horário da coleta: 11:00 h. } \\
\hline $\begin{array}{c}\text { Profundidades } \\
(\mathrm{m})\end{array}$ & $\begin{array}{c}\text { Valores } \\
\text { de pH }\end{array}$ & $\begin{array}{c}\text { Condutividade } \\
(\mu \mathrm{S} / \mathrm{cm})\end{array}$ & $\begin{array}{c}\text { Valores de } \\
\text { turbidez }(\mathrm{uT})\end{array}$ & $\begin{array}{c}\text { Valores de } \\
\text { Oxigênio dissolvido } \\
(\mathrm{mg} / \mathrm{L})\end{array}$ & $\begin{array}{c}\text { Temperatura } \\
\left({ }^{0} \mathrm{C}\right)\end{array}$ \\
\hline 0,00 & 6,28 & 314,00 & 4,00 & 0,39 & 24,30 \\
\hline 0,50 & 6,23 & 314,00 & 4,00 & 0,35 & 24,00 \\
\hline 1,00 & 6,22 & 315,00 & 4,00 & 0,32 & 24,00 \\
\hline 1,50 & 6,24 & 315,00 & 4,00 & 0,03 & 23,90 \\
\hline 2,00 & 6,21 & 315,00 & 4,00 & 0,08 & 23,80 \\
\hline 2,40 & 6,23 & 314,00 & 185,00 & 0,03 & 23,80 \\
\hline
\end{tabular}

Observação: o alto valor encontrado para a turbidez a $2,40 \mathrm{~m}$ deve-se, provavelmente a ressuspensão de material. 
Tabela 5.38 - Ficha de bordo: parâmetros físico-químicos medidos na estação 3, na campanha de Novembro/98

Estação 3

Horário da coleta: 11:35 h.

\begin{tabular}{c|c|c|c|c|c}
\hline $\begin{array}{c}\text { Profundidades } \\
(\mathrm{m})\end{array}$ & $\begin{array}{c}\text { Valores } \\
\text { de } \mathrm{pH}\end{array}$ & $\begin{array}{c}\text { Valores de } \\
\text { condutividade } \\
(\mu \mathrm{S} / \mathrm{cm})\end{array}$ & $\begin{array}{c}\text { Valores de } \\
\text { turbidez }(\mathrm{uT})\end{array}$ & $\begin{array}{c}\text { Valores de } \\
\text { Oxigênio dissolvido } \\
(\mathrm{mg} / \mathrm{L})\end{array}$ & $\begin{array}{c}\text { Temperaturas } \\
\left({ }^{0} \mathrm{C}\right)\end{array}$ \\
\hline 0,00 & 8,12 & 234,00 & -- & 12,07 & 27,60 \\
\hline 0,50 & 8,12 & 234,00 & -- & 11,79 & 26,00 \\
\hline 1,00 & 7,92 & 229,00 & -- & 10,77 & 25,70 \\
\hline 1,50 & 7,78 & 230,00 & -- & 10,63 & 25,10 \\
\hline 2,00 & 6,44 & 260,00 & -- & 4,68 & 24,00 \\
\hline 2,50 & 6,42 & 263,00 & -- & 1,42 & 23,70 \\
\hline 3,00 & 6,28 & 242,00 & -- & 1,46 & 23,70 \\
\hline 3,50 & 6,19 & 245,00 & -- & 1,48 & 23,00 \\
\hline 4,00 & 6,15 & 213,00 & -- & 0,45 & 22,80 \\
\hline 4,50 & 6,11 & 211,00 & -- & 0,75 & 22,60 \\
\hline 5,00 & 6,11 & 211,00 & -- & 0,70 & 22,60 \\
\hline 5,50 & 6,03 & 212,00 & -- & 0,00 & 22,40 \\
\hline 6,00 & 6,02 & 213,00 & -- & 0,00 & 22,40 \\
\hline 6,50 & 6,02 & 214,00 & -- & 0,00 & 22,30 \\
\hline 7,00 & 6,01 & 227,00 & -- & 0,00 & 22,30 \\
\hline 7,50 & 6,01 & 215,00 & -- & 0,00 & 22,30 \\
\hline 8,00 & 6,01 & 214,00 & -- & 0,00 & 22,30 \\
\hline 8,10 & 6,00 & 255,00 & -- & 0,00 & 22,20 \\
\hline
\end{tabular}

Analisando-se os valores da matéria em suspensão total e suas frações, Tabela 5.40, observa-se o predomínio de material inorgânico nas estações 1 e 2 . Nas estações 1 e 2, podese inferir, como anteriormente comentado, que seus elevados valores de material inorgânico sejam conseqüência da influência de aportes do rio Atibaia.

$\mathrm{Na}$ estação 3 predominou o material orgânico, resultado já esperado, devido à presença de macrófitas e algas nesse compartimento.

$\mathrm{Na}$ estação 4, o material orgânico foi predominante apenas na parte superior, entretanto, as diferenças encontradas na parte intermediária e no fundo, não são consideradas significativas.

As concentrações de carbono orgânico dissolvido foram maiores na grande maioria das estações, devidas à alta atividade do fitoplâncton e das macrófitas aquáticas, excretandoo, através do metabolismo celular. Além disso, essa alta concentração de carbono orgânico dissolvido já era esperada, pela concentração significativa de algas e também e pela presença de macrófitas em grande quantidade (Tabela 5.41). 
Tabela 5.39 - Ficha de bordo: parâmetros físico-químicos medidos na estação 4, na campanha de Novembro/98.

\begin{tabular}{c|c|c|c|c|c}
\hline \multicolumn{7}{c}{ Horário da coleta: 12:45 h. } \\
\hline $\begin{array}{c}\text { Profundidades } \\
(\mathrm{m})\end{array}$ & $\begin{array}{c}\text { Valores } \\
\text { de pH }\end{array}$ & $\begin{array}{c}\text { Valores de } \\
\text { Condutividade } \\
(\mu \mathrm{S} / \mathrm{cm})\end{array}$ & $\begin{array}{c}\text { Valores de } \\
\text { turbidez (uT) }\end{array}$ & $\begin{array}{c}\text { Valores de } \\
\text { Oxigênio dissolvido } \\
(\mathrm{mg} / \mathrm{L})\end{array}$ & $\begin{array}{c}\text { Temperatura } \\
\left({ }^{\circ} \mathrm{C}\right)\end{array}$ \\
\hline 0,00 & 6,75 & 201,00 & 2,00 & 3,64 & 25,30 \\
\hline 0,50 & 6,75 & 200,00 & 2,00 & 3,96 & 25,60 \\
\hline 1,00 & 6,76 & 200,00 & 2,00 & 3,92 & 24,70 \\
\hline 1,50 & 6,70 & 200,00 & 3,00 & 3,25 & 24,20 \\
\hline 2,00 & 6,70 & 200,00 & 1,00 & 2,10 & 23,90 \\
\hline 2,50 & 6,65 & 200,00 & 2,00 & 1,47 & 23,70 \\
\hline 3,00 & 6,68 & 200,00 & 2,00 & 1,68 & 23,50 \\
\hline 3,50 & 6,64 & 200,00 & 2,00 & 1,90 & 23,00 \\
\hline 4,00 & 6,61 & 199,00 & 3,00 & 1,54 & 22,90 \\
\hline 4,50 & 6,58 & 199,00 & 3,00 & 1,54 & 22,80 \\
\hline 5,00 & 6,55 & 200,00 & 3,00 & 1,32 & 22,80 \\
\hline 5,50 & 6,54 & 200,00 & 3,00 & 1,30 & 22,70 \\
\hline 6,00 & 6,54 & 200,00 & 3,00 & 0,84 & 22,70 \\
\hline 6,50 & 6,67 & 200,00 & 3,00 & 0,80 & 22,70 \\
\hline 7,00 & 6,41 & 199,00 & 3,00 & 0,98 & 22,60 \\
\hline 7,50 & 6,41 & 201,00 & 3,00 & 0,99 & 22,60 \\
\hline 8,00 & 6,41 & 201,00 & 3,00 & 0,43 & 22,60 \\
\hline 8,50 & 6,33 & 201,00 & 3,00 & 0,13 & 22,60 \\
\hline 9,00 & 6,32 & 201,00 & 3,00 & 0,14 & 22,60 \\
\hline 9,50 & 6,30 & 201,00 & 3,00 & 0,04 & 22,50 \\
\hline 10,00 & 6,22 & 201,00 & 3,00 & 0,81 & 22,50 \\
\hline 10,50 & 6,21 & 201,00 & 2,00 & 1,33 & 22,50 \\
\hline 11,00 & 6,17 & 202,00 & 2,00 & 1,60 & 22,50 \\
\hline 11,50 & 6,14 & 202,00 & 2,00 & 1,65 & 22,50 \\
\hline 12,00 & 6,13 & 203,00 & 2,00 & 1,71 & 22,50 \\
\hline 12,50 & 6,15 & 202,00 & 2,00 & 1,85 & 22,50 \\
\hline 13,00 & 6,14 & 202,00 & 2,00 & 1,85 & 22,50 \\
\hline 13,50 & 6,14 & 206,00 & 2,00 & 2,10 & 22,50 \\
\hline 14,00 & 6,16 & 207,00 & 2,00 & 2,11 & 22,50 \\
\hline 14,50 & 6,16 & 207,00 & 2,00 & 2,12 & 22,40 \\
\hline 15,00 & 6,17 & 207,00 & 2,00 & 2,13 & 22,40 \\
\hline 15,50 & 6,17 & 209,00 & 2,00 & 2,14 & 22,30 \\
\hline 16,00 & 6,19 & 209,00 & 2,00 & 2,14 & 22,40 \\
\hline 16,50 & 6,19 & 211,00 & 2,00 & 2,14 & 22,40 \\
\hline 17,00 & 6,17 & 215,00 & 2,00 & 2,14 & 22,30 \\
\hline 17,50 & 6,17 & 218,00 & 2,00 & 2,15 & 22,20 \\
\hline & & & & & \\
\hline
\end{tabular}


Tabela 5.40 - Resultados das análises de material em suspensão total e das frações orgânicas e inorgânicas das amostras de água da campanha de Novembro/98

\begin{tabular}{l|c|c|c}
\hline \multicolumn{1}{c|}{ Estações } & MST (mg/L) & MSO (mg/L) & MSI (mg/L) \\
\hline 1 & 12,40 & 4,90 & 7,50 \\
\hline 2 & 16,30 & 5,50 & 10,80 \\
\hline 3 (superior) & 12,80 & 11,20 & 2,67 \\
\hline 3 (intermediário) & 13,20 & 10,10 & 3,10 \\
\hline 3 (fundo) & 6,30 & 4,30 & 2,00 \\
\hline 4 (superior) & 5,70 & 4,90 & 0,80 \\
\hline 4 (intermediário) & 7,30 & 3,50 & 3,80 \\
\hline 4 (fundo) & 5,30 & 2,50 & 2,80 \\
\hline
\end{tabular}

Tabela 5.41 - Resultados das análises de carbono total e das frações orgânicas $e$ inorgânicas das amostras de água da campanha de Novembro/98

\begin{tabular}{l|c|c|c}
\hline \multicolumn{1}{c|}{ Estação } & CT $(\mathbf{m g} / \mathbf{L})$ & COT $(\mathbf{m g} / \mathbf{L})$ & $\mathbf{C I}$ (mg/L) \\
\hline 1 & 8,99 & 5,29 & 3,70 \\
\hline 2 & 8,28 & 4,19 & 4,09 \\
\hline 3 (superior) & 13,60 & 7,92 & 5,67 \\
\hline 3 (intermediário) & 11,03 & 6,04 & 4,99 \\
\hline 3 (fundo) & 9,87 & 4,97 & 4,90 \\
\hline $4 \mathrm{~s}$ & 10,17 & 5,08 & 5,09 \\
\hline $4 \mathrm{i}$ & 10,39 & 5,29 & 5,10 \\
\hline $4 \mathrm{f}$ & 9,56 & 4,65 & 4,99 \\
\hline
\end{tabular}

Nas amostras de sedimento foram analisados o teor de carbono orgânico total (Tabela 5.42), assim como os teores de umidade a 60 e $110^{\circ} \mathrm{C}$ (Tabela 5.43). Os valores da concentração de carbono total foram considerados baixos quando comparados aos encontrados por PATELLA (1998) no sedimento do reservatório de Guarapiranga, também eutrofizado, correspondendo aproximadamente ao dobro dos valores determinados para Salto Grande.

ESTEVES \& CAMARGO (1982), em trabalho de caracterização de sedimentos de 17 reservatórios no estado de São Paulo, inclusive Salto Grande, classificaram os mesmos como sendo do tipo mineral. Nesses reservatórios o maior valor encontrado de carbono total foi $6,83 \mathrm{mg} / \mathrm{L}$ e o menor 1,28 $\mathrm{mg} / \mathrm{L}$.

A umidade total dos sedimentos é equiparável aos valores encontrados por AIROLDI (1997) em solos de trincheira de São Vicente (SP), sendo dessa forma, considerados relativamente baixos 
Tabela 5.42 e 5.43 - Resultados das análises de Carbono total e Umidade Total a temperaturas de $60^{\circ} \mathrm{C} e 110^{\circ} \mathrm{C}$, das amostras de sedimento da campanha de Novembro/98

\begin{tabular}{c|c}
\hline Estação & COT (mg/L) \\
\hline 1 & 2,30 \\
\hline 2 & 1,39 \\
\hline 3 & 0,72 \\
\hline 4 & 4,74 \\
\hline
\end{tabular}

\begin{tabular}{c|c|c|c}
\hline Estação & $\mathbf{U}_{\mathbf{6 0}}(\boldsymbol{\%})$ & $\mathbf{U}_{\mathbf{1 1 0}}(\boldsymbol{\%})$ & $\mathbf{U T}(\boldsymbol{\%})$ \\
\hline 1 & 41,78 & 11,37 & 53,15 \\
\hline 2 & 35,89 & 12,45 & 48,34 \\
\hline 3 & 47,23 & 9,69 & 56,92 \\
\hline 4 & 38,49 & 12,23 & 50,72 \\
\hline
\end{tabular}

d) Fevereiro

Na campanha de Fevereiro foram feitas coletas de água e sedimento em todas as estações (1, 2, 3 e 4). Nessa campanha, não houve diferenças consideráveis entre as estações, exceto para as concentrações de oxigênio dissolvido (Tabelas 5.44, 5.45, 5.46 a 5.47).

Tabela 5.44 - Ficha de bordo: parâmetros físico-químicos medidos na estação 1, na campanha de Fevereiro/99

\section{Estação 1}

Horário da coleta: 11:25

\begin{tabular}{c|c|c|c|c|c}
\hline $\begin{array}{c}\text { Profundidades } \\
(\mathrm{m})\end{array}$ & $\begin{array}{c}\text { Valores } \\
\text { de } \mathrm{pH}\end{array}$ & $\begin{array}{c}\text { Valores de } \\
\text { Condutividade } \\
(\mu \mathrm{S} / \mathrm{cm})\end{array}$ & $\begin{array}{c}\text { Valores de } \\
\text { turbidez (uT) }\end{array}$ & $\begin{array}{c}\text { Valores de } \\
\text { Oxigênio dissolvido } \\
(\mathrm{mg} / \mathrm{L})\end{array}$ & $\begin{array}{c}\text { Temperaturas } \\
\left({ }^{0} \mathrm{C}\right)\end{array}$ \\
\hline 0,00 & 6,44 & 94,00 & 38 & 6,27 & 24,7 \\
\hline 0,50 & 6,43 & 94,00 & 38 & 6,65 & 24,7 \\
\hline 1,00 & 6,41 & 97,00 & 38 & 6,15 & 24,6 \\
\hline 1,50 & 6,43 & 98,00 & 38 & 6,47 & 24,6 \\
\hline 2,00 & 6,41 & 98,00 & 39 & 6,50 & 24,6 \\
\hline
\end{tabular}

Tabela 5.45 - Ficha de bordo: parâmetros físico-químicos medidos na estação 2, na campanha de Fevereiro/99

\begin{tabular}{c|c|c|c|c|c}
\hline \multicolumn{7}{c}{ Estação 2 } \\
\hline $\begin{array}{c}\text { Profundidades } \\
(\mathrm{m})\end{array}$ & $\begin{array}{c}\text { Valores } \\
\text { de } \mathrm{pH}\end{array}$ & $\begin{array}{c}\text { Valores de } \\
\text { condutividade } \\
(\mu \mathrm{S} / \mathrm{cm})\end{array}$ & $\begin{array}{c}\text { Valores de } \\
\text { turbidez }(\mathrm{uT})\end{array}$ & $\begin{array}{c}\text { Valores de } \\
\text { Oxigênio dissolvido } \\
(\mathrm{mg} / \mathrm{L})\end{array}$ & $\begin{array}{c}\text { Temperaturas } \\
\left({ }^{0} \mathrm{C}\right)\end{array}$ \\
\hline 0,00 & 6,65 & 94,00 & 53 & 5,94 & 25,0 \\
\hline 0,50 & 6,51 & 94,00 & 58 & 5,64 & 25,0 \\
\hline 1,00 & 6,33 & 94,00 & 56 & 5,80 & 24,9 \\
\hline
\end{tabular}


Tabela 5.46 - Ficha de bordo: parâmetros físico-químicos medidos na estação 3, na campanha de Fevereiro/99

\begin{tabular}{c|c|c|c|c|c}
\hline \multicolumn{7}{c}{ Horário da coleta: 12:45 } \\
\hline $\begin{array}{c}\text { Profundidades } \\
(\mathrm{m})\end{array}$ & $\begin{array}{c}\text { Valores } \\
\text { de pH }\end{array}$ & $\begin{array}{c}\text { Valores de } \\
\text { condutividade } \\
(\mu \mathrm{S} / \mathrm{cm})\end{array}$ & $\begin{array}{c}\text { Valores de } \\
\text { turbidez }(\mathrm{uT})\end{array}$ & $\begin{array}{c}\text { Valores de } \\
\text { Oxigênio dissolvido } \\
(\mathrm{mg} / \mathrm{L})\end{array}$ & $\begin{array}{c}\text { Temperaturas } \\
\left({ }^{0} \mathrm{C}\right)\end{array}$ \\
\hline 0,00 & 6,44 & 72,00 & -- & 3,07 & 26,6 \\
\hline 0,50 & 6,31 & 104,00 & -- & 2,90 & 26,6 \\
\hline 1,00 & 6,41 & 104,00 & -- & 2,75 & 26,4 \\
\hline 1,50 & 6,16 & 104,00 & -- & 3,39 & 26,1 \\
\hline 2,00 & 6,16 & 104,00 & -- & 2,17 & 25,8 \\
\hline 2,50 & 6,12 & 73,00 & -- & 2,36 & 25,6 \\
\hline 3,00 & 6,15 & 103,00 & -- & 2,48 & 25,5 \\
\hline 3,50 & 6,09 & 102,00 & -- & 2,61 & 25,4 \\
\hline 4,00 & 6,09 & 101,00 & -- & 3,00 & 25,4 \\
\hline 4,50 & 6,09 & 101,00 & -- & 3,21 & 25,4 \\
\hline 5,00 & 6,09 & 100,00 & -- & 3,46 & 25,4 \\
\hline 5,50 & 6,09 & 99,00 & -- & 3,49 & 25,3 \\
\hline 6,00 & 6,08 & 100,00 & -- & 3,58 & 25,3 \\
\hline 6,50 & 5,99 & 81,00 & -- & 3,23 & 25,3 \\
\hline 7,00 & 6,05 & 99,00 & -- & 3,17 & 25,2 \\
\hline 7,50 & 6,02 & 101,00 & -- & 2,15 & 25,2 \\
\hline 8,00 & 5,99 & 105,00 & -- & 1,30 & 25,2 \\
\hline 8,50 & 5,98 & 106,00 & -- & 0,92 & 25,1 \\
\hline 9,00 & 5,98 & 103,00 & -- & 1,78 & 25,1 \\
\hline 9,50 & 6,01 & 101,00 & -- & 2,25 & 25,0 \\
\hline 10,00 & 6,02 & 99,00 & -- & 2,06 & 24,9 \\
\hline & & & & &
\end{tabular}

Tabela 5.47 - Ficha de bordo: parâmetros físico-químicos medidos na estação 4, na campanha de Fevereiro/99

\begin{tabular}{c|c|c|c|c|c}
\hline \multicolumn{7}{c}{ Horário da coleta: 13:35 } \\
\hline $\begin{array}{c}\text { Profundidades } \\
(\mathrm{m})\end{array}$ & $\begin{array}{c}\text { Valores } \\
\text { de pH }\end{array}$ & $\begin{array}{c}\text { Valores de } \\
\text { Condutividade } \\
(\mu \mathrm{S} / \mathrm{cm})\end{array}$ & $\begin{array}{c}\text { Valores de } \\
\text { turbidez }(\mathrm{uT})\end{array}$ & $\begin{array}{c}\text { Valores de } \\
\text { Oxigênio dissolvido } \\
(\mathrm{mg} / \mathrm{L})\end{array}$ & $\begin{array}{c}\text { Temperaturas } \\
\left({ }^{0} \mathrm{C}\right)\end{array}$ \\
\hline 0,00 & 6,52 & 93,00 & -- & 4,80 & 27,7 \\
\hline 0,50 & -- & -- & -- & -- & -- \\
\hline 1,00 & -- & -- & -- & -- & -- \\
\hline 1,50 & 6,12 & 96,00 & -- & 3,13 & 26,6 \\
\hline 2,00 & -- & -- & -- & -- & -- \\
\hline 2,50 & 6,21 & 99,00 & -- & 2,19 & 26,2 \\
\hline 3,00 & 5,93 & 98,00 & -- & 1,81 & 26,3 \\
\hline 3,50 & -- & -- & -- & -- & -- \\
\hline 4,00 & -- & -- & -- & -- & -- \\
\hline 4,50 & 5,92 & 98,00 & -- & 1,69 & 26,3 \\
\hline 5,00 & 5,98 & 100,00 & -- & 1,15 & 26,1 \\
\hline
\end{tabular}


$\mathrm{O}$ pH entre as estações variou de 5,92 a 6,65; a condutividade de 94 a $104 \mu \mathrm{S} / \mathrm{cm}$ e a temperatura de 24,6 a $27,7^{\circ} \mathrm{C}$.

A única diferença significativa entre as estações foi a variação do oxigênio dissolvido. Nas duas primeiras estações, os valores variaram de 5,64 a 6,65 mg/L, enquanto que, nas duas últimas, os valores chegaram a variar de 3,07 a 0,92 mg/L na estação 3 e de 4,80 a 1,15 na estação 4. Essa redução da concentração de oxigênio pode ser explicada pela elevada precipitação nessa campanha, visto que, a elevada concentração de material em suspensão inorgânico causa um sombreamento para as algas, ou seja, falta radiação para a realização da fotossíntese, causando menor produção de oxigênio. Outros fatores que podem explicar o consumo de oxigênio dissolvido no verão são o aumento na concentração de sólidos em suspensão e, conseqüentemente, a presença de bactérias adsorvidas, e também o aumento da temperatura, aumentando a atividade bacteriana e, conseqüentemente, aumentando a taxa de decomposição, levando a um maior consumo de oxigênio.

A taxa de material em suspensão foi bastante elevada na primeira e na segunda estação, sendo que em todas as estações houve predomínio de material inorgânico (Tabela 5.48). Esse grande aporte de inorgânicos no reservatório foi devido à elevada precipitação nessa campanha, que apresentou uma média de 198,3 mm, como visto na Tabela 5.26. Os rios que abastecem o reservatório não têm proteção de matas ciliares, permitindo que com as chuvas, bastante material seja carreado para suas águas. O mesmo problema acontece no reservatório, onde podem ser vistas plantações de cana-de-açúcar adentrando suas margens.

Como esperado, pela baixa taxa de residência das águas, houve predomínio também do carbono inorgânico (Tabela 5.49).

Tabela 5.48 - Resultados das análises de material em suspensão total e das frações orgânicas e inorgânicas das amostras de água da campanha de Fevereiro/99

\begin{tabular}{c|c|c|c}
\hline Estações & MST & MSO & MSI \\
\hline 1 & 114,00 & 10,00 & 104,00 \\
\hline 2 & 213,00 & 43,00 & 170,00 \\
\hline 3 & 47,25 & 13,75 & 33,50 \\
\hline $4(0 \mathrm{~m})$ & 17,80 & 5,10 & 12,70 \\
\hline $4(2,5 \mathrm{~m})$ & 14,50 & 3,90 & 10,60 \\
\hline $4(5 \mathrm{~m})$ & 13,70 & 3,90 & 9,80 \\
\hline
\end{tabular}


Tabela 5.49 - Resultados das análises de Carbono total e das frações orgânicas e inorgânicas das amostras de água da campanha de Fevereiro/99

\begin{tabular}{c|c|c|c}
\hline Estação & CT $(\mathbf{m g} / \mathbf{L})$ & $\mathbf{C O}(\mathbf{m g} / \mathbf{L})$ & $\mathbf{C I} \mathbf{~ m g / L )}$ \\
\hline 1 & 8,22 & 2,48 & 5,74 \\
\hline 2 & 9,51 & 3,10 & 6,41 \\
\hline 3 & 8,76 & 2,72 & 6,04 \\
\hline $4(0 \mathrm{~m})$ & 8,69 & 2,77 & 5,92 \\
\hline $4(2,5 \mathrm{~m})$ & 8,20 & 2,36 & 5,83 \\
\hline $4(5 \mathrm{~m})$ & 8,26 & 2,41 & 5,85 \\
\hline
\end{tabular}

Nas amostras de sedimento foram analisados os teores de carbono total (Tabela 5.50) e também o teor de umidade a 60 e $105^{\circ} \mathrm{C}$ (Tabela 5.51). Os valores encontrados para CT em Fevereiro, quando comparados aos valores encontrados na campanha de Novembro, foram considerados equivalentes para as estações 1 e 3 e sofreram decréscimo em torno de $1 \mathrm{mg} / \mathrm{L}$ para as estações 2 e 4.

Em relação aos valores de umidade para as estações 2, 3 e 4, esses sofreram acréscimo na campanha de Fevereiro.

Tabela 5.50 e 5.51 - Resultados das análises de Carbono total e Umidade Total $\left(60^{\circ} \mathrm{C}\right.$ e $110^{\circ} \mathrm{C}$ ) das amostras de sedimento da campanha de Fevereiro/98

\begin{tabular}{|c|c|c|c|}
\hline \multicolumn{2}{|c|}{ Estação } & \multicolumn{2}{|c|}{ CT (mg/L) } \\
\hline \multicolumn{2}{|c|}{1} & \multicolumn{2}{|c|}{2,07} \\
\hline \multicolumn{2}{|c|}{2} & \multicolumn{2}{|c|}{0,57} \\
\hline \multicolumn{2}{|c|}{3} & \multicolumn{2}{|c|}{0,62} \\
\hline \multicolumn{2}{|c|}{4} & \multicolumn{2}{|c|}{3,64} \\
\hline Estação & $\mathrm{U}_{60}(\%)$ & $\mathrm{U}_{110}(\%)$ & UT $(\%)$ \\
\hline 1 & 40,48 & 9,52 & 50,00 \\
\hline 2 & 47,50 & 9,11 & 56,61 \\
\hline 3 & 61,24 & 7,45 & 68,69 \\
\hline 4 & 64,39 & 5,14 & 69,53 \\
\hline
\end{tabular}




\subsubsection{Análises Cromatográficas}

\subsubsection{Valores para o cálculo das equações de calibração para análise quantitativa dos clorofenóis}

Os valores das concentrações injetadas de cada clorofenol (2,5-DCP; 2,4,6-TCP; 2,3,6-TCP; 2,3,4-TCP e PCP) e as médias das duas áreas de pico mais aproximadas entre as três originadas nos cromatogramas estão apresentadas nas Tabelas 5.52 e 5.54, respectivamente para análise quantitativa dos teores dos clorofenóis em amostras de água e de sedimento. O composto 2,4-DBP foi utilizado como padrão interno. A partir desses valores, foram calculadas as equações apresentadas nas Tabelas 5.53 e 5.56. Todas as áreas encontradas na injeção de cada concentração, as médias e os gráficos com o cálculo das equações estão apresentados no Anexo F.

c) Equações de calibração para análise quantitativa de clorofenóis nas amostras de água

As amostras de água foram preparadas como descrito no item 4.2.4.4 do capítulo de Material e Métodos. Na Tabela 5.52 são apresentadas as concentrações de dopagem com os padrões em $\mu \mathrm{g} / \mathrm{L}$, e os respectivos valores de áreas de picos obtidos.

Tabela 5.52 - Concentrações de clorofenóis em água e áreas de cromatogramas

\begin{tabular}{c|c|c|c|c|c|c}
\hline $\begin{array}{c}\text { Concentração } \\
(\boldsymbol{\mu g} / \mathbf{L})\end{array}$ & $\mathbf{2 , 5}$ DCP & $\mathbf{2 , 4 , 6 - T C P}$ & $\mathbf{2 , 3 , 6 - T C P}$ & $\mathbf{2 , 3 , 4 - T C P}$ & PCP & $\mathbf{2 , 4 - D B P}$ \\
\hline $1,00 \times 10^{-2}$ & $4,33 \times 10^{4}$ & $1,72 \times 10^{6}$ & $2,01 \times 10^{6}$ & $1,01 \times 10^{6}$ & $2,94 \times 10^{6}$ & $9,22 \times 10^{4}$ \\
\hline $5,00 \times 10^{-2}$ & $3,29 \times 10^{5}$ & $1,25 \times 10^{7}$ & $1,30 \times 10^{7}$ & $9,61 \times 10^{6}$ & $1,56 \times 10^{7}$ & $1,13 \times 10^{5}$ \\
\hline $1,00 \times 10^{-1}$ & $7,10 \times 10^{5}$ & $1,81 \times 10^{7}$ & $1,77 \times 10^{7}$ & $1,62 \times 10^{7}$ & $2,19 \times 10^{7}$ & $1,38 \times 10^{5}$ \\
\hline $2,50 \times 10^{-1}$ & $2,53 \times 10^{6}$ & $2,51 \times 10^{7}$ & $2,36 \times 10^{7}$ & $2,20 \times 10^{7}$ & $2,61 \times 10^{7}$ & $5,24 \times 10^{4}$ \\
\hline
\end{tabular}

Comparando-se as áreas dos cromatogramas encontradas na injeção dos padrões, com as obtidas na injeção das amostras de águas do reservatório de Salto Grande, foi observado que essas últimas estavam próximas das áreas encontradas para a menor concentração injetada, logo, as equações para a água foram calculadas considerando apenas as três menores concentrações (Tabela 5.53):

Tabela 5.53 - Equações obtidas a partir dos valores das áreas dos cromatogramas para a preparação das curvas de calibração de clorofenóis em água (Anexo C)

\section{Clorofenóis}

Equações

$\mathbf{R}^{2}$ 


\begin{tabular}{c|c|c}
2,5 DCP & $\mathrm{y}=7 \times 10^{6} \mathrm{X}-34764$ & 0,9997 \\
\hline $2,4,6-\mathrm{TCP}$ & $\mathrm{y}=2 \times 10^{8} \mathrm{X}+1 \times 10^{6}$ & 0,9408 \\
\hline $2,3,6-\mathrm{TCP}$ & $\mathrm{y}=2 \times 10^{8} \mathrm{X}+2 \times 10^{6}$ & 0,9195 \\
\hline $2,3,4-\mathrm{TCP}$ & $\mathrm{y}=2 \times 10^{8} \mathrm{X}+19465$ & 0,9802 \\
\hline PCP & $\mathrm{y}=2 \times 10^{8} \mathrm{X}+2 \times 10^{6}$ & 0,9371 \\
\hline
\end{tabular}

d) Equações de calibração para análise quantitativa das amostras de sedimento

As amostras de sedimento foram preparadas como descrito no item 4.2.4.4 de Material e Métodos. As concentrações de dopagem e os resultados obtidos estão apresentados na Tabela 5.54.

Tabela 5.54 - Concentrações de clorofenóis nas amostras de sedimentos e áreas obtidas nas análises por $C G / D C E$

\begin{tabular}{c|c|c|c|c|c|c}
\hline $\begin{array}{c}\text { Concentração } \\
(\boldsymbol{\mu g} / \mathbf{K g})\end{array}$ & $\mathbf{2 , 5}$ DCP & $\mathbf{2 , 4 , 6 - T C P}$ & $\mathbf{2 , 3 , 6 - T C P}$ & $\mathbf{2 , 4 - D B P}$ & $\mathbf{2 , 3 , 4 - T C P}$ & PCP \\
\hline 0,50 & ------- & ------- & ------- & ------- & $1,07 \times 10^{5}$ & $5,60 \times 10^{5}$ \\
\hline 2,50 & $1,15 \times 10^{5}$ & $3,31 \times 10^{6}$ & $2,48 \times 10^{6}$ & $4,79 \times 10^{4}$ & $1,84 \times 10^{6}$ & $3,14 \times 10^{6}$ \\
\hline 5,00 & $2,14 \times 10^{5}$ & $6,40 \times 10^{6}$ & $5,76 \times 10^{6}$ & $4,02 \times 10^{4}$ & $2,80 \times 10^{6}$ & $4,50 \times 10^{6}$ \\
\hline 12,50 & $6,35 \times 10^{4}$ & $1,10 \times 10^{7}$ & $1,08 \times 10^{7}$ & $7,96 \times 10^{4}$ & $8,71 \times 10^{6}$ & $1,58 \times 10^{7}$ \\
\hline
\end{tabular}

Nas amostras tratadas com soluções de clorofenóis na concentração de $0,50 \mu \mathrm{g} / \mathrm{Kg}$, foram feitas limpezas utilizando-se coluna de sílica 3,0 cm e 5,0 $\mathrm{mL}$ de hexano/acetona 3:1 como eluente. No entanto, quando as amostras foram injetadas, apenas foram detectadas áreas de 2,3,4-TCP e do PCP. A partir da concentração de $2,50 \mu \mathrm{g} / \mathrm{Kg}$, as amostras não passaram por processo de limpeza, uma vez que, considerando os resultados desse teste, antes e após o procedimento de limpeza, bem como resultados obtidos em testes anteriores, como descrito no item 5.2.2.3 deste capítulo, tornou-se evidente que havia perdas na coluna de limpeza.

Para ter-se noção dessa perda, foram comparadas três amostras dopadas com 2,5 $\mu \mathrm{g} / \mathrm{Kg}$ de solução de clorofenóis, sendo que em duas não foram realizados os procedimentos de limpeza. Na amostra em que a limpeza foi feita, procedeu-se como estabelecido em Material e Métodos, porém, posteriormente ao eluente indicado, fez-se passar $5 \mathrm{~mL}$ de acetona pela coluna, sendo essa solução recolhida em outro frasco, concentrada, derivatizada e injetada.

Na Tabela 5.55 são mostrados os resultados encontrados para os procedimentos anteriormente descritos, onde se observam perdas na coluna de limpeza.

Tabela 5.55 - Teste para verificação de perda de clorofenóis ocorridas na coluna de limpeza 


\begin{tabular}{c|c|c|c|c|c|c}
\hline Amostra & 2,5 DCP & 2,4,6-TCP & 2,3,6-TCP & 2,4-DBP & 2,3,4-TCP & PCP \\
\hline $\mathrm{a}^{(1)}$ & ------- & $4,97 \times 10^{-4}$ & ------- & ------- & -------- & ------- \\
\hline $\mathrm{aa}^{(2)}$ & $5,3 \times 10^{-4}$ & $2,02 \times 10^{-6}$ & $1,61 \times 10^{-6}$ & $3,26 \times 10^{-4}$ & $8,22 \times 10^{-5}$ & ------- \\
\hline $\mathrm{b}^{(3)}$ & $1,21 \times 10^{-5}$ & $3,48 \times 10^{-6}$ & $2,62 \times 10^{-6}$ & $5,11 \times 10^{-4}$ & $1,86 \times 10^{-6}$ & $3,70 \times 10^{-6}$ \\
\hline $\mathrm{c}^{(3)}$ & $1,09 \times 10^{-5}$ & $3,14 \times 10^{-6}$ & $2,34 \times 10^{-6}$ & $4,46 \times 10^{-4}$ & $1,82 \times 10^{-6}$ & $2,58 \times 10^{-6}$ \\
\hline
\end{tabular}

Obs.: (1) Amostra em que foi feita a limpeza; (2) Amostra a, após passagem da acetona; (3)

Amostras b e c dopadas com $2,50 \mu \mathrm{g} / \mathrm{Kg}$, sem limpeza.

Como pode ser visto nesses resultados, é possível afirmar que nas amostras de Salto Grande, submetidas à limpeza, ocorreu perda de substâncias e as áreas dos picos foram subestimadas.

As equações determinadas a partir dos resultados da Tabela 5.54 são mostradas na Tabela 5.56, sendo que as áreas das amostras submetidas à limpeza não foram consideradas.

Tabela 5.56 - Equações obtidas a partir dos valores das áreas dos cromatogramas para a preparação das curvas de calibração de clorofenóis nos sedimentos

\begin{tabular}{c|c|c}
\hline Clorofenóis & Equações & $\mathbf{R}^{\mathbf{2}}$ \\
\hline $2,4,6-\mathrm{TCP}$ & $\mathrm{y}=4 \times 10^{7} \mathrm{X}+2 \times 10^{6}$ & 0,9719 \\
\hline $2,3,6-\mathrm{TCP}$ & $\mathrm{y}=4 \times 10^{7} \mathrm{X}+1 \times 10^{6}$ & 0,9754 \\
\hline $2,3,4-\mathrm{TCP}$ & $\mathrm{y}=4 \times 10^{7} \mathrm{X}-291261$ & 0,9872 \\
\hline PCP & $\mathrm{y}=7 \times 10^{7} \mathrm{X}-992977$ & 0,9794 \\
\hline
\end{tabular}

\subsubsection{Valores de clorofenóis nas amostras de Salto Grande}

A identificação dos clorofenóis nas amostras de Salto Grande foi baseada no tempo de retenção dos compostos presentes nas amostras, em relação ao tempo de retenção dos padrões. A utilização do tempo de retenção pode incorrer em erros, visto que diferentes compostos podem apresentar o mesmo tempo de retenção e serem eluídos simultaneamente. Entretanto, os compostos encontrados tanto na água quanto no sedimento têm grande probabilidade de serem clorofenóis, já que houve bastante coerência entre os tempos de retenção e os compostos detectados tanto nas amostras de água quanto nas de sedimento. A confirmação só seria possível com o auxílio de um instrumento analítico auxiliar, via de regra, um espectrômetro de massas ou um cromatógrafo acoplado a um detector de massas.

Foram enviadas para a Central Analítica do Instituto de Química da Universidade Estadual de Campinas, para análise em cromatógrafo a 
gás acoplado a um detector de massas, duas amostras, sendo uma de padrões de clorofenóis $(1,0 \mathrm{mg} / \mathrm{L})$ e a outra, uma amostra de sedimento que apresentou a maior das áreas de picos no CG/DCE. Nas condições empregadas, nenhum sinal considerável foi detectado em nenhuma das amostras. Deve-se ressaltar, que a sensibilidade do detector de massas é bem inferior à do detector por captura de elétrons. Logo, os derivados de clorofenóis presentes no padrão e os possivelmente presentes na amostra, estavam em concentrações inferiores ao limite de detecção do detector de massas da Central Analítica do Instituto de Química da Universidade Estadual de Campinas. Para aumentar-se a concentração dos compostos, de forma a tornar possível a detecção pelo massa, teríase que aumentar a quantidade de sedimento e água usados nas extrações. No entanto, neste trabalho, isso não foi possível, pela quantidade de material que se dispunha.

Os resultados da presença de clorofenóis serão discutidos preferencialmente em relação às áreas de picos dos cromatogramas, evitando-se a discussão dos valores de concentrações, em geral, em limites inferiores a 0,01 $\mu \mathrm{g} / \mathrm{L}$ para água e $0,50 \mu \mathrm{g} / \mathrm{Kg}$ para sedimento. A posteriori, no item 5.5, serão considerados os resultados das análises cromatográficas para a mesma estação nas 4 campanhas, correlacionando-os com os valores obtidos nos demais parâmetros físico-químicos analisados, bem como em relação às condições climatológicas da região à época das coletas. As características hidráulicas e morfométricas do reservatório também serão correlacionadas aos demais resultados.

\subsubsection{1 $\quad 1^{a}$ Campanha (Maio)}

As primeiras modificações feitas no método de ZUIN (1997) adotado neste trabalho, ocorreram nessa campanha, visto que havia a necessidade de adaptar-se um procedimento de extração proposto, para as amostras de Salto Grande. Como nas amostras desse reservatório esperava-se uma menor concentração de clorofenóis que nas amostras de ZUIN (1997), visto que esta trabalhou com amostras de uma área potencialmente contaminada, as primeiras alterações foram no tempo de extração e forma de agitação, visando um maior e melhor contato das amostras com o solvente. No presente trabalho, optou-se por uma agitação em incubador rotativo, durante 14 horas (overnight). ZUIN (1997) utilizou para extração dos 
clorofenóis um funil de separação de 2 L, com agitação manual, não especificando o tempo de agitação.

Foram também testados o volume de amostra na extração e diferentes colunas de limpeza. Nessa campanha não se utilizou nenhum padrão interno nas análises cromatográficas (Tabela 1A/anexos).

As amostras de água da estação 2 foram coletadas em coluna d'água com profundidade de dois metros. As amostras A, B e C, indicadas na Figura 5.2, são amostras de água da mesma estação 2, porém alterando-se as condições de extração. Nas amostras A e C utilizou-se um volume de $1 \mathrm{~L}$, e na amostra B, um volume de 0,5 L. Foram testadas como colunas de limpeza a de Sílica (coluna de 1,0 cm) na amostra B, e a de Florisil (coluna de 1,0 $\mathrm{cm})$ na amostra C. Na amostra A não foi feita limpeza.

Os resultados dos picos de áreas dos cromatogramas das análises das amostras de Maio (estação 2) são apresentados nas Tabelas 1D e 2D dos Anexos. Os resultados das análises são apresentados em áreas de cromatogramas, bem como o respectivo tempo de retenção, em minutos.

O melhor resultado encontrado, em pico de área de cromatograma, foi obtido na amostra A. Comparando-a com a amostra B, pode-se concluir que houve perdas consideráveis de substâncias na amostra B, ou pelo menor volume utilizado na extração ou pela adsorção à coluna, ou ainda, por ambos. Outra possível fonte de perdas pode estar relacionada à presença de emulsão ocorrida nas amostras de água dessa estação. Com a formação dessa camada entre a água e o hexano, possivelmente devido a presença de material em suspensão, maior quantidade de sulfato de sódio foi utilizada na secagem e provavelmente causou perda de uma parte de clorofenóis.

Os valores apresentados para os clorofenóis (PoC's), na Figura 5.2, são as áreas de picos dos cromatogramas obtidos nas injeções em CG/DCE, das amostras de água da estação 2. Os valores obtidos utilizando as equações da Tabela 5.53 mostram que a amostra A apresentou 2,5-DCP em torno de 0,02 $\mu \mathrm{g} / \mathrm{L}$, e para os demais clorofenóis as concentrações foram menores que $0,01 \mu \mathrm{g} / \mathrm{L}$. Esses valores estão abaixo do limite máximo exigido pela Portaria 36 (1990) do Diário Oficial da União/Ministério da Saúde, de 0,10 $\mu \mathrm{g} / \mathrm{L}$.

As amostras de sedimentos foram analisadas após extração com ultra-som e os resultados, apresentados na Figura 5.3. As Tabelas 1E e 2E em Anexos mostram os valores dos picos de áreas dos cromatogramas de clorofenóis após análises em CG/DCE. As amostras A, B e C indicadas nessas Tabelas e na Figura 5.3, referem-se a triplicatas de cada estação. As extrações de sedimento dessa campanha foram feitas apenas em ultra-som, por 
não haver mais amostras disponíveis para extração em Soxhlet e sob agitação com barra magnética.

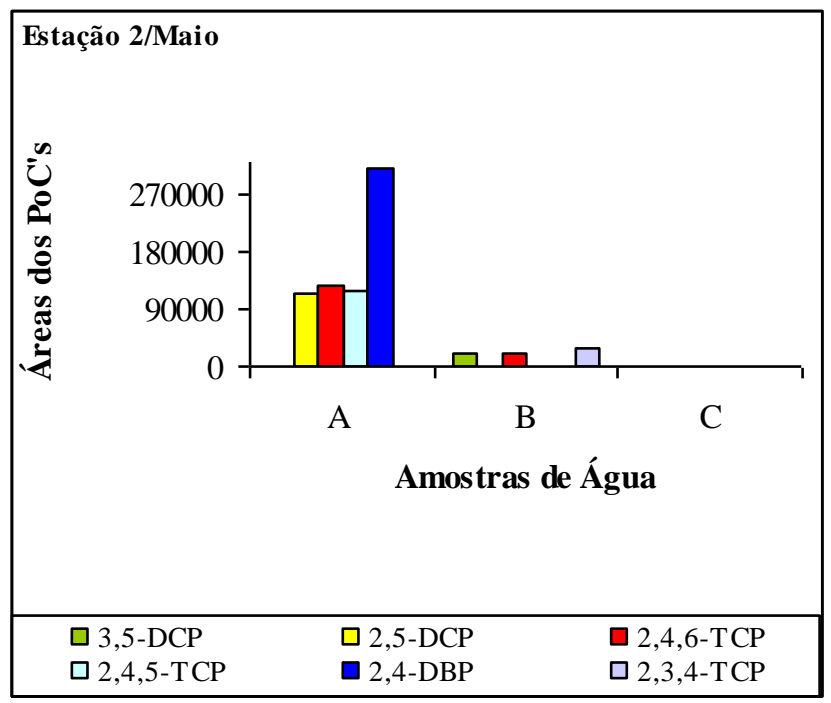

FIGURA 5.2 - VALORES DAS ÁREAS DE CROMATOGRAMAS DAS AMOSTRAS DE ÁGUA DA ESTAÇÃO 2, COLETADAS EM MAIO/98, ANALISADAS EM TRIPLICATA (A, B E C)

Na estação 2, somente foi detectado o padrão interno, com respostas bastante similares em duas amostras da triplicata (áreas nos cromatogramas de 147.546 e 141.294). Apesar de terem sido detectados clorofenóis nas amostras de água dessa estação, as concentrações encontradas foram baixas. A possibilidade de adsorção em material em suspensão poderia justificar as concentrações relativamente baixas de clorofenóis nas amostras de água, já que foi determinada uma concentração de material em suspensão de $28,21 \mathrm{mg} / \mathrm{L}$ e com um tempo de residência das águas no reservatório de 49 dias, pudesse ocorrer a deposição de material em suspensão. Entretanto, nos sedimentos não foram verificados clorofenóis. Esta estação está próxima a entrada do reservatório, em que o Rio Atibaia flui para alimentá-lo, assim considerando a velocidade do sistema, poder-se-ia inferir observações realizadas por outros autores em estudos realizados com água corrente de canal, simulando um curso de um rio. Nesses estudos, citados por DAMIANOVIC (1997), o PCP adicionado foi removido por uma combinação de mecanismos físico-químicos, como adsorção, volatilização e fotólise. A fotólise foi mais evidente na superfície e muito atenuada no fundo. A fotólise foi responsável por 5 a $28 \%$ da remoção, em função da luminosidade; a volatilização contribuiu com menos de $0,006 \%$, a adsorção com menos de $5 \%$. O mecanismo de remoção mais importante foi devido a degradação microbiana entre 26 a $46 \%$, que não 
pode ser descartada em um sistema como o reservatório de Salto Grande, que recebe um conjunto de águas residuárias capazes de promover o crescimento e a ação microbiana.

$\mathrm{Na}$ estação 4 foram detectadas 3 substâncias semelhantes às encontradas na análise da água da estação 2, em áreas também bastante similares: 2,5-DCP; 2,4,6-TCP e 2,4,5-TCP. Nessa estação não foi feita análise da água, não sendo possível fazer inferências sobre água e sedimento. Na campanha de maio as áreas dos cromatogramas obtidas nas análises de clorofenóis no sedimento da estação 4, em geral, foram bastante semelhantes, sempre em torno de 60.000 , correspondendo a uma concentração menor que $2,50 \mu \mathrm{g} / \mathrm{Kg}$ para todas as substâncias detectadas e de possível quantificação pelas equações da Tabela 5.56. Os valores das áreas de picos podem estar subestimados devido a prováveis perdas na coluna de limpeza.
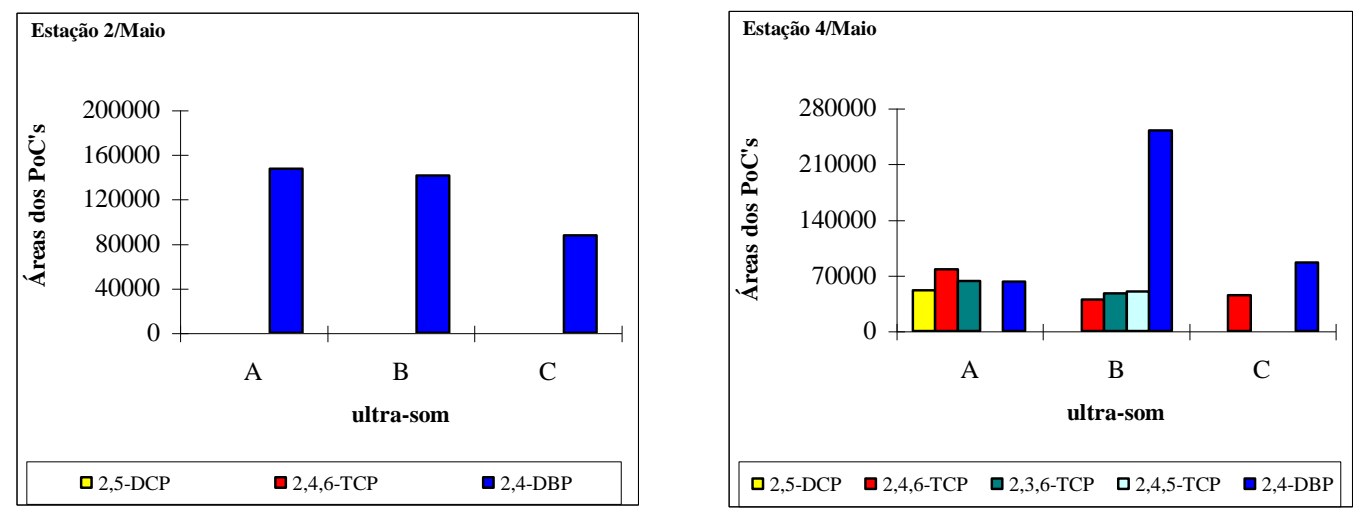

FIGURA 5.3 - VALORES DE ÁREAS DOS CROMATOGRAMAS DAS AMOSTRAS DE SEDIMENTO, DAS ESTAÇÕES 2 E 4, COLETADAS EM MAIO/98, ANALISADAS EM TRIPLICATA (A, B E C)

\subsubsection{2 $2^{\mathrm{a}}$ Campanha (Junho)}

Nessa campanha também foram feitas alterações nos procedimentos analíticos para as amostras de água, buscando a obtenção de áreas de picos mais similares, entre as réplicas das amostras.

Não foram feitas limpezas nas amostras de água dessa campanha, porém ainda utilizou-se a "lavagem" com $50 \mathrm{~mL}$ de n-hexano, por 2 vezes, após a extração de 16 horas, como na primeira campanha. Essa "lavagem" consistia em acrescentar n-hexano purificado, no hexano da extração das amostras, fazendo-se uma agitação manual, por aproximadamente 
5 minutos e retirando-se água residual, se houvesse. Empregaram-se alíquotas de $120 \mu \mathrm{L}$ de 2,4-dibromofenol como padrão interno nas amostras analisadas.

Foram feitas análises cromatográficas em duplicata das amostras de água da estação 2, e somente foi encontrado PCP, cujas áreas de picos nos cromatogramas foram da ordem de 4123786 para a amostra A, correspondendo a uma concentração de $0,011 \mu \mathrm{g} / \mathrm{L}$ e, 318559, para amostra B; correspondendo a uma concentração menor que $0,010 \mu \mathrm{g} / \mathrm{L}$ (Figura 5.4). O composto PCP também foi observado nas amostras de sedimentos da estação 2 e 4 (Figuras 5.5), com valores de picos de áreas variáveis entre as triplicatas. Para a estação 2, considerando-se os métodos de extração com o ultra-som e o Soxhlet, detectou-se o PCP, com áreas de 57221 e 103710, respectivamente. Deve-se considerar que não foram realizadas limpezas nas amostras extraídas com o Soxhlet, mas foram feitas nas amostras extraídas pelo método do ultra-som, e perdas podem ter ocorrido nas colunas de limpeza. $\mathrm{Na}$ estação 4, entre as triplicatas das amostras extraídas com ultra-som foram observadas áreas de pico de 232206 e 71790, sendo que em uma das amostras, o composto PCP não foi detectado. Na análise com o Soxhlet foi observada uma área de 100940. Essas áreas encontradas para os clorofenóis (PoC's) no sedimento corresponderam a concentrações menores que $2,50 \mu \mathrm{g} / \mathrm{Kg}$.

As amostras de água da estação 4 foram feitas em triplicatas, porém, os valores não foram próximos entre elas, exceto para o PCP, como pode ser visto na Figura 5.3. Para o 2,5DCP, por exemplo, as triplicatas apresentaram concentrações de $0,012 \mu \mathrm{g} / \mathrm{L}, 0,016 \mu \mathrm{g} / \mathrm{L}$, e $0,010 \mu \mathrm{g} / \mathrm{L}$. O valor do pico de área 2,3,6-TCP foi de 1410515, um dos maiores valores determinados em todas as campanhas o grupo de clorofenóis analisados. Entretanto, não houveram picos de áreas similares entre as réplicas.

As amostras de sedimento foram submetidas à extração com ultra-som, em triplicata, e duas amostras foram extraídas com Soxhlet e agitação com barra magnética, respectivamente Os valores das áreas de picos em cromatogramas são apresentados na Tabela 3E e 4E dos Anexos. Em geral, as amostras de sedimento dessa campanha, apresentaram valores de áreas dos cromatogramas inferiores aos das campanhas de Novembro e Fevereiro, e superiores aos determinados nas amostras de Maio, correspondendo a concentrações menores que $0,50 \mu \mathrm{g} / \mathrm{Kg}$ para o pentaclorofenol e menores que $2,50 \mu \mathrm{g} / \mathrm{Kg}$ para os demais clorofenóis. (Figura 5.5).

A coluna d'água, entre essas duas estações, tem profundidades bem diferentes: a maior profundidade determinada para a coluna d'água da estação 2 foi $2,20 \mathrm{~m}$, e para a estação quatro, igual a 14,80 m. As amostras de água foram coletadas sempre na superfície da coluna d'água. O composto PCP esteve presente nas duas estações, na água e sedimento, 
sendo que na estação 2 foi o único a ser observado nas amostras de águas e sedimentos. A concentração de PCP na água sofreu decréscimo da estação 2 para a 4. Na estação 4 foram encontrados diferentes tipos de clorofenóis, tanto no sedimento quanto na água, entretanto não houve similaridade entre os valores de áreas dos cromatogramas nas réplicas das amostras de água.

Considerando-se que o tempo de residência nessa campanha foi o segundo maior entre as campanhas, 74 dias, e que houve semelhança entre os valores dos parâmetros físicoquímicos entre as duas estações, exceto para os valores de $\mathrm{pH}$ e condutividade, pode-se atribuir as diferenças dos clorofenóis entre as estações à velocidade do fluxo da água, maior na estação 2 podendo ter provocado a diluição dos compostos, assim como o pH menor na estação 4, permitindo sua solubilização no compartimento água. No sedimento, pela alta adsorção em material em suspensão apresentada pelos organoclorados e em se tratando de um período com baixo fluxo (maior tempo de residência), a taxa de sedimentação desse material formando os sedimentos é alta, apresentando então os mesmos clorofenóis encontrados no compartimento água, além de outros que podem ter se acumulado.

Cabe comentar que na água, o PCP, em geral, está presente na forma ionizada, podendo absorver radiação e sofrer degradação catalítica. Uma pequena parcela do composto pode ainda sofrer volatilização ou ser degradada por microrganismos. Entretanto, a maior parte do PCP presente adsorve à matéria suspensa na água e acaba sendo incorporada ao sedimento, o que pode alterar a disponibilidade do composto a outros processos de degradação. Ao todo, acredita-se que o composto permaneça na água por um período de duas horas a 120 dias (NAKAYAMA, 1999).

Nas Figuras 5.4 e 5.5 estão representados os valores das réplicas das amostras pelas letras A, B e C.
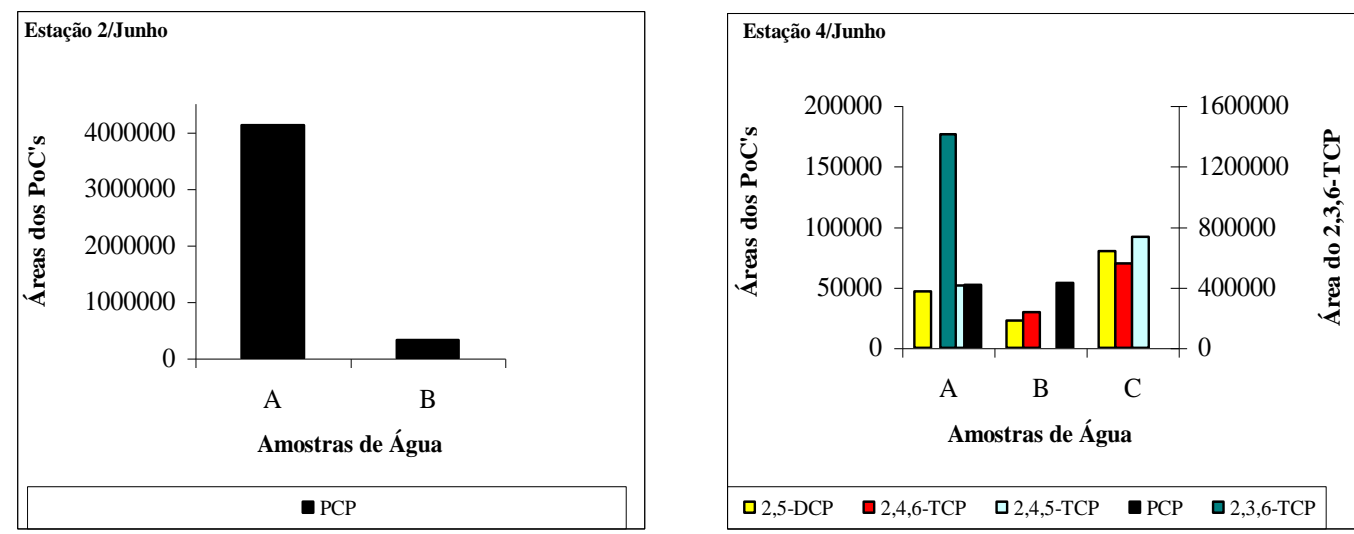
FIGURA 5.4 - VALORES DE ÁREAS DOS CROMATOGRAMAS DAS AMOSTRAS DE ÁGUAS DAS ESTAÇÕES 2 E 4, COLETADAS EM JUNHO/98, ANALISADAS EM DUPLICATA (A E B) E TRIPLICATA (A, B E C).
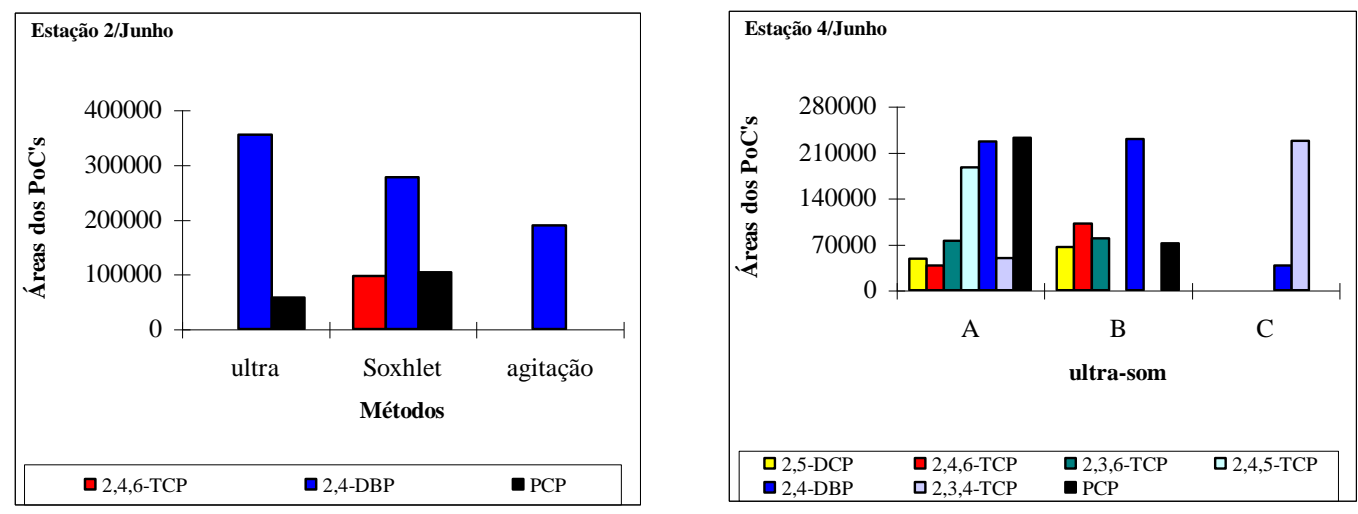

FIGURA 5.5 - VALORES DE ÁREAS DOS CROMATOGRAMAS DAS AMOSTRAS DE SEDIMENTO DAS ESTAÇÕES 2 E 4, COLETADAS EM JUNHO/98, ANALISADAS EM TRIPLICATA (A, B E C) PARA O ULTRA-SOM E EXTRAÍDA SEM REPETIÇÃO EM SOXHLET E COM AGITAÇÃO COM BARRA MAGNÉTICA.

\subsubsection{2 $\quad 3^{a}$ Campanha (Novembro)}

Nessa campanha outras alterações foram feitas nos procedimentos de análises, visto que os valores das áreas dos cromatogramas da $1^{\mathrm{a}}$ e $2^{\mathrm{a}}$ campanhas continuavam com valores de áreas pouco similares entre réplicas de uma mesma amostra. O volume utilizado na acidificação das amostras anterior aos procedimentos de extração, indicado por ZUIN (1997), foi uma das alterações. A adição de 1,0 mL de ácido sulfúrico nas amostras não foi eficiente para aprimorar o método extrativo e, assim, substituiu-se a alíquota de 1,0 mL do ácido para 1,0 L de amostra (condição empregada nas amostras da $1^{\mathrm{a}}$ e $2^{\mathrm{a}}$ campanhas), por 2,0 $\mathrm{mL}$ para 1,0 $\mathrm{L}$ de amostra. As amostras da $3^{\mathrm{a}}$ e $4^{\mathrm{a}}$ campanhas também foram acidificadas dessa forma, como visto na Tabela 4.2 de Material e Métodos. $\mathrm{O} \mathrm{pH}$ foi lido com fita de $\mathrm{pH}$, estando sempre abaixo do valor 2. A acidificação é necessária para que o equilíbrio de ionização dos clorofenóis presentes nas amostras privilegie a forma molecular, solúvel no solvente usado em todas as extrações, o hexano. No entanto, ao empregar uma maior quantidade de ácido, não observou-se alteração nas respostas das análises cromatográficas, podendo-se inferir que a acidificação não era necessária (ver Tabelas $4 \mathrm{D}, 5 \mathrm{D}, 6 \mathrm{D}, 7 \mathrm{D}$ 8D e 9D dos Anexos).

Com esses resultados obtidos das amostras oriundas das estações 1, 2, 3 e 4 (amostras coletadas na superfície), buscou-se otimizar novamente os procedimentos para 
extração e análise cromatográfica. As amostras de água da estação 4 coletadas nas profundidades de 8 e $14 \mathrm{~m}$ foram filtradas em filtro de fibra de vidro GF/C (Whatman), 0,45 $\mu \mathrm{m}$ e no procedimento foram eliminadas as lavagens sucessivas com n-hexano. Os valores das áreas de pico dos cromatogramas com essas alterações foram bastante similares, como pode ser visto nas Tabelas 10D e 11D dos Anexos, sendo as amostras da $4^{\mathrm{a}}$ campanha também tratadas pelo mesmo procedimento. Acreditou-se que a falta de reprodutibilidade poderia ser tanto devido às perdas decorrentes das lavagens, quanto da presença de material em suspensão, que provavelmente são pontos de adsorção dos clorofenóis, como comentado por STRACHAN et al. (1982).

Segundo DAMIANOVIC (1997), muitos poluentes aromáticos como hidrocarbonetos aromáticos policlorados são altamente apolares, apresentando baixa solubilidade em água e tendência à adsorção em matéria orgânica de solos e sedimentos. Quando atingem corpos d'água profundos, o composto PCP por exemplo, pode complexar-se com co-solventes, como ácidos fúlvico e húmico, diminuindo sua capacidade de adsorção e facilitando o mecanismo de transporte como partícula coloidal. A adsorção de PCP é limitada pela solubilidade da forma protonada a baixo $\mathrm{pH}$ e pela forma desprotonada a elevado pH. A forma neutra do PCP é fortemente hidrofóbica, com solubilidade de 11 a 14 $\mathrm{mg} / \mathrm{L}$ e coeficiente de partição de 5:1. Dessa forma, essa substância pode ser fortemente adsorvida em soluções aquosas, tanto em sistema de águas superficiais, profundas ou em sistemas ricos em matéria orgânica.

Todas as amostras dessa campanha foram dopadas com $120 \mu \mathrm{L}$ do padrão interno, 2,4-dibromofenol. 2,3,6-TCP foi constatado em todas as amostras de água de todas as estações analisadas nessa campanha, apresentando áreas de pico relevantes nos cromatogramas das estações 2 e 3 nas amostras de água das profundidades de 2 e $7 \mathrm{~m}$, e na amostra de superfície da estação 4. Nessas estações o material em suspensão orgânico foi o mais representativo, exceto na estação 2.

2,3,4-TCP também esteve presente na maioria das estações, exceto na amostra da estação 3 da profundidade de $2 \mathrm{~m}$ e na amostra de superfície da estação 4. Porém, as áreas dos picos nos cromatogramas foram inferiores `as encontradas para o 2,3,6-TCP na maioria das estações, exceto na estação 4, amostras de águas coletadas nas profundidades de 8 e 14m. Nas estações 1, 2 e 4, predominou o material em suspensão inorgânico nas amostras de água das profundidades de 8 e $14 \mathrm{~m}$. O PCP também esteve presente em todas as estações, exceto na profundidade de $14 \mathrm{~m}$ da estação 4, mas com menores valores das áreas obtidas nas determinações cromatográficas se comparadas àquelas observadas para 2,3,6-TCP. 
Todas as áreas dos cromatogramas obtidas nas análises das amostras de água corresponderam a concentrações inferiores a $0,01 \mu \mathrm{g} / \mathrm{L}$.

Essa campanha foi a que apresentou amostras com a maior variedade de clorofenóis em todas as estações (Figura 5.6), frente aos padrões estudados nesse trabalho. A primeira e a segunda estações apresentaram bastante similaridade entre alguns parâmetros como pH, condutividade, turbidez, temperatura, material em suspensão inorgânico como predominante e carbono orgânico como predominante, somente variando a concentração de oxigênio dissolvido. Entretanto, as análises cromatográficas da estação 2 apresentaram maior variedade de clorofenóis, porém com valores de áreas menores e não semelhantes entre as réplicas. Comparando-se os valores das áreas de picos dos cromatogramas comuns às duas estações, apenas os correspondentes ao composto 2,4,6-TCP apresentaram maiores áreas na estação 2; os demais, referentes aos compostos 2,3,6-TCP, 2,3,4-TCP e PCP, foram maiores na estação 1 .

$\mathrm{Na}$ estação 3, comparando-se as 3 profundidades $(0,2$ e $7 \mathrm{~m})$ em que a coleta foi feita, os valores das áreas de picos dos cromatogramas encontrados para as amostras à uma profundidade de $2 \mathrm{~m}$ foram os maiores, e com boas réplicas. Os valores de áreas dos cromatogramas encontrados para as amostras à uma profundidade de $7 \mathrm{~m}$ foram menores, entretanto, uma maior variedade de clorofenóis foi encontrada nessa camada.

$\mathrm{Na}$ estação 4, comparando-se as camadas onde a coleta foi feita, as áreas correspondentes ao PCP foram diminuindo nas amostras da superfície até a profundidade de $14 \mathrm{~m}$. Os valores das áreas de picos dos cromatogramas do composto 2,3,6-TCP foram elevados na superfície, entretanto houve um decréscimo a valores semelhantes nas amostras coletadas às profundidades de 8 e 14 m. 2,3,4-TCP foi detectado nas profundidades de 8 e 14 $\mathrm{m}$, não sendo detectado na superfície.

Nas amostras de sedimento, a distribuição dos clorofenóis entre as estações foi mais irregular. Considerando-se as substâncias extraídas em todos os métodos utilizados, somente 2,3,4-TCP esteve presente em todas as estações dessa campanha (Figura 5.7). Esse fato possivelmente foi devido à alta taxa de deposição de material em suspensão nessa campanha, provocada pelo elevado tempo de residência, cerca de 102 dias. 

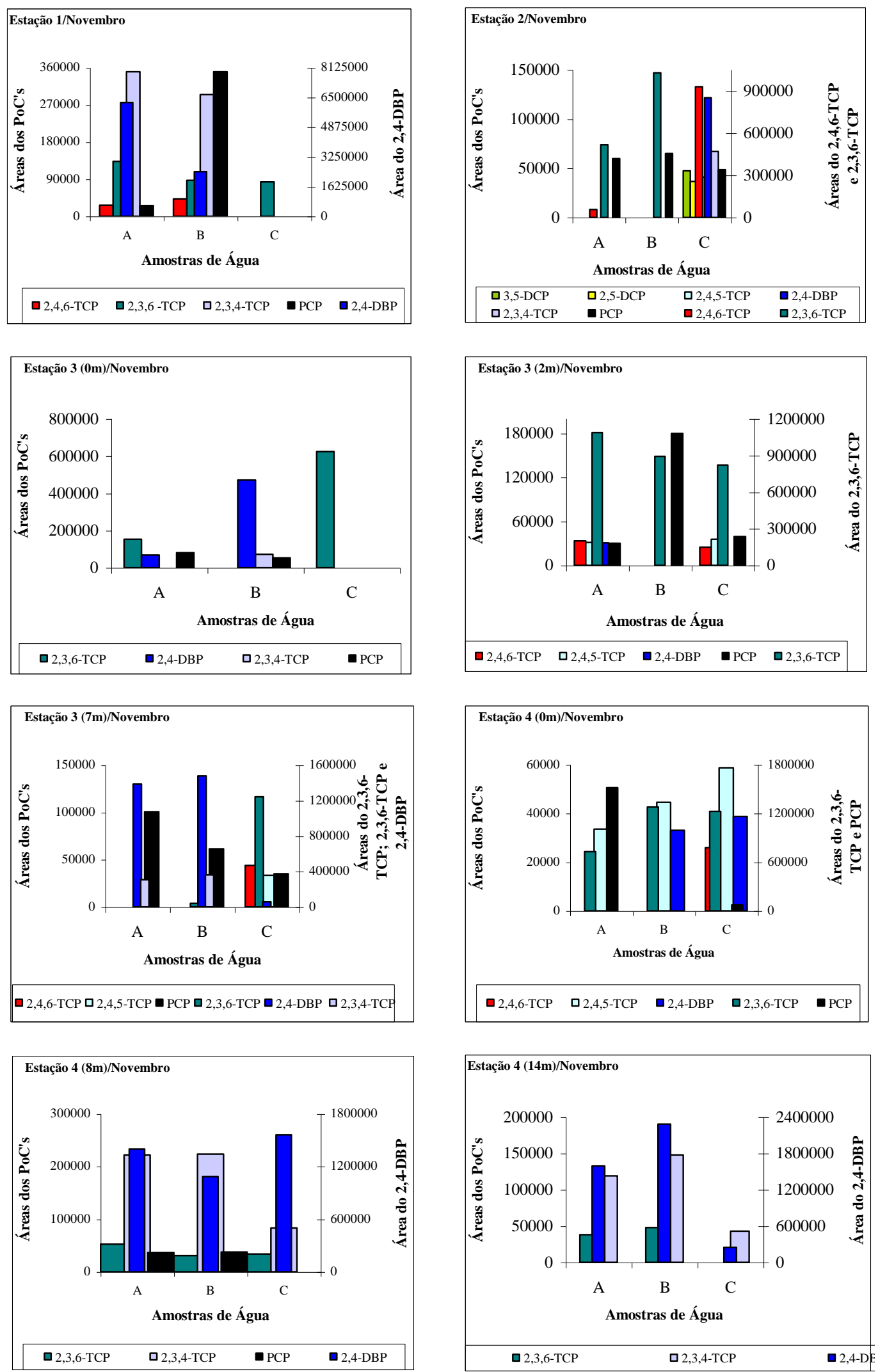
FIGURA 5.6 - VALORES DE ÁREAS DOS CROMATOGRAMAS DAS AMOSTRAS DE ÁGUAS DAS ESTAÇÕES 1,2, 3 E 4, COLETADAS EM NOVEMBRO/98, ANALISADAS EM TRIPLICATA ( $A, B E C)$.

Nas amostras de sedimento, a distribuição dos clorofenóis entre as estações foi mais irregular. Considerando-se as substâncias extraídas em todos os métodos utilizados, somente o composto 2,3,4-TCP esteve presente em todas as estações dessa campanha (Figura 5.7). Esse fato possivelmente foi devido à alta taxa de deposição de material em suspensão nessa campanha, provocada pelo alto tempo de residência, permitindo uma constante renovação do sedimento.

Nas estações 1 e 4, houve uma maior variedade de substâncias presentes, basicamente as mesmas, considerando a extração utilizando agitação e Soxhlet, sendo as áreas encontradas menores que $2,50 \mu \mathrm{g} / \mathrm{Kg}$ para os clorofenóis encontrados.

Nas estações 2 e 3, a variedade de clorofenóis encontrada foi bem menor. As substâncias presentes foram PCP, 2,3,4-TCP e 2,4,5-TCP, estando as concentrações calculadas de PCP em valores inferiores a $0,50 \mu \mathrm{g} / \mathrm{Kg}$ e para 2,3,4-TCP, menores que $2,5 \mu \mathrm{g} / \mathrm{Kg}$. Deve-se ressaltar, que na estação 3, apenas o método do ultra-som foi utilizado.

Os teores de carbono total nas estações 1 e 4, em que uma maior variedade de clorofenóis foi observada, foram superiores aos obtidos nas amostras das estações 2 e 3. 

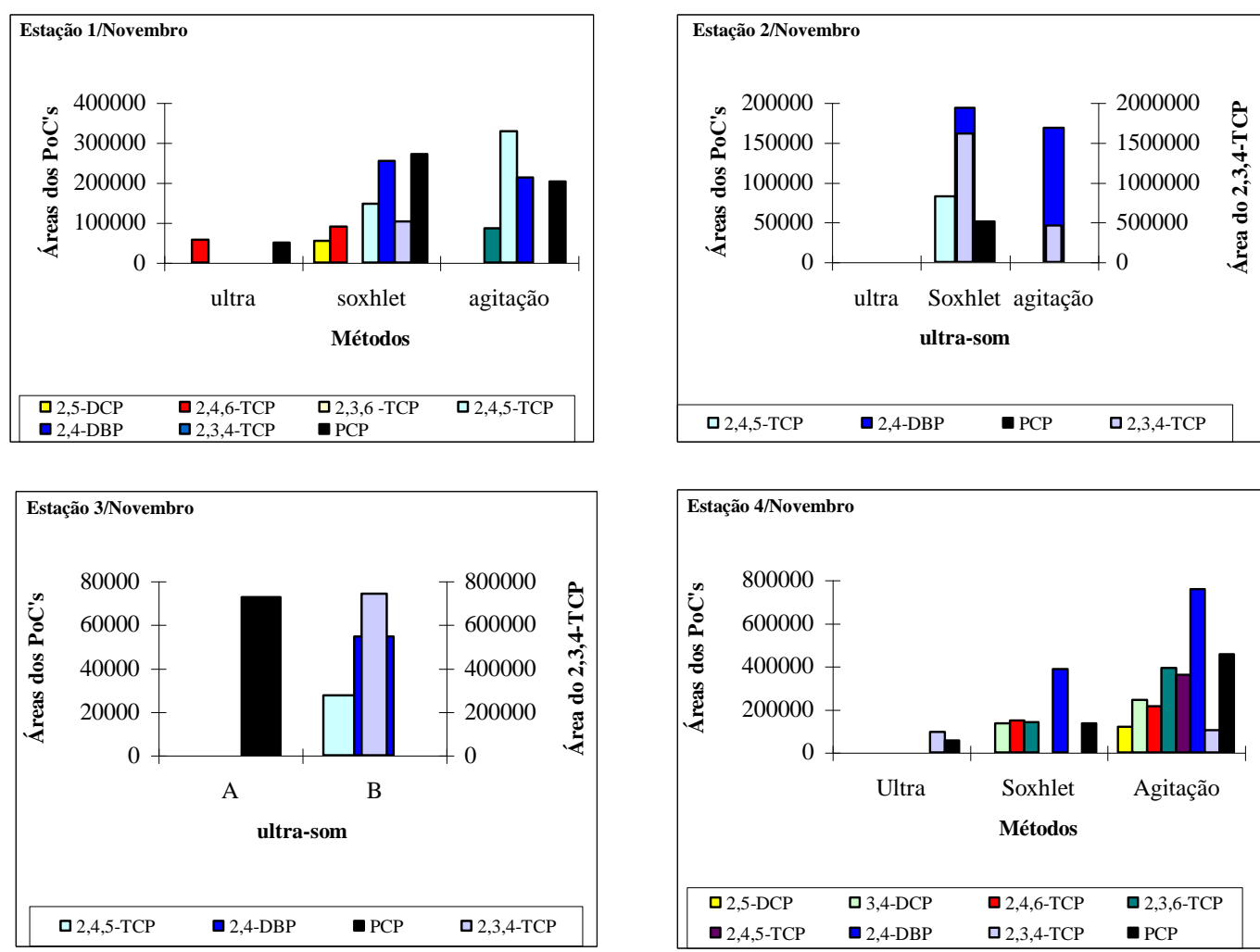

FIGURA 5.7 - VALORES DE ÁREA DES CROMATOGRAMAS DAS AMOSTRAS DE SEDIMENTO DAS ESTAÇÕES 1,2, 3 E 4, COLETADAS EM NOVEMBRO/98, ANALISADAS EM TRIPLICATAS (A, $B E C)$.

\subsection{4 ${ }^{\mathrm{a}}$ Campanha (Fevereiro)}

Nas análises das amostras de água da campanha de Novembro e Fevereiro, o composto 2,3,4-TCP esteve presente em todas as estações (Figura 5.8). PCP também foi encontrado na maioria das estações, não sendo verificado nas amostras de superfície da estação 4. As respostas das estações 1 e 2 foram bastante similares, verificando-se as presenças dos compostos PCP e 2,3,4-TCP nas triplicatas, porém, as áreas encontradas na estação 2 foram bem menores para 2,3,4-TCP. As concentrações dos clorofenóis foram menores que $0,010 \mu \mathrm{g} / \mathrm{Kg}$. As respostas das amostras das estações 3 e 4 foram semelhantes, apresentando sempre os compostos 2,3,4-TCP e 2,3,6-TCP. PCP também esteve presente nas amostras das estações 3 e 4, nessa última nas profundidades de 2,5 e $4 \mathrm{~m}$. 
Nas análises das amostras de sedimentos da estação 1 observaram-se resultados similares nas réplicas, empregando-se como métodos extrativos o ultra-som e o Soxhlet (Figura 5.9). Pela análise das amostras extraídas com o ultra-som, 2,3,6-TCP esteve presente nas estações 1,2 e 3, assim como foi detectado pelo método de extração com agitação na estação 4.

Comparando-se as respostas encontradas nas análises dos sedimentos e das águas, diferentes tipos de clorofenóis foram determinados nas estações 2 e 4, sendo bastante similares em ambas as amostras. Considere-se que os tipos de clorofenóis encontrados são aqueles cujos padrões cromatográficos permitem comparação. As concentrações determinadas de PCP foram menores que $0,50 \mu \mathrm{g} / \mathrm{kg}$, e para os demais clorofenóis inferiores a $2,50 \mu \mathrm{g} / \mathrm{Kg}$.

Como na campanha de Novembro, as estações 1 e 4 em Fevereiro de 1999 apresentaram uma maior variedade de clorofenóis, assim como as maiores áreas de picos de cromatogramas. Os valores de carbono orgânico total também foram maiores para estas duas estações. 

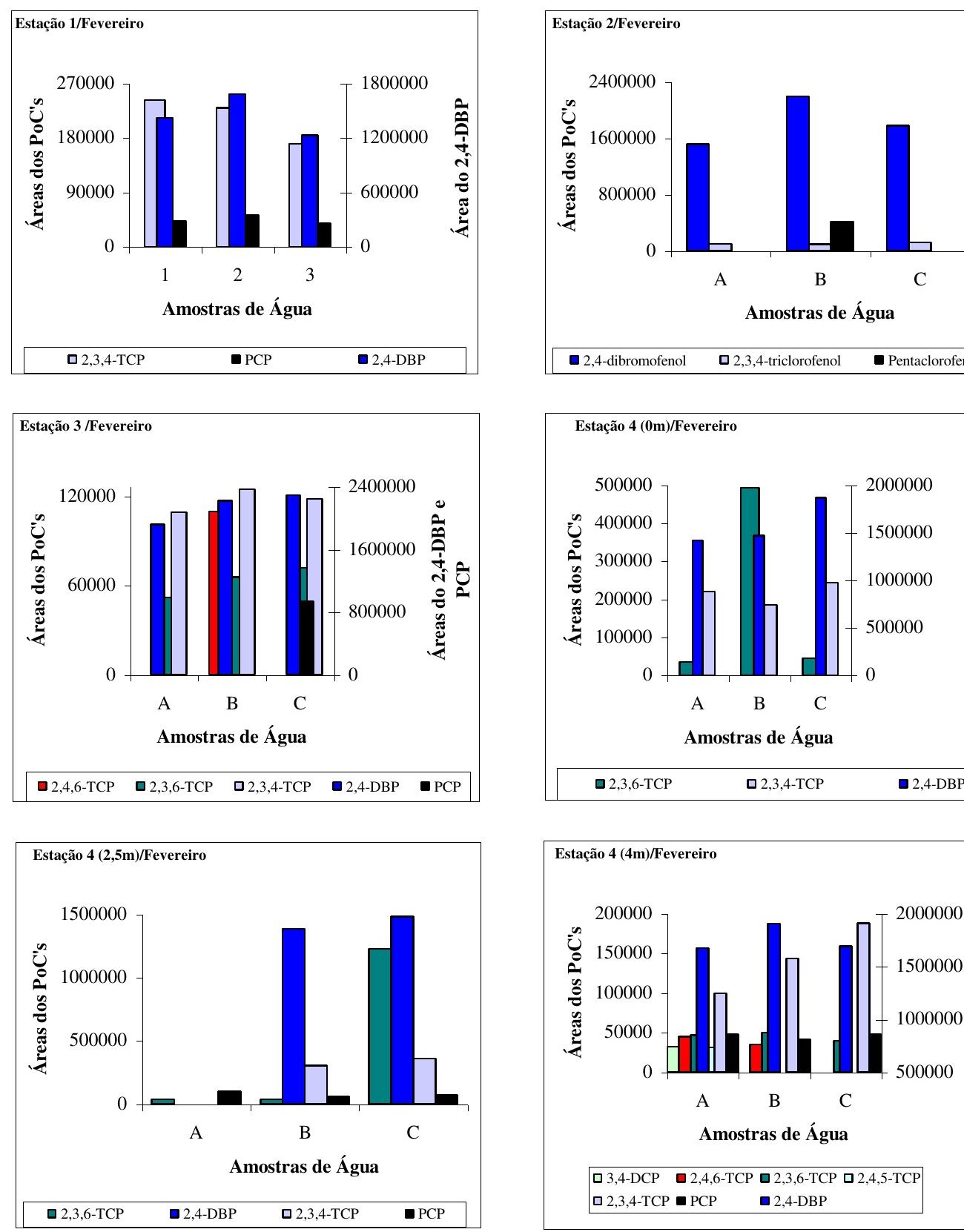

FigURA 5.8 - VALORES DAS ÁREAS DE CROMATOGRAMAS DAS AMOSTRAS DE ÁGUAS DAS ESTAÇÕES 1, 2, 3 E 4, COLETADAS EM FEVEREIRO/99, ANALISADAS EM TRIPLICATA $(A, B E C)$ 

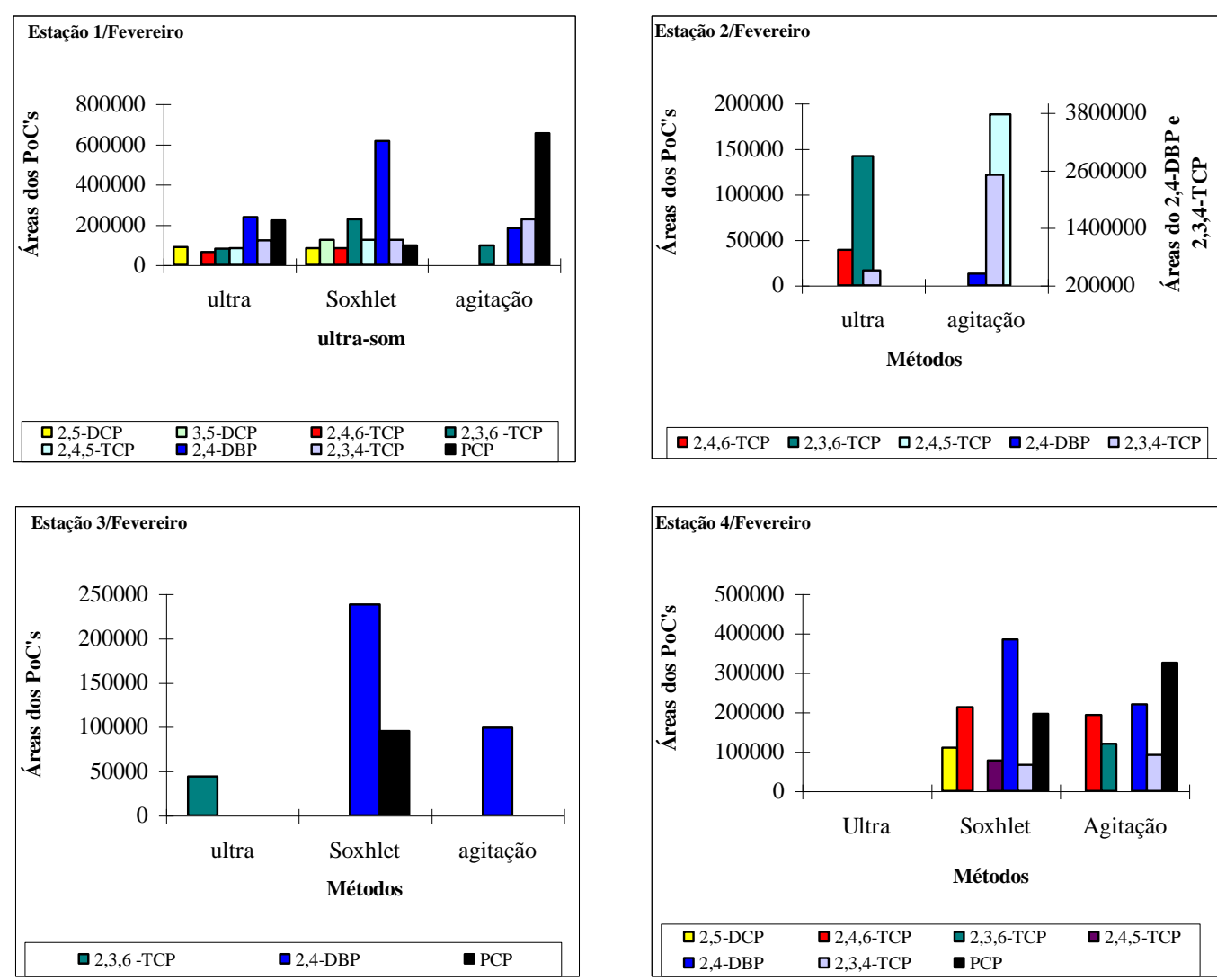

FIGURA 5.9 - VALORES DE ÁREAS DOS CROMATOGRAMAS DAS AMOSTRAS DE SEDIMENTOS DAS ESTAÇÕES 1, 2, 3 E 4, COLETADAS EM FEVEREIRO/99

\subsection{Resultados e Discussão por Estação}

\subsubsection{Estação 1}

Nessa estação foram feitas coletas apenas em Novembro de 1998 e Fevereiro de 1999. Na Figura 5.10 está apresentada uma vista parcial dessa estação, onde pode ser visto o ponto de captação de água para a cidade de Sumaré, em coleta feita em Novembro de 1998. 


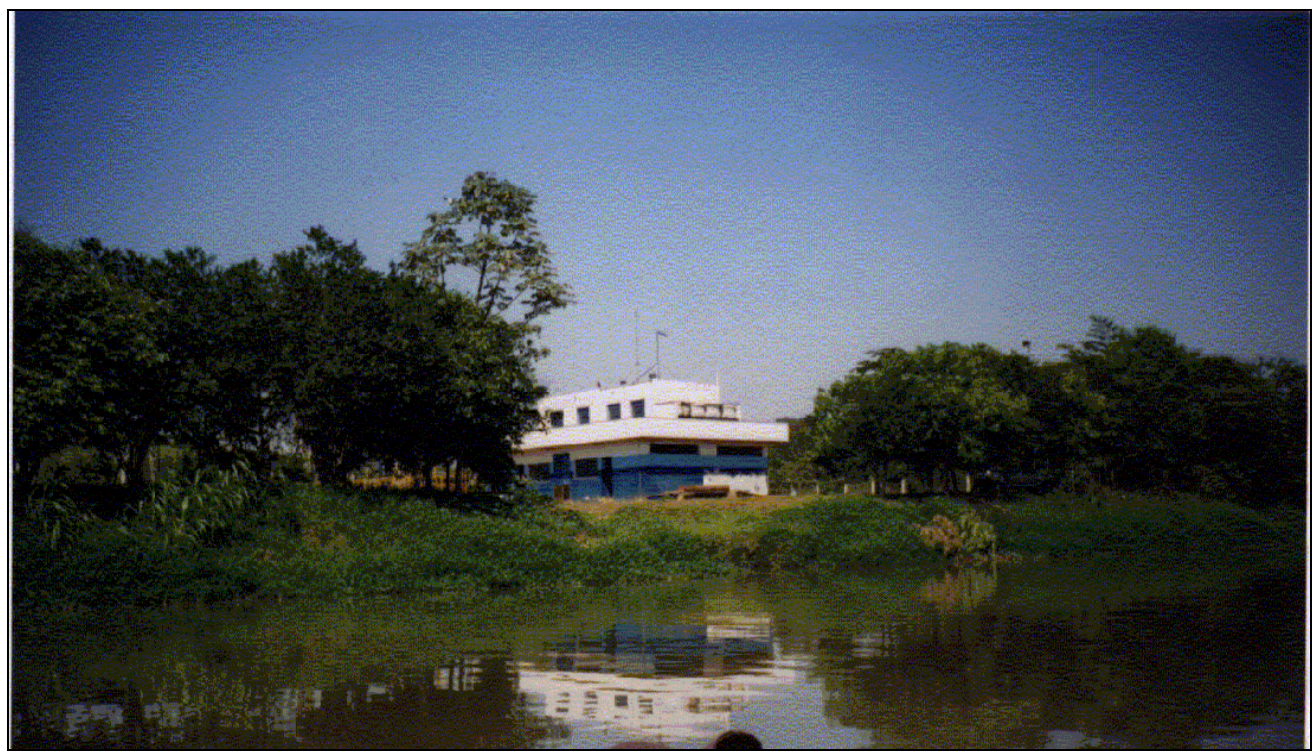

FIGURA 5.10 - VISTA PARCIAL DO ENTORNO DA ESTAÇÃO 1, PONTO DE CAPTAÇÃO DE ÁGUA PARA

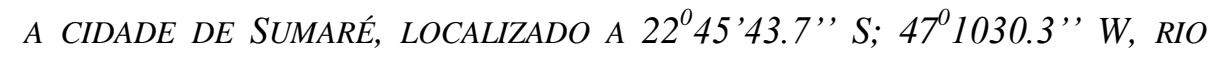
ATIBAIA, COLETA DE NOVEMBRO DE 1998.

Os parâmetros físico-químicos medidos nas colunas d'água da estação 1, nas campanhas de Novembro e Fevereiro, estão apresentados na Figura 5.11.
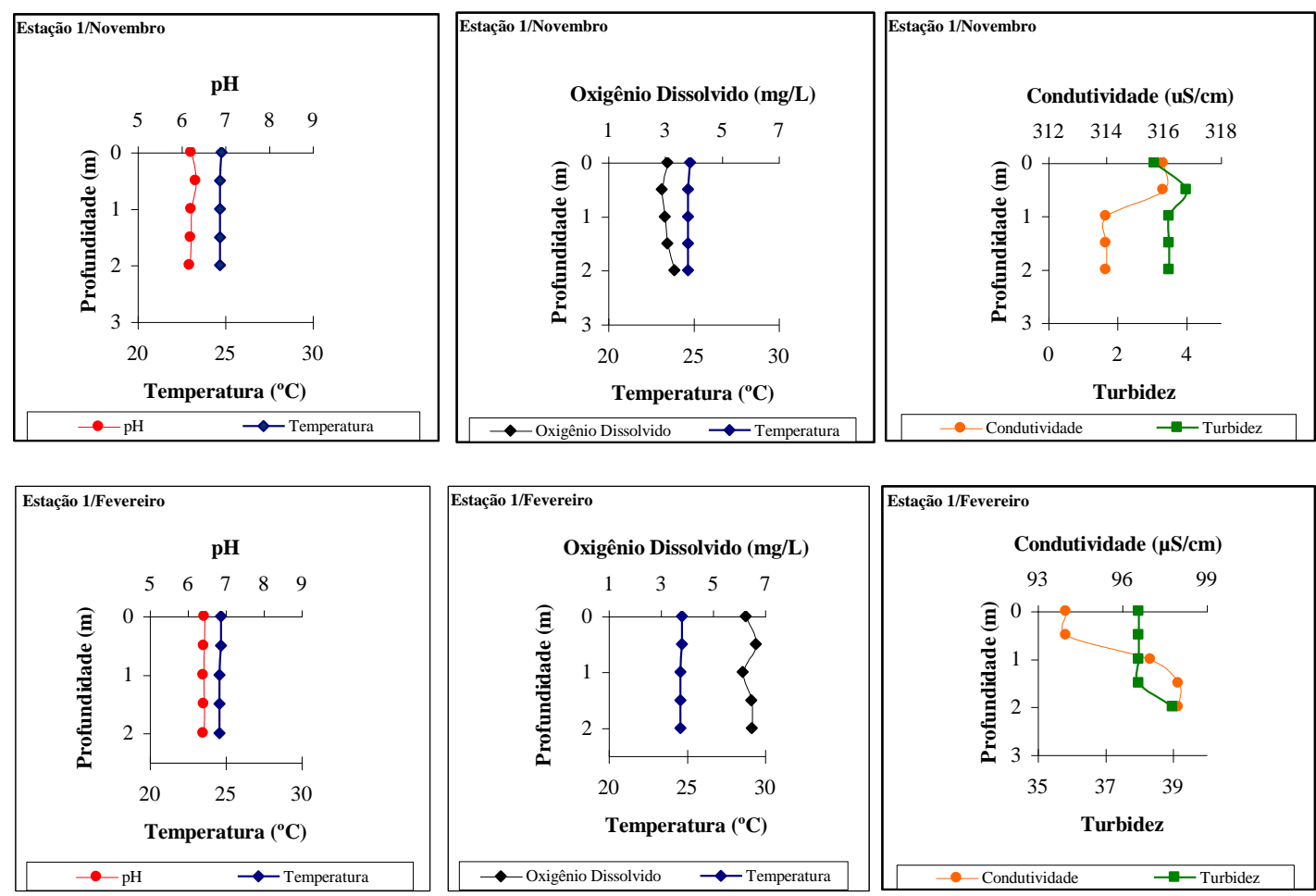

Figura 5.11 - Perfis de pH, temperatura $\left({ }^{\circ} \mathrm{C}\right)$, oxigênio dissolvido $(\mathrm{mg} / \mathrm{L})$, condutividade ( $\mu \mathrm{S} / \mathrm{cm})$ e turbidez, na Estação 1, campanhas de Novembro e Fevereiro 
$\mathrm{Na}$ análise da água, 2,3,4-TCP e PCP foram encontrados em ambas as campanhas, sendo que as áreas de pico de 2,3,4-TCP nos cromatogramas corresponderam a concentrações em torno de $0,010 \mu \mathrm{g} / \mathrm{L}$.

Em Novembro, a amostra que apresentou melhor resposta para o padrão interno foi considerada como valor de resposta. Ocorreu decréscimo nas áreas de pico de PCP dos cromatogramas nessa estação, nas coletas de Novembro para Fevereiro, de 350.651 para 40.284, respectivamente. Pode ter havido diluição de compostos no sistema devida às chuvas. Na Figura 5.12, são apresentados os valores das áreas dos cromatogramas das amostras de água da estação 1 nas campanhas de Novembro e Fevereiro.

NAS DUAS CAMPANHAS PREDOMINOU O MATERIAL INORGÂNICO EM SUSPENSÃO, SENDO QUE, EM FEVEREIRO, A DIFERENÇA ENTRE O CONTEÚdO DE MATERIAIS ORGÂNICOS E INORGÂNICOS FOI MUITO MAIOR, DEVIDA, PRINCIPALMENTE, `A INTENSA PRECIPITAÇÃO QUE FACILITA A INTRODUÇÃO DE MATERIAL INORGÂNICO NAS ÁGUAS DO RiO ATIBAIA. NA FigURA 5.13, SÃO APRESENTAdOS ESSES VALORES PARA AS AMOSTRAS DE ÁGUA DA ESTAÇÃO 1 DAS $3^{\mathrm{A}}$ E $4^{\mathrm{A}}$ CAMPANHAS.

Ao considerar-se as características do solo no entorno do reservatório e sua influência na época de chuvas, pode-se comentar alguma interferência físico-química na disponibilidade de clorofenóis na água do reservatório. Se em regime de chuvas mais intensas ocorre grande movimentação de material lixiviado para dentro de um sistema aquático, esses com certeza podem servir como suporte para adsorção de compostos organoclorados. O predomínio de material inorgânico pode ter possibilitado a adsorção dos clorofenóis nesse período mais chuvoso. Por exemplo, solos mineralizados permitem maior mobilidade do PCP, ao contrário de solos arenosos, argilosos ácidos e ricos em matéria orgânica (NAKAYAMA, 1999). A região do reservatório de Americana possui solos caracteristicamente argilosos.

A análise dos clorofenóis dos sedimentos coletados nessa estação foi feita em triplicata, utilizando-se a extração pelos três métodos estudados: ultra-som (amostras estudadas em triplicata), Soxhlet e agitação . Os clorofenóis extraídos com ultra-som foram 2,4,6-TCP em ambas as campanhas, com valores de áreas de pico próximas a 60.000, e PCP, também detectado em ambas as campanhas, valores de picos de área em torno de $60.000 \mathrm{em}$ Novembro. Pelos cálculos, os valores das áreas corresponderam a concentrações inferiores a $0,50 \mu \mathrm{g} / \mathrm{Kg}$ para 2,4,6-TCP, e menores que $0,50 \mu \mathrm{g} / \mathrm{Kg}$ para PCP.

Pela extração com o Soxhlet, além de 2,4,6-TCP e PCP, também foi comum nas duas campanhas, o 2,5-DCP. Assim como foi observado para os valores de áreas de pico das 
amostras de água, PCP sofreu decréscimo entre as campanhas de Novembro e Fevereiro, considerando as áreas de pico dos cromatogramas de 271.296 para 97.394, respectivamente.

Pelo método de extração com agitação, observaram-se os clorofenóis 2,3,6-TCP com áreas em torno de 90.000 em ambas as campanhas, e PCP, com valores de 202.841 para 652. 973, respectivamente, para Novembro e para Fevereiro. Na Figura 5.14 são apresentados os valores das áreas de pico dos cromatogramas para os três métodos de extração empregados para sedimentos da estação 1. Cada método foi representado por uma letra, sendo o ultrasom (u), o Soxhlet (S) e a agitação sob barra magnética (a). No método do ultra-som, foram plotadas no gráfico as áreas mais representativas e as mais semelhantes entre as triplicatas. Todos os demais gráficos serão apresentados dessa forma.

Os teores de carbono orgânico e a umidade nessa estação praticamente não sofreram alteração entre as campanhas de Novembro e Fevereiro (Figura 5.15).

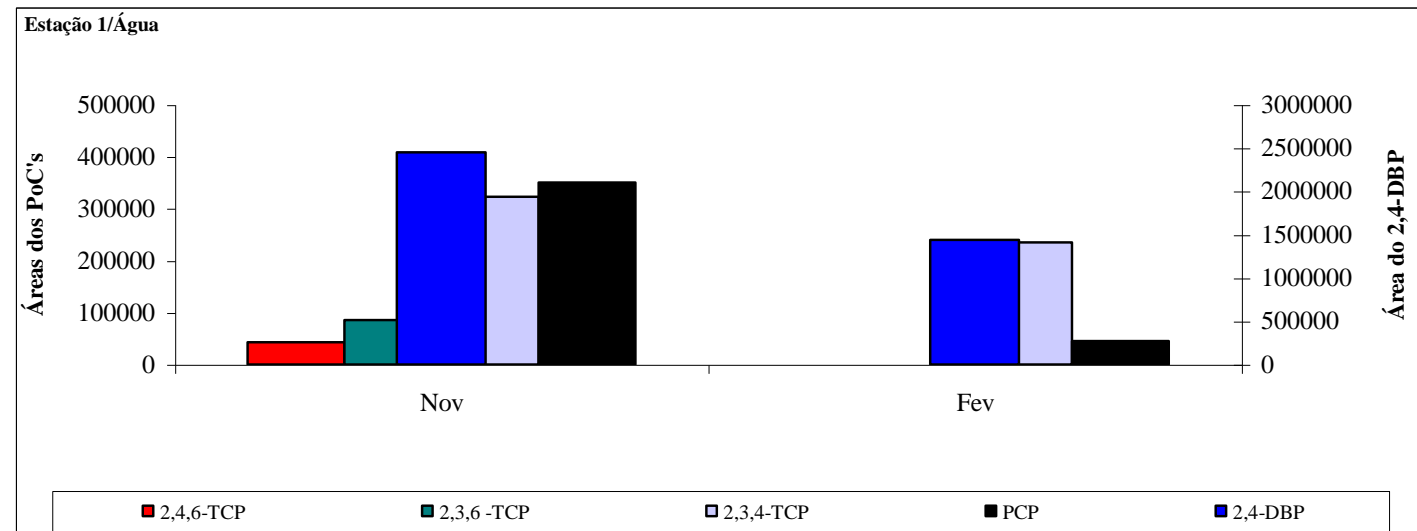

FIGURA 5.12 - VALORES DAS ÁREAS OBTIDAS PELAS ANÁLISES CROMATOGRÁFICAS DAS AMOSTRAS DE ÁGUA DA ESTAÇÃO 1, COLETADAS EM NOVEMBRO/98 E FEVEREIRO/99
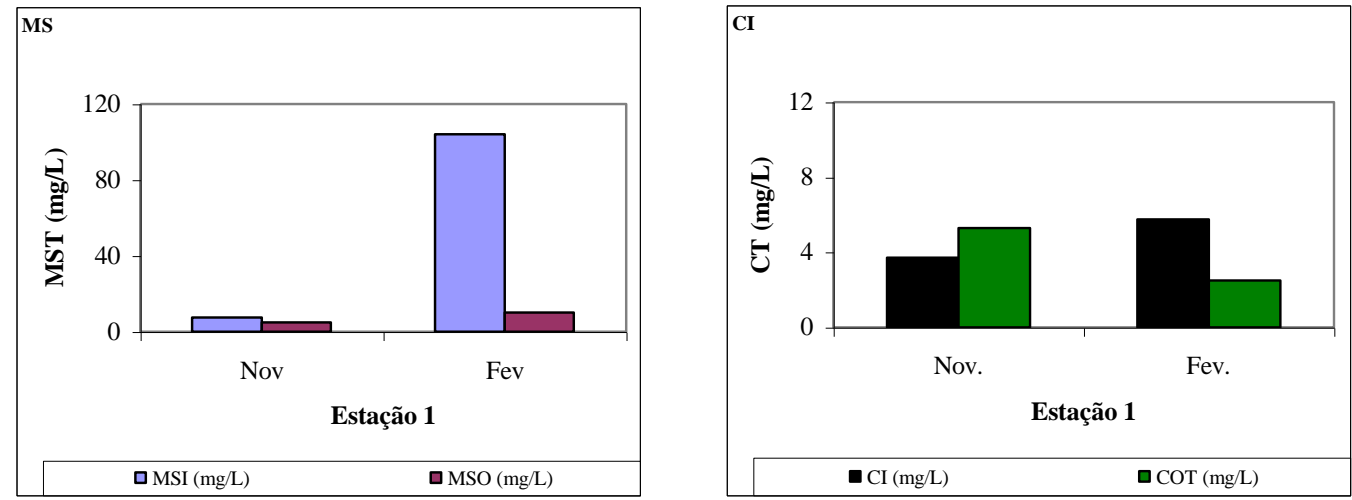


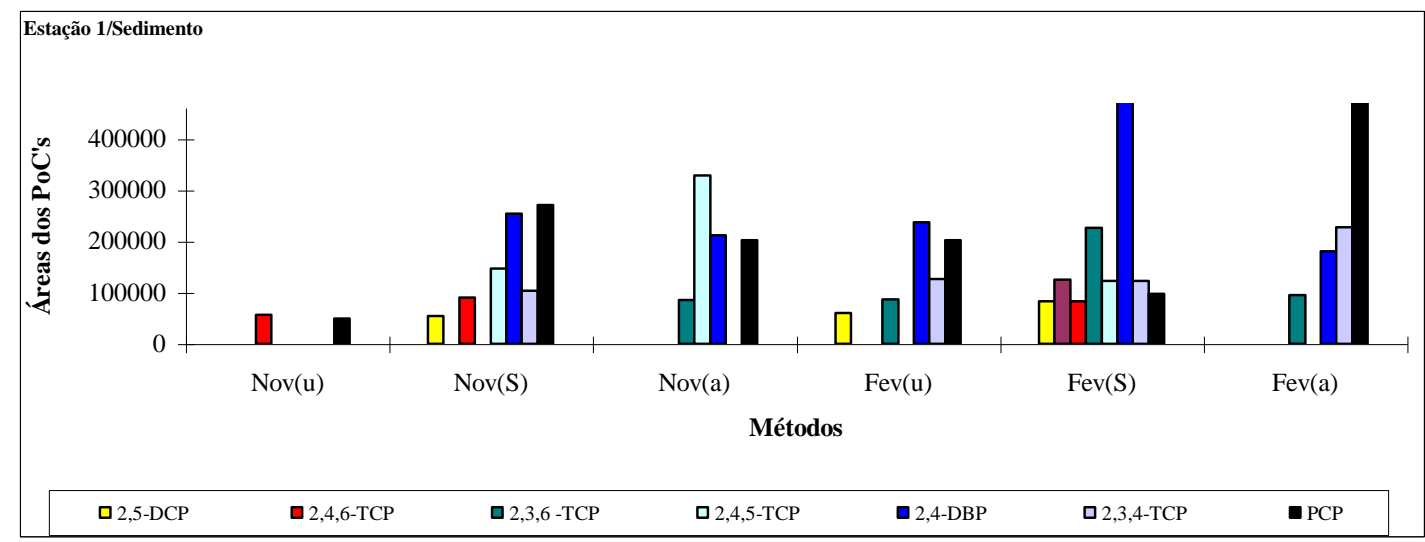

FIGURA 5.14 - VALORES DAS ÁREAS OBTIDAS POR ANÁLISE CROMATOGRÁFICA DAS AMOSTRAS DE SEDIMENTO DA ESTAÇÃO 1 DE NOVEMBRO/98 E FEVEREIRO/99.
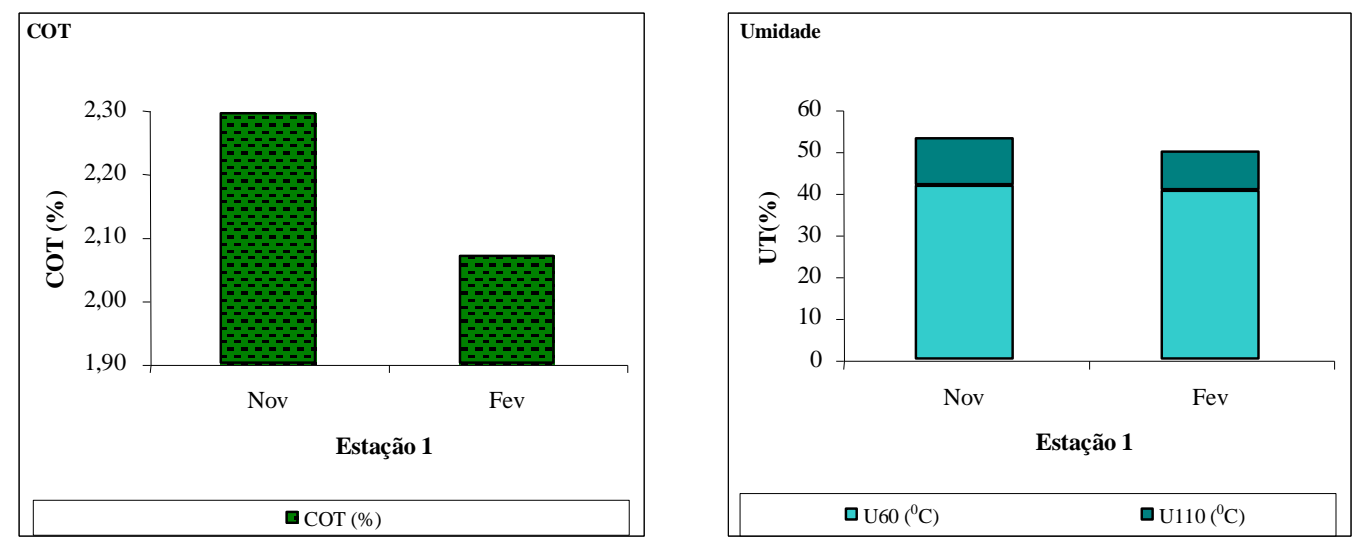

Figura 5.15 - Valores de carbono orgânico total e umidade total a $60^{\circ} \mathrm{C}$ e $110^{\circ} \mathrm{C}$ das amostras de sedimento da estação 1 de Novembro/98 e Fevereiro/99.

Na estação 1, verificou-se que o conteúdo de material em suspensão inorgânico foi predominante nas duas campanhas, possivelmente pelo carreamento de material pelo rio, já que esta estação está localizada no mesmo e tem uma velocidade de fluxo maior que todas as estações. Outro fator que contribuiu bastante para este elevado conteúdo inorgânico na $4^{\mathrm{a}}$ campanha é a influência de chuvas, provavelmente devido a lixiviação de materiais do solo do entorno para o reservatório. Isso pode influenciar os valores de condutividade, turbidez e oxigênio dissolvido, mostrados nas Tabelas 5.36 e 5.44. na $2^{\text {a }}$ campanha, uma possível explicação é o carreamento de material inorgânico. Na estação 1 , o pH da coluna d'água até $2 \mathrm{~m}$ sempre esteve próximo a faixa de 6,1 a 6,4 em ambas as campanhas, no entanto, os 
valores de condutividade diminuíram muito de Novembro/98 para Fevereiro/99, cerca de 316 para $94 \mu \mathrm{S} / \mathrm{cm}$, respectivamente. Isso pode ser devido ao aumento do fluxo de correntes em virtude da precipitação nesses meses, de 26 para 198mm, segundo o CIAGRI (1999), que também justifica o aumento do teor de oxigênio dissolvido de 3 para $6,5 \mathrm{mg} / \mathrm{L}$ e de turbidez de 3,5 uT para 38 uT. Os principais clorofenóis encontrados foram PCP, 2,3,4-TCP, 2,4,6TCP e 2,5-DCP.

\subsubsection{Estação 2}

Nesta estação, foram feitas coletas de água e sedimento nos meses de Maio, Junho e Novembro de 1998 e Fevereiro de 1999. Na Figura 5.16, tem-se uma visão da paisagem da estação obtida na coleta de Novembro/98.

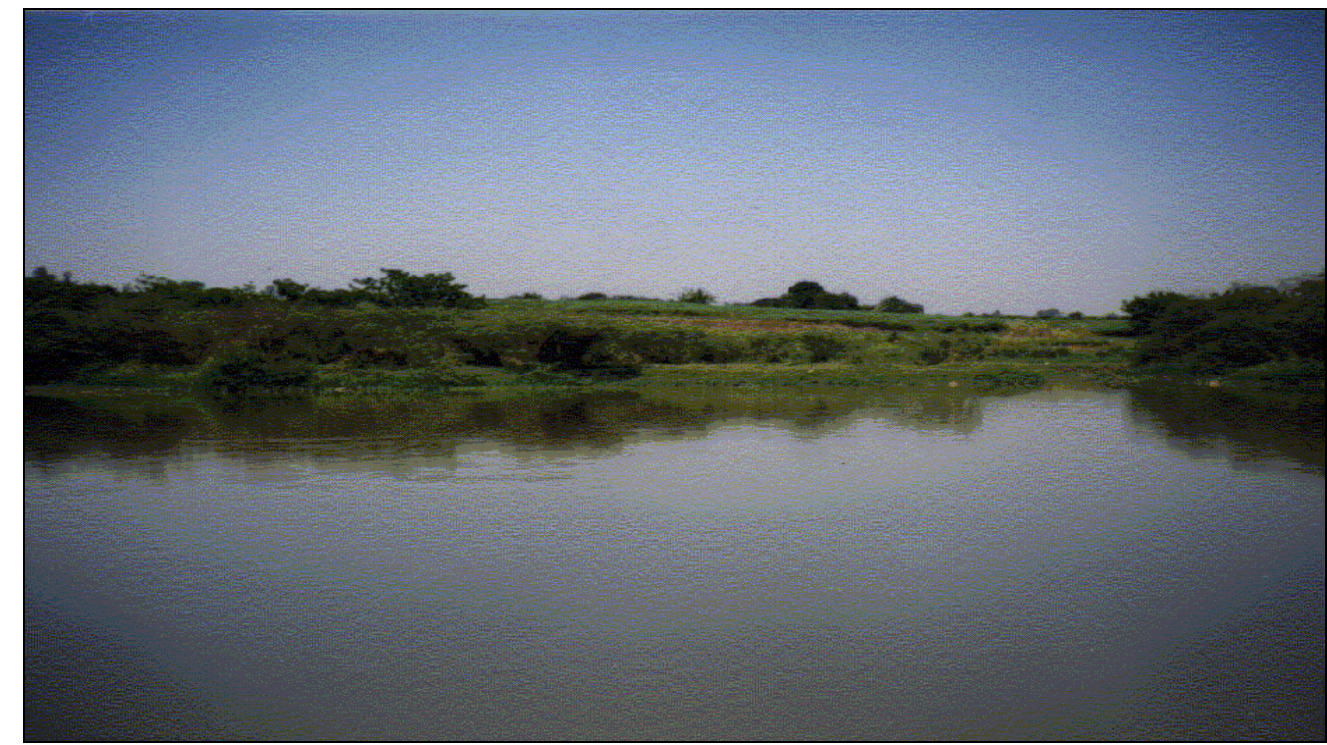

FigURA 5.16 - VISTA PARCIAL DO ENTORNO DA ESTAÇÃO 2, ENTRADA DO ALAGADO,

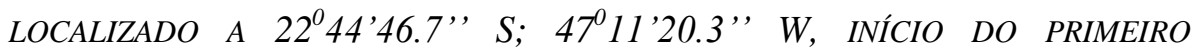
COMPARTIMENTO, COLETA DE NOVEMBRO DE 1998.

O composto PCP foi comum em todas as campanhas, apresentando maiores valores de áreas em Junho de 1998 e Fevereiro de 1999, respectivamente, de 4.123.786 e 413.033. O valor da área de pico de PCP, no cromatograma, em Junho, foi obtido apenas em uma amostra das três réplicas, correspondendo a uma concentração de $0,011 \mu \mathrm{g} / \mathrm{L}$. Porém, devese considerar que nessa campanha ainda não se obtinha áreas similares entre as triplicatas, devido, provavelmente, a uma acidificação inadequada e a distribuição irregular de material em suspensão, que é um possível ponto de adsorção de clorofenóis. 
O composto 2,3,4-TCP não foi detectado apenas na campanha de Junho e apresentou maior área de pico em Fevereiro de 1999, igual a 94.253. Todas as áreas de pico encontradas para os clorofenóis nessa estação corresponderam a concentrações inferiores a $0,01 \mu \mathrm{g} / \mathrm{L}$, exceto para PCP, como já foi visto e para 2,5-DCP, que apresentou concentrações de $0,021 \mu \mathrm{g} / \mathrm{L}$ na campanha de Maio e de $0,010 \mu \mathrm{g} / \mathrm{L}$ na campanha de Novembro. Essas áreas de pico em cromatogramas são apresentadas na Figura 5.17.

Em Maio, houve predominância do teor de carbono orgânico, e em Junho e Fevereiro predominaram teores de carbono inorgânico. Em Novembro, o carbono orgânico foi aproximadamente igual ao carbono inorgânico (Figura 5.18).

As análises do sedimento mostraram que nenhum clorofenol foi comum a todas as campanhas, como pode ser observado na Figura 5.19. Na campanha de Novembro, não foi detectado nenhum clorofenol pelo método extrativo com ultra-som, sendo que em Maio, Junho e Fevereiro, apenas 2,4,6-TCP esteve presente, com concentrações inferiores a $2,50 \mu \mathrm{g} / \mathrm{Kg}$.

A análise de carbono e umidade total foram feitas apenas para as amostras de Novembro e Fevereiro, sendo os valores obtidos apresentados na Figura 5.20.

O conteúdo de carbono orgânico total para a campanha de Novembro foi quase 3 vezes maior que o da campanha de Fevereiro, enquanto que, a umidade total de Novembro foi aproximadamente $8 \%$ menor que a umidade total de Fevereiro. Estes valores podem ser explicados pela elevada precipitação e pelo tempo de residência. Em Novembro, o tempo de residência foi maior devido a menor precipitação, e a taxa de deposição foi maior que a de Fevereiro, permitindo uma maior predominância de material orgânico no sedimento.

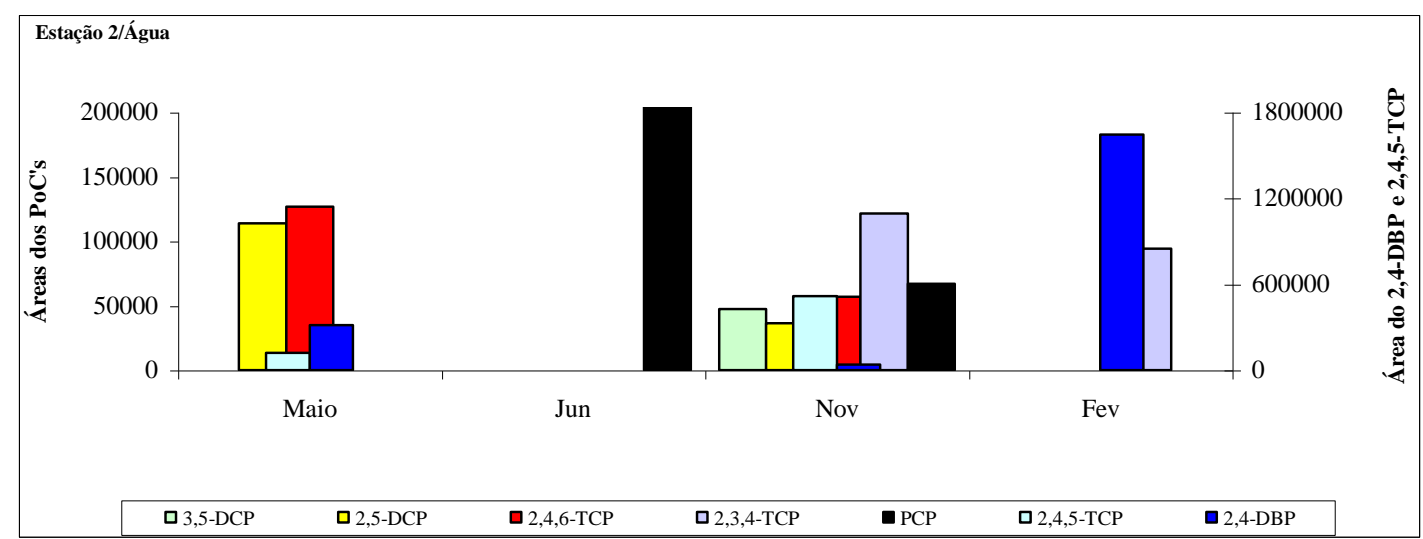

Figura 5.17 - Valores das áreas obtidas pelas análises cromatográficas das amostras de água da estação 2 de Maio, Junho e Novembro/98 e Fevereiro/99. 

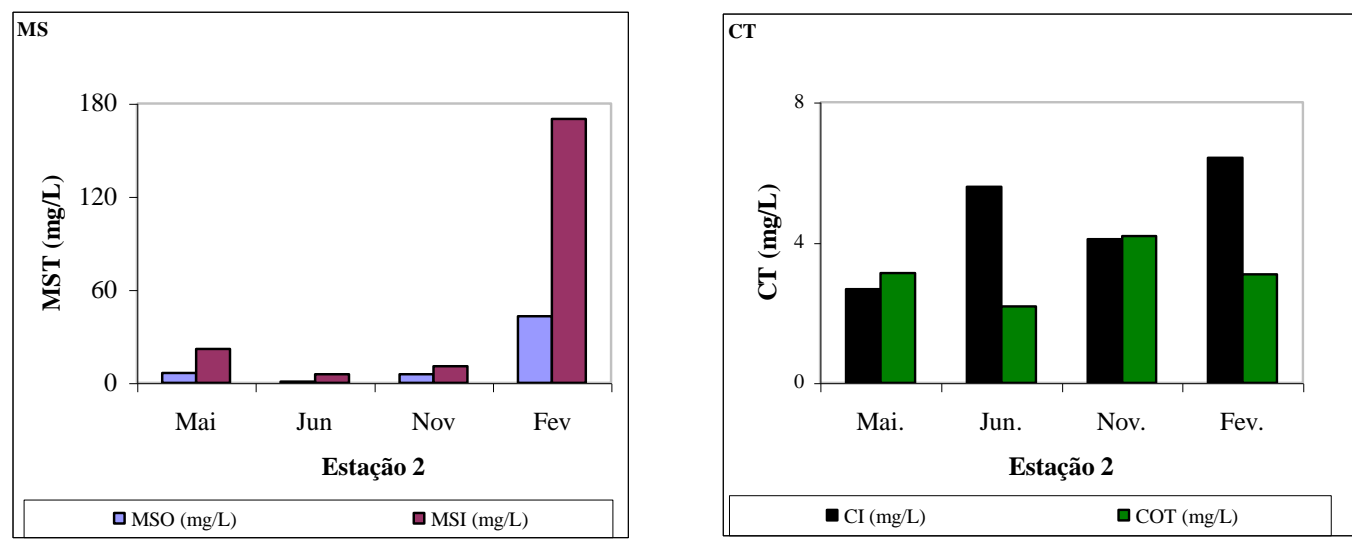

FIGURA 5.18 - VALORES DO MATERIAL EM SUSPENSÃO TOTAL, FRAÇÕES INORGÂNICAS E ORGÂNICAS E CARBONO TOTAL, FRAÇÕES INORGÂNICAS E ORGÂNICAS DAS AMOSTRAS DE ÁGUA DA ESTAÇÃO 2 DE MAIO, JUNHO E NOVEMBRO/98 E FEVEREIRO/99.

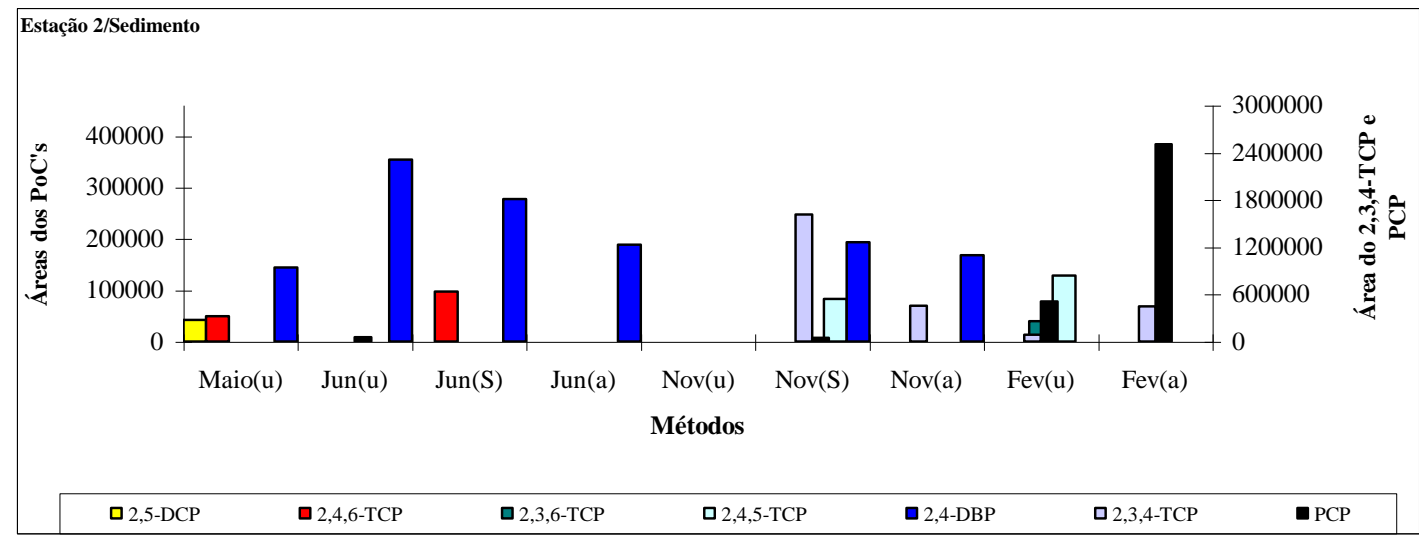

FIGURA 5.19 - VALORES DAS ÁREA OBTIDAS POR ANÁLISES CROMATOGRÁFICAS DAS AMOSTRAS DE SEDIMENTO DA ESTAÇÃO 2 DE MAIO, JUNHO E NOVEMBRO/98 E FEVEREIRO/99.
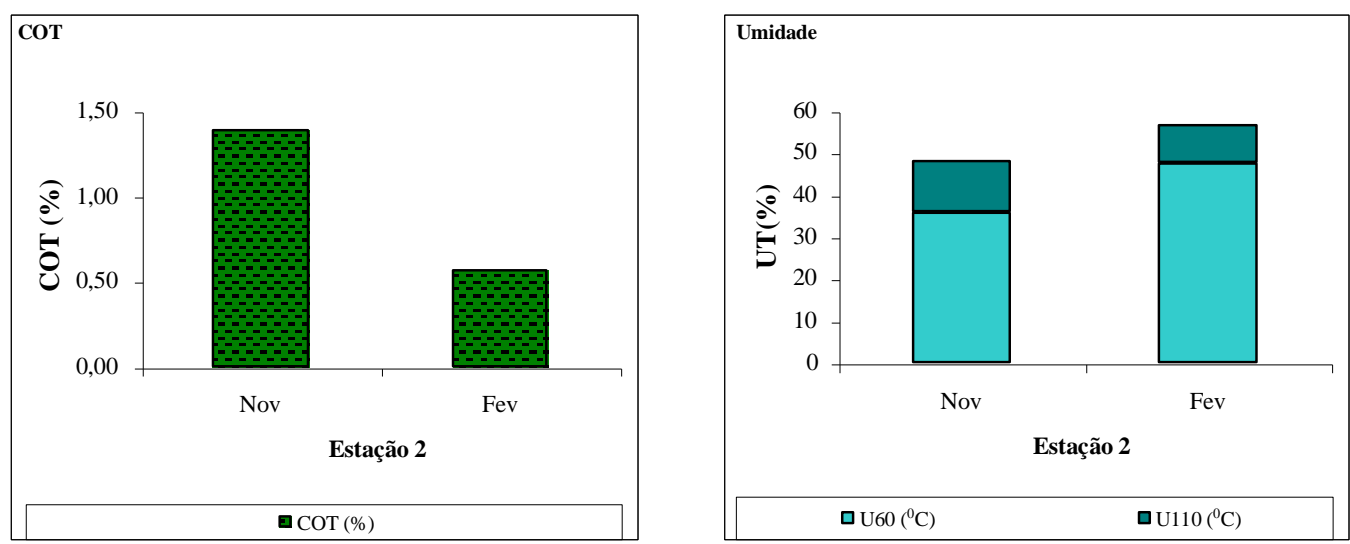


\section{FIGURA 5.20 - VALORES DE CARBONO ORGÂNICO TOTAL E UMIDADE TOTAL A $60^{\circ} \mathrm{C}$ E $110^{\circ} \mathrm{C}$ DAS AMOSTRAS DE SEDIMENTO DA ESTAÇÃO 2 DE NOVEMBRO/98 E FEVEREIRO/99}

$\mathrm{Na}$ estação 2, verificou-se que nas amostras de água predominou o conteúdo de material em suspensão inorgânico provavelmente devido a grande influência que esta estação sofre do rio Atibaia, recebendo aportes de material, visto que se localiza no início do reservatório. Os valores de condutividade, turbidez e oxigênio dissolvido, mostrados nas Tabelas 5.27, 5.30, 5.35 e 5.43 sofreram pequenas variações nas estações, porém superiores entre as campanhas, exceto para os valores de $\mathrm{pH}$ da coluna d'água até $2,40 \mathrm{~m}$, que oscilaram entre as campanhas na faixa de 6,21 a 6,81. Os valores de condutividade da primeira a quarta campanha, estiveram próximos a, respectivamente, 2,93, 104, 314 e $94 \mu \mathrm{S} / \mathrm{cm}$. É provável que o acréscimo na campanha de Novembro tenha sido devido à intensa atividade fotossintética observada nessa época, ao mesmo tempo em que ocorria a degradação da matéria orgânica nas camadas mais profundas. Os valores de turbidez decresceram de 30 uT para 6 uT da primeira para segunda campanha, mantendo-se em 4 uT na terceira, e 53 uT na segunda. Esses valores talvez possam ser explicados pela precipitação medida no período amostrado, como observado na Tabela 5.26, a precipitação diminuiu de 97,60 $\mathrm{mm}$ para 26,60 $\mathrm{mm}$, de Maio para Junho, apresentando valores semelhantes ao de Junho, em Novembro, e igual a 198,30 mm em Fevereiro. Os valores de oxigênio dissolvido nessa estação nas quatro campanhas foram de 2,16 e 2,89 mg/L, respectivamente para a primeira e segunda, decrescendo a $0,03 \mathrm{mg} / \mathrm{L}$ na terceira e igual a $5,94 \mathrm{mg} / \mathrm{L}$ na quarta campanha. Os valores determinados em todas as campanhas para a maioria das estações são considerados baixos devido ao estado de hipereutrofização em que se encontra o reservatório, com predominância de decomposição em determinados compartimentos. Os principais clorofenóis encontrados na água foram PCP e 2,3,4-TCP, e no sedimento 2,4,6TCP.

As variáveis físico-químicas medidas nas colunas d'água da estação 2, em todas as campanhas, estão apresentadas na Figura 5.21. 

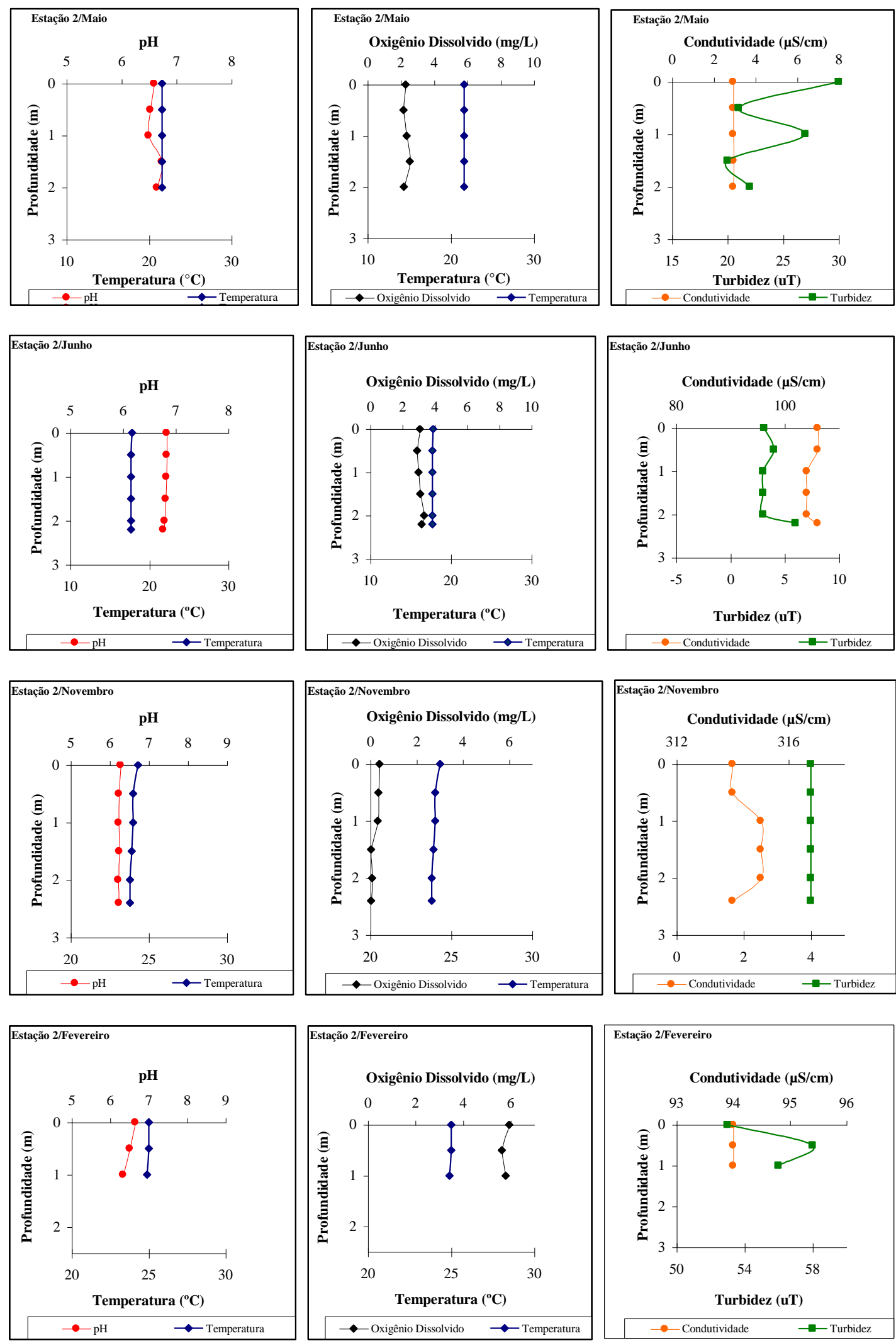

Figura 5.21 - Perfis de pH, temperatura $\left({ }^{\circ} \mathrm{C}\right)$, oxigênio dissolvido $(\mathrm{mg} / \mathrm{L})$, condutividade ( $\mu$ S/cm) e turbidez, na Estação 2, campanhas de Maio, Junho e Novembro de 1998 e Fevereiro de 1999. 


\subsubsection{Estação 3}

Nessa estação foram feitas coletas apenas nas campanhas de Novembro e Fevereiro. Nas Figuras 5.22 e 5.23, podem ser notadas as diferenças entre as campanhas de Novembro e Fevereiro, atribuídas principalmente à elevada precipitação ocorrida na campanha de Fevereiro e conseqüente carreamento de material para o reservatório.

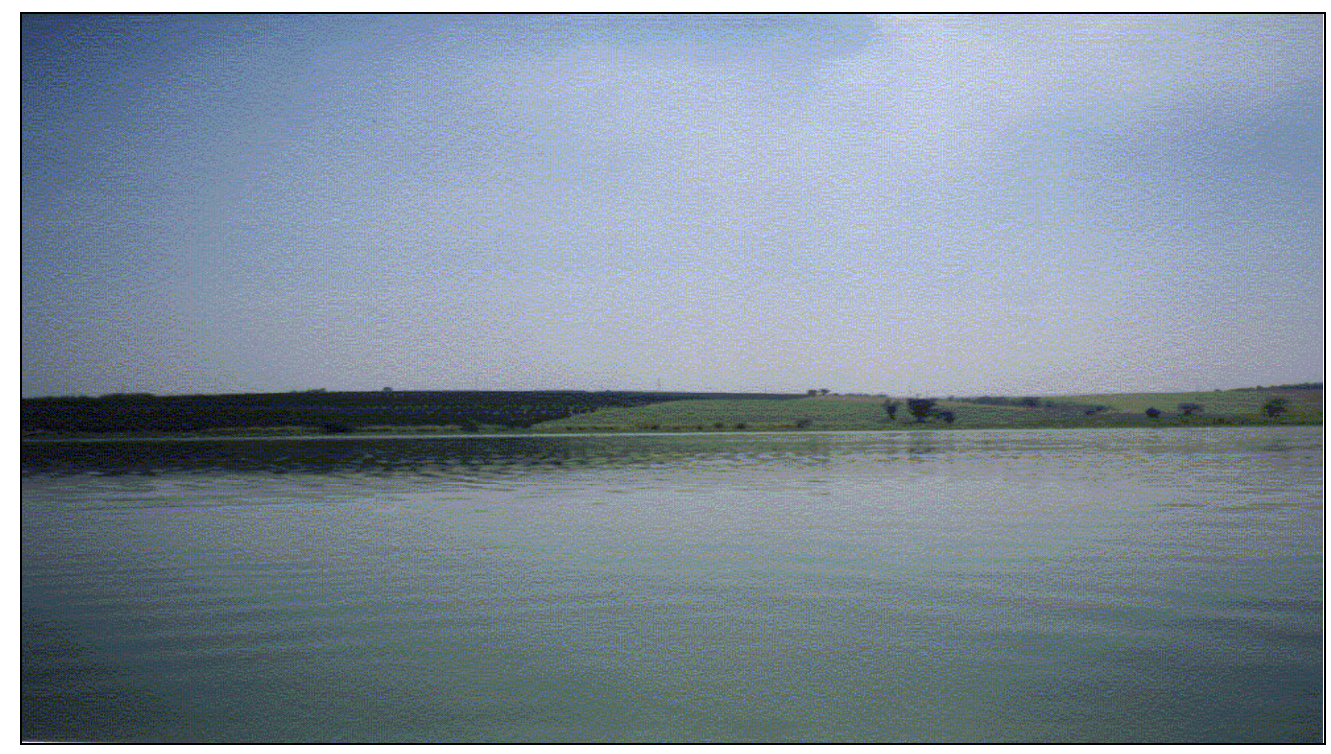

FIGURA 5.22 - VISTA PARCIAL DO ENTORNO DA ESTAÇÃO 3, LOCALIZADA A 22 43'32.8'" S; $47^{\circ} 13^{\prime} 45^{\prime \prime}$ ' W, CENTRO DO SEGUNDO COMPARTIMENTO, COLETA DE NOVEMBRO DE 1998 .

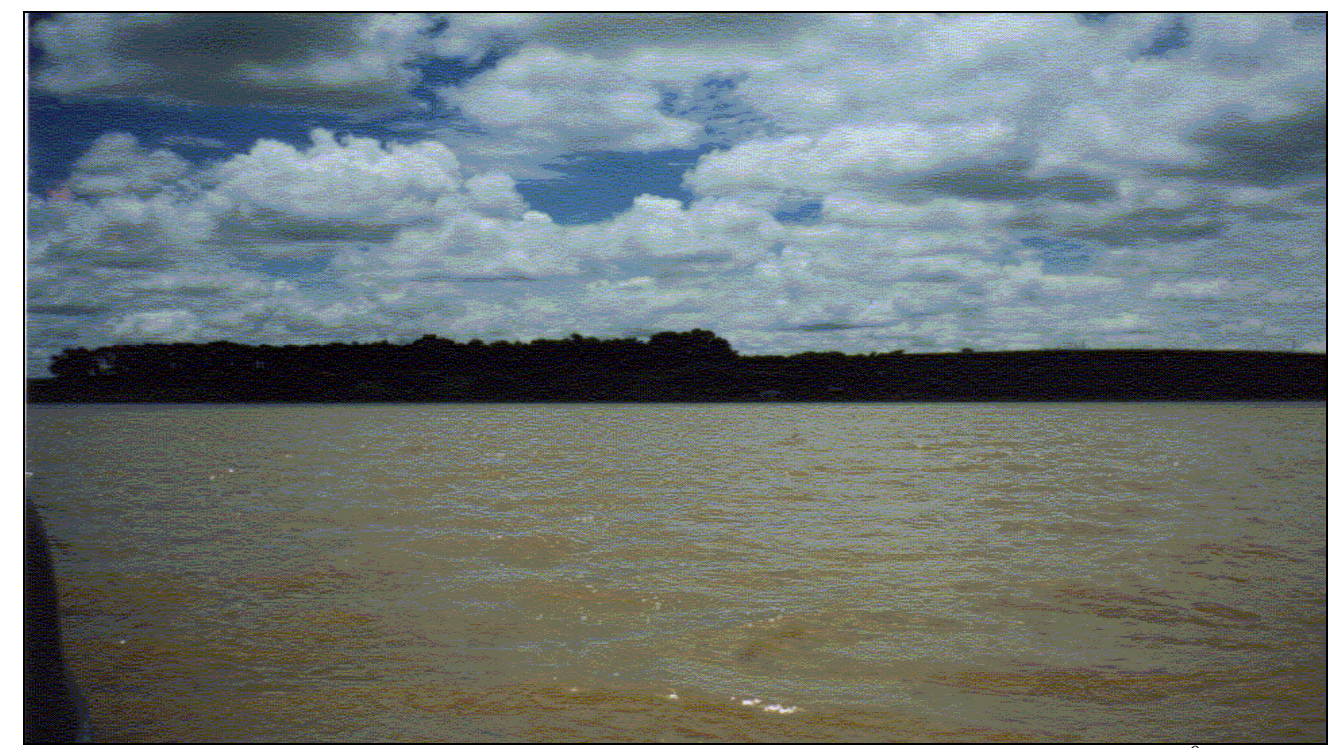

FIGURA 5.23 - VISTA PARCIAL DO ENTORNO DA ESTAÇ̃̃O 3, LOCALIZADA A 220 43'32.8'" S; $47^{\circ} 13$ ' $45^{\prime}$ ' $W$, CENTRO DO SEGUNDO COMPARTIMENTO, COLETA DE FEVEREIRO DE 1999. 
Na campanha de Novembro houve estratificação química da água e a coleta foi feita em 3 profundidades.

O composto 2,3,6-TCP esteve presente em ambas as campanhas, entretanto apresentou-se com maiores áreas de picos nos cromatogramas da campanha de Novembro, nas três profundidades coletadas, respectivamente para 0,2 e $7 \mathrm{~m}$ a $624.503 ; 857.951$ e 1245.420, todas estas áreas correspondem a concentrações inferiores a $0,01 \mu \mathrm{g} / \mathrm{L}$.

A substância 2,5-DCP somente foi detectada em uma das amostras da triplicata realizada na camada mais profunda da campanha de Novembro $(7 \mathrm{~m})$, não sendo detectada na campanha de Fevereiro, entretanto, a área de pico de cromatograma encontrada nessa amostra correspondeu a uma concentração de $0,013 \mu \mathrm{g} / \mathrm{L}$, enquanto as concentrações para os demais clorofenóis detectados corresponderam a valores inferiores a $0,01 \mu \mathrm{g} / \mathrm{L}$.

Os cromatogramas das análises de Novembro e Fevereiro mostraram que houve um decréscimo de 2,3,4-TCP de uma campanha para outra. Em Novembro, esse composto foi detectado em duas profundidades diferentes, na superfície e em $7 \mathrm{~m}$, com maiores valores nessa última. O valor médio das áreas dos picos foi de 333.89. Em Fevereiro, a área média dos picos dos cromatogramas da triplicata foi 121.351 para o composto 2,3,4-TCP. Esse decréscimo ocorrido nas áreas de pico do clorofenol pode ser devido `a diluição favorecida pela maior precipitação na campanha de Fevereiro e pode ser observado na Figura 5.26.

O composto PCP também esteve presente nas amostras das campanhas de Novembro, nas três profundidades, e em Fevereiro, sendo que a maior área de PCP encontrada nos cromatogramas foi nessa última campanha, igual a 937975. Não se pode considerar esse valor como conclusivo, visto que foi encontrado em apenas uma das amostras das triplicatas realizadas.

O material em suspensão orgânico predominou em todas as camadas da campanha de Novembro, como pode ser visto na Figura 5.27. Esse valor era esperado, visto que, dentre as campanhas, o tempo de residência de Novembro foi o maior, permitindo uma maior deposição de material. Em Fevereiro, houve predominância do material em suspensão inorgânico e do carbono inorgânico devido, principalmente, ao aporte de material carreado pelas chuvas. Estas últimas considerações sobre material em suspensão são observadas na análise das Figuras 5.24 e 5.25. Na campanha de Novembro, o elevado número de macrófitas e também o florescimento de algas, foram verificados também em toda extensão do reservatório, o que não ocorreu na campanha de Fevereiro. 


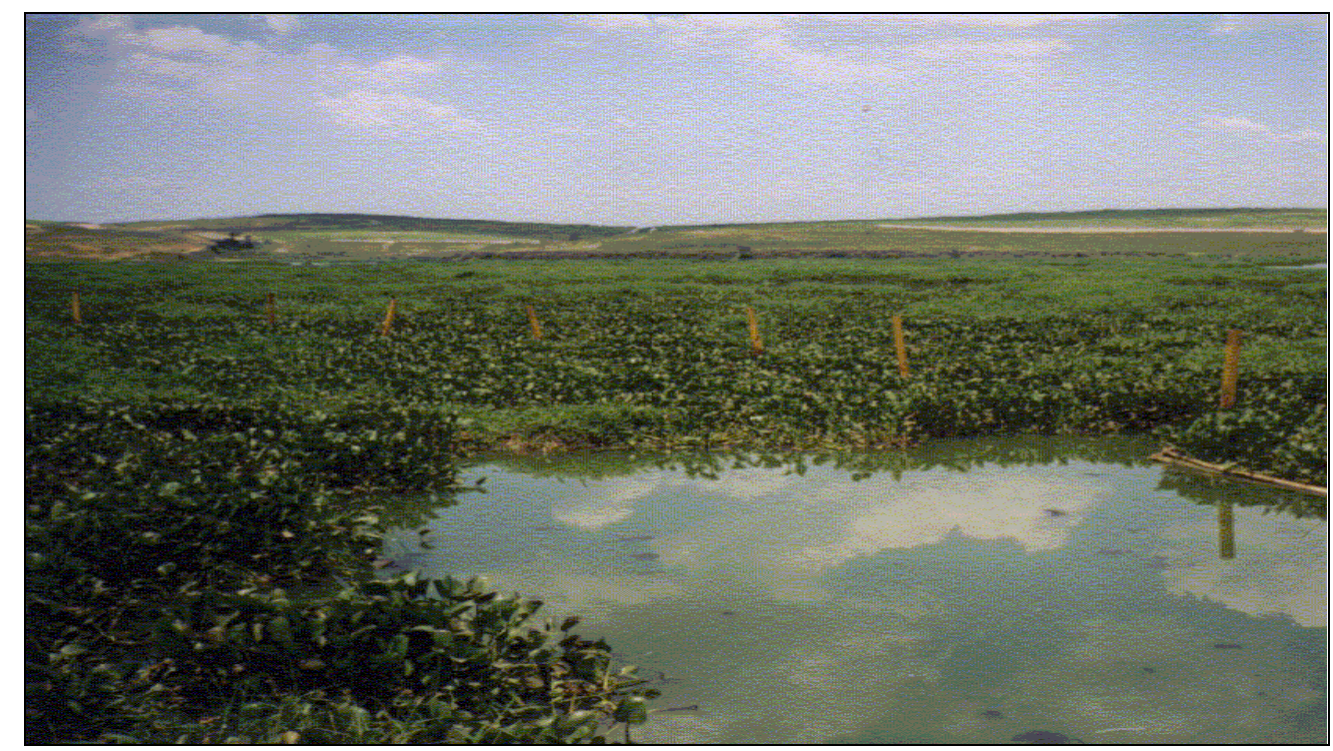

FIGURA 5.24 - VISTA PARCIAL DO PONTO DE SAÍDA DOS BARCOS PARA AS COLETAS, COLETA DE NOVEMBRO DE 1998.

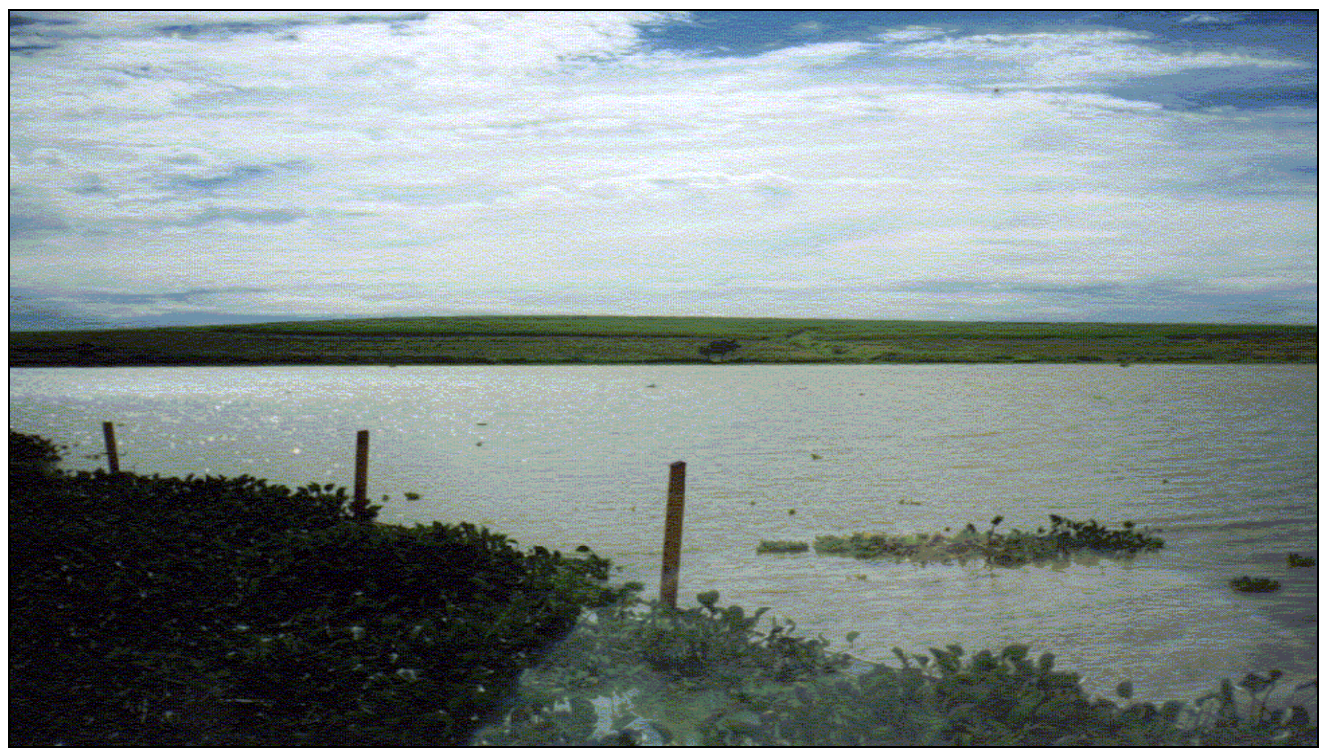

FIGURA 5.25 - VISTA PARCIAL DO PONTO DE SAÍDA DOS BARCOS PARA AS COLETAS, COLETA DE FEVEREIRO DE 1999.

$\mathrm{Na}$ análise dos sedimentos da campanha de Novembro foi utilizado apenas o método extrativo do ultra-som. Comparando-se os valores de áreas de picos cromatográficos encontrados nessa estação em Novembro e Fevereiro, utilizando-se o ultra-som como método extrativo, não foram encontrados clorofenóis comuns às 2 campanhas. Na campanha de Novembro foram detectados 2,3,4-TCP, em concentração de 0,025 $\mu \mathrm{g} / \mathrm{Kg}$, e PCP, em concentrações inferiores $2,5 \mu \mathrm{g} / \mathrm{Kg}$, e na campanha de Fevereiro, apenas 2,3,6-TCP, também em concentrações inferiores a 2,5 $\mu \mathrm{g} / \mathrm{Kg}$. Estes valores podem ser observados na Figura 
5.27. Os resultados com extração em Soxhlet mostraram que a detecção foi apenas do composto PCP na campanha de Fevereiro.

O carbono total da campanha de Novembro foi $10 \%$ maior que o da campanha de Fevereiro, enquanto que a umidade total foi $12 \%$ menor (Figura 5.29).

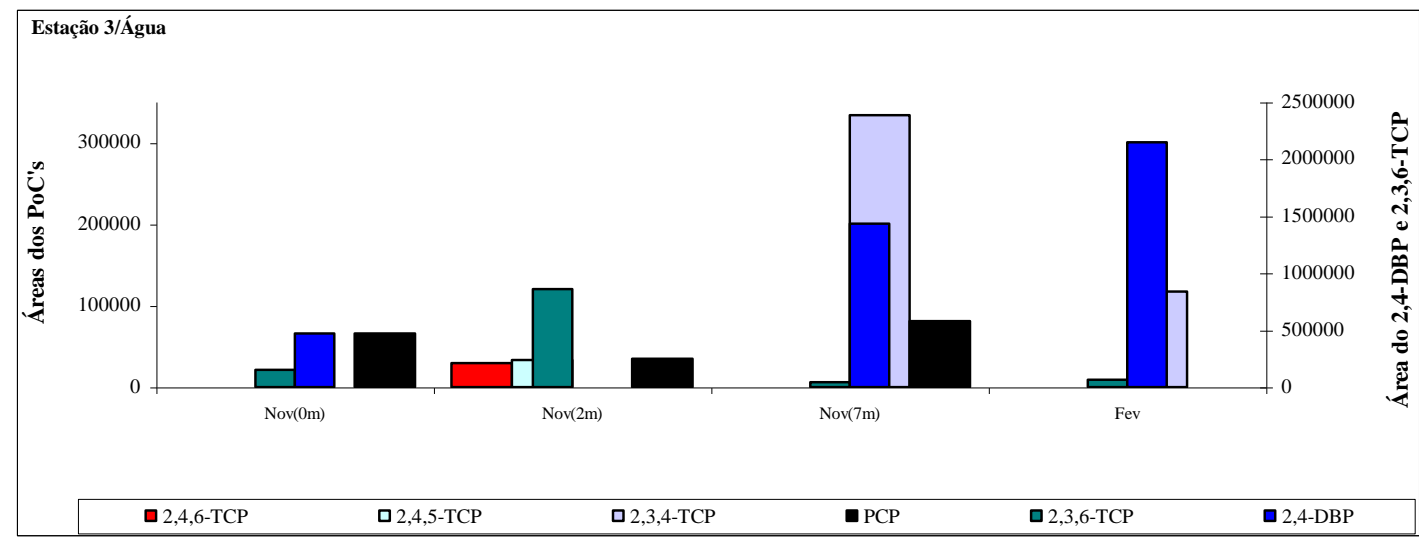

FIGURA 5.26 - VALORES DAS ÁREAS OBTIDAS PELAS ANÁLISES CROMATOGRÁFICAS DAS AMOSTRAS DE ÁGUA DA ESTAÇÃO 3 DE NOVEMBRO/98 E FEVEREIRO/99.
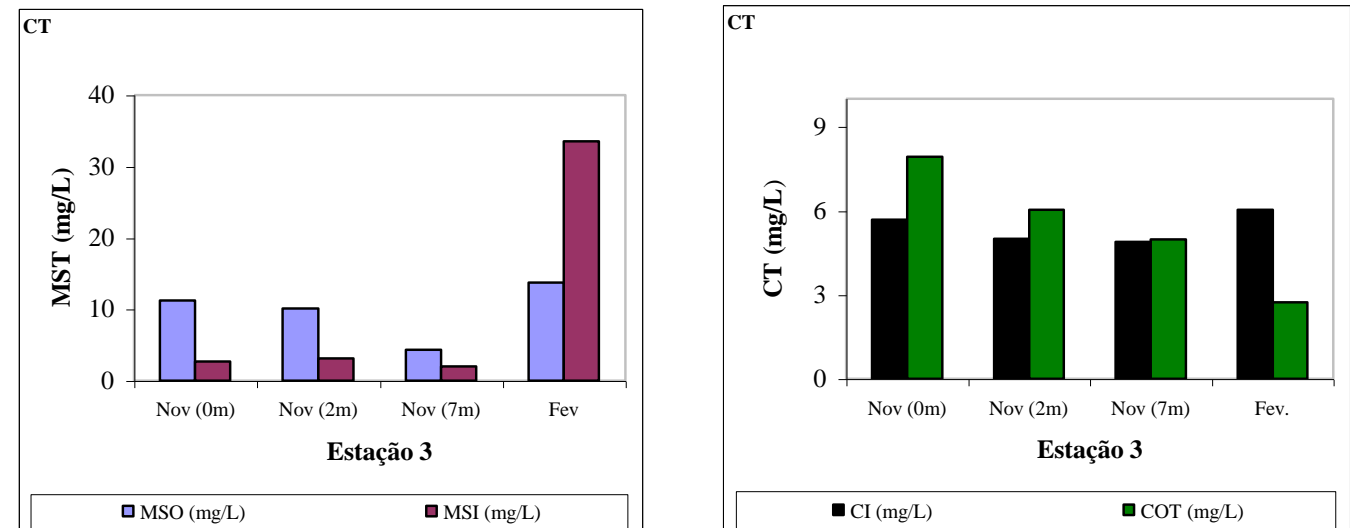

FIGURA 5.27 - VALORES DO MATERIAL EM SUSPENSÃO TOTAL, FRAÇÕES INORGÂNICAS E ORGÂNICAS E CARBONO TOTAL, FRAÇÕES INORGÂNICAS E ORGÂNICAS DAS AMOSTRAS DE ÁGUA DA ESTAÇÃO 3 DE NOVEMBRO/98 E FEVEREIRO/99. 


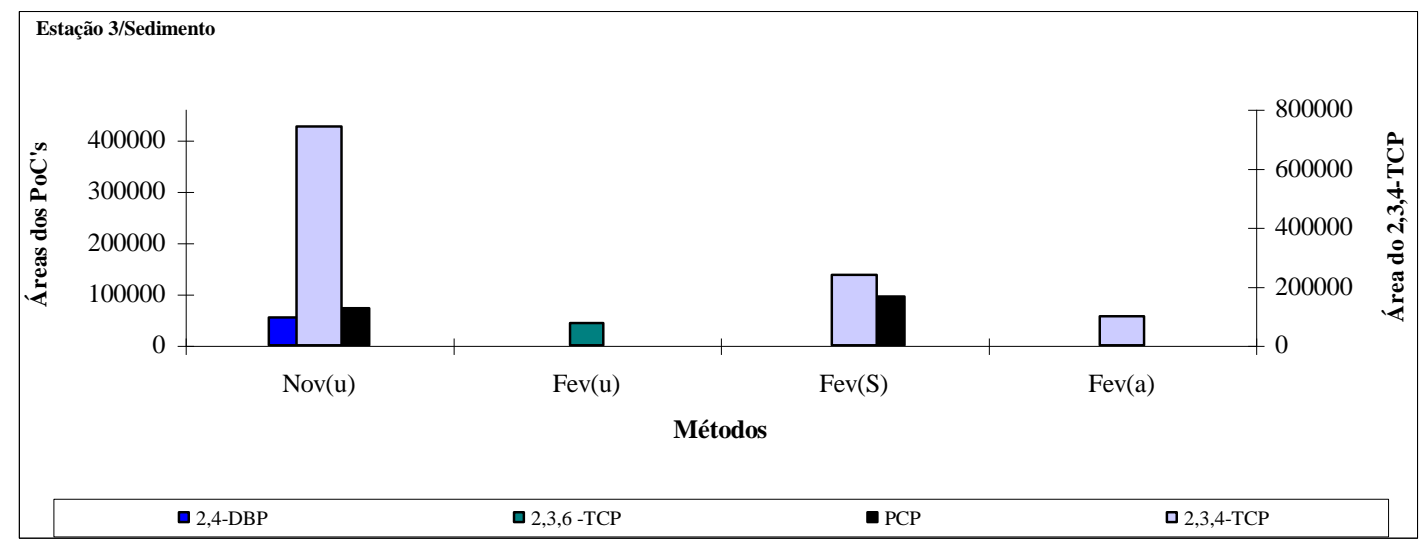

FIGURA 5.28 - VALORES DAS ÁREAS OBTIDAS PELAS ANÁLISES CROMATOGRÁFICAS DAS AMOSTRAS DE SEDIMENTO DA ESTAÇÃO 3 DE NOVEMBRO/98 E FEVEREIRO/99.
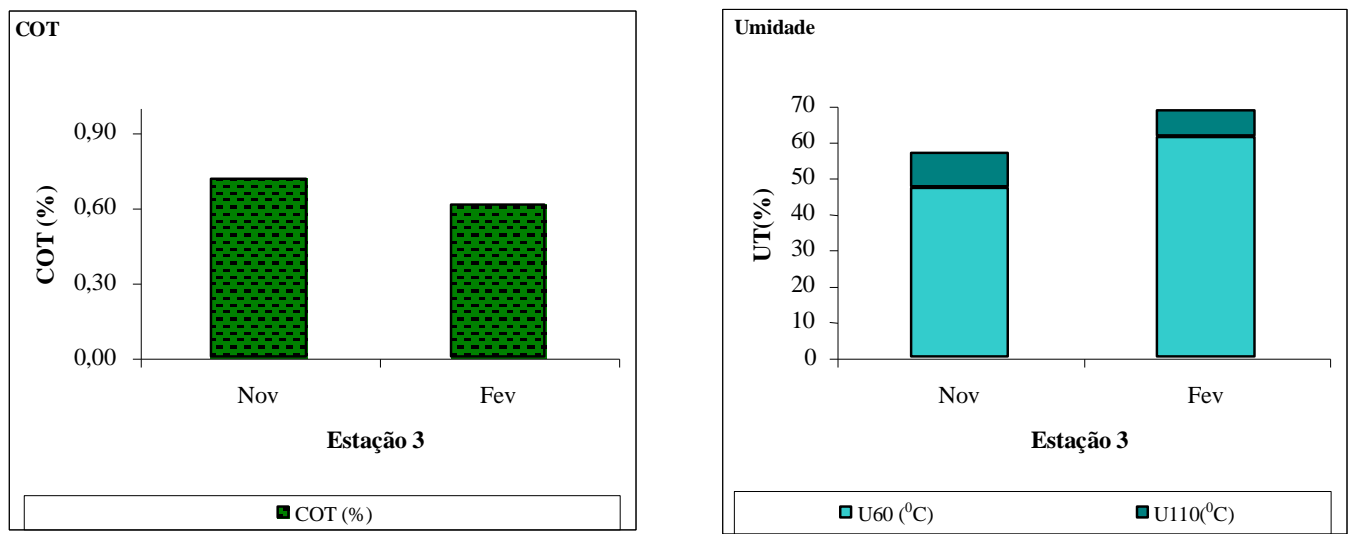

FIGURA 5.29 - VALORES DE CARBONO ORGÂNICO TOTAL E UMIDADE TOTAL A $60^{\circ} \mathrm{C}$ E $110^{\circ} \mathrm{C}$ DAS AMOSTRAS DE SEDIMENTO DA ESTAÇÃO 3, COLETADAS EM NOVEMBRO/98 E FEVEREIRO/99.

Na estação 3, verificou-se que o conteúdo de material em suspensão orgânico predominou em Novembro e o inorgânico em Fevereiro, justificados pelo maior comprimento do dia e conseqüentemente maior biomassa de macrófitas e algas em Novembro e a carga inorgânica elevada em Fevereiro é devido ao aporte de material em conseqüência da intensa precipitação. Na coluna d'água até $10 \mathrm{~m}$, houve estratificação térmica e química apenas na campanha de Novembro, cujas causas podem ser devidas a diversos fatores, como alta radiação (Tabela 5.24), horário em que a coleta foi feita (pico máximo de insolação), baixa precipitação (Tabela 5.26) e provavelmente pela baixa incidência de ventos no dia da coleta (Tabela 5.23), condições essas que possibilitam intensa atividade fotossintética na superfície, degradação da matéria orgânica no fundo e baixa circulação da água. 
Quanto aos clorofenóis encontrados na água, 2,36-TCP, 2,3,4-TCP e PCP foram comuns em ambas as campanhas, sendo que para 2,3,4-TCP houve um decréscimo na concentração de Novembro para Fevereiro possivelmente devido a diluição. Na análise dos sedimentos não houve clorofenóis comuns às duas campanhas.

Os parâmetros físico-químicos medidos nas colunas d'água da estação 3, nas campanhas de Novembro e Fevereiro, estão apresentados na Figura 5.30.
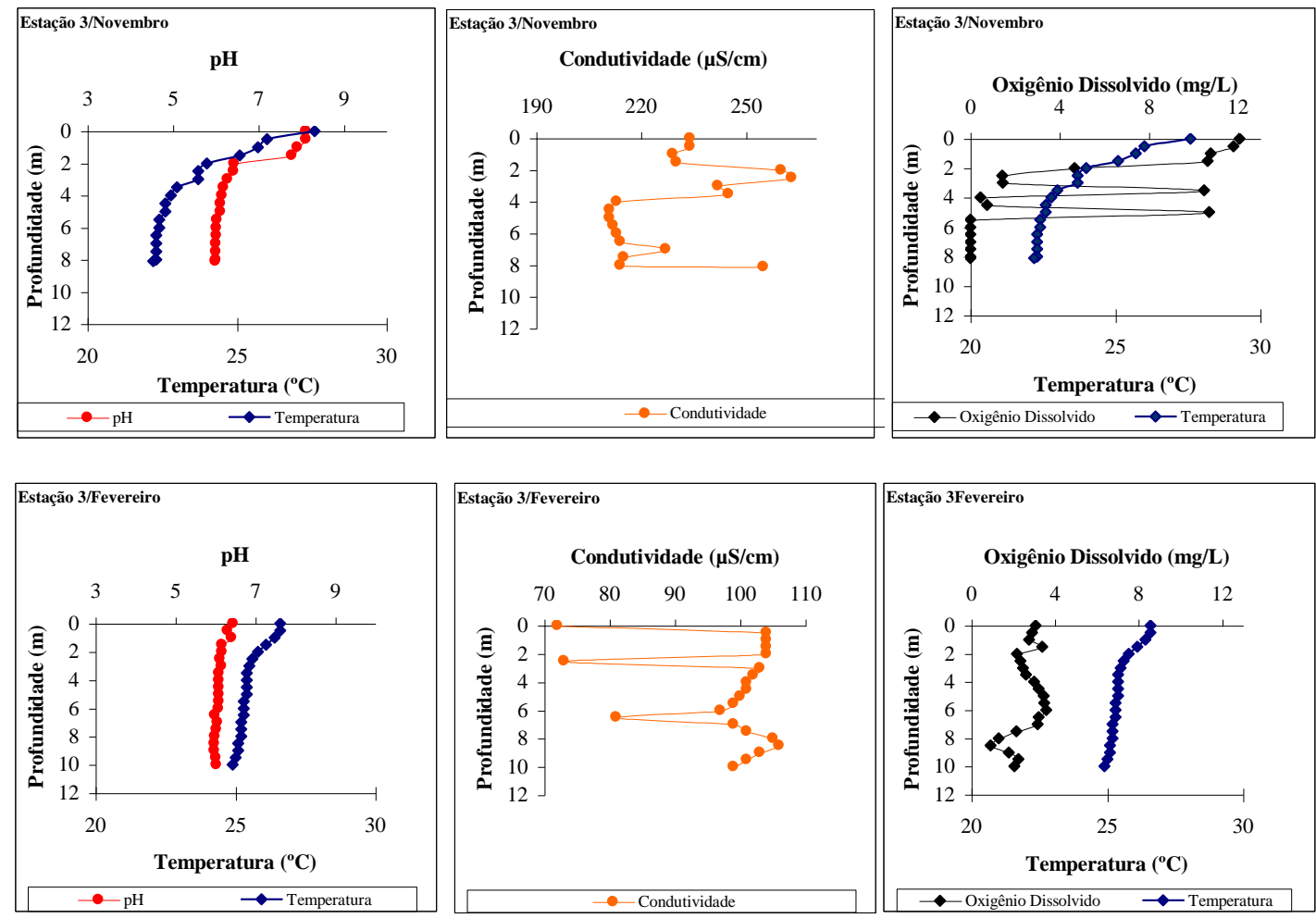

Figura 5.30 - Perfis de pH, temperatura $\left({ }^{\circ} \mathrm{C}\right)$, oxigênio dissolvido $(\mathrm{mg} / \mathrm{L})$, condutividade ( $\mu \mathrm{S} / \mathrm{cm})$ e turbidez, na Estação 3, campanhas de Novembro e Fevereiro

\subsubsection{Estação 4}

Foram feitas coletadas de água nas campanhas de Junho e Novembro de 1998 e Fevereiro de 1999. Para o sedimento foram feitas nessa estação coletas em todas as campanhas. Uma visão da estação está apresentada na Figura 5.31. 


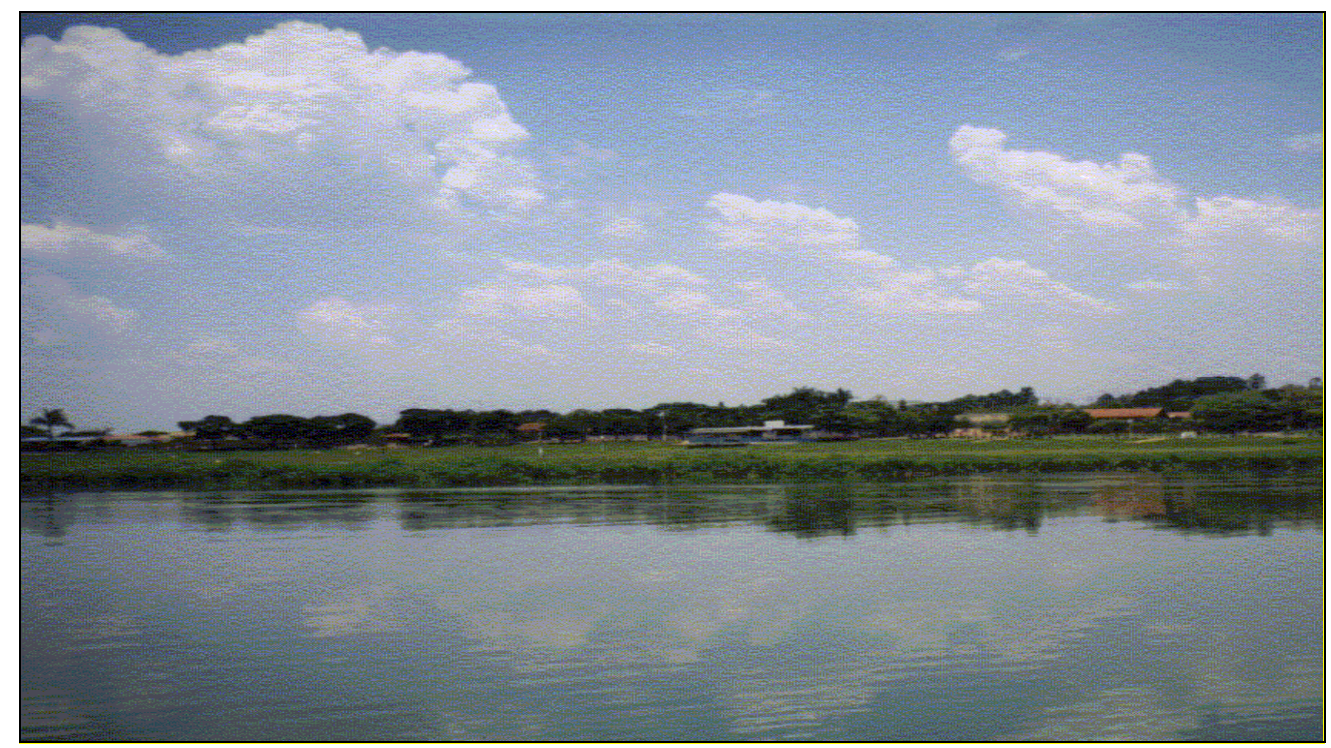

FIGURA 5.31 - VISTA PARCIAL DO ENTORNO DA ESTAÇÃO 4, LOCALIZADA A 22041'58.3'” S; 47'16'38.6" W, CENTRO DO SEGUNDO COMPARTIMENTO, COLETA DE NOVEMBRO DE 1998.

Houve estratificação no reservatório nas campanhas de Novembro e Fevereiro, tendo sido realizadas coletas em 3 profundidades, na superfície, a 8 e $14 \mathrm{~m}$ em Novembro, e na superfície e a 2, 5 e 4 em Fevereiro.

O composto 2,3,6-TCP foi comum a todas as campanhas, estando presente inclusive nas 3 profundidades coletadas em Novembro e em Fevereiro, sempre em concentrações inferiores a $0,010 \mu \mathrm{g} / \mathrm{L}$. Foram registradas maiores áreas de picos nos cromatogramas dos meses de Junho e Novembro na superfície, respectivamente, 1.410 .515 e 1.253.805. Ao contrário do que ocorreu na estação 3, para a campanha de Novembro, quando as maiores áreas dos cromatogramas foram detectadas no fundo, nessa estação a maior área foi registrada na superfície. Em Fevereiro, as áreas dos cromatogramas apresentaram-se como na estação 3, como pode ser observado na Figura 5.32.

A substância PCP também foi encontrada nos cromatogramas em todas as campanhas, em concentrações inferiores a $0,010 \mu \mathrm{g} / \mathrm{L}$, porém não foi detectado na camada inferior do reservatório, tanto na campanha de Novembro, como na superfície do reservatório, na campanha de Fevereiro.

O composto 2,5-DCP somente foi detectado na campanha de Junho, sendo determinadas concentrações de 0,012, 0,016 e inferior a $0,01 \mu \mathrm{g} / \mathrm{L}$ nas amostras da triplicata.

O material em suspensão inorgânico foi maior na superfície do reservatório em Novembro e nas 3 camadas de Fevereiro (superfície, 8 e 14m). Na camada inferior do reservatório, na campanha de Novembro, a 4m, o material em suspensão orgânico foi 
aproximadamente igual ao material inorgânico (Figura 5.33). Em Novembro, o carbono inorgânico foi aproximadamente igual ao inorgânico em todas as camadas (superfície, 8 e 14m) e em Fevereiro, foi maior em todas as camadas (superfície, 2,5 e 4m).

Observando-se os resultados das análises do sedimento, independente do método de extração de clorofenóis empregado, 2,5-DCP, 2,3,6-TCP e 2,4,5-TCP foram registrados em todas as campanhas (Figura 5.34). 2,3,4-TCP só não foi registrado na campanha de Maio. Na campanha de Fevereiro, através da extração por ultra-som não detectou-se nenhum pico de clorofenol, e na campanha de Novembro, apenas detectaram-se os compostos 2,3,4-TCP e o PCP, em concentrações inferiores a $2,50 \mu \mathrm{g} / \mathrm{Kg}$. Nas campanhas de Maio e Junho registraram-se diferentes áreas de clorofenóis, apresentando os seguintes compostos em comum: 2,5-DCP, 2,4,6-TCP, 2,3,6-TCP e 2,3,4-TCP, em concentrações inferiores a 2,50 $\mu \mathrm{g} / \mathrm{Kg}$. Nas extrações com o Soxhlet feitas em Junho, Novembro e Fevereiro, os compostos 2,4,6-TCP e PCP foram detectados. Através do método de extração com agitação, empregado nas mesmas campanhas, além de 2,4,6-TCP e de PCP, foi detectado também 2,3,6-TCP.

O teor de carbono total da campanha de Novembro foi $1 \%$ maior que o teor de Fevereiro. Enquanto a umidade total de Fevereiro foi aproximadamente 19\% maior que a de Novembro, provavelmente devido à elevada precipitação na última campanha (Figura 5.35).

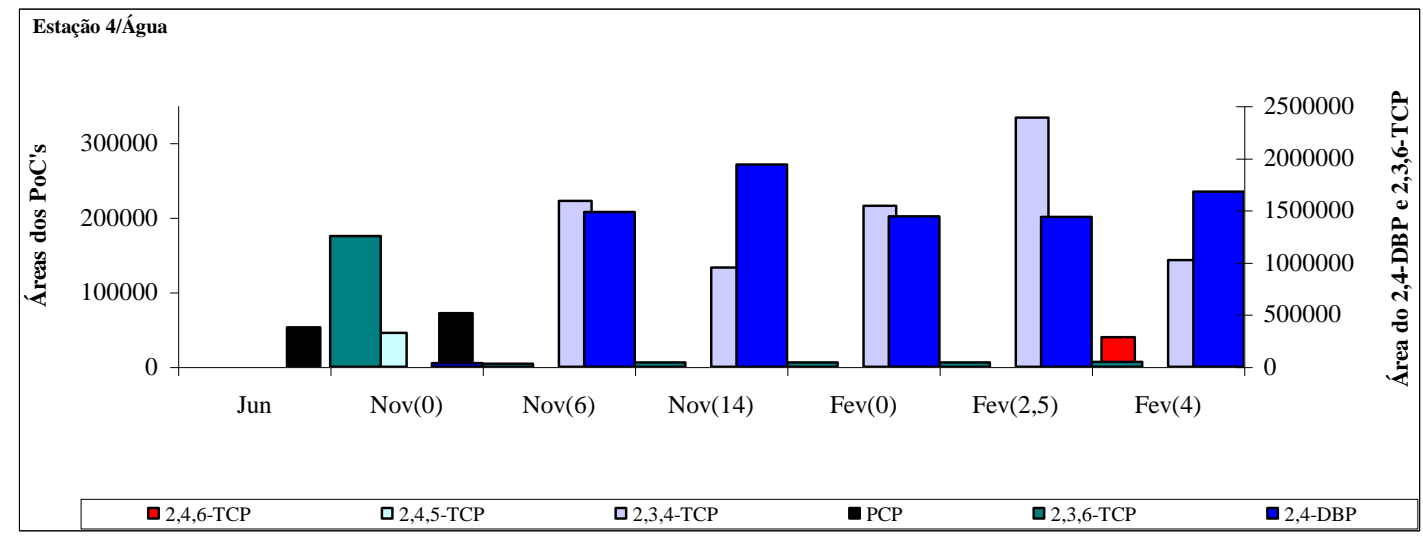

FIGURA 5.32 - VALORES DAS ÁREAS OBTIDAS PELAS ANÁLISES CROMATOGRÁFICAS DAS AMOSTRAS DE ÁGUA DA ESTAÇÃO 4, COLETADAS EM MAIO, JUNHO E NOVEMBRO/98 E FEVEREIRO/99. 

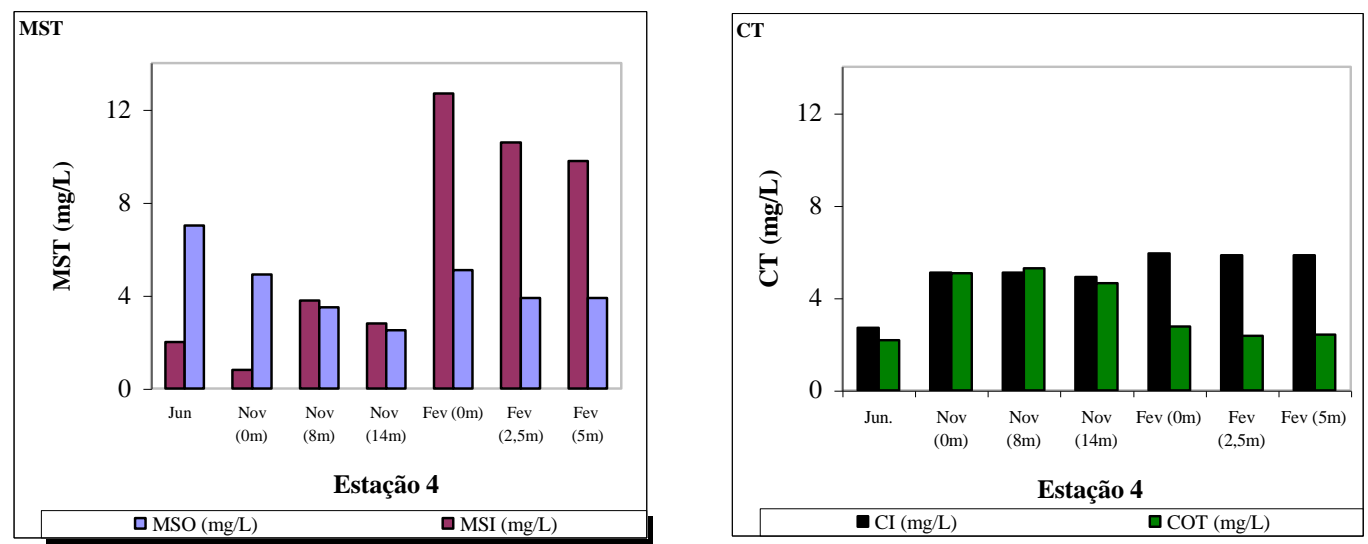

Figura 5.33 - Valores do material em suspensão total, frações inorgânicas e orgânicas e carbono total, frações inorgânicas e orgânicas, das amostras de água da estação 4, coletadas em Maio, Junho e Novembro/98 e Fevereiro/99.

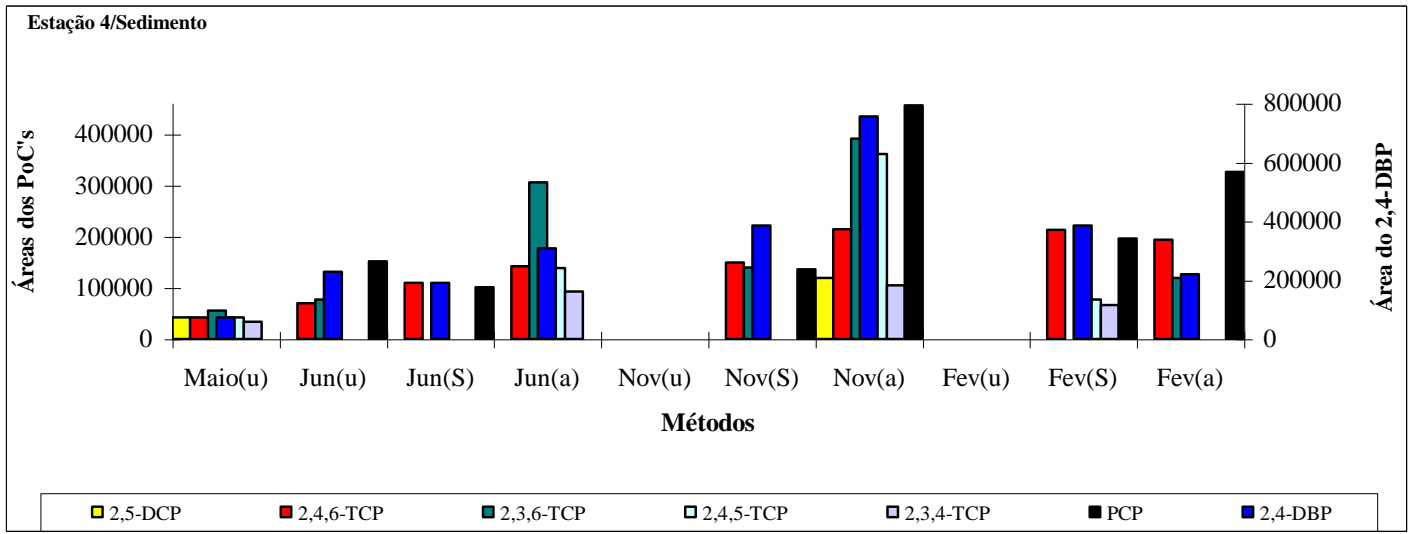

FIGURA 5.34 - VALORES DAS ÁREAS OBTIDAS PELAS ANÁLISES CROMATOGRÁFICAS DAS AMOSTRAS DE SEDIMENTO DA ESTAÇÃO 4, COLETADAS EM MAIO, JUNHO E NOVEMBRO/98.
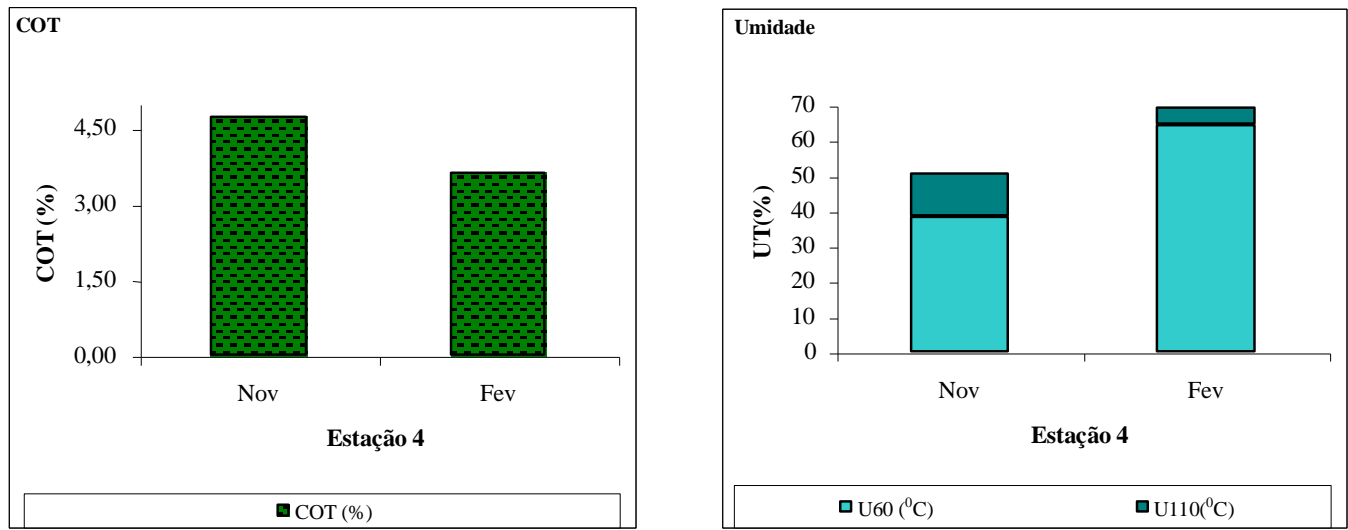
FIGURA 5.35 - VALORES DE CARBONO ORGÂNICO TOTAL E UMIDADE TOTAL A $60^{\circ} \mathrm{C}$ E $110^{\circ} \mathrm{C}$ DAS AMOSTRAS DE SEDIMENTO DA ESTAÇÃO 4, COLETADAS EM MAIO, JUNHO E NOVEMBRO/98 E FEVEREIRO/99.

$\mathrm{Na}$ segunda campanha as análises visaram basicamente a caracterização do reservatório. Nessa estação foram coletadas amostras de água em diferentes profundidades na $3^{\mathrm{a}}$ e $4^{\mathrm{a}}$ campanhas. Em Fevereiro, houve predominância de material inorgânico nas três profundidades coletadas, enquanto em Novembro este conteúdo foi variável, com predomínio do material orgânico na superfície, porém a diferença entre o conteúdo inorgânico e orgânico nas outras camadas não foi considerada significativa. Os valores de condutividade foram reduzidos praticamente à metade, de Novembro a Fevereiro. Uma possível explicação para este fato é a atividade fotossintética e a degradação de matéria orgânica determinada na campanha de Novembro, pelo alto florescimento de algas a grande decomposição de matéria orgânica com consumo de oxigênio.

$\mathrm{Na}$ análise de clorofenóis em amostras de água dessa estação, os compostos 2,3,6TCP e PCP foram comuns a todas as campanhas, em concentrações inferiores a 0,010 $\mu \mathrm{g} / \mathrm{L}$. Para o sedimento, utilizando o método de extração ultra-som, foram comuns as campanhas de Maio, Junho e Fevereiro os compostos 2,3,6-TCP e 2,4,6-TCP, em concentrações inferiores a 2,50 $\mu \mathrm{g} / \mathrm{Kg}$. O composto 2,3,4-TCP foi comum a todas as campanhas apresentando sempre concentrações inferiores a $2,50 \mu \mathrm{g} / \mathrm{Kg}$.

Os parâmetros físico-químicos medidos nas colunas d'água da estação 4, em todas as campanhas, estão apresentados na Figura 5.36. 

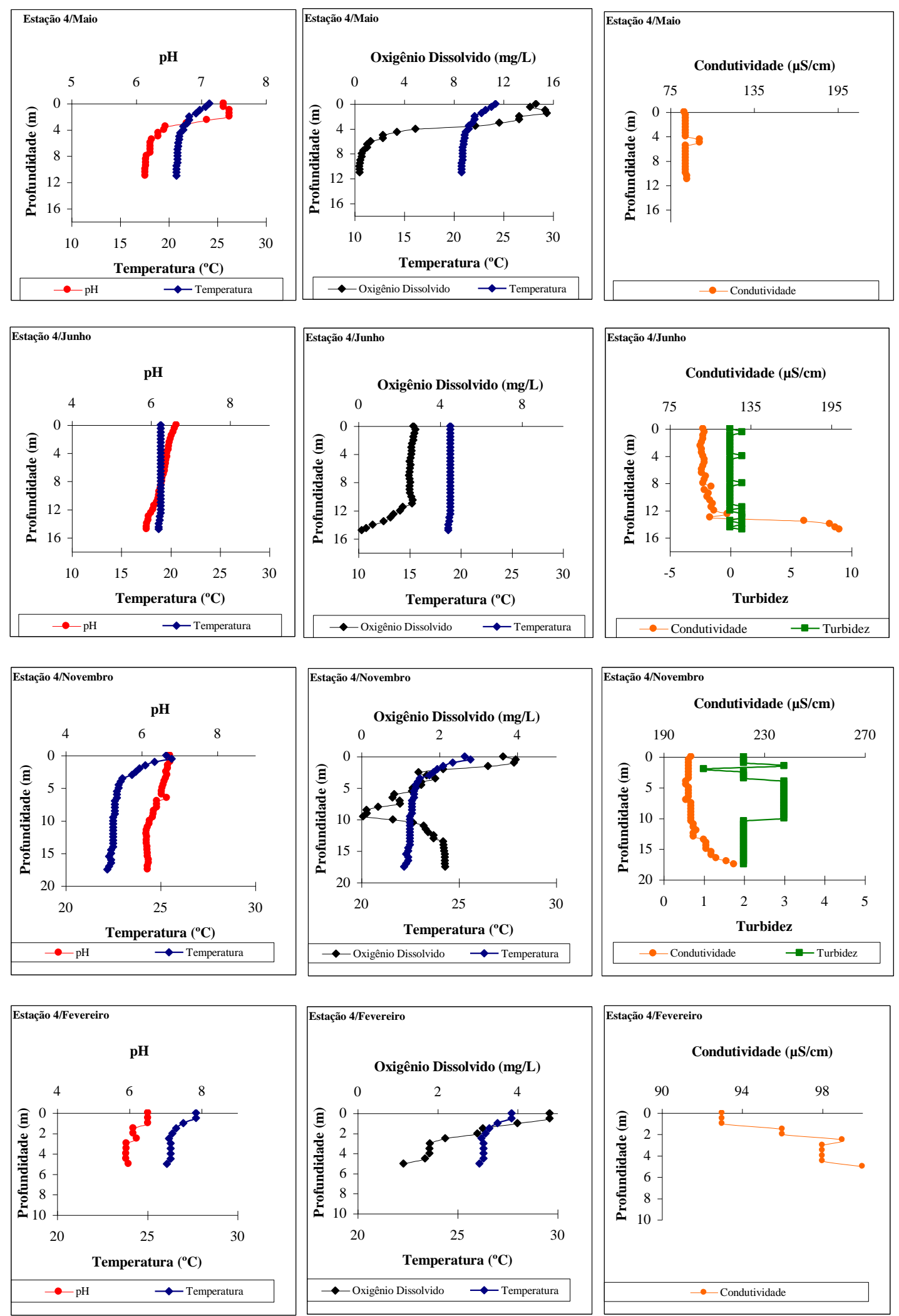

FIGURA 5.36 - PERFIS DE PH, TEMPERATURA $\left({ }^{\circ} \mathrm{C}\right)$, OXIGÊNIO DISSOLVIDO (MG/L), CONDUTIVIDADE ( $\mu$ S/CM) E TURBIDEZ, NA ESTAÇÃO 4, CAMPANHAS DE MAIO, JUNHO, E NOVEMBRO DE 1998 E FEVEREIRO DE 1999. 


\section{CONCLUSÕES E RECOMENDAÇÕES}

Neste trabalho procurou-se caracterizar o reservatório de Salto Grande quanto às concentrações de clorofenóis, verificando-se suas presenças por meio de coletas, extrações e análises cromatográficas, correlacionando parâmetros físico-químicos, hidráulicos e morfométricos, bem como, buscando na literatura dados que indicassem o lançamento desses compostos no rio Atibaia. Dessa forma, as conclusões são apresentadas, primeiramente considerando as condições do reservatório por campanha, através dos resultados obtidos de todos os parâmetros analisados, bem como os clorofenóis detectados em cada campanha. Posteriormente, são colocadas as conclusões referentes às técnicas experimentais e, para finalizar esse capítulo, são relacionadas as recomendações.

\section{Condições do reservatório entre os meses de Maio de 1998 a Fevereiro de 1999:}

$\mathrm{Na} 1^{\text {a }}$ campanha, em Maio de 1998, verificou-se estratificação química e térmica na estação 4, a primeira possivelmente condicionada pela segunda, devido a fatores como: ausência de aporte de oxigênio para as camadas de água mais profundas, pela ausência de períodos de circulação completa; sendo a velocidade dos ventos as menores observadas durante o período de estudo; maior tempo de residência da água, característico de estação seca, e em decorrência disto há um maior tempo para sedimentação e conseqüentemente acúmulo de matéria orgânica nas camadas mais profundas. $\mathrm{Na}$ estação 2 predominou material inorgânico, possivelmente pelo aporte do rio Atibaia, visto que essa estação sofre grande 
influência do mesmo. As concentrações de clorofenóis encontradas nessa campanha, bem como em todas as demais, estão abaixo do limite máximo exigido pela Portaria 36 (1990) do Diário Oficial da União/Ministério da Saúde, que é de 0,10 $\mu \mathrm{g} / \mathrm{L}$. Entretanto, em todas as campanhas foram encontrados clorofenóis, mesmo que em baixas concentrações. Na estação 2, nas análises cromatográficas, foram detectados 2,5-DCP, em concentração em torno de $0,020 \mu \mathrm{g} / \mathrm{L}$, e 2,4,6-TCP e 2,3,4-TCP, em concentrações inferiores a $0,010 \mu \mathrm{g} / \mathrm{L}$.

$\mathrm{O}$ melhor resultado entre as réplicas foi obtido em amostra que não passou por limpeza, sugerindo que possa ter havido perdas por adsorção à coluna. Outra possível fonte de perdas nas amostras de água dessa estação pode estar relacionada à presença de

emulsão, 
possivelmente devida à presença de material em suspensão, exigindo mais sulfato de sódio na secagem e perdendo-se, provavelmente, parte da amostra. A possibilidade de adsorção em material em suspensão poderia justificar as concentrações relativamente baixas de clorofenóis nas amostras de água. Nos sedimentos não foram verificados clorofenóis na estação 2 , provavelmente pela baixa taxa de sedimentação de material, causada pela sua localização no rio Atibaia, consequentemente com maior fluxo de água. Nos sedimentos da estação 4 foram detectadas três substâncias semelhantes às encontradas na análise da água da estação 2, em áreas também bastante similares: 2,5-DCP; 2,4,6-TCP e 2,4,5-TCP, correspondendo a uma concentração menor que $2,50 \mu \mathrm{g} / \mathrm{Kg}$. Esses valores também podem estar subestimados devido a prováveis perdas na coluna de limpeza.

Na $2^{\text {a }}$ Campanha, em Junho de 1998, as alterações feitas no procedimento para análise da água, como a eliminação da limpeza e a maior acidificação das amostras de água não resultaram em áreas mais similares entre as réplicas. As concentrações de PCP na água sofreram decréscimo da estação 2; concentrações de $0,011 \mu \mathrm{g} / \mathrm{L}$ e, na réplica, concentração inferior a $0,010 \mu \mathrm{g} / \mathrm{L}$; para a 4 , concentrações bem inferiores a $0,01 \mu \mathrm{g} / \mathrm{L}$, possivelmente pela maior velocidade do fluxo da água na estação 2 podendo ter provocado a diluição dos compostos, assim como o $\mathrm{pH}$ menor na estação 4, permitindo sua solubilização no compartimento água, visto que o tempo de residência nessa campanha foi o segundo maior entre as campanhas, e que houve uniformidade entre os parâmetros das duas estações, exceto para $\mathrm{pH}$ e condutividade. Nas amostras de água da estação 4 foram detectados 2,5-DCP, em concentrações de 0,012 $\mu \mathrm{g} / \mathrm{L}, \quad 0,016 \mu \mathrm{g} / \mathrm{L}$, e $0,010 \mu \mathrm{g} / \mathrm{L}$ e 2,3,6-TCP, 2,4,6-TPC e PCP em concentrações inferiores a $0,010 \mu \mathrm{g} / \mathrm{L}$. Em geral, as amostras de sedimento dessa campanha, apresentaram valores de picos de áreas dos cromatogramas inferiores aos das campanhas de Novembro e Fevereiro, e superiores aos determinados nas amostras de Maio, correspondendo a concentrações de PCP menores que 0,50 $\mu \mathrm{g} / \mathrm{Kg}$, e para os demais clorofenóis, menores que $2,50 \mu \mathrm{g} / \mathrm{Kg}$. Provavelmente houve alta adsorção em material em suspensão e, em se tratando de um período com baixo fluxo, maior tempo de residência, a alta taxa de sedimentação fez com que o sedimento apresentasse os mesmos clorofenóis encontrados no compartimento água, 
além de outros que podem ter-se acumulado. Nessa campanha não foram observadas diferenças relevantes entre as 2 estações, como na primeira campanha, provavelmente pelas baixas temperaturas registradas, facilitando a circulação completa da coluna d'água. As velocidades elevadas dos ventos no dia da coleta, também podem ter influenciado na quebra das estratificações química e térmica.

Na campanha de Novembro de 1998, apenas houve estratificação química na $3^{\text {a }}$ estação, provavelmente provocada pela alta taxa de radiação solar e elevada atividade das algas. Nas estações 1 e 2 predominou material inorgânico, provavelmente devido a aportes do rio Atibaia. Na estação 3 predominou o material orgânico, provavelmente devido à presença de macrófitas e algas nesse compartimento, assim como na parte superior da coluna d'água da estação 4 . Os teores de carbono orgânico total dos sedimentos, quando comparados aos encontrados no reservatório do Guarapiranga, também eutrofizado, foram considerados baixos; deve-se considerar que os sedimentos de Salto Grande já foram caracterizados como sendo do tipo mineral. Quanto às análises cromatográficas, a filtração das amostras da $4^{\mathrm{a}}$ estação (profundidades de $8 \mathrm{~m}$ e $14 \mathrm{~m}$ ) e a eliminação das lavagens sucessivas com n-hexano, conduziram a bons resultados, com áreas de pico de cromatogramas similares entre as réplicas. Acredita-se que a falta de reprodutibilidade poderia ser tanto de perdas decorrentes das lavagens, quanto pela adsorção dos clorofenóis no material em suspensão presente. Essa campanha foi a que apresentou amostras com a maior variedade de clorofenóis em todas as estações. O composto 2,3,6-TCP foi constatado em todas as amostras de água, nas quatro estações analisadas nessa campanha, 2,3,4-TCP também esteve presente na maioria das estações, exceto na amostra da estação 3, à profundidade de $2 \mathrm{~m}$, e na amostra de superfície da estação 4, o composto PCP esteve presente em todas as estações, exceto na profundidade de $14 \mathrm{~m}$ da estação 4 . Todas as áreas de picos dos cromatogramas obtidas nas análises das amostras de água corresponderam a concentrações inferiores a $0,010 \mu \mathrm{g} / \mathrm{L}$. Nas amostras de sedimento, a distribuição dos clorofenóis entre as estações foi mais irregular, possivelmente devida às altas taxas de sedimentação, diferenciadas nos diversos compartimentos estudados. Deve-se 
considerar também a velocidade diferenciada do fluxo em direção à barragem. Somente o composto 2,3,4-TCP foi encontrado em todas as estações dessa campanha, possivelmente devido à alta taxa de deposição de material em suspensão nessa época, provocada pelo elevado tempo de residência, cerca de 102 dias, permitindo a remoção dos compostos por mecanismos, como adsorção, volatilização, fotólise ou degradação microbiológica. Nas estações 1 e 4, foi encontrada uma maior variedade de clorofenóis em concentrações menores que $2,50 \mu \mathrm{g} / \mathrm{Kg}$. Nas estações 2 e 3, a variedade de clorofenóis encontrada foi bem menor, estando presentes PCP, em concentrações inferiores a $0,50 \mu \mathrm{g} / \mathrm{Kg}$, e 2,3,4-TCP, em concentrações menores que $2,50 \mu \mathrm{g} / \mathrm{Kg}$.

$\mathrm{Na} 4^{\mathrm{a}}$ Campanha, em Fevereiro de 1999, a concentração de oxigênio foi baixa. A elevada precipitação nessa campanha pode ter influído no predomínio de carbono inorgânico encontrado, possivelmente pelo aporte de material carreado pela chuva e pela baixa taxa de residência da água. Comparando-se as respostas encontradas nas análises de amostras de sedimentos e de água, diferentes tipos de clorofenóis foram encontrados nas estações 2 e 4, entrada e saída do reservatório, sendo bastante similares em ambas as amostras, provavelmente pelo alto fluxo da água e baixo tempo de residência da água. Os compostos 2,3,4-TCP e PCP foram encontrados em todas as estações, em concentrações inferiores a 0,010 $\mu \mathrm{g} / \mathrm{L}$. As respostas das estações 3 e 4 foram semelhantes, apresentando sempre os compostos 2,3,4-TCP, 2,3,6-TCP e PCP, em concentrações inferiores a 0,010 $\mu \mathrm{g} / \mathrm{L}$. Em amostras de sedimento, o 2,3,6-TCP esteve presente nas estações 1,2 e 3 . As concentrações determinadas de PCP foram menores que $0,50 \mu \mathrm{g} / \mathrm{kg}$, e para os demais clorofenóis, inferiores a 2,50 $\mu \mathrm{g} / \mathrm{Kg}$. Como na campanha de Novembro, as estações 1 e 4, em Fevereiro de 1999, apresentaram uma maior variedade de clorofenóis.

\section{Procedimentos utilizados:.}

$\mathrm{Na}$ análise de parâmetros físico-químicos em campo, o instrumento Horiba satisfez plenamente todas as necessidades, sendo os resultados adequados para caracterizar cada estação. Nas demais análises, umidade do sedimento, material em suspensão e carbono total, apenas os resultados desta última foram questionáveis, visto que as amostras foram filtradas em campo, analisando-se dessa forma, o carbono orgânico dissolvido. $\mathrm{O}$ ideal seria que 
fossem feitas analisando todo o carbono orgânico presente na amostra, sem eliminar o carbono orgânico particulado.

Para a extração de clorofenóis da água, durante o trabalho, foram feitas alterações que se mostraram eficientes, como a acidificação, a eliminação de lavagens sucessivas com o solvente e a filtração das amostras. A acidificação, além de ter grande importância na preservação das amostras de água, também mostrou ser importante na análise de clorofenóis. A filtração permitiu, juntamente com a eliminação de lavagens sucessivas com n-hexano, que as áreas de picos cromatográficos obtidas entre as réplicas fossem bastante similares, eliminando também a formação de emulsão.

Foram feitos vários testes para análise de sedimentos, alterando-se desde a forma de extração, composição e volume de solvente, quantidade de amostra, diferentes colunas de limpeza e diferentes eluentes. Nos procedimentos de extração testados, considerando-se os testes iniciais com Soxhlet, não se obteve reprodutibilidade em nenhuma das amostras, ou seja, amostras do mesmo ponto, extraídas da mesma forma, apresentaram variações qualitativas e quantitativas de clorofenóis. Provavelmente o tempo de extração e o uso do Soxhlet tenham sido subdimensionados, para a natureza do sedimento testado. Outro procedimento testado foi a agitação com barra magnética. Por esse procedimento houve boa extração dos clorofenóis, sendo que amostra acidificada apresentou melhores resultados; as áreas encontradas para PCP foram bastante consideráveis e muito superiores àquelas encontradas em todos os testes com o Soxhlet. Entretanto, o método foi considerado pouco prático devido às sucessivas lavagens com o solvente n-hexano e necessidade de separação em funil. A extração por ultra-som foi outro procedimento testado e escolhido para as análises das amostras de Salto Grande. Comparado aos demais procedimentos, apresentou boa capacidade de extração, e valores de áreas reprodutíveis, além de ser mais simples e rápido. Os melhores resultados foram obtidos utilizando-se 20 gramas de amostra, $25 \mathrm{~mL}$ de solução de n-hexano/acetona 4:1, coluna de sílica $(3,0 \mathrm{~cm})$ e solução de n-hexano acetona 3:1 como eluente, além das amostras acidificadas terem apresentado melhores resultados do que as não acidificadas e as alcalinilizadas.

Provavelmente, se a quantidade de amostra utilizada na extração fosse aumentada e fossem eliminados os procedimentos de limpeza, maiores concentrações seriam obtidas e até possibilitaria identificação com detector de massas.

Neste trabalho pôde-se perceber que, para a identificação de substâncias químicas em amostras ambientais, o procedimento ideal a ser tomado seria aquele que visasse uma 
perfeita sintonia entre o trabalho feito no campo e aquele feito em laboratório, permitindo que as amostras coletadas fossem analisadas no mais curto período de tempo possível. Entretanto, os cuidados tomados, como a refrigeração e acidificação das amostras de água no campo, permanecendo sob baixas temperaturas em laboratório $\left(4^{0} \mathrm{C}\right)$, a refrigeração das amostras de sedimentos no campo com posterior congelamento em laboratório, caracterizaram-se como procedimentos efetivos para manutenção da amostras antes da extração, consistindo em prática importante para minimizar a degradação química e microbiana dos clorofenóis.

\section{Recomendações:}

Quando trabalha-se com a identificação e quantificação de poluentes, em amostras ambientais, além de todos os cuidados recomendados neste trabalho, mesmo com todos os parâmetros analisados, o ideal é que fosse feito um monitoramento da área, caracterizando todos os possíveis interferentes, como matéria orgânica, material em suspensão, lançamento de efluentes, dentre outros, para determinar a rota dos poluentes nessas amostras, bem como sua remoção por adsorção, fotólise ou degradação microbiológica.

Quanto às análises cromatográficas, seria desejável que as amostras fossem analisadas com metodologia por adição de padrão, através do qual, amostras originais e dopadas com concentrações conhecidas de padrões são injetadas seqüencialmente, permitindo a obtenção de resultados muito mais próximos dos reais. Este procedimento, além de quantificar mais adequadamente os clorofenóis presentes, também serve como alternativa a alguns procedimentos de limpeza, visto que há perdas consideráveis de substâncias nas colunas. 


\section{REFERÊNCIAS BIBLIOGRÁFICAS}

ACPO (2000). Associação de contaminados por organoclorados. http:// sites.uol.com.Br/acpo94/.

AGOSTINHO, A. A.; GOMES, L. C. (1997). Reservatório de Segredo: bases ecológicas para o manejo. Maringá, Eduem,. Cap. 2, p. 19-34; Cap. 3, p. 91-147.

AIROLDI, F. P. S. (1997). Determinação de pentaclorofenol e hexaclorobenzeno em solo contaminado por resíduos industriais. São Carlos. 60p. Dissertação (Mestrado) Instituto de Química de São Carlos/ Escola de Engenharia de São Carlos, Universidade de São Paulo.

ALONSO, M.C.; PUIG, D.; SILGONER, F.; GRASSERBAUER, M. \& BARCELÓ, D. (1998). Determination of priority phenolic compounds in soil samples by various extraction methods followed by liquid chromatography-atmospheric pressure chemical ionization mass spectrometry. Journal of Chromatography A, v. 823, n.1-2, p. 231-39, out.

BELTRAN, J.; LÓPEZ, F.J.; HERNÁNDEZ, F. (1993). Solid-phase extraction of pesticide residues from ground water: comparison between extraction cartridges and extraction discs. Analyctica chemical Acta, v.283, p.297-303.

BITAR, A. L. (1998). Fluxo de nitrogênio e seu uso por duas macrófitas aquáticas (Eichhornia crassipes e Pistia stratiotes), no reservatório de Salto Grande (Americana SP). São Carlos/SP, 1997. 97p. Dissertação (Mestrado) - Escola de Engenharia de São Carlos, Universidade de São Paulo.

BOTTURA, G. (1998). - A compreensão das formas de relação da população com o meioambiente. Estudo de caso no Reservatório de Salto Grande (Americana - SP). São Carlos/SP, 1998. 122p. Dissertação (Mestrado) - Escola de Engenharia de São Carlos, Universidade de São Paulo. 
BRANCO, S. M. (1986). Efeitos Biológicos da Poluição. 3.ed. In: BRANCO, S. M.. Hidrobiologia aplicada à Engenharia Sanitária. São Paulo : CETESB/ASCETESB. Cap. 8, p.317- 356 .

BRANCO, S. M. (1999). Água, meio ambiente e saúde. In: TUNDISI, J.G.; TUNDISIMATSUMURA, T.; ROCHA, O. Águas doces no Brasil. Cap. 7, p. 227-247.

BRANCO, S. M.; ROCHA, A. A. (1977). Poluição, Proteção e Usos Múltiplos de Represas. São Paulo, CETESB/ Editora Edgard Blücher Ltda.

BRUCKMEIER, B.F.A.; JUTTNER, I.; SCHRAMM, K-W.; WINKLER, R.; STEINBERG, C.E.W.; KETTRUP, A. (1997). PCBs e PCDD/Fs em sedimentos de lagos de Grober Arbersee, Floresta Da Bavária e sul da Alemanha. Environmental Pollution, v.95, n.1, p. $19-25$.

BRUNER, F. (1993) Gas chromatographic environmental analysis: principles, techniques, instrumentation. Urbino, Vch.

CALHEIROS, D. F. (1993) Ecotoxicologia de compostos organoclorados persistentes em um ecossistema eutrófico : Represa de Barra Bonita (Médio Tietê - SP). São Carlos. 198p. Dissertação (Mestrado) - Escola de Engenharia de São Carlos, Universidade de São Paulo.

CALIJURI, M.C. et al. (1997) Bases limnológicas e Ecológicas para o Manejo da Qualidade da Água e usos múltiplos do reservatório de Salto Grande (SP). Projeto apresentado ao CNPq.

CETESB - COMPANHIA DE TECNOLOGIA DE SANEAMENTO AMBIENTAL (1998)

- Caracterização de Águas: critérios, interpretação e alternativas para a seleção de parâmetros físico-químicos. Fenóis. Relatório 023/80/GAQ.

CETESB - COMPANHIA DE TECNOLOGIA DE SANEAMENTO AMBIENTAL (1999)

- Bacia do rio Atibaia. Watershed Management 2000 - Aprimoramento da Gestão ambiental dos recursos hídricos do estado de São Paulo Relatório técnico preliminar, julho de 1999.

CHAU, A. S. Y.; AFGHAN, B. K. (1982) Analysis of pesticides in water. V.1 Significance, Principles, Techniques, and Chemistry of Pesticides. Canada, CRC Press. 
CHERONIS, N. D.; ENTRIKIN, J.B. (1963) Identification of organic compounds. USA, Wiley International edition/ John Wiley \& Sons/ Interscience Publishers.

CIAGRI (1999). Dados climatológicos. http://www.ciagri.usp.br/ emdabreu/.

COELHO, M. P. (1993). Análise do Processo de assoreamento do Reservatório de Salto Grande (Americana/SP). Rio Claro. 133p. Dissertação (Mestrado) - Universidade Estadual Paulista / Instituto de Geociências e Ciências Exatas, Campus de Rio Claro.

COLLINS, C.H.; BRAGA, G.L. (1987). Introdução a métodos cromatogragráficos. Campinas, ed. da Unicamp.

CPLA (COORDENADORIA DE PLANEJAMENTO AMBIENTAL) (1994). Bacia do Rio Piracicaba: estabelecimento de metas ambientais e reenquadramento dos corpos d'água. Piracicaba, Secretaria do Meio Ambiente de São Paulo.

CROMPTON, T. R. (1985). Determination of organic substances in water. Great Britain, Wiley Interscience Publication. v.2. Cap.4, p. 314-25.

DAMIANOVIC, M.H.R.Z. (1997). Degradação de pentaclorofenol (PCP) em reatores anaeróbios horizontais de leito fixo. São Carlos. 174p. Tese (Doutorado) - Escola de Engenharia de São Carlos. Universidade de São Paulo.

DEBERDT, G. L. B. (1997). Produção primária e caracterização da comunidade fitoplanctônica no reservatório de Salto Grande (Americana - SP) em duas épocas do ano. São Carlos. 439p. Dissertação (Mestrado) - Escola de Engenharia de São Carlos. Universidade de São Paulo.

DELL'ACQUA, R. C (1983) Gas chromatographic analysis in waste chemistry. In: GROB, R. L. Chromatographic analysis of the environment. 2.ed. USA, Marcel Dekker. Cap.12, p.195-344.

DI CORCIA, A.; BELLIONI, A.; MADBOULY, M. D.; MARCHESE, S. (1996). Trace determination of phenols in natural waters extraction by a new graphitizes carbon black cartridge followed by liquid chromatography and re-analysis after phenol derivatization. Journal of Chromatography A, v.733, p. 383-93.

EAWAG news (1995). Dübendorf, Switzerland, Swiss Federal for Enviromental Science and technology (EAWAG), CH-8600, 37E, p.3-5, Jan. 
ECKENFELDER, W. W. Jr. (1989) Industrial water pollution control 2.ed. Singapore, McGraw-Hill International editions/Civil Engineering Series.

ESTEVES, F. A. (1998). Fundamentos da limnologia. 2. ed. Rio de Janeiro, editoa Interciência, FINEP, 575p.

FAWELL, J. K.; HUNT, S. (1988). Environmental Toxicology: organic pollutants. Great Britain, British Library in Publication Data. Cap.8, p. 196-203.

FIEHN, O.; JEKEL, M. (1997). Analysis of phenolic compounds in industrial wastewater with high-performance liquid chromatography and post-column reaction detection.. Journal of Chromatography A, v.769, p. 189-200.

FOLCH, I.; VAQUERO, M. T.; COMELLAS, L.; BROTO-PUIG, F. (1996). Extraction and clean-up methods for improvement of the chromatographic determination of polychlorinated biphenyls in sewage sludge-amended soils: elimination of lipids and sulphur. Journal of Chromatography A, v.719, p. 121-130.

FONSECA, A. L. (1997). Avaliação da qualidade da água na Bacia do Rio Piracicaba/SP através de testes de toxicidade com invertebrados. São Carlos. 211p. Tese (Doutorado) - Escola de Engenharia de São Carlos, Universidade de São Paulo.

GAO, J. P., MAGUHN, J., SPITZAUER, K, P. A. (1997). Distribution of pesticides in the sediment of the small teufelsweiher pond (Southern Germany).Water Research, v.31, n.11, p. 2811-2919, nov.

GASPAR, I. F.; POLESE, L.; MINELLI, E. V.; RIBEIRO, M. L.; JARDIM, E. F. G. (1997). Determination of Pentachlorophenol in Drinking water. J. Braz. Chem. Soc., v. 8, n.5, $515-518$.

GEISSLER, A.; SCHOLER, H.F. (1994). Gas chromatographic determination of phenol, methylphenols, chlorophenols, nitrophenols and nitroquinones in water at $0.1 \mathrm{~g} \mathrm{l}^{-1}$ Water Research. v. 28, n.10, p. 2047-53, oct.

GIULIANY, B. E. (1983). Gas chromatographic analysis in water pollution. In: GROB, R.

L. Chromatographic analysis of the environment. . 2.ed. USA, Marcel Dekker. Cap.6, p. 195-344. 
GREEN, M.B.; HARTLEY, G.S.; WEST, T.F. (1987). Chemicals for Crop Improvement and Pest Management. 3. ed. USA, Pergamon Press.

GROB, R.L. (1982). Enviromental problem solving using gas and liquid chromatography. 1.ed. Journal of Chromatography Library, v.21. p. 137-165.

GUENZI, W.D.; AHLRICHS, J.L.; CHESTERS, G.; BLOODWORTH, M. E.; NASH, R.G. (1974). Pesticides in soil \& water. Madison, Soil Science Society of America. Cap.16, p.451-538.

GUOLAN, H.; WEIHUA, Z.; ZHIREN, Z. (1996). Separation for positional isomers of Chlorophenols by reverse phase HPLC. J. Liq. Chrom. \& Rel. Technol., v.19, n.6, p.899-909.

HASKELL, P. T. (1985). Pesticide Application: Principles and Practice. New York, Clarendon Press/Oxford. Cap. 8, p.190-201: Environmental Aspects.

HATRÍK, S.; TEKEL, J. (1996). Extraction methodology and chromatography for the determination of residual pesticides in water. Journal of Chromatography A, v.733, p. 217-233.

ISAACSON, P. J.; FRINK, C. R. (1984). Non reversible Sorption of Phenolic Compounds by Sediment Fractions: The Role of Sediment Organic Matter. Environmental Sci. Technol., v. 18, n. 1, p.43-8.

IWATA, H.; TANABE, S..; SAKAI,N.; NISHIMURA, A.; TATSUKAWA, R. (1994) Geographical distribution of persistent organochlorines in air, water and sediments from Asia and Oceania, and their implications for global redistribution from lower latitudes. Environmental Pollution, v. 85, p. 15-33.

JUNG, M.W.; LEE, D.W.; RHEE, J.S.; PAENG, K.J. (1996) On-line preconcentration with solid-phase extraction for the determination of phenol and chlorophenols in aqueous samples by high-performance liquid chromatography. Analytical Sciences, v. 12, p. 98184 , dec.

KEITH, L. H. (1988) Principles of environmental sampling. Washington, American Society/ACS professional reference book. 
KHODADOUST, P.; SUIDAN, M. T., ACHESON, C.M., BRENER, R.C. (1999). Solvent extraction of pentachlorophenol from contamined soils using water-ethanol mixtures. Chemosphere, v.38, n.11, p. 2681-93, may.

KURÁN, P.; SOJÁK L. (1996). Environmental analysis of volatile organic compounds in water and sediment by gas chromatography. Journal of Chromatography A, v.733, p. 119-141.

LANÇAS, F. M. (1993). Cromatografia em fase gasosa. São Carlos, Acta.

LEE, H.B.; CHAU, A. S. Y. (1983). Analysis of Pesticide residues by Chemical Derivatization VII. Chromatographic Properties of Pentafluorobenzyl Ether Derivatives of Thirty-Two Phenols. J. Assoc. Off. Anal. Chem, v. 66, n. 4.

LEE, M. R; YEH, Y. C.; HSIANG, W.S.; HWANG, B. H. (1998). Solid-phase microextraction and gas chromatography mass spectrometry for determining chlorophenols from landfill leaches and soil. Journal of Chromatography A, v.806, n.2, p. 317-324, May.

LEITE, M.A. (1998). Variação espacial e temporal da taxa de sedimentação no Reservatório de Salto Grande (Americana - SP) e sua influência sobre as características limnológicas do sistema. São Carlos. 146p. Dissertação (Mestrado) Escola de Engenharia de São Carlos, Universidade de São Paulo.

LIMA, C. A.; ROMANELLI, M. C. M. (1995) Ocorrência de elevados índices de fenóis nas águas superficiais da sub-bacia do Rio Verde: a investigação como forma de abordagem. In: Anais do IV Encontro Anual da Seção Brasileira da International Association for Impact Assessment - IAIA. Belo Horizonte, 1995. Anais. Belo Horizonte, IAIA, 192-199.

LLOMPART, M.P.; LORENZO, R.A.; CELA, R.; JOCELYN PARÉ, J. R. (1997). Optimization of a Microwave-assisted Extraction Method for phenol and methylphenol isomers in soil samples using a central composite design. Analyst, v. 122, p.133-137, feb. 
LORES, E. M.; EDGERTON, T. R.; MOSEMAN, R. F. (1981). Method for the confirmation of chlorophenols in human urine by LC with and eletrochemical detector. Journal of Chromatographic Science, v. 19, p. $466-469$.

LUKE, M.A. (1975). Extraction and clean upon organochlorine, organophosphate and hidrocarbon pesticides in produce for determination by gas-liquid chromatographic. $J$. of the AOAC.,v.58, n.5, p.1020.

MANAHAM, S. E. (1991). Environmental chemistry. 5.ed. EUA, Lewis Publishers Inc.

MANUAL DE AVALIAÇÃO DE IMPACTOS AMBIENTAIS (1992). Curitiba, Surehma,.

MARTINIS, B. S. (1993). Desenvolvimento de sistemas de extração com fluido supercrítico para a análise de resíduos de pesticidas. São Carlos. 114p. Dissertação (Mestrado) Instituto de Física e Química de São Carlos/Escola de Engenharia de São Carlos, Universidade de São Paulo.

MINOTI, R. T.. (1993). Variação anual da produção primária e estrutura da comunidade fitoplanctônica no reservatório de Salto Grande (Americana - SP). São Carlos. 142p. Dissertação (Mestrado) - Escola de Engenharia de São Carlos, Universidade de São Paulo.

MONTICELI, J. J.; MARTINS, J.P.S. (1993). A luta pela água: nas bacias dos rios Piracicaba e Capivari. 1.ed. Capivari, editora EME.

MOORE, D.W.; DILLON, T.M.; GAMBLE, E.W. (1995). Long-term storage of sediments: implications for sedimen toxicity testing. Environmental Pollution, p. 147-154.

MORAES, A. R. (1999). Estimativa do estoque de elementos químicos em macrófitas aquáticas do Reservatório de Salto Grande (Americana - SP). São Carlos. 90p. Dissertação (Mestrado) - Escola de Engenharia de São Carlos, Universidade de São Paulo.

MORRISON, R. J.; HARRISON, N.; GANGAIYA, P. (1996). Organochlorine contaminants in the estuarine and coastal marine environments of the Fiji Islands. Environmental Pollution, v. 93, n.2, p. $159-167$. 
MUDROCH, A.; MACKNIGHT, S.D. (1991). Handbook of techniques for aquatic sediments sampling. 2.ed. Boca Raton, CRC. Cap. 2, p.6.

MUIR, J.; EDULJEE, G. (1999). PCP in the freshwater and marine environment of the European Union. The Science of the total environmental, v. 236, 1-3, n.15, p.41-56, sept.

NIELSEN., D. M. (1991). Practical handbook of groundwater monitoring. New York, Lewis Publishers, INC.

OUBINA, A.; PUIG, D.; GASCÓN, J.; BARCELÓ, D. (1997). Determination of pentachlorophenol in certified waste waters, soil samples and industrial effluents using ELISA and liquid solid extraction followed by liquid chromatography. Analytical Chemical Acta, v.346, p. 49-59.

PERDUE, E.M.;GJESSING, E. T. (1990). Organic acids in aquatic ecosystem. New York, John Wiley \& Sons.

PERES, R. G. (1997). Extração (LLE, SPE, SFE) e análise cromatográfica de pesticidas organoclorados em água. São Carlos. 107p. Dissertação (Mestrado) - Instituto de Química de São Carlos, Universidade de São Paulo.

PERRIN, D. D.; ARMAREGO, W. L. F.; PERRIN, D. R. (1980). Purification of laboratory chemicals. 2 ed. Vol. 2. Inglaterra, Pergamon Press Ltda. P. 557-559.

PIERCE JR., R. H.; VICTOR, E D. M. (1978). O uso de padrões e destino do pentaclorofenol no ambiente - $O$ destino do pentaclorofenol em um ecossistema aquático. New York and London, Plenum Press, v.12, p.41 - 52.

PINTO, J. V.; YOUNG, T. C.; BOOTY, W.G. (1984). Aquatic sediments. Journal WPCF, v. 56, n. 6, p.780-787, Jun.

RAO, K. R. (1978). Pentachlorophenol: chemistry, pharmacology and environmental toxicology.

RIOS, L. (1993). Estudo limnológico e fatores ecológicos em Ribeirões e Córregos da Bacia hidrográfica do Ribeirão do Feijão (estado de São Paulo). São Carlos. 152p. Dissertação (Mestrado) - Escola de Engenharia de São Carlos, Universidade de São Paulo. 
RIOS, L. (1999). Distribuição espaço-temporal e balanço de massa do fósforo na represa de Salto Grande - Americana (São Paulo). São Carlos. 159p. Tese (Doutorado) - Escola de Engenharia de São Carlos, Universidade de São Paulo.

ROMANINI, P.U. (1989) Distribuição e ecologia alimentar de peixes no reservatório de Americana, SP. São Paulo. v.1. Dissertação (Mestrado) - Instituto de Biociências, Universidade de São Paulo.

SALVADOR, N.N.B. (1990). Avaliação de impactos sobre a qualidade dos recursos hídricos. São Paulo. X págs. Tese (Doutorado) - Escola de Engenharia de São Carlos, Universidade de São Paulo.

SANTOS, F. J.; JÁUREGUI, O.; PINTO, F. J.; AND GALCERAN, M. T. (1998). Experimental design approach for the optimization of supercritical fluid extraction of chlorophenols from polluted soils. Journal of Chromatography A, v. 823, n.9, 1-2, p.249-258, Oct.

SANTSCHI, P. H.; LENHART, J. J.; HONEYMAN, B. D. (1997). Heterogeneous processes affecting trace contaminant distribution in estuaries: The role of natural organic matter. Marine Chemistry, v.58, n.1-2, p. 99-125, Oct.

SAWYER, C. N.; MCCARTY P. L.; PARKIN, G.F. (1994). Chemistry for environmental engineering. 4.ed. McGraw-Hill international editions

SCOPE WORKSHOP ON SOIL AND GROUNDWATER POLLUTION (1994). Soil and Groundwater Pollution: fundamentals, risk assessment and legislation. Cesky Krumlov, Czech Republic, Kluwer Academic Publishers,.

SECRETARIA DO MEIO-AMBIENTE de SÃO PAULO/COORDENADORIA DE PLANEJAMENTO AMBIENTAL-CPLA (1994). Bacia do rio Piracicaba: estabelecimento de metas ambientais e reenquadramento dos corpos d'água. Piracicaba, Centro de editoração Wanda E. S. Barbosa.

SKOOG, D. A.; LEARY, J.J. (1992). Principles of Instrumental Analysis. 4. ed. Philadelphia, Philadelphia Saunders.

SMEWW - Standard Methods for the Examination of Water and Wastewater. (1995). American Public Health Association, American Water Works Association, Water Pollution Control Federation. 11. ed. New York. 
SOJO, L. E.; DJAUHARI, J. (1999). Determination of chlorophenolics in waters by membrane solid-phase extraction: comparison between $\mathrm{C} 18$ and activated carbon membranes and between models of extraction and elution. Journal of Chromatography A, v.840, n.1, p.21-30, Apr.

SPRINGER A. M. (1993). Industrial Environmental Control: pulp and paper industry 2.ed. Tappi Press Atlanta, Georgia USA.

STAN, H. J. (1989). Application of capillary gas chromatography with mass selective detection to pesticide residue analysis, Journal of chromatography, v.467, p.85.

TEIXEIRA, C.; TUNDISI, J. G.; KUTNER, M. B. (1965). Plâncton studies in a mangrove II. The standing-stock and some ecological factors. Bolm. Inst. Oceanogr. V. 24, p. 23-41.

TESAROVÁ, E.; PACÁKOVÁ, V. (1983). Gas and High-Performance Liquid Chromatography of Phenols. Chromatographia, v. 17, n. 5, May .

THAO, V. D.; MASAHIDE, K.; RYO, T. (1993). Persistent organochlorine residues in soils from tropical and sub-tropical Asian countries. Environmental Pollution, v.81, p. 61-71.

TONISSI, F. B. (1999). Avaliação ecotoxicológica do reservatório de Salto Grande, Americana (SP) como subsídio para a análise de qualidade ambiental do sistema. São Paulo. 137p. Dissertação (Mestrado) - Escola de Engenharia de São Carlos, Universidade de São Paulo.

TUNDISI, J.G.; TUNDISI-MATSUMURA, T.; ROCHA, O. (1999). Limnologia de Águas interiores , impactos, conservação e recuperação de ecossistemas aquáticos. In: Águas doces no Brasil. Cap. 6, p. 195-223.

VICINO, J.R.L. (1993). Extração em fase sólida de pesticidas organofosforados e organoclorados de matrizes aquosas. São Paulo. 151p. Dissertação (Mestrado) - Escola de Engenharia de São Carlos, Universidade de São Paulo.

VIDAL, L.H. (1991). Otimização da análise de pesticidas clorados na presença de PCB's em sistemas aquáticos. X págs. São Paulo. Dissertação (Mestrado) - Escola de Engenharia de São Carlos, Universidade de São Paulo. 
WENER S., MORGAN J.J. (1995). .Aquatic Chemistry: chemical equilibria and rates in natural waters. 3.ed. New York, Wiley interscience publication.

ZHI, Z.; RIOS, A.; VALCÁRCEL, M. (1996). Continuous-flow method for the determination of phenols at low levels in water and soil leachates using solid-phase extraction for simultaneous preconcentration and separation. Analyst, vol. 121, p.1-6, Jan.

ZUIN V. G. (1997). Determinação de pentaclorofenol e hexaclorobenzeno em águas naturais de subsuperfície de áreas afetadas por resíduos de organoclorados. São Carlos. 66p. Dissertação (Mestrado) - Instituto de Química de São Carlos, Universidade de São Paulo. 
TABela A.1. Procedimentos DE EXTRAÇão COM SOXHLET E RESPOSTA ANALíTICA, ATRAVÉS DA CROMATOGRAFIA GASOSA

Teste 1 - Volume do solvente e tempo de extração

\section{Amostra: Sedimento da Represa do Lobo \\ Quantidade de amostra: $5 \mathrm{~g}$ \\ Dopagem: $100 \mu \mathrm{L}$ de solução de Clorofenóis $(1 \mathrm{mg} / \mathrm{L})$}

Obs.: (a) Além do n-hexano, testou-se a utilização da acetona como solvente, porém a amostra ficou muito densa após a concentração em

rotaevaporador; (b) (*) não houve refluxo nesse período porque o volume de solvente utilizado foi insuficiente; (c) as amostras 1 A e 1B são

duplicatas, assim como as amostras $2 \mathrm{~A}$ e $2 \mathrm{~B}$.

Conclusões: Aumentamos o volume de $200 \mathrm{~mL}$ de Hexano para $300 \mathrm{~mL}$ e houve refluxo, porém, o método não atingiu a capacidade extrativa esperada

\begin{tabular}{|c|c|c|c|}
\hline Amostra & Tempo de Extração & Volume de Solvente & 2,3,5-TCP \\
\hline $1 \mathrm{~A}$ & \multirow[t]{2}{*}{3 horas $(*)$} & \multirow[t]{2}{*}{$200 \mathrm{~mL}$ de Hexano } & 71990 \\
\hline $1 \mathrm{~B}$ & & & 100446 \\
\hline $2 \mathrm{~A}$ & \multirow[t]{2}{*}{6 horas } & \multirow[t]{2}{*}{$300 \mathrm{~mL}$ de Hexano } & 84053 \\
\hline $2 \mathrm{~B}$ & & & n.d.* \\
\hline
\end{tabular}

Obs.: * n.d. - não determinado 
TABElA A.2. PROCEDIMENTOS DE EXTRAÇÃO COM SOXHLET E RESPOSTA ANALÍTICA, ATRAVÉS DA CROMATOGRAFIA GASOSA

Teste 2 - Limpeza das amostras

Amostra: Sedimento de Salto Grande/Estação 2 (perfil 1)/Maio

Quantidade de amostra: $5 \mathrm{~g}$

Dopagem: Não houve dopagem com solução de clorofenóis e também não houve dopagem com padrão interno (2,4 -DBP)

Solvente: $250 \mathrm{~mL}$ de n-hexano

Tempo de extração: 6 horas

Eluente para limpeza nas colunas: $10 \mathrm{~mL}$ de solução de hexano /acetona 3:1 e $10 \mathrm{~mL}$ de solução de hexano /acetona 2:1

Obs.:(a) a amostra foi peneirada para retirada de partículas grosseiras e centrifugada para retirar o excesso de água; (b) como as amostras ficaram muito amareladas, e de acordo com a literatura (PERRIN et al., 1980), resolveu-se testar métodos para limpeza das amostras; (c) as colunas eram previamente umedecidas com n-hexano, após o que fazia-se passar um volume de 1 mL da amostra; o volume era recolhido, denominado descarte e analisado separadamente; em seguida, passava-se pela coluna os eluentes, sendo recolhidos em um frasco; (d) em cada quadro da tabela, o primeiro número representa a amostra e o segundo o número representa a área do descarte.

Conclusões: A resposta para a coluna de sílica $3 \mathrm{~cm}$, na segunda amostra, foi consideravelmente maior que a resposta para o Florisil (3 cm), porém, não houve reprodutibilidade. 


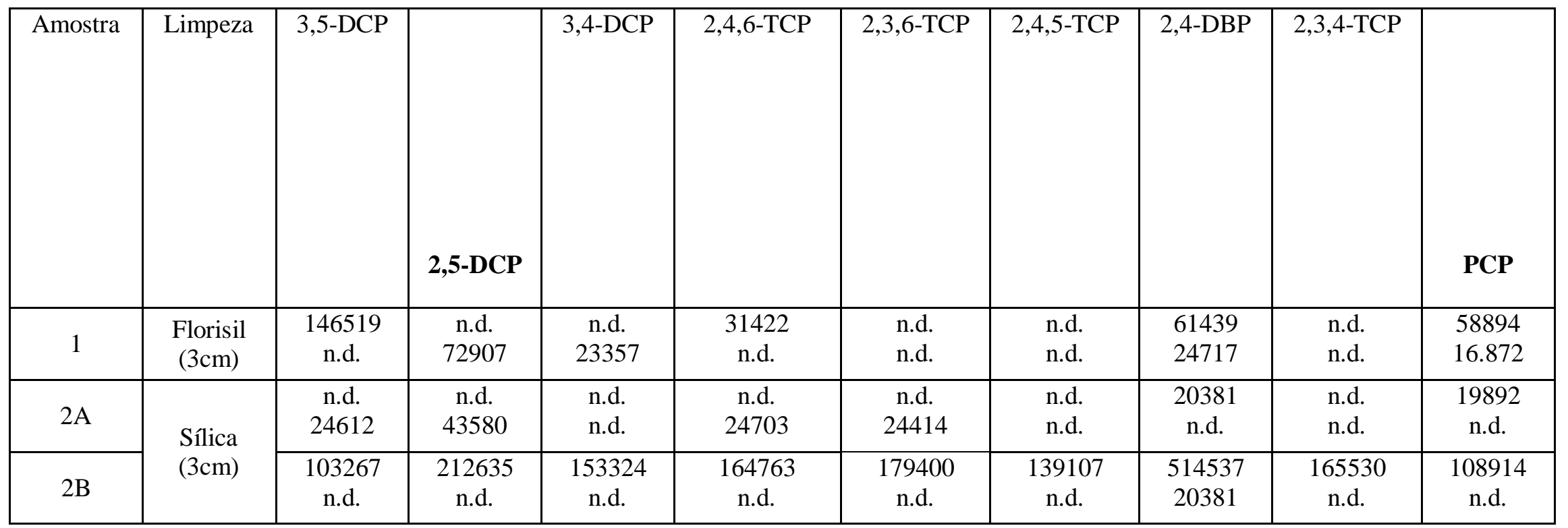

TABELA A.3. PROCEDIMENTOS DE EXTRAÇÃO COM SOXHLET E RESPOSTA ANALÍTICA, ATRAVÉS DA CROMATOGRAFIA GASOSA

Teste 3 - Limpeza das amostras

Amostra: Sedimento de Salto Grande/Estação 2 (perfil 1)/Maio

Quantidade de amostra: $5 \mathrm{~g}$

Dopagem: $5 \mu \mathrm{L}$ de solução de Clorofenóis (1 mg/L). Não houve dopagem com padrão interno

Solvente: $250 \mathrm{~mL}$ de $\mathrm{n}$-hexano

Tempo de extração: 3 horas

Eluente para limpeza nas colunas: $10 \mathrm{~mL}$ de solução de hexano /acetona 3:1 e $10 \mathrm{~mL}$ de solução de hexano /acetona 2:1

Conclusões: (a) boas respostas para o 2,4,6-TCP para Sílica $(3 \mathrm{~cm}$ ) e Florisil $(1 \mathrm{~cm})$; (b) no caso do 3,5-DCP pareceu ocorrer perda nas colunas, verificada na análise do descarte; (c) nas colunas de Sílica e Florisil $1 \mathrm{~cm}$ houve perda de PCP no descarte, sendo a maior nesta última coluna; (d).com 3 
horas de extração, a capacidade extrativa foi sensivelmente menor, comparando-se com teste anterior, em que não houve dopagem e o tempo de extração foi de 6 horas.

\begin{tabular}{|c|c|c|c|c|}
\hline Amostra & Limpeza & $3,5-\mathrm{DCP}$ & $2,4,6-\mathrm{TCP}$ & PCP \\
\hline 1 & Sílica $(1 \mathrm{~cm})$ & $\begin{array}{l}93979 \text { (amostra); } \\
38525 \text { (descarte) }\end{array}$ & $\begin{array}{c}\text { n.d. } \\
\text { 29291(descarte) }\end{array}$ & 20053 (amostra); 48276 (descarte) \\
\hline 2 & Sílica $(3 \mathrm{~cm})$ & $\begin{array}{l}\text { n.d. } \\
\text { n.d. }\end{array}$ & $\begin{array}{l}26116 \text { (amostra); } \\
38098 \text { (descarte) }\end{array}$ & $\begin{array}{c}\text { n.d. } \\
21009 \text { (descarte) }\end{array}$ \\
\hline 1 & Florisil (1cm) & $\begin{array}{l}314607 \text { (amostra) } \\
40309 \text { (descarte) }\end{array}$ & $\begin{array}{c}22998 \text { (amostra) } \\
\text { n.d. }\end{array}$ & $\begin{array}{c}\text { n.d. } \\
151734 \text { (descarte) }\end{array}$ \\
\hline 2 & Florisil $(3 \mathrm{~cm})$ & $\begin{array}{l}40073 \text { (amostra); } \\
66612 \text { (descarte) }\end{array}$ & $\begin{array}{l}\text { n.d. } \\
\text { n.d. }\end{array}$ & $\begin{array}{c}90236 \text { (amostra) } \\
\text { n.d. }\end{array}$ \\
\hline
\end{tabular}

TABela A.4. Procedimentos DE EXTRAÇão COM SOXHLET E RESPOSTA ANALÍTICA, ATRAVÉS DA CROMATOGRAFIA GASOSA

Teste 4 - Limpeza das amostras

Amostra: Sedimento de Salto Grande/Estação 2 (perfil 1)/Maio
Quantidade de amostra: $5 \mathrm{~g}$
Dopagem: $10 \mu \mathrm{L}$ de solução de Clorofenóis $(1 \mathrm{mg} / \mathrm{L})$. Não houve dopagem com padrão interno
Solvente: $250 \mathrm{~mL}$ de n-hexano
Tempo de extração: 6 horas
Eluentes para limpeza nas colunas: $10 \mathrm{~mL}$ de sol. de hexano/acetona $3: 1$ e $10 \mathrm{~mL}$ de solução de hexano/acetona 2:1
Conclusão: (a) a coluna de Sílica $(1 \mathrm{~cm})$ apresentou melhor resultado que a de Florisil $(3 \mathrm{~cm})$




\begin{tabular}{|c|c|c|c|c|c|c|}
\hline Amostra & Coluna & $3,5-\mathrm{DCP}$ & $2,4,6-\mathrm{TCP}$ & $2,4-\mathrm{DBP}$ & $2,3,4-\mathrm{TCP}$ & PCP \\
\hline 1 & Sílica & n.d. & 44716 & n.d. & n.d. & n.d. \\
& $(1 \mathrm{~cm})$ & 32858 & $20797(3: 1)$ & $36179(3: 1)$ & n.d. & $2463393(3: 1)$ \\
& & n.d. & $44815(2: 1)$ & n.d. & $50217(3: 1)$ & $1629024(2: 1)$ \\
\hline 1 & Florisil $(3 \mathrm{~cm})$ & n.d. & n.d. & n.d. & $59666(3: 1)$ & $22935(3: 1)$ \\
& & $29394(3: 1)$ & $44832(3: 1)$ & $51976(3: 1)$ & $44022(2: 1)$ & $34894(2: 1)$ \\
& & $25636(2: 1)$ & $26176(2: 1)$ & n.d. & n.d. & n.d. \\
\hline
\end{tabular}


TABela A.5. Procedimentos DE EXTRAÇão COM SOXHLET E RESPOSTA ANALítiCA, ATRAVÉS DA CROMATOGRAFIA GASOSA

\section{Teste 5 - Limpeza das amostras}

\begin{tabular}{|c|c|c|c|c|c|c|c|c|c|}
\hline \multicolumn{10}{|c|}{ Amostra: Sedimento de Salto Grande/Estação 4 (perfil 1)/Maio } \\
\hline \multicolumn{10}{|c|}{ Quantidade de amostra: $5 \mathrm{~g}$} \\
\hline \multicolumn{10}{|c|}{ Dopagem: Não houve dopagem com solução de clorofenóis e também não houve dopagem com padrão interno (2,4 -DBP) } \\
\hline \multicolumn{10}{|c|}{ Solvente: $300 \mathrm{~mL}$ de n-hexano } \\
\hline \multicolumn{10}{|c|}{ Tempo de extração: 6 horas } \\
\hline \multicolumn{10}{|c|}{ Limpeza: Sílica (1cm) } \\
\hline \multicolumn{10}{|c|}{$\begin{array}{l}\text { Observação: (a) foram passados pela coluna } 5 \mathrm{~mL} \text { de } \mathrm{n} \text {-hexano por } 3 \text { vezes sucessivas e em cada eluição, o eluato era recolhido em um frasco, } \\
\text { concentrado a } 1 \mathrm{~mL} \text {, derivatizado e injetado }\end{array}$} \\
\hline \multicolumn{10}{|c|}{ Conclusões: Não houve incremento algum nas áreas na $2^{\mathrm{a}}$ e $3^{\mathrm{a}}$ eluição } \\
\hline Amostra & Eluente & 3,5-DCP & 2,5-DCP & $3,4-\mathrm{DCP}$ & $2,4,6-\mathrm{TCP}$ & $2,3,6-\mathrm{TCP}$ & $2,4,5-\mathrm{TCP}$ & $2,4-\mathrm{DBP}$ & $2,3,4-\mathrm{TCP}$ \\
\hline \multirow{3}{*}{1} & $1^{\mathrm{a}}$ eluição & 36137 & 45067 & 55757 & 55590 & 52658 & 45387 & 62858 & 29865 \\
\hline & $2^{\mathrm{a}}$ eluição & 26770 & n.d. & n.d. & 32835 & n.d. & n.d. & n.d. & n.d. \\
\hline & $3^{\mathrm{a}}$ eluição & 25894 & n.d. & n.d. & n.d. & n.d. & n.d. & n.d. & n.d. \\
\hline
\end{tabular}


Tabela B.1. Procedimentos de extração com agitação com barra magnética e resposta analítica, através da cromatografia gasosa

Teste 1 - Extração, tipo e volume de solvente

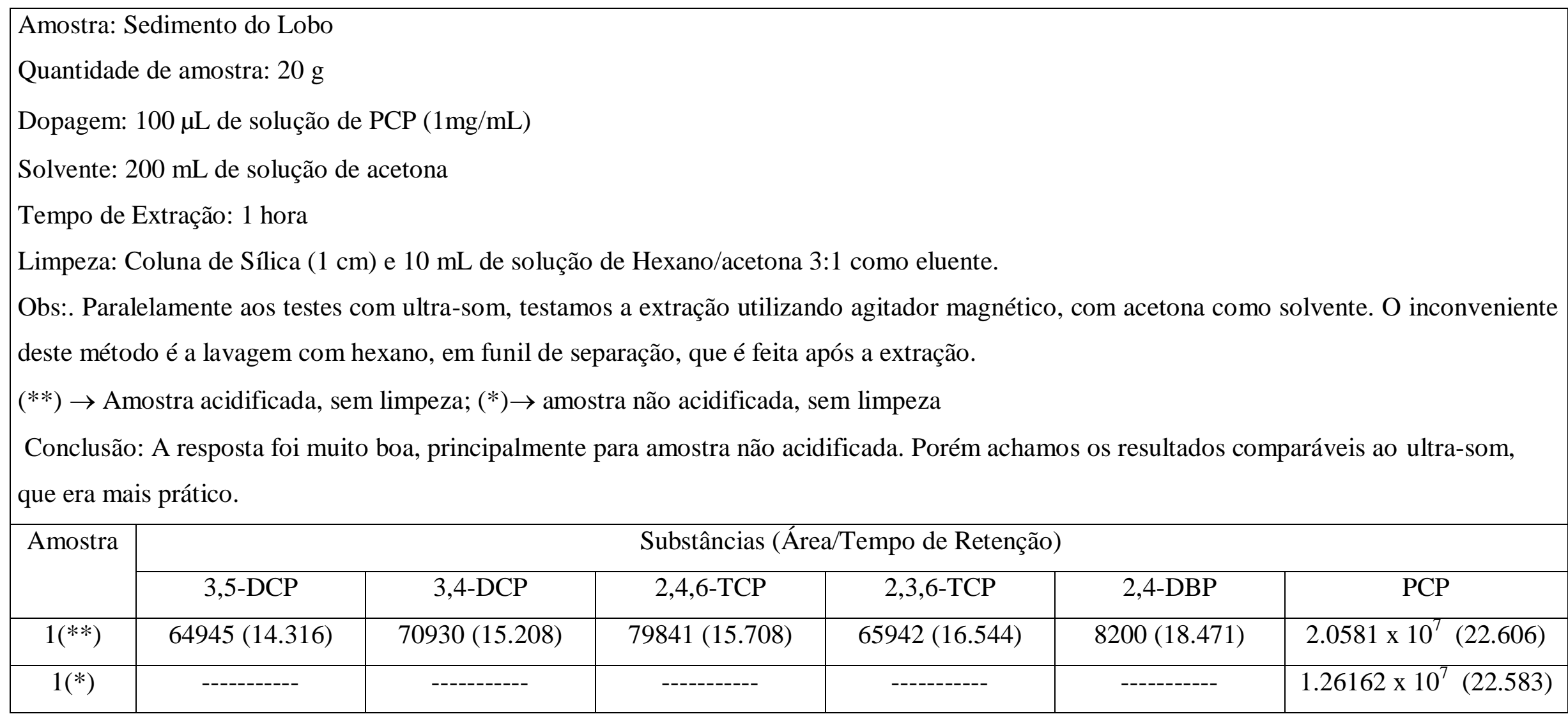


Tabela C.1. Procedimentos de extração com ultra-som e resposta analítica, através da cromatografia gasosa. -

\section{Teste 1 - Coluna de limpeza}

\begin{tabular}{|c|c|c|c|c|}
\hline \multicolumn{5}{|c|}{ Amostra: Sedimento da Represa do Lobo } \\
\hline \multicolumn{5}{|c|}{ Quantidade de amostra: $10 \mathrm{~g}$} \\
\hline \multicolumn{5}{|c|}{ Dopagem: $50 \mu \mathrm{L}$ de solução de Clorofenóis $(1 \mathrm{mg} / \mathrm{L})$} \\
\hline \multicolumn{5}{|c|}{ Solvente: 50 mL de Hexano } \\
\hline \multicolumn{5}{|c|}{ Tempo de extração: 1 hora } \\
\hline \multicolumn{5}{|c|}{ Eluentes: $5 \mathrm{~mL}$ de Hexano/acetona 3:1 } \\
\hline \multicolumn{5}{|c|}{$\begin{array}{l}\text { Conclusões: Como não estávamos obtendo bons resultados com o Soxhlet, resolvemos testar outros métodos. O primeiro método testado foi o } \\
\text { Ultra-som e o primeiro solvente o n-hexano. A resposta foi bem satisfatória comparada ao Soxhlet. }\end{array}$} \\
\hline Amostra & Limpeza & $3,5-\mathrm{DCP}$ & 2,4,6-TCP & PCP \\
\hline \multirow{2}{*}{$\begin{array}{r}1 \mathrm{~A} \\
1 \mathrm{~B}\end{array}$} & \multirow{2}{*}{ Sílica $3 \mathrm{~cm}$} & \multirow{2}{*}{ 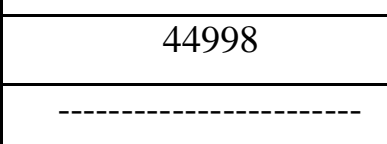 } & \multirow{2}{*}{ 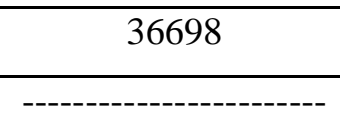 } & \multirow{2}{*}{$\begin{array}{l}9812373 \\
4136005\end{array}$} \\
\hline & & & & \\
\hline $1 \mathrm{C}$ & C18 & ------------------------ & ------------------------ & 322474 \\
\hline
\end{tabular}


Tabela C..2. Procedimentos de extração com ultra-som e resposta analítica, através da cromatografia gasosa. -

Teste 2 - Utilização de amostra acidificada ou não acidificada com n-hexano/acetona 4:1

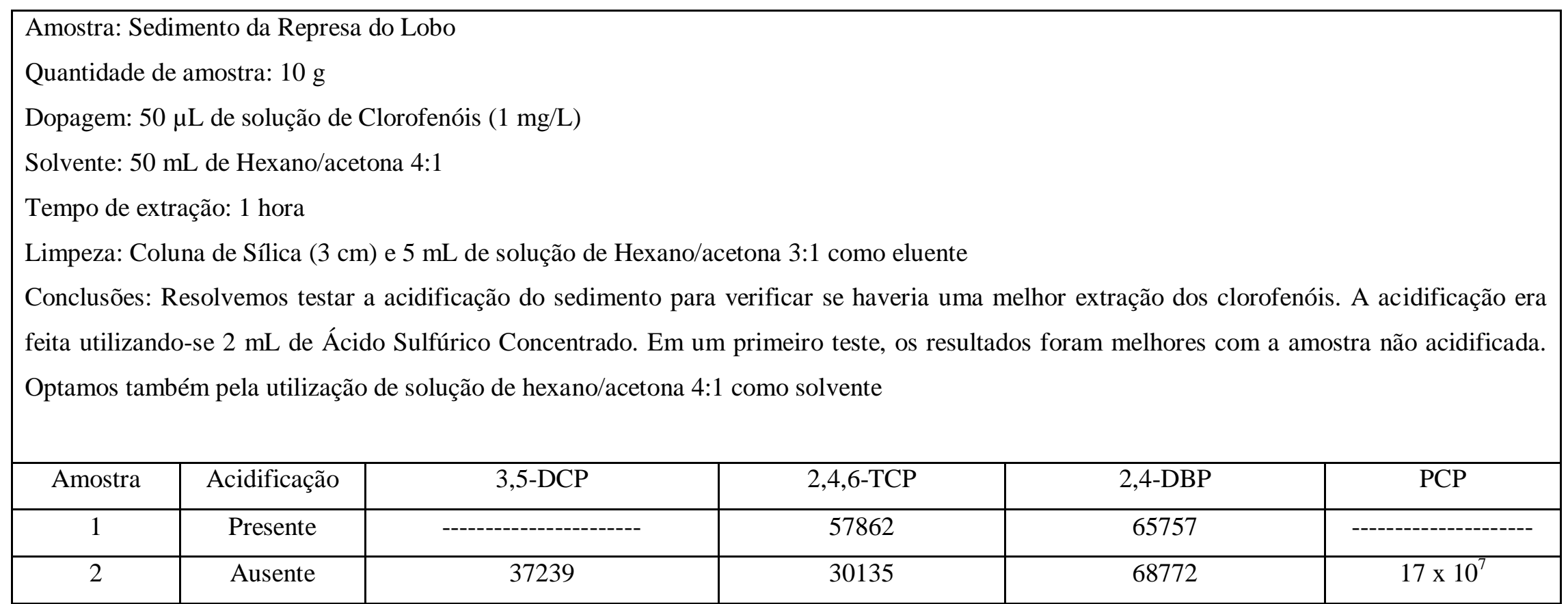


Tabela C.3. Procedimentos de extração com ultra-som e resposta analítica, através da cromatografia gasosa. -

Teste 3 - Utilização de amostra acidificada ou não acidificada com n-hexano/acetona 3:1

\begin{tabular}{|c|c|c|c|c|c|c|c|}
\hline \multicolumn{8}{|c|}{$\begin{array}{l}\text { Amostra: Sedimento da Represa de Salto Grande/ Estação 4/ Maio } \\
\text { Quantidade de amostra: } 20 \mathrm{~g} \\
\text { Dopagem: } 100 \mu \mathrm{L} \text { de solução de Clorofenóis }(1 \mathrm{mg} / \mathrm{L}) \\
\text { Tempo de extração: } 1 \text { hora } \\
\text { Limpeza: Coluna de Sílica }(3 \mathrm{~cm}) \text { e } 5 \mathrm{~mL} \text { de solução de Hexano/acetona } 3: 1 \text { como eluente } \\
\text { Conclusão: Utilizando o sedimento da Represa de Salto Grande, dopado, fizemos novamente o teste da acidificação e com outro solvente. A } \\
\text { resposta foi melhor para a amostra acidificada }\end{array}$} \\
\hline Amostra & Acidificação & Solvente & $3,5-\mathrm{DCP}$ & $3,4-\mathrm{DCP}$ & $2,4-\mathrm{DBP}$ & $2,3,4-\mathrm{TCP}$ & $\mathrm{PCP}$ \\
\hline $1 \mathrm{~A}$ & 政 & $\begin{array}{c}25 \mathrm{~mL} \text { de Hexano/acetona } \\
3: 1\end{array}$ & 167747 & 1010770 & 143287 & 108909 & 136128 \\
\hline 1B & Ausente & $\begin{array}{c}25 \mathrm{~mL} \text { de Hexano/acetona } \\
3: 1\end{array}$ & 105030 & 130447 & 170006 & 120580 & -------------- \\
\hline
\end{tabular}


Tabela C.4. Procedimentos de extração com ultra-som e resposta analítica, através da cromatografia gasosa. -

Teste 4 - Utilização de amostra acidificada alcalinizada com diferentes solventes

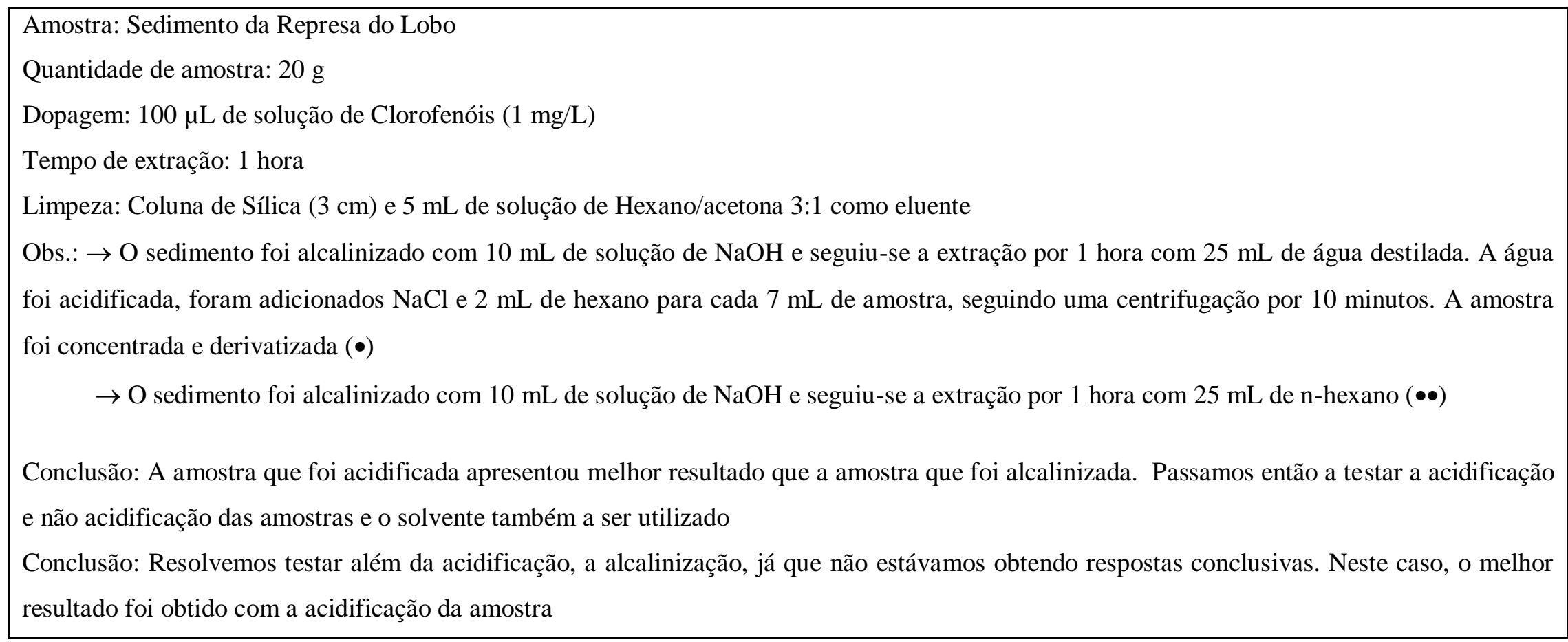




\begin{tabular}{|c|c|c|c|c|c|c|c|}
\hline Amostra & Acidificação/Alcalinização & Solvente & $3,5-\mathrm{DCP}$ & 2,5-DCP & $2,4,6-\mathrm{TCP}$ & 2,3,4-TCP & PCP \\
\hline 1 & & Água & 52172 & 21733 & 27785 & -------- & 143263 \\
\hline & ALCALINIZAÇÃ̃ (•) & & & & & & \\
\hline $2 \mathrm{~A}$ & Alcalinização (••) & $25 \mathrm{~mL}$ de hexano & 28092 & -------- & ------- & -------- & 1029772 \\
\hline $2 \mathrm{~B}$ & Alcalinização (••) & $25 \mathrm{~mL}$ de Hexano & 37061 & 21481 & 37368 & ------- & 24124 \\
\hline 4 & Acidificação & $25 \mathrm{~mL}$ de Hexano & 30603 & 21308 & 47626 & 63960 & $156 \times 10^{7}$ \\
\hline
\end{tabular}

Tabela C.5. Procedimentos de extração com ultra-som e resposta analítica, através da cromatografia gasosa. -

Teste 5 - Utilização de amostra acidificada ou não acidificada com diferentes tipos de solventes 


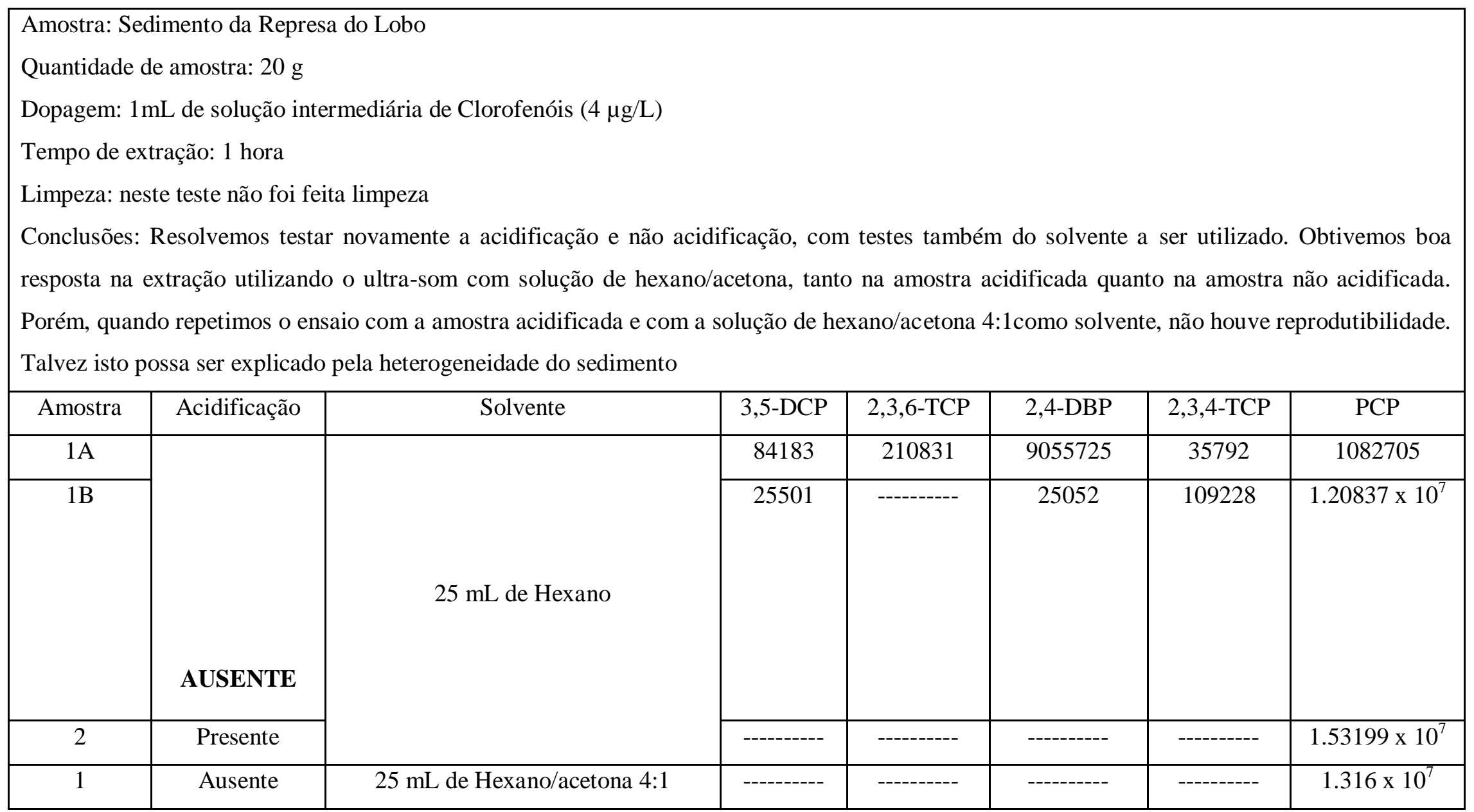




\begin{tabular}{|c|c|c|c|c|c|c|c|}
\hline 2 & & & ---------- & --------- & ---------- & ---------- & $1.74427 \times 10^{7}$ \\
\hline & PRESENTE & & & & & & \\
\hline $1 \mathrm{~A}$ & \multirow{3}{*}{ Presente } & \multirow{3}{*}{$25 \mathrm{~mL}$ de Hexano/acetona $4: 1$} & ---------- & ---------- & ---------- & ---------- & $1.6206 \times 10^{7}$ \\
\hline $1 \mathrm{~B}$ & & & ---------- & 75049 & 3178882 & 152009 & 731216 \\
\hline $1 \mathrm{C}$ & & & ---------- & --------- & 1468739 & 88477 & 250248 \\
\hline
\end{tabular}

Tabela C.6. Procedimentos de extração com ultra-som e resposta analítica, através da cromatografia gasosa. -

Teste 6 - Utilização de diferentes solventes com ou sem limpeza

Amostra: Sedimento da Represa de Salto Grande/ Estação 4/ Maio
Quantidade de amostra: $20 \mathrm{~g}$
Dopagem: não houve dopagem com solução de clorofenóis, apenas com o padrão interno ( $800 \mu \mathrm{L}$ de solução $2,5 \mu \mathrm{g} / \mathrm{L})$
Tempo de extração: 1 hora
Obs.: Estes 20 gramas de sedimento eram obtidos pela mistura de 5 gramas de cada perfil coletado na estação 4 . Estas amostras não foram
acidificadas
Conclusões: Utilizando o sedimento de Salto Grande, testamos os 2 tipos de solventes. A melhor resposta foi obtida com solução de
hexano/acetona 4:1, mas tivemos novamente o problema de reprodutibilidade




\begin{tabular}{|c|c|c|c|c|c|c|c|}
\hline Amostra & Solvente & Limpeza & $3,4-\mathrm{DCP}$ & $2,3,6-\mathrm{TCP}$ & 2,4-DBP & 2,3,4-ТCP & PCP \\
\hline $1 \mathrm{~A}$ & \multirow{2}{*}{$\begin{array}{l}25 \mathrm{~mL} \text { de } \\
\text { Hexano/acetona } \\
4: 1\end{array}$} & \multirow[b]{2}{*}{ Não houve } & 40309 & ---------- & 78081 & ---------- & 150815 \\
\hline $1 \mathrm{~B}$ & & & ---------- & 133392 & 6226888 & 350168 & ------------- \\
\hline $1 \mathrm{~A}$ & \multirow{2}{*}{$50 \mathrm{~mL}$ de Hexano } & \multirow{2}{*}{$\begin{array}{l}\text { Sílica }(5 \mathrm{~cm}) \text { com } 5 \mathrm{~mL} \text { de solução } \\
\text { de Hexano/acetona 2:1 como eluente }\end{array}$} & 132581 & 75453 & 265755 & 79290 & 54447 \\
\hline 1B & & & 58848 & 76671 & 99243 & 21537 & 52970 \\
\hline
\end{tabular}


Tabela D.1 - Resultados das injeções em CG/DCE das amostras de água da campanha de maio/98/Estação 2

\begin{tabular}{|c|c|c|c|c|c|c|c|}
\hline \multirow{2}{*}{$\begin{array}{c}\text { Amostra } \\
\mathrm{s}\end{array}$} & \multicolumn{7}{|c|}{ Substâncias (Área/Tempo de retenção) } \\
\hline & $3,5-\mathrm{DCP}$ & $2,5-\mathrm{DCP}$ & $\begin{array}{c}2,4,6- \\
\text { TCP }\end{array}$ & $\begin{array}{c}2,4,5- \\
\text { TCP }\end{array}$ & 2,4-DBP & $\begin{array}{c}2,3,4- \\
\text { TCP }\end{array}$ & PCP \\
\hline A & & $\begin{array}{r}113.946 \\
(15.092) \\
\end{array}$ & $\begin{array}{r}126.612 \\
(15.928) \\
\end{array}$ & $\begin{array}{r}119.034 \\
(18.082) \\
\end{array}$ & $\begin{array}{r}312.965 \\
(18.609) \\
\end{array}$ & --------- & \\
\hline $\mathrm{B}$ & $\begin{array}{c}21.509 \\
(14.278)\end{array}$ & & $\begin{array}{c}21.466 \\
(16.153)\end{array}$ & & & $\begin{array}{c}27.459 \\
(18.825)\end{array}$ & $\begin{array}{c}26780 \\
(22.509 \\
)\end{array}$ \\
\hline
\end{tabular}

Tabela D.2 - Resultados das injeções em CG/DCE das amostras de água da campanha de junho/98/Estação 2

\begin{tabular}{c|c}
\hline Amostr & Substâncias (Área/ tempo de Retenção) \\
\cline { 2 - 2 } as & PCP \\
\hline A & 4123786 \\
& $(22.544)$ \\
\hline B & 318559 \\
& $(22.545)$ \\
\hline
\end{tabular}

Tabela. D.3 - Resultados das injeções em CG/DCE das amostras de água da campanha de junho/98/Estação 4

\begin{tabular}{c|c|c|c|c|c}
\hline \multirow{2}{*}{$\begin{array}{c}\text { Amostra } \\
\mathrm{S}\end{array}$} & \multicolumn{5}{|c}{ Substâncias (Área/ tempo de Retenção) } \\
\cline { 2 - 6 } & $2,5-\mathrm{DCP}$ & $2,4,6-\mathrm{TCP}$ & $2,3,6$-TCP & $2,4,5-\mathrm{TCP}$ & PCP \\
\hline \multirow{2}{*}{$\mathrm{A}$} & --------- & 22.047 & 1.410 .515 & 21.486 & 51.846 \\
& & $(15.966)$ & $(16.7902)$ & $(18.176)$ & $(22.549)$ \\
\hline B & 22.412 & --------- & --------- & ---------- & 53.396 \\
& $(14.913)$ & & & & $(22.569)$ \\
\hline C & ---------- & --------- & --------- & --------- & 133.654 \\
& & & & & $(22.546)$ \\
\hline
\end{tabular}

Tabela. D.4 - Resultados das injeções em CG/DCE das amostras de água da campanha de novembro/98/Estação 1

\begin{tabular}{c|c|c|c|c|c|c|c}
\hline \multirow{3}{*}{ Amostras } & \multicolumn{7}{|c}{ Substâncias (Área/Tempo de Retenção) } \\
\cline { 2 - 8 } & $3,4-\mathrm{DCP}$ & $\begin{array}{c}2,4,6- \\
\text { TCP }\end{array}$ & $\begin{array}{c}2,3,6- \\
\text { TCP }\end{array}$ & $\begin{array}{c}2,4,5- \\
\text { TCP }\end{array}$ & $2,4-\mathrm{DBP}$ & $\begin{array}{c}2,3,4- \\
\text { TCP }\end{array}$ & PCP \\
\hline \multirow{2}{*}{$\mathrm{A}$} & & 26726 & 133392 & & 6226888 & 350168 & 25948 \\
& & $(15.765)$ & $(16.811)$ & & $(18.531)$ & $(19359)$ & $(22.564)$ \\
\hline \multirow{2}{*}{$\mathrm{B}$} & & 42459 & 87305 & & 2451468 & 295337 & 350651 \\
& & $(15.720)$ & $(16.850)$ & & $(18.544)$ & $(19368)$ & $(22.567)$ \\
\hline
\end{tabular}




\begin{tabular}{c|c|c|c|c|c|c|c}
\hline C & ------- & ------- & 83.428 & & & & \\
& & & $(16798)$ & & --------- & ------ & ------- \\
\hline
\end{tabular}

Tabela. D.5 - Resultados das injeções em CG/DCE das amostras de água da campanha de novembro/98/Estação 2

\begin{tabular}{|c|c|c|c|c|c|c|c|}
\hline \multirow[t]{2}{*}{ Amostras } & \multicolumn{7}{|c|}{ Substâncias (Área/Tempo de Retenção) } \\
\hline & 2,5-DCP & $\begin{array}{l}2,4,6- \\
\text { TCP }\end{array}$ & $\begin{array}{c}2,3,6- \\
\text { TCP }\end{array}$ & $\begin{array}{c}2,4,5- \\
\text { TCP }\end{array}$ & 2,4-DBP & $\begin{array}{c}2,3,4- \\
\text { TCP }\end{array}$ & PCP \\
\hline A & & $\begin{array}{c}57.043 \\
(15.716)\end{array}$ & $\begin{array}{l}516.897 \\
(16.815)\end{array}$ & & & & $\begin{array}{c}59.674 \\
(22.571)\end{array}$ \\
\hline B & & & $\begin{array}{c}1.027 .20 \\
4 \\
(16.797)\end{array}$ & & & -------- & $\begin{array}{r}64.800 \\
(22.552)\end{array}$ \\
\hline $\mathrm{C}$ & $\begin{array}{c}36.537 \\
(15.072)\end{array}$ & & $\begin{array}{c}\text {---------- } \\
--\end{array}$ & $\begin{array}{c}40.877 \\
(18.368)\end{array}$ & $\begin{array}{l}121.501 \\
(18.749)\end{array}$ & $\begin{array}{c}66.801 \\
(19.344)\end{array}$ & \\
\hline
\end{tabular}

Tabela. D.6 - Resultados das injeções em CG/DCE das amostras de água da campanha de novembro/98/Estação 3 (superfície)

\begin{tabular}{c|c|c|c|c}
\hline \multirow{2}{*}{ Amostras } & \multicolumn{4}{|c}{ Substâncias (Área/Tempo de Retenção) } \\
\cline { 2 - 5 } & $2,3,6-\mathrm{TCP}$ & $2,4-\mathrm{DBP}$ & $2,3,4-\mathrm{TCP}$ & PCP \\
\hline $\mathrm{A}$ & 151.847 & 68.678 & ---------- & 79.846 \\
& $(16.786)$ & $(18.512)$ & & $(22.547)$ \\
\hline B & --------- & 470.142 & 71.856 & 52.115 \\
& & $(18.515)$ & $(19.345)$ & $(22.549)$ \\
\hline C & 624.503 & --------- & ------- & ---- \\
& $(16.792)$ & & & \\
\hline
\end{tabular}

Tabela. D.7-Resultados das injeções em CG/DCE das amostras de água da campanha de novembro/98/Estação 3 (intermediário)

\begin{tabular}{c|c|c|c|c}
\hline \multirow{2}{*}{ Amostras } & \multicolumn{4}{|c}{ Substâncias (Área/Tempo de Retenção) } \\
\cline { 2 - 5 } & $2,4,6-\mathrm{TCP}$ & $2,3,6-\mathrm{TCP}$ & $2,4-\mathrm{DBP}$ & PCP \\
\hline A & 33.413 & 1.087 .533 & 30.997 & 30.375 \\
& $(15.724)$ & $(16.792)$ & $(18.517)$ & $(22.545)$ \\
\hline B & --------- & 893.460 & --------- & 180.195 \\
& & $(16.793)$ & & $(22.548)$ \\
\hline C & 24.991 & 822.442 & ---------- & 39.221 \\
& $(15.734)$ & $(16.801)$ & & $(22.556)$ \\
\hline
\end{tabular}


Tabela. D.8 - Resultados das injeções em CG/DCE das amostras de água da campanha de novembro/98/Estação 3 (fundo)

\begin{tabular}{c|c|c|c|c|c}
\hline \multirow{2}{*}{ Amostras } & \multicolumn{5}{|c}{ Substâncias (Área/Tempo de Retenção) } \\
\cline { 2 - 6 } & $2,4,6-T C P$ & $2,3,6-T C P$ & $2,4-D B P$ & $2,3,4-T C P$ & PCP \\
\hline A & -------- & -------- & 1385490 & 307254 & 100519 \\
& & & $(18504)$ & $(19333)$ & $(22535)$ \\
\hline B & -------- & 41011 & 1481475 & 360537 & 61304 \\
& & $(16792)$ & $(18506)$ & $(19334)$ & $(22536)$ \\
\hline C & 44.067 & 1.245 .420 & 58.228 & -------- & 35.228 \\
& $(15.717)$ & $(16.792)$ & $(18.445)$ & & $(22.544)$ \\
\hline
\end{tabular}

Tabela. D.9 - Resultados das injeções em CG/DCE das amostras de água da campanha de novembro/98/Estação 4 (superfície)

\begin{tabular}{c|c|c|c|c}
\hline \multirow{2}{*}{ Amostras } & \multicolumn{4}{|c}{ Substâncias (Área/Tempo de Retenção) } \\
\cline { 2 - 5 } & $2,4,6-\mathrm{TCP}$ & $2,3,6-\mathrm{TCP}$ & $2,4-\mathrm{DBP}$ & PCP \\
\hline $\mathrm{A}$ & --------- & 727.598 & -------- & 1.517 .811 \\
& & $(16.783)$ & & $(22.534)$ \\
\hline $\mathrm{B}$ & --------- & 1.281 .471 & 75.607 & -------- \\
& & $(16.779)$ & $(18.727)$ & 72.013 \\
\hline $\mathrm{C}$ & 25.947 & 1.226 .139 & 38.785 & $(22.533)$ \\
\hline
\end{tabular}

Tabela.D.10 - Resultados das injeções em CG/DCE das amostras de água da campanha de novembro/98/Estação 4 (intermediário)

\begin{tabular}{c|c|c|c|c}
\hline \multirow{2}{*}{ Amostras } & \multicolumn{4}{|c}{ Substâncias } \\
\cline { 2 - 5 } & $2,3,6-\mathrm{TCP}$ & $2,4-\mathrm{DBP}$ & $2,3,4-\mathrm{TCP}$ & PCP \\
\hline $\mathrm{A}$ & 52.789 & 1.400 .204 & 221.736 & 36.745 \\
& $(16.813)$ & $(18.514)$ & $(19.340)$ & $(22.537)$ \\
\hline $\mathrm{B}$ & 31.014 & 1.086 .697 & 223.863 & 37.452 \\
& $(16.801)$ & $(18.511)$ & $(19.338)$ & $(22.538)$ \\
\hline $\mathrm{C}$ & 33.693 & 1.562 .260 & 83.328 & ------ \\
& $(16.819)$ & $(18.535)$ & $(19.366)$ & \\
\hline
\end{tabular}

Tabela. D.11 - Resultados das injeções em CG/DCE das amostras de água da campanha de novembro/98/Estação 4 (fundo)

\begin{tabular}{c|c|c|c}
\hline \multirow{2}{*}{ Amostras } & \multicolumn{3}{|c}{ Substâncias } \\
\cline { 2 - 4 } & $2,3,6-\mathrm{TCP}$ & $2,4-\mathrm{DBP}$ & $2,3,4-\mathrm{TCP}$ \\
\hline $\mathrm{A}$ & 38.159 & $1.593 .396 *$ & 118.875 \\
& $(16.806)$ & $(18.520)$ & $(19.350)$ \\
\hline $\mathrm{B}$ & 48.068 & $2.282 .585 *$ & 147.890 \\
& $(16.807)$ & $(18.520)$ & $(19.349)$ \\
\hline $\mathrm{C}$ & --------- & 249.362 & 43.159 \\
& & $(18.518)$ & $(19.348)$ \\
\hline
\end{tabular}


Obs:. (*) Houve algum problema com estas amostras: a resposta para o 2,4-dibromofenol está fora do padrão

Tabela. D.12 - Resultados das injeções em CG/DCE das amostras água da campanha de fevereiro/98/Estação 1

\begin{tabular}{c|c|c|c}
\hline \multirow{2}{*}{$\begin{array}{c}\text { Amostra } \\
\mathrm{s}\end{array}$} & \multicolumn{3}{|c}{ Substâncias } \\
\cline { 2 - 4 } & $2,4-\mathrm{DBP}$ & $2,3,4-\mathrm{TCP}$ & $\mathrm{PCP}$ \\
\hline $\mathrm{A}$ & $1.415 .428(18.531)$ & $242.258(19.360)$ & $42.341(22.576)$ \\
\hline $\mathrm{B}$ & $1.679 .322(18.527)$ & $229.071(19.356)$ & $52.402(22.576)$ \\
\hline $\mathrm{C}$ & $1.226 .770(18.525)$ & $169.784(19.355)$ & $38.227(22.567)$ \\
\hline
\end{tabular}

Tabela.D.13 - Resultados das injeções em CG/DCE das amostras de água da campanha de fevereiro/98/Estação 2

\begin{tabular}{c|c|c|c}
\hline \multirow{2}{*}{$\begin{array}{c}\text { Amostra } \\
\mathrm{s}\end{array}$} & \multicolumn{3}{|c}{ Substâncias } \\
\cline { 2 - 4 } & $2,4-\mathrm{DBP}$ & $2,3,4-\mathrm{TCP}$ & PCP \\
\hline $\mathrm{A}$ & $1.513 .311(18.520)$ & $94.703(19.351)$ & ---------- \\
\hline $\mathrm{B}$ & $2.195 .668(18.521)$ & $93.802(19.351)$ & $413.033(22.571)$ \\
\hline $\mathrm{C}$ & $1.776 .398(18.526)$ & $117.784(19.356)$ & --------- \\
\hline
\end{tabular}

Tabela. D.14 - Resultados das injeções em CG/DCE das amostras de água da campanha de fevereiro/98/Estação 3

\begin{tabular}{c|c|c|c|c}
\hline \multirow{2}{*}{$\begin{array}{c}\text { Amostra } \\
\mathrm{s}\end{array}$} & \multicolumn{4}{|c}{ Substâncias (Área/ tempo de Retenção) } \\
\cline { 2 - 5 } $\mathrm{A}$ & $2,3,6$-TCP & $2,4-\mathrm{DBP}$ & $2,3,4-\mathrm{TCP}$ & PCP \\
\hline \multirow{2}{*}{$\mathrm{B}$} & $51.820(16.840)$ & $\begin{array}{c}1.921 .131 \\
(18.535)\end{array}$ & $\begin{array}{c}109.135 \\
(19.361)\end{array}$ & --------- \\
\hline \multirow{2}{*}{$\mathrm{C}$} & \multirow{2}{*}{$71.718(16.860)$} & $\begin{array}{c}2.226 .307 \\
(18.541)\end{array}$ & $\begin{array}{c}124.619 \\
(19.363)\end{array}$ & ---------- \\
\hline
\end{tabular}

Tabela. D.15 - Resultados das injeções em CG/DCE das amostras de água da campanha de fevereiro/98/Estação4(superfície)

\begin{tabular}{c|c|c|c}
\hline \multirow{2}{*}{$\begin{array}{c}\text { Amostra } \\
\mathrm{s}\end{array}$} & \multicolumn{3}{|c}{ Substâncias (Área/ tempo de Retenção) } \\
\cline { 2 - 4 } & $2,3,6-\mathrm{TCP}$ & $2,4-\mathrm{DBP}$ & $2,3,4-\mathrm{TCP}$ \\
\hline $\mathrm{A}$ & $35.298(16.796)$ & $1.416 .408(18.513)$ & $219.386(19.342)$ \\
\hline $\mathrm{B}$ & $49.3229(16.785)$ & $1.468 .770(18.503)$ & $185.413(19.333)$ \\
\hline $\mathrm{C}$ & $44.173(16.789)$ & $1.866 .209(18.506)$ & $243.597(19.335)$ \\
\hline
\end{tabular}

Tabela. D.16 - Resultados das injeções em CG/DCE das amostras de água da campanha de fevereiro/98/Estação 4 (intermediário)

\begin{tabular}{c|c|c|c|c}
\hline \multirow{2}{*}{$\begin{array}{c}\text { Amostra } \\
\mathrm{s}\end{array}$} & \multicolumn{4}{|c}{ Substâncias (Área/ tempo de Retenção) } \\
\cline { 2 - 5 } $\mathrm{A}$ & $2,3,6-\mathrm{TCP}$ & $2,4-\mathrm{DBP}$ & $2,3,4-\mathrm{TCP}$ & PCP \\
\hline & 39.315 & 1.385 .490 & 307.254 & 100.519 \\
& $(16.790)$ & $(18.504)$ & $(19.333)$ & $(22.533)$ \\
\hline $\mathrm{B}$ & 41.011 & 1.481 .475 & 360.537 & $61.304(22.536)$ \\
& $(16.791)$ & $(18.506)$ & $(19.334)$ & \\
\hline
\end{tabular}


Tabela. D.17 - Resultados das injeções em CG/DCE das amostras de água da campanha de fevereiro/98/Estação 4 (fundo)

\begin{tabular}{c|c|c|c|c|c|c}
\hline \multirow{2}{*}{$\begin{array}{c}\text { Amostra } \\
\mathrm{s}\end{array}$} & \multicolumn{6}{|c}{ Substâncias (Área/ tempo de Retenção) } \\
\cline { 2 - 7 } & $\begin{array}{c}2,4,6- \\
\text { TCP }\end{array}$ & $\begin{array}{c}2,3,6- \\
\text { TCP }\end{array}$ & $\begin{array}{c}2,4,5- \\
\text { TCP }\end{array}$ & $2,4-\mathrm{DBP}$ & $\begin{array}{c}2,3,4- \\
\text { TCP }\end{array}$ & PCP \\
\hline $\mathrm{A}$ & 44.600 & 46.526 & 30.754 & 1.672 .492 & 99.367 & 47.911 \\
& $(16.028)$ & $(16.841)$ & $(18.205)$ & $(18.536)$ & $(19.362)$ & $(22.559)$ \\
\hline $\mathrm{B}$ & 35.109 & 49.939 & -------- & 1900633 & 143.334 & 41.097 \\
& $(16.019)$ & $(16.832)$ & & $(18.530)$ & $(19.357)$ & $(22.553)$ \\
\hline $\mathrm{C}$ & -------- & 39.446 & -------- & 1688048 & 187.550 & 48.510 \\
& & $(16.795)$ & & $(18.510)$ & $(19.339)$ & $(22.541)$ \\
\hline
\end{tabular}


Tabela E.1 - Resultados das injeções em CG/DCE das amostras de sedimento da campanha de maio/98/Estação 2

\begin{tabular}{c|c|c|c}
\hline \multirow{2}{*}{ Amostras } & \multicolumn{3}{|c}{ Substâncias (Área/ tempo de Retenção) } \\
\cline { 2 - 4 } & $2,5-\mathrm{DCP}$ & $2,4,6-\mathrm{TCP}$ & $2,4-\mathrm{DBP}$ \\
\hline A & - & - & 147546 \\
& --------------- & $(18,510)$ \\
\hline B & 42512 & 49021 & 141294 \\
& $\left(155^{\prime} 396\right)$ & $(15,666)$ & $(18,504)$ \\
\hline C & --------------- & 87631 \\
& $-----18,504)$ \\
\hline
\end{tabular}

Tabela E.2 - Resultados das injeções em CG/DCE das amostras de sedimento da campanha de maio/98/Estação 4

\begin{tabular}{c|c|c|c|c|c}
\hline \multirow{2}{*}{$\begin{array}{c}\text { Extração/Amos } \\
\text { tra }\end{array}$} & \multicolumn{5}{|c}{ Substâncias (Área/ tempo de Retenção) } \\
\cline { 2 - 6 } & $2,5-\mathrm{DCP}$ & $2,4,6-\mathrm{TCP}$ & $2,3,6$-TCP & $2,4,5-\mathrm{TCP}$ & $2,4-\mathrm{DBP}$ \\
\hline Ultra/A & 51204 & 77420 & 62798 & ----------- & 62300 \\
& $\left(15^{\prime} 133\right)$ & $\left(15^{\prime} 733\right)$ & $\left(16^{\prime} 899\right)$ & & $\left(18^{\prime} 452\right)$ \\
\hline Ultra/B & ----------- & 39229 & 47557 & 49560 & 251814 \\
& & $\left(16^{\prime} 064\right)$ & $\left(16^{\prime} 798\right)$ & $\left(18^{\prime} 058\right)$ & $\left(18^{\prime} 521\right)$ \\
\hline Ultra/C & ----------- & 44702 & ---------- & ---------- & 86378 \\
& & $\left(15^{\prime} 714\right)$ & & & $\left(18^{\prime} 521\right)$ \\
\hline
\end{tabular}

Tabela E.3 - Resultados das injeções em CG/DCE das amostras de sedimento da campanha de junho/98/Estação 2

\begin{tabular}{c|c|c|c}
\hline \multirow{2}{*}{$\begin{array}{c}\text { Extração/Amo } \\
\text { stra }\end{array}$} & \multicolumn{3}{|c}{ Substâncias (Área/ tempo de Retenção) } \\
\cline { 2 - 4 } & $2,4,6-\mathrm{TCP}$ & $2,4-\mathrm{DBP}$ & $\mathrm{PCP}$ \\
\hline Ultra/A & 31360 & 124881 & ----------- \\
& $\left(15^{\prime} 746\right)$ & $\left(18^{\prime} 519\right)$ & \\
\hline Ultra/B & ---------- & 161445 & ----------- \\
& & $\left(18^{\prime} 520\right)$ & 57221 \\
\hline Ultra/C & ----------- & 354643 & $\left(22^{\prime} 558\right)$ \\
& & $\left(18^{\prime} 526\right)$ & 103710 \\
Soxhlet/única & 97423 & 276914 & $\left(22^{\prime} 420\right)$ \\
\hline Agitação/única & $\left(15^{\prime} 731\right)$ & $\left(18{ }^{\prime} 531\right)$ & ----------- \\
& ---------- & 188870 & \\
\hline
\end{tabular}


Tabela E.4- Resultados das injeções em CG/DCE das amostras de sedimento da campanha de junho/98/Estação 4

\begin{tabular}{|c|c|c|c|c|c|c|}
\hline \multirow{2}{*}{$\begin{array}{l}\text { Extração/Amost } \\
\text { ra }\end{array}$} & \multicolumn{6}{|c|}{ Substâncias (Área/ tempo de Retenção) } \\
\hline & $\begin{array}{l}2,4,6- \\
\text { TCP }\end{array}$ & $\begin{array}{c}2,3,6- \\
\text { TCP }\end{array}$ & $\begin{array}{c}2,4,5- \\
\text { TCP }\end{array}$ & 2,4-DBP & $\begin{array}{l}2,3,4- \\
\text { TCP }\end{array}$ & PCP \\
\hline Ultra/A & --------- & $\begin{array}{c}75344 \\
\left(16^{\prime} 928\right)\end{array}$ & $\begin{array}{c}186878 \\
\left(18^{\prime} 199\right)\end{array}$ & $\begin{array}{c}226568 \\
\left(18^{\prime} 546\right)\end{array}$ & $\begin{array}{c}49095 \\
(19 ’ 377)\end{array}$ & $\begin{array}{r}232206 \\
(22 ’ 575)\end{array}$ \\
\hline Ultra/B & $\begin{array}{c}101487 \\
\left(15^{\prime} 752\right)\end{array}$ & $\begin{array}{c}79072 \\
(16 ’ 900)\end{array}$ & ---------- & $\begin{array}{c}229736 \\
(18,522)\end{array}$ & --------- & $\begin{array}{c}71790 \\
(22 ’ 549)\end{array}$ \\
\hline Ultra/C & ---------- & ---------- & ---------- & $\begin{array}{c}37903 \\
\left(18^{\prime} 750\right)\end{array}$ & --------- & --------- \\
\hline $\begin{array}{l}\text { Soxhlet/ } \\
\text { Única }\end{array}$ & $\begin{array}{l}110046 \\
\left(16^{\prime} 002\right)\end{array}$ & ---------- & ---------- & $\begin{array}{c}191055 \\
\left(18^{\prime} 526\right)\end{array}$ & $\begin{array}{c}\text {---------- } \\
--\end{array}$ & $\begin{array}{c}100940 \\
(22 ’ 591)\end{array}$ \\
\hline $\begin{array}{l}\text { Agitação/ } \\
\text { Única }\end{array}$ & $\begin{array}{c}142615 \\
(15,896)\end{array}$ & $\begin{array}{c}306397 \\
\left(16^{\prime} 854\right)\end{array}$ & $\begin{array}{r}138886 \\
\left(17^{\prime} 908\right)\end{array}$ & $\begin{array}{c}308272 \\
\left(18^{\prime} 533\right)\end{array}$ & $\begin{array}{c}92298 \\
\left(19^{\prime} 032\right)\end{array}$ & $\begin{array}{c}155149 \\
\left(22^{\prime} 476\right)\end{array}$ \\
\hline
\end{tabular}

Tabela E.5 - Resultados das injeções em CG/DCE das amostras de sedimento da campanha de novembro/98/Estação 1

\begin{tabular}{|c|c|c|c|c|c|}
\hline \multirow{2}{*}{$\begin{array}{c}\text { Extração/Amost } \\
\text { ra }\end{array}$} & \multicolumn{5}{|c|}{ Substâncias (Área/ tempo de Retenção) } \\
\hline & 2,4,6-TCP & $\begin{array}{c}2,3,6- \\
\text { TCP }\end{array}$ & $2,4,5-\mathrm{TCP}$ & 2,4-DBP & PCP \\
\hline Ultra/A & -------- & $\begin{array}{l}------- \\
\end{array}$ & -------- & ------- & ------- \\
\hline Ultra/B & -------- & -------- & -------- & $\begin{array}{l}------- \\
\end{array}$ & $\begin{array}{c}49494 \\
\left(22^{\prime} 538\right)\end{array}$ \\
\hline Ultra/C & ------- & ------- & -------- & ------- & -------- \\
\hline Soxhlet/única & $\begin{array}{c}89969 \\
\left(16^{\prime} 015\right)\end{array}$ & -------- & $\begin{array}{c}147037 \\
\left(18^{\prime} 198\right)\end{array}$ & $\begin{array}{c}253927 \\
(18 ' 535)\end{array}$ & $\begin{array}{c}271296 \\
\left(22^{\prime} 512\right)\end{array}$ \\
\hline Agitação/única & -------- & $\begin{array}{c}85073 \\
\left(16^{\prime} 908\right)\end{array}$ & $\begin{array}{c}328183 \\
\left(18^{\prime} 179\right)\end{array}$ & $\begin{array}{c}212329 \\
\left(18^{\prime} 527\right)\end{array}$ & $\begin{array}{c}202841 \\
\left(22^{\prime} 512\right)\end{array}$ \\
\hline
\end{tabular}

Tabela E.6- Resultados das injeções em CG/DCE das amostras de sedimento da campanha de novembro/98/Estação 2

Extração/Amost $\quad$ Substâncias (Área/ tempo de Retenção)




\begin{tabular}{|c|c|c|c|c|}
\hline $\mathrm{ra}$ & 2,4,5-ТCP & 2,4-DBP & 2,3,4-TCP & $\mathrm{PCP}$ \\
\hline Ultra/A & & & & \\
\hline Ultra/B & & & & \\
\hline Ultra/C & & & & \\
\hline Soxhlet/única & $\begin{array}{c}82625 \\
\left(18^{\prime} 197\right)\end{array}$ & $\begin{array}{c}193542 \\
(18,532)\end{array}$ & $\begin{array}{l}1611446 \\
(19 ' 308)\end{array}$ & $\begin{array}{c}50819 \\
\left(22^{\prime} 568\right)\end{array}$ \\
\hline Agitação/única & ------------- & $\begin{array}{c}168546 \\
(18,530)\end{array}$ & $\begin{array}{c}457810 \\
\left(19^{\prime} 134\right)\end{array}$ & \\
\hline
\end{tabular}

Tabela E.7 - Resultados das injeções em CG/DCE das amostras de sedimento da campanha de novembro/98/Estação 3

\begin{tabular}{c|c|c|c}
\hline \multirow{2}{*}{$\begin{array}{c}\text { Extração/Amo } \\
\text { stra }\end{array}$} & \multicolumn{3}{|c}{ Substâncias (Área/ tempo de Retenção) } \\
\cline { 2 - 4 } & $2,4-\mathrm{DBP}$ & $2,3,4-\mathrm{TCP}$ & $\mathrm{PCP}$ \\
\hline Ultra/A & ----------- & ----------- & 72721 \\
& 54627 & 741210 & $\left(22^{\prime} 538\right)$ \\
\hline Ultra/B & $\left(18^{\prime} 748\right)$ & $\left(199^{\prime} 144\right)$ & \\
& ---------- & ---------- & ---------- \\
\hline Ultra/C & & & \\
\hline Soxhlet/única & & & \\
\hline Agitação/única & & & \\
\hline
\end{tabular}

Tabela E.8 - Resultados das injeções em CG/DCE das amostras de sedimento da campanha de novembro/98/Estação 4

\begin{tabular}{|c|c|c|c|c|c|c|c|}
\hline \multirow[b]{2}{*}{$\begin{array}{c}\text { Extração/Amo } \\
\text { stra }\end{array}$} & \multicolumn{7}{|c|}{ Substâncias (Área/ tempo de Retenção) } \\
\hline & $\begin{array}{c}2,5- \\
\text { DCP }\end{array}$ & $\begin{array}{c}2,4,6- \\
\text { TCP }\end{array}$ & $\begin{array}{c}2,3,6- \\
\text { TCP }\end{array}$ & $\begin{array}{c}2,4,5- \\
\text { TCP }\end{array}$ & $\begin{array}{c}2,4- \\
\text { DBP }\end{array}$ & $\begin{array}{c}2,3,4- \\
\text { TCP }\end{array}$ & PCP \\
\hline Ultra/A & $\begin{array}{c}------- \\
---\end{array}$ & $\begin{array}{c}\text {-------- } \\
----\end{array}$ & $\begin{array}{c}-------- \\
---\end{array}$ & $\begin{array}{c}\text {-------- } \\
----\end{array}$ & $\begin{array}{c}-------- \\
---\end{array}$ & $\begin{array}{c}\text {-------- } \\
----\end{array}$ & ------ \\
\hline Ultra/B & $\begin{array}{c}------- \\
--- \\
\end{array}$ & $\begin{array}{c}------- \\
--- \\
\end{array}$ & $\begin{array}{c}------- \\
---\end{array}$ & $\begin{array}{c}------- \\
--- \\
\end{array}$ & $\begin{array}{c}------- \\
--- \\
\end{array}$ & $\begin{array}{c}------- \\
---\end{array}$ & $\begin{array}{c}------- \\
--- \\
\end{array}$ \\
\hline Ultra/C & --- & ------ & --- & --- & -------- & $\begin{array}{c}94260 \\
\left(19^{\prime} 20\right. \\
8)\end{array}$ & $\begin{array}{c}56411 \\
(22 ' 49 \\
9)\end{array}$ \\
\hline Soxhlet/única & --- & $\begin{array}{c}14888 \\
0 \\
\left(155^{\prime} 99\right. \\
5)\end{array}$ & $\begin{array}{c}14001 \\
0 \\
\left(16^{\prime} 84\right. \\
2)\end{array}$ & -------- & $\begin{array}{c}38605 \\
1 \\
(18,52 \\
4)\end{array}$ & -------- & $\begin{array}{c}13557 \\
0 \\
\left(22^{\prime} 56\right. \\
1)\end{array}$ \\
\hline Agitação/única & $\begin{array}{c}11898 \\
8 \\
\left(15^{\prime} 01\right. \\
8)\end{array}$ & $\begin{array}{c}21435 \\
4 \\
\left(15^{\prime} 89\right. \\
5)\end{array}$ & $\begin{array}{c}39085 \\
1 \\
\left(166^{\prime} 78\right. \\
0)\end{array}$ & $\begin{array}{c}36158 \\
2 \\
\left(18^{\prime} 17\right. \\
2)\end{array}$ & $\begin{array}{c}75699 \\
8 \\
\left(18^{\prime} 52\right. \\
8)\end{array}$ & $\begin{array}{c}10462 \\
8 \\
\left(19^{\prime} 14\right. \\
0)\end{array}$ & $\begin{array}{c}45686 \\
8 \\
(22 ’ 52 \\
8)\end{array}$ \\
\hline
\end{tabular}


Tabela E.9 - Resultados das injeções em CG/DCE das amostras de sedimento da campanha de fevereiro/98/Estação 1

\begin{tabular}{|c|c|c|c|c|c|c|}
\hline \multirow[b]{2}{*}{$\begin{array}{c}\text { Extração/Amo } \\
\text { stra }\end{array}$} & \multicolumn{6}{|c|}{ Substâncias (Área/ tempo de Retenção) } \\
\hline & $\begin{array}{l}2,4,6- \\
\text { TCP }\end{array}$ & $\begin{array}{l}2,3,6- \\
\text { TCP }\end{array}$ & $\begin{array}{c}2,4,5- \\
\text { TCP }\end{array}$ & 2,4-DBP & $\begin{array}{c}2,3,4- \\
\text { TCP }\end{array}$ & PCP \\
\hline Ultra/A & & $\begin{array}{c}41366 \\
\left(16^{\prime} 902\right)\end{array}$ & & & & $\begin{array}{c}184793 \\
(22 ’ 557)\end{array}$ \\
\hline Ultra/B & $\begin{array}{c}64569 \\
\left(15^{\prime} 750\right)\end{array}$ & $\begin{array}{c}95506 \\
\left(17^{\prime} 009\right)\end{array}$ & $\begin{array}{c}82553 \\
\left(17^{\prime} 988\right)\end{array}$ & & $\begin{array}{c}130678 \\
\left(19^{\prime} 281\right)\end{array}$ & $\begin{array}{c}62148 \\
(22 ’ 564)\end{array}$ \\
\hline Ultra/C & & $\begin{array}{c}78911 \\
\left(16^{\prime} 900\right)\end{array}$ & & & $\begin{array}{c}121943 \\
(19 ’ 286)\end{array}$ & $\begin{array}{l}219485 \\
(22 ’ 506)\end{array}$ \\
\hline Soxhlet/única & $\begin{array}{c}82635 \\
\left(16^{\prime} 064\right)\end{array}$ & $\begin{array}{l}226624 \\
\left(16^{\prime} 847\right)\end{array}$ & & $\begin{array}{l}615992 \\
\left(18^{\prime} 525\right)\end{array}$ & $\begin{array}{l}123323 \\
(19 ’ 292)\end{array}$ & $\begin{array}{c}97394 \\
(22 ' 569)\end{array}$ \\
\hline Agitação/única & & $\begin{array}{c}95479 \\
\left(16^{\prime} 914\right)\end{array}$ & & & & $\begin{array}{l}652973 \\
(22 ’ 511)\end{array}$ \\
\hline
\end{tabular}

Tabela E.10 |- Resultados das injeções em CG/DCE das amostras de sedimento da campanha de fevereiro/98/Estação 2

\begin{tabular}{|c|c|c|c|c|}
\hline \multirow{2}{*}{$\begin{array}{c}\text { Extração/Amo } \\
\text { stra }\end{array}$} & \multicolumn{4}{|c|}{ Substâncias (Área/ tempo de Retenção) } \\
\hline & 2,4,6-TCP & 2,4,5-TCP & 2,4-DBP & $2,3,4-\mathrm{TCP}$ \\
\hline Ultra/A & ---------' & ------------ & $\begin{array}{c}89702 \\
\left(18^{\prime} 761\right)\end{array}$ & $\begin{array}{l}510098 \\
\left(19^{\prime} 105\right)\end{array}$ \\
\hline Ultra/B & ------------ & ------------ & ------------- & ------------ \\
\hline Ultra/C & $\begin{array}{c}39311 \\
\left(15^{\prime} 712\right)\end{array}$ & & & \\
\hline Soxhlet/única & & & & \\
\hline Agitação/única & & $\begin{array}{c}187533 \\
\left(18^{\prime} 245\right)\end{array}$ & $\begin{array}{l}445316 \\
\left(18^{\prime} 530\right)\end{array}$ & $\begin{array}{l}2506337 \\
\left(19^{\prime} 174\right)\end{array}$ \\
\hline
\end{tabular}

Tabela E.11 - Resultados das injeções em CG/DCE das amostras de sedimento da campanha de fevereiro/98/Estação 3 


\begin{tabular}{|c|c|c|}
\hline stra & 2,4-DBP & $\mathrm{PCP}$ \\
\hline Ultra/A & ------------ & ------------ \\
\hline Ultra/B & ------------- & ----------- \\
\hline Ultra/C & ------------- & ------------- \\
\hline Soxhlet/única & $\begin{array}{c}237976 \\
\left(18^{\prime} 524\right)\end{array}$ & $\begin{array}{c}95454 \\
(22 ’ 562)\end{array}$ \\
\hline Agitação/única & $\begin{array}{c}99121 \\
\left(18^{\prime} 531\right)\end{array}$ & \\
\hline
\end{tabular}

Tabela E.12- Resultados das injeções em CG/DCE das amostras de sedimento da campanha de fevereiro/98/Estação 4

\begin{tabular}{|c|c|c|c|c|c|c|}
\hline \multirow[b]{2}{*}{$\begin{array}{c}\text { Extração/Amo } \\
\text { stra }\end{array}$} & \multicolumn{6}{|c|}{ Substâncias (Área/ tempo de Retenção) } \\
\hline & $\begin{array}{l}2,4,6- \\
\text { TCP }\end{array}$ & $\begin{array}{c}2,3,6- \\
\text { TCP }\end{array}$ & $\begin{array}{c}2,4,5- \\
\text { TCP }\end{array}$ & 2,4-DBP & $\begin{array}{r}2,3,4- \\
\text { TCP }\end{array}$ & PCP \\
\hline Ultra/A & -------- & -------- & -------- & -------- & --------- & -------- \\
\hline Ultra/B & $\begin{array}{l}-------- \\
-1\end{array}$ & $\begin{array}{ll}------- \\
--\end{array}$ & $\begin{array}{ll}------- \\
--\end{array}$ & $\begin{array}{ll}------- \\
\end{array}$ & $\begin{array}{ll}------- \\
--\end{array}$ & $\begin{array}{l}-------- \\
-\end{array}$ \\
\hline Ultra/C & 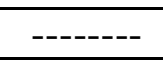 & -------- & $\begin{array}{ll}------- \\
\end{array}$ & $\begin{array}{ll}------- \\
\end{array}$ & $\begin{array}{ll}------- \\
\end{array}$ & $\begin{array}{ll}------- \\
\end{array}$ \\
\hline Soxhlet/única & $\begin{array}{l}212550 \\
\left(16^{\prime} 007\right)\end{array}$ & & $\begin{array}{c}77304 \\
\left(17^{\prime} 971\right)\end{array}$ & $\begin{array}{c}384577 \\
\left(18^{\prime} 530\right)\end{array}$ & $\begin{array}{c}66820 \\
\left(19^{\prime} 178\right)\end{array}$ & $\begin{array}{l}195950 \\
\left(22^{\prime} 481\right)\end{array}$ \\
\hline Agitação/única & & $\begin{array}{l}119488 \\
\left(16^{\prime} 908\right)\end{array}$ & & $\begin{array}{l}219341 \\
\left(18^{\prime} 526\right)\end{array}$ & & $\begin{array}{l}325992 \\
(22 ' 506)\end{array}$ \\
\hline
\end{tabular}




\section{Curva de calibração para sedimento}

Tabela $1 F-$ Concentrações de padrões de clorofenóis e áreas de picos encontradas para amostras de sedimento

\begin{tabular}{|c|c|c|c|c|c|c|}
\hline \multirow{2}{*}{$\begin{array}{c}\text { Concentração } \\
(\mu \mathrm{g} / \mathrm{L})\end{array}$} & \multicolumn{5}{|c|}{ Área cromatográfica } \\
\hline & $2,5 \mathrm{DCP}$ & $2,4,6-\mathrm{TCP}$ & $2,3,6-\mathrm{TCP}$ & $2,4-\mathrm{DBP}$ & $2,3,4-\mathrm{TCP}$ & PCP \\
\hline Branco & & & & & & \\
\hline Branco & & & & & & \\
\hline Branco* & & & & 46322 & 93906 & \\
\hline 2,50 & & & & & & \\
\hline 2,50 & & & & & 107197 & 560217 \\
\hline 2,50 & & & & & 46113 & \\
\hline 0,05 & & 49701 & & & & \\
\hline $0,05^{*}$ & 120782 & 3479672 & 2614638 & 51104 & 1856873 & 3697446 \\
\hline $0,05^{*}$ & 109297 & 3138197 & 2339889 & 44616 & 1816660 & 2575550 \\
\hline 5,00 & 256031 & 7453337 & 6275664 & 43554 & 3426531 & 5074944 \\
\hline $5,00^{*}$ & 86368 & 3259950 & 2770073 & & 1840999 & 4713961 \\
\hline $5,00^{*}$ & 172592 & 5344711 & 5246371 & 36880 & 2166703 & 3928576 \\
\hline 12,50 & & & & & & \\
\hline $12,50^{*}$ & 63485 & 10994700 & 10841800 & 79598 & 8713428 & 15784500 \\
\hline
\end{tabular}

Obs:. As amostras marcadas por asterisco não passaram por processo de limpeza

Tabela 2F- Teste de limpeza de amostra utilizando coluna de sílica (3 cm)

\begin{tabular}{|c|c|c|c|c|c|c|}
\hline $\begin{array}{c}\text { Concentração } \\
(\mu \mathrm{g} / \mathrm{L})\end{array}$ & \multicolumn{6}{|c|}{ Teste de limpeza } \\
\cline { 2 - 7 } & $2,5 \mathrm{DCP}$ & $2,4,6-\mathrm{TCP}$ & $2,3,6-\mathrm{TCP}$ & $2,4-\mathrm{DBP}$ & $2,3,4-\mathrm{TCP}$ & PCP \\
\hline $2,50 \mathrm{a}$ & & & & & & \\
\hline $2,50 \mathrm{acet}$ & 53899 & 2019099 & 1613200 & 32582 & 822186 & \\
\hline Soma & 53899 & 2068800 & 1613200 & 32582 & 822186 & \\
\hline
\end{tabular}

Tabela 3F-Concentrações de padrão de clorofenóis e médias dos picos cromatográficos

\begin{tabular}{|c|c|c|c|c|c|c|}
\hline $\begin{array}{c}\text { Concentração } \\
(\mu \mathrm{g} / \mathrm{L})\end{array}$ & \multicolumn{7}{|c|}{ Teste de limpeza } \\
\cline { 2 - 7 } & $2,5 \mathrm{DCP}$ & $2,4,6-\mathrm{TCP}$ & $2,3,6-\mathrm{TCP}$ & $2,4-\mathrm{DBP}$ & $2,3,4-\mathrm{TCP}$ & PCP \\
\hline 2,50 & $1,15 \mathrm{E}+05$ & $3,31 \mathrm{E}+06$ & $2,48 \mathrm{E}+06$ & $4,79 \mathrm{E}+04$ & $1,84 \mathrm{E}+06$ & $3,14 \mathrm{E}+06$ \\
\hline 5,00 & $2,14 \mathrm{E}+05$ & $6,40 \mathrm{E}+06$ & $5,76 \mathrm{E}+06$ & $4,02 \mathrm{E}+04$ & $2,80 \mathrm{E}+06$ & $4,50 \mathrm{E}+06$ \\
\hline 12,50 & $6,35 \mathrm{E}+04$ & $1,10 \mathrm{E}+07$ & $1,08 \mathrm{E}+07$ & $7,96 \mathrm{E}+04$ & $8,71 \mathrm{E}+06$ & $1,58 \mathrm{E}+07$ \\
\hline
\end{tabular}

Tabela $4 F-$ Equações das curvas de calibração e desvios

\begin{tabular}{|c|c|c|}
\hline Clorofenóis & Equações \\
\hline $2,4,6-\mathrm{TCP}$ & & $\mathrm{y}=4 \mathrm{E}+07 \mathrm{x}+2 \mathrm{E}+06$ \\
\hline $2,3,6-\mathrm{TCP}$ & & $\mathrm{y}=4 \mathrm{E}+07 \mathrm{x}+1 \mathrm{E}+06$ \\
\hline $2,3,4-\mathrm{TCP}$ & & $\mathrm{y}=4 \mathrm{E}+07 \mathrm{x}-291261$ \\
\hline PCP & & $\mathrm{y}=7 \mathrm{E}+07 \mathrm{x}-992977$ \\
\hline
\end{tabular}




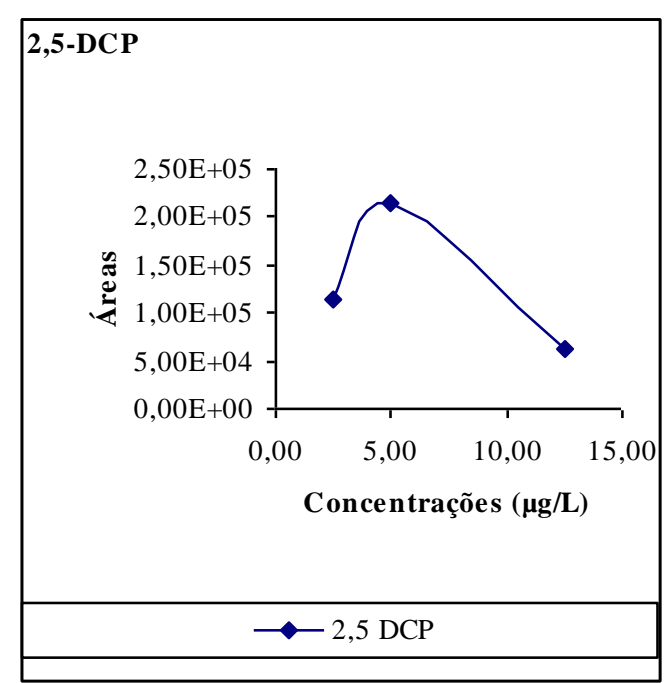

(a)

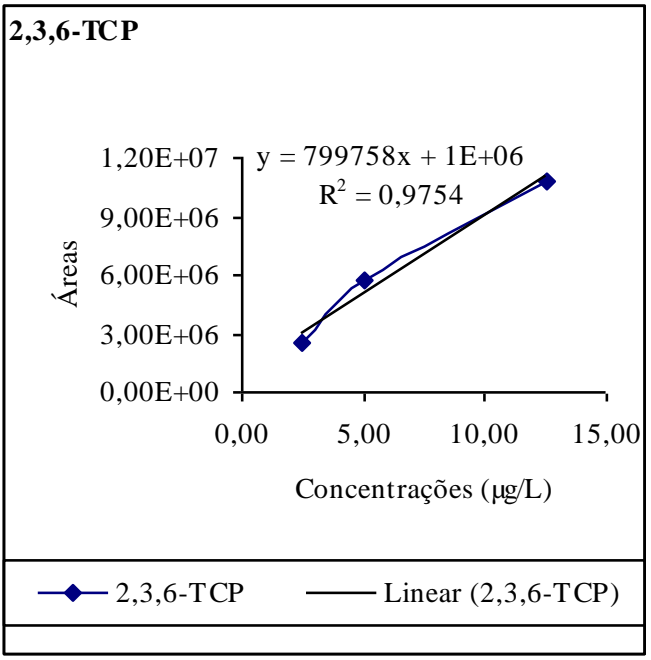

(b)

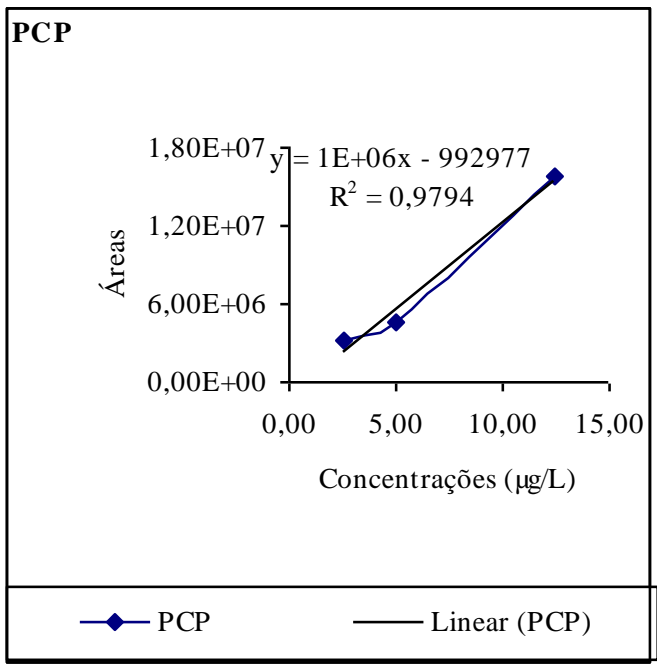

(e)

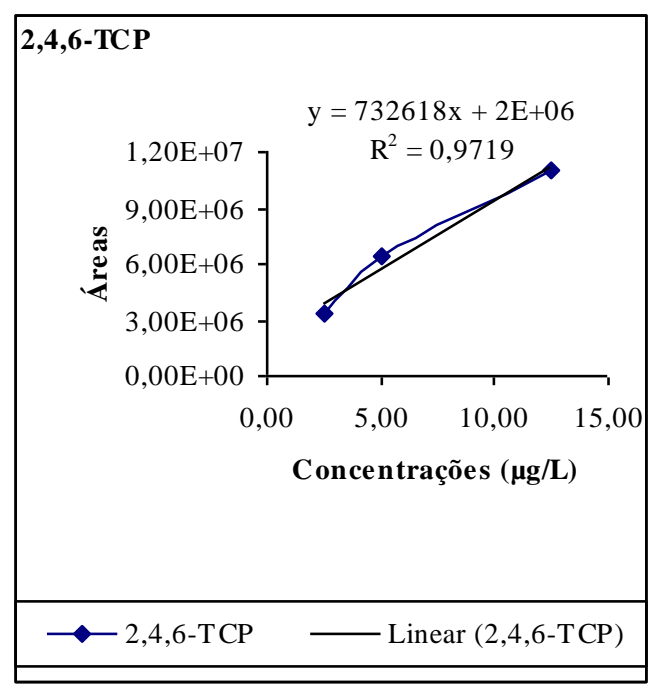

(b)

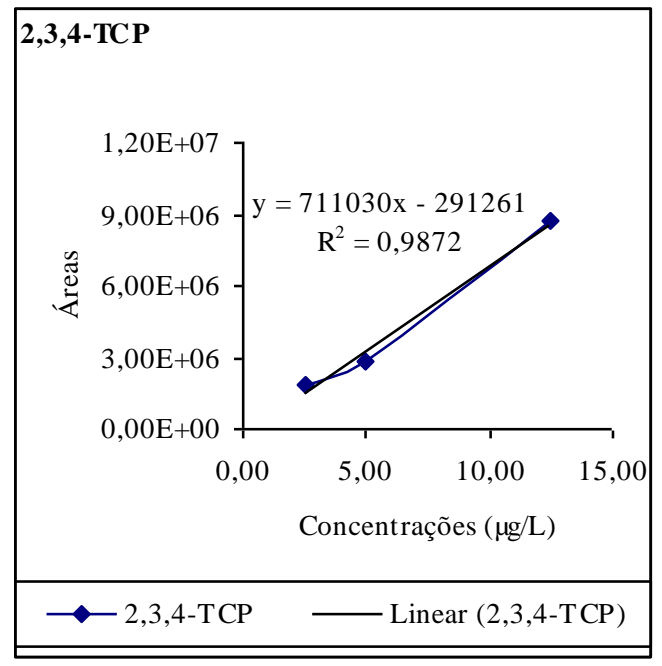

(d)

Figura 5F - Gráficos da curva de calibração para amostras de sedimento para padrões de 2,5diclorofenol (a); 2,4,6-triclorofenol (b); 2,3,6-triclorofenol (c); 2,3,4-triclorofenol (d); pentaclorofenol (e). 
Curva de calibração para água

Tabela 5F- Concentrações de padrões de clorofenóis e áreas de picos encontradas para amostras de agua

\begin{tabular}{|c|c|c|c|c|c|c|}
\hline $\begin{array}{c}\text { Concentração } \\
(\mu \mathrm{g} / \mathrm{L})\end{array}$ & $2,5 \mathrm{DCP}$ & $2,4,6-\mathrm{TCP}$ & $2,3,6-\mathrm{TCP}$ & $2,4-\mathrm{DBP}$ & $2,3,4-\mathrm{TCP}$ & PCP \\
\cline { 2 - 7 } & 44900 & 1671991 & 1954673 & 79236 & 827878 & 3294204 \\
\hline 0,01 & 58955 & 2075651 & 2492568 & 94655 & 1041581 & 4146846 \\
\hline 0,01 & 41732 & 1761832 & 2061797 & 89798 & 968451 & 2585268 \\
\hline 0,01 & 327711 & 11600000 & 12677800 & 92438 & 9283147 & 15256500 \\
\hline 0,05 & 351534 & 12745800 & 13708900 & 117193 & 10998400 & 17713500 \\
\hline 0,05 & 307755 & 12301700 & 13249200 & 109263 & 9931248 & 15852700 \\
\hline 0,05 & 511661 & 16204670 & 16035500 & 108774 & 14782900 & 19808200 \\
\hline 0,10 & 999747 & 18562400 & 18159100 & 144410 & 16281200 & 21237600 \\
\hline 0,10 & 719413 & 17663600 & 17292300 & 130886 & 16078100 & 22525100 \\
\hline 0,10 & &
\end{tabular}

Obs:. As amostras marcadas por asterisco não passaram por processo de limpeza

Tabela 6F- Concentrações de padrão de clorofenóis e médias dos picos de área cromatográfica

\begin{tabular}{|c|c|r|r|r|r|c|}
\hline $\begin{array}{c}\text { Concentração } \\
(\mu \mathrm{g} / \mathrm{L})\end{array}$ & \multicolumn{7}{|c|}{ Área cromatográfica } \\
\cline { 2 - 7 } & $2,5 \mathrm{DCP}$ & $2,4,6-\mathrm{TCP}$ & $2,3,6-\mathrm{TCP}$ & $2,4-\mathrm{DBP}$ & $2,3,4-\mathrm{TCP}$ & PCP \\
\hline $1,0 \mathrm{E}-02$ & $4,33 \mathrm{E}+04$ & $1,72 \mathrm{E}+06$ & $2,01 \mathrm{E}+06$ & $9,22 \mathrm{E}+04$ & $1,01 \mathrm{E}+06$ & $2,94 \mathrm{E}+06$ \\
\hline $5,0 \mathrm{E}-02$ & $3,29 \mathrm{E}+05$ & $1,25 \mathrm{E}+07$ & $1,30 \mathrm{E}+07$ & $1,13 \mathrm{E}+05$ & $9,61 \mathrm{E}+06$ & $1,56 \mathrm{E}+07$ \\
\hline $1,0 \mathrm{E}-01$ & $7,10 \mathrm{E}+05$ & $1,81 \mathrm{E}+07$ & $1,77 \mathrm{E}+07$ & $1,38 \mathrm{E}+05$ & $1,62 \mathrm{E}+07$ & $2,19 \mathrm{E}+07$ \\
\hline
\end{tabular}

Tabela $7 F$ - Equações das curvas de calibração e desvios

\begin{tabular}{|c|c|c|}
\hline Clorofenóis & Equações & $\mathrm{R}^{2}$ \\
\hline $2,5 \mathrm{DCP}$ & $\mathrm{y}=7 \times 10^{6} \mathrm{x}-34764$ & $\mathrm{R}^{2}=0,9997$ \\
\hline $2,4,6-\mathrm{TCP}$ & $\mathrm{y}=2 \times 10^{8} \mathrm{x}+1 \times 10^{6}$ & $\mathrm{R}^{2}=0,9408$ \\
\hline $2,3,6-\mathrm{TCP}$ & $\mathrm{y}=2 \times 10^{8} \mathrm{x}+2 \times 10^{6}$ & $\mathrm{R}^{2}=0,9195$ \\
\hline $2,3,4-\mathrm{TCP}$ & $\mathrm{y}=2 \times 10^{8} \mathrm{x}+19465$ & $\mathrm{R}^{2}=0,9802$ \\
\hline PCP & $\mathrm{y}=2 \times 10^{8} \mathrm{x}+2 \times 10^{6}$ & $\mathrm{R}^{2}=0,9371$ \\
\hline
\end{tabular}




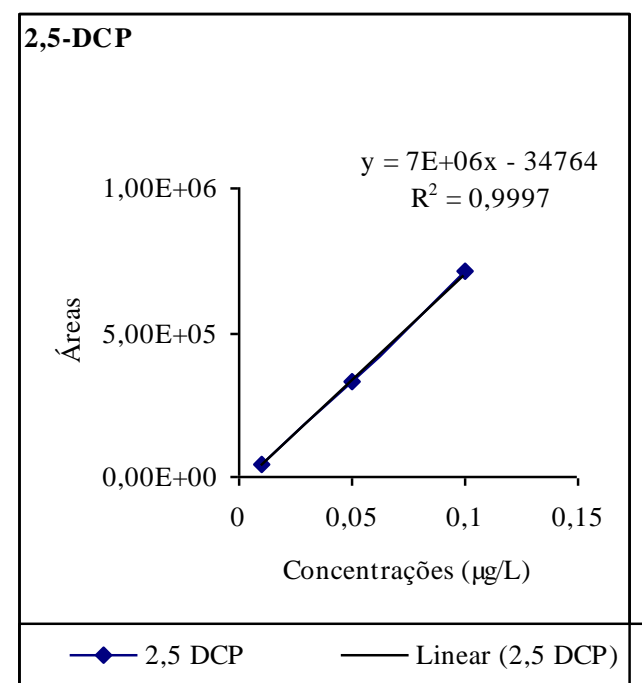

(a)

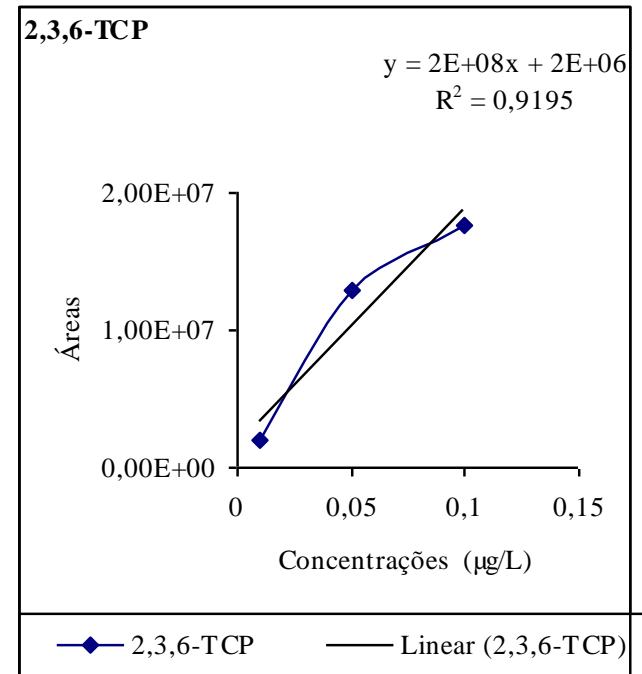

(c)

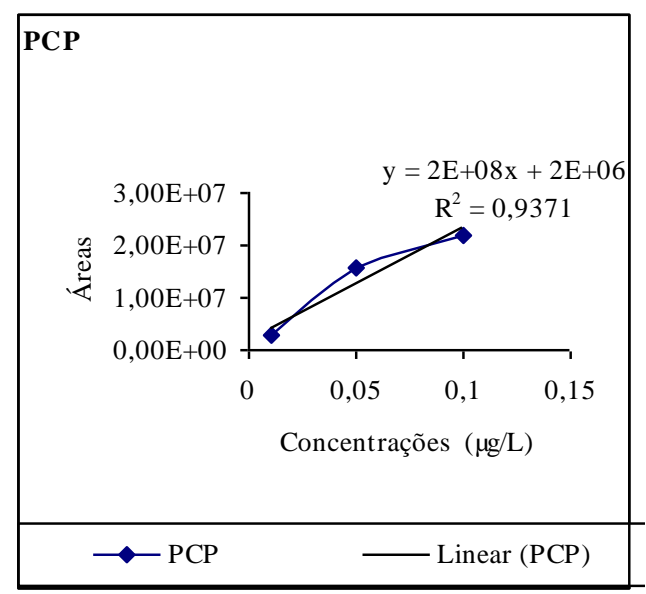

(e)

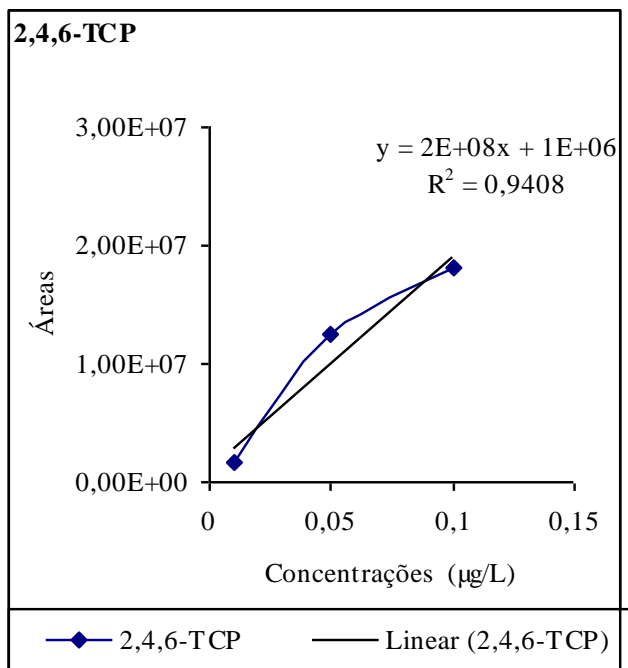

(b)

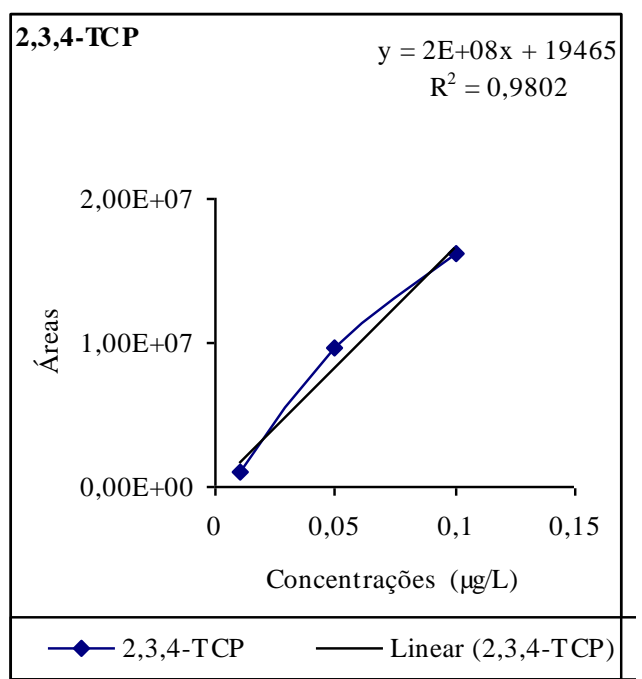

(d)

Figura 6F - Gráficos da curva de calibração para amostras de água para padrões de 2,5diclorofenol (a); 2,4,6-triclorofenol (b); 2,3,6-triclorofenol (c); 2,3,4-triclorofenol (d); pentaclorofenol (e). 


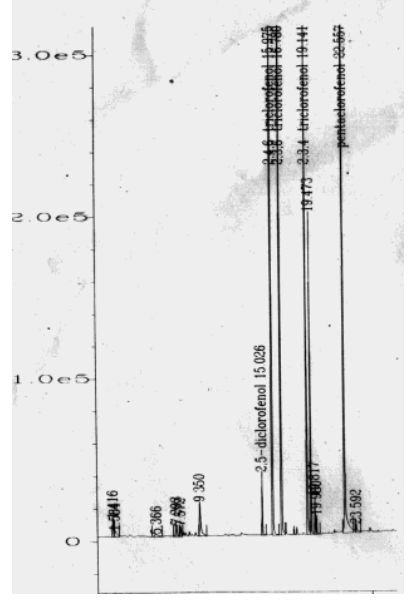

(a)

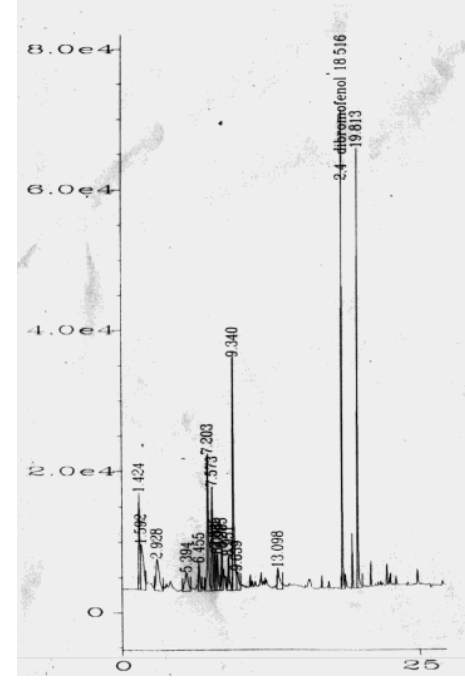

(b)

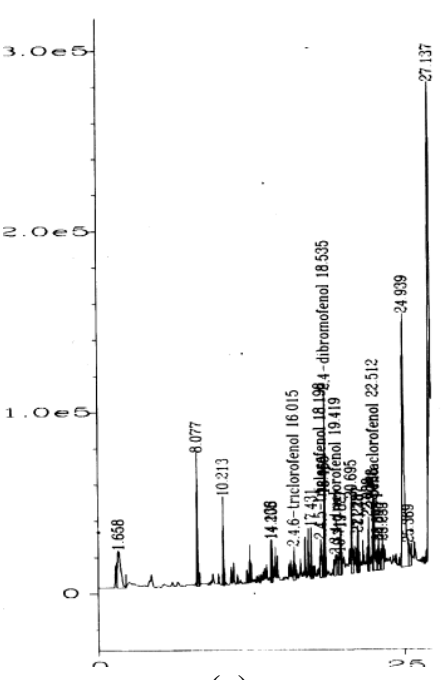

(c)

Figura 1G - Cromatograma dos padrões cromatográficos (a); do padrão interno dibromofenol (b); e de amostra de sedimento do ponto de coleta 1, extraída com soxhlet, na estação de novembro.

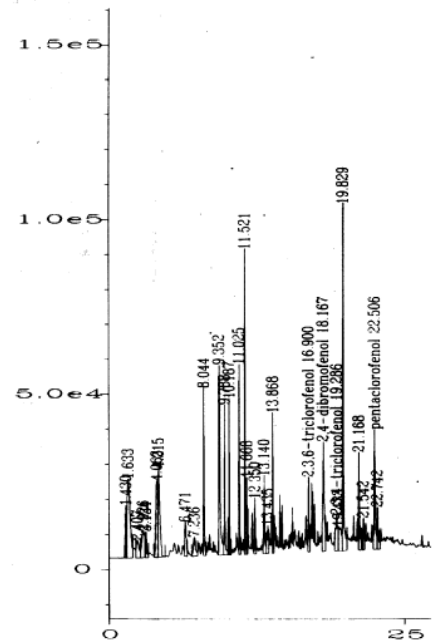

(a)

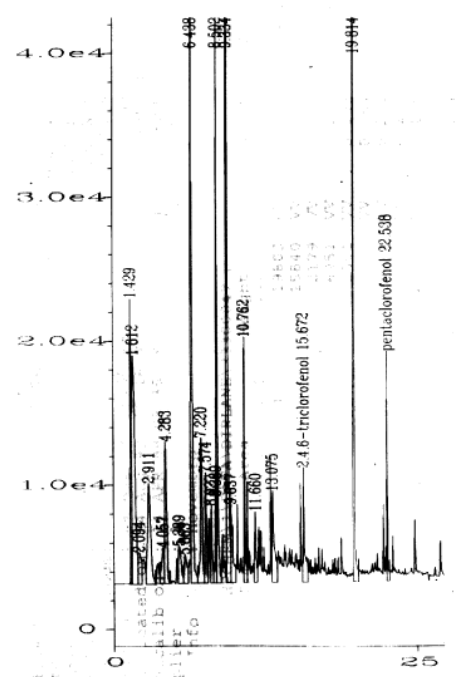

(b)

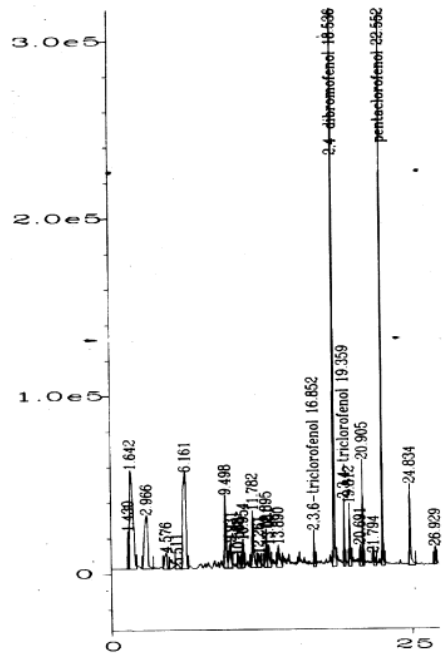

(c)

Figura 2G - Cromatograma da amostra: de sedimento coletada no ponto 1, na campanha de fevereiro e extraída com ultra som (a); de sedimento coletada no ponto 1, na campanha de novembro e extraída com ultra som (b); da amostra de água coletada no ponto 3 , na campanha de fevereiro (c) 


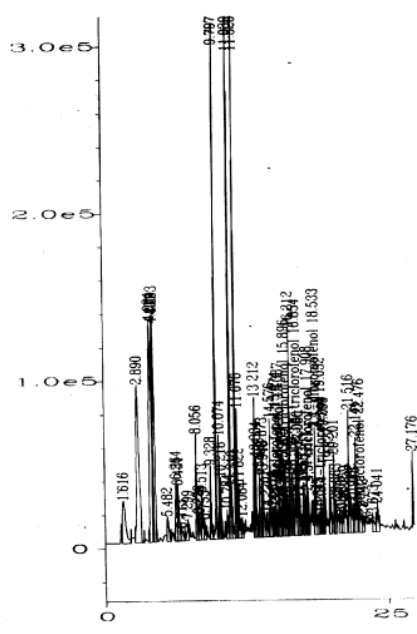

(a)

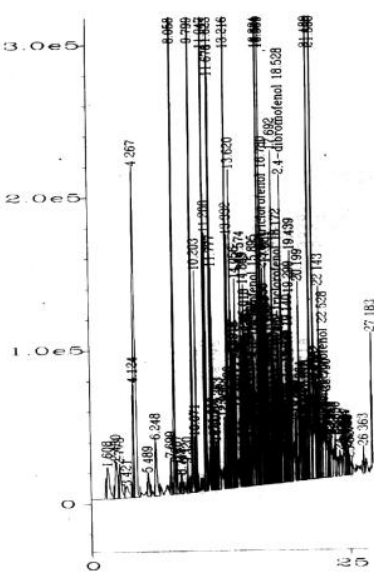

(b)

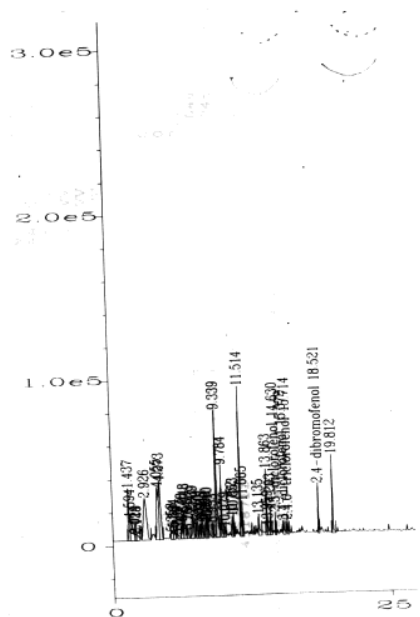

(c)

Figura 3G - Cromatograma da amostra: de sedimento coletada no ponto 4, na campanha de junho e extraída com agitação (a); de sedimento coletado no ponto 4, na campanha de novembro e extraída com agitação (b); da amostra de sedimento, coletada no ponto 4, na campanha de maio e extraída com soxhlet (c).

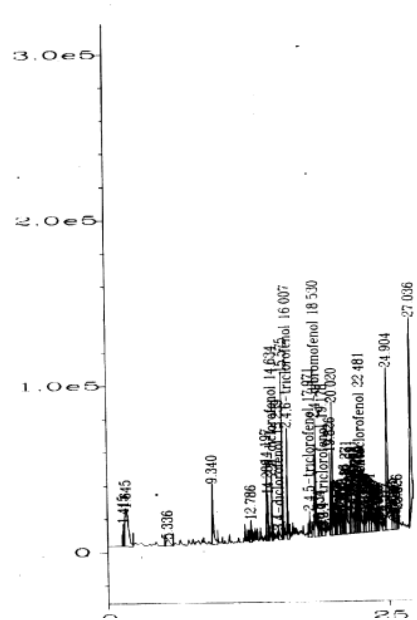

(a)

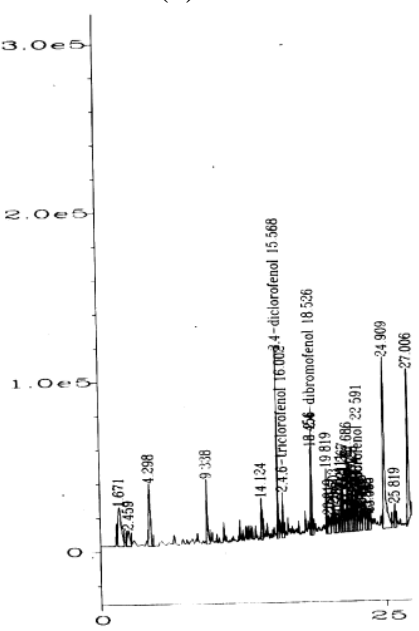

(b)

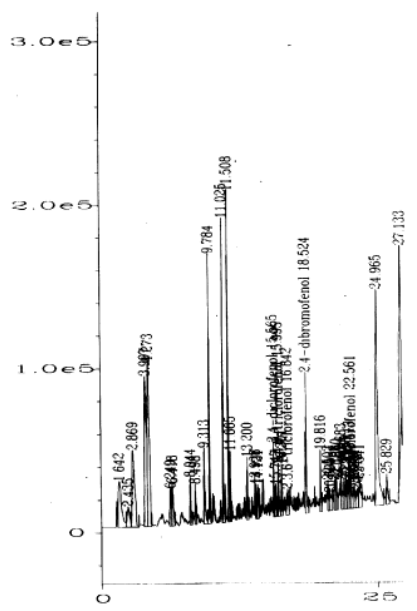

(c)

Figura 4G - Cromatograma da amostra: de sedimento coletada no ponto 4, na campanha de fevereoro e extraída com soxhlet (a); de sedimento coletado no ponto 4, na campanha de junho e extraída com soxhlet (b); da amostra de sedimento, coletada no ponto 4, na campanha de novembro e extraída com soxhlet (c). 


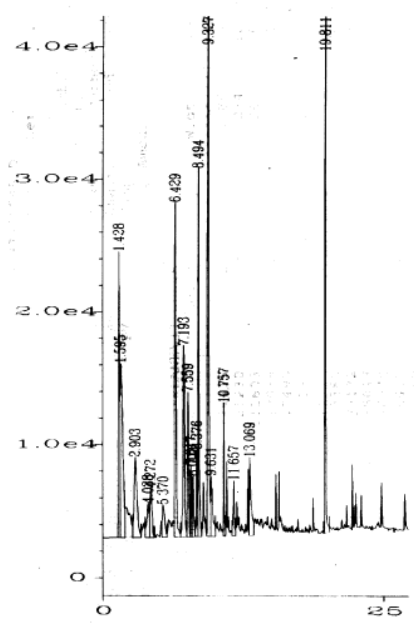

(a)

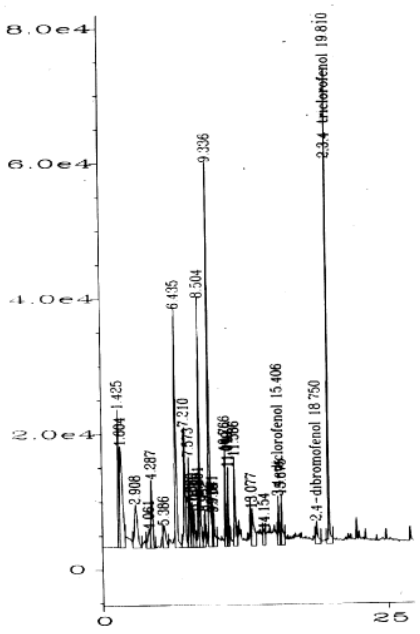

(b)

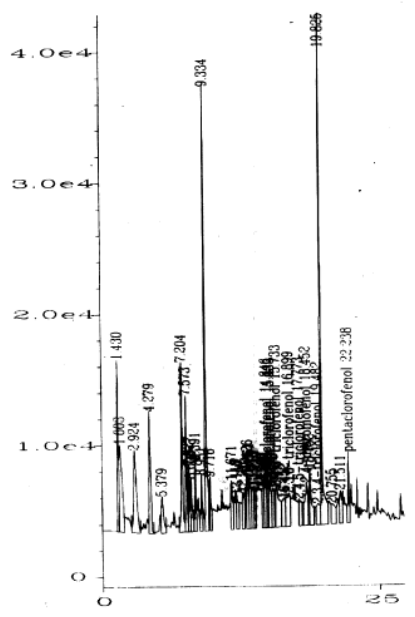

(c)

Figura 5G - Cromatograma da amostra: de sedimento coletada no ponto 4, na campanha de fevereiro e extraída com ultra-som (a); de sedimento coletado no ponto 4, na campanha de junho e extraída com ultra-som (b); da amostra de sedimento, coletada no ponto 4, na campanha de novembro e extraída com ultra-som (c).

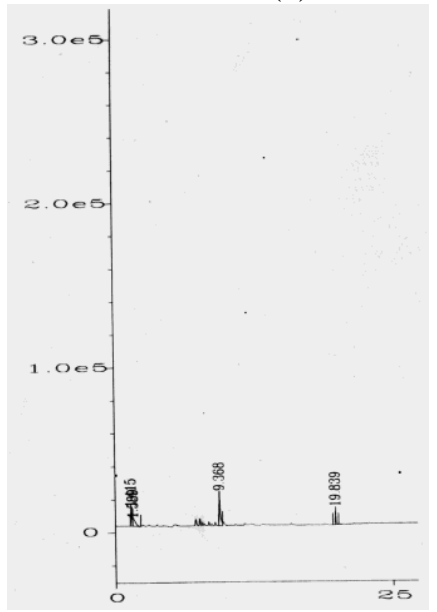

(a)

Figura 6G - Cromatograma do solvente hexano purificado, utilizado nas extrações 